BRUNA CATOIA

\title{
LAJES ALVEOLARES PROTENDIDAS: CISALHAMENTO EM REGIÃO FISSURADA POR FLEXÃO
}

Tese apresentada à Escola de Engenharia de São Carlos da Universidade de São Paulo como parte dos requisitos para obtenção do título de Doutor em Ciências, Programa de Engenharia Civil (Estruturas).

Versão corrigida. A original encontra-se na Escola de Engenharia de São Carlos da Universidade de São Paulo, EESC-USP.

Linha de pesquisa:

Estruturas de concreto e alvenaria

Orientador: Libânio Miranda Pinheiro Co-orientador: Marcelo de Araujo Ferreira 
AUTORIZO A REPRODUÇÃO E DIVULGAÇÃO TOTAL OU PARCIAL DESTE TRABALHO, POR QUALQUER MEIO CONVENCIONAL OU ELETRÔNICO, PARA FINS DE ESTUDO E PESQUISA, DESDE QUE CITADA A FONTE.

Ficha catalográfica preparada pela Seção de Tratamento da Informação do Serviço de Biblioteca - EESC/USP

Lajes alveolares protendidas: cisalhamento em região fissurada por flexão / Bruna Catoia ; orientador Libânio Miranda Pinheiro ; Co-orientador Marcelo de Araujo Ferreira. -- São Carlos, 2011.

Tese (Doutorado) - Programa de Pós-Graduação e Área de Concentração em Engenharia de Estruturas -- Escola de Engenharia de São Carlos da Universidade de São Paulo.

1. Cisalhamento. 2. Lajes alveolares protendidas. 3. Flexão. 4. Ensaios. 5. Modelo de ruptura. 6. Normalização. I. Título. 


\section{FOLHA DE JULGAMENTO}

\section{Candidato: Engenheira BRUNA CATOIA PERIOTTO.}

Tese defendida e julgada em 21.06.2011 perante a Comissão Julgadora:

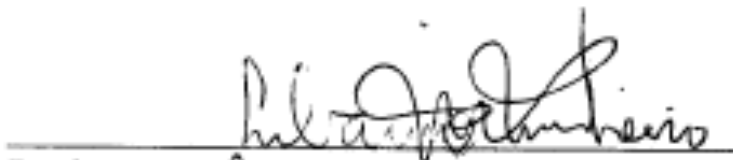

Prof. Dr. LIBÂNO MIRANDA PINHEIRO - (Orientador)

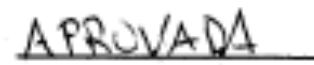

(Escola de Engenharia de Såo Carlos/USP)

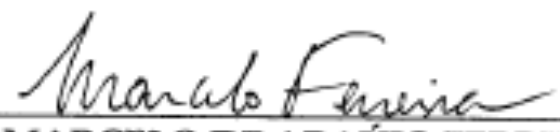

Prof. Dr. MARCELO DE ARAÚJO FERREIRA

APROVAOA

(Universidade Federal de São Carlos/UFSCar)

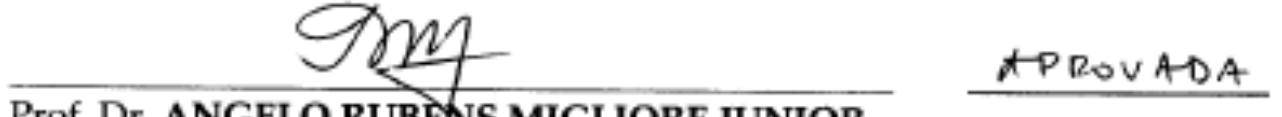

Prof. Dr. ANGELO RUBENS MIGLIORE JUNIOR

(Fundação Educacional de Barretos/FEB)

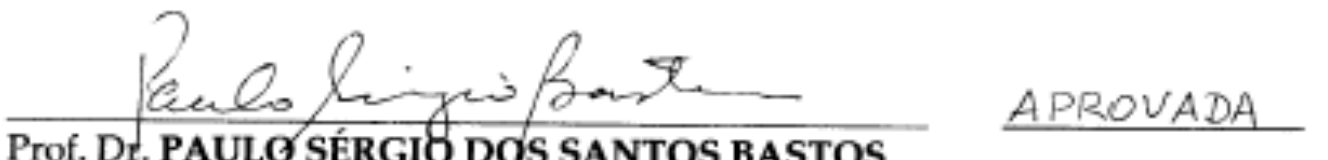

(Universidade Estadual Paulista "Júlio de Mesquita Filho"/UNESP/campus de Bauru)

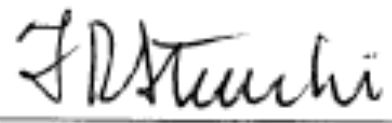

Prof. Titular FERNANDO REBOUÇAS STUCCHI

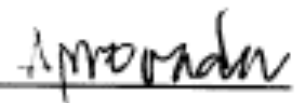

(Escola Politécnica/USP)

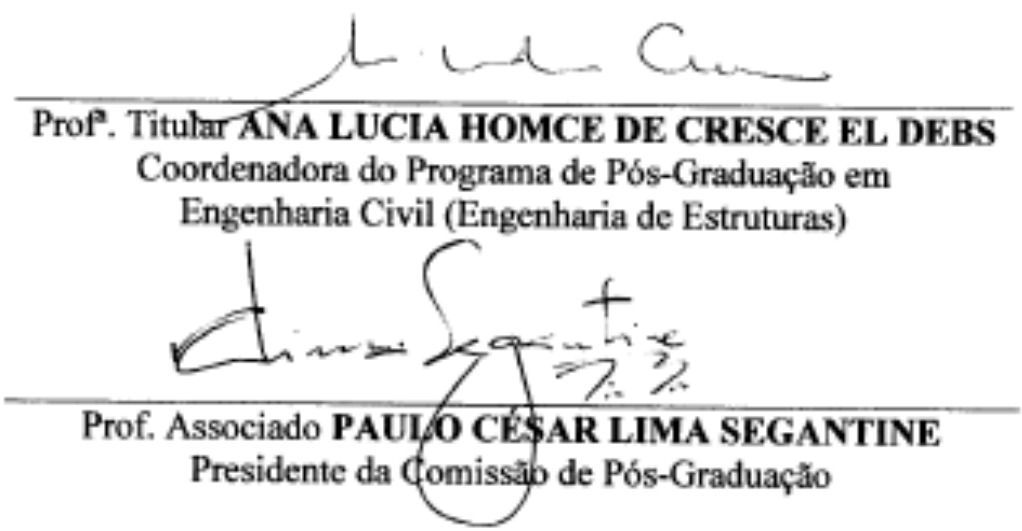



Dedica este trabalha as grandes respansáueis par tuda, minha mãe Lucia Helena Cataia e meu pai Raberta Carlas Cataia, verdadeiras heráis nas leatalhas da vida. 



\section{AGRADECIMENTOS}

Aos meus amados pais Lucia Helena Catoia e Roberto Carlos Catoia, exemplos de união, coragem e amor, agradeço de coração pela incansável luta em me tornar uma pessoa de bem.

Ao meu esposo Fernando Periotto, pela contribuição na realização dos ensaios, por suas palavras tão abençoadas e confortadoras e pelo grande amor e compreensão, principalmente nas muitas horas que não pude estar ao seu lado.

Ao amigo e irmão Thiago Catoia, pelo companheirismo durante essa difícil jornada, pelas valiosas horas de estudo, pelas vitórias alcançadas juntos e pelo amor que nos faz tão unidos.

À verdadeira amiga e querida irmã Micheli Catoia, pela paciência nas horas tristes, pelos conselhos e por estar sempre presente em todos os momentos da minha vida, contribuindo com todo seu amor e carinho.

Ao meu orientador, Libânio Miranda Pinheiro, por toda contribuição, por me acolher num momento tão difícil e pelo indispensável apoio, amizade e compreensão.

Ao meu co-orientador, Marcelo de Araujo Ferreira, pela incansável luta em me apoiar, por suas idéias e pela contribuição indispensável a esta pesquisa.

Ao grande professor e amigo Roberto Chust Carvalho, por ser uma pessoa tão especial, por estar sempre disposto a ajudar com toda sua sabedoria e experiência e pelas muitas contribuições prestadas a esta pesquisa.

À professora Ana Lúcia H. C. El Debs, pelas sugestões dadas no exame de qualificação.

Aos professores Fernando Rebouças Stucchi, Paulo Sérgio dos Santos Bastos e Ângelo Rubens Migliore Junior, pelas sugestões oferecidas como banca de defesa.

Ao professor José Carlos A. Cintra, pelas preciosas técnicas de apresentação.

À professora Ruth de Gouvêa Duarte, pelos ensinamentos, que contribuíram para a elaboração do texto.

Ao CNPq, pela bolsa e pelo apoio financeiro.

Em especial, às empresas "CASSOL PRÉ-FABRICADOS", "LAJEAL LAJES ALVEOLARES", "LEONARDI" e "MUNTE CONSTRUÇÕES INDUSTRIALIZADAS", pela grande contribuição.

À ABCIC, pela doação do laboratório do NETPRE e pelas demais contribuições para realização deste trabalho.

À minha avó Joanna Mathias Muzzeti (in memoriam) que, apesar de pouca instrução, acreditava e incentivava a educação. 
À tia Luci Regina Muzzeti, pelo exemplo de uma vida de disciplina, dedicação e sucesso profissional, pessoa que eu admiro desde pequena, diante de tanto esforço e horas de estudo.

Ao Marcelo Pinarelli Cover, pelo carinho dedicado à minha família e por me proporcionar momentos especiais.

À Regina Candeloro Grabarz, por me acompanhar em momentos tão especiais, por sua amizade e carinho.

Ao amigo Isaías de Oliveira Júnior, pelo companheirismo dedicado à minha família, contagiando a todos com sua serenidade e amor ao próximo.

A todos os funcionários do Departamento de Engenharia de Estruturas da EESC-USP.

Aos colegas do NETPRE, Altibano Ortenzi Junior, Fernando Menezes de Almeida Filho, Olivia Oliveira da Costa, Luís Augusto Bachega, Matheus L. Gonçalves Marquesi e Carolina Camilo, pela grande contribuição ao longo deste trabalho. 


\section{RESUMO}

CATOIA, B. Lajes alveolares protendidas: cisalhamento em região fissurada por flexão. 2011. 325p. Tese (Doutorado) - Escola de Engenharia de São Carlos, Universidade de São Paulo. São Carlos, 2011.

Esta pesquisa teve como principal objetivo analisar o comportamento de lajes alveolares protendidas de uso corrente no Brasil (pequenas espessuras e alta protensão) quanto ao cisalhamento em região fissurada por ação do momento fletor, para diferentes situações: sem e com capa e com preenchimento parcial de alvéolos. Foi desenvolvido um estudo teórico com o emprego de equacionamentos analíticos disponíveis na literatura técnica, envolvendo as recomendações da norma brasileira NBR 6118:2003 (Projeto de Estruturas de Concreto), do ACI-318:2008 (Building code requirements for structural concrete) e da EN 1992-1-1 (2004) (Eurocode 2- Projeto de estruturas de betão - Parte 1-1: Regras gerais e regras para edifícios). Foram feitas comparações com resultados experimentais obtidos a partir de inúmeros ensaios de lajes alveolares protendidas. As unidades ensaiadas nesta pesquisa foram disponibilizadas por quatro empresas brasileiras de intensa atividade no mercado, sendo analisadas as capacidades resistentes de diferentes tipos. Assim, foram realizados 96 ensaios, 31 para a determinação da capacidade resistente à flexão e 65 , ao cisalhamento, sendo selecionados modelos de lajes com grande emprego no mercado brasileiro. A partir desses ensaios, foi possível entender melhor o comportamento das lajes alveolares protendidas produzidas no Brasil. Com as diversas análises, considerando os ensaios experimentais e um vasto estudo teórico quanto ao dimensionamento dessas lajes, verificou-se a adequabilidade de equações de diferentes normas. Assim, foi possível identificar o equacionamento que melhor representa o comportamento das peças produzidas no Brasil, considerando inclusive peculiaridades de comportamento, que apresentam diferenças constratantes com relação a unidades produzidas em outros países. A partir desses estudos, produziuse um amplo memorial de cálculo, considerando as diversas tipologias de lajes estudadas, com o objetivo de contribuir de modo didático com os engenheiros de estrururas. Logo, com esta pesquisa, foi possível não somente melhorar o entendimento do comportamento de tais lajes alveolares, como também fornecer subsídios para a avaliação desses elementos, considerando as características específicas das lajes produzidas no Brasil e, assim, contribuir para a padronização do dimensionamento junto à norma brasileira NBR 14861 (Laje pré-fabricada - Painel alveolar de concreto protendido).

Palavras-chave: Lajes alveolares protendidas. Cisalhamento. Flexão. Ensaios. Modo de ruptura. Normalização. 



\section{ABSTRACT}

\section{CATOIA, B. Prestressed hollow core slabs: shear in region fissured due to} bending. 2011. 325p. Thesis (Doctoral) - Escola de Engenharia de São Carlos, Universidade de São Paulo. São Carlos, 2011.

This work had as major objective to analyze the behavior of Brazilian prestressed hollow core slabs - small thickness and high level of prestressing - considering shear in a cracked region due to bending moment, for different design situations: without concrete topping, with concrete topping and with filling the voids. A theoretical study was developed with the use of analytical equations available in the technical literature, involving the recommendations of the Brazilian code NBR 6118:2003 (Design of concrete structures), ACI-318: 2008 (Building code requirements for structural concrete) and EN 1992-1-1 (2004) (Eurocode 2: Design of concrete structures - Part 1-1: General rules and rules for buildings), comparing experimental results from many prestressed hollow core slabs tests. The slabs tested in this study were provided by four different Brazilian companies with intense activity in the market, and the resistant capacity of different typologies was analyzed. Thus 96 tests were made, 31 to determine the bending capacity and 64 for the determination of shear strength, and were selected slab models from the Brazilian market that are highly employed. From these tests, it was possible a better understanding of the prestressed hollow core slabs behavior produced in Brazil. With several analysis considering the experimental tests and an ample theoretical study about the design of these slabs, the adequacy of different codes equations were verified. Thus, it was possible to identify the equations that best represent the behavior of elements produced in Brazil, also considering the behaviour peculiarities of these slabs that have contrasting differences, if compared with units produced in other countries. From these studies it was produced a large design manual, considering the various types of studied slabs, aiming to contribute in a didactic way to the structural engineers. So, with this research, it was possible not only to improve comprehension of the behavior of such prestressed hollow core slabs, as well as provide information for evaluation of these elements, considering the specific characteristics of the slabs fabricated in Brazil and thus to contribute with the standardization of the design in the Brazilian code NBR 14861 (Prefabricated slab - Prestressed concrete hollow core panel). 



\section{LISTA DE SÍMBOLOS}

$a_{g} \quad$ - Tamanho máximo do agregado graúdo

$a_{v} \quad$ - Vão submetido a cisalhamento

$A_{c} \quad$ - Área total da seção transversal de concreto

$A_{c p} \quad$ - Área da seção transversal de concreto acima do ponto crítico

$A_{p} \quad$ - Área total da seção transversal de aço protendido

$A_{p s} \quad$ - Área da armadura protendida localizada no lado tracionado pela flexão

$A_{s} \quad$ - Área da armadura longitudinal tracionada pela flexão

$A_{s t} \quad$ - Área da armadurade tração prolongada de um comprimento $\geq\left(\mathrm{l}_{\mathrm{bd}}+\mathrm{d}\right)$ além da seção considerada

$A_{\text {Tот }}$ - Área total da seção transversal da unidade alveolar

b - Largura da unidade de laje

$b_{c} \quad$ - Largura dos alvéolos preenchidos, quando transformados em uma seção retangular equivalente

$b_{v} \quad$ - Largura da viga

$b_{\mathrm{w}} \quad$ - Soma das larguras das nervuras das unidades de lajes alveolares

$b^{\prime}{ }_{w} \quad$ - Soma das larguras das nervuras das unidades de lajes alveolares de seção composta com alvéolos preenchidos

$C_{R d, c}$ - Coeficiente igual a $0,18 / \gamma_{c}$

d - Altura útil da seção transversal do elemento de laje alveolar ou da viga

d' - Altura útil da seção transversal do elemento de laje alveolar de seção composta

$d_{p}$ - Distância da extremidade da fibra comprimida ao centro da armadura protendida, que deve ser maior que $0,8 \mathrm{~h}$ (in)

$d_{v} \quad$ - Altura de cisal hamento ou braço de alavanca à flexão, adotado igual a 0,9 d

e - Excentricidade dos cabos protendidos

$\mathrm{E}_{\mathrm{C}} \quad$ - Módulo de elasticidade do concreto moldado no local

$\mathrm{E}_{\mathrm{p}} \quad$ - Módulo de elasticidade do concreto pré-moldado

$f_{b p d} \quad$ - Resistência de aderência de cálculo entre armadura e concreto na ancoragem de armaduras ativas, pré-tracionadas

$\mathrm{F}_{\mathrm{c}} \quad$ - Força no concreto

$\mathrm{f}_{c}^{\prime}$ - Resistência cilíndrica do concreto à compressão (Psi) 
$f_{c d} \quad-$ Resistência de cálculo do concreto à compressão

$f_{c j} \quad$ - Resistência do concreto à compressão na data do ensaio

$f_{c k} \quad$ - Resistência característica do concreto à compressão

$f_{c t} \quad$ - Resistência do concreto à tração

$f_{c t d} \quad$ - Resistência de cálculo do concreto pré-moldado à tração

$f_{\text {ctf }} \quad$ - Resistência à tração na flexão

$f_{c t j} \quad$ - Resistência do concreto à tração na data do ensaio

$f_{c t k} \quad$ - Resistência característica do concreto à tração

$f_{c t k, \text { inf }}$ - Resistência característica inferior do concreto à tração

$\mathrm{f}_{\mathrm{ct}, \mathrm{m}}$ - Resistência média do concreto à tração

$f_{d}$ - Tensão devida à carga permanente, sem fator de segurança, na fibra extrema, onde a tensão de tração é causada pela aplicação de forças externas (Psi)

$\mathrm{F}_{\mathrm{p}} \quad$ - Força de protensão

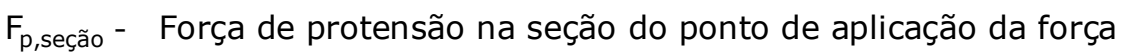

$f_{p c} \quad$ - Tensão resultante de compressão no concreto no centro da seção (Psi)

$f_{\mathrm{pe}}$ - Tensão de compressão no concreto devida ao efeito somente da força de protensão (após todas as perdas), na fibra extrema da seção, onde a tensão de tração é causada por forças aplicadas externamente (Psi)

$f_{\text {pyd }} \quad$ - Resistência de escoamento de cálculo do aço de protensão

$f_{\text {pyk }}$ - Resistência de escoamento característica do aço de protensão

$f_{\text {ptk }}$ - Resistência característica da armadura ativa à tração

$f_{p o}$ - Tensão no aço protendido quando é nula a deformação do concreto ao redor

$\mathrm{F}_{\mathrm{t}} \quad$ - Força na armadura

h - Altura total do elemento de laje

$\mathrm{h}_{\mathrm{c}} \quad$ - Altura dos alvéolos preenchidos quando transformados em uma seção retangular equivalente

$h_{c p} \quad$ - Distância entre o ponto crítico e a face inferior da unidade de laje

$\mathrm{H}_{\llcorner\mathrm{A}} \quad$ - Altura da laje

$\mathrm{H}_{\text {TOT }}$ - Altura total considerando laje e capa, quando houver

$I_{c} \quad$ - Momento de inércia da seção bruta de concreto

$I_{y} \quad$ - Momento de inércia da seção transversal

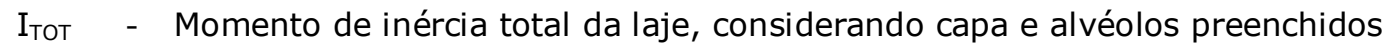

k - Coeficiente $\mathrm{k}=1,6-\mathrm{d} \geq 1$ ( $\mathrm{d}$ em metros) 
$k^{\prime} \quad$ - Coeficiente $k^{\prime}=1,6-d^{\prime} \geq 1$ (d em metros)

L $\quad$ - Comprimento da unidade de laje

$\ell_{\mathrm{bp}} \quad$ - Comprimento de ancoragem básico

$\ell_{\text {bpd }} \quad$ - Comprimento de ancoragem necessário

$\ell_{\text {bpt }} \quad$ - Comprimento de transferência

$\ell_{\mathrm{t}} \quad$ - Comprimento de transferência da força de protensão

M - Momento fletor

$M_{\text {cre }} \quad$ - Momento que causa a fissuração na seção devido às forças externas (Ib.in)

$M_{\text {máx }} \quad$ - Momento máximo de cálculo na seção devido às forças externas (Ib.in)

$M_{p} \quad$ - Momento devido a protensão

$M_{r} \quad$ - Momento de fissuração

$M_{R} \quad$ - Momento resistente

$M_{R d} \quad$ - Momento resistente de cálculo

$M_{R k} \quad$ - Momento resistente característico

$M_{u} \quad$ - Momento último

$M_{u, \exp }$ - Momento último, correspondente a $V_{u, \exp }$, obtido no ensaio (somando o momento correspondente ao peso próprio).

$M_{x d} \quad$ - Momento fletor atuante, na posição " $x$ "

$M_{y}\left(x_{c p}\right)$ - Momento fletor no ponto crítico

$M_{0} \quad$ - Momento de descompressão

n - Quantidade de alvéolos preenchidos quando transformados em uma seção retangular equivalente

$\mathrm{N} \quad$ - Força normal

$\mathrm{N}_{\mathrm{Ed}} \quad$ - Força normal na seção devida às ações aplicadas ou à protensão (em N)

$\mathrm{N}_{\mathrm{p}} \quad$ - Força normal de protensão

$\frac{\mathrm{dN}_{\mathrm{p}}}{\mathrm{dx}} \quad$ - Gradiente das forças nos cabos protendidos

$\mathrm{P}_{\infty} \quad$ - Força final de protensão, depois de todas as perdas

$\mathrm{S}_{\mathrm{cp}} \quad$ - Momento estático da área acima do ponto crítico

$s_{x} \quad-$ Espaçamento da fissura

$\mathrm{V} \quad$ - Força cortante

$\mathrm{V}_{\mathrm{ci}} \quad$ - Força cortante resistente nominal do concreto quando a fissuração diagonal resulta da combinação de momento e cisalhamento (lb) 
$V_{d} \quad$ - Força cortante na seção devida à carga permanente sem fator de segurança (Ib)

$\mathrm{V}_{\mathrm{i}} \quad$ - Força cortante de cálculo na seção, devida a forças externas, ocorrendo simultaneamente com $\mathrm{M}_{\text {máx }}(\mathrm{Ib})$

$V_{p} \quad$ - Componente vertical da força efetiva de protensão (Ib)

$\mathrm{V}_{\mathrm{R}} \quad$ - Força cortante resistente

$\mathrm{V}_{\mathrm{Rd}, \mathrm{c}}$ - Força cortante resistente de cálculo (em N)

$\mathrm{V}_{\mathrm{Rdf}}$ - Força cortante resistente em zona de flexão, para lajes sem capa e sem alvéolos preenchidos

$\mathrm{V}_{\text {Rdf }} \quad$ - Força cortante resistente em zona de flexão, para lajes sem capa estrutural e com preenchimento nos alvéolos

$\overline{\mathrm{V}_{\mathrm{Rdf}}} \quad$ - Força cortante resistente em zona de flexão, para lajes com capa estrutural

$\overline{\mathrm{V}_{\mathrm{Rdf}}^{\prime}}$ - Força cortante resistente em zona de flexão, para lajes com capa estrutural e com preenchimento nos alvéolos

$V_{R d 2} \quad-$ Força cortante resistente dada por $V_{R d 2}=1 / 2 v f_{c d} b_{w} 0.9 d$

$\mathrm{V}_{\mathrm{Rd} 2}^{\prime} \quad$ - Força cortante resistente dada por $\mathrm{V}_{\mathrm{Rd} 2}^{\prime}=1 / 2 v \mathrm{f}_{\mathrm{cd}} \mathrm{b}_{\mathrm{w}}{ }_{\mathrm{w}} 0.9 \mathrm{~d}^{\prime}$

$\mathrm{V}_{\mathrm{Rd}, \mathrm{SF}} \quad$ - Força cortante resistente na flexão, para seções fissuradas

$\mathrm{V}_{\mathrm{Rk}}$ - Força cortante resistente característica (valor final, sem coeficiente de ponderação)

$\mathrm{V}_{\mathrm{s}, \mathrm{máx}}$ - Força cortante máxima de serviço

$\mathrm{V}_{\mathrm{u}, \exp } \quad$ - Força cortante última obtida no ensaio (somando o peso próprio)

$V_{x d} \quad$ - Força cortante atuante, para seção fissurada por flexão, na posição " $x^{\prime \prime}$

$\mathrm{V}_{\mathrm{z}} \quad$ - Força cortante na posição z

x - Posição da linha neutra em relação à borda comprimida

$\mathrm{x}_{\mathrm{cp}} \quad$ - Coordenada do ponto crítico

W - Módulo de resistência da seção

z - Posição da tensão avaliada na seção transversal em relação ao eixo central

$\mathrm{z}_{\mathrm{cp}} \quad$ - Coordenada do ponto crítico

$y_{t} \quad$ - Distância do centro de gravidade à fibra mais tracionada

$\alpha$ - Coeficiente igual a 1,2 para seções " $T$ " ou duplo " $T$ " e 1,5 para seções retangulares

$\varepsilon_{\mathrm{c}} \quad$ - Deformação específica do concreto 
$\varepsilon_{\mathrm{cu}} \quad$ - Encurtamento último do concreto

$\varepsilon_{\mathrm{pt}} \quad$ - Deformação específica da armadura de protensão após todas as perdas

$\varepsilon_{s} \quad$ - Deformação específica do aço

$\varepsilon_{\mathrm{su}} \quad$ - Alongamento último da armadura

$\varepsilon_{\text {total }}$ - Deformação específica total da armadura de protensão no instante do colapso

$\varepsilon_{x} \quad$ - Deformação longitudinal na metade da altura do elemento, onde a tensão de cisalhamento é considerada $V /\left(b_{w} d_{v}\right)$

$\varepsilon_{7} \quad$ - Deformação específica da armadura de protensão devida à descompressão

$\phi \quad$ - Diâmetro da barra da armadura

$\phi_{\text {alv }}$ - Diâmetro dos alvéolos

$\gamma_{c}$ - Coeficiente de minoração da resitência do concreto

$\lambda$ - Coeficiente real de segurança

$\eta_{\mathrm{p} 1}$ - Coeficiente de aderência, igual a 1,0 para fios lisos, 1,2 para cordoal has de 3 e 7 fios e 1,4 para fios dentados

$\eta_{\mathrm{p} 2}$ - Coeficiente igual a 1,0 para situações de boa aderência e 0,7 para má aderência

$\rho_{1} \quad$ - Taxa de armadura da seção alveolar pré-moldada

$\rho_{1}^{\prime} \quad$ - Taxa de armadura da seção alveolar pré-moldada composta

$\sigma_{\mathrm{c}} \quad$ - Tensão no concreto

$\sigma_{\mathrm{cpm}}$ - Tensão de compressão do concreto devida à força de protensão

$\sigma_{\mathrm{p}} \quad$ - Tensão na armadura de protensão

$\sigma_{\mathrm{pi}}$ - Tensão na armadura ativa imediatamente após a aplicação da protensão

$\sigma_{\mathrm{x}} \quad$ - Tensão normal de tração

$\sigma_{1}$ - Tensão principal

$\tau_{t} \quad$ - Tensão de cisalhamento referente à transferência de força de protensão

$\tau_{\mathrm{xz}} \quad$ - Tensão de cisalhamento no plano $\mathrm{xz}$

$v$ - Tensão de cisalhamento 


\section{SUMÁRIO}

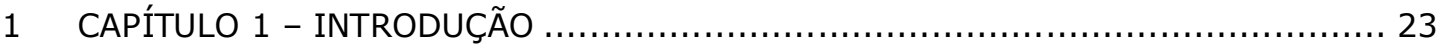

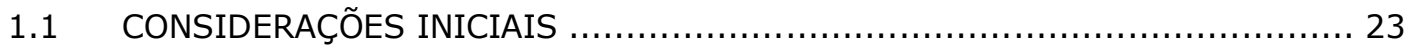

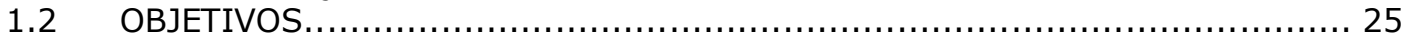

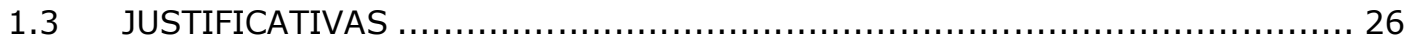

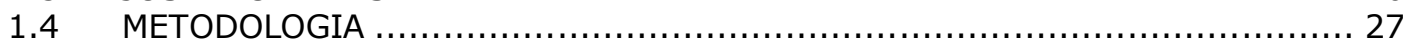

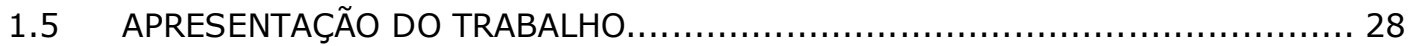

2 CAPÍTULO 2 - CARACTERÍSTICAS E APLICAÇÕES DAS LAJES ............................ 29

2.1 HISTÓRICO DAS LAJES ALVEOLARES PROTENDIDAS ............................ 29

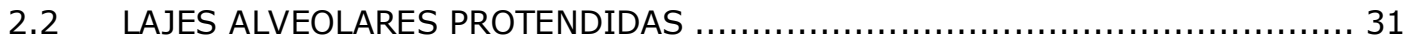

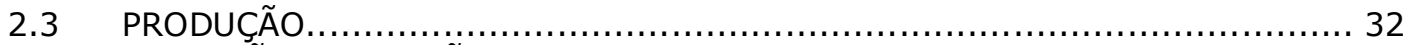

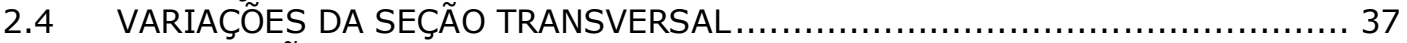

2.5 DISPOSIÇÕES CONSTRUTIVAS EM UNIDADES ALVEOLARES $\ldots \ldots \ldots \ldots \ldots \ldots \ldots . \ldots \ldots$

2.6 LAJES COM CAPA DE CONCRETO MOLDADO NO LOCAL ........................... 39

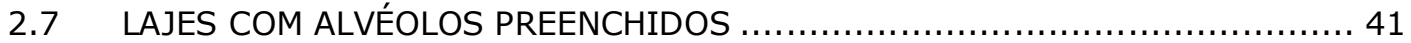

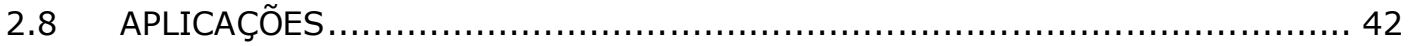

3 CAPÍTULO 3 - FUNDAMENTAÇÃO TEÓRICA.......................................... 45

3.1 COMPORTAMENTO DE LAJES SEM ARMADURA DE CISALHAMENTO $\ldots \ldots \ldots \ldots . . . . .46$

3.2 MECANISMOS DE FUNCIONAMENTO PRÓXIMO AO COLAPSO .....................49 49

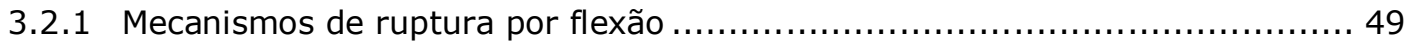

3.2.2 Mecanismos de ruptura por cisalhamento ....................................... 51

3.2.3 Mecanismos de ruptura em unidades alveolares com capa........................... 57

3.2.4 Desenvolvimento da fissura em ensaio típico ao cisalhamento.................. 57

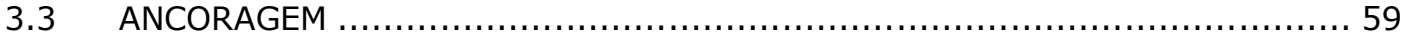

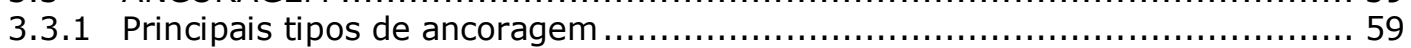

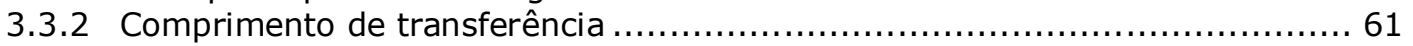

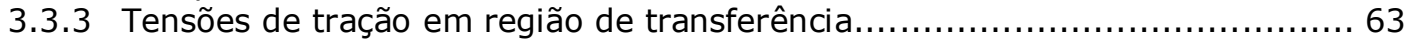

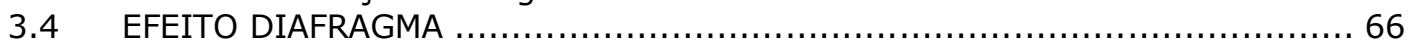

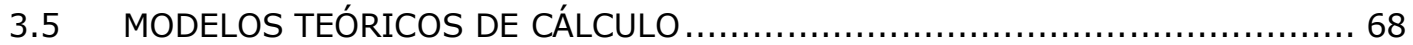

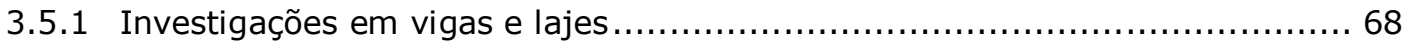

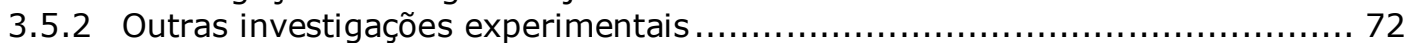

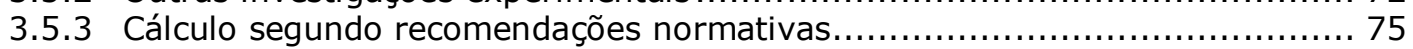

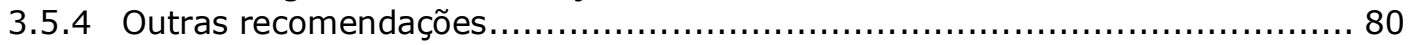

3.5.5 Críticas à equação recomendada para lajes sem capa .......................... 86

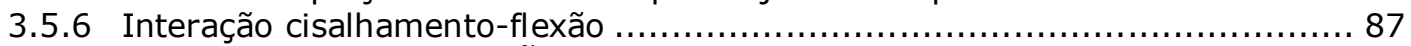

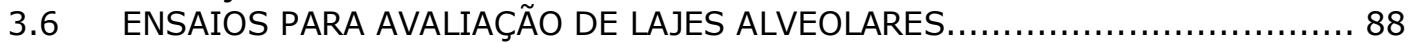

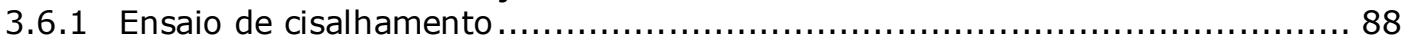

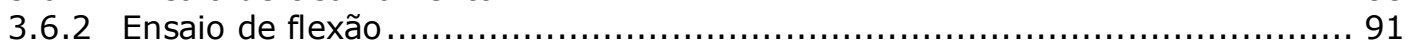

3.6.3 Ensaio com interação de cisalhamento e flexão ...................................... 92

4 CAPÍTULO 4 - PESQUISAS REALIZADAS ................................................ 93

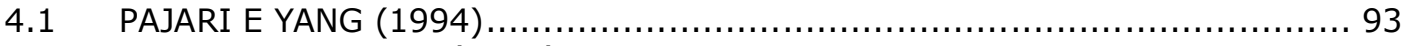

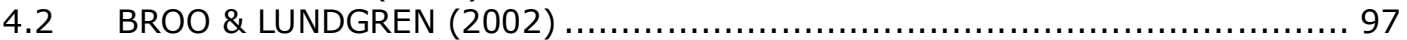

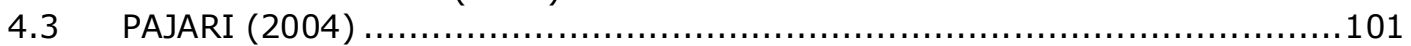

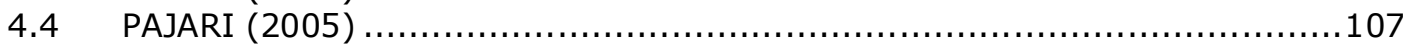

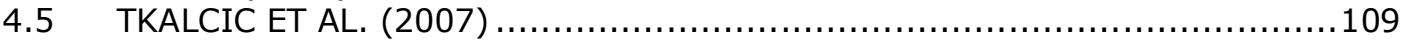

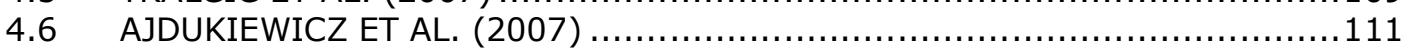




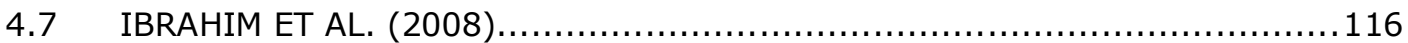

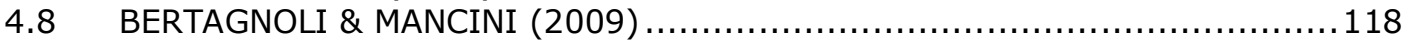

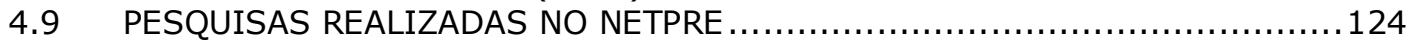

5 CAPÍTULO 5 - CARACTERÍSTICAS DOS ENSAIOS E DOS MODELOS ...................125

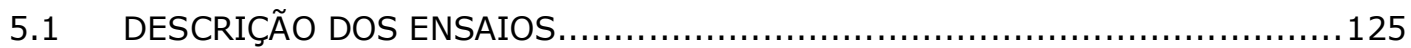

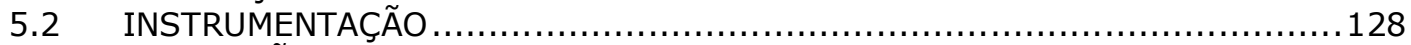

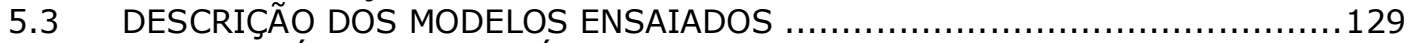

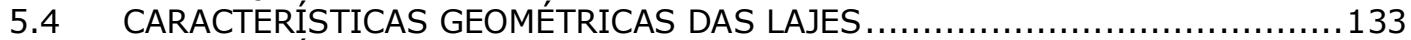

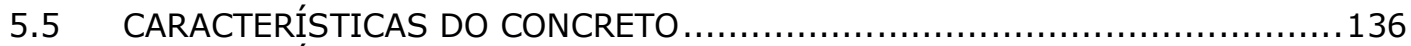

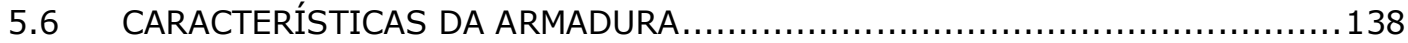

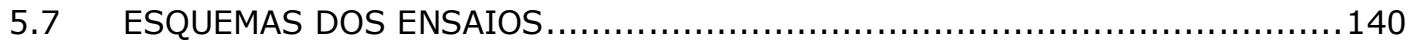

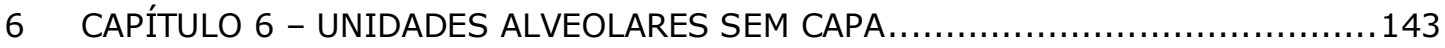

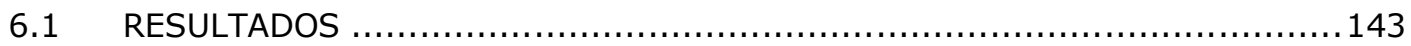

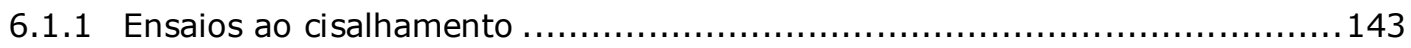

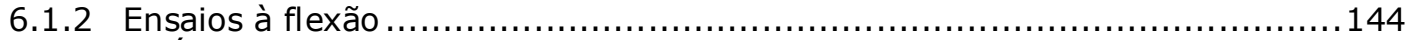

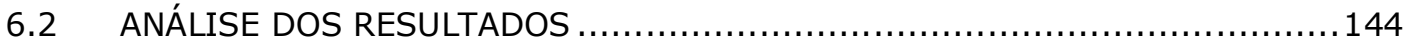

6.2.1 Análise dos ensaios de cisalhamento............................................ 144

6.2.2 Considerações sobre lajes sem capa ensaiadas ao cisalhamento.................159

6.2 .3 Análise dos ensaios de flexão...................................................... 163

6.2.4 Considerações sobre as unidades sem capa ensaiadas à flexão ......................166

6.2.5 Resistência do concreto à tração e módulo de elasticidade.........................167

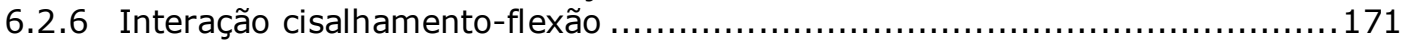

6.2.7 Correlações entre valores experimentais e teóricos..................................... 174

7 CAPÍTULO 7 - UNIDADES ALVEOLARES COM CAPA .................................. 179

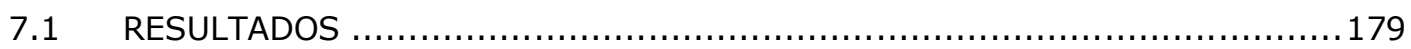

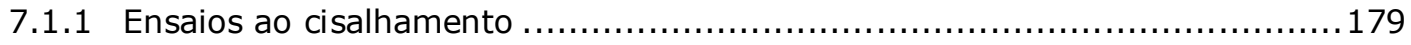

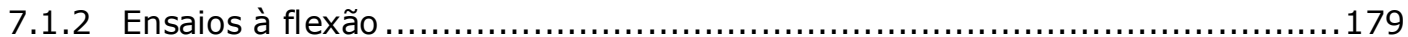

7.2 ANÁLISE DOS RESULTADOS ............................................................ 180

7.2.1 Análise dos ensaios de cisalhamento......................................... 180

7.2.2 Considerações sobre lajes com capa ensaiadas ao cisalhamento .................186

7.2 .3 Análise dos ensaios de flexão................................................... 187

7.2.4 Considerações sobre as lajes com capa ensaiadas à flexão ........................190

7.2.5 Correlações dos valores experimentais com os teóricos ...........................191

8 CAPÍTULO 8 - UNIDADES COM ALVÉOLOS PREENCHIDOS............................. 193

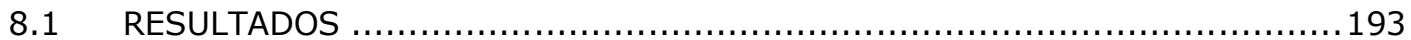

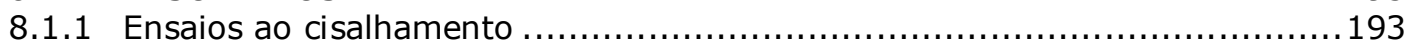

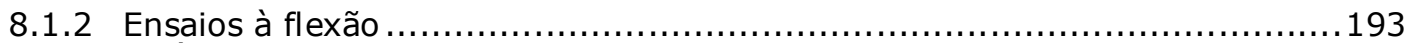

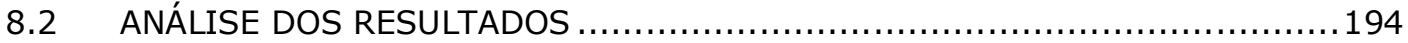

8.2.1 Análise dos ensaios de cisalhamento........................................... 194

8.2.2 Lajes com alvéolos preenchidos ensaiadas ao cisal hamento ......................200

8.2.3 Análise dos ensaios de flexão..................................................... 203

8.2.4 Lajes com alvéolos preenchidos ensaiadas à flexão...........................204

8.2.5 Variações no cálculo das unidades com alvéolos preenchidos ......................205

8.2.6 Correlações dos valores experimentais e teóricos ..................................210

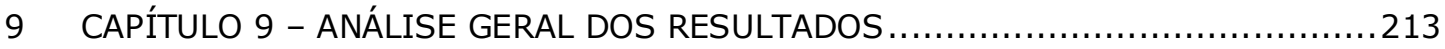

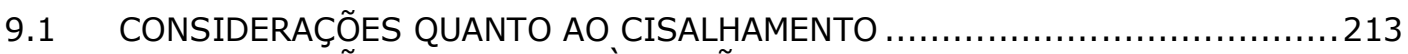

9.2 CONSIDERAÇÕES RELATIVAS À FLEXÃO .......................................... 215

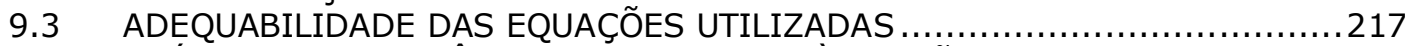

9.4 ANÁLISE DA RESISTÊNCIA DO CONCRETO À TRAÇÃO...........................219

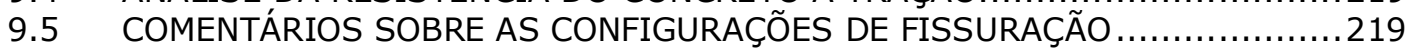




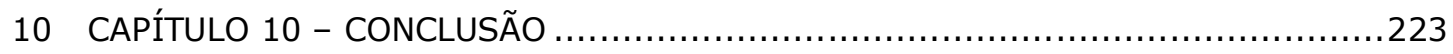

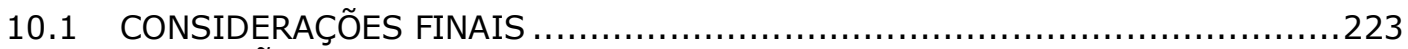

10.2 SUGESTÕES PARA TRABALHOS FUTUROS............................................. 229

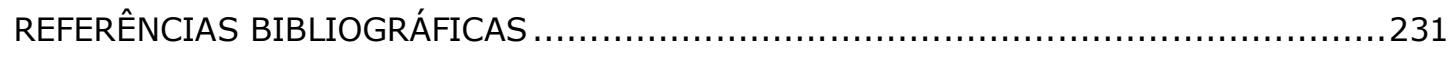

ANEXO A - DEFINIÇÕES E EQUAÇÕES RELATIVAS À ANCORAGEM .........................235

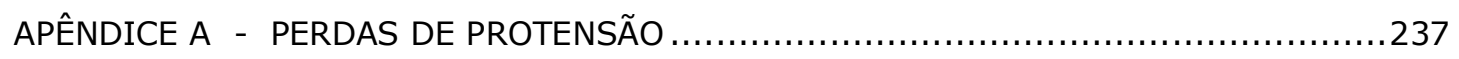

APÊNDICE B - FLEXÃO EM LAJES ALVEOLARES ........................................279

APÊNDICE C - CISALHAMENTO EM UNIDADES ALVEOLARES PROTENDIDAS ..............301

APÊNDICE D - RESULTADOS EXPERIMENTAIS ..........................................

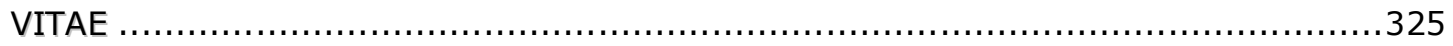




\subsection{CONSIDERAÇÕES INICIAIS}

A indústria de pré-fabricados busca atender as demandas da sociedade, oferecendo, com seus produtos: economia, eficiência, desempenho técnico, segurança e condições favoráveis de trabalho. A utilização das estruturas pré-fabricadas permite obter significativa eficiência estrutural, com o emprego de elementos mais esbeltos. Além disso, garante o uso otimizado dos materiais, com redução do desperdício de recursos. Assim, a utilização desse sistema torna possível a obtenção de edifícios com maiores áreas livres e vãos superiores aos convencionais, o que já pode ser observado nos vãos de lajes e de coberturas usuais do sistema.

O emprego de peças pré-fabricadas de concreto na construção civil representa um razoável progresso em termos construtivos, permitindo a racionalização e o aperfeiçoamento técnico das obras.

Os elementos pré-fabricados podem ser utilizados nos mais variados setores da construção civil, tais como: edificações industriais, comerciais e residenciais, construção pesada e infraestrutura urbana, rodoviária e ferroviária.

Os elementos para pisos estão entre os produtos pré-moldados mais antigos. As primeiras lajes alveolares foram desenvolvidas na década de 1950, quando evoluíram as técnicas de protensão em longas pistas. Por mais de 30 anos os tipos de unidades produzidas pouco mudaram. Nos Estados Unidos as peças típicas apresentavam uma espessura de $300 \mathrm{~mm}$. Houve um aumento de pesquisas realizadas na Europa na década de 1980, relacionadas com unidades de laje alveolar, que conduziram a um avanço tecnológico permitindo a produção econômica de unidades com espessuras maiores que $300 \mathrm{~mm}$. A produção desses tipos de lajes também se espalhou pelos Estados Unidos.

As lajes alveolares correspondem a um dos mais avançados tipos de unidades prémoldadas. Dezenas de milhões de metros quadrados de lajes são fabricadas todo ano ao redor do mundo, com o emprego predominante na América do Norte e na Europa Ocidental; sua tecnologia de fabricação é bem desenvolvida em países como Alemanha e Estados Unidos. 
Essas lajes alveolares possuem uma concepção arrojada, podendo ser usadas nos mais variados sistemas estruturais, funcionando como laje de piso ou como painéis de fechamento. Esse tipo de laje é mais utilizado em edificações, uma vez que a facilidade de manuseio, transporte, armazenagem e aplicação em grandes vãos reduzem a espessura média da estrutura, permitindo ganhos nas fundações, além de possuir capacidade de carga muito superior às das lajes convencionais de concreto armado de mesma espessura. Segundo a FIP (1992), as lajes alveolares protendidas podem suportar uma carga de utilização superior a $30 \mathrm{kN} / \mathrm{m}^{2}$, são geralmente empregadas para vencer vãos entre $4 \mathrm{~m}$ e $20 \mathrm{~m}$, com espessuras que variam de $100 \mathrm{~mm}$ a mais de 400 $\mathrm{mm}$, sendo a largura padrão de 1,2 m. Porém, larguras maiores ou menores também são utilizadas. Segundo Melo (2004), no mercado da construção civil, o sistema de pisos constituído por lajes alveolares corresponde àquele que obteve maior sucesso, devido ao fato de possuir fácil instalação e permitir o alcance de grandes vãos, o que facilita o layout e otimiza a estrutura, seja ela moldada in loco, metálica ou de elementos reticulados pré-fabricados.

O grande emprego das lajes alveolares protendidas é justificado por suas inúmeras vantagens, entre as quais se podem citar:

- Uma grande gama de aplicações, como pisos, coberturas e paredes;

- Baixos custos de produção;

- Processo de produção altamente mecanizado e automatizado;

- Forros falsos podem ser omitidos;

- Características vantajosas carga-vão, por causa do baixo peso próprio, decorrente do emprego de concreto de alta resistência e da alta taxa de protensão;

- Isolamento acústico.

De acordo com a FIP (1992), as lajes são geralmente usadas como pisos ou como unidades de cobertura. Os fundos das lajes podem ser entregues, pela fábrica, com isolamento térmico. Alguns produtores têm desenvolvido aplicações para vigas e painéis de parede alveolar, que podem ser ou de uma camada ou do tipo sanduíche, incluindo o isolamento térmico, sendo que cada uma dessas aplicações tem suas próprias exigências especiais de produção.

A fabricação das lajes alveolares protendidas pode ocorrer basicamente por dois métodos: moldagem com fôrmas deslizantes (concreto com elevado slump) e moldagem por extrusão (concreto com baixo slump), em longas pistas de concretagem, sendo este último tipo o mais utilizado. Além disso, o processo de produção na fábrica pode ser automatizado praticamente em todas as etapas, com uma montagem rápida no canteiro, sem a necessidade de fôrmas ou de escoramentos. 
Entretanto, para garantir a qualidade dos pavimentos com lajes alveolares, é necessário que haja o controle de todas as fases: projeto, fabricação, transporte e montagem. Para um adequado controle de qualidade das peças, devem ser considerados alguns fatores referentes às características das lajes alveolares e de sua produção, tais como:

- Lajes normalmente sem armadura transversal ou de cisalhamento;

- Projeto considerando altos valores da resistência do concreto à tração;

- Produção por extrusão em longas pistas, de até 150 m, com máquinas especiais;

- Mistura do concreto muito seca (para a extrusão) e, portanto, a água contida é crítica para a compactação do concreto e para a aderência dos cabos;

- Concreto lançado pela máquina é imediatamente auto-suportado.

Nesta pesquisa, estudam-se o comportamento e o desempenho mecânico dos elementos de lajes alveolares, principalmente quanto à interação dos mecanismos de cisalhamento e flexão, uma vez que existe a carência, na literatura técnica nacional, de tal análise. Para isso, empregam-se equacionamentos analíticos e um estudo experimental para sua validação. É importante ressaltar que são estudadas unidades com alvéolos de formato circular, resistência do concreto à compressão variando de $40 \mathrm{MPa} a$ $55 \mathrm{MPa}$, nível de protensão variando de $1140 \mathrm{MPa}$ a $1460 \mathrm{MPa}$, altura da laje entre $15 \mathrm{~cm}$ e $26 \mathrm{~cm}$, todas produzidas com equipamento europeu, pelo método da extrusão.

Assim, este trabalho justifica-se como uma contribuição para consolidação dos conhecimentos nacionais sobre os sistemas de pavimentos formados por lajes alveolares, visando o desenvolvimento de tecnologia nacional.

\subsection{OBJETIVOS}

O principal objetivo desta pesquisa é analisar o comportamento e o desempenho mecânico de lajes alveolares protendidas brasileiras - pequenas espessuras e alta protensão - quanto ao cisalhamento em região fissurada por flexão, considerando diferentes situações de projeto, com e sem capa, com e sem alvéolos parcialmente preenchidos, por meio da realização de ensaios experimentais e da análise dos mecanismos resistentes.

Além disso, pretende-se encontrar o equacionamento que melhor representa o comportamento das lajes alveolares de uso corrente no Brasil, tanto no que diz respeito aos valores teóricos previstos, quanto na identificação de fatores capazes de afetar o desempenho das unidades.

Os objetivos específicos são:

- Desenvolver o estado da arte, envolvendo os procedimentos para análise, o projeto e a produção de lajes alveolares protendidas; 
- Realizar um estudo teórico, com o emprego de equacionamentos existentes na literatura técnica, com o intuito de aprofundar o conhecimento quanto ao comportamento dessas lajes, uma vez que ainda não existe um modelo clássico que represente a interação dos mecanismos de cisalhamento e de flexão em lajes alveolares protendidas brasileiras, que apresentam características peculiares no processo produtivo;

- Comparar os estudos teóricos com resultados experimentais, obtidos em ensaios de lajes alveolares protendidas;

- Realizar 31 ensaios para a determinação da capacidade resistente à flexão e 65 ao cisalhamento. Sendo ensaiadas à flexão 11 peças sem capa, $14 \mathrm{com}$ capa e 6 com alvéolos parcialmente preenchidos, e ao cisalhamento, 30 peças sem capa, 17 com capa e 18 com alvéolos preenchidos.

Assim, diante de um vasto estudo experimental e teórico, foi possível aprofundar o entendimento relacionado a este tipo de elemento, o que permitiu a definição de critérios para sua avaliação compatíveis com suas características, contribuindo para a padronização de seu dimensionamento junto à norma brasileira NBR 14861 (Laje préfabricada - Painel alveolar de concreto protendido), além de fornecer diretrizes para projeto .

\subsection{JUSTIFICATIVAS}

Os novos desafios enfrentados pela Indústria da Construção Civil, principalmente no setor de edificações, podem ser resumidos pela necessidade de se conjugar a redução de custos com a elevação dos níveis de qualidade de processos e de produtos, com a adoção de procedimentos gerenciais mais eficientes e da racionalização das técnicas construtivas. A pesquisa sistemática e a difusão do conhecimento podem proporcionar o desenvolvimento tecnológico exigido pelo setor.

O estudo se justifica plenamente pelo crescente emprego no Brasil das estruturas pré-moldadas para edifícios de múltiplos pavimentos, sendo grande o emprego de elementos pré-moldados na composição de pisos.

O painel alveolar corresponde a um elemento pré-moldado extremamente versátil, que pode ser aplicado nos principais tipos de sistemas construtivos encontrados no país, seja em edificações de alvenaria, de concreto ou de metal. Entretanto, atualmente não existe uma sistematização de métodos analíticos para a determinação de procedimentos de projeto relacionados à interação de cisalhamento, flexão e torção, que correspondem a parâmetros essenciais para análise e melhoria do desempenho desses painéis. 
Dessa forma, esta pesquisa é justificada principalmente pela falta de padronização desses procedimentos técnicos no Brasil. Pretende-se realizar um estudo aprofundado do comportamento real das lajes alveolares, a fim de fornecer parâmetros para o projeto desse tipo de elemento.

A pesquisa ainda se justifica pelo interesse do meio técnico em empregar cada vez mais lajes alveolares no Brasil, inclusive em um momento em que a norma brasileira NBR 14861 (Laje pré-fabricada - Painel alveolar de concreto protendido) encontra-se em fase de revisão.

Diante disso, existe uma grande oportunidade, a partir de um programa de cooperação tecnológica universidade-empresa, em que diferentes indústrias de prémoldados, associadas à Associação Brasileira de Construção Industrializada de Concreto - ABCIC, disponibilizaram um grande número de lajes para serem ensaiadas pelo Núcleo de Estudo e Tecnologia em Pré-Moldados de Concreto - NETPRE. Com a parceria EESCUSP e UFSCar e a co-orientação desta pesquisa pelo coordenador do NETPRE, criou-se a proposta da elaboração de pesquisa de doutorado, com o objetivo da realização de uma análise mais aprofundada dos mecanismos resistentes e da comparação dos resultados experimentais com os dos modelos teóricos existentes na literatura técnica nacional e internacional.

\subsection{METODOLOGIA}

Para alcançar os objetivos propostos, foi importante realizar um levantamento bibliográfico com relação aos elementos de laje alveolar, a partir da utilização de diversos recursos: acervo da biblioteca central Escola de Engenharia de São Carlos - USP; acervo da biblioteca do Sistema Integrado de Bibliotecas - SIBI - USP; acesso à rede internet; colaboração de empresas de engenharia e de associações que possuem interesse na pesquisa e acesso à base de dados do NETPRE da Universidade Federal de São Carlos.

Além disso, foi importante realizar um estudo teórico, a partir de equacionamentos analíticos existentes na literatura técnica.

Também, foi possível desenvolver um estudo experimental dos elementos alveolares, com a realização de ensaios físicos no NETPRE, que, juntamente com algumas empresas fabricantes de lajes alveolares, possibilitaram a análise experimental de um número significativo desses elementos pré-fabricados de lajes alveolares protendidas.

Assim, com esses dados experimentais, foi possível a realização de comparações com os resultados teóricos desenvolvidos.

Com isso, puderam ser realizadas análises dos resultados dos ensaios por meio de gráficos, dos mecanismos resistentes na ruína, observados nos ensaios, e por comparações, tanto entre os valores experimentais como entre os obtidos com equacionamentos analíticos, expressos na revisão bibliográfica. 


\subsection{APRESENTAÇÃO DO TRABALHO}

O trabalho é composto por dez capítulos, sendo que no primeiro encontra-se a introdução.

No segundo capítulo são apresentadas as características e as aplicações das lajes alveolares, englobando o processo de produção, as disposições construtivas etc.

No terceiro se encontra a fundamentação teórica, sendo apresentadas as principais considerações sobre o comportamento das lajes alveolares, englobando a descrição dos mecanismos de funcionamento, da ancoragem etc.

No quarto capítulo encontram-se as principais pesquisas realizadas.

O quinto trata das características dos ensaios e dos modelos, com a descrição desses modelos e a caracterização dos respectivos materiais empregados.

No sexto capítulo são consideradas as unidades alveolares sem a presença de capa, sendo apresentados os resultados dos ensaios e suas respectivas análises.

O sétimo capítulo apresenta os resultados dos ensaios e respectivas análises, para as lajes com a presença de capa estrutural.

No oitavo encontram-se os resultados dos ensaios e as respectivas análises, para as lajes com a presença de alvéolos preenchidos.

O nono trata de uma análise geral dos resultados obtidos para os diversos tipos de unidades ensaiadas.

No décimo capítulo é apresentada a conclusão do trabalho e algumas sugestões para pesquisas futuras.

Em seguida são indicadas, em ordem alfabética, as referências bibliográficas, que incluem as obras consultadas durante o desenvolvimento deste trabalho.

No final, encontram-se os anexos e os apêndices.

No anexo $A$ encontram-se algumas definições e equações relativas à ancoragem.

Nos apêndices $A, B$ e $C$ são apresentados exemplos de cálculo, sendo referentes às perdas de protensão no apêndice $A$, à flexão nas unidades alveolares protendidas no apêndice $B$, e ao cisalhamento no apêndice $C$.

No apêndice $D$ são apresentados os gráficos dos resultados experimentais para todas as peças ensaiadas, tanto à flexão quanto ao cisalhamento. 


\section{Características e aplicações das lajes}

Lajes alveolares correspondem a um tipo especial de laje totalmente feitas de concreto, com alvéolos ocos longitudinais, de tamanho adequado para criar nervuras. Essas lajes podem conter armaduras ativas (protendidas) ou armaduras passivas, sendo as lajes protendidas as mais empregadas em todo mundo.

Como a laje alveolar não possui armadura transversal, a resistência ao cisalhamento depende inteiramente da resistência do concreto à tração. Por essa razão a qualidade do concreto deve ser constantemente controlada e certificada em todos os estágios da produção.

\subsection{HISTÓRICO DAS LAJES ALVEOLARES PROTENDIDAS}

De acordo com ASSAP (2002), em 1930 o alemão Wilhelm Schaefer, juntamente com um amigo de nome Kuen, lançaram as bases para a realização de algo muito semelhante ao que hoje se chama de laje alveolar.

Era uma laje estrutural isolada composta de uma camada alveolar de concreto pozolânico entre duas camadas de concreto armado normal.

Ao final dos anos 1940 e começo dos 1950, após anos de mudanças na linha de produção baseadas em tentativa e erro, a fábrica de Schaefer começou a ter algum sucesso. Licenças para produção foram vendidas a cinco companhias na Alemanha Oriental e Ocidental e uma nos Estados Unidos.

O mais importante dos produtores da Alemanha Ocidental, Buderus'sche Eisenwerke, foi o primeiro a introduzir protensão nas lajes alveolares em sua fábrica em Burgsolms, a qual ainda está em operação. Cálculos estáticos foram estudados pelo professor Friedrich da Universidade Técnica de Graz, na Áustria.

Logo em seguida, em torno de 1955, a camada de concreto pozolânico foi abandonada para permitir a produção de lajes alveolares de concreto monolítico, com vãos e capacidades menos limitadas pela baixa resistência da pozolana ao cisalhamento.

No mesmo ano, a companhia americana que havia comprado a fábrica de Schaefer introduziu a protensão e desenvolveu a tal ponto que também se tornou produtora de fábricas patenteadas com o nome de "Spancrete". 
Nessas fábricas, as lajes alveolares eram concretadas uma sobre as outras, separadas por uma simples folha de plástico. Quando a laje superior endurecia naturalmente, uma serra com disco diamantado era montada nessa pilha de lajes, sendo cada uma cortada e removida.

A fábrica, com as mesmas configurações encontradas hoje, com o emprego de uma máquina moldadora (slipform - fôrma deslizante) com vibração, em pistas de moldagem única, foi projetada em 1955 por Max Gessner de Lonchham, em Munique.

Em 1957 as empresas da Alemanha Ocidental, Max Roth Kg e Weiler Kg, compraram a patente de Gessner, e em 1961 começou a expansão gradual de lajes alveolares produzidas por máquinas moldadoras, em toda Europa e no mundo.

Em 1960 a companhia Spiroll no Canadá desenvolveu uma máquina original para a produção das lajes alveolares por meio de uma rosca giratória que expulsava o concreto, denominada extrusora. Com esse novo procedimento, concreto com baixa relação água/cimento era compactado e vibrado. Os alvéolos foram caracterizados por uma típica seção circular, completamente diferente da usual seção alongada, produzida com as máquinas moldadoras (fôrmas deslizantes). O processo de extrusão também foi recebido favoravelmente, especialmente no Norte da Europa e no bloco Soviético e, como é o caso em que há dois sistemas concorrentes, a corrida pela supremacia entre as fôrmas deslizantes (slipforms) e o sistema por extrusão gerou grandes benefícios ao desenvolvimento das lajes alveolares pré-fabricadas em todo o mundo.

A companhia italiana Nordimpianti System, a qual desde 1974 se especializou na construção de máquinas slipform, merece especial menção devido ao impulso que deu ao aumento das dimensões das lajes alveolares. Em 1987 a Nordimpianti ganhou admiração pela bem sucedida construção de maquinário para a produção de uma importante série de lajes alveolares com três alvéolos, tendo alturas de $50 \mathrm{~cm}, 60 \mathrm{~cm}, 70 \mathrm{~cm}$ e $80 \mathrm{~cm}$; as últimas três alturas são ainda hoje um recorde.

No Brasil, a tecnologia de produção das lajes alveolares passou a ser empregada na década de 1980 e teve a sua consolidação a partir de 2001, acompanhando o maior crescimento das estruturas pré-moldadas no Brasil.

O uso das lajes alveolares como soluções para pisos em construções mistas tem aumentado consideravelmente em todos os continentes, começando por Europa e EUA, indo até países asiáticos e africanos.

Atualmente a tecnologia de produção das lajes alveolares é bastante desenvolvida e consolidada. Apesar do alto custo inicial do maquinário, a produção é praticamente automatizada, com grande produtividade. Dessa forma, havendo demanda de mercado, esse tipo de produto apresenta-se bastante competitivo devido à racionalização de materiais, com redução considerável de concreto e de aço, e também pela grande economia nas fôrmas, ausência de escoramento e maior velocidade na montagem. 


\subsection{LAJES ALVEOLARES PROTENDIDAS}

As lajes alveolares são constituídas por painéis de concreto, na sua maioria protendidos, que possuem seção transversal de altura constante e alvéolos longitudinais (vazios na estrutura), os quais têm a finalidade principal de reduzir o peso próprio e diminuir a quantidade de concreto, em comparação com lajes maciças de mesma altura. Comparando com uma laje maciça, a porcentagem de vazios varia entre $30 \%$ e $50 \%$. As unidades de laje alveolar e suas diferentes partes podem ser observadas na Figura 2.1.

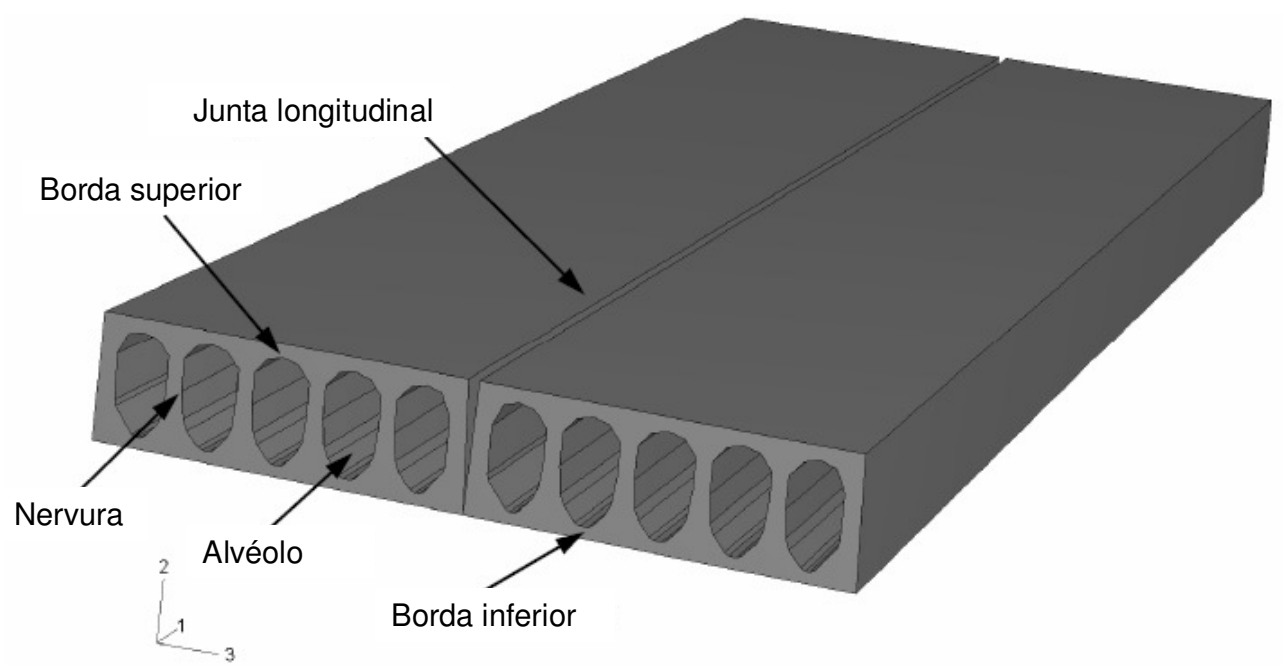

Figura 2.1: Unidades alveolares e suas diferentes partes. [Rettne \& Edekling (2006)]

A concepção hiperestática da estrutura é permitida pela execução do capeamento, que deve garantir o monolitismo da laje.

Os elementos de laje alveolar de concreto armado são utilizados em alguns países em construções habitacionais e possuem geralmente largura de $30 \mathrm{~cm}$ a $60 \mathrm{~cm}$. Já nos elementos de concreto protendido, as pistas de protensão são construídas com aço ou concreto, com largura de $120 \mathrm{~cm}$ e comprimento de $80 \mathrm{~m}$ a $150 \mathrm{~m}$. Os principais parâmetros de projeto são: o grau de protensão, o tipo de cordoalhas e a espessura dos elementos. Geralmente as lajes protendidas são utilizadas para vencer vãos que variam de $5 \mathrm{~m}$ a $15 \mathrm{~m}$ e possuem altura de $15 \mathrm{~cm}$ a $30 \mathrm{~cm}$, podendo atingir até $50 \mathrm{~cm}$.

Atualmente, tais lajes também estão sendo produzidas com alturas de $60 \mathrm{~cm}, 70 \mathrm{~cm}$ e até $80 \mathrm{~cm}$, mas por razões de segurança, com essas alturas, elas devem possuir estribos verticais nas nervuras e um mínimo de armadura na parte inferior, com tela soldada contínua.

As estruturas de piso devem possuir capacidade portante e rigidez, garantir a distribuição de forças transversais concentradas e das ações horizontais, por efeito de diafragma. Além disso, dependendo de seu uso, as lajes também devem possuir isolamento térmico e acústico, resistência ao fogo etc. 
Um critério muito importante no projeto das lajes alveolares protendidas está relacionado com a ruptura por tração devida ao cisalhamento. A determinação dessa resistência ao cisalhamento é muito difícil de ser realizada por meio da consideração teórica, embora o mecanismo de ruptura seja bem definido. Assim, foi estabelecido um método de ensaio padrão que permite a determinação da resistência ao cisalhamento, além de proporcionar a identificação de muitos parâmetros que influenciam na capacidade resistente da laje. Esse método é detalhado no item 3.6.1.

\subsection{PRODUÇÃO}

O sistema de lajes alveolares obteve um grande sucesso no mercado da construção civil devido às condições favoráveis de manuseio, transporte, armazenagem e aplicação em grandes vãos, facilitando o layout e a otimização, com redução da espessura média da estrutura e ganho nas fundações, além de possuir capacidade de carga muito superior à das lajes convencionais de concreto armado.

Quanto maior a padronização e a racionalização do projeto, maior é a eficiência estrutural das lajes, resultando em um menor custo. Por se tratar de um produto altamente industrializado, o número de horas-homem na produção é baixo; caso haja alguma intervenção manual, seu custo eleva-se consideravelmente, pois há uma diminuição da característica industrial-mecanizada.

Como já foi citado, há basicamente dois processos de fabricação das lajes alveolares: por fôrma deslizante ou por extrusão (mais utilizado). No processo por fôrma deslizante, as unidades de laje são produzidas a partir do deslizamento da fôrma, a fabricação ocorre em várias camadas de concreto, que é lançado e compactado pela máquina de produção em dois ou quatro estágios, e a compactação é realizada externamente por vibradores. Nesse caso emprega-se concreto com melhor trabalhabilidade, quando comparado com o da extrusão. A Figura 2.2 mostra uma máquina utilizada nesse processo produtivo.

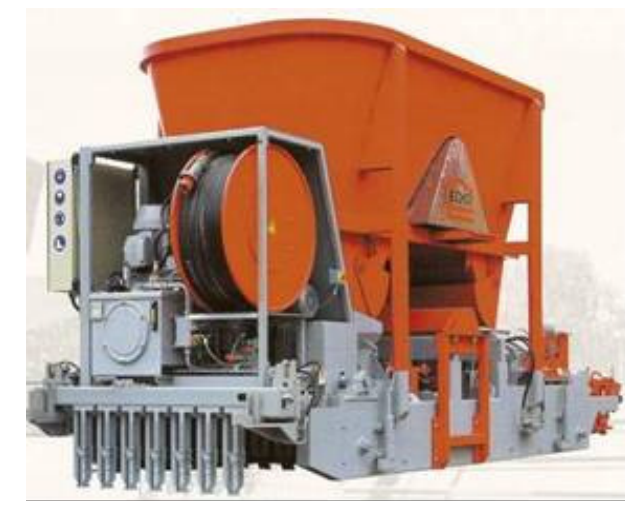

Figura 2. 2: Fôrma deslizante. [Elliott (2005)] 
O processo por extrusão permite a formação de um bloco único. Através de uma máquina extrusora, o concreto é expulso e comprimido nas paredes do molde, sendo utilizado um baixo fator água-cimento, próximo ao necessário para a hidratação do cimento, que garante elevada resistência à compressão e menor porosidade do concreto (Figura 2.3a). Os alvéolos são formados pela compactação do concreto por tubos helicoidais, como mostrado na Figura 2.3b. Nesse método há apenas um estágio de lançamento e de compactação do concreto.

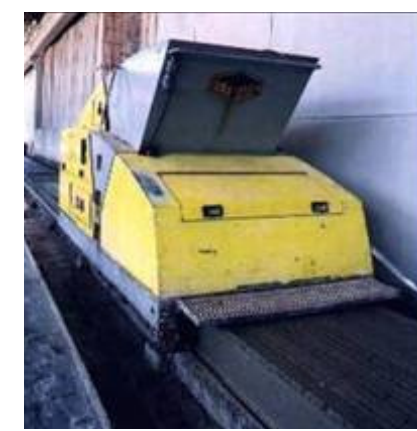

a)

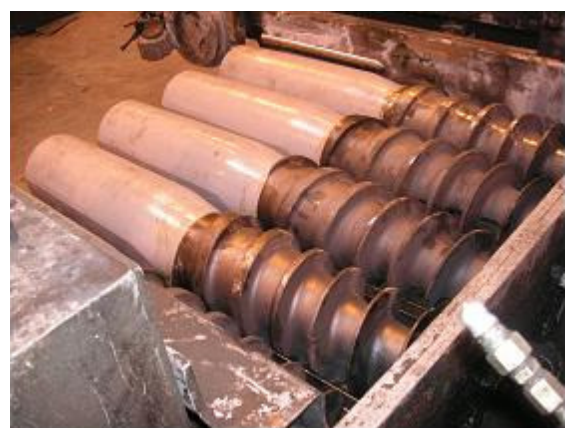

b)

Figura 2.3: a) Extrusora; b) Detalhe das hélices. [Rettne \& Edekling (2006)]

A Figura 2.4 mostra a moldagem do concreto em uma extrusora, em uma só etapa.

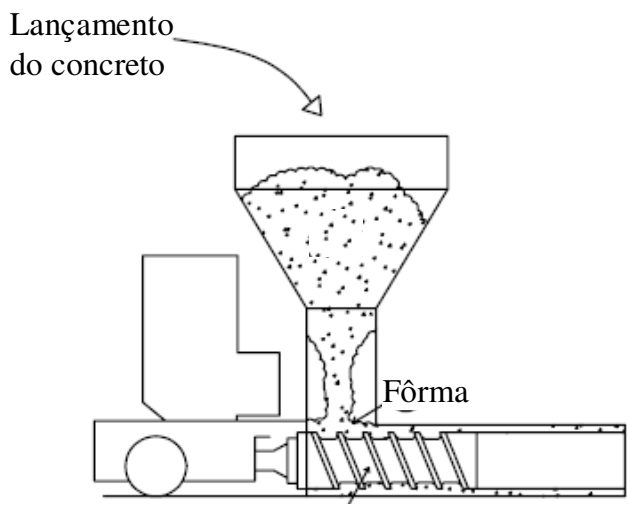

Hélices

Figura 2.4: Corte longitudinal da máquina extrusora [TKALČIĆ et al. (2007)]

Na Europa é empregado outro processo de produção, denominado "carrossel", no qual as pistas se movimentam e os equipamentos de concretagem ficam parados, evitando o transporte de concreto pela fábrica e criando um ambiente mais seco e limpo. Além disso, existe maior facilidade de transporte interno das peças e os serviços secundários são executados na própria pista de concretagem, como, por exemplo, a fixação dos suportes para içamento ou a realização de rasgos para inserir armaduras de continuidade. Assim, os elementos de laje fabricados com esse sistema se dirigem à expedição ou à área de estocagem sem a necessidade da realização de serviços adicionais, como perfuração, cortes parciais ou outros. 
Esse processo permite economia de espaço e racionalização do consumo de energia empregada durante a cura, que ocorre em área específica da fábrica. Também é empregada uma técnica para a reutilização da água utilizada na limpeza das pistas e dos equipamentos, com captação por canaletas laterais, o que garante economia do consumo de água no processo de produção. Um detalhe da pista de concretagem e do equipamento fixo pode ser observado na Figura 2.5. O sentido do movimento das pistas está indicado pelas setas.

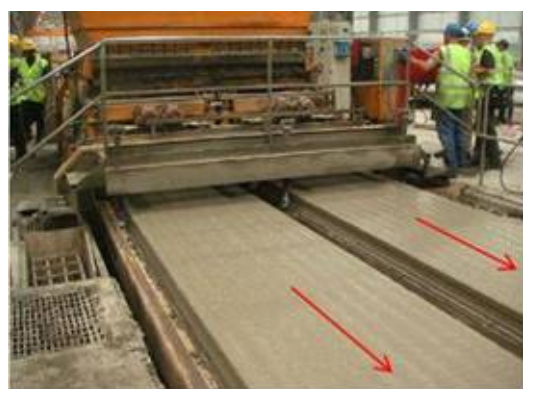

Figura 2.5: Sistema de fôrma tipo carrossel. [Elliott (2005)]

Por ser a extrusão o processo mais utilizado na fabricação das unidades de laje alveolar, a seguir são descritas as principais etapas desse tipo de produção.

- Inicialmente os cabos de protensão são dispostos sobre as pistas de concretagem e, posteriormente, protendidos com tensão previamente estipulada. Em seguida é realizada a ancoragem das cordoalhas em cabeceiras próprias para essa finalidade, localizadas na extremidade da pista. Essas etapas podem ser observadas na Figura 2.6.

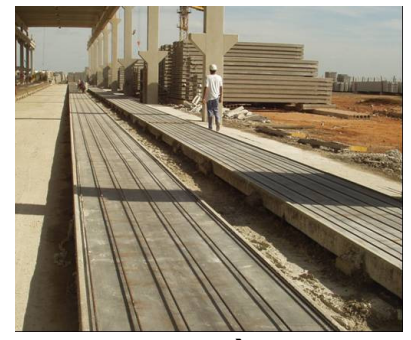

a)

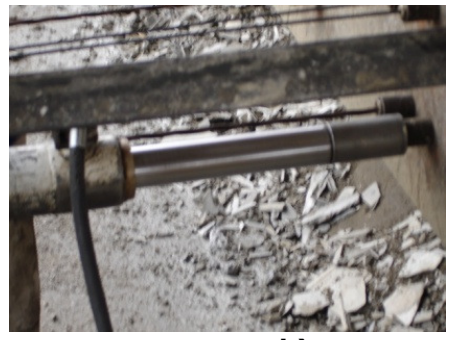

b)

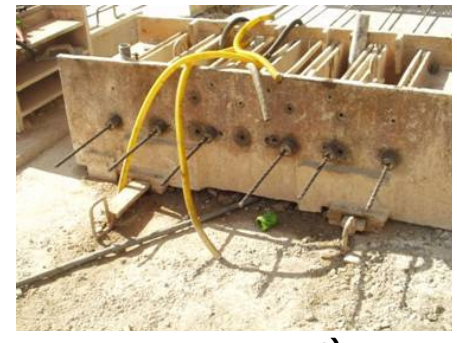

c)

Figura 2.6: a) Disposição dos cabos na pista; b) Protensão dos cabos; c) Ancoragem dos cabos.

- Após a protensão, o desmoldante é aplicado sobre a pista. Para evitar o contato dos cabos protendidos com o desmoldante, deve-se encapar cada cabo, à medida que esse desmoldante é colocado, sendo necessária especial atenção nesta etapa, que pode ser observada na Figura 2.7. 

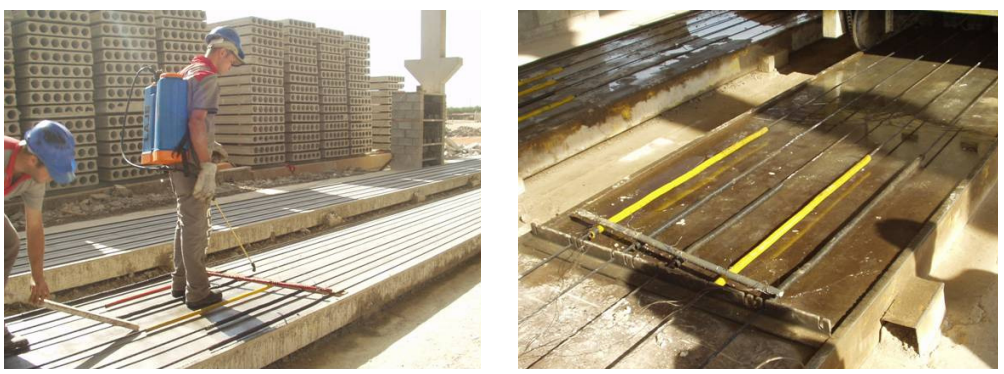

Figura 2.7: Proteção dos cabos e aplicação de desmoldante na pista de concretagem.

- À medida que o concreto é inserido na extrusora, ela expira o concreto na fôrma definitiva, moldando as lajes, como se observa na Figura 2.8 .
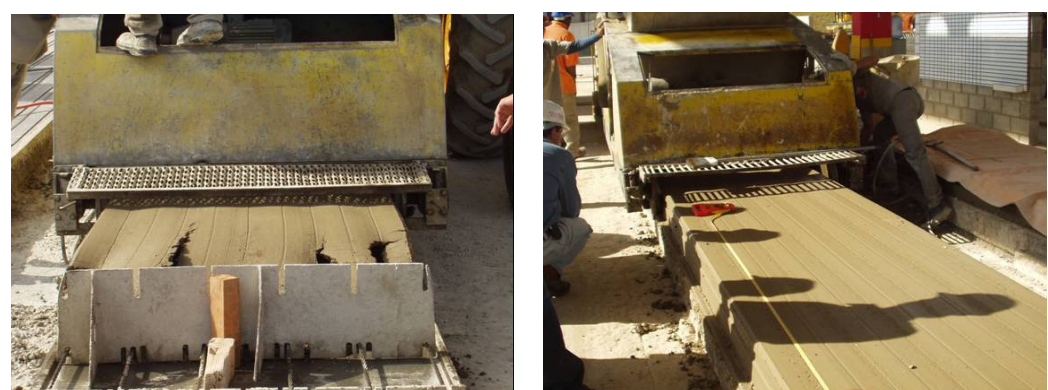

Figura 2.8: Moldagem das unidades alveolares.

- Após a concretagem na pista, a cura do concreto é feita com vapor d'água com temperatura controlada (Figura 2.9a). Quando o concreto adquire resistência suficiente, por exemplo $30 \mathrm{MPa}$, é feito o corte das lajes com uma serra de disco diamantado, de acordo com o especificado em projeto (Figura 2.9b). A partir desse instante, a protensão começa a atuar nos elementos.

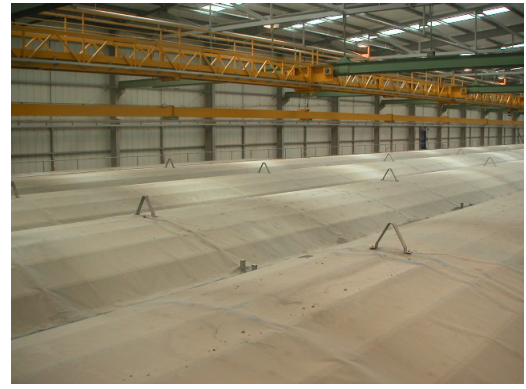

a)

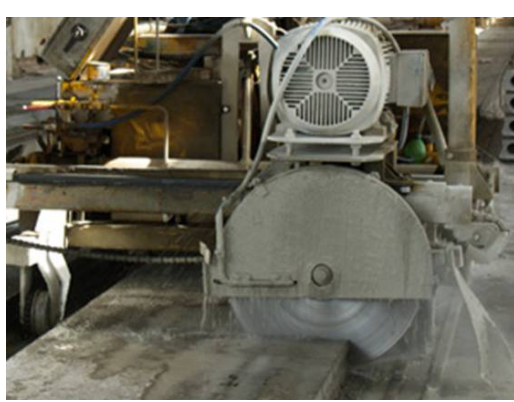

b)

Figura 2.9: a) Cura a vapor; b) Corte dos elementos de laje alveolar.

- Ao serem retiradas da pista, as lajes passam por inspeção final (cria-se uma ficha individual de cada peça) e são encaminhadas ao setor de estocagem ou diretamente carregadas nos caminhões para a entrega na obra. $\mathrm{O}$ transporte deve ser realizado por carretas específicas para essa finalidade. 
- A descarga das peças na obra deve ser feita, sempre que possível, diretamente no local de montagem. Quando elas forem temporiariamente estocadas na obra, devem ser armazenadas seguindo as recomendações de FIP (1992), conforme as seguintes restrições:

$\rightarrow$ Não devem ser apoiadas diretamente no solo, ou umas sobre as outras, mas em local plano, niveladas sobre dois apoios de madeira distantes de $200 \mathrm{~mm}$ a $400 \mathrm{~mm}$ das extremidades;

$\rightarrow$ Devem ser empilhadas com uma altura máxima de $3,5 \mathrm{~m}$ a $5 \mathrm{~m}$, dependendo do tipo de laje. Essa altura deve ser bem menor para lajes muito longas.

- A montagem é feita com equipamentos de içamento em que as lajes são transportadas e colocadas na posição de serviço. Após essa etapa, as lajes são niveladas e rejuntadas.

- Por serem executadas em pistas de concretagem, as lajes apresentam a superfície inferior lisa, eliminando a necessidade de revestimento. Já na face superior, o ideal é a superfície ser áspera, principalmente se houver a necessidade de capeamento. Neste caso é colocada na capa uma tela soldada para melhor distribuição das cargas.

Após a montagem, as lajes são equalizadas através de sistemas de torniquetes. A equalização começa com a colocação, na parte inferior da laje, de chapas de aço com cunhas de madeira, que são transpassadas por hastes verticais roscadas que ultrapassam a face superior. Na sequência, colocam-se os torniquetes de aço na face superior e também cunhas de madeira. Finalmente, apertam-se esses torniquetes até que a laje fique nivelada (Figura 2.10).
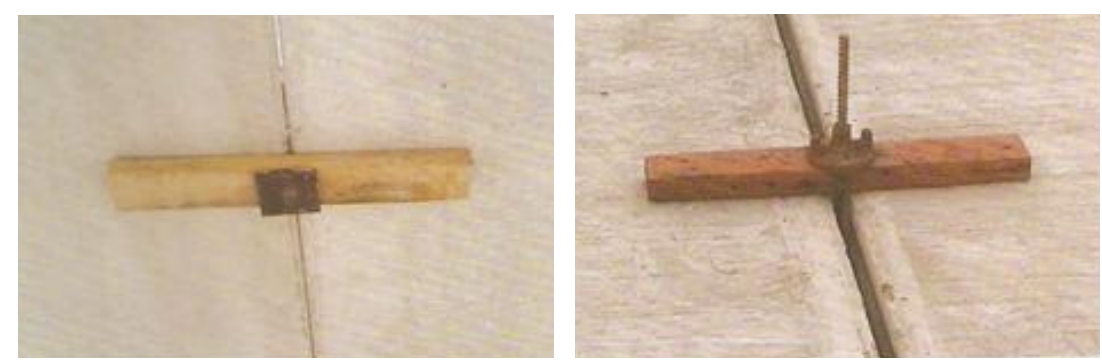

Figura 2.10: Detalhe de um torniquete. [Manual técnico de lajes alveolares - Cassol Pré-Fabricados]

A laje alveolar, quando protendida, apresenta uma contraflecha natural decorrente de suas características intrínsecas, que não pode ser determinada com exatidão, pois depende diretamente da cura realizada. 
Durante todo o ano, há variações naturais de temperatura e, principalmente, da umidade relativa do ar, que afetam o processo de cura e, portanto, influenciam na contraflecha. Dessa forma, quando é feito o alívio da protensão, sendo os esforços introduzidos na peça, as características climáticas durante o processo de cura proporcionam uma contraflecha específica e própria para cada unidade alveolar.

A capa de concreto deve ser locada a partir da contraflecha média do pano de várias lajes alveolares, depois de efetuada a equalização das peças. A partir desse ponto, deve ser adotada a espessura da capa, em geral de $5 \mathrm{~cm}$.

Em panos de lajes muito grandes, o efeito da retração e da variação térmica é significativo, sendo necessária a execução de juntas de indução de fissuras nas capas das lajes, evitando que a armação seja afetada.

O ciclo completo, compreendido por preparo da pista, concretagem, cura do concreto e liberação da laje para o transporte, é de aproximadamente 24 horas.

Vale ressaltar que a paginação das lajes, ou seja, a distribuição delas em planta, é um dos aspectos mais importantes do projeto, pois é a partir dessa paginação que se verifica a viabilidade econômica do sistema. Ligada à modulação, a distribuição das lajes deve ser estudada de forma racional, de modo a maximizar a repetição.

\subsection{VARIAÇÕES DA SEÇÃO TRANSVERSAL}

Existem muitas variações da seção transversal de unidades alveolares. Os alvéolos podem ter seção transversal de forma circular, oval, retangular etc. Essa forma será determinada pelo sistema de produção, isto é, o tipo de equipamento empregado para a fabricação das peças influenciará no formato dos alvéolos. Alguns exemplos de seções transversais estão indicados na Figura 2.11, na qual pode-se observar que os lados das seções transversais não são planos. Há entalhes nas laterais, próximas ao topo, as chamadas chaves de cisalhamento, e há saliências nas partes inferiores.

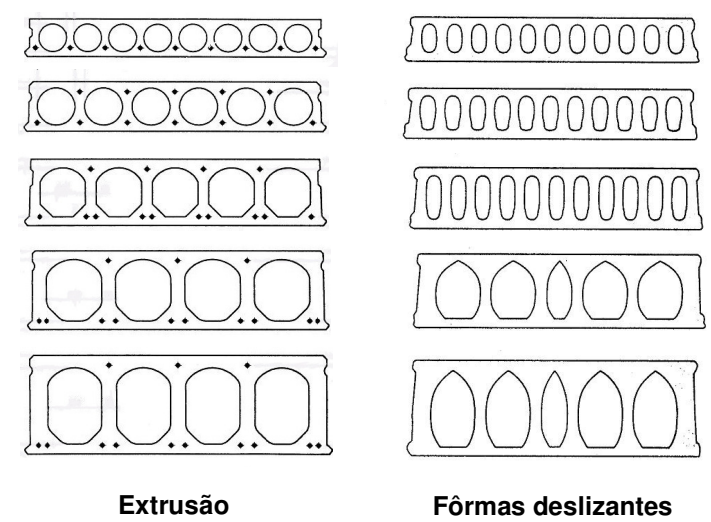

Figura 2.11: Exemplos de seções transversais dos elementos de laje alveolar. 
Quando as juntas entre as unidades alveolares de piso são grauteadas, as chaves de cisalhamento melhoram a interação das unidades, na direção transversal. As saliências na parte inferior fazem o graute permanecer na junta, durante a moldagem.

\subsection{DISPOSIÇÕES CONSTRUTIVAS EM UNIDADES ALVEOLARES}

De acordo com o Manual da FIB (2000), quando as unidades alveolares são unidas, a abertura da junta longitudinal deve possuir uma dimensão suficiente para garantir seu adequado preenchimento. O mínimo valor indicado corresponde a $30 \mathrm{~mm}$, e pode ser observado na Figura 2.12.

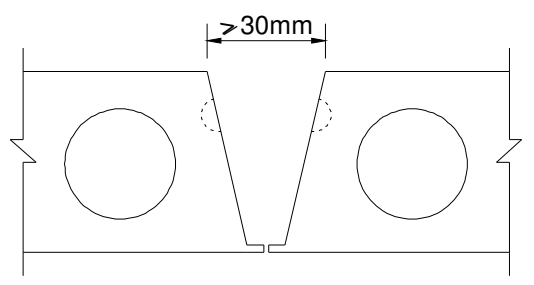

Figura 2.12: Abertura necessária ao adequado preenchimento da junta longitudinal. [Adaptado da FIB (2000)]

Para impedir a perda de graute utilizado no preenchimento, a parte inferior da junta longitudinal deve ser a mais fechada possível. Entretanto, se forem empregadas armaduras nessas juntas, é estabelecido um limite para a abertura, no nível do eixo da armadura, como pode ser observado na Figura 2.13.

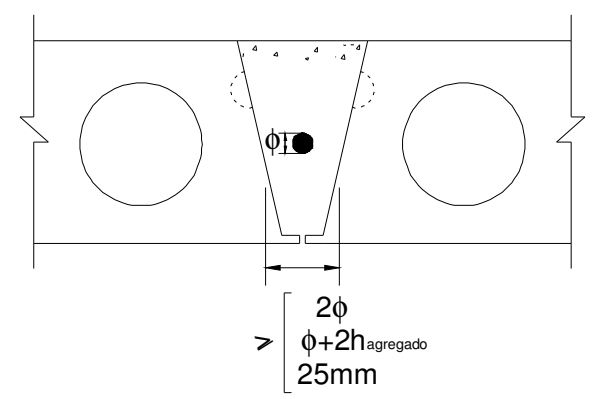

Figura 2.13: Espaço destinado à colocação de armadura. [Adaptado da FIB (2000)]

Também de acordo como Manual da FIB (2000), a chave de cisalhamento deve ter profundidade de pelo menos $10 \mathrm{~mm}$, com altura mínima de $40 \mathrm{~mm}$, como pode ser observado na Figura 2.14.

Ainda segundo o Manual da FIB (2000), as unidades alveolares devem ser posicionadas lado a lado, de tal modo que as aberturas entre as unidades não permitam que ocorra ruptura por tração, devida ao cisalhamento no concreto moldado no local, sem reforço. 

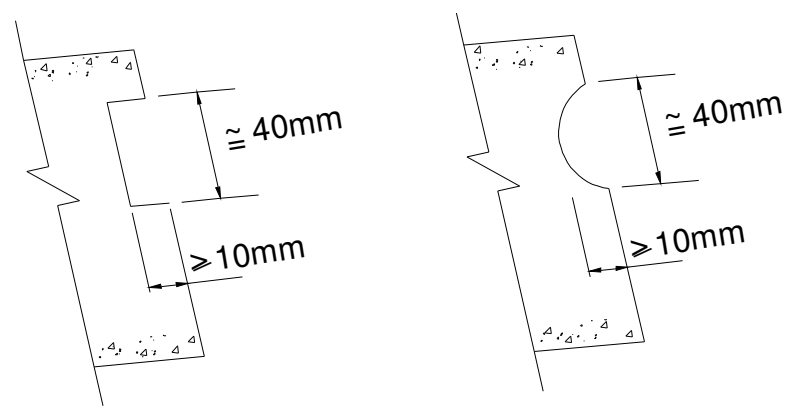

Figura 2.14: Chaves de cisalhamento. [Adaptado da FIB (2000)]

\subsection{LAJES COM CAPA DE CONCRETO MOLDADO NO LOCAL}

As lajes alveolares podem ser utilizadas com a presença de capa estrutural de concreto moldado in loco (Figura 2.15) com espessura mínima de $5 \mathrm{~cm}$, mas esta pode variar de acordo com a contraflecha da laje (Figura 2.16). Além de aumentar a resistência da laje ao cisalhamento, no caso de estruturas de piso, ela garante o nivelamento da superfície da laje e a correção da contraflecha causada pela protensão dos painéis alveolares.

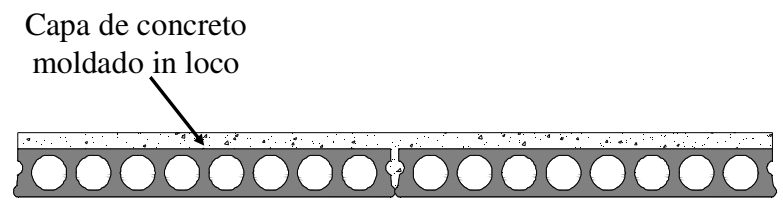

Figura 2.15: Emprego de capa estrutural de concreto moldado in loco.

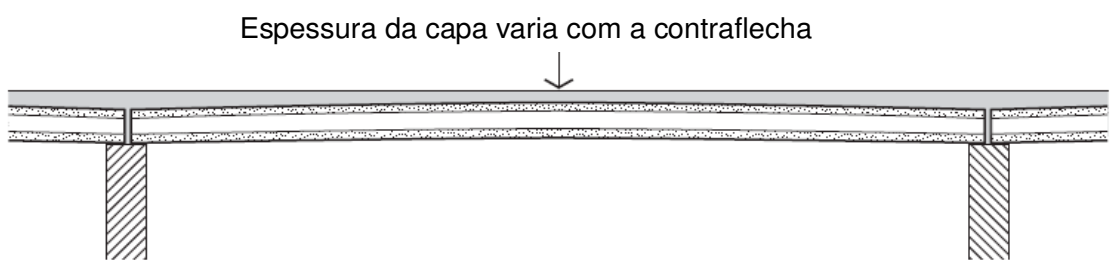

Figura 2.16: Variação da espessura da capa. [NPCAA (2003)]

Na Europa, como são empregadas peças com elevadas alturas, não existe a necessidade do emprego da capa em todas as situações de projeto. Além disso, a não consideração da capa também é possível devido ao emprego de ligações especiais entre as lajes e as vigas (Figura 2.17) e de melhores juntas longitudinais, com mecanismos desenvolvidos para garantir melhor transferência de cisalhamento (Figura 2.18).

No Brasil, como as lajes geralmente utilizadas são mais baixas, é usual o emprego de capa para conformação de pavimento composto, que fornece diversas vantangens, como: aumenta a capacidade portante do pavimento (melhorando tanto a resistência à flexão como ao cisalhamento), permite a continuidade entre os elementos estruturais e garante $o$ efeito diafragma. 


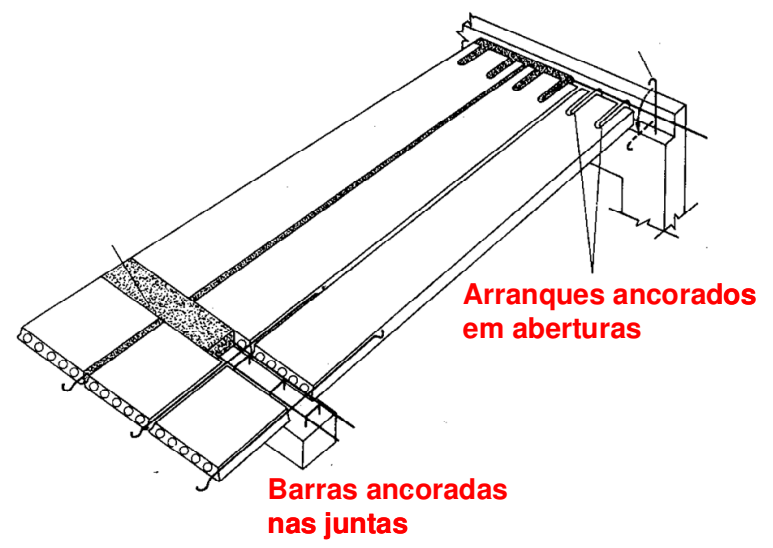

Figura 2.17: Ligações entre lajes e vigas, usadas na Europa. [Elliott (2005)]

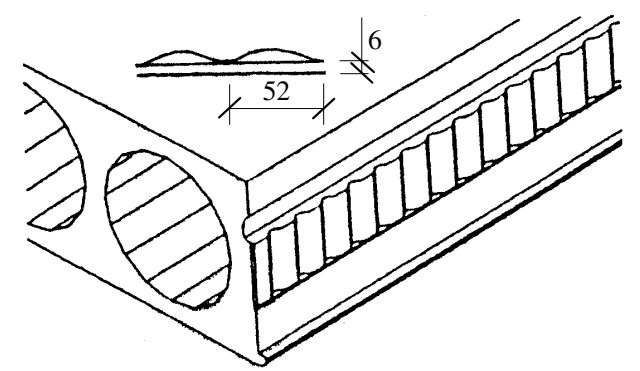

Figura 2.18: Junta longitudinal com mecanismo para transferência de esforços. [Elliott (2005)]

Assim, é de extrema importância que, quando considerada em projeto, a capa efetivamente funcione de forma solidarizada.

Entretanto, técnicas incorretas de construção e preparação das superfícies geram problemas para o comportamento global da estrutura, quando considerada de forma monolítica. O empreiteiro frequentemente ignora o efeito do teor de umidade, retração ou características da superfície da laje, durante a construção da capa de concreto.

A transferência de cisalhamento horizontal, na interface com a capa moldada no local, é um requisito essencial para assegurar a ação conjunta dos dois elementos.

Quando o concreto moldado no local é lançado em uma unidade pré-moldada, a segurança tem que ser garantida pela aderência e pela resistência ao cisalhamento entre as superfícies de contato.

De acordo com a FIP (1982), superfície lisa e limpa tem melhor aderência global do que superfícies rugosas empoeiradas e sujas, onde ocorrem rupturas localizadas da aderência.

Assim, para uma boa aderência é importante que a superfície superior da laje seja rugosa (Figura 2.19) e que os contaminantes sejam removidos, quer por jato de água, quer por limpeza a vácuo ou a ar comprimido. Limpeza com vassoura não é suficiente para eliminar a poeira localizada nas pequenas depressões da interface. 
Além da rugosidade, o tratamento da superfície desempenha um importante papel com relação à transferência da tensão de cisalhamento através da superfície, devido a:

a) Poeira, detritos, água, entre outros, são comumente encontrados nas cavidades da superfície, sendo difícil sua remoção;

b) Se a superfície do elemento pré-moldado, antes do lançamento, é muito seca, esse elemento absorverá água do concreto moldado no local, de modo que a qualidade adjacente à interface passa a ser governada pela capacidade da interface;

c) Se a superfície é muito úmida, ou seja, encharcada, a relação água-cimento na interface será muito elevada, resultando em fraca resistência de aderência.

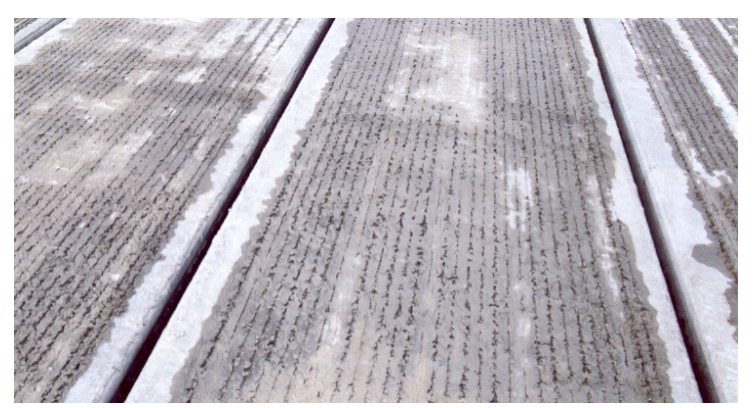

Figura 2.19: Superfície rugosa em lajes alveolares. [Elliott (2005)]

\subsection{LAJES COM ALVÉOLOS PREENCHIDOS}

No emprego de lajes alveolares, quando é necessário vencer vãos maiores ou suportar cargas mais elevadas, algumas alternativas são avaliadas para tal situação, tais como: a utilização de arranjos com maior número de cordoalhas; aumento da resistência do concreto, aumento da altura da laje e, ainda, pode-se realizar o preenchimento de alvéolos nas extremidades da peça pré-moldada.

O preenchimento dos alvéolos pode ser realizado com o intuito de melhorar a resistência da laje alveolar ao cisalhamento. Por meio de pesquisas realizadas junto a fabricantes de lajes alveolares, foi constatado que a adoção da prática de preenchimento de alvéolos é corrente e considerada como eficiente para até dois alvéolos.

Os alvéolos podem ser preenchidos na pista, juntamente com a moldagem das peças, ou na obra. Quando o preenchimento é realizado na pista, geralmente é empregado o mesmo concreto usado na fabricação dos elementos e esse procedimento é feito antes da liberação da protensão. Assim, nesse caso, a seção transversal composta, ou seja, laje juntamente com os alvéolos preenchidos, receberá o efeito da protensão quando da liberação dos cabos. Tal efeito afeta o cálculo desses elementos, como será visto no capítulo referente a alvéolos preenchidos (capítulo 9). Quando o preenchimento é realizado em obra, os concretos são diferentes, tanto na idade quanto na resistência e, nesse caso, a liberação da protensão é realizada quando a seção ainda é simples. 
Para o caso em que os alvéolos são preenchidos em obra, maiores cuidados são necessários para garantir boa aderência entre o concreto de preenchimento e o da laje.

Os procedimentos de corte das lajes com serra promovem o acúmulo de pó nas peças, que precisa ser retirado antes do preenchimento dos alvéolos, caso contrário comprometerá a aderência entre os concretos.

Além disso, como são empregados concretos com diferentes idades, para a laje e para os alvéolos, pode acontecer a perda de água do concreto de menor idade, devido a outra superfície estar muito seca, compromentendo a resistência de aderência entre esses dois concretos.

\subsection{APLICAÇÕES}

Até 1970 , as lajes alveolares foram usadas quase que exclusivamente com apoios simples. As pequenas alturas das lajes então produzidas $(12 \mathrm{~cm}, 15 \mathrm{~cm}, 20 \mathrm{~cm}$ e $25 \mathrm{~cm}$ ) não permitiam longos vãos ou grandes cargas.

Com o tempo, foi desenvolvido o conceito de seção composta, proporcionando maior eficiência tanto para a laje como para viga, o que conduziu ao crescimento das aplicações das unidades de laje alveolares em pisos e ao uso generalizado desses elementos em todos os tipos de construções.

Assim, as lajes alveolares protendidas pré-fabricadas passaram a representar uma das soluções estruturais mais avançadas para sistemas de piso, podendo ser utilizadas extensivamente em todo tipo de construção, não somente para estruturas pré-moldadas, mas também em combinação com outros materiais, como por exemplo: estruturas metálicas, de madeira, de concreto moldado no local etc.

Alguns exemplos de aplicações das unidades alveolares em diversos sistemas construtivos podem ser observados na Figura 2.20 e na Figura 2.21 .

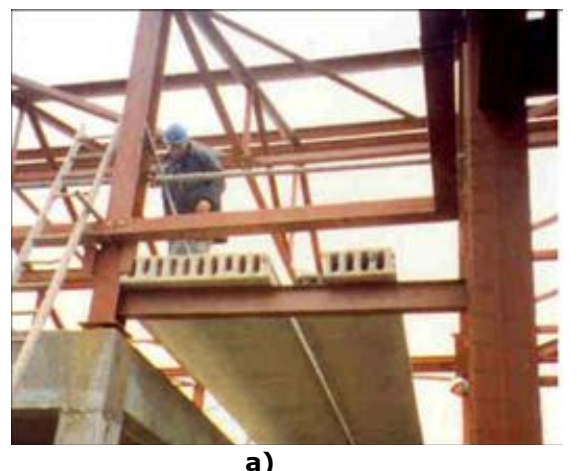

a)

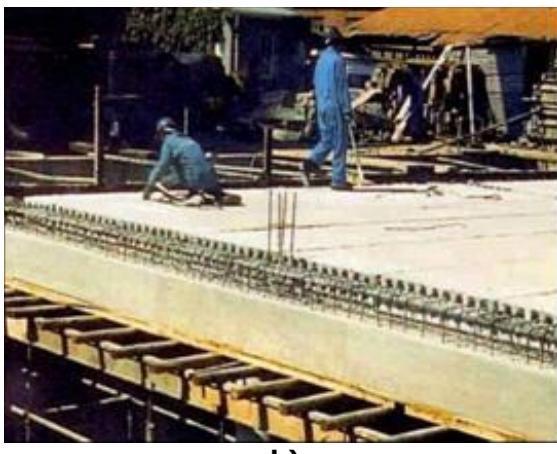

b)

Figura 2.20: a) Lajes alveolares sobre estrutura metálica (UK); b) Lajes alveolares sobre concreto moldado no local (África do Sul, 2001). [Elliott (2005)] 


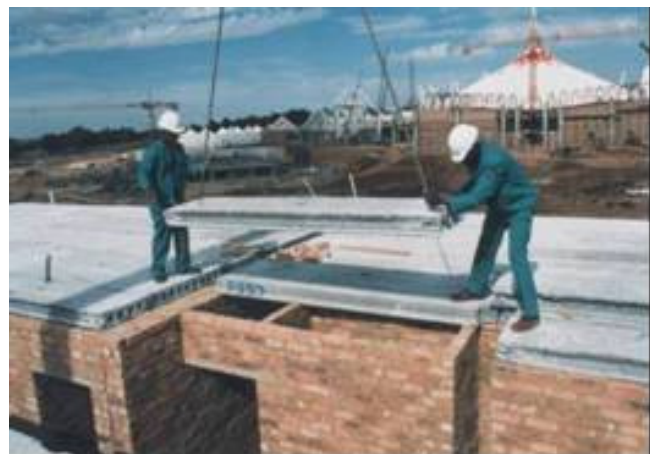

a)

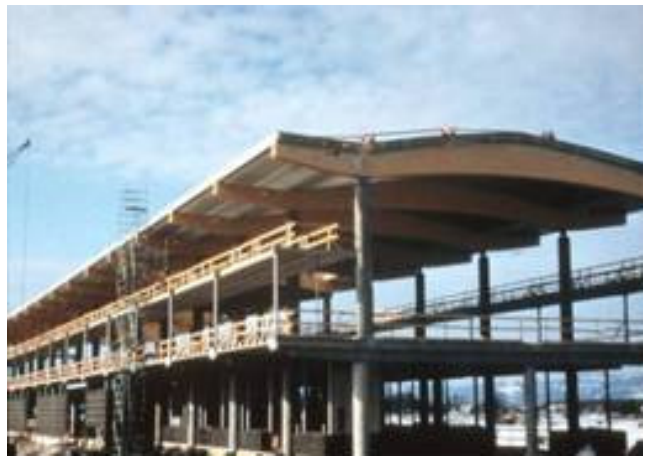

b)

Figura 2.21: a) Lajes alveolares sobre alvenaria estrutural (África do Sul, 2001);

b) Lajes alveolares sobre estrutura de madeira (Finlândia, 2005). [Elliott (2005)]

Atualmente, lajes alveolares de grandes alturas permitem a construção de pisos com vãos de até $20 \mathrm{~m}$ sob cargas industriais, não mais com apoio simples, mas com restrições de continuidade estrutural e mesmo extremidades engastadas.

Essas possíveis aplicações favoreceram a adoção de pisos de lajes alveolares na construção de obras subterrâneas, onde é de importâcia primordial a estrutura ser monolítica, como é o caso da construção da garagem subterrânea de um edifício de múltiplos pavimentos, indicada na Figura 2.22.

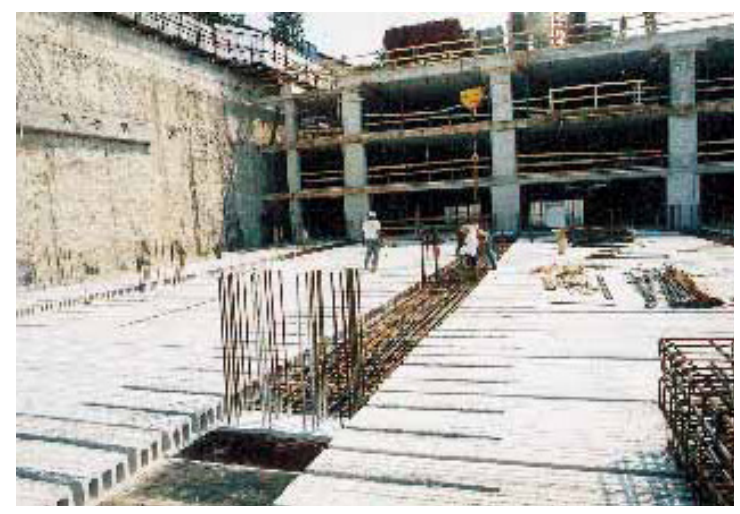

Figura 2.22: Pisos de lajes alveolares em uma garagem subterrânea de um edifício de múltiplos pavimentos. [ASSAP (2002)]

Além disso, a grande versatilidade das lajes alveolares permite que elas também sejam usadas não somente como pisos, mas também como paredes de tanques para tratamento de água (Figura 2.23a), como muros de arrimo e, eficientemente, como paredes externas e estruturais para construções de todos os tamanhos (Figura 2.23b).

Atualmente também está sendo produzido um tipo específico de laje alveolar, com três alvéolos, que é utilizado como arquibancada de estádios (Figura 2.24). 

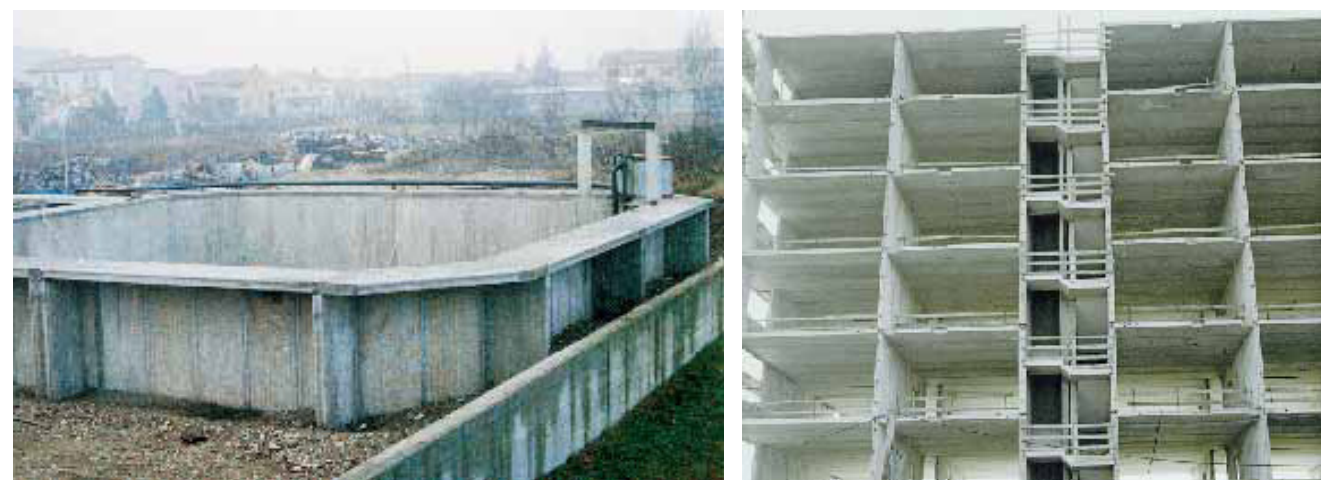

Figura 2.23: a) Paredes de lajes alveolares de um tanque de tratamento de água; b) Pisos e paredes estruturais alveolares em um edifício residencial de múltiplos pavimentos. [ASSAP (2002)]

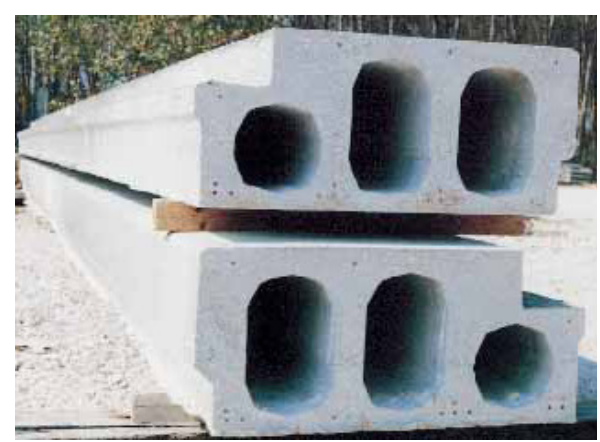

Figura 2. 24: Lajes com formato especial utilizadas em arquibancadas de estádios. [ASSAP (2002)]

De acordo com ASSAP (2002), inúmeros exemplos de edifícios com múltiplos pavimentos, vantajosamente erguidos com tais paredes estruturais, demonstram que todos os possíveis usos desse muito especial elemento pré-moldado ainda não foram totalmente explorados. Seu desenvolvimento em todo o mundo deve, portanto, ser considerado como ainda no início; o futuro certamente verá seu emprego em aplicações que ainda não foram concebidas. 


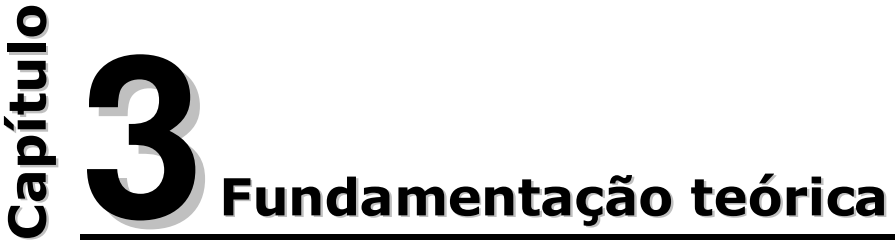

Na década de 1990 ocorreram diversas modificações, especialmente na área de tecnologia, causando grandes impactos e impulsionando o desenvolvimento de vários setores da economia, inclusive o da construção civil. Com isso, as empresas construtoras passaram a adotar novas tecnologias, com o intuito de diminuir custos, aumentar os níveis de industrialização dos processos de produção e a qualidade do produto final.

A utilização de elementos pré-fabricados nas edificações corresponde a uma dessas novas tecnologias, pois a pré-fabricação é considerada como um instrumento capaz de incrementar os níveis de industrialização dos processos construtivos.

O emprego de elementos pré-fabricados nas construções começou realmente a ter importância, tanto econômica quanto tecnológica, a partir da Segunda Guerra Mundial. As primeiras construções que utilizaram grandes elementos pré-fabricados de concreto armado surgiram na Europa, e a necessidade de se construir em grande escala levou à utilização intensiva do pré-fabricado. Tanto os EUA quanto o Canadá e o Brasil foram influenciados pela cultura europeia da pré-fabricação.

No Brasil, assim como nos EUA e no Canadá, não ocorreu uma crise aguda de falta de edificações em grande escala, como houve na Europa após a Segunda Guerra Mundial, mas a preocupação com a racionalização e a "industrialização" de processos cosntrutivos surgiu no final da década de 1950.

Segundo a Associação Brasileira da Construção Industrializada - ABCI (1989), não existiu no Brasil uma política de desenvolvimento tecnológico para o setor da construção industrializada. A utilização de elementos pré-fabricados, até o início da década de 1990, foi decorrente do arrojo dos empresários que, interessados no avanço da industrialização, buscavam redução de custos e maior velocidade na execução dos seus empreendimentos. Por isso, até os dias de hoje, a utilização de processos construtivos com pré-fabricados, tanto de elementos estruturais como de painéis de fechamento, é mais expressivo nas construções industriais, comerciais e empreendimentos hoteleiros.

Atualmente, as lajes alveolares estão situadas entre os elementos pré-moldados mais utilizados no mundo, principalmente na Europa Ocidental e na América do Norte, cuja técnica de execução é bem desenvolvida. 


\subsection{COMPORTAMENTO DE LAJES SEM ARMADURA DE CISALHAMENTO}

As unidades de lajes alveolares são normalmente constituídas por cordoalhas protendidas, posicionadas em uma ou mais camadas na região inferior das nervuras, e em alguns casos também podem ser inseridas cordoalhas na região superior.

Normalmente não há armaduras de cisalhamento, e isso deve ser levado em consideração no cálculo das peças.

De acordo com Lindström (2007), a força de protensão é introduzida por aderência e o valor de cálculo do comprimento de transferência depende do nível de protensão e do tipo das cordoalhas usadas.

Para uma laje fissurada por flexão, a capacidade resistente da ancoragem das cordoalhas é essencial.

Em uma situação geral de projeto, a resistência ao cisalhamento, para os relevantes modos de ruptura (por flexão e cisalhamento e por tração devida ao cisalhamento), precisa ser avaliada ao longo do vão da laje alveolar, em cada localização, e comparada com valores de cálculo das forças na seção.

Se uma região próxima ao apoio está fissurada pela flexão, é essencial checar a capacidade de ancoragem para a força real da cordoalha.

De acordo com Fusco (2008), nas lajes sem armadura de cisalhamento, a fissuração por flexão pode ocorrer sem a inviabilização da integridade da peça, pois tal fissuração possui menor concentração quando comparada com a das vigas. A ruptura da peça somente ocorre com o surgimento da chamada fissura crítica, que corresponde à primeira fissura inclinada, característica da ruptura por força cortante.

Conforme Fusco (2008), a segurança em relação a estados limites últimos de forças cortantes em peças maciças de concreto sem armadura de cisalhamento é garantida por diferentes mecanismos resistentes. Dois modelos do funcionamento da região de concreto situada entre duas fissuras adjacentes podem justificar a resistência ao cisalhamento de peças fissuradas por flexão. Tais modelos são denominados: modelo de cooperação máxima da zona fissurada (em que é admitida a cooperação máxima do concreto entre fissuras) e modelo de cooperação mínima da zona fissurada (em que é admitida a cooperação mínima do concreto entre fissuras). Os modelos podem ser observados na Figura 3.1.

Ainda segundo Fusco (2008), admite-se, no modelo de cooperação máxima da zona fissurada, que três diferentes mecanismos resistentes alternativos são responsáveis pela transmissão da força cortante ao longo do elemento, sendo que cada mecanismo contribui com a transmissão de uma parcela da força cortante total. Assim, a força cortante é transmitida por meio do banzo comprimido (parcela $V_{1}$ ), engrenamento dos agregados (parcela $V_{2}$ ) e efeito de pino da armadura (parcela $V_{3}$ ). 
A parcela $V_{2}$ é transmitida por meio da fissura de flexão, pelo engrenamento existente entre os grãos do agregado graúdo, e retransmitida adiante por tensões de tração na alma da peça. $A$ parcela $V_{3}$ é transmitida por meio da fissura de flexão, pela armadura de flexão, que se comporta como um pino de ligação entre as duas faces da fissura, sendo retransmitida adiante por tração no trecho da alma entre duas fissuras adjacentes.
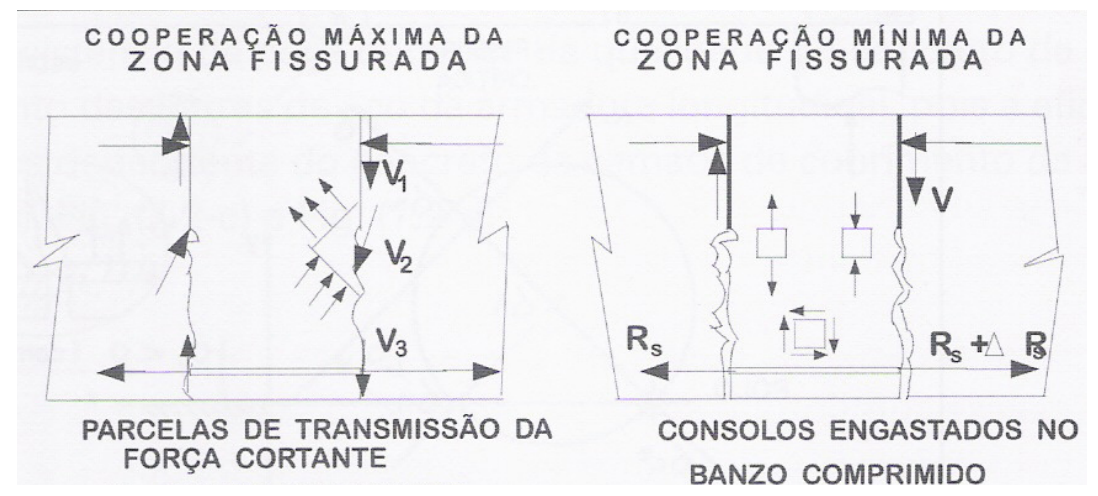

Figura 3.1: Modelos do funcionamento da região de concreto situada entre duas fissuras adjacentes. [Fusco (2008)]

Considerando o segundo modelo (modelo de cooperação mínima da zona fissurada), admite-se a transmissão integral da força cortante pelo banzo comprimido da peça, e que os trechos da alma entre duas fissuras adjacentes tenham o comportamento de consolos engastados no banzo comprimido, que permitem a variação da força de tração na armadura de flexão ao longo do comprimento desses trechos.

Esse modelo admite que o mecanismo de viga continue a existir até a ruptura da peça, após a formação da fissura crítica, sendo que a resistência à força cortante seria garantida pela resultante das tensões no banzo comprimido da peça (cuja componente transversal equilibra a força cortante).

No caso do modelo de cooperação máxima do concreto, admite-se que ocorra uma alteração do mecanismo de funcionamento da peça fletida, a partir do mecanismo de viga, para um comportamento global análogo ao mecanismo de treliça, em que as tensões diagonais de tração permitem a resistência da peça, como pode ser observado na Figura 3.2.

Fissuras com superfícies bastante irregulares contribuem para que ocorra a alteração do mecanismo resistente ao cisalhamento, pois permitem, ao longo delas, a transmissão de forças por meio do engrenamento dos grãos do agregado graúdo. Tal engrenamento permite a transmissão de forças oblíquas através das fissuras. 


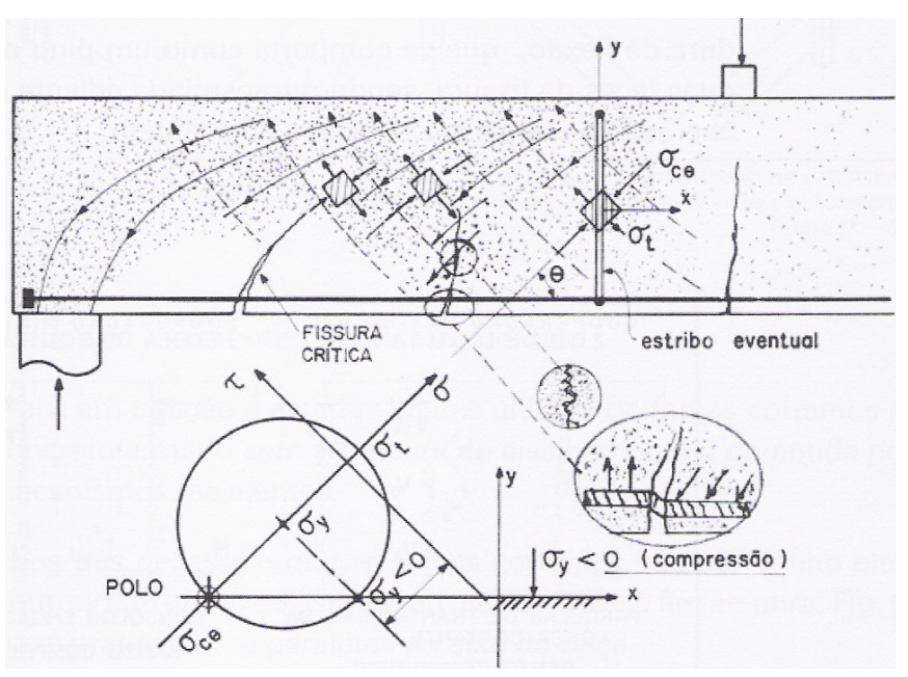

Figura 3. 2: Resistência ao cisalhamento em peças fissuradas. [Fusco (2008)]

De forma análoga, a maior rigidez do aço em relação ao concreto fornece às barras da armadura longitudinal a capacidade de funcionarem como pinos de ligação, que possibilitam a solidarização dos dois trechos da peça separados pelas fissuras, aumentando a região do concreto que colabora na transmissão da força cortante. A contribuição do efeito de pino à resistência da peça depende da qualidade do concreto da região de envolvimento das barras de aço da armadura longitudinal (Figura 3.3).

Com o aumento da força cortante, as tensões diagonais de tração chegam à ruptura do concreto, surgindo a fissura crítica, e consequentemente a ruptura final da peça.

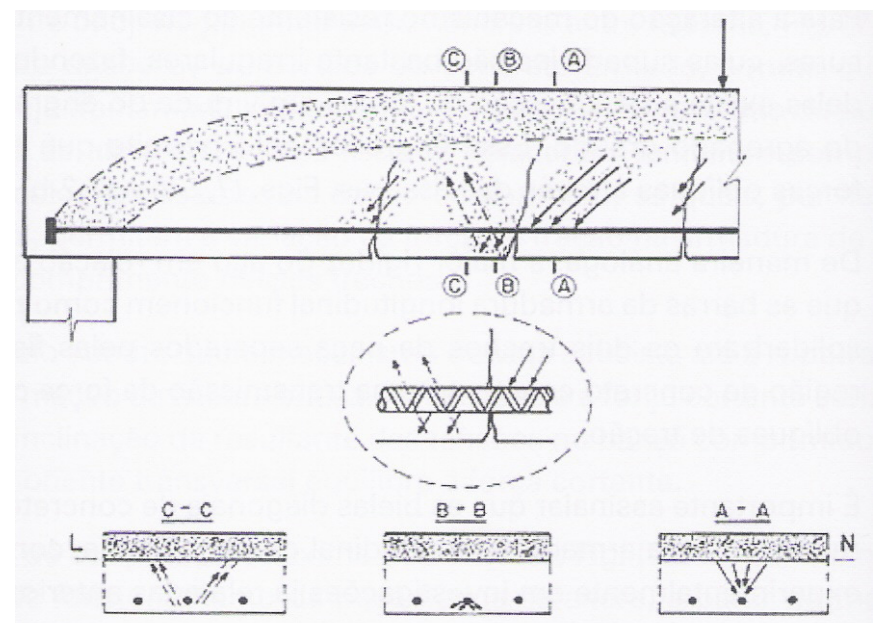

Figura 3.3: Direções das forças internas devidas ao efeito de pino, considerando momentos positivos. [Fusco (2008)]

Tendo como base esses mecanismos resistentes a forças cortantes, nas lajes sem armadura de cisalhamento, o andamento geral do fluxo de tensões de compressão, desde as forças aplicadas até os apoios, pode ser idealizado como na Figura 3.4. 


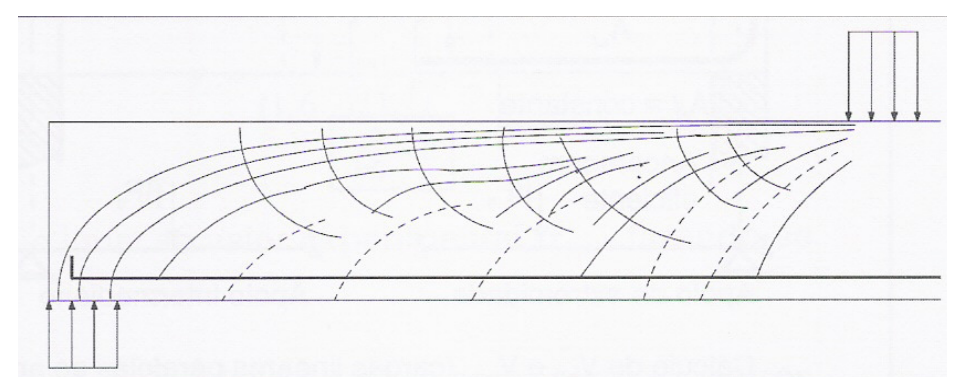

Figura 3.4: Andamento do fluxo de tensões. [Fusco (2008)]

\subsection{MECANISMOS DE FUNCIONAMENTO PRÓXIMO AO COLAPSO}

De acordo com Yang (1994), nos cálculos, o comportamento das lajes alveolares é simplificado e admite-se que elas atuem como vigas simplesmente apoiadas, sem tensão causada por momento fletor negativo e por momento torçor.

De forma geral, as lajes alveolares podem apresentar diferentes mecanismos de ruptura: perda da ancoragem por escorregamento da armadura; cisalhamento com tensão no ponto crítico da nervura superior à resistência do concreto à tração; cisalhamento em região fissurada (com efeito combinado de cisalhamento, flexão e escorregamento); cisalhamento combinado com torção (em peças que não são planas); flexão (ELU), com grande possibilidade, próximo à ruptura, do escorregamento da armadura ativa junto ao apoio; interação dos mecanismos de flexão e cisalhamento, que pode ocorrer em peças com pequenos vãos e/ou com carregamentos mais elevados; e combinação de flexão e escorregamento da armadura ativa.

Kong \& Evans (2001) concluíram, depois de muitos ensaios, que o modo de ruptura é fortemente dependente da relação entre o vão submetido ao cisalhamento $\left(a_{v}\right)$ e a altura efetiva (d). Além disso, dependendo do tipo de carregamento a que a laje está submetida, um determinado mecanismo de ruptura pode prevalecer ou pode haver combinação de mecanismos.

Os mecanismos de ruptura foram resumidos por Pajari (1989), Girhammar (1992) e Rettne \& Edekling (2006) em mecanismos de ruptura por flexão e por cisalhamento, que são descritos a seguir.

\subsubsection{Mecanismos de ruptura por flexão}

Segundo Pajari (1989) e Rettne \& Edekling (2006), os mecanismos de ruptura na flexão em lajes alveolares podem estar associados aos seguintes mecanismos isolados ou por combinação deles:

- Fissuração por tração na fibra superior, devida à solicitação por flexão após a retirada de ancoragem dos cabos protendidos, ultrapassando a resistência do concreto à tração (Figura 3.5); 


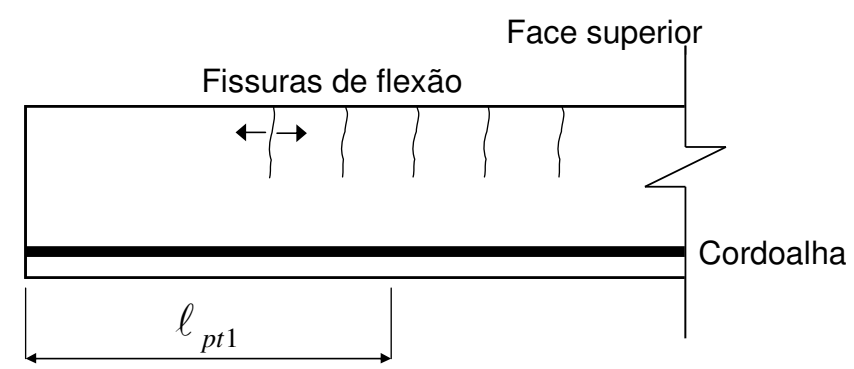

Figura 3.5: Fissuras por tração na fibra superior.

- Fissuração por tração na fibra inferior, para momentos positivos superiores ao momento de fissuração, ultrapassando a resistência do concreto à tração (Figura 3.6);
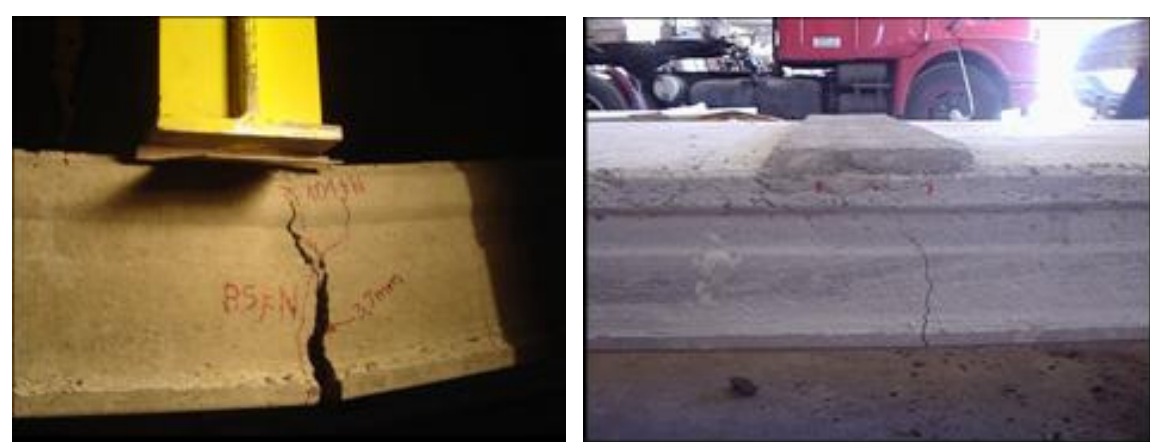

Figura 3.6: Fissuras de flexão em elementos de laje alveolar.

- Ruptura das cordoalhas por tração devida à flexão;

- Ruptura do concreto à compressão devida à flexão;

- Deformação excessiva da laje.

Considerando os ensaios de flexão com aplicação de uma força concentrada, dependendo do comprimento da laje, fissuras de flexão podem se propagar na forma de uma fissura diagonal, caso o cisalhamento na seção seja significante. Nesse caso, haverá uma interação dos mecanismos de flexão e cisalhamento. Se essa região estiver longe do apoio, deve-se ter uma condição de ancoragem ainda razoável e a maior probabilidade é que essa fissura diagonal avance em direção à face superior da laje, devendo ocorrer ruptura por compressão do concreto. Por outro lado, para o caso de uma laje de pequeno comprimento, seria mais provável que se desenvolvesse uma fissura de fendilhamento, a partir do encontro da fissura de flexão com a fissura diagonal (Figura 3.7).

Segundo Kong \& Evans (2001), quando a carga concentrada está aplicada a uma distância do apoio de modo que $a_{v} / d>6$, a ruptura tende a ocorrer por flexão. 

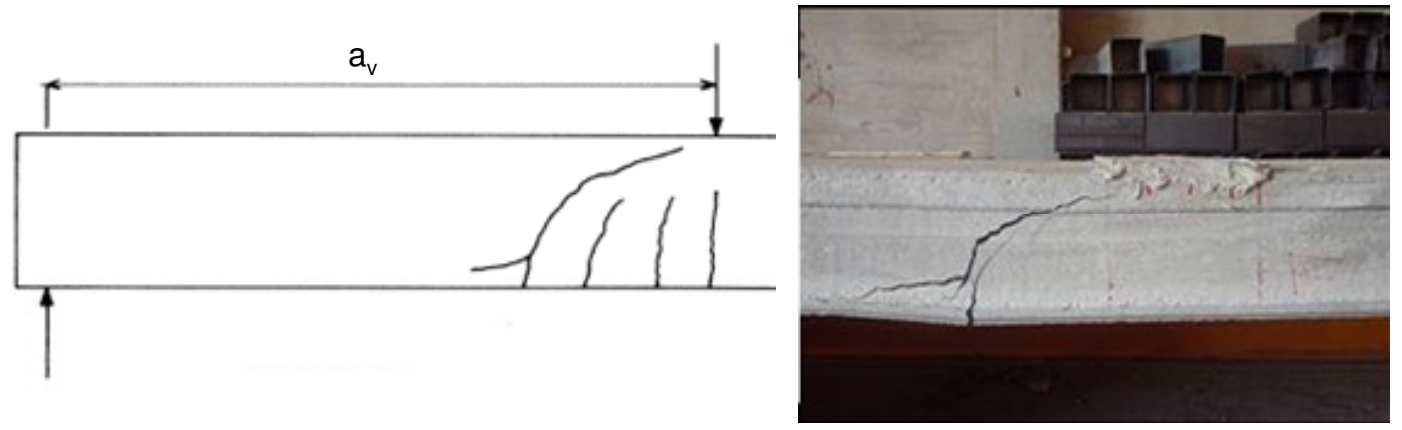

Figura 3.7: Interação de fissuras de cisalhamento com fissuras de flexão em ensaio de flexão de uma laje de 0,2 $\mathrm{m}$ de espessura e 3,0 $\mathrm{m}$ de vão.

\subsubsection{Mecanismos de ruptura por cisalhamento}

De acordo com Yang (1994), os procedimentos de projeto das lajes alveolares protendidas contra ruptura por flexão são similares aos utilizados para vigas maciças protendidas, em que a tensão de tração no Estado Limite Último (ELU) é tradicionalmente suportada pela armadura. Não há uma teoria geral aceita para verificar a resistência de elementos de concreto armado ao cisalhamento, tornando problemática a previsão dessa resistência no caso de lajes alveolares protendidas. A técnica de produção para os elementos alveolares, especialmente pelo método da extrusão, não permite o emprego de armadura de cisalhamento.

O comprimento dos apoios de lajes alveolares protendidas usualmente é de apenas poucos centímetros. Devido ao fato da protensão nas barras necessitar de certo comprimento para ser transferida, tensão adicional de cisalhamento é produzida na região de transferência. Em adição, a grande proporção de vazios torna as lajes alveolares protendidas suscetíveis à ruptura por cisalhamento.

Em projeto, geralmente é desejável assegurar que as resistências últimas sejam governadas mais pela flexão do que pelo cisalhamento. Rupturas por cisalhamento, que na realidade são ruínas ocasionadas pela combinação de forças cortantes e momentos fletores, são caracterizadas por pequenas flechas e falta de ductilidade. Às vezes há pequeno aviso antes da ruptura ocorrer, e isso torna a ruptura por cisalhamento particularmente desagradável.

Os mecanismos de ruptura por cisalhamento podem ser resumidos em:

- Ruptura da nervura por tração devida ao cisalhamento;

- Ruptura da nervura por compressão devida ao cisalhamento;

- Ruptura por escorregamento devido ao cisalhamento ao longo de uma fissura inclinada;

- Falha na ancoragem dos cabos;

- Fissuração do concreto devida à interação de cisalhamento e flexão. 


\section{- Ruptura da nervura por tração devida ao cisalhamento}

Segundo Engstrom (2005), a distribuição da tensão de cisalhamento em uma seção de laje alveolar solicitada por força cortante e momento fletor é diferente nos estádios 1 e 2, ou seja, antes e após a fissuração (Figura 3.8a e Figura 3.8b, respectivamente).

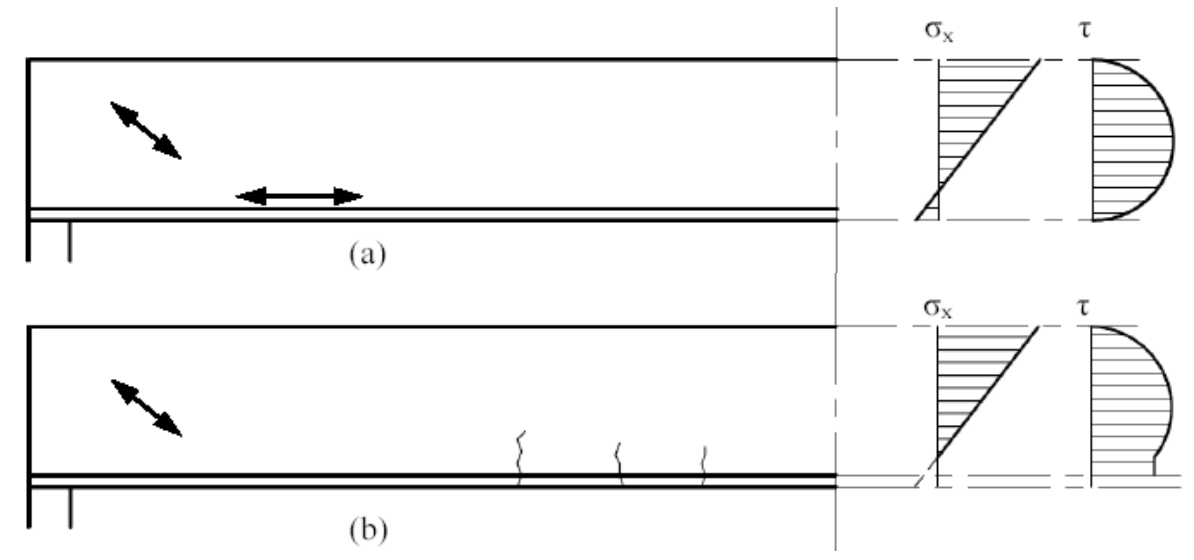

Figura 3.8: Tensões normais e de cisalhamento em um elemento protendido submetido a força cortante e momento fletor, no Estádio 1 (a) e no Estádio 2 (b). [Engstrom (2005)]

Se a resistência do concreto à tração é alta suficiente na borda inferior da laje alveolar protendida, em região não fissurada na flexão (Estádio 1, Figura 3.8a), pode ocorrer uma fissura inclinada na nervura (Figura 3.9) quando sua tensão principal de tração alcançar a resistência do concreto à tração. A fissura diagonal se propaga nos dois sentidos, ascendente e descendente, e resulta em uma ruptura imediata.

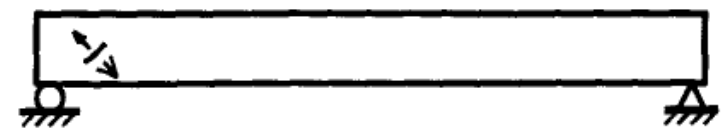

Figura 3.9: Ruptura da nervura por tração diagonal devida ao cisalhamento. [Yang (1994)]

A fissura é geralmente formada na região onde termina a influência favorável da tensão normal vertical causada pela reação no apoio (Telford (1988)) e a força de protensão ainda não se desenvolveu totalmente. Esse mecanismo caracteriza um tipo de ruptura brusca. Na prática, uma fissura na parte da nervura próxima ao apoio usualmente pode conduzir à ruptura à tração por cisalhamento, porque as nervuras da laje alveolar protendida são geralmente muito estreitas e não há armadura de cisalhamento, uma vez que a laje é produzida pelo método da extrusão.

De modo contrário, para uma peça submetida ao cisalhamento com a presença de fissuras de flexão (Figura 3.8b) a distribuição das tensões tangenciais ao longo da seção apresenta um aumento na parte inferior da laje, na região da cordoalha, aparecendo então uma interação das fissuras de flexão com as fissuras diagonais de cisalhamento. 


\section{- Fissuração do concreto devida à interação de cisalhamento e flexão}

Se a tensão normal próxima ao apoio é quase nula (o momento é quase zero), a tensão principal na região depende principalmente da tensão de cisalhamento. Nesse caso, no ponto onde a tensão principal é maior (ponto crítico), a tensão de cisalhamento é máxima. Entretanto, para elementos protendidos, também existe tensão normal devida à força de protensão. Além disso, as regiões próximas aos apoios são zonas de perturbação, onde a força de protensão, em elementos pré-tracionados, é transferida ao concreto por tensões de aderência. Portanto, em elementos protendidos, a posição do ponto crítico é incerta.

Um elemento protendido submetido a esforços de flexão e cisalhamento pode apresentar três diferentes configurações de fissuras, conforme ilustrado na Figura 3.10.

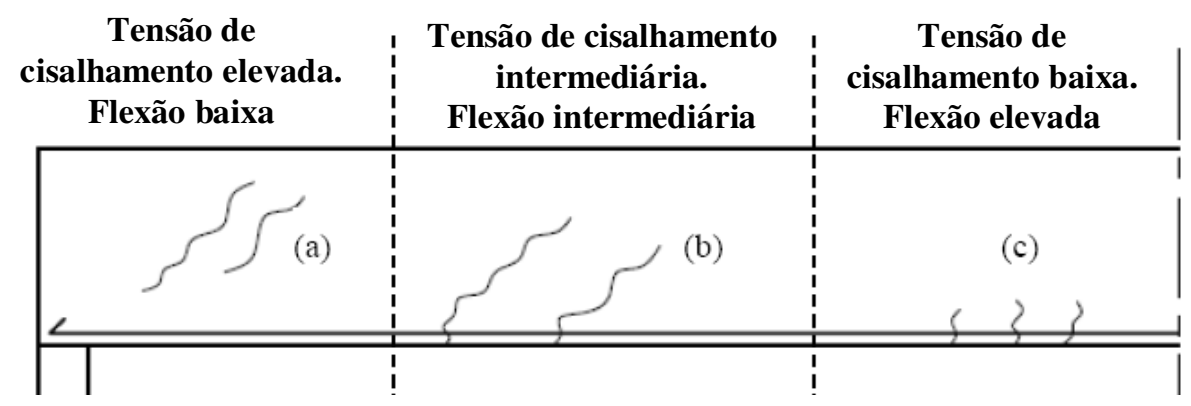

Figura 3.10: Elemento de concreto protendido submetido a flexão e cisalhamento. a) Fissuras na nervura devidas ao cisalhamento; b) Fissuras de cisalhamento e flexão; c) Fissuras de flexão. [Rettne \& Edekling (2006)]

Próximo ao apoio, onde o cisalhamento é maior e o momento é quase nulo, a fissuras inclinadas de cisalhamento aparecerão na nervura quando a tensão de tração principal alcançar a resistência do concreto à tração no ponto crítico, conforme observado na Figura 3.10a. No caso de carregamento distribuído, onde as regiões centrais da laje possuem momentos mais elevados e cisalhamento reduzido, é mais comum a incidência de fissuras de flexão, conforme a Figura 3.10c. Entretanto, nas regiões intermediárias, as fissuras de flexão podem se propagar em fissuras inclinadas de cisalhamento (Figura 3.10b), onde a tensão de cisalhamento é mais elevada. Em geral, estas fissuras são denominadas fissuras de cisalhamento e flexão, pois de fato tem-se uma interação dos mecanismos de flexão e de cisalhamento, sendo que o mecanismo de ruptura nem sempre é bem definido, mas é resultado da interação ou da combinação de mecanismos.

Segundo Kong \& Evans (2001), quando a carga concentrada está aplicada a uma distância do apoio que respeite a relação $6>a_{v} / d>2,5$, a ruptura tende a ocorrer por cisalhamento, mas existe a interação de fissuras de flexão com fissuras inclinadas de cisalhamento. 
Com referência à Figura 3.11, com o aumento da força $V$, a fissura de flexão $a-b$, próxima ao apoio, propagar-se-ia gradualmente em direção ao ponto de carregamento, tornando-se uma fissura inclinada, que é conhecida como fissura de cisalhamento e flexão, mas que frequentemente é chamada simplesmente de fissura diagonal. (Figura 3.11: fissura a-b-c).

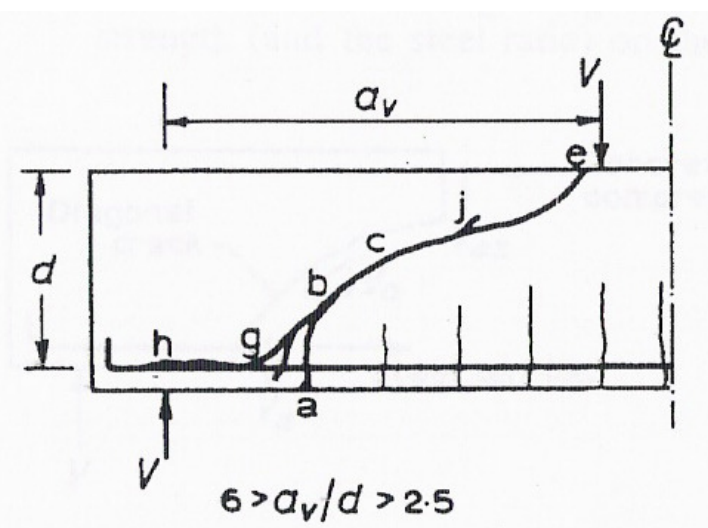

Figura 3.11: Situação em que 6,0 > $a_{v} / d>2,5$. [Kong e Evans (2001)]

Com aumento adicional em $\mathrm{V}$, a ruptura pode ocorrer de dois modos. Se a relação $\frac{a_{v}}{d}$ é relativamente alta, a fissura diagonal rapidamente se estenderia até " $e$ ", resultando em colapso por ruptura da peça em dois pedaços. Esse modo de ruptura é frequentemente chamado de ruptura por tração diagonal. Nesse modo de ruptura, a força última é a mesma que aquela necessária à formação da fissura diagonal. Se a relação $\frac{a_{v}}{d}$ é relativamente baixa, a fissura diagonal tende a parar em algum lugar em "j" (Figura 3.11), e um número de fissuras aleatórias verticais pode se desenvolver no concreto ao longo da armadura longitudinal de tração. Quando $V$ é ainda maior, a fissura diagonal se amplia e se propaga ao longo do nível da armadura de tração (Figura 3.11: fissura g-h). O aumento da força cortante causa a destruição da aderência entre o concreto e o aço, usualmente conduzindo ao fendilhamento do concreto ao longo de g-h. Se a armadura longitudinal não tem gancho na extremidade, a destruição da aderência e o fendilhamento do concreto causarão o colapso imediato. Se existirem ganchos, o aumento da força na armadura longitudinal causará a destruição do concreto existente ao redor do gancho, onde ocorre o colapso. Esse modo de ruptura é frequentemente chamado de ruptura por tração devida ao cisalhamento ou fal ha da ancoragem devida ao cisalhamento. Novamente, a força última não é muito maior que a força de fissuração diagonal. 
Na Figura 3.12 é apresentada a ilustração de um mecanismo de ruptura ocorrido em um ensaio típico de cisalhamento, para uma relação $a_{v} / d=0,5 / 0,165=3,0$.

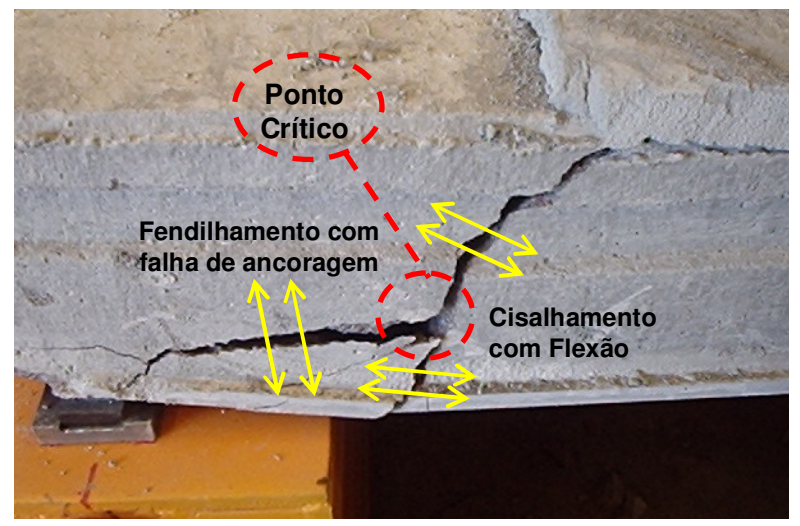

Figura 3.12: Combinação de fissuras de cisalhamento com efeito da flexão e fendilhamento por falha de ancoragem, em ensaio de cisalhamento com $a_{v} / d=3,0$.

\section{- Ruptura da nervura por compressão devida ao cisalhamento}

Esse tipo de ruptura (Figura 3.13) ocorre quando a tensão principal de compressão na nervura alcança a resistência do concreto à compressão.

$\mathrm{Na}$ região de concreto entre fissuras inclinadas de cisalhamento podem surgir novas fissuras, por conta da tensão de compressão elevada e da tensão de tração perpendicular a ela. Esse tipo é conhecido como ruptura por compressão devida ao cisalhamento.

Entretanto, de acordo com Yang (1994), é impossível ocorrer esse tipo de ruptura nas lajes alveolares protendidas sem armadura de cisalhamento, uma vez que a ruptura da nervura por tração devida ao cisalhamento ocorre antes, sendo decisiva para esse tipo de elemento.

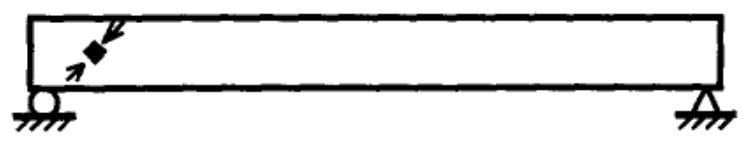

Figura 3.13: Ruptura da nervura por compressão devida ao cisalhamento. [Yang (1994)]

Segundo Kong \& Evans (2001), quando a carga concentrada está aplicada a uma distância do apoio que respeita a relação $2,5>a_{v} / d>1$, frequentemente a fissura diagonal se forma independentemente e não como um desenvolvimento de uma fissura à flexão (Figura 3.14). A viga usualmente permanece estável após tal fissuração. Neste caso, o aumento adicional na força $V$ irá causar a fissura diagonal para penetrar na zona de compressão do concreto, no ponto de carregamento, até eventualmente ocorrer a ruptura por esmagamento do concreto, às vezes de forma explosiva (Figura 3.14 porção sombreada). 
Este modo de ruptura é usualmente chamado de ruptura por compressão devida ao cisalhamento. Para esse modo, a força última é, às vezes, mais do que o dobro daquela relativa à fissura diagonal.

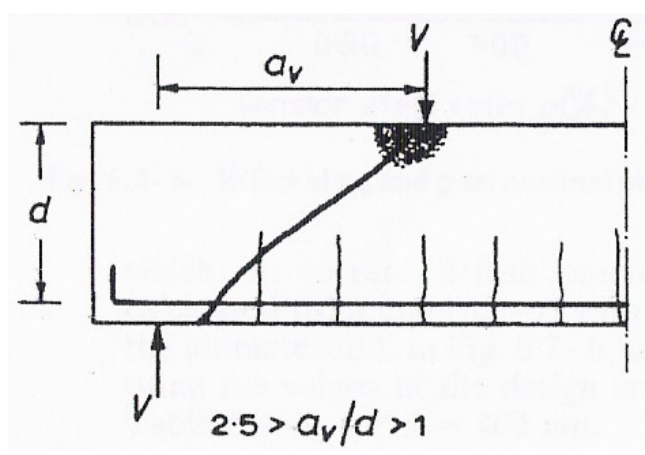

Figura 3.14: Situação em que 2,5 > $a_{v} / d>1,0$. [Kong e Evans (2001)]

Ainda segundo Kong \& Evans (2001), quando a carga concentrada está aplicada a uma distância do apoio com $a_{v} / d<1$, a fissura diagonal se forma ao longo de uma linha, unindo os pontos de carregamento e de apoio (Figura 3.15).

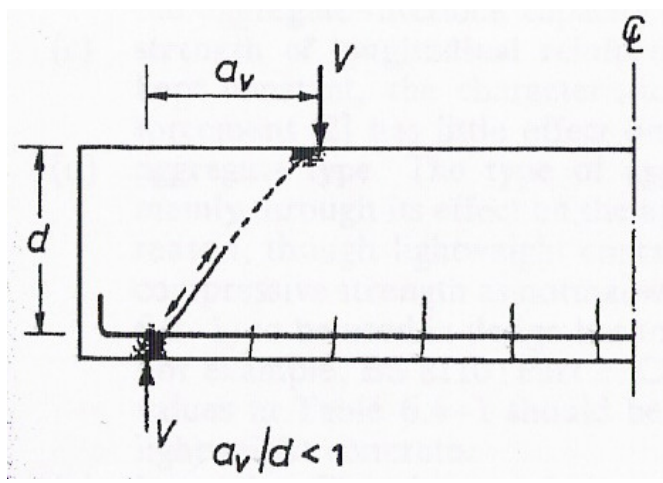

Figura 3.15: Situação em que $a_{v} / d<1,0$. [Kong e Evans (2001)]

Ela ocorre principalmente como resultado da ação da força de compressão, que é transmitida diretamente ao apoio, a partir do ponto de carregamento. Essa fissura diagonal frequentemente se inicia em cerca de $d / 3$ acima da face inferior da viga. Com o aumento da força $V$, a fissura diagonal se propagaria simultaneamente em direção aos pontos de carregamento e apoio.

Quando a fissura penetra no concreto a maiores profundidades, no ponto de carregamento ou no ponto de apoio, ocorre ruptura por esmagamento do concreto. Para este modo de ruptura, frequentemente a força última é várias vezes maior que a força relativa à fissura diagonal. 


\section{- Ruptura por escorregamento devido ao cisalhamento}

Ruptura por escorregamento devido ao cisalhamento de um elemento de concreto sem armadura transversal ocorre quando $o$ atrito e o efeito de intertravamento nas fissuras, assim como o efeito de pino da armadura passiva ou do aço de protensão, são insuficientes para transferir o cisalhamento.

\subsubsection{Mecanismos de ruptura em unidades alveolares com capa}

De acordo com Girhammar e Pajari (2008), o elemento alveolar com capa pode chegar à ruína de três modos: o primeiro corresponde à ruptura por cisalhamento na interface do elemento alveolar com a capa de concreto (Figura 3.16a); o segundo está relacionado com a ruptura da nervura por tração devida ao cisalhamento na unidade alveolar (Figura 3.16b); o terceiro mecanismo ocorre com a ruptura das cordoalhas (Figura 3.16c).

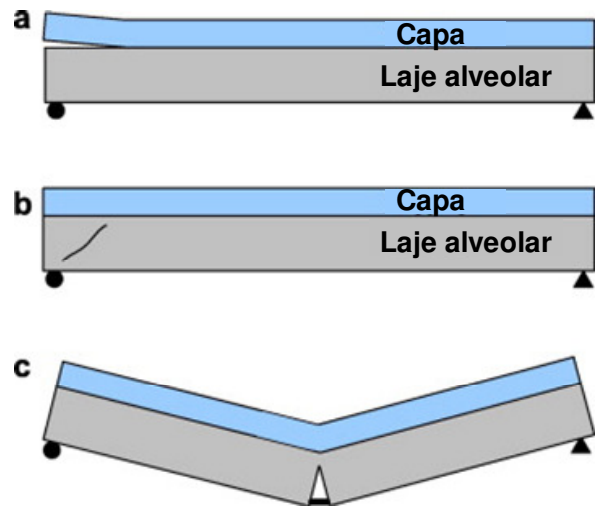

Figura 3.16: Alguns mecanismos de ruptura em laje alveolar com capa. a) Cisalhamento na interface; b) Ruptura da nervura por tração devida ao cisalhamento; c) Ruptura dos cabos. [Girhammar e Pajari (2008)]

\subsubsection{Desenvolvimento da fissura em ensaio típico ao cisalhamento}

Neste item é apresentado um exemplo de ruptura por tração da nervura devida ao cisalhamento, que pode ocorrer quando uma laje alveolar de elevada altura (400 mm) é submetida ao cisalhamento em zona fissurada por flexão (Figura 3.17). Tal ensaio é descrito no item 3.6.1.

Inicialmente, é possível observar o aparecimento de fissura de flexão na região de aplicação do carregamento, como pode ser observado na Figura 3.18. Em seguida aparece fissura de flexão com cisalhamento, que se propaga ao longo da altura da laje, como pode ser observado na Figura 3.19.

Dando continuidade ao ensaio, ocorre o aparecimento de fissura de cisalhamento na nervura (Figura 3.20a) pouco antes da ruptura da laje (Figura 3.20b). 


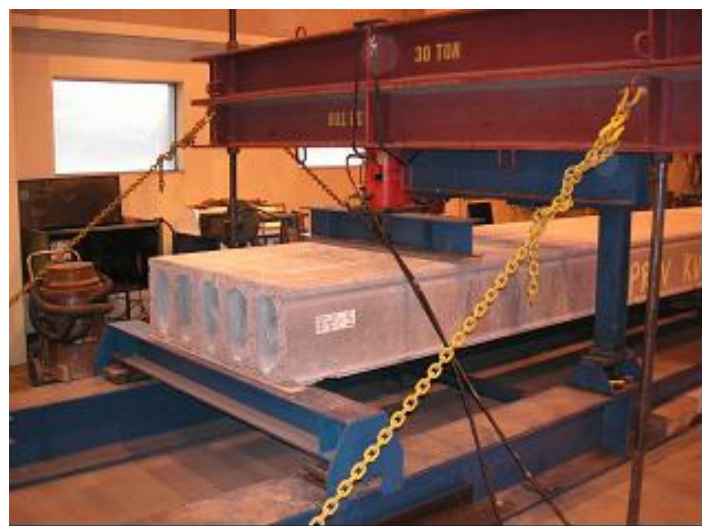

Figura 3.17: Ensaio típico para a determinação da resistência de lajes alveolares ao cisalhamento. [Rettne \& Edekling (2006)]

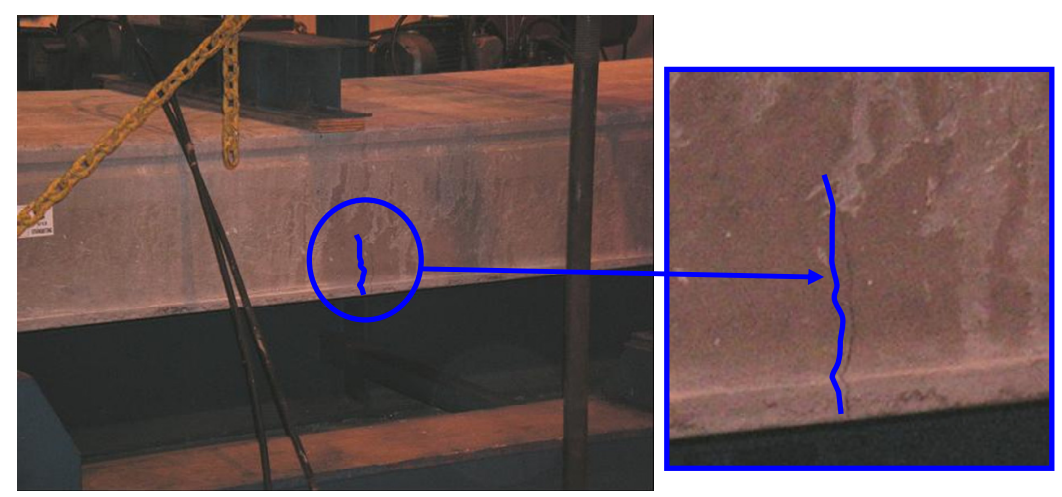

Figura 3.18: Aparecimento de fissura de flexão. [Rettne \& Edekling (2006)]

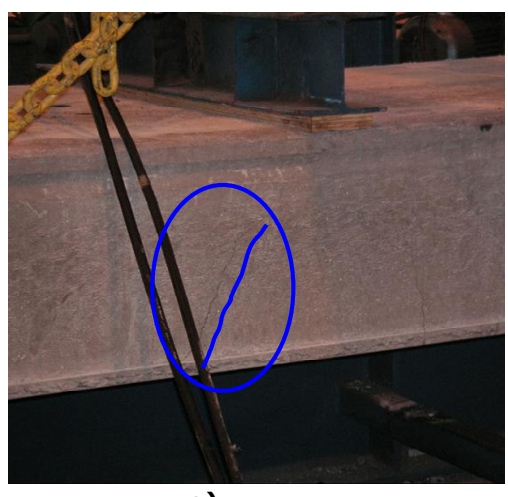

a)

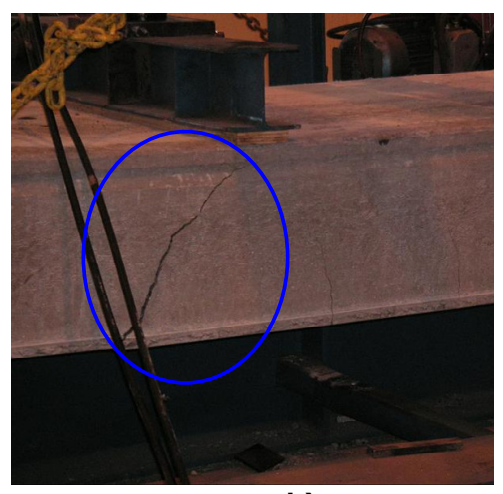

b)

Figura 3.19: a) Aparecimento de fissura de flexão com cisalhamento; b) Propagação da fissura de flexão e cisalhamento. [Rettne \& Edekling (2006)] 


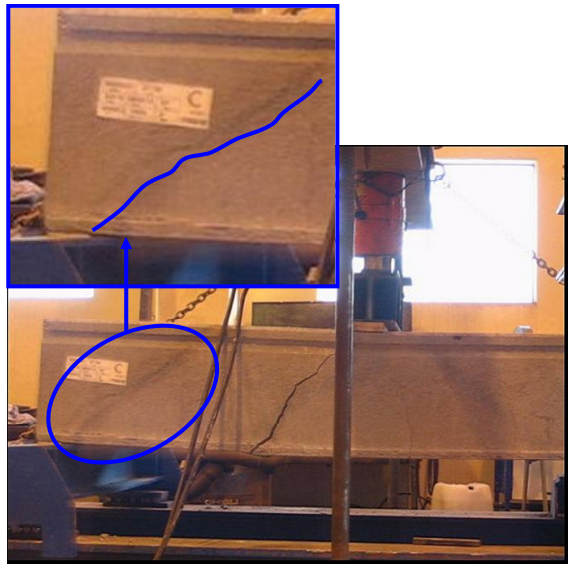

a)

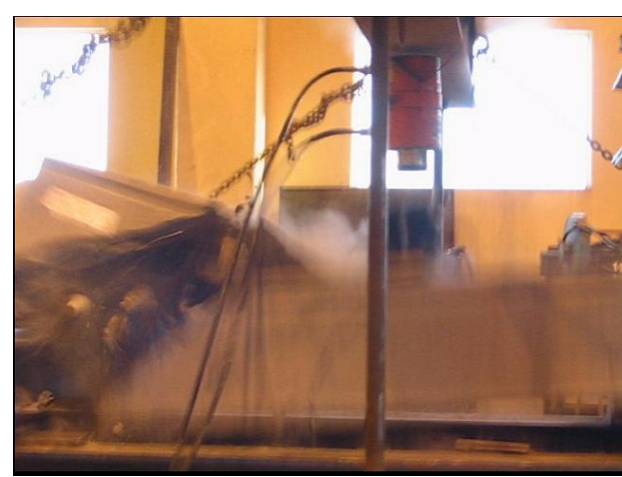

b)

Figura 3.20: a) Aparecimento de fissura devida ao cisalhamento, b) Ruptura da laje logo após o aparecimento da fissura na nervura. [Rettne \& Edekling (2006)]

\subsection{ANCORAGEM}

Neste item serão considerados os principais tipos de ancoragem e as tensões de tração em região de transferência.

\subsubsection{Principais tipos de ancoragem}

De acordo com Carvalho (2008), podem ser distinguidos dois tipos de ancoragem da armadura ativa: as que dependem de elementos mecânicos adicionais e aquelas em que a transferência do esforço entre aço e concreto é feita pela aderência entre eles.

No concreto protendido com pós-tração, a transferência da força de protensão é dada por dispositivos como cunhas, blocos de aço, placa repartidora etc. Assim, a transferência de ação se dá pelo conjunto de elementos, não sendo usada, em princípio, a aderência aço-concreto, que somente será completada após a injeção de calda de cimento.

No caso da pré-tração, a transferência de ação se faz como no concreto armado, por aderência aço-concreto, não havendo dispositivo de ancoragem ou de distribuição de tensão. Em princípio, as armaduras ativas de pré-tração apresentam comportamento similar ao das armaduras passivas, quanto à aderência, existindo os fenômenos de adesão, atrito e engrenagem mecânica.

A aderência por adesão é caracterizada pela resistência à separação dos materiais, que ocorre na interface das barras com a pasta, devida a ligações físico-químicas geradas durante as reações de pega do cimento, e pode ser facilmente destruída por deslocamentos relativos entre a barra e a massa de concreto que a envolve.

$\mathrm{O}$ atrito manifesta-se quando existe a tendência ao deslocamento relativo entre os materiais, e depende da rugosidade superficial da barra e da pressão transversal exercida pelo concreto sobre ela, em função da retração. 
A aderência mecânica depende da conformação superficial das barras, sendo que as de alta aderência mobilizam forças localizadas, aumentando significativamente a aderência. De acordo com Leonhardt \& Mönnig (1977), mesmo uma barra lisa pode apresentar aderência mecânica, em virtude de sua rugosidade superficial, devida à corrosão e ao processo de fabricação, gerando um denteamento da superfície.

Segundo Leonhardt (1983), no caso da protensão com aderência inicial, a força de protensão a ancorar é três a quatro vezes maior que na ancoragem de barras nervuradas de concreto armado, de mesma seção transversal. Dessa forma, considerando forças tão elevadas, a ancoragem por aderência somente pode ser garantida com o desenvolvimento de uma aderência mecânica, que é obtida quando a armadura de protensão for nervurada ou apresentar um perfilado adequado, capaz de produzir um denteamento entre a armadura de protensão e o concreto. Para cordoalhas de sete fios, o deslizamento é impedido pelo chamado efeito de "saca-rolha".

A Figura 3.21 mostra, esquematicamente, o contato entre o concreto e a superfície da armadura em uma cordoalha que, por ter o centro dos seus fios descrevendo uma espiral, acentuam esse contato, criando o efeito de "saca-rolha". Tal efeito faz com que haja uma maior superfície de contato, além de um engrenamento mecânico.

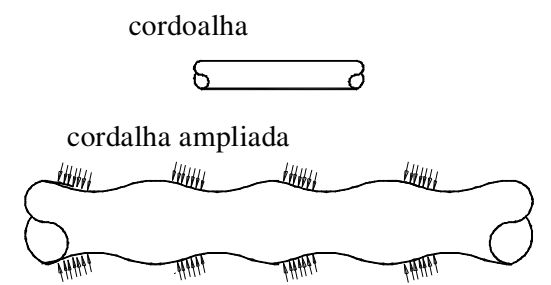

Figura 3.21: Detalhe das forças que ocorrem na superfície de uma cordoalha e do concreto que a envolve. [Carvalho (2008)]

No Anexo A apresentam-se definições e equacionamentos relativos a ancoragem.

Existe ainda o efeito Hoyer, que é desprezado, a favor da segurança, e decorre do aumento do diâmetro que a armadura ativa possui quando a extremidade do fio, ao ficar sem tensão, se deforma transversalmente. Esse efeito faz com que a parte da armadura sem tensão forme uma "cabeça de prego", ajudando a impedir o deslizamento. Tal efeito é muito influenciado pela fissuração e pela fluência do concreto.

Inicialmente, os inventores do processo de protensão com aderência inicial (Wettstein e Hoyer) empregaram fios muito finos, obtendo um sucesso limitado. Entretanto, Hoyer esclareceu o efeito da ancoragem (denominado efeito Hoyer) e ficou evidenciado que a ancoragem por aderência, que depende exclusivamente da adesão, não se mantém ao longo do tempo, havendo o escorregamento dos fios e a consequente perda da protensão. Dessa forma, a obtenção de uma ancoragem confiável somente é possível com uma ancoragem mecânica. 
De acordo com Leonhardt (1983), a tensão na armadura, produzida pela protensão, deve ser absorvida em um trecho da extremidade do fio. Para que isso ocorra, o fio e suas nervuras apoiam-se no concreto, sendo a força de protensão transferida para o concreto pelas trajetórias de compressão, as quais se iniciam com certa inclinação e depois se desenvolvem com curvatura decrescente. Essa curvatura das trajetórias de compressão faz com que, em todas as direções radiais em torno da armadura de protensão, surjam forças de tração transversais no concreto (também denominadas forças de fendilhamento). Na Figura 3.22 pode-se observar o processo de ancoragem por aderência.

Quando, no Estado Limite Último, a armadura ativa está na iminência do deslizamento, ocorre um complexo estado de tensões no concreto, além de sua microfissuração.

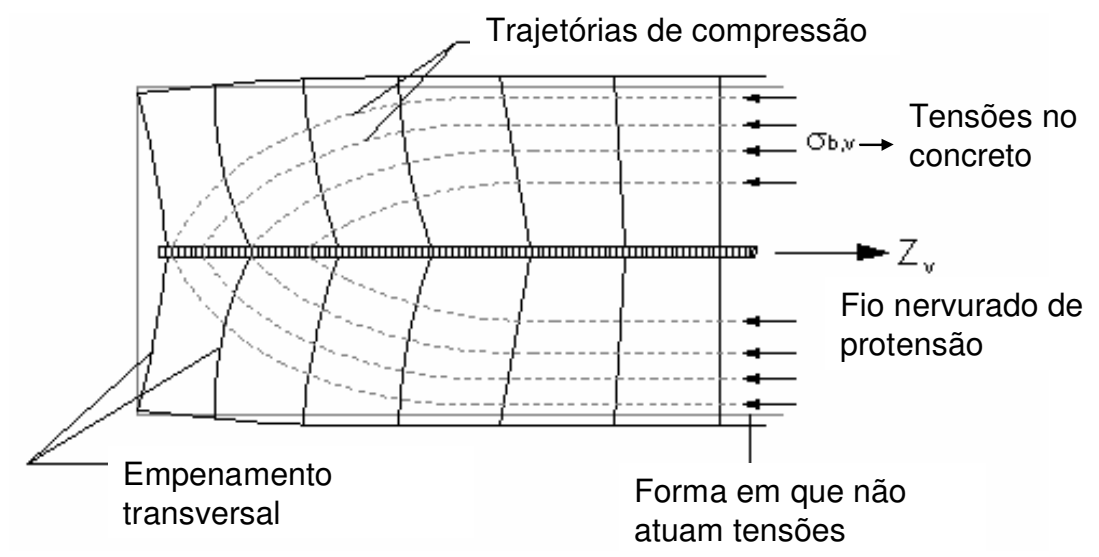

Figura 3.22: Desenvolvimento das tensões. [adaptado de Leonhardt (1983)]

\subsubsection{Comprimento de transferência}

Para analisar a capacidade de ancoragem das cordoalhas, é comum considerar primeiro como a força de protensão é introduzida no concreto, na extremidade do elemento. Quando a cordoalha é liberada ela tende a voltar para sua posição inicial, tendendo a encurtar. Devido à configuração das barras, a cordoalha desenvolverá tensões decorrentes do atrito. Se essas tensões forem suficientemente grandes, um estado limite de equilíbrio é alcançado e as cordoalhas param de escorregar.

O comprimento necessário para o desenvolvimento de toda a força de protensão é chamado de comprimento de transferência $\left(I_{t}\right)$. Ao longo desse comprimento a força de protensão se desenvolve aproximadamente de acordo com uma curva parabólica, como pode ser observado na Figura 3.23.

De acordo com Walraven \& Mercx (1983), se em algum lugar ao longo do comprimento de transferência aparece uma fissura de flexão, dificilmente será possível aumentar a tensão no aço, devido ao estado limite de equilíbrio que existe nessa área. 
Se a fissura ocorre fora do comprimento de transferência, é possível um aumento na tensão no aço. Em ambos os lados da fissura a tensão no aço é aumentada além de um determinado comprimento que é suficiente para transmitir a força adicional nas barras, devida à fissuração, pela tensão de aderência do concreto. Entretanto se a tensão elevada devida à fissura é muito grande, a zona afetada (região b, na Figura 3.23) invade a região de ancoragem (região a, na Figura 3.23) e o equilíbrio da zona de transferência é perturbado, possibilitando o escorregamento das cordoalhas. Se a distância da extremidade do elemento é grande o suficiente, a tensão última nas cordoalhas pode ser alcançada. Essa distância é denominada de comprimento de desenvolvimento $\left(I_{d}\right)$.
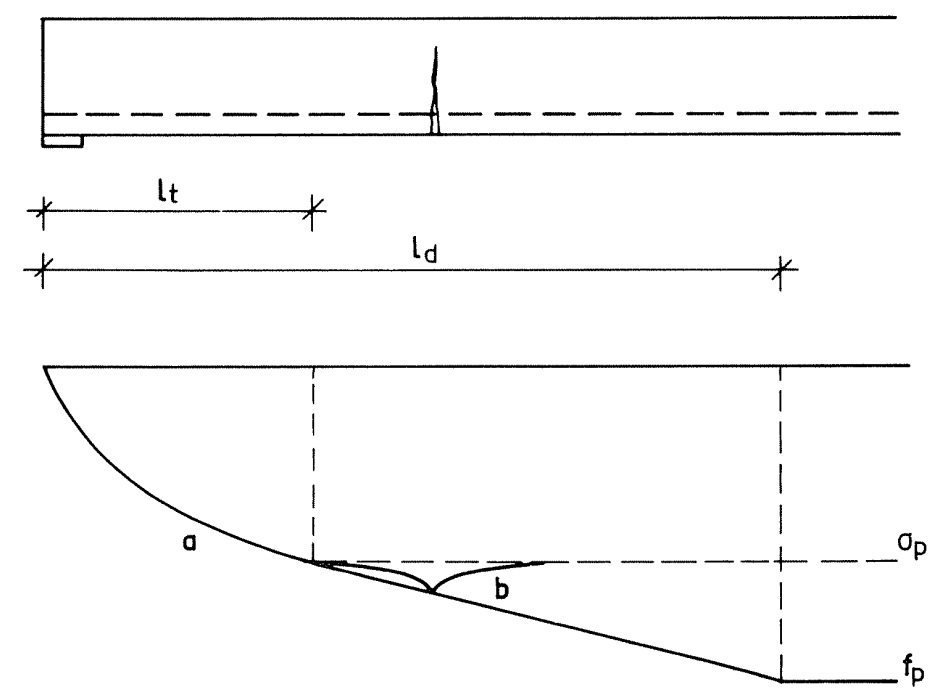

Figura 3.23: Situação crítica de fissuração em relação a falha de ancoragem. [Walraven \& Mercx (1983)]

A FIP (1982) supõe que a fissura crítica de flexão ocorre na distância correspondente a 1,25 $\mathrm{I}_{\mathrm{t}}$ com relação ao apoio, na seção transversal limite da zona de transferência.

O cálculo do comprimento de trasnferência é recomendado em algumas referências, com a consideração de valores inferior, médio e superior.

De acordo com o EC2 (2004), o valor de projeto do comprimento de transferência deve ser considerado como o mais desfavorável entre dois limites, dependendo da situação de projeto:

$I_{p t 1}=0,8 I_{p t}$

$I_{p t 1}=1,2 I_{p t}$

O valor do comprimento de transferência $\left(I_{p t}\right)$ é obtido com a expressão:

$I_{p t}=\alpha_{1} \alpha_{2} \phi \frac{\sigma_{\mathrm{pm} 0}}{f_{\mathrm{bpt}}}$ 
$\alpha_{1}$ : 1,0 (liberação gradual da protensão), 1,25 (liberação repentina da protensão);

$\alpha_{2}$ : 0,19 (barras de 3 e 7 fios);

$\phi$ : diâmetro nominal da cordoalha;

$\sigma_{\mathrm{pmo}}$ : tensão na barra logo após a liberação da protensão;

$f_{b p t}$ : tensão de aderência $-f_{b p t}=\eta_{p 1} \cdot \eta_{1} \cdot f_{c t d}(t)$.

$\eta_{\mathrm{p} 1}$ : coeficiente que considera o tipo de cordoalha e a situação de aderência na liberação da protensão. $\eta_{p 1}=3,2$ para cordoalhas com 3 e 7 fios;

$\eta_{1}=1,0$ para boas condições de aderência;

$f_{c t d}(t)$ : valor de projeto da resistência do concreto à tração, no instante da liberação da protensão.

Segundo o EC2 (2004), normalmente o menor valor é usado para verificações de tensões locais na liberação da protensão, e o maior valor, para estados limites últimos (cisalhamento, ancoragem etc).

De acordo com o ACI 318:2008, a resistência ao cisalhamento pode ser avaliada substituindo o comprimento de transferência por $50 \phi$ ( $\phi$ é o diâmetro da cordoalha) na avaliação quanto ao desenvolvimento da protensão na seção.

ASSAP (2002) apresenta dois valores para o comprimento de transferência, correspondendo a: valor médio do comprimento de transferência $\left(I_{b p}\right)$ e limite superior do comprimento de transferência $\left(I_{\mathrm{bpd} d}\right)$. Tais valores são definidos de acordo com as seguintes expressões:

$\mathrm{I}_{\mathrm{bp}}=70 \phi$

$\mathrm{I}_{\mathrm{bpd}}=1,2 \cdot \mathrm{I}_{\mathrm{bp}}=1,2 \cdot 70 \phi=84 \phi$

\subsubsection{Tensões de tração em região de transferência}

A ancoragem de armaduras protendidas por aderência é muito influenciada pela presença ou ausência de fissuras na região de transferência da força de protensão.

Para evitar fissuração é indispensável verificar as tensões de tração na região de transferência.

Situações de fissuração na região da ancoragem são causadas por tensões de tração denominadas "bursting", "splitting" e "spalling".

\section{- "Bursting"}

Denomina-se "bursting" a tensão de tração que é gerada pelo escorregamento das cordoalhas na extremidade da laje. Nessa região a armadura estirada pode, por ser cortada, tornar-se uma cunha que, com a retração do concreto, pode criar tensões de tração perpendiculares à armadura. 
Cordoalhas incorretamente posicionadas em seções de concreto muito estreitas podem causar "busting", como indicado na Figura 3.24.

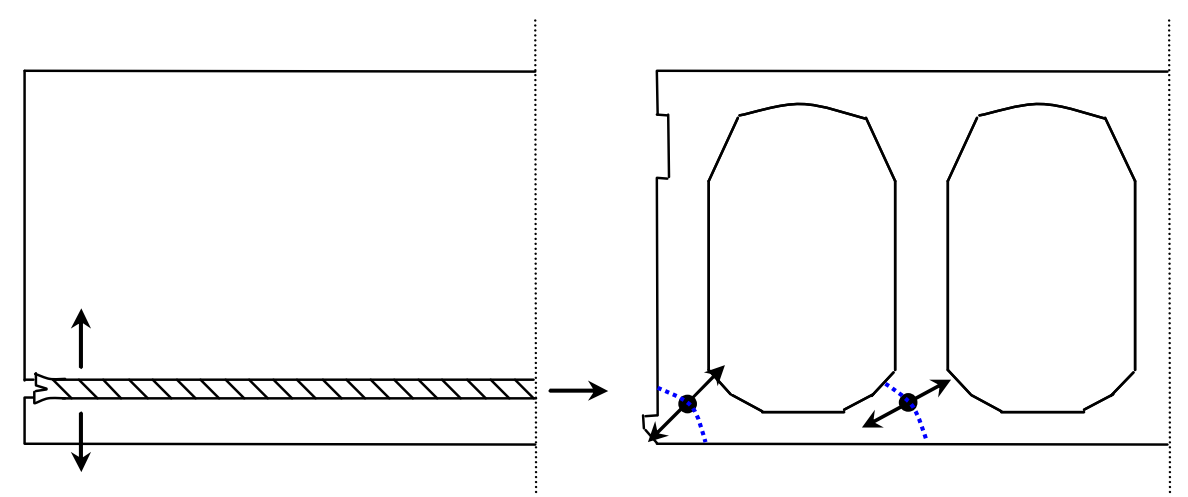

Figura 3.24: "Bursting", tensão que pode causar pequenas fissuras na extremidade da laje alveolar. [ASSAP (2002)]

O comprimento das fissuras devidas a esse fenômeno usualmente não é maior que $8 \mathrm{~cm}$ a $10 \mathrm{~cm}$, e a única consequência é o prolongamento da região de ancoragem ao comprimento da fissura.

Essas fissuras podem favorecer o escorregamento das cordoalhas além de limites aceitáveis.

Os problemas citados não surgem quando são respeitadas as espessuras adequadas dos cobrimentos das cordoalhas. Assim, esses casos de "bursting" são facilmente contidos pelo concreto.

\section{- "Splitting"}

Essas tensões são causadas pelo desenvolvimento da protensão na região de ancoragem, como ilustrado na Figura 3.25. A ancoragem progressiva das barras tracionadas transfere gradualmente as forças de protensão ao concreto.

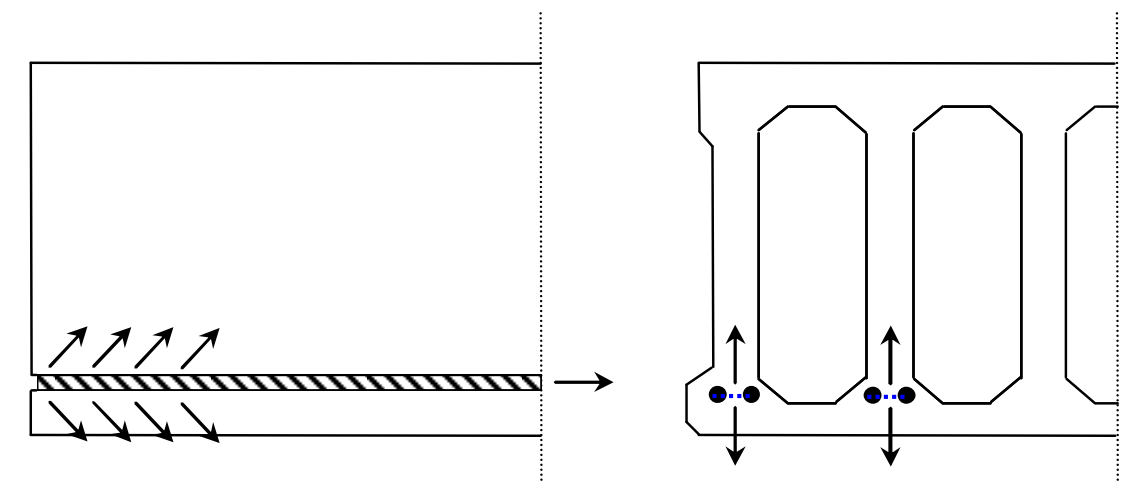

Figura 3.25: "Splitting" na extremidade da laje, que pode causar pequenas fissuras que unem as cordoalhas que estão muito próximas umas das outras. [ASSAP (2002)] 
Como tais forças possuem uma tendência de inclinação, são geradas tensões de tração no concreto. Se essa tensão de tração for maior que a resistência do concreto à tração, podem aparecer fissuras horizontais típicas, indo de uma cordoalha a outra, a ponto de quase causar o descolamento da borda inferior da laje. Essas lesões, como aquelas causadas pelo "bursting", são de profundidade limitada e representam um problema de estética na extremidade da laje.

Como no caso de "bursting", as fissuras podem prolongar a região de ancoragem ao comprimento das fissuras e também podem favorecer o escorregamento das barras no concreto da extremidade das lajes.

A tensão "splitting" também é evitada mantendo um cobrimento adequado das cordoalhas.

Essas lesões, eventualmente, envolvem a região do apoio da laje. Assim, se a extensão de tais lesões for limitada, a laje permanece aceitável.

\section{- "Spalling"}

Esta tensão não deve ser confundida com "splitting", uma vez que ocorre acima do eixo das cordoalhas, na região da extremidade das lajes alveolares, onde as nervuras estão com suas mínimas larguras (Figura 3.26).

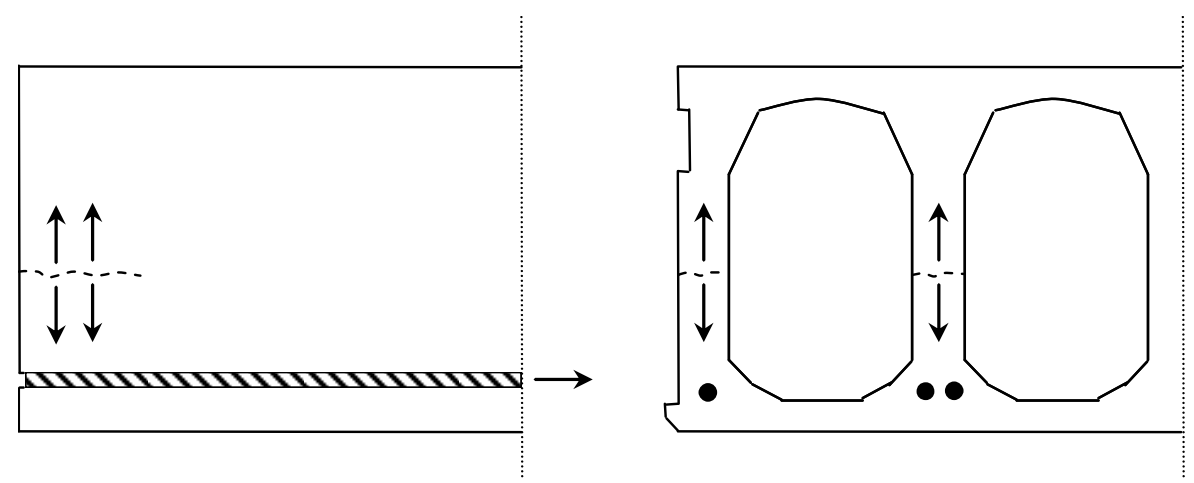

Figura 3.26: "Spalling", que pode causar lesões na extremidade da laje protendida. [ASSAP (2002)]

Essas tensões também são causadas pelo desenvolvimento da protensão no concreto das extremidades da laje. Essa região de ancoragem sofre uma combinação de tensões de flexão e de compressão que tende a separá-la da ainda quase inerte parte superior.

As tensões de flexão e de compressão combinadas ocorrem por meio de linhas de fluxo de tensões cujas direções não são paralelas ao eixo da laje.

No caso de excesso de cordoalhas, tensões de tração podem superar a resistência do concreto à tração, no instante do corte de cada peça. Isto pode levar a fissuras horizontais que são comumente conhecidas pelos fabricantes como "boca de jacaré".

Quando as fissuras começam a aparecer nas nervuras, elas rapidamente se estendem por grande comprimento. 
De acordo com ASSAP (2002), quando uma laje alveolar apresenta uma fissura horizontal em uma das nervuras, ela pode ser aceita, seguindo uma avaliação de possíveis consequências. Quando uma fissura "spalling" aparece em duas ou três nervuras, a laje deve ser rejeitada.

Fissuras horizontais nas extremidades podem progredir durante 0 transporte e 0 içamento, o que reduz a resistência das peças ao cisalhamento.

Para reduzir a tensão de tração "spalling" nas nervuras armadas com duas ou mais cordoalhas, uma delas normalmente é revestida, neutralizando-a por um comprimento de $50 \mathrm{~cm}$ a $70 \mathrm{~cm}$, a partir das extremidades.

\subsection{EFEITO DIAFRAGMA}

De acordo com Elliott (2002), a estabilidade global de construções pré-moldadas de concreto é obtida basicamente de duas formas.

A primeira ocorre quando as ações horizontais do vento são transmitidas, através das estruturas de piso, para as paredes de contraventamento ou para estruturas resistentes ao momento fletor. Qualquer tipo de estrutura de piso pode ser projetado e construído para funcionar dessa forma, mas alguns problemas surgem quando são empregadas estruturas compostas por elementos pré-moldados individuais, como as lajes alveolares ou as do tipo duplo T. O principal problema está relacionado com a ligação dos elementos pré-moldados, pois se a estrutura corresponder a um elemento sólido, as ações horizontais são diretamente transmitidas através da área do piso. Dessa forma, os elementos em um sistema de piso não resistirão a carregamentos separadamente uns dos outros, então é desejado um certo grau de interação dos elementos adjacentes.

Para obter uma distribuição transversal dos efeitos do carregamento, no caso de forças concentradas, e evitar deslocamentos verticais desiguais nas juntas Iongitudinais, as ligações do piso devem ser projetadas para desenvolver a ação de chave de cisalhamento, que garante a interação dos elementos adjacentes.

A segunda forma ocorre quando as ações horizontais distribuídas em cada pavimento são transmitidas para a fundação através dos pilares ou dos elementos de contraventamento. Nas situações em que a distância entre os elementos de contraventamento é grande, entre $6 \mathrm{~m}$ e $10 \mathrm{~m}$, o piso tem que ser projetado como uma chapa, e pode ser chamado de diafragma, que deve resistir a forças cortantes e a momentos fletores.

O efeito diafragma pode ser obtido a partir da união dos painéis alveolares, com o emprego de concreto moldado no local. Além disso, a ação do diafragma também pode ser concebida com o emprego de uma capa de concreto armado moldado por toda a área do piso. 
Com o efeito diafragma, a força horizontal deve ser transferida para as unidades de contraventamento, e as ligações entre os pisos e as unidades de contraventamento devem interagir para resistir a tais forças, como pode ser observado na Figura 3.27.

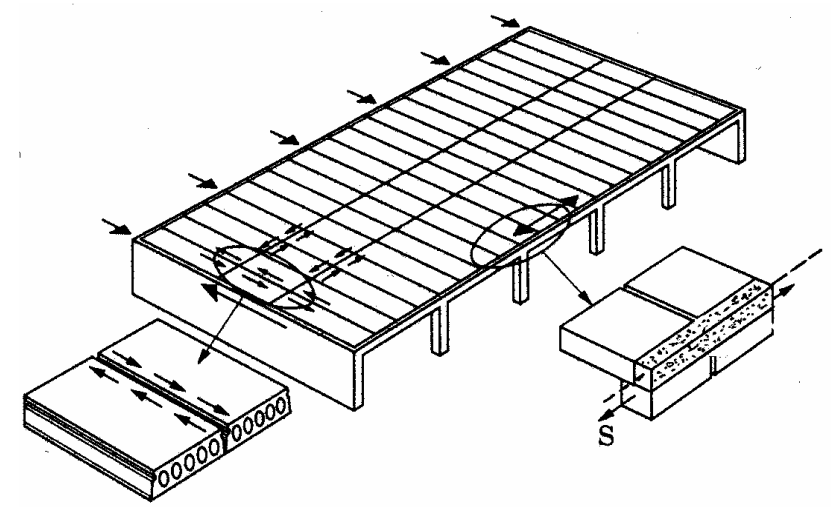

Figura 3.27: Efeito diafragma em pisos pré-moldados. [Elliott (2005)]

De acordo com Elliott (2002), quando é realizado o intertravamento dos elementos de lajes alveolares, a estrutura de piso passa a trabalhar como uma parede, as ações verticais são absorvidas pelos apoios e parte pelas chaves de cisalhamento. Essas chaves asseguram a transferência dos esforços horizontais através do engrenamento longitudinal entre os elementos de laje, gerando o efeito de arco no plano do pavimento (Figura 3.28).

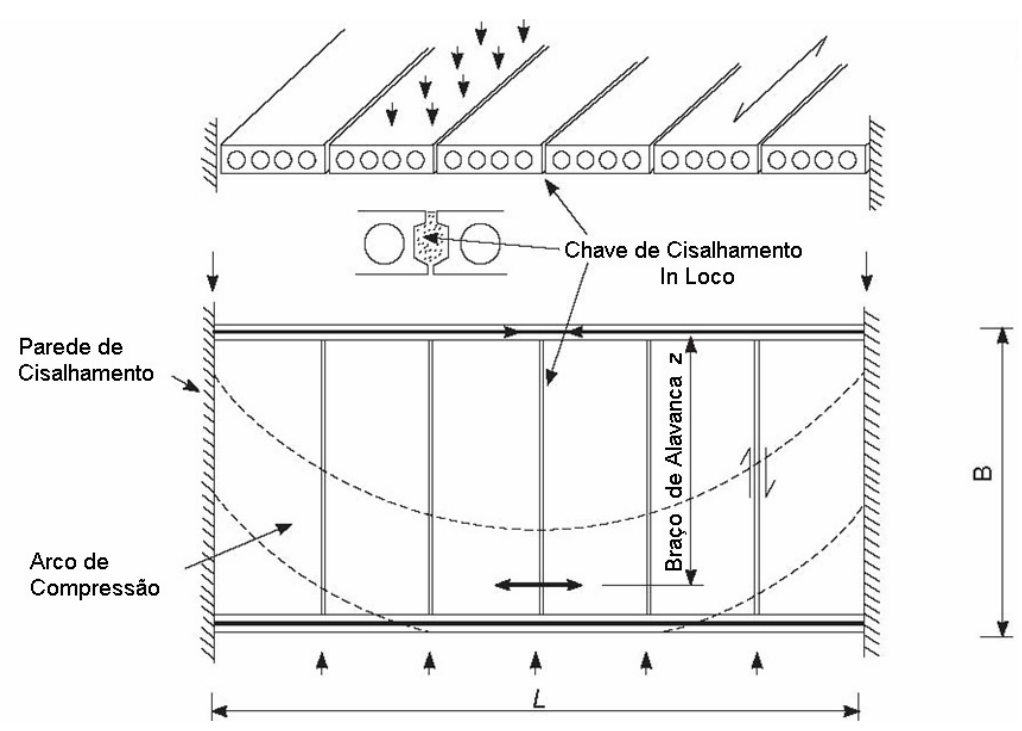

Figura 3.28: Efeito de engrenamento dos elementos de laje alveolar ao formar pavimentos. [Elliott (2002)]

Unidades alveolares são normalmente projetadas como simplesmente apoiadas. A armadura, na forma de cabos pré-tracionados, é posicionada na parte inferior das unidades, para fornecer resistência ao momento positivo. 
Às vezes é colocada armadura na parte superior da unidade, para proteger contra a fissuração devida à flexão que ocorre durante o manuseio, à retração e aos efeitos térmicos. Entretanto, tal armadura não resiste os momentos negativos nos apoios. Para esta finalidade, deve ser colocada armadura através dos apoios, como indicado na Figura 3.29 , com o preenchimento das aberturas e juntas, com concreto moldado no local.
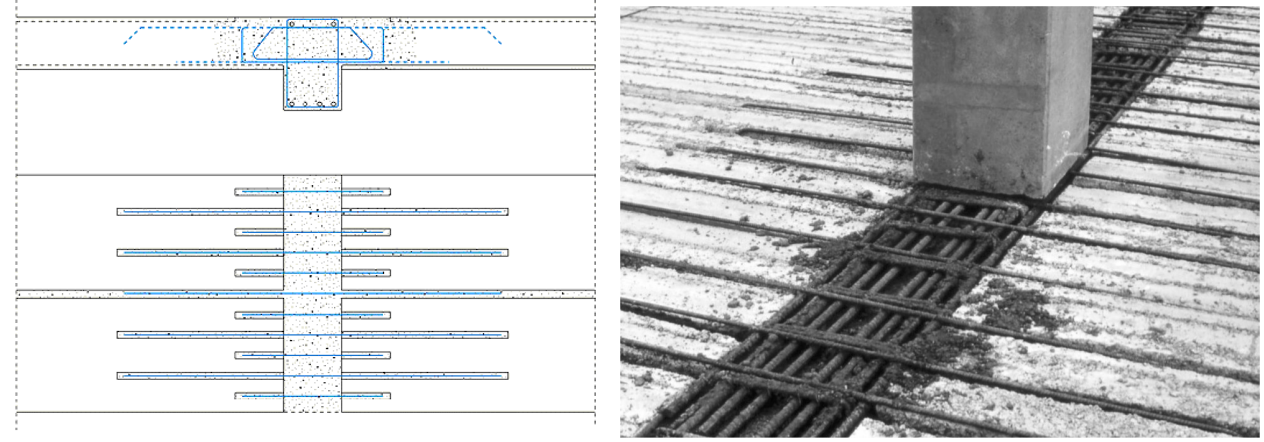

Figura 3.29: Armadura para momento fletor negativo. [Elliott (2005)]

\subsection{MODELOS TEÓRICOS DE CÁLCULO}

A seguir serão apresentadas algumas investigações experimentais que proporcionaram o desenvolvimento dos principais modelos teóricos para cálculo da resistência ao cisalhamento de lajes alveolares sem armadura transversal. Tais dimensionamentos foram estudados por diversos pesquisadores e deram origem às equações atualmente recomendadas por diversas normas.

\subsubsection{Investigações em vigas e lajes}

Inúmeras pesquisas experimentais realizadas por 19 diferentes grupos de investigadores, na segunda metade do século XX (no período de 1959 a 1974), mostraram que o valor de cálculo da força cortante resistente, de peças maciças sem armadura de cisalhamento, depende da resistência do concreto, da taxa de armadura longitudinal de flexão e da espessura da peça. Essa força cortante resistente pode ser expressa por:

$\mathrm{V}_{\mathrm{Rd} 1}=\tau_{\mathrm{Rd} 1} \cdot \mathrm{b}_{\mathrm{w}} \cdot \mathrm{d}$

$\tau_{\mathrm{Rd} 1}$ : valor de cálculo da tensão resistente para peças sem armadura de cisalhamento;

$\mathrm{b}_{\mathrm{w}}$ : largura da alma;

d: altura útil da peça.

\section{- Influência da armadura longitudinal na resistência ao cisalhamento}

De acordo com FUSCO (2008), diversas pesquisas foram desenvolvidas por esses 19 grupos de pesquisadores. 
Primeiramente foi estudada a influência da armadura longitudinal na resistência ao cisalhamento (sendo ensaiadas cerca de 150 vigas e faixas de laje biapoiadas, sem armadura de cisalhamento). Essa influência decorre da capacidade que a armadura longitudinal possui de proporcionar a transferência de esforços diagonais pelo engrenamento dos agregados graúdos ao longo da espessura da peça, além de garantir o efeito de pino, que possibilita a transferência de esforços diagonais através das fissuras, os quais tendem a se ancorar na própria armadura de flexão.

Com $o$ intuito de isolar a influência da taxa de armadura $\left(\rho_{1}=A_{s} / b_{w} \cdot d\right)$ na resistência ao cisalhamento, os resultados foram ajustados em função da altura útil da peça e da resistência do concreto, por meio da variável:

$$
\mathrm{y}_{1}=\frac{\tau_{\mathrm{wu} 1}}{(1,6-\mathrm{d}) \cdot \sqrt{\mathrm{f}_{\mathrm{cc}}}}
$$

$\tau_{\mathrm{wu} 1}$ : igual ao valor experimental $\tau_{\mathrm{vu}}$, com: $\mathrm{k}=1,6-\mathrm{d} \geq 1$ para $\mathrm{d} \leq 0,6 \mathrm{~m}$

A partir dos resultados dessas análises, concluiu-se que os valores referentes à taxa de armadura superiores a $2 \%$ não garantem um aumento significativo da resistência ao cisalhamento. Assim, determinou-se que a influência média da taxa $\rho_{1}$ sobre essa resistência ao cisalhamento é expressa pela regressão linear $y_{1, m}=0,090 \cdot\left(1+52 \cdot p_{1}\right)$.

Com isso, para uma taxa $\rho_{1}$, com $95 \%$ de probabilidade, a sua influência sobre a resistência ao cisalhamento pode ser expressa, de maneira simplificada, por $\alpha=\left(1+50 \rho_{1}\right)$, não se considerando valores de $\rho_{1}$ superiores a $2 \%$.

\section{- Influência da altura útil na resistência ao cisalhamento}

A partir das análises já realizadas, foram desenvolvidos ensaios (em 255 vigas e faixas de lajes biapoiadas, sem armadura transversal) para verificar a influência da altura útil $d$ da peça na resistência ao cisalhamento. Com o intuito de isolar a influência de $d$, os resultados experimentais foram ajustados em função da taxa $\rho_{1}$ (por meio do coeficiente $\left.\alpha=\left(1+50 \rho_{1}\right)\right)$ e da resistência do concreto $\left(f_{c c}\right)$, analisando a influência pela variável $\mathrm{y}_{2}$ determinada experimentalmente e dada por:

$$
y_{2}=\frac{\tau_{\mathrm{wu} 1}}{\left[\left(1+50 \rho_{1}\right) \cdot \sqrt{f_{\mathrm{cc}}}\right.} \quad \tau_{\mathrm{wu} 1} \text { : igual ao valor experimental } \tau_{\mathrm{vu}}, \text { com: } \rho_{1} \leq 2 \%
$$

Segundo Fusco (2008), a importância da altura útil na resistência ao cisalhamento provém de sua influência no controle da abertura de fissuras de flexão. Tal controle, realizado essencialmente pela armadura de flexão, perde sua eficiência à medida que a espessura da peça aumenta, uma vez que a armadura se afasta cada vez mais dos pontos superiores da seção transversal. 
Assim, segundo tais análises experimentais realizadas, a resistência específica ao cisalhamento diminui com o aumento da altura útil.

Com os resultados experimentais observou-se que a influência da altura útil da peça deixa de ser significativa a partir de um valor máximo de 0,6 m. Então, foi obtida a influência média da altura útil d sobre a resistência específica ao cisalhamento, expressa pela seguinte regressão linear: $y_{2, m}=0,090 \cdot(1,75-1,25 . d)$

Pode-se adotar a seguinte expressão simplificada, que está a favor da segurança, particularmente para as lajes de menor espessura: $k=(1,6-d)$ (com d em metros).

\section{- Influência do tipo de carregamento na resistência ao cisalhamento}

Em seguida, foram realizados novos ensaios (em 479 vigas e faixas de laje biapoiadas, sem armadura de cisalhamento) com o intuito de estudar a influência do tipo de carregamento na resistência à força cortante.

Para este caso, os resultados foram ajustados em relação à taxa de armadura longitudinal e à altura útil d da peça, considerando os coeficientes $\alpha=\left(1+50 \rho_{1}\right)$ e $\mathrm{k}=(1,6-\mathrm{d})$ com suas respectivas restrições: $\alpha \leq 2$ e $\mathrm{k} \geq 1$. Para tal análise, estudou-se a influência da distância relativa a/d do carregamento ao apoio, por meio da seguinte variável, considerando primeiramente carregamentos em linha paralela ao apoio:

$$
y_{3}=\frac{\tau_{w u 1}}{(1,6-d)\left(1+50 \rho_{1}\right) \cdot \sqrt{f_{c c}}}
$$

\section{Cargas atuando em linha paralela ao apoio}

Para este caso, considerando as cargas atuando em linha paralela ao apoio, observou-se que:

- Para cargas diretas em linha suficientemente afastada do apoio, a resistência depende apenas do engrenamento dos agregados, do efeito de pino da armadura de flexão e da própria resistência do concreto à tração. Para o caso de cargas afastadas dos apoios $(a>3 d)$, a resistência média da laje ao cisalhamento corresponde a um valor constante, dependente somente de sua espessura e da resistência do concreto à tração (expressa por um número proporcional a $\sqrt{f_{c c}}$ ). Considerando este caso, a regressão linear média corresponde a $\mathrm{y}_{3, \mathrm{~m}}=0,096$, sendo independente da relação a $/ d>3$. O quantil característico de $y_{3}$ corresponde a:

$\mathrm{y}_{3 \mathrm{k}}=\frac{0,096}{1,39}=0,070$

Com todas essas análises, determinou-se o valor da resistência equivalente a:

$\tau_{\text {vuk }}=y_{3 k} \cdot\left(1+50 \cdot \rho_{1}\right) \cdot(1,6-d) \cdot \sqrt{f_{c k}}$ 
Portanto, a expressão resultante das análises, considerando elemento sem armadura de cisalhamento e de concreto armado, para cargas aplicadas em linha paralela ao apoio, corresponde a :

$$
\tau_{\mathrm{Rd} 1}=0,070 \cdot\left(1+50 \cdot \rho_{1}\right) \cdot(1,6-\mathrm{d}) \cdot \sqrt{\mathrm{f}_{\mathrm{ck}}}
$$

- Para cargas diretas em linha próxima do apoio, ocorre uma diminuição da força cortante efetiva, pois uma parcela da carga é equilibrada diretamente por bielas inclinadas que saem da linha de carga seguindo em direção ao apoio. Tal fenômeno particular pode ser interpretado como um aumento fictício da resistência ao cisalhamento próximo aos apoios diretos. Nesse caso, a favor da segurança, admitiuse que a resistência seja a mesma que para cargas afastadas do apoio.

\section{Cargas diretas uniformemente distribuídas}

Para cargas diretas uniformemente distribuídas também é feita uma análise por meio da variável $y_{3}$ anteriormente definida. Nesse caso, considerou-se como variável independente 0 valor ( $L / 2 d)$, sendo $L$ o comprimento do vão da peça. Assim, a regressão média da variável $y_{3}$ corresponde a $y_{3 m}=0,154 \cdot \frac{1}{1-3 d / L}$.

Nesse processo aleatório, para o quantil de $5 \%$ resulta:

$$
\mathrm{y}_{3 \mathrm{k}}=0,099 \cdot \frac{1}{1-3 \mathrm{~d} / \mathrm{L}} \text {. }
$$

A favor da segurança, considerando lajes de pequena espessura relativa, ou seja, $\mathrm{d} \leq \mathrm{L} / 20$, tem-se respectivamente: $\mathrm{y}_{3 \mathrm{~m}}=0,18$ e $\mathrm{y}_{3 \mathrm{k}}=0,11$.

Assim, com tais análises, considerando elemento de concreto armado sem armadura de cisalhamento e carga uniformemente distribuída, a expressão resulta:

$\tau_{\mathrm{Rd} 1}=0,11 \cdot\left(1+50 \cdot \rho_{1}\right) \cdot(1,6-\mathrm{d}) \cdot \sqrt{f_{\mathrm{ck}}}$

Observando as expressões obtidas, verifica-se que a resistência à força cortante, considerando carregamentos uniformemente distribuídos, é cerca de $50 \%$ superior à resistência determinada considerando carregamentos em linha, aplicados longe dos apoios $(0,11 / 0,07=1,57)$. Tal aumento ocorre devido ao fato de que, considerando cargas diretas em linha, mesmo longe dos apoios, a resistência ao cisalhamento depende em grande parte da resistência do concreto à tração. Assim, o carregamento praticamente define o posicionamento da fissura crítica que levará a laje à ruptura. Considerando carregamentos distribuídos, a parcela resistente transmitida pelo banzo comprimido da peça pode se manifestar, permitindo o aumento de resistência constatado experimentalmente. Todas essas análises são descritas por Fusco (2008) e são apresentadas por Hedman \& Losberg (1978). 


\subsubsection{Outras investigações experimentais}

Ainda no século XX (no período de 1974 a 1998), foram realizadas novas investigações experimentais com o intuito de investigar a resistência de vigas de seção retangular, sem a presença de armadura de cisalhamento.

A equação básica adotada para determinar a resistência ao cisalhamento com flexão em elementos sem armadura de cisalhamento, equação essa na qual se acreditou que ela levasse em conta adequadamente os fatores de maior influência, como resistência do concreto, taxa de armadura longitudinal e altura da seção transversal, corresponde a:

$\mathrm{V}_{\mathrm{u}}=\mathrm{C} \cdot \mathrm{k} \cdot\left(100 \cdot \rho_{\mathrm{I}} \cdot \mathrm{f}_{\mathrm{c}}\right)^{1 / 3} \cdot \mathrm{b}_{\mathrm{w}} \cdot \mathrm{d}$

k : fator de escala igual a $1+(200 / d)^{1 / 2}$;

$\rho_{\mathrm{l}}$ : taxa de armadura longitudinal;

$\mathrm{f}_{\mathrm{c}}$ : resistência cilíndrica do concreto à compressão $\left(\mathrm{N} / \mathrm{mm}^{2}\right)$;

C: coeficiente a ser determinado.

Realizou-se uma seleção de um número representativo de ensaios ao cisalhamento, considerando uma variação de parâmetros tão ampla e tão bem distribuída quanto possível, dentro de limites práticos. Isso já foi feito por König \& Fischer (1995). Uma visão geral dos parâmetros testados é dada na Figura 3.30.
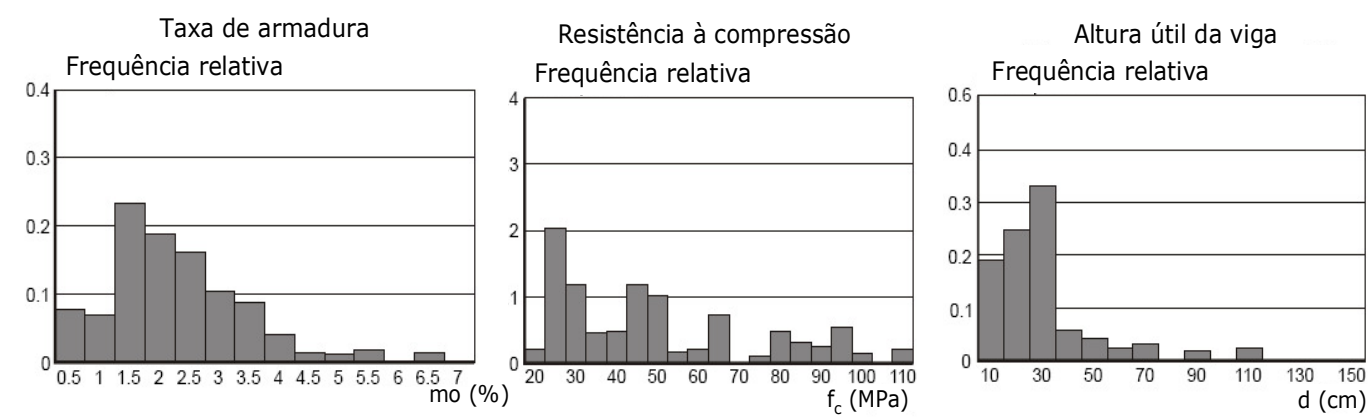

Largura da viga

Frequência relativa

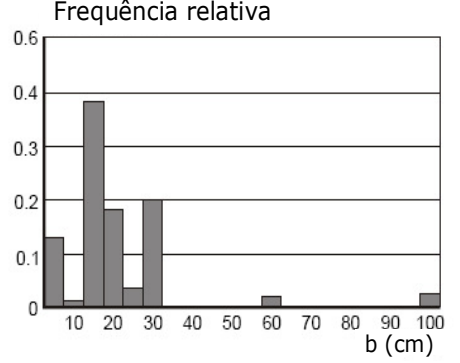

Relação a/d

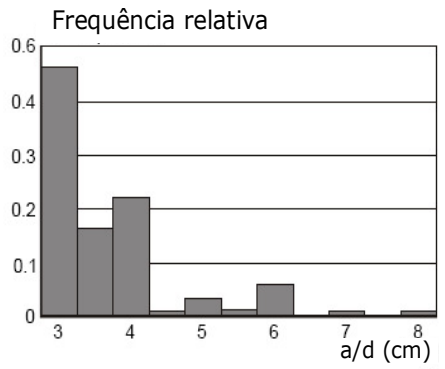

Figura 3.30: Frequência relativa de parâmetros do banco de dados dos ensaios usados por König \& Fischer (1995) 
Como resultado de suas análises, esses pesquisadores descobriram que um coeficiente $C=0,12$ seria um bom limite inferior.

Na Figura 3.31 é mostrado que a precisão dos valores previstos por essa equação é substancialmente melhor do que a da antiga fórmula de EC-1992-1-1. Nessa figura, HSC refere-se ao concreto de elevada resistência, e NSC, ao concreto de resistência normal.

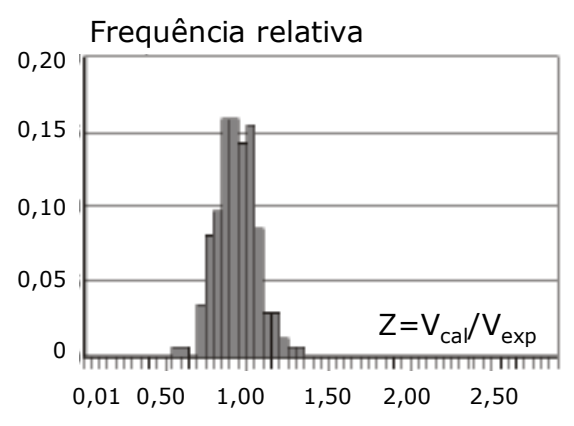

a)

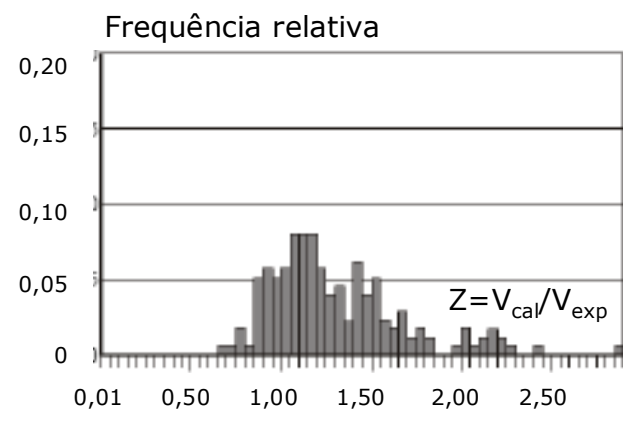

b)

Figura 3.31: a) Resistência ao cisalhamento de acordo com o MC 90: frequência relativa para HSC e

NSC de acordo com König \& Fischer (1995); b) Resistência ao cisalhamento de acordo com EN 1992-1-1: frequência relativa para HSC e NSC de acordo com König \& Fischer (1995).

Como complemento, Reagan (1999) mostra uma avaliação que confirma os achados de König \& Fischer (1995). No entanto, foi argumentado que a equação 3.10 tem duas desvantagens.

$V_{R d, c}=0,12 \cdot k \cdot\left(100 \cdot \rho_{I} \cdot f_{c}\right)^{1 / 3} \cdot b_{w} \cdot d$

A primeira é que ela não faz distinção entre as combinações de carga permanente e acidental, para os quais são aplicados níveis de segurança diferentes. Portanto a equação foi modificada com a introdução do fator de segurança do concreto, resultando em:

$\mathrm{V}_{\mathrm{Rd}, \mathrm{c}}=\left(0,18 / \gamma_{\mathrm{c}}\right) \cdot \mathrm{k} \cdot\left(100 \cdot \rho_{1} \cdot \mathrm{f}_{\mathrm{ck}}\right)^{1 / 3} \cdot \mathrm{b}_{\mathrm{w}} \cdot \mathrm{d}$

A segunda é que a capacidade resistente ao cisalhamento vai para zero quando $\rho_{1}=0$. Além disso, pretendeu-se ter um valor simples para $V_{R d, c}$ em uma primeira verificação da capacidade de carga.

Em muitos países, formulações simples têm sido utilizadas com base em:

$$
\mathrm{V}_{\mathrm{Rd}, \mathrm{c}}=\mathrm{C} \cdot \mathrm{f}_{\mathrm{ctd}} \cdot \mathrm{b}_{\mathrm{w}} \cdot \mathrm{d}
$$

$\mathrm{f}_{\text {ctd }}$ : valor de cálculo da resistência do concreto à tração;

C: coeficiente.

A prática em diversos países, porém, é bem diferente, porque $C$ varia na faixa de 0,3 a 0,75 . Considerando o valor de $C$, pode-se notar que essa equação é uma simplificação de outra mais precisa. 
Para ter validade geral, mesmo para casos raros, mas ainda possíveis, C deveria ser baseado na combinação mais desfavorável de parâmetros. Isso significa que o caso governante corresponde a uma laje com grande altura d da seção transversal e baixa taxa de armadura longitudinal.

Kani (1966) mostrou que é improvável acontecer falhas por cisalhamento para taxas de armaduras longitudinais menores que $0,6 \%$. Entretanto sua análise foi baseada em vigas com altura efetiva da seção transversal de somente $d=270 \mathrm{~mm}$.

Para alturas maiores $o$ valor crítico de $\rho_{0}$ diminui. Portanto, foram selecionadas falhas ao cisalhamento relatadas na literatura, relativas a valores grandes de $\mathrm{d}$ e pequenos de $\rho_{0}$ (Tabela 3.1). O valor mais desfavorável para $C$ corresponde a 0,34 , encontrado nos ensaios de Áster \& Koch (ensaios número 11 e 16), com d = $500 \mathrm{~mm}$ e $\mathrm{d}=750 \mathrm{~mm}$, e $\rho_{0}=0,46$ e $0,42 \%$, respectivamente.

Tabela 3.1: Determinação de C com base nos ensaios selecionados.

\begin{tabular}{|c|c|c|c|c|c|c|c|c|c|c|}
\hline Viga & $\underset{(\mathrm{mm})}{\mathrm{d}}$ & $\begin{array}{c}\mathrm{b} \\
(\mathrm{mm})\end{array}$ & $a / d$ & $\begin{array}{c}\rho_{0} \\
(\%)\end{array}$ & $\begin{array}{c}f_{\mathrm{cm}} \\
(\mathrm{MPa})\end{array}$ & $\begin{array}{l}V_{u, \exp } \\
(\mathrm{MPa})\end{array}$ & $\begin{array}{c}f_{\mathrm{ck}} \\
(\mathrm{MPa})\end{array}$ & $\begin{array}{c}\mathrm{f}_{\mathrm{ctm}} \\
(\mathrm{MPa})\end{array}$ & $\begin{array}{c}f_{\mathrm{ctk}} \\
(\mathrm{MPa})\end{array}$ & C \\
\hline 2 & 250 & 1000 & 3,7 & 0,64 & 27,5 & 0,88 & 19,5 & 2,17 & 1,52 & 0,58 \\
\hline 3 & 250 & 1000 & 3,7 & 0,91 & 27,6 & 0,90 & 19,6 & 2,18 & 1,52 & 0,59 \\
\hline 11 & 500 & 1000 & 3,7 & 0,46 & 28,4 & 0,53 & 20,4 & 2,24 & 1,56 & 0,34 \\
\hline 12 & 500 & 1000 & 3,7 & 0,65 & 27,6 & 0,66 & 19,6 & 2,18 & 1,52 & 0,43 \\
\hline 16 & 750 & 1000 & 3,7 & 0,42 & 28,3 & 0,53 & 20,3 & 2,23 & 1,56 & 0,34 \\
\hline \multicolumn{11}{|c|}{ Walraven (1978) } \\
\hline A1 & 125 & 200 & 3 & 0,83 & 27,5 & 1,19 & 19,5 & 2,17 & 1,52 & 0,78 \\
\hline A2 & 420 & 200 & 3 & 0,74 & 27,5 & 0,84 & 19,5 & 2,17 & 1,52 & 0,55 \\
\hline A3 & 720 & 200 & 3 & 0,79 & 27,5 & 0,70 & 19,5 & 2,17 & 1,52 & 0,46 \\
\hline
\end{tabular}

Então um valor $\mathrm{C}=0,35$ seria apropriado para a equação de projeto simplificado. Em EN 1992-1-1:2001 é usado um valor de 0,40. Um argumento pode ser que a maior parte dos casos práticos é constituída de lajes com pequena altura, submetidas a carga uniforme, onde a força cortante máxima não coincide com o máximo momento, e a taxa de armadura é pequena o suficiente para garantir ruptura por flexão.

O caso raro de uma laje com grande altura, taxa de armadura muito baixa e uma carga em linha na posição mais crítica em relação ao apoio deveria ter uma segurança um pouco menor. Por outro lado a fórmula deveria sempre ser segura o suficiente para levar em conta todos os casos possíveis (não prováveis), o que seria um argumento a favor da utilização de 0,35.

As equações de EN 1991-1-1:2001 contêm também um termo 0,15. $\sigma_{\mathrm{p}}$ relativo à influência de uma força axial na resistência ao cisalhamento, por exemplo a protensão.

Basicamente a influência da protensão pode ser levada em conta como proposto por Hedman \& Losberg (1978). Alegou-se que, com relação ao comportamento ao cisalhamento de uma viga protendida, que após o momento de descompressão ser atingido, ela pode ser considerada como uma viga de concreto armado. 
A partir de ensaios em vigas com seção crítica ao cisalhamento, constatou-se que o termo referente à contribuição da protensão na resistência ao cisalhamento $\left(V_{p}\right)$ corresponderia a um valor entre $0,15 . \sigma_{\mathrm{cp}}$.b.d e $0,25 . \sigma_{\mathrm{cp}}$.b.d.

Assim, o coeficiente 0,15 correspondeu ao limite inferior em regiões críticas ao cisalhamento.

\subsubsection{Cálculo segundo recomendações normativas}

Os cálculos teóricos das lajes alveolares frequentemente consideram a presença da capa de concreto, com espessura média em torno de $50 \mathrm{~mm}$, formando uma seção composta. Essa consideração contribui para o aumento da capacidade resistente à flexão e ao cisalhamento. Entretanto, a rugosidade da laje alveolar influencia na solidarização com a capa, afetando o comportamento do conjunto.

As lajes alveolares são empregadas em diversos países, sendo suas espessuras diferentes para cada tipo de região. No Brasil, são comuns as espessuras entre $150 \mathrm{~mm}$ e 300 mm, enquanto nos EUA e na Europa essas dimensões variam entre 265 mm e 500 $\mathrm{mm}$. Como no Brasil são empregadas lajes com menor altura, em geral, as situações de projeto resultam em mais armadura de protensão, quando comparadas com lajes de mesmos vãos e carregamentos, usadas nos EUA e na Europa.

Assim, é importante observar que existe grande diferença no comportamento das lajes brasileiras, em comparação com as usadas em outros países, o que prejudica a utilização dos mesmos critérios para a avaliação dos elementos.

Nos apêndices A, B e C são apresentados exemplos numéricos para cada tipo de laje ensaiada, sendo descritos todos os métodos de cálculo e as equações empregadas para o dimensionamento das lajes alveolares protendidas.

\section{- Modelo de cálculo recomendado pela NB1-NBR 6118:2003}

A norma brasileira NBR 6118:2003 apresenta uma única expressão (Equação 3.12) para a verificação da resistência ao cisalhamento de lajes alveolares protendidas.

$\mathrm{V}_{\mathrm{Rd} 1}=\left[0,25 \cdot \mathrm{f}_{\mathrm{ctd}} \cdot \mathrm{k} \cdot\left(1,2+40 \rho_{1}\right)+0,15 \cdot \sigma_{\mathrm{cp}}\right] \cdot \mathrm{b}_{\mathrm{w}} \cdot \mathrm{d}$

$\mathrm{V}_{\mathrm{Rd} 1}$ : resistência de projeto ao cisalhamento;

$f_{c t d}$ : resistência à tração de projeto do concreto pré-moldado $f_{c t d}=f_{c t k, \text { inf }} / \gamma_{c}$;

$\rho_{1}$ : taxa de armadura da seção alveolar pré-moldada $\rho_{1}=\frac{A_{s 1}}{b_{w} \cdot d} \leq 0,02$;

$\sigma_{\mathrm{cp}}$ : tensão de compressão do concreto devida à força de protensão $-\sigma_{\mathrm{cp}}=\frac{\mathrm{N}_{\mathrm{sd}}}{\mathrm{A}_{\mathrm{c}}}$;

$\mathrm{k}$ : coeficiente $\mathrm{k}=1,6-\mathrm{d} \geq 1$; 
$\mathrm{A}_{\mathrm{s} 1}$ : área da armadura de tração;

$b_{w}$ : largura mínima da seção ao longo da altura útil d;

$\mathrm{N}_{\mathrm{sd}}$ : força longitudinal na seção devida à protensão ou carregamento (compressão positiva).

Como a NBR 6118:2003 não faz qualquer recomendação quanto ao cálculo do cisalhamento das lajes alveolares protendidas com capa e com alvéolos preenchidos, são feitas considerações nesta pesquisa para o emprego da equação 3.12.

A equação é empregada considerando a altura útil, para o caso sem capa, e altura útil total (altura útil da laje somada a altura da capa), para o caso com capa.

Para o caso das lajes com alvéolos preenchidos, esta pesquisa faz algumas considerações.

Com o preenchimento realizado antes da aplicação da protensão (em fábrica), consideram-se os alvéolos preenchidos, no cálculo da largura das nervuras $\left(b_{w}\right)$, e a área composta (laje com alvéolos preenchidos), no cálculo da tensão de protensão, como pode ser observado na expressão:

$V_{R d 1}^{\prime}=\left[0,25 \cdot f_{c t d} \cdot k \cdot\left(1,2+40 \cdot \rho_{1}^{\prime}\right)+0,15 \cdot \sigma_{c p}^{\prime}\right] \cdot b^{\prime}{ }_{w} \cdot d$

$b_{w}^{\prime}=b_{w}+n \cdot b_{c} \cdot E_{c} / E_{p}$

$\sigma_{c p}^{\prime}=\frac{N_{s d}}{A_{\text {tot }}}$

$\rho_{1}^{\prime}=\frac{A_{s 1}}{b^{\prime}{ }_{w} \cdot d}$

$A_{\text {tot }}$ : área da seção composta, considerando os alvéolos preenchidos;

$\mathrm{n}$ : quantidade de alvéolos preenchidos quando transformados em uma seção retangular equivalente;

$\mathrm{b}_{\mathrm{c}}$ : largura dos alvéolos preenchidos, quando transformados em uma seção retangular equivalente;

Com o preenchimento realizado após a liberação da protensão (em obra), não é considerado o preenchimento na parcela referente à protensão, como pode ser observado na expressão:

$\mathrm{V}_{\mathrm{Rd} 1}^{\prime}=0,25 \cdot \mathrm{f}_{\mathrm{ctd}} \cdot \mathrm{k}^{\mathrm{b}} \mathrm{b}_{\mathrm{w}} \cdot \mathrm{d} \cdot\left(1,2+40 \cdot \rho_{1}^{\prime}\right)+0,15 \cdot \sigma_{\mathrm{cp}} \cdot \mathrm{b}_{\mathrm{w}} \cdot \mathrm{d}$

Como na Europa as lajes possuem maiores alturas, sendo menor a força de protensão introduzida no concreto e consequentemente menor a tensão de tração na nervura, quando comparada com as peças produzidas no Brasil, não é usual o preenchimento dos alvéolos antes da aplicação da protensão. 
Diferentemente do procedimento realizado na Europa, no Brasil é comum a execução do preenchimento dos alvéolos antes da liberação da protensão, possibilitando que maior seção receba as tensões de protensão, evitando tensões de tração excessivas.

Assim, nas peças ensaiadas, como os preenchimentos foram executados antes da liberação da protensão e, portanto, na fábrica, é importante a consideração de tal efeito no desempenho da laje.

Para analisar e adequar a melhor forma de cálculo, quando da consideração dos alvéolos preenchidos, também foram realizados cálculos considerando a contribuição de $2 / 3$ dos alvéolos preenchidos, para os dois casos, com preenchimento na fábrica e na obra, com $b_{w}^{\prime}=b_{w}+n \cdot \frac{2}{3} \cdot b_{c} \cdot E_{c} / E_{p}$.

A partir dos critérios de projeto da NBR 6118:2003 e com base nos modelos clássicos do cálculo de concreto protendido, podem ser determinados o momento de fissuração e o momento fletor último.

A partir dos dados dos materiais e das forças de protensão aplicadas na fabricação, fornecidas pelos fabricantes das lajes analisadas, podem ser determinadas as perdas iniciais e, com base nesses dados, podem ser calculados os valores esperados para as resistências ao cisalhamento e à flexão.

Para a comparação com os resultados experimentais, os valores teóricos das resistências devem ser calculados sem a consideração dos coeficientes de segurança dos materiais. Dessa forma, o coeficiente real de segurança $(\lambda)$ entre o resultado experimental e o teórico pode ser obtido pela equação 3.15 .

$$
\lambda_{V}=\frac{V_{\text {exp }}}{V_{\text {teórico }}} \text { e } \quad \lambda_{M}=\frac{M_{\exp }}{M_{\text {teórico }}}
$$

\section{- Modelo de cálculo recomendado pelo EC2 - EN 1992-1-1:2004 e MC90 - (CEB-FIP 1990)}

De acordo com a norma europeia EN 1992-1-1:2004, em elementos pré-tracionados com um único vão e sem armadura transversal, a força cortante resistente de cálculo em zonas não fissuradas à flexão, ou Tension Shear Capacity, pode ser obtida pela equação:

$\mathrm{V}_{\mathrm{Rd}, \mathrm{c}}=\frac{\mathrm{I} \cdot \mathrm{b}_{\mathrm{w}}}{\mathrm{S}} \cdot \sqrt{\left(\mathrm{f}_{\mathrm{ctd}}\right)^{2}+\alpha_{1} \cdot \sigma_{\mathrm{cp}} \cdot \mathrm{f}_{\mathrm{ctd}}}$

I: momento de inércia da seção;

$\mathrm{b}_{\mathrm{w}}$ : menor largura da seção transversal na área tracionada $(\mathrm{mm})$;

S: primeiro momento de área ou momento estático da seção acima e em relação ao eixo central;

$\alpha_{1}: I_{x} / I_{p t 2} \leq 1$ para armaduras pré-tracionadas, $I_{x} / I_{p t 2}=1$ para outros tipos de protensão; 
$\mathrm{I}_{\mathrm{x}}$ : distância da seção considerada, a partir do ponto inicial do comprimento de transferência;

$I_{p t 2}$ : valor do limite superior do comprimento de transferência do elemento protendido, equivalente a $1,2 . \mathrm{I}_{\mathrm{pt}}$;

$\sigma_{\mathrm{cp}}$ : tensão de compressão do concreto no eixo central, devida à força de protensão;

$\mathrm{f}_{\text {ctd }}$ : resistência de cálculo do concreto à tração.

Considerando elementos pré-tracionados com um único vão e sem armadura transversal, a força cortante resistente de cálculo em zonas fissuradas à flexão, ou Flexural Shear Capacity, pode ser calculada pela expressão:

$V_{R d, c}=\left|C_{R d, c} \cdot k \cdot\left(100 \cdot \rho_{1} \cdot f_{c k}\right)^{1 / 3}+0,15 \cdot \sigma_{c p}\right| b_{w} \cdot d$

Deve ter um valor mínimo de:

$V_{R d, c}=\left(0,035 \cdot k^{3 / 2} \cdot f_{c k}{ }^{1 / 2}+0,15 \cdot \sigma_{c p}\right) b_{w} \cdot d$

$C_{R d, c}=\frac{0,18}{\gamma_{c}}$

$\mathrm{k}=1+\sqrt{\frac{200}{\mathrm{~d}}} \leq 2,0$ com d em mm;

$\rho_{1}:$ taxa de armadura longitudinal $\rho_{1}=A_{s t} /\left(b_{w} \cdot d\right) \leq 0,02 ;$

$A_{s t}$ : área da armadura de tração prolongada de um comprimento $\geq\left(\ell_{\mathrm{bd}}+\mathrm{d}\right)$ além da seção considerada;

$\mathrm{b}_{\mathrm{w}}$ : menor largura da seção transversal na área tracionada $(\mathrm{mm})$;

$\sigma_{\mathrm{cp}}=\mathrm{N}_{\mathrm{Ed}} / \mathrm{A}_{\mathrm{c}}<0,2 . \mathrm{f}_{\mathrm{cd}}(\mathrm{MPa})$;

$\mathrm{N}_{\mathrm{Ed}}$ : força normal na seção devida às ações aplicadas ou à protensão (em $\mathrm{N}$ );

$A_{c}$ : área da seção transversal de concreto $\left(\mathrm{mm}^{2}\right)$;

$\mathrm{V}_{\mathrm{Rd}, \mathrm{c}}$ : força cortante resistente de cálculo (em $\mathrm{N}$ ).

De acordo com a norma EN 1168:2005, para uma laje com capa, o cálculo para a determinação da força cortante resistente de cálculo em zonas fissuradas por flexão, recomendado pelo EC2 (equação 3.17), pode ser feito substituindo $d$ por $d^{\prime}$ (altura útil da seção composta) e $\rho$ por $\rho$ ', sendo:

$\mathrm{d}^{\prime}=\mathrm{d}+\mathrm{h}_{\mathrm{c}} \rightarrow$ com $\mathrm{h}_{\mathrm{c}}$ igual à altura da capa.

$\rho^{\prime}=\frac{A_{p}}{b_{w} \cdot d^{\prime}}$ 
Além disso, para laje com alvéolo preenchido, de acordo com a norma EN 1168:2005, a força cortante resistente de cálculo deve ser obtida considerando a contribuição de apenas $2 / 3$ dos alvéolos preenchidos.

Para o cálculo do cisalhamento em zona fissurada por flexão, o MC90 recomenda a mesma equação que o EC2 (equação 3.17), porém, utilizando $C_{R d, c}=0,12$.

\section{- Modelo de cálculo recomendado pelo ACI - ACI 318:2008}

O emprego de armadura transversal geralmente não é possível para lajes alveolares e, assim, a resistência ao cisalhamento, particularmente para lajes com elevada altura, pode ser limitada pela resistência do concreto ao cisalhamento.

O ACI 318:2008 fornece requisitos para avaliar essa resistência, os quais devem ser usados na medida que o cisalhamento corresponde a um fator controlador no projeto das unidades de lajes alveolares.

De acordo com o ACI 318:2008, a força cortante última $\left(\mathrm{V}_{\mathrm{u}}\right)$ é limitada ao menor valor entre $\phi \mathrm{V}_{\mathrm{ci}}$ (força cortante resistente à fissuração devida ao cisalhamento e à flexão) e $\phi \mathrm{V}_{\mathrm{cw}}$ (força cortante resistente à fissuração da nervura devida ao cisalhamento). Para unidades de laje alveolar simplesmente apoiadas, a força cortante resistente à fissuração devida ao cisalhamento na nervura adjacente ao apoio usualmente não controla o projeto da unidade, exceto quando o projeto incluir elevados carregamentos e cargas não uniformes. $O$ valor de $\phi$ para cálculos de cisal hamento é 0,75 .

A força cortante resistente nominal prevista para o concreto (força cortante resistente à fissuração da nervura devida ao cisalhamento) $V_{c w}$ segundo o ACI 318:2008, é dada pela seguinte expressão:

$V_{c w}=\left(3,5 \cdot \sqrt{f^{\prime}{ }_{c}}+0,3 \cdot f_{p c}\right) \cdot b_{w} \cdot d_{p}+V_{p}$

$\mathrm{f}^{\prime}{ }_{\mathrm{C}}$ : resistência cilíndrica do concreto à compressão $(\mathrm{Psi})$;

$f_{p c}$ : tensão resultante de compressão no concreto no centro da seção transversal (Psi);

$\mathrm{b}_{\mathrm{w}}$ : largura total da nervura (in);

$d_{p}$ : distância da extremidade da fibra comprimida ao centro da armadura protendida, que deve ser maior que $0,8 \mathrm{~h}$ (in);

h: espessura total da laje, incluindo a capa de concreto (in);

$V_{p}$ : componente vertical da força efetiva de protensão (lb).

Quando a seção crítica se encontrar a uma distância menor que h/2 a partir do apoio, pode ser projetada para $V_{u}$ (força cortante última na seção, considerando fatores de segurança) determinada na distância $h / 2$. 
Essa distância $\mathrm{h} / 2$, entretanto, está frequentemente mais próxima da extremidade do elemento do que o comprimento de transferência para o aço protendido. Em tais casos deve ser considerada uma redução da tensão de protensão no cálculo de $\mathrm{V}_{\mathrm{cw}}$. De acordo com o ACI 318:2008, pode-se assumir a tensão de protensão variando linearmente a partir de zero, na extremidade da laje, até $f_{p c}$, ao final do comprimento de transferência.

O valor da força cortante resistente à fissuração devida ao cisalhamento e à flexão $\left(V_{\mathrm{ci}}\right)$ pode ser obtida pela expressão:

$\mathrm{V}_{\mathrm{ci}}=0,6 \cdot \sqrt{\mathrm{f}_{\mathrm{c}}} \cdot \mathrm{b}_{\mathrm{w}} \cdot \mathrm{d}_{\mathrm{p}}+\mathrm{V}_{\mathrm{d}}+\frac{\mathrm{V}_{\mathrm{i}} \cdot \mathrm{M}_{\mathrm{cre}}}{\mathrm{M}_{\max }}$

$\mathrm{V}_{\mathrm{ci}}$ : força cortante resistente nominal do concreto quando a fissuração diagonal resulta da combinação de momento e cisal hamento (Ib);

$V_{d}$ : força cortante na seção devida à carga permanente sem fator de segurança (Ib);

$V_{i}$ : força cortante de cálculo na seção, devida a forças externas, ocorrendo simultaneamente com $\mathrm{M}_{\text {máx }}(\mathrm{lb})$;

$M_{\text {máx }}$ : momento máximo de cálculo na seção devido às forças externas (lb.in);

$M_{c r e}$ : momento que causa a fissuração na seção devido às forças externas (Ib.in),

$M_{\text {cre }}=\left(\frac{I}{y_{t}}\right) \cdot\left(6 \cdot \sqrt{f^{\prime}{ }_{c}}+f_{p e}-f_{d}\right)$

$f_{p e}$ : tensão de compressão no concreto devida ao efeito somente da força de protensão (após todas as perdas), na fibra extrema da seção, onde a tensão de tração é causada por forças aplicadas externamente (Psi);

$\mathrm{f}_{\mathrm{d}}$ : tensão devida à carga permanente, sem fator de segurança, na fibra extrema da seção, onde a tensão de tração é causada pela aplicação de forças externas (Psi);

$\mathrm{y}_{\mathrm{t}}$ : distância do eixo central da seção bruta, desprezando a armadura, até a face tracionada (in).

Nesta pesquisa, são apresentadas comparações entre valores experimentais e teóricos, determinados seguindo as recomendações da NBR 6118:2003, EC2 (2004) e ACI (2008), considerando as lajes sem e com capa.

\subsubsection{Outras recomendações}

O emprego da capa de concreto solidarizada sobre a laje alveolar pode, no projeto, contribuir para a redução de armadura protendida. Além disso, o emprego da seção composta garante um aumento da resistência à flexão, contribui para um acréscimo do momento de inércia, aumenta o efeito de diafragma, com a redução da deslocabilidade lateral do pavimento, e reduz a deformabilidade vertical da laje. 
Com o intuito de considerar no projeto a seção composta, é importante que a solidarização entre a capa e a laje seja verificada por meio de ensaios experimentais de elementos com e sem capa estrutural, sendo os resultados experimentais posteriormente comparados com os obtidos pelos equacionamentos teóricos.

Atualmente, um procedimento que tem sido empregado para aumentar a capacidade resistente ao cisalhamento é o preenchimento dos alvéolos com concreto não-retrátil. Da mesma forma, é importante verificar experimentalmente a parcela da contribuição do preenchimento dos alvéolos.

\section{- Modelo de cálculo recomendado pela FIB (2000)}

O Manual de Projeto para Lajes Alveolares da FIB (2000) apresenta equações para a consideração da contribuição da capa de concreto e do preenchimento dos alvéolos, visando o aumento da resistência ao cisalhamento. Para diferentes situações de lajes, sem e com capa, sem e com preenchimento dos alvéolos, as resistências ao cisalhamento estão apresentadas nas equações de 3.22 a 3.25 .

a) Elemento de laje alveolar sem capa estrutural

$\mathrm{V}_{\mathrm{Rdf}}=0,25 \cdot \mathrm{f}_{\mathrm{ctd}} \cdot \mathrm{b}_{\mathrm{w}} \cdot \mathrm{d} \cdot \mathrm{k} \cdot\left(1,2+40 \rho_{1}\right)+0,15 \cdot \sigma_{\mathrm{cpm}} \cdot \mathrm{b}_{\mathrm{w}} \cdot \mathrm{d} \leq \mathrm{V}_{\mathrm{Rd} 2}$

b) Elemento de laje alveolar com capa estrutural

$\overline{V_{R d f}}=0,25 \cdot f_{c t d} \cdot b_{w} \cdot d^{\prime} \cdot k^{\prime} \cdot\left(1,2+40 \rho_{1}^{\prime}\right)+0,15 \cdot \sigma_{c p m} \cdot b_{w} \cdot d^{\prime} \leq V^{\prime}{ }_{R d 2}$

c) Elemento de laje alveolar sem capa estrutural e com preenchimento dos alvéolos

$\mathrm{V}_{\mathrm{Rdf}}^{\prime}=0,25 \cdot \mathrm{f}_{\mathrm{ctd}} \cdot \mathrm{b}_{\mathrm{w}}{ }_{\mathrm{w}} \cdot \mathrm{d} \cdot \mathrm{k} \cdot\left(1,2+40 \rho_{1}^{\prime}\right)+0,15 \cdot \sigma_{\mathrm{cpm}} \cdot \mathrm{b}_{\mathrm{w}} \cdot \mathrm{d} \leq \mathrm{V}_{\mathrm{Rd} 2}^{\prime}$

d) Elemento de laje alveolar com capa estrutural e alvéolos preenchidos

$\overline{V_{R d f}^{\prime}}=0,25 \cdot f_{c t d} \cdot b_{w}^{\prime} \cdot d^{\prime} \cdot k^{\prime} \cdot\left(1,2+40 \rho_{1}^{\prime}\right)+0,15 \cdot \sigma_{c p m} \cdot b_{w} \cdot d^{\prime} \leq V_{R d 2}^{\prime}$

Nessas equações tem-se:

$A_{p}$ : Área total da seção transversal de aço protendido;

$b_{w}$ : Soma das larguras das nervuras das unidades de lajes alveolares;

$\mathrm{b}_{\mathrm{w}}^{\prime}$ : Soma das larguras das nervuras das unidades de lajes alveolares de seção composta, com alvéolos preenchidos, sendo $b_{w}^{\prime}=b_{w}+n \cdot b_{c} \cdot E_{c} / E_{p}$;

$b_{c}$ : Largura dos alvéolos preenchidos, quando transformados em uma seção retangular equivalente;

$E_{c} / E_{p}$ : Relação entre o módulo de elasticidade do concreto moldado no local e do concreto pré-moldado;

d: $\quad$ Altura efetiva da seção transversal do elemento de laje alveolar;

d': Altura efetiva da seção transversal do elemento de laje alveolar de seção composta; 
$f_{\text {ctd }}$ : Resistência de cálculo do concreto pré-moldado à tração;

$k$ : coeficiente $k=1,6-d \geq 1$ ( $d$ em metros);

$k^{\prime}: \quad$ coeficiente $k^{\prime}=1,6-d^{\prime} \geq 1$ ( $d^{\prime}$ em metros);

n: Quantidade de alvéolos preenchidos quando transformados em uma seção retangular equivalente;

$P_{\infty}: \quad$ Força final de protensão, depois de todas as perdas;

$V_{\mathrm{Rdf}}$ : Força cortante resistente de cálculo em zona de flexão, para lajes sem capa e sem alvéolos preenchidos;

$V^{\prime}{ }_{R d f}$ : Força cortante resistente de cálculo em zona de flexão, para lajes sem capa estrutural e com preenchimento dos alvéolos;

$\overline{V_{R d f}}:$ Força cortante resistente de cálculo em zona de flexão, para lajes com capa estrutural;

$\overline{V_{\text {Rdf }}^{\prime}}$ : Força cortante resistente de cálculo em zona de flexão, para lajes com capa estrutural e com preenchimento dos alvéolos;

$\mathrm{V}_{\mathrm{Rd2}}$ : Valor limite da força cortante resistente de cálculo; $\mathrm{V}_{\mathrm{Rd} 2}=\frac{1}{2} \cdot v \cdot \mathrm{f}_{\mathrm{cd}} \cdot \mathrm{b}_{\mathrm{w}} \cdot 0,9 . \mathrm{d}$; e $v=0,7-f_{c k} / 200 \geq 0,5 ; V^{\prime}{ }_{R d 2}=\frac{1}{2} \cdot v \cdot f_{c d} \cdot b^{\prime}{ }_{w} \cdot 0,9 \cdot d^{\prime} ;$

$\rho_{1}$ : Taxa de armadura da seção alveolar pré-moldada; $\rho_{1}=\frac{A_{p}}{b_{w} \cdot d} ;$

$\rho_{1}^{\prime}$ : Taxa de armadura da seção alveolar pré-moldada composta; $\rho_{1}^{\prime}=\frac{A_{p}}{b^{\prime}{ }_{w} \cdot d^{\prime}}$;

$\sigma_{\mathrm{cpm}}$ : Tensão de compressão do concreto devida à força de protensão; $\sigma_{\mathrm{cpm}}=\frac{\mathrm{P}_{\infty}}{\mathrm{A}}$.

\section{- Modelo de cálculo recomendado por Yang}

De acordo com Pajari (2005), a existência da força de cisalhamento é evidenciada na Figura 3.32. A parte mais baixa da laje tende a se contrair quando os cabos protendidos são liberados. Se a parte inferior (B) e a parte superior (A) são unidas, deve haver tensão de cisalhamento que mantém as partes juntas. Se não existir contato entre $A$ e $B$, ocorre o ilustrado na Figura 3.32b.

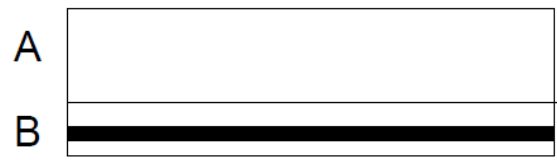

a)

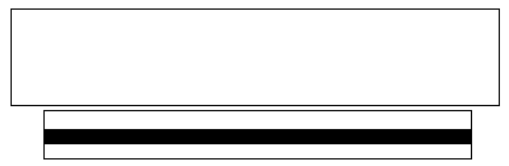

b)

Figura 3.32: Ilustração do que acontece sem tensão de cisalhamento no alívio da força de protensão: a) Antes de soltar os cabos; b) Após soltar os cabos. [Pajari (2005)] 
No caso de uma camada de cabo protendido, Yang (1994) propôs que a tensão de cisalhamento seja calculada com a seguinte equação:

$\tau_{x z}=\frac{1}{b_{w}}\left[\left(\frac{A_{c p}}{A}-\frac{S_{c p} \cdot e}{I_{y}}\right) \cdot \frac{d N_{p}}{d x}+\frac{S_{c p}}{I_{y}} \cdot v_{z}\right]$

$\mathrm{b}_{\mathrm{w}}: \quad$ soma das larguras das nervuras;

$\frac{\mathrm{dN}_{\mathrm{p}}}{\mathrm{dx}}$ : gradiente das forças nos cabos protendidos;

e: excentricidade da força no cabo;

A : área da seção transversal da laje;

$A_{c p}$ : área da seção transversal do concreto acima do eixo considerado;

$\mathrm{S}_{\mathrm{cp}}$ : primeiro momento de área ou momento estático da seção de concreto acima do eixo considerado;

$I_{y}$ : momento de inércia da seção transversal;

$\mathrm{V}_{\mathrm{z}}$ : força de cisalhamento.

O primeiro termo da equação 3.26 é a tensão de cisalhamento $\left(\tau_{t}\right)$ referente à transferência de força de protensão. Portanto, essa tensão é dada por:

$\tau_{t}=\frac{1}{b_{w}}\left(\frac{A_{c p}}{A}-\frac{S_{c p} \cdot e}{I_{y}}\right) \frac{d N_{p}}{d x}$

Da mesma forma, no caso de existir apenas uma camada de cabo, a tensão normal de tração pode ser obtida a partir da equação 3.28.

$\sigma_{x}=-\frac{N_{p}}{A}+\frac{N_{p}}{I_{y}} \cdot e \cdot z-\frac{V_{z}}{I_{y}} \cdot x_{c p} \cdot z$

z: posição da tensão avaliada na seção transversal em relação ao eixo central (z é positivo abaixo do eixo);

$\mathrm{x}_{\mathrm{cP}}$ : coordenada do ponto crítico.

O momento fletor no ponto crítico $\left(\mathrm{M}_{\mathrm{y}}\left(\mathrm{x}_{\mathrm{cp}}\right)\right)$ pode ser expresso, aproximadamente, por: $\mathrm{M}_{\mathrm{y}}\left(\mathrm{x}_{\mathrm{cp}}\right) \approx \mathrm{V}_{\mathrm{z}} \mathrm{x}_{\mathrm{cp}}$.

A ruptura da nervura por tração ocorre se a tensão principal $\left(\sigma_{1}\right)$ no ponto crítico alcançar a resistência do concreto à tração $\left(f_{c t}\right)$, dada por:

$f_{c t}=\sigma_{1}=\frac{\sigma_{x}}{2}+\frac{1}{2} \sqrt{\sigma_{x}{ }^{2}+4 \tau_{x y}{ }^{2}}$ 
Substituindo (3.26) e (3.28) em (3.29) é possível determinar a força cortante resistente da nervura, expressa pela seguinte fórmula:

$V_{R}=\frac{b \cdot I_{y}}{S_{c p}} \cdot\left\{\begin{array}{l}\frac{b}{2 \cdot S_{c p}} \cdot f_{c t} \cdot x_{c p} \cdot z_{c p}+\frac{S_{c p}}{b} \cdot\left(\frac{e}{I_{y}}-\frac{A_{c p}}{A \cdot S_{c p}}\right) \frac{d N_{p}}{d x}+ \\ {\left[\left(\frac{b}{2 \cdot S_{c p}} \cdot f_{c t} \cdot x_{c p} \cdot z_{c p}\right)^{2}+\left(\frac{e}{I_{y}}-\frac{A_{c p}}{A \cdot S_{c p}}\right) \cdot f_{c t} \cdot x_{c p} z_{c p}+\left(\frac{1}{A}-\frac{z_{c p} \cdot e}{I_{y}}\right) \cdot N_{p} \cdot f_{c t}+f_{c t}{ }^{2}\right]^{\frac{1}{2}}}\end{array}\right\}$

$\mathrm{h}_{\mathrm{cp}}$ : distância entre o ponto crítico e a superfície inferior da unidade de laje alveolar;

$x_{c p}, z_{c p}$ : coordenadas do ponto crítico, sendo $x_{c p}=h_{c p} / \tan \beta, \beta \approx 35^{\circ}$;

$\mathrm{f}_{\mathrm{ct}}$ : resistência do concreto à tração;

$A_{c p}$ : área acima do ponto crítico;

$\mathrm{S}_{\mathrm{cp}}$ : primeiro momento de área ou momento estático da seção acima do ponto crítico;

$\mathrm{N}_{\mathrm{p}}$ : força de protensão das cordoalhas, no ponto crítico;

e: distância do centro das cordoalhas de protensão ao centro da seção transversal;

b : largura total das nervuras da unidade de laje, no ponto crítico;

A : área de toda a seção transversal;

$I_{y}$ : momento de inércia.

Os símbolos geométricos estão ilustrados na Figura 3.33.

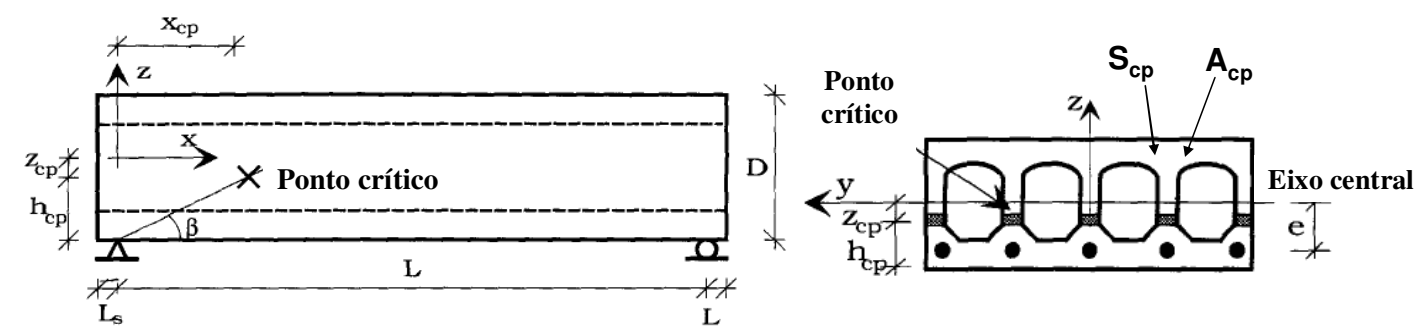

Figura 3.33: Parâmetros geométricos da seção transversal considerada. [Yang (1994)]

Yang (1994) realizou uma calibração com análise por elementos finitos, a qual mostra que a posição $(x, z)$ mais crítica, próxima ao apoio, é encontrada ao longo de uma linha inclinada com ângulo de $35^{\circ}$ em relação ao eixo horizontal. Acima dessa linha inclinada, a ruptura por tração devida ao cisalhamento não é crítica, por conta da influência da tensão de compressão vertical próxima ao apoio. Mais distante do apoio, dentro da região não fissurada, todos os pontos da nervura devem ser verificados.

De acordo com Yang (1994), a tensão de compressão vertical devida à reação do apoio é levada em consideração como mostrado na Figura 3.34. 
Escolhendo pontos próximos ao longo da linha, denominados pontos considerados, e calculando a tensão principal máxima em cada um deles, o ponto crítico onde a tensão principal tem seu valor máximo pode ser determinado para cada caso de carregamento. Pela variação da carga, é determinada a resistência de cisalhamento da nervura.

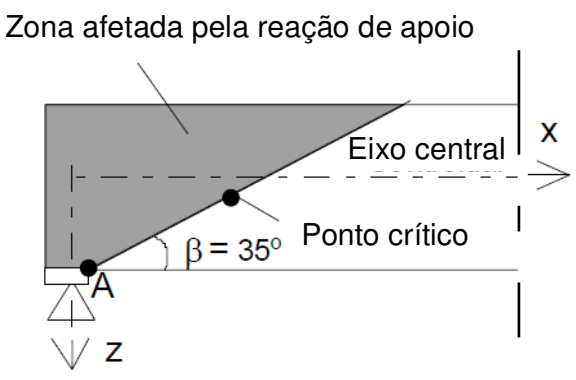

a)

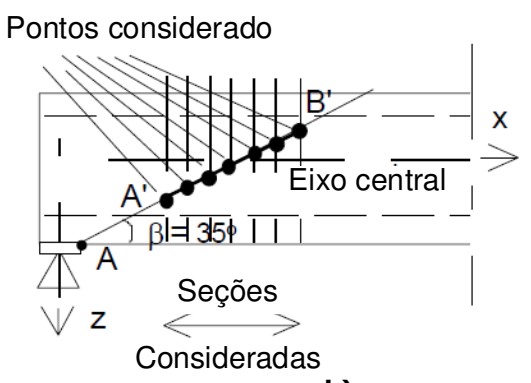

b)

Figura 3.34: a) Possível localização do ponto crítico próximo à região afetada pela reação do apoio; b) Pontos e seções levadas em consideração nos cálculos. [Pajari (2005)]

\section{- Modelo de cálculo recomendado por Collins et al. (2008)}

De acordo com Collins et al. (2008), para elementos sem armadura transversal, a resistência ao cisalhamento pode ser determinada pela seguinte expressão:

$$
V_{c}=\frac{0,4}{\left(1+1500 \cdot \varepsilon_{x}\right)} \cdot \frac{1300}{\left(1000+s_{x e}\right)} \cdot \sqrt{f^{\prime}{ }_{c}}
$$

$\mathrm{f}_{c}^{\prime}$ : resistência cilíndrica do concreto à compressão. Para concretos de elevada resistência o valor de $\sqrt{f^{\prime}}$ não deve ser maior que $8 \mathrm{MPa}$.

O parâmetro $s_{x e}$, termo que leva em consideração a influência do tamanho do agregado, $a_{g}$, é determinado pela seguinte equação:

$$
s_{x e}=\frac{35}{16+a_{g}} \cdot s_{x} \geq 0,85 \cdot s_{x}
$$

$S_{\mathrm{x}}$ : espaçamento da fissura que pode ser considerado igual a $d_{\mathrm{v}}$, para elementos com armadura longitudinal somente no lado tracionado pela flexão, como no caso das lajes alveolares $\left(s_{x} \approx d_{v}=0,9 . d\right)$.

$\mathrm{a}_{\mathrm{g}}$ : tamanho máximo do agregado graúdo, que deve ser considerado igual a zero para concreto de elevada resistência ( $f_{c k}>70 \mathrm{MPa}$ ) ou concreto leve, de acordo com Collins et al. (2008) (em mm).

Para um elemento que possui armadura de protensão reta em relação ao eixo, Collins et al. (2008) recomenda que a deformação longitudinal,$\varepsilon_{x}$, seja calculada pela seguinte expressão: 
$\varepsilon_{x}=\frac{V \cdot\left(1+M / V \cdot d_{v}\right)+0,5 \cdot N-A_{p s} \cdot f_{p 0}}{2 \cdot\left(E_{s} \cdot A_{s}+E_{p} \cdot A_{p s}\right)}$

$\varepsilon_{x}$ : deformação longitudinal na metade da altura do elemento, onde a tensão de cisalhamento é considerada $\mathrm{V} /\left(\mathrm{b}_{\mathrm{w}} \mathrm{d}_{\mathrm{v}}\right)$;

M: momento fletor;

$\mathrm{N}$ : carga axial;

$A_{s}$ : área da armadura longitudinal tracionada pela flexão;

$A_{p s}$ : área da armadura protendida localizada no lado tracionado pela flexão;

V: força cortante;

$\mathrm{E}_{\mathrm{p}}$ : módulo de elasticidade do aço protendido;

$\mathrm{d}_{\mathrm{v}}$ : altura de cisalhamento ou braço de alavanca à flexão, adotado igual a 0,9d;

$b_{\mathrm{w}}$ : largura da nervura;

$f_{p 0}$ : tensão no aço protendido quando é nula a deformação do concreto ao redor.

A partir dessas equações, pode-se observar que a resistência ao cisalhamento é extremamente sensível ao valor do comprimento de transferência $\left(I_{t}\right)$. Isso torna difícil o dimensionamento das unidades alveolares, pois esse comprimento $I_{t}$ é difícil de ser determinado com precisão, uma vez que esse valor varia de $50 \phi$ a $84 \phi$ (de acordo com recomendações do ACI (2008) e de ASSAP (2002)).

\subsubsection{Críticas à equação recomendada para lajes sem capa}

O EC2-Comentary (2008) critica a equação para lajes sem capa (a qual é recomendada tanto pela FIB (2000) quanto pela NBR 6118:2003), indicando dois problemas no que diz respeito ao uso dessa equação. Primeiramente, o papel da resistência do concreto não está correto. Segundo o EC2-Comentary (2008), para classes de concreto de menor resistência, os desvios não são muito grandes, mas se a resistência aumenta, os desvios rapidamente alcançam um nível inaceitável.

Além disso, de acordo com o EC2-Comentary, outro problema dessa equação é que ela foi obtida principalmente para vigas, que rompem por cisalhamento com flexão, e não é válida para elementos que geralmente rompem por tração devida ao cisalhamento.

Entretanto, tais críticas à equação recomendada pela FIB (2000) para lajes sem capa são baseadas nas análises referentes aos tipos de unidades alveolares comumente empregadas na Europa. Assim, cabe ressaltar que tais lajes possuem características muito distintas dos elementos empregados no Brasil, tanto no que diz respeito à geometria, protensão e resistência do concreto como também quanto ao comportamento desses elementos nas proximidades da ruína. 


\subsubsection{Interação cisalhamento-flexão}

Elementos lineares, como vigas ou elementos de lajes unidirecionais, são normalmente sujeitos a ação de carregamento transversal na qualidade de cargas concentradas, cargas distribuídas ou pela combinações dos dois tipos. Em cada seção ao longo do elemento linear, momento fletor e força cortante podem ser identificados para cada situação de carregamento. Na seção transversal com o maior momento fletor, normalmente a força cortante é zero. Dependendo da situação de carregamento, entretanto, em outras seções tem-se ambos: momento fletor e força cortante. Em alguns casos pode haver contribuição substancial desses dois esforços.

Os mecanismos resistentes que governam o cisalhamento e a flexão, na mesma posição ao longo de um elemento linear, podem não ser totalmente independentes uns dos outros. Se a flexão não é desprezível no estado limite último, provavelmente aparecerão fissuras de flexão, e a força cortante, no mesmo local, tem que ser resistida na região fissurada por flexão.

De acordo com Lindström (2007), quando ambos, cisalhamento e flexão, estão presentes, eles não podem ser, independentemente, totalmente utilizados na mesma posição, e isto indica que a ação combinada necessita satisfazer à seguinte condição de interação para cada posição, na região fissurada por flexão:

$\left(\frac{V_{x d}}{V_{R d, S F}}\right)^{2}+\left(\frac{M_{x d i}}{M_{R d}}\right)^{2} \leq 1$

$\mathrm{V}_{\mathrm{Rd}, \mathrm{SF}}$ : Força cortante resistente de cálculo, para seções fissuradas por flexão;

$M_{R d}$ : Momento resistente de cálculo, em região onde as cordoalhas são totalmente ancoradas por aderência;

$\mathrm{V}_{\mathrm{xd}}$ : Força cortante atuante na ruptura, para seção fissurada por flexão, na posição "x" (obtida no ensaio);

$M_{x d i}$ : Momento fletor atuante na ruptura, na posição " $x$ " (obtido no ensaio).

De acordo com Lindström (2009), uma rápida melhoria pode ser conseguida tornando a relação de utilização combinada linearmente dependente do efeito da carga, mantendo o mesmo critério de ruptura. Isso pode ser feito ajustando a equação para:

$$
\left[\left(\frac{V_{x d}}{V_{R d, S F}}\right)^{n}+\left(\frac{M_{x d i}}{M_{R d}}\right)^{n}\right]^{1 / n} \leq 1
$$

n: coeficiente variável 


\subsection{ENSAIOS PARA AVALIAÇÃO DE LAJES ALVEOLARES}

Lajes alveolares são elementos com características únicas e específicas. Segundo Van Acker (2007), quando surgiram essas lajes alveolares, primeiro se desenvolveu o processo de fabricação, e depois vieram as pesquisas para a evolução dos modelos de cálculo. Sendo assim, inicialmente os procedimentos usados para lajes protendidas com seções retangulares foram adaptados para as lajes alveolares, e empregados com auxílio da verificação experimental. Por essa razão, existiu uma grande preocupação com a padronização dos ensaios na Europa, nos anos 1980.

Devido ao fato de essas lajes não apresentarem armadura transversal, dependendo exclusivamente da qualidade da ancoragem por aderência das cordoalhas protendidas e da resistência do concreto à tração, há necessidade de um rigoroso controle de qualidade para este tipo de produto. Por essa razão, os manuais da FIP (1982) recomendam que os fabricantes de lajes alveolares tenham um procedimento de ensaio reconhecido e instalações para testes regulares, como parte da planta da fábrica.

\subsubsection{Ensaio de cisalhamento}

A resistência das lajes alveolares ao cisalhamento está totalmente relacionada com a resistência do concreto à tração, uma vez que esse tipo de laje não possui qualquer armadura transversal. Além disso, a resistência ao corte também é diretamente influenciada pela forma geométrica dos alvéolos, pela dosagem do concreto e pelo processo de fabricação. A resistência do concreto à tração é difícil de ser determinada a partir de métodos tradicionais, e a influência da forma da seção transversal e do método de fabricação não pode ser determinada diretamente.

Assim, foi desenvolvido um ensaio padrão para determinar a resistência das lajes alveolares ao cisalhamento, para verificar o funcionamento da extrusora e, também, para determinar alguns parâmetros relacionados à capacidade resistente de apoio. Tal ensaio padrão é indicado no manual da FIP (1992) e na norma europeia EN1168-2005.

A peça a ser ensaiada deve ser um elemento de largura real, com vão de $4 \mathrm{~m}$ ou $15 \mathrm{~h}$ (sendo $\mathrm{h}$ a altura total), prevalecendo o maior valor. $\mathrm{O}$ ensaio deve ser realizado em temperatura entre $0^{\circ} \mathrm{C}$ e $40^{\circ} \mathrm{C}$. Para obter valores de referência da resistência do concreto, testemunhos devem ser extraídos do elemento. Ao invés desses testemunhos, cubos ou cilindros também podem ser usados como referência para o valor da resistência, mas apenas sob a condição de que seja provado que a compactação deles esteja de acordo com a compactação da laje, pela comparação de densidade.

A transferência de força para a laje deverá ser realizada por uma viga rígida, de preferência metálica (Figura 3.35a e Figura 3.35b), com altura mínima de 150 mm, mas é indicado o uso de $250 \mathrm{~mm}$ no caso de ser utilizado um macaco hidráulico. 


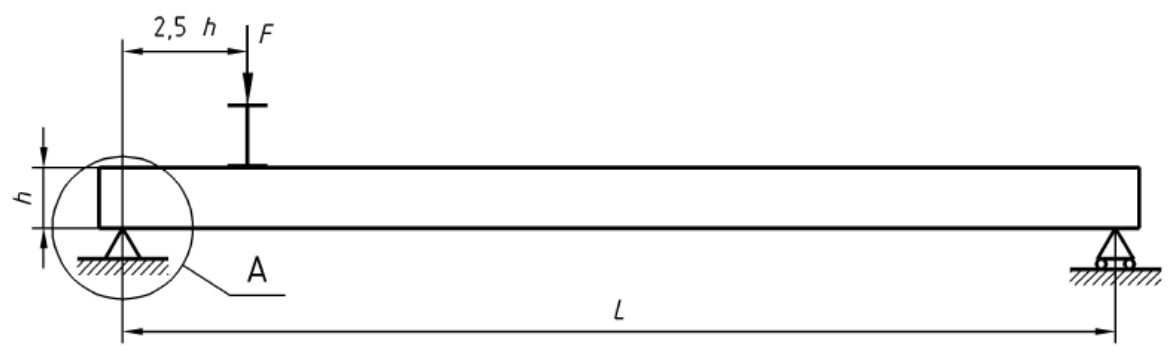

a) Uma linha de aplicaçãode força

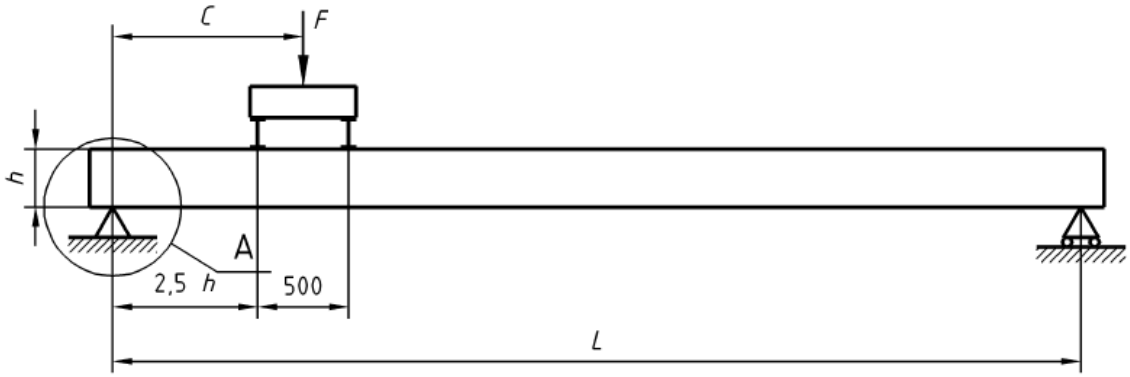

b) Duas linhas de aplicação de força

A

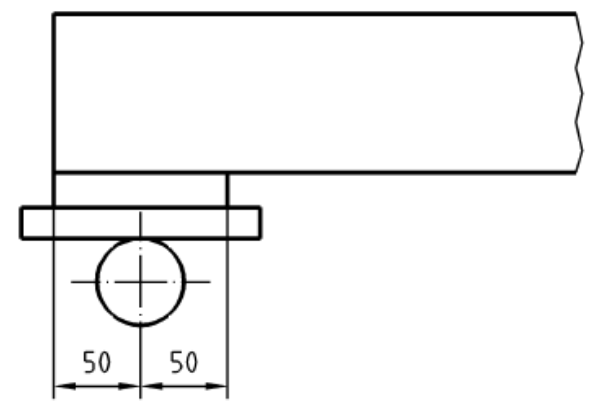

c) Detalhe do apoio em a) e b)

Figura 3.35: Possíveis arranjos para o ensaio. [EN 1168:2005]

As amostras a serem ensaiadas devem ser produzidas na mesma pista de concretagem e com o mesmo concreto empregado na produção efetiva das lajes.

A fim de obter um efeito desfavorável da flexão sobre o mecanismo de resistência ao cisalhamento, tal ensaio padrão estabelece que o carregamento seja aplicado a uma distância de 2,5 h do apoio (h é a altura da laje).

Ao longo de toda a largura deverá haver uma distribuição uniforme de forças. O apoio mais próximo do ponto de aplicação da carga deve ser móvel, de forma que nenhuma força axial seja gerada pela rotação do elemento no apoio. Entre o elemento e a viga de apoio, pode ser empregado um material para a distribuição de cargas. Tal material pode ser: madeira compensada de espessura $10 \mathrm{~mm}$, neoprene ou uma faixa de argamassa ou de gesso. Esse material deve compensar as irregularidades da superfície da laje e alguma eventual curvatura do elemento na direção transversal (Figura 3.35c). 


\section{- Caracterização do concreto}

Segundo a FIP (1992), os valores característicos da resistência do concreto podem ser determinados a partir de ensaios de compressão normal e compressão diametral realizados com três a seis testemunhos cilíndricos, os quais devem ser ensaiados imediatamente após serem extraídos. Eles devem ser retirados de um pedaço da laje alveolar a ser ensaiada, sendo essa faixa com comprimento variando entre $50 \mathrm{~mm}$ e 200 $\mathrm{mm}$. Quando a resistência do concreto é determinada antes da liberação da protensão, esse trecho de laje pode ser serrado da extremidade da laje na pista de protensão, e o testemunho deve ser extraído da parte superior da laje alveolar. Segundo a FIP (1992), o desvio padrão dos ensaios dos corpos de prova extraídos é maior do que os corpos de prova cúbicos ou cilíndricos.

Para controle de qualidade, os testemunhos devem ser extraídos conforme apresentado na Figura 3.36 e mantidos sob condições úmidas. Então, são determinadas as resistências à compressão e ao fendilhamento por tração, de acordo com padrões internacionais.

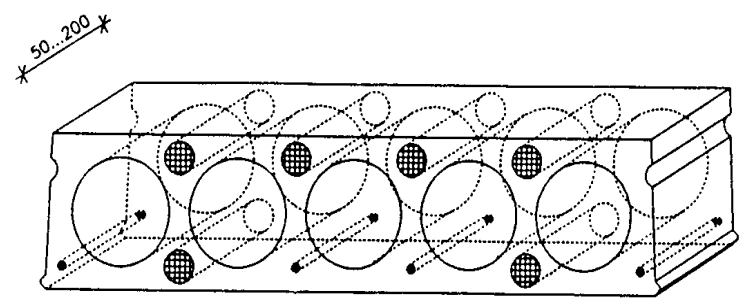

Figura 3.36: Amostra para extração de corpos de prova. [FIP (1992)]

A extração dos corpos de prova deve ser realizada com o emprego de equipamentos próprios para essa finalidade, como pode ser observado na Figura 3.37.

De modo geral, para lajes produzidas por extrusão, os testemunhos extraídos da parte inferior da laje apresentam valores de resistência um pouco maiores que os da parte superior da laje, em virtude de haver um grau de compactação maior na região inferior da laje.
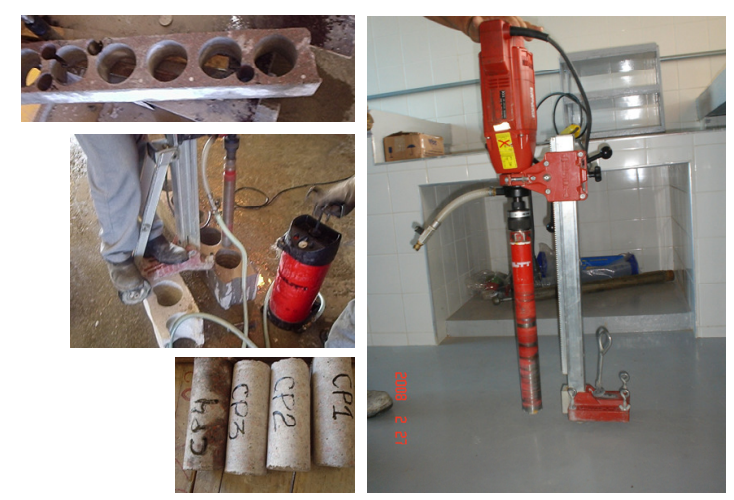

Figura 3.37: Equipamento para a extração de testemunhos de concreto. 
A qualidade do concreto pode ser determinada por ensaios de corpos de prova moldados, cúbicos, cilíndricos ou prismáticos, sendo importante que o concreto das amostras seja o mesmo utilizado na laje. Devido ao fato do concreto ser muito seco, é necessário vibrar o concreto na moldagem dos corpos de prova. Procurando solucionar esse problema, existem equipamentos na Europa que permitem reproduzir, com boa aproximação, a compactação do concreto usado na laje, que passou pelo processo de extrusão, conforme apresentado na Figura 3.38.
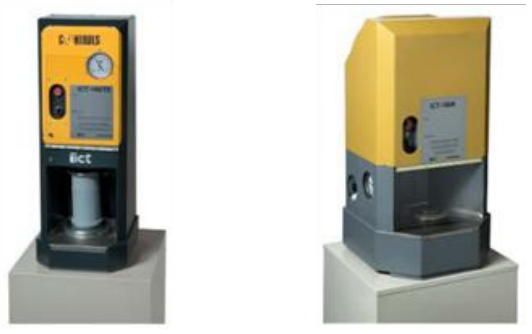

Figura 3.38: Equipamentos utilizados em ensaio de compactação de concreto com baixa trabalhabilidade [Invelop Oy (2009)]

\subsubsection{Ensaio de flexão}

Com o intuito de obter informações sobre a força de protensão e a resistência do concreto à tração na flexão, a parte remanescente da laje pode ser aproveitada para a realização de um ensaio posterior.

De acordo com a FIP (1992), é recomendado um ensaio de flexão padrão, que é realizado com uma laje de vão equivalente a $3 \mathrm{~m}$, sendo a força aplicada no meio do vão, como pode ser observado na Figura 3.39.

Durante o ensaio, a força deve ser aumentada até ocorrerem fissuras por flexão. A partir daí, a laje é descarregada e novamente carregada. Assim, quando o momento de descompressão $\left(\mathrm{M}_{0}\right)$ for atingido, as fissuras abrirão novamente.

Por meio do momento de fissuração $\left(M_{r}\right)$ e do momento de descompressão $\left(M_{0}\right)$, é possível obter a resistência à tração na flexão $\left(f_{c t f}\right)$ e a tensão de protensão no aço $\left(\sigma_{p}\right)$, com o emprego das seguintes equações:

$$
\begin{aligned}
f_{c t f} & =\frac{M_{r}-M_{0}}{W} \\
\sigma_{p} & =\frac{M_{0}}{A_{p}\left(\frac{W}{A_{c}}+e\right)}
\end{aligned}
$$

Nessas equações tem-se:

$A_{p}$ : área total da seção transversal de aço protendido;

W : módulo de resistência da seção; 
$A_{c}$ : área total da seção transversal do concreto;

e: excentricidade dos cabos protendidos.
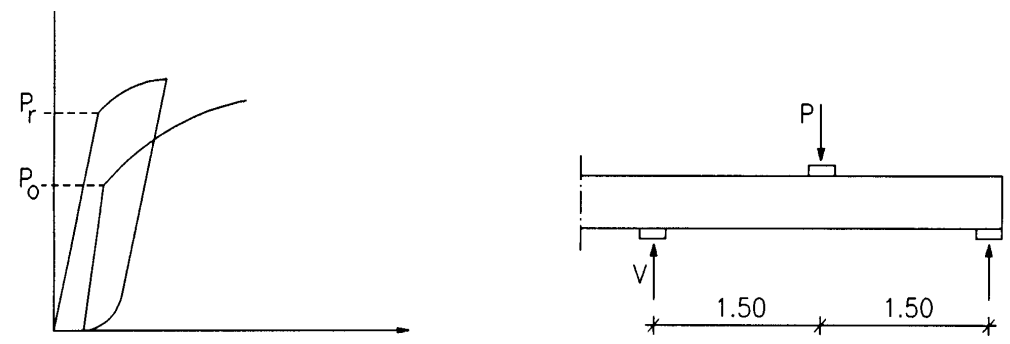

Figura 3.39: Ensaio para determinação da resistência do concreto à tração na flexão e da tensão de protensão no aço. [FIP (1992)]

\subsubsection{Ensaio com interação de cisalhamento e flexão}

De acordo com a FIP (1982), pode-se realizar a investigação experimental de uma laje, com ruptura pela interação de cisalhamento com flexão, em um ensaio com a aplicação de somente uma força, a uma distância de $1 \mathrm{~m}$ ou o equivalente a $5 \mathrm{~h}$ a partir do apoio, em uma laje de comprimento de $3 \mathrm{~m}$, como pode ser observado na Figura 3.40 .

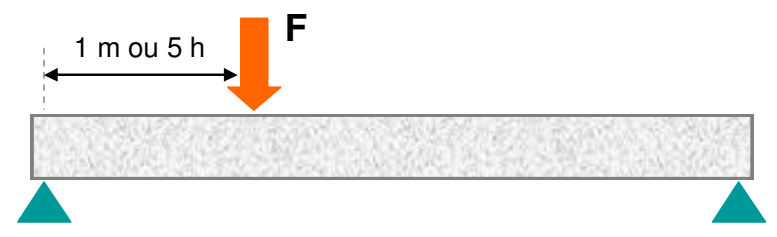

Figura 3.40: Ensaio indicado para observar a interação de flexão com cisalhamento. 
Inúmeras pesquisas foram realizadas com relação às lajes alveolares em todo mundo. $\mathrm{Na}$ Europa foi desenvolvido um projeto de pesquisa denominado HOLCOTORS. Esse projeto tinha como objetivo desenvolver métodos numéricos para a análise e métodos simplificados para o projeto de lajes alveolares protendidas submetidas ao cisalhamento e à torção. Os modelos de cálculo foram desenvolvidos pela Universidade de Tecnologia de Chalmers, na Suécia. Os ensaios usados para a verificação dos modelos foram realizados e documentados pelo Centro de Pesquisa Técnica (VTT), da Finlândia. A seguir serão descritas algumas pesquisas realizadas nesse Centro de Pesquisa e em outras partes do mundo.

\subsection{PAJARI E YANG (1994)}

Pajari e Yang (1994), realizaram diversos ensaios de cisalhamento em unidades de laje alveolar. O objetivo dos ensaios era estudar o efeito do preenchimento dos alvéolos na capacidade resistente ao cisalhamento vertical de lajes alveolares submetidas a forças verticais e horizontais. Esse tipo de situação ocorre quando as lajes são apoiadas em vigas flexíveis. O objetivo também era verificar se os custos dos ensaios de piso poderiam ser simulados com a utilização de alternativas mais simples e baratas.

Dois diferentes tipos de lajes alveolares foram submetidos a duas forças, uma vertical e outra horizontal, como mostrado na Figura 4.1.

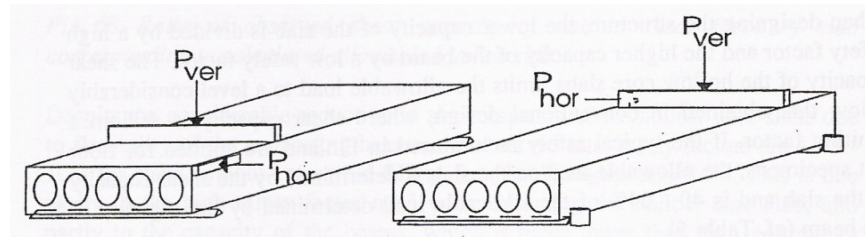

Figura 4.1: Esquema do carregamento do ensaio. [Pajari e Yang (1994)]

Na Figura 4.2 pode-se observar o arranjo do ensaio de cisalhamento, com a indicação dos equipamentos utilizados e das características mais importantes pertinentes ao ensaio. Nesta figura também é possível observar a utilização de um aparato de concreto para distribuição da força aplicada, que apresenta variação do comprimento $\left(L_{c 1}\right)$ dependendo do modelo ensaiado. 

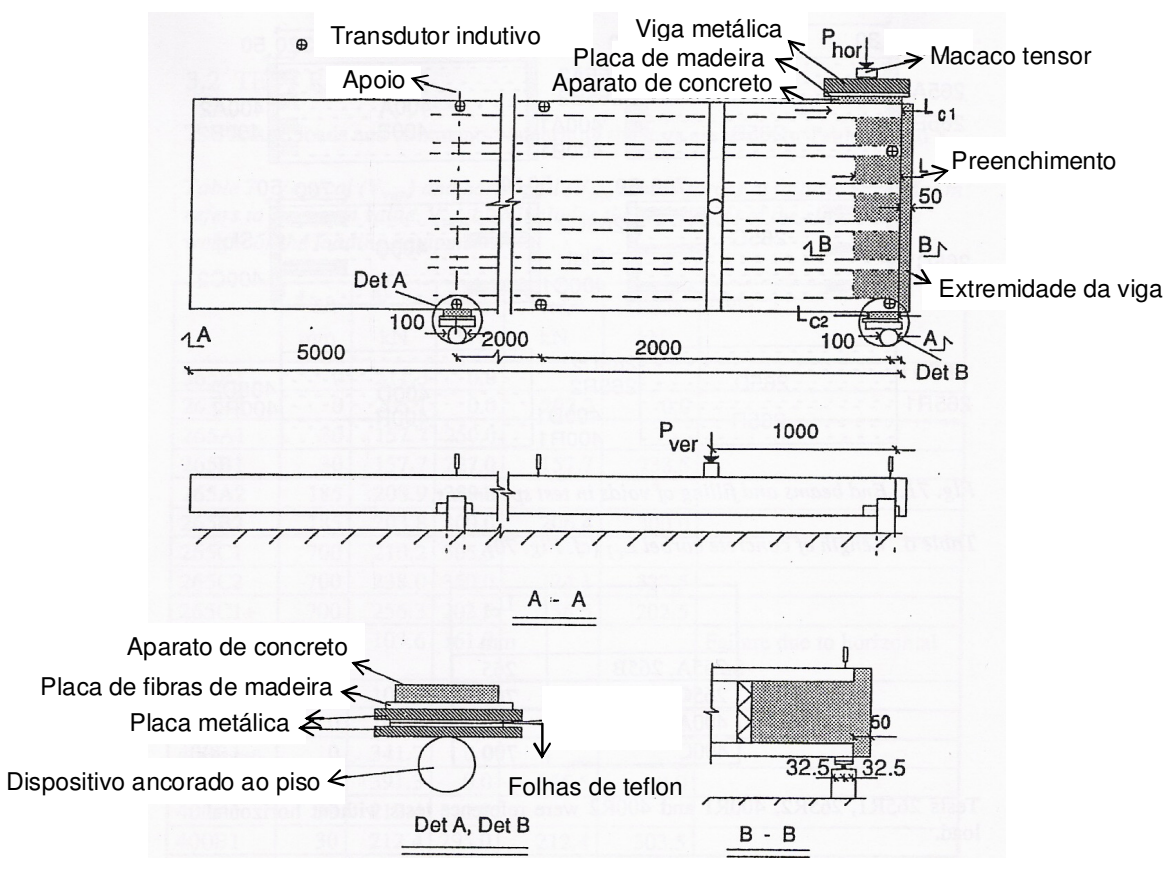

Figura 4.2: Arranjo do ensaio de cisalhamento (medidas em mm). [Pajari e Yang (1994)]

As seções transversais nominais dos dois tipos podem ser observados na Figura 4.3. As lajes de altura $265 \mathrm{~mm}$ possuíam 10 cordoalhas, e as de $400 \mathrm{~mm}, 11$ cordoalhas. Essas cordoalhas tinham 12,7 mm de diâmetro, com área da seção transversal 93 mm². De acordo com o fabricante das lajes, a protensão inicial nas cordoalhas foi de $1100 \mathrm{MPa}$. Todas as lajes de mesma espessura foram retiradas de um mesmo lote.
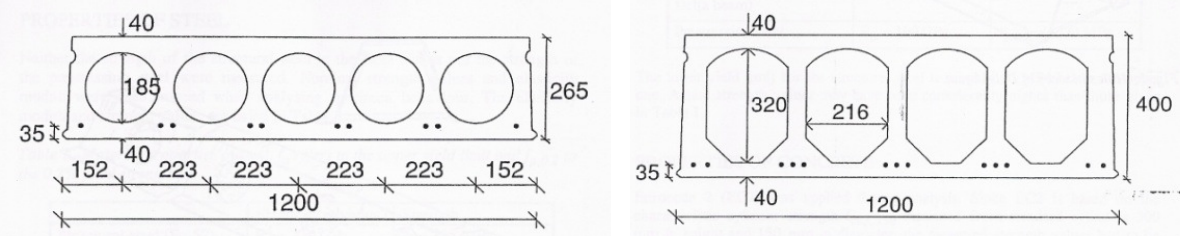

Figura 4.3: Seção transversal nominal dos dois tipos de laje estudados. [Pajari e Yang (1994)]

Foram usados dois tipos principais de amostra: uma em que os alvéolos não foram preenchidos e outra em que eles foram parcialmente preenchidos com concreto. Foram utilizados três comprimentos de preenchimento ( $L_{\text {ench }}$ ): um pequeno (cerca de $30 \mathrm{~mm}$ ); um médio (cerca de $185 \mathrm{~mm}$ e $320 \mathrm{~mm}$ ); e um grande (cerca de $700 \mathrm{~mm}$ ).

Para compactar corretamente os preenchimentos mais longos, foram feitas ranhuras nos alvéolos, ao longo de seus comprimentos, como mostrado na Figura 4.4. Foram feitos dez modelos, sendo cinco de cada espessura de laje. Depois de carregar as extremidades de cada modelo, foram realizados 20 ensaios.

Os dez tipos de modelos foram denominados: 265A, 265B, 265C, 265D, 265R, 400A, 400B, 400C, 400D e 400R. 
Como foram ensaiadas as duas extremidades de cada peça, elas receberam o acréscimo do número 1 e 2 em cada código. Além disso, em alguns casos os modelos possuíram características distintas para cada lado da peça, sendo importante a diferenciação das extremidades, como, por exemplo, o modelo 265A, que possui preenchimentos diferentes em cada extremidade, as quais são denominadas de $265 \mathrm{~A} 1 \mathrm{e}$ 265A2. As denominações e as características dos modelos podem ser observadas na Figura 4.4. O comprimento do aparato de concreto $\left(L_{c 1}\right)$, empregado em cada modelo, é dado na Tabela 4.1.

Tabela 4.1: Comprimento do aparato de concreto $L_{c 1}$ [Pajari e Yang (1994)].

\begin{tabular}{c|c}
\hline Modelo & $\left.\mathbf{L}_{\mathbf{c 1}} \mathbf{( m m}\right)$ \\
\hline $265 \mathrm{~A} \mathrm{265B}$ & 265 \\
$265 \mathrm{C}$ & 700 \\
$400 \mathrm{~A} \mathrm{400B}$ & 400 \\
$400 \mathrm{C}$ & 700 \\
\hline
\end{tabular}

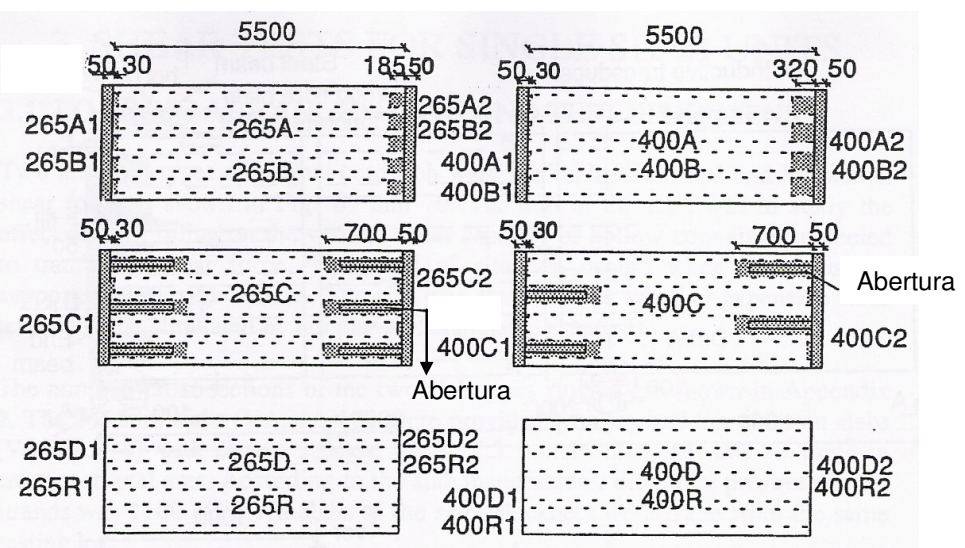

Figura 4.4: Extremidade de vigas e preenchimento dos alvéolos. [Pajari e Yang (1994)]

Os ensaios foram realizados na seguinte ordem: 265R1, 265R2, 400R1, 400R2, 265A, 265B1，265C1，400A1，400B1，400C1，265A2，265B2，265C2，400A2，400B2，400C2， 400D1, 400D2, 265D1, 265D2. Foram ensaios de referência, sem a aplicação de força horizontal: 265R1, 265R2, 400R1 e 400R2.

Durante os ensaios de $265 \mathrm{C} 1$, foi descoberto que o aparato de concreto (na borda apoiada horizontalmente), com medidas $130 \mathrm{~mm} \times 50 \mathrm{~mm} \times 25 \mathrm{~mm}$, usado em todos os ensaios anteriores, estava muito fraco, começando a ceder na força horizontal de 305 kN. Subsequentemente, a força horizontal foi mantida constante (199 kN) e a vertical foi aumentada até a ruptura. Quando o aparato de concreto também cedeu durante o ensaio de 400A1, o modelo foi descarregado, sendo feita uma alteração em suas medidas, que passou a ter $200 \mathrm{~mm} \times 80 \mathrm{~mm} \times 25 \mathrm{~mm}$, e a estrutura foi carregada novamente até a ruptura. Assim, esse aparato de maior dimensão foi utilizado em todos os ensaios restantes, com a aplicação de força horizontal. 
Em alguns casos, a laje não rompeu totalmente sob a força horizontal. Nesses casos, a força vertical foi aumentada até a ruptura da peça. Na Tabela 4.2 um sinal de mais (+) após o código do modelo indica que o ensaio continuou até a ruptura.

\section{- Resultados dos ensaios}

As forças de ruptura e comentários referentes aos ensaios estão na Tabela 4.2.

Tabela 4.2: Forças verticais e horizontais na ruptura. [Pajari e Yang (1994)]

\begin{tabular}{|c|c|c|c|c|}
\hline Modelo & $\begin{array}{c}\text { Lench } \\
(\mathrm{mm})\end{array}$ & $\begin{array}{l}\mathbf{V}_{\text {vert }} \\
(k N)\end{array}$ & $\begin{array}{l}V_{\text {hor }} \\
(k N)\end{array}$ & Observações \\
\hline $265 \mathrm{R} 1$ & 0 & 211,3 & 0 & \multirow{2}{*}{ Ensaios de referência } \\
\hline 265R2 & 0 & 203,1 & 0 & \\
\hline $265 \mathrm{~A} 1$ & 30 & 157,7 & 250 & \\
\hline 265B1 & 30 & 157,7 & 227 & \\
\hline $265 A 2$ & 185 & 208,9 & 300 & \\
\hline 265B2 & 185 & 203,8 & 300 & \\
\hline $265 C 1$ & 700 & 210,2 & 305 & $\begin{array}{l}\text { O aparato de concreto usado para distribuir a força horizontal } \\
\text { começou a ceder antes da ruptura da laje alveolar. No ensaio, } \\
\text { a força vertical continuou sendo aumentada enquanto a força } \\
\text { horizontal foi reduzida }\end{array}$ \\
\hline $265 C 2$ & 700 & 238,0 & 350 & \\
\hline $265 C 1+$ & 700 & 256,3 & 202,5 & \\
\hline $265 \mathrm{D} 1$ & 0 & 103,6 & 161 & Ruptura devida à força horizontal \\
\hline 265D2 & 0 & 106,9 & 173 & \\
\hline 265D1+ & 0 & 105,6 & 0 & \\
\hline 400R1 & 0 & 341,7 & 0 & \\
\hline $400 R 2$ & 0 & 391,3 & 0 & $\begin{array}{l}\text { A capacidade do atuador ( } 500 \mathrm{kN}) \text { não foi suficiente para } \\
\text { romper a laje. O ensaio foi interrompido e dois atuadores } \\
\text { aplicaram força até a ruptura da laje por cisalhamento }\end{array}$ \\
\hline $400 A 1$ & 30 & 212,4 & 312 & $\begin{array}{l}\text { O aparato de concreto usado para distribuir a força horizontal } \\
\text { começou a ceder antes da ruptura da laje. O ensaio foi } \\
\text { interrompido. Depois da moldagem de outro aparato, com } \\
\text { maiores dimensões, o ensaio continuou até a ruptura. }\end{array}$ \\
\hline 400B1 & 30 & 212,4 & 295 & \\
\hline $400 \mathrm{~A} 2$ & 320 & 377,4 & 465 & \\
\hline 400B2 & 320 & 362,4 & 400 & \\
\hline $400 C 1$ & 700 & 257,4 & 375 & $\begin{array}{c}\text { Ruptura localizada devida à força horizontal. } \\
\text { Subsequentemente, a força vertical foi aumentada. A força } \\
\text { vertical de ruptura foi consideravelmente maior que a força } \\
\text { vertical na ruptura horizontal. }\end{array}$ \\
\hline $400 C 2$ & 700 & 201,8 & 320 & $\begin{array}{l}\text { A borda superior fissurou transversalmente durante o ensaio } \\
400 \mathrm{C} 1 \text {. A fissura de cisalhamento começou na fissura de } \\
\text { flexão, que surgiu dentro do maior vão de cisalhamento. Para } \\
\text { impedir essa ruptura, o ensaio foi interrompido e o arranjo de } \\
\text { carregamento alterado. }\end{array}$ \\
\hline $400 C 1+$ & 700 & 351,5 & 70 & Após ruptura local \\
\hline $400 \mathrm{C} 2+$ & 0 & 321,8 & 331 & Após ruptura local \\
\hline 400D1 & 0 & 113,6 & 146 & \multirow{2}{*}{$\begin{array}{c}\text { Ruptura devida à força horizontal. Subsequentemente, a } \\
\text { força vertical foi aumentada. A força vertical de ruptura foi } \\
\text { consideravelmente maior que a força vertical na ruptura } \\
\text { horizontal }\end{array}$} \\
\hline 400D2 & 0 & 109,6 & 141 & \\
\hline 400D1+ & 0 & 196,7 & 0 & Após ruptura horizontal \\
\hline 400D2+ & 0 & 176,4 & 0 & Após ruptura horizontal \\
\hline
\end{tabular}

\section{- Discussão dos resultados}

Quando não houve preenchimento dos alvéolos, a força horizontal reduziu consideravelmente a capacidade resistente vertical ao cisalhamento. 
Os modelos 400D1 e 400D2 foram muito mais sensíveis à força horizontal do que 265D1 e 265D2. Isso ocorreu devido aos primeiros modelos apresentarem as seções transversais com geometria mais desfavorável.

Por comparação com modelos sem preenchimento dos alvéolos, um pequeno preenchimento $(30 \mathrm{~mm})$, juntamente com a extremidade da viga, garantiu, para a laje, um reforço considerável contra a força horizontal.

Com preenchimento médio (185 mm e $320 \mathrm{~mm}$ ), a força vertical e a horizontal na ruptura foram, ambas, no mínimo tão altas quanto a capacidade resistente ao cisalhamento obtida nos ensaios de referência. Em outras palavras, nenhuma redução da capacidade resistente vertical ao cisalhamento foi observada, apesar da elevada força horizontal.

Um longo preenchimento $(700 \mathrm{~mm})$ dos alvéolos pareceu trabalhar melhor para lajes de $265 \mathrm{~mm}$. Para as de $400 \mathrm{~mm}$ ocorreu uma ruptura local devida a uma reação concentrada do apoio horizontal. A área de distribuição da força horizontal nesses ensaios foi menor do que em estruturas de piso reais.

\subsection{BROO \& LUNDGREN (2002)}

Broo \& Lundgren (2002) realizaram diversas análises numéricas empregando elementos finitos, sendo criados e testados vários modelos. Com a análise dos modelos com ruptura por tração devida ao cisalhamento, foram obtidos os gráficos ilustrados na Figura 4.5.

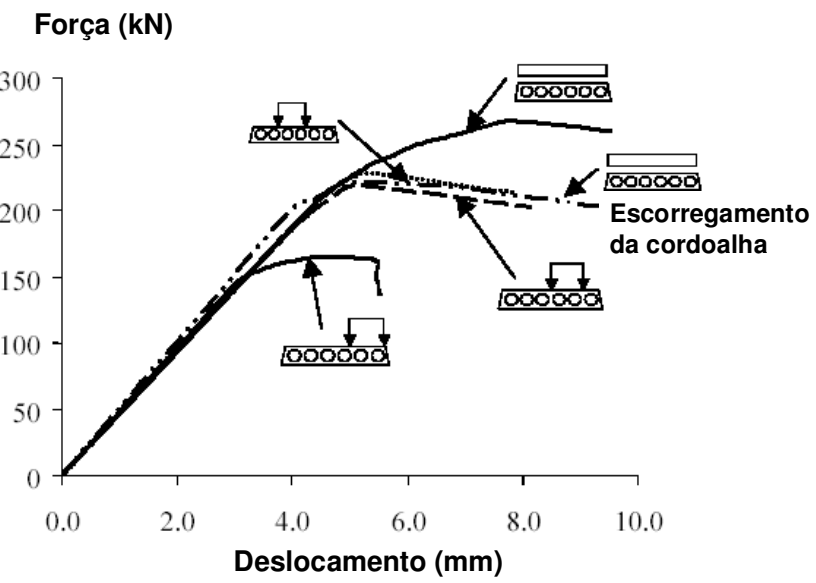

Figura 4.5: Força versus deslocamento no centro da seção transversal onde a força foi aplicada, para diferentes casos de carregamento, a partir de análises preliminares para unidades de lajes alveolares protendidas com espessura de $200 \mathrm{~mm}$. [Broo \& Lundgren (2002)]

Além disso, Broo \& Lundgren (2002) realizaram um ensaio com o intuito de provocar uma ruptura por cisalhamento com flexão. O principal arranjo para tal ensaio pode ser observado na Figura 4.6. 
O modo de ruptura por cisalhamento com flexão tem início com uma fissura de flexão que se transforma em uma fissura inclinada, e termina com um deslocamento devido ao cisalhamento ao longo da fissura.

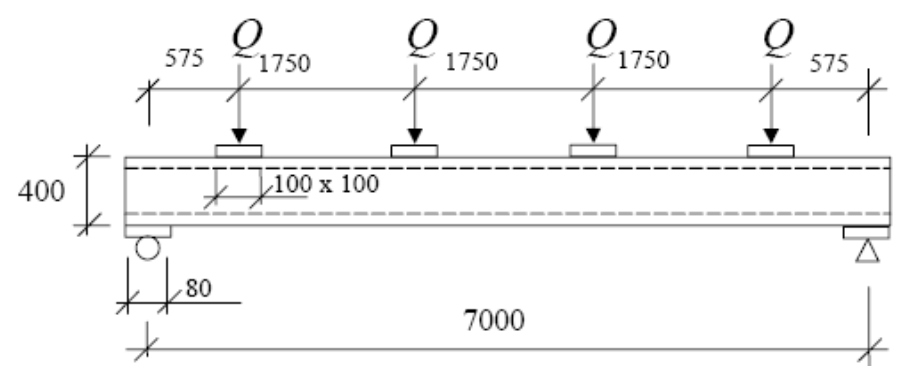

Figura 4.6: Principal arranjo para o ensaio de cisalhamento e flexão. [Broo \& Lundgren (2002)]

Infelizmente, o ensaio não ocorreu como planejado. O resultado foi uma ruptura brusca por tração devida ao cisalhamento. Então, algumas análises foram realizadas para investigar a possibilidade de obter uma ruptura de cisalhamento e flexão.

Assim, Broo \& Lundgren (2002) desenvolveram diversas análises, considerando algumas variações nos arranjos de ensaio, com o intuito de investigar quando seria possível ocorrer uma ruptura devida à combinação de cisalhamento e flexão. Dessa forma, foi analisado um modelo com as seguintes variações:

- Protensão inicial de $1000 \mathrm{MPa}$;

- Mesma protensão anterior, mas com o dobro dos valores das forças próximas ao meio do vão;

- Mesmas forças anteriores, mas com protensão inicial de $600 \mathrm{MPa}$;

- Mesmas forças anteriores, mas sem protensão.

Para essas análises, o principal interesse foi estudar os modos de ruptura. A possibilidade de comparar forças reais com as empregadas nos modelos foi considerada como menos importante. Entretanto, somente metade da nervura foi modelada, e também foi utilizada uma linha simétrica no meio do vão.

O gráfico de força versus flecha pode ser observado na Figura 4.7. Alguns eventos importantes estão marcados nessa curva, por exemplo, quando diferentes fissuras aparecem, e quando o aço de protensão começa a escoar. Como pode ser visto, uma fissura de tração devida ao cisalhamento desenvolve-se no apoio, ao mesmo tempo em que a armadura começa a escoar. Posteriormente, a força aumentou ligeiramente, e a força máxima é limitada por uma ruptura na zona de compressão, na força mais próxima ao meio do vão. O modo de ruptura na análise é essencialmente por flexão, mas deve ser notado que a ruptura por tração devida ao cisalhamento está muito próxima. 

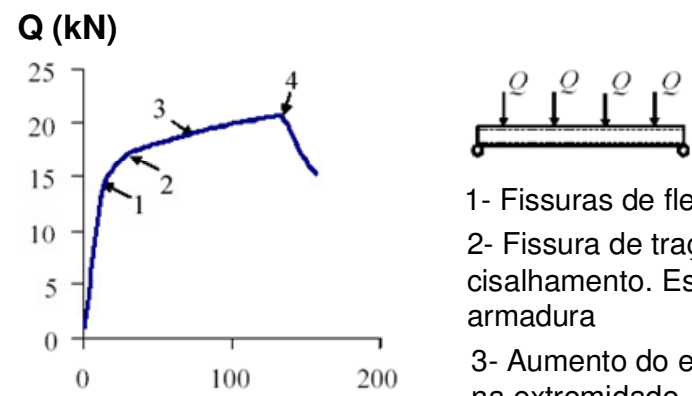

1- Fissuras de flexão

2- Fissura de tração devida ao cisalhamento. Escoamento da armadura

3- Aumento do escorregamento na extremidade

Flecha no meio do vão (mm)

4- Ruptura por compressão

Figura 4.7: Força versus deslocamento vertical no meio do vão, com a indicação do desenvolvimento da fissuração, obtido na análise das amostras ensaiadas com protensão inicial de 1000 MPa. [Broo \& Lundgren (2002)]

No modelo, são transferidas tensões de tração maiores que a resistência do concreto à tração. O material usado deveria limitar a tensão de tração à resistência do concreto. Porém, é possível a transferência de tensões suplementares, por conta de um efeito denominado "stress locking". Assim, Broo \& Lundgren (2002) concluíram que uma ruptura por tração devida ao cisalhamento é bastante provável de ocorrer na realidade. $\mathrm{Na}$ análise o "stress locking" pode evitar esse modo de ruptura.

Como o modo de ruptura no ensaio realizado foi por tração devida ao cisalhamento, foi realizada uma nova análise, sendo duplicadas as forças mais próximas ao meio do vão, como pode ser observado na Figura 4.8.
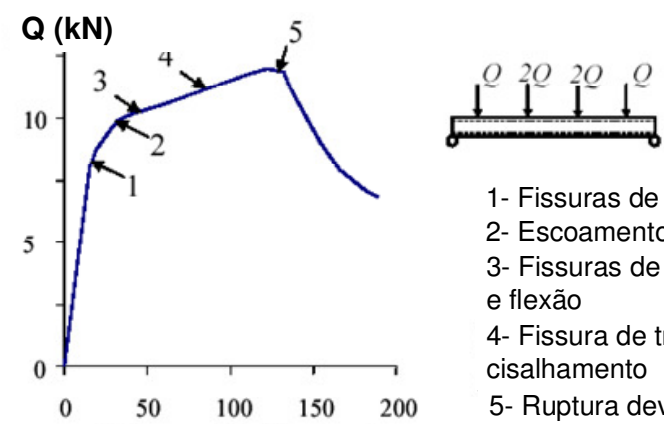

1- Fissuras de flexão

2- Escoamento da armadura

3- Fissuras de cisalhamento

e flexão

4- Fissura de tração devida ao cisalhamento

Flecha no meio do vão (mm)

5- Ruptura devida à compressão

Figura 4.8: Força versus deslocamento vertical no meio do vão, com a indicação do desenvolvimento da fissuração, obtido nas análises de uma amostra similar à apresentada anteriormente, mas com as forças duplicadas próximas ao meio do vão. [Broo \& Lundgren (2002)]

A intenção foi aumentar a força cortante no segundo trecho do vão, para provocar uma ruptura pela combinação de cisalhamento com flexão. Como pode ser observado na Figura 4.8, fissuras de cisalhamento e flexão agora apareceram antes das fissuras de tração devidas ao cisalhamento. O aço de protensão começa a escoar antes de desenvolver fissuras de flexão e cisalhamento. Na análise, tem-se ruptura por flexão. No entanto, na realidade, pode ocorrer uma ruptura por cisalhamento e flexão. 
Assim, Broo \& Lundgren (2002) concluíram que, a fim de obter uma ruptura por cisalhamento e flexão, empregando a primeira configuração de ensaio, a protensão deveria ser diminuída.

Dois casos foram investigados, um com protensão inicial de $600 \mathrm{MPa}$ e outro sem protensão. Os resultados estão na Figura 4.9 e na Figura 4.10, respectivamente.

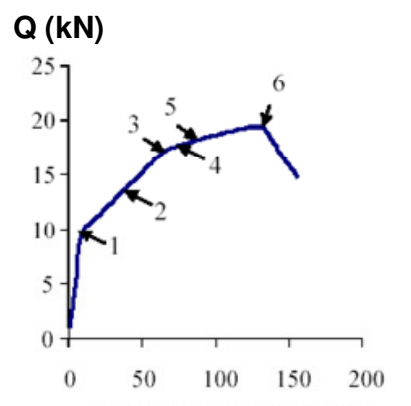

Flecha no meio do vão (mm)

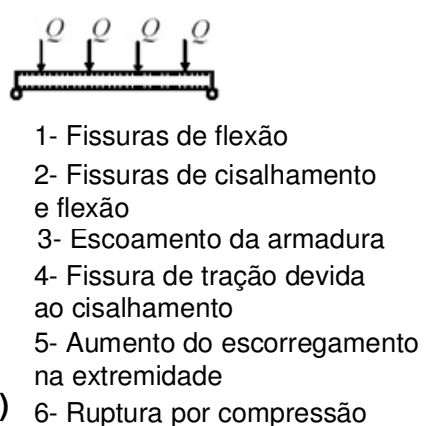

Figura 4.9: Força versus deslocamento vertical no meio do vão, com a indicação do desenvolvimento da fissuração, na análise das amostras ensaiadas com protensão inicial de 600 MPa. [Broo \& Lundgren (2002)]

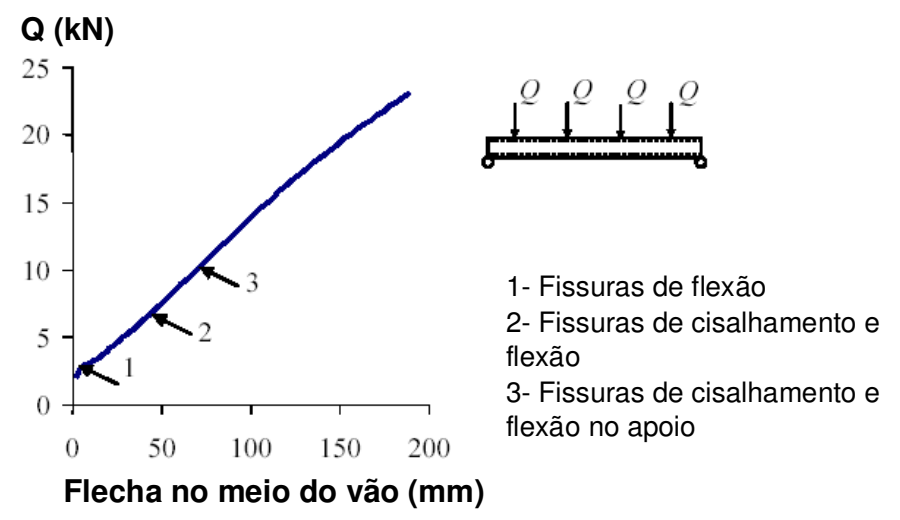

Figura 4.10: Força versus deslocamento vertical no meio do vão, modelo sem protensão, com uma maior capacidade de ancoragem na extremidade. [Broo \& Lundgren (2002)]

Quando a protensão inicial foi reduzida para $600 \mathrm{MPa}$, apareceram fissuras de cisalhamento e flexão antes do aço de protensão começar a escoar. Na análise, foi possível aumentar a força após o aparecimento das fissuras de cisalhamento e flexão, mas grandes tensões de tração foram transferidas. A força máxima foi obtida quando o lado comprimido rompeu. Na realidade, não se pode afirmar que seria possível aumentar muito a força após a formação das fissuras de cisalhamento e flexão.

Para investigar se a ruptura por cisalhamento e flexão poderia ser descrita em tais análises, um caso extremo foi analisado, sem qualquer protensão, sem enfraquecimento do concreto na compressão, com armadura elástica, e com um aumento da capacidade da ancoragem na extremidade. 
Essas escolhas foram feitas a fim de evitar outros possíveis modos de ruptura. 0 resultado dessa análise é apresentado na Figura 4.10. Como pode ser visto, fissuras de cisalhamento e flexão apareceram para uma força muito pequena. No entanto, elas não conduziram a ruptura; ao invés disso, a força pode ser aumentada sem limite. Isto é possível devido ao efeito "stress locking". A transferência de tensões maiores do que a de tração foram constatadas logo que apareceram as fissuras de cisalhamento e flexão, e as tensões transferidas tornaram-se tanto maiores quanto mais elevada foi a força aplicada. Já na força $\mathrm{Q}=10 \mathrm{kN}$, a maior tensão de tração no concreto foi de $14 \mathrm{MPa}$, para ser comparada com a resistência à tração, considerada de 3,42 MPa. Assim, Broo \& Lundgren (2002) concluíram que a ruptura de cisalhamento e flexão não pode ser descrita nesse tipo de modelo. No entanto, após os resultados dos dois primeiros tipos de análises, concluíram que a ocorrência de uma ruptura por cisalhamento e flexão é bastante improvável, para lajes em que são empregados os níveis de protensão recomendados por norma.

\subsection{PAJARI (2004)}

Os ensaios documentados por esse pesquisador foram planejados para representar torção pura, sem momento fletor, força de cisalhamento ou contribuição de lajes vizinhas. Os resultados foram utilizados, principalmente, para calibração de métodos de cálculo numérico. Eles também forneceram um limite menor para o ângulo máximo de torção e para o momento torçor, quando uma unidade de laje isolada é torcida. Esses limites são, entretanto, muito conservadores, devido às disposições de ensaio: a extremidade da laje em balanço e a falta de força imposta sobre a laje aumentam a tensão de tração crítica na borda superior do elemento de laje, resultando em uma ruptura nessa superfície.

\section{- Ensaios}

Quatro ensaios de torção em unidades de laje foram realizados em 2002. Algumas características dos modelos são dadas na Tabela 4.3.

Tabela 4.3: Características dos modelos ensaiados por Pajari (2004).

\begin{tabular}{|c|c|c|c|c|}
\hline Modelo & $\begin{array}{c}\text { Altura } \\
(\mathbf{m m})\end{array}$ & Cordoalha & $\begin{array}{c}\text { Protensão } \\
\text { inicial (MPa) }\end{array}$ & $\begin{array}{c}\text { Comprimento } \\
(\mathbf{m})\end{array}$ \\
\hline PT200A & 200 & $7 \phi 12,7$ & 900 & 5,0 \\
PT200B & 200 & $7 \phi 12,7$ & 900 & 5,0 \\
\hline PT400A & 400 & $7 \phi 12,7$ & 1000 & 7,0 \\
PT400B & 400 & $7 \phi 12,7$ & 1000 & 7,0 \\
\hline
\end{tabular}

As condições de suporte e carregamento estão apresentadas na Figura 4.11. 


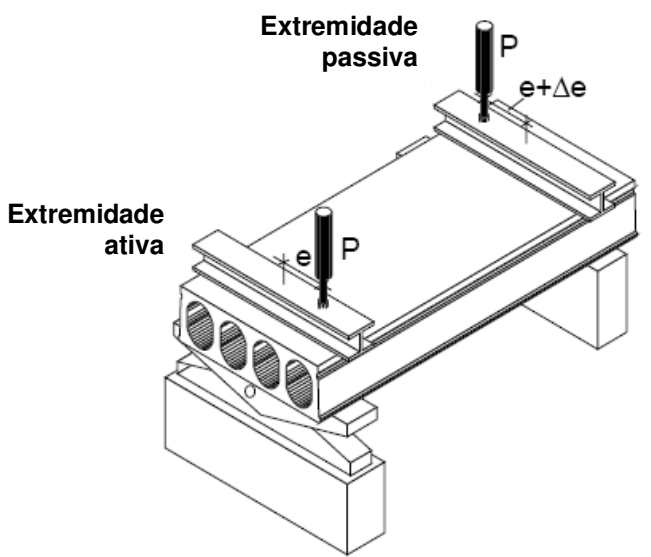

Figura 4.11: Esquema do ensaio de torção. [Pajari (2004)]

A extremidade ativa da laje estava livre para girar em torno de um eixo paralelo ao eixo longitudinal da peça, quando ela se encontrava em sua posição inicial.

Uma vez que esse eixo de rotação estava localizado abaixo do centro da seção transversal da laje, a rotação foi acompanhada por deslocamentos longitudinais e laterais da mesma ordem que o deslocamento vertical. Em outras palavras, em adição à deformação, a laje estava sujeita a um movimento de corpo rígido. Foi dada atenção especial para permitir tal movimento sem forças de restrição adicionais.

$\mathrm{Na}$ extremidade passiva, o apoio era capaz de mover longitudinalmente. Graças aos roletes individuais, ver Figura $4.12 a$ e b, o apoio passivo também estava livre para girar em torno do eixo vertical.

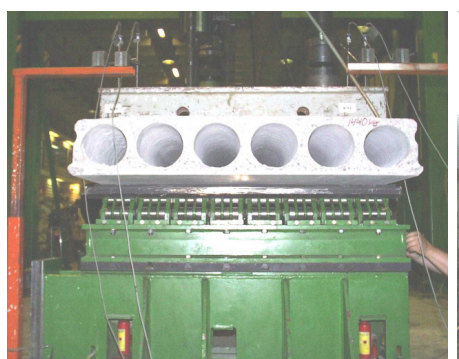

a)

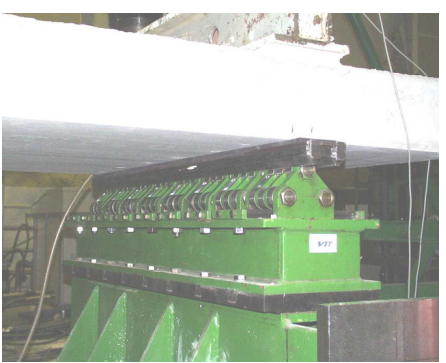

b)

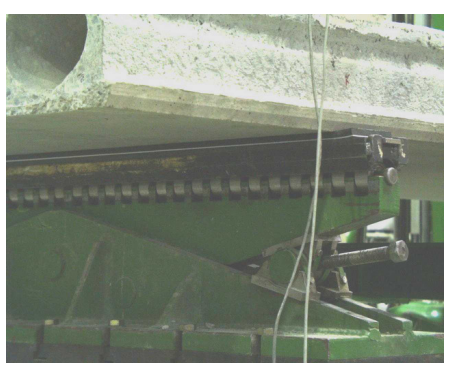

c)

Figura 4.12: Detalhes dos apoios. a) e b) Apoio na extremidade passiva do modelo PT200A; c) Detalhe do apoio da extremidade ativa antes do ensaio, cuja rotação era impedida por um dispositivo ajustável à direita. [Pajari (2004)]

$\mathrm{Na}$ extremidade ativa, as restrições contra a rotação em torno do eixo vertical (eixo perpendicular ao apoio metálico) foram eliminadas por folhas de teflon colocadas entre o apoio metálico e a tira de neoprene localizada sob a laje. $\mathrm{O}$ apoio da extremidade ativa pode ser observado com detalhe na Figura 4.12c. Dois pinos metálicos soldados ao apoio metálico impediram que o centro do teflon e a faixa de neoprene, e consequentemente também o centro da extremidade da laje, deslizassem em relação ao centro do apoio. Esse detalhe pode ser observado na Figura 4.13. 


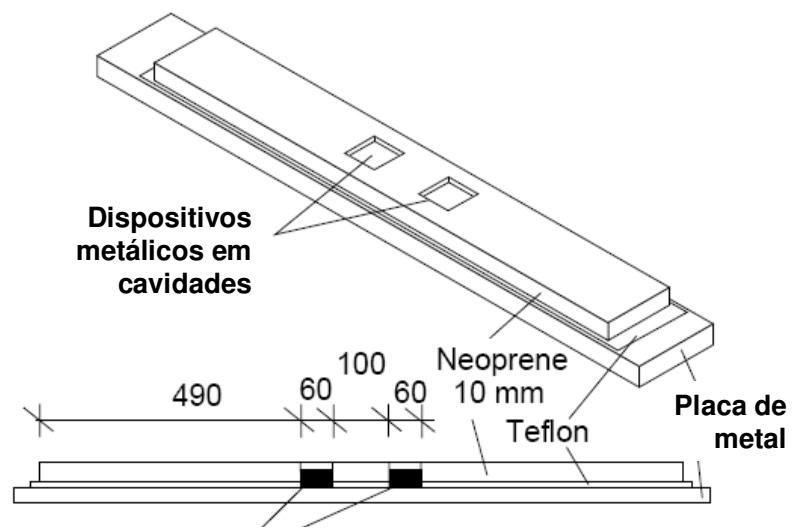

Dispositivos metálicos, soldados na placa, em cavidades de $40 \times 60$

Figura 4.13: Apoio na extremidade ativa (dimensões em mm). [Pajari (2004)]

A laje foi submetida a duas forças concentradas localizadas em lados opostos à linha central. Para estabilizar o modelo, a força aplicada na extremidade passiva teve uma excentricidade um pouco maior do que na extremidade ativa. Detalhes dos apoios bem como a localização das forças e instrumentos de medição estão ilustrados na Figura 4.14.

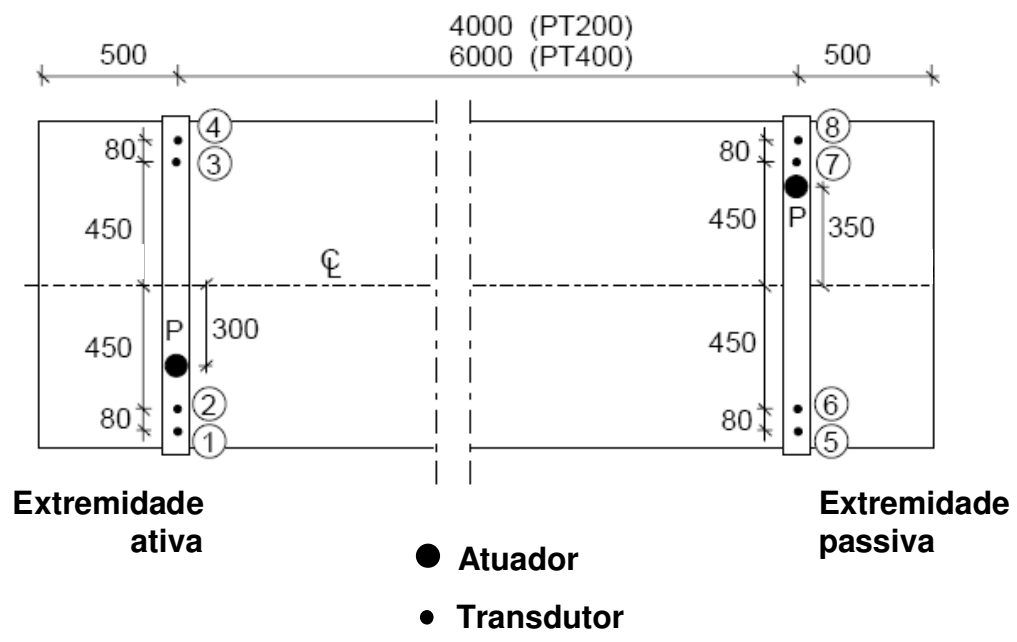

Figura 4.14: Detalhes do ensaio de torção [Pajari (2004)]

Como pode ser observado na Figura 4.14, os deslocamentos das lajes foram medidos por oito transdutores numerados de 1 a 8 , os quais foram fixados no piso do laboratório. O número de transdutores foi escolhido visando garantir a obtenção das rotações, em caso de mau funcionamento de algum instrumento.

\section{- Estratégias de carregamento}

Os ensaios foram realizados sob controle de deslocamentos. As etapas foram:

* Desbloqueio dos dispositivos da extremidade ativa, permitindo a rotação dessa extremidade da laje. Os transdutores foram zerados; 
* Aumento da força até metade da força máxima estimada;

+ Diminuição da força até próximo de zero;

* Depois de três ciclos de carregamento, como descrito nos dois passos anteriores, aumento da deformação até a ruína, tão longe quanto possível.

O alongamento do atuador na extremidade ativa foi usado para controlar os deslocamentos. Foram feitas tentativas para manter a taxa de alongamento tão constante quanto possível.

\section{- Resultados}

Em todos os ensaios, as primeiras fissuras surgiram na parte superior da laje, em um ângulo de $45^{\circ} \mathrm{com}$ o eixo longitudinal, como pode ser observado na Figura 4.15. O aparecimento dessas fissuras foi seguido por uma brusca e permanente redução do momento torçor. Portanto, a ruína aconteceu juntamente com a primeira fissura.

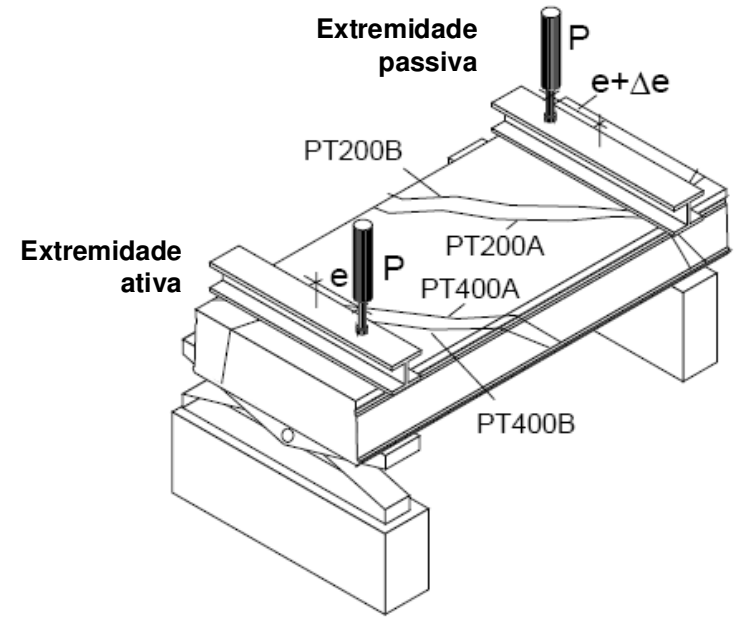

Figura 4.15: Modo de ruína em ensaios. [Pajari (2004)]

As ruínas das lajes de $200 \mathrm{~mm}$ e $400 \mathrm{~mm}$ ocorreram na extremidade passiva e na ativa, respectivamente. A ruína próxima ao apoio era mais provável do que no meio do vão, onde o momento fletor devido ao peso da laje reduziu a tensão principal máxima na borda superior. Além disso, as condições de apoio sempre criam algum local de distúrbio no campo de tensão, o qual pode facilitar a ruína no apoio. Assim, pode-se concluir que o modo de ruína foi, em todos os ensaios, exatamente como esperado do ponto de vista teórico.

Para as lajes de $200 \mathrm{~mm}$ a resistência à torção após a fissuração foi de aproximadamente $50 \%$ da resistência máxima, e para as lajes de $400 \mathrm{~mm}$, a resistência correspondeu a $40 \%$ da máxima. Após a ruína houve uma diminuição do momento torçor com aumento da rotação, mas não houve colapso. 
A ductilidade observada nos ensaios pode ser atribuída à camada inferior protendida da laje. Uma estrutura de piso compreende diversas unidades de laje, e isto significa que, após a primeira fissura, uma unidade de laje pode ainda participar do mecanismo de transferência de carga.

Na Figura 4.16, o ângulo relativo de torção está ilustrado para todos os modelos ensaiados, antes da fissuração. A inclinação da curva fornece a rigidez da laje à torção.

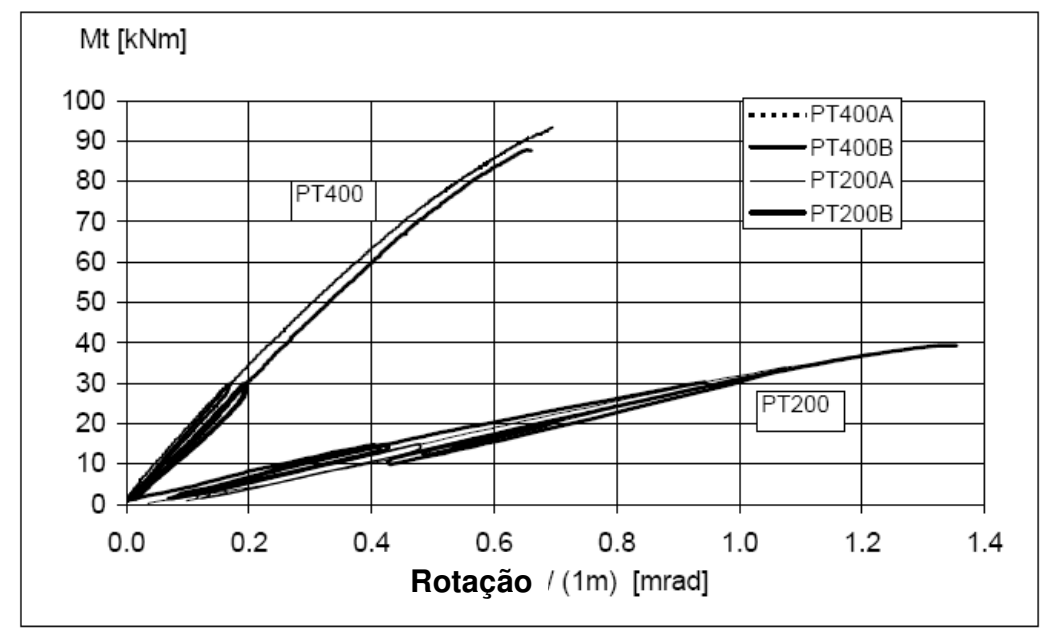

Figura 4.16: Comparação da rigidez à torção das lajes de 200 mm e 400 mm [Pajari (2004)].

\section{- Dados sobre o concreto}

A resistência do concreto à compressão foi medida em testemunhos retirados das lajes por perfuração (diâmetro de $50 \mathrm{~mm}$ ). A partir desses testemunhos, foi possível determinar as resistências características equivalentes a corpos de prova cilíndricos de $150 \mathrm{~mm} \times 300 \mathrm{~mm}$. Essa resistência foi determinada considerando $85 \%$ dos valores encontrados para os testemunhos, como pode ser observado na Tabela 4.4.

Tabela 4.4: Resistências do concreto à compressão, dos modelos ensaiado por Pajari (2004)

\begin{tabular}{|c|c|c|c|c|c|}
\hline Modelo & $\mathbf{f}_{\mathbf{c}, \mathbf{5 0}(\mathbf{M P a})}$ & $\mathbf{f}_{\mathbf{c}, \mathbf{1 5 0}}(\mathbf{M P a})$ & $\mathbf{f}_{\mathbf{c t m}}(\mathbf{M P a})$ & $\mathbf{f}_{\mathbf{c t k}}(\mathbf{M P a})$ & $\mathbf{E}_{\mathbf{c}}(\mathbf{G P a})$ \\
\hline PT200A & 60,1 & 51,1 & 4,15 & 2,91 & 33,0 \\
PT200B & 59,2 & 50,3 & 4,11 & 2,88 & 32,9 \\
\hline PT400A & 62,2 & 52,9 & 4,25 & 2,97 & 33,4 \\
PT400B & 62,2 & 52,9 & 4,25 & 2,97 & 33,4 \\
\hline
\end{tabular}

$\mathrm{f}_{c, 50}$ : Resistência característica à compressão das amostras de $50 \mathrm{~mm}$;

$f_{c, 150}$ : Resistência característica à compressão para corpos de prova de $150 \mathrm{~mm} \times 300 \mathrm{~m}$;

$\mathrm{f}_{\mathrm{ctm}}$ : Resistência média à tração;

$f_{\text {ctk: }}$ : Resistência característica à tração;

$\mathrm{E}_{\mathrm{c}}$ : Módulo de elasticidade do concreto. 


\section{- Análise dos resultados}

Considerando uma perda de protensão de $50 \mathrm{MPa}$, foram determinados os valores previstos e, consequentemente, foi possível fazer uma comparação com os valores obtidos nos ensaios, como pode ser observado na Tabela 4.5. A fissuração da borda superior em cima do apoio correspondeu ao modo crítico de ruína. Os valores de $\phi_{\text {obs }}$ correspondem aos últimos valores de ângulo de torção entre os apoios, antes da fissuração.

Tabela 4.5: Comparação entre os resultados previstos e os observados nos ensaios Pajari (2004).

\begin{tabular}{|c|c|c|c|c|c|c|c|}
\hline Modelo & $\begin{array}{c}\phi_{\text {obs }} \\
\text { (mrad) }\end{array}$ & $\begin{array}{l}M_{t, o b s} \\
\text { (kN.m) }\end{array}$ & $\begin{array}{l}M_{t, p r e} i l \\
(\mathbf{k N} \cdot \mathbf{m})\end{array}$ & $\begin{array}{l}M_{t, p r e} \\
\text { (kN.m) }\end{array}$ & $\frac{M_{t, p r e}^{\{1\}}}{M_{t, o b s}}$ & $\frac{M_{t, p r e}^{(2)}}{M_{t, o b s}}$ & $\frac{\mathrm{GI}_{\mathrm{t}, \mathrm{pre}}}{\mathrm{GI}_{\mathrm{t}, \mathrm{obs}}}$ \\
\hline PT200A & $\begin{array}{l}4,86 \\
5,35\end{array}$ & $\begin{array}{l}37,45 \\
3938\end{array}$ & $\begin{array}{l}34,9 \\
348\end{array}$ & $\begin{array}{l}22,9 \\
229\end{array}$ & $\begin{array}{l}0,93 \\
0,88\end{array}$ & $\begin{array}{l}0,61 \\
0\end{array}$ & $\begin{array}{l}0,64 \\
071\end{array}$ \\
\hline & & & & & & & \\
\hline PT400A & 4,17 & 92,96 & 103,6 & 61,74 & 1,11 & 0,66 & 0,98 \\
\hline PT400B & 3,92 & 87,38 & 106,9 & 63,05 & 1,22 & 0,72 & 1,01 \\
\hline
\end{tabular}

(1) Calculado usando a resistência média à tração $f_{c t m}$

(2) Calculado usando a resistência característica inferior à tração $f_{c t k \text {,inf }}$

$\mathrm{M}_{\mathrm{t}, \mathrm{obs}}$ : Momento torçor observado no ensaio;

$\mathrm{M}_{\mathrm{t}, \text { pre: }}$ Momento torçor previsto no cálculo;

$\mathrm{GI}_{\mathrm{t}, \mathrm{pre}}$ : Rigidez à torção prevista no cálculo;

$\mathrm{GI}_{\mathrm{t}, \mathrm{obs}}$ : Rigidez à torção observada no ensaio;

G: Módulo de cisalhamento;

$\mathrm{I}_{\mathrm{t}}$ : Módulo de torção;

$\phi_{\text {obs: }}$ Último valor do ângulo de torção entre os apoios, antes da fissuração.

A comparação com os valores observados mostra que a rigidez à torção das lajes de $400 \mathrm{~mm}$ é prevista com exatidão pelo método de cálculo simples, mas para as lajes de $200 \mathrm{~mm}$ os valores previstos são subestimados em cerca de $30 \%$. Essa diferença não pode ser eliminada pela alteração, nos cálculos, do valor referente ao módulo de elasticidade. Assim, uma análise numérica é necessária para esclarecer as razões dessa diferença tão grande.

A resistência à torção, calculada utilizando a resistência média do concreto à tração, é maior do que a observada para as lajes de $400 \mathrm{~mm}$, mas menor do que a relativa às lajes de $200 \mathrm{~mm}$.

A partir da resistência característica inferior do concreto à tração, ao invés da resistência média, ocorreu uma grande redução dos valores previstos, uma vez que a relação entre as resistências previstas e as observadas correspondeu a 70\% e 60\%, para as lajes de $400 \mathrm{~mm}$ e $200 \mathrm{~mm}$, respectivamente. 
Quando as unidades de laje são cortadas por serra, o concreto não alcança sua resistência final. A ação mecânica da alta velocidade da serra pode causar fissuras longitudinais no local do corte, como indicado na Figura 4.17. Tais fissuras, devido ao corte por serra ou a outras razões, podem, às vezes, ser muito longas. Nas unidades de laje ensaiadas não foram observadas fissuras longitudinais visíveis na borda superior antes do ensaio, mas algum local danificado pode ter existido.

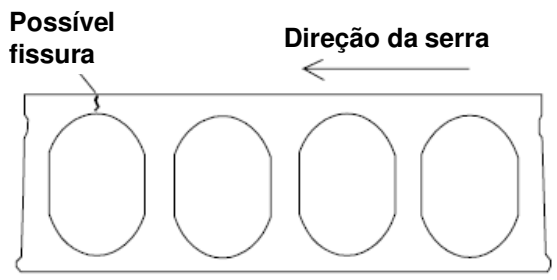

Figura 4.17: Fissura causada pelo corte da laje [Pajari (2004)]

\subsection{PAJARI (2005)}

Pajari (2005) analisou 49 lajes ao cisalhamento, com seções transversais diversas, variando a espessura de $200 \mathrm{~mm}$ a $500 \mathrm{~mm}$. Entretanto, no presente trabalho será dada maior atenção ao estudo das lajes alveolares protendidas com $200 \mathrm{~mm}$ e alvéolos circulares (tipo de laje mais usual no Brasil). Foram ensaiadas quatro lajes alveolares protendidas de $200 \mathrm{~mm}$ de espessura, com sete cordoalhas de $12,7 \mathrm{~mm}$ de diâmetro (área de $93 \mathrm{~mm}^{2}$ ) e com tensão de protensão inicial da ordem de $1100 \mathrm{MPa}$.

Em cada ensaio, foram medidas características geométricas da laje, que incluíram: comprimento da laje; largura total da seção na parte inferior, central e superior da laje; espessura na seção central e nas duas bordas; escorregamento para cada cordoalha; largura e altura de cada alvéolo; espessura mínima do flange superior e inferior e de cada nervura.

Com os ensaios, os resultados experimentais foram comparados com os teóricos, calculados a partir das recomendações do EC2 (EN 1992:2004) e do método de Yang. Além disso, para cada método, o cálculo foi realizado utilizando a resistência média e a resistência característica inferior do concreto à tração.

A comparação das resistências observadas com os valores calculados empregando a resistência média à tração encontra-se na Figura 4.18. Para um modelo de cálculo perfeito, os pontos deveriam estar sobre a linha contínua $\mathrm{V}_{\text {obs }}=\mathrm{V}_{\text {pre, }}$ e para um bom modelo de cálculo, deveria haver pontos em ambos os lados da mesma linha. Isto claramente não é o caso do método do EC2, o qual se mostra não conservador. $O$ ajuste para o método de Yang é muito melhor, mas ainda não é o ideal. 

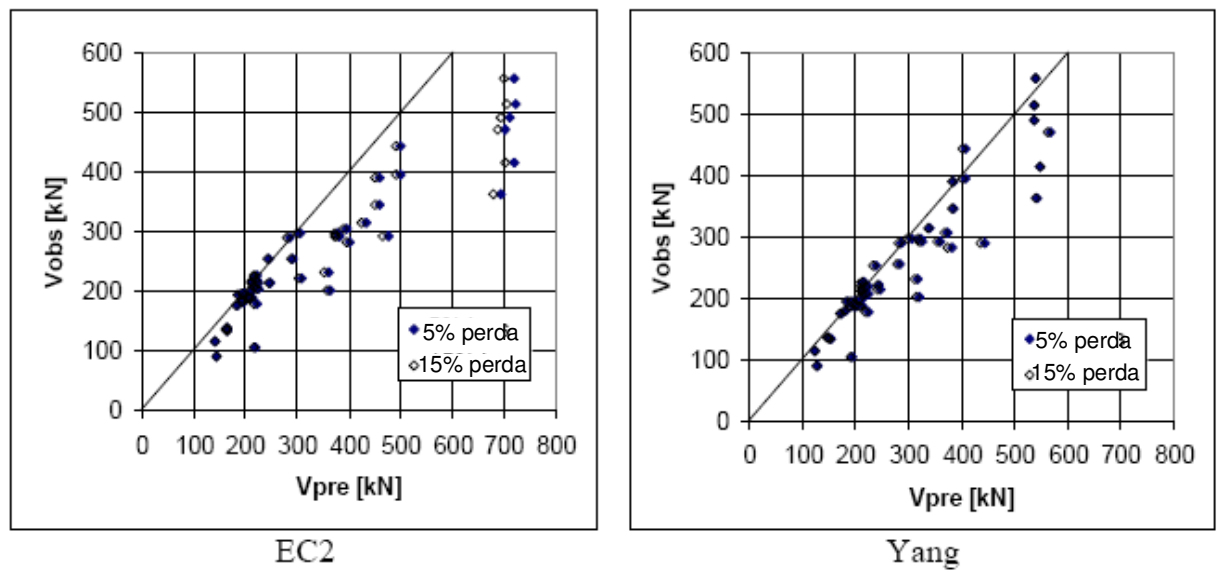

Figura 4.18: Relação entre o valor observado $\left(V_{\text {obs }}\right)$ e o previsto teoricamente $\left(V_{\text {pre }}\right)$ para todas as lajes ensaiadas, empregando a resistência média à tração e os métodos recomendados pelo EC2 e por Yang. [PAJARI (2005)]

Para uma melhor análise das lajes com $200 \mathrm{~mm}$ de espessura, seus resultados foram separados e podem ser observados na Tabela 4.6, considerando as recomendações do EC2, e na Tabela 4.7, com o cálculo pelo método de Yang.

Tabela 4.6: Resistência ao cisalhamento observada ( $V_{\text {obs }}$ ) e resistência ao cisalhamento calculada $\left(V_{\text {pre }}\right)$ usando o método do EC2. Foram consideradas duas diferentes perdas de protensão (5\% e $15 \%$ ) e dois valores de resistência à tração. [PAJARI (2005)]

\begin{tabular}{|c|c|c|c|c|c|c|c|c|c|}
\hline & & \multicolumn{4}{|c|}{ Resistência média à tração } & \multicolumn{4}{|c|}{ Resistência característica à tração } \\
\hline \multicolumn{2}{|c|}{ Perda de protensão } & \multicolumn{2}{|c|}{$5 \%$} & \multicolumn{2}{|c|}{$15 \%$} & \multicolumn{2}{|c|}{$\mathbf{5 \%}$} & \multicolumn{2}{|c|}{$15 \%$} \\
\hline Laje & $\begin{array}{c}V_{\text {obs }} \\
(k N)\end{array}$ & $\begin{array}{c}\mathbf{V}_{\text {pre }} \\
(\mathbf{k N})\end{array}$ & $\frac{\mathrm{V}_{\text {obs }}}{\mathrm{V}_{\text {pre }}}$ & $\begin{array}{c}\mathbf{V}_{\text {pre }} \\
(\mathbf{k N})\end{array}$ & $\frac{\mathrm{V}_{\text {obs }}}{\mathrm{V}_{\text {pre }}}$ & $\begin{array}{c}\text { V }_{\text {pre }} \\
(\mathbf{k N})\end{array}$ & $\frac{V_{\text {obs }}}{V_{\text {pre }}}$ & $\begin{array}{c}\text { V }_{\text {pre }} \\
(\mathbf{k N})\end{array}$ & $\frac{\mathrm{V}_{\text {obs }}}{\mathrm{V}_{\text {pre }}}$ \\
\hline 31200 & 90,2 & 145,7 & 0,619 & 143,9 & 0,626 & 107,3 & 0,840 & 105,5 & 0,854 \\
\hline 33200 & 115,6 & 142,7 & 0,810 & 141,0 & 0,819 & 105,2 & 1,099 & 103,4 & 1,118 \\
\hline 40200 & 106,0 & 218,7 & 0,484 & 216,0 & 0,491 & 161,1 & 0,658 & 158,4 & 0,669 \\
\hline 63200 & 137,5 & 165,7 & 0,830 & 163,8 & 0,839 & 121,6 & 1,131 & 119,7 & 1,148 \\
\hline
\end{tabular}

Tabela 4.7: Resistência ao cisalhamento observada ( $V_{\text {obss }}$ ) e resistência ao cisalhamento calculada (Vpre) usando o método de Yang. Foram consideradas duas diferentes perdas de protensão (5\% e $15 \%$ ) e dois valores de resistência à tração. [PAJARI (2005)]

\begin{tabular}{|c|c|c|c|c|c|c|c|c|c|}
\hline \multirow{2}{*}{\multicolumn{2}{|c|}{ Perda de protensão }} & \multicolumn{4}{|c|}{ Resistência média à tração } & \multicolumn{4}{|c|}{ Resistência característica à tração } \\
\hline & & \multicolumn{2}{|c|}{$\mathbf{5 \%}$} & \multicolumn{2}{|c|}{$15 \%$} & \multicolumn{2}{|c|}{$\mathbf{5 \%}$} & \multicolumn{2}{|c|}{$15 \%$} \\
\hline Laje & $\begin{array}{l}V_{\text {obs }} \\
(\mathbf{k N})\end{array}$ & $\begin{array}{c}\text { V }_{\text {pre }} \\
(\mathbf{k N})\end{array}$ & $\frac{\mathrm{V}_{\text {obs }}}{\mathrm{V}_{\text {pre }}}$ & $\begin{array}{c}\mathbf{V}_{\text {pre }} \\
(\mathbf{k N})\end{array}$ & $\frac{\mathrm{V}_{\text {obs }}}{\mathrm{V}_{\text {pre }}}$ & $\begin{array}{c}\mathbf{V}_{\text {pre }} \\
(\mathbf{k N})\end{array}$ & $\frac{\mathrm{V}_{\text {obs }}}{\mathrm{V}_{\text {pre }}}$ & $\begin{array}{c}V_{\text {pre }} \\
(\mathbf{k N})\end{array}$ & $\frac{\mathrm{V}_{\text {obs }}}{\mathrm{V}_{\text {pre }}}$ \\
\hline 31200 & 90,2 & 128,04 & 0,704 & 126,69 & 0,712 & 93,1 & 0,969 & 92,0 & 0,98 \\
\hline 33200 & 115,6 & 124,56 & 0,928 & 123,34 & 0,937 & 90,2 & 1,281 & 89,3 & 1,294 \\
\hline 40200 & 106,0 & 193,44 & 0,548 & 190,55 & 0,556 & 142,9 & 0,742 & 140,4 & 0,755 \\
\hline 63200 & 137,5 & 148,07 & 0,928 & 146,08 & 0,941 & 108,9 & 1,263 & 107,2 & 1,283 \\
\hline
\end{tabular}

Para um modelo de cálculo válido, a média da relação $V_{o b s} / V_{p r e}$ deveria ser próxima de 1,0. Observando os resultados obtidos para as lajes com $200 \mathrm{~mm}$ de espessura, podese notar que o método de Yang fornece um ajuste melhor do que o do EC2, mas ainda não é conservador, pois a média está abaixo de 1,0 .

O valor de cálculo da resistência ao cisalhamento foi obtido assumindo que a resistência característica inferior à tração corresponde a 70\% da resistência média. 
Do ponto de vista de projetistas, é mais importante saber se um modelo de cálculo prediz corretamente o menor valor característico da resistência ao cisalhamento. Se este for o caso e fatores de segurança são aplicados nas propriedades de resistência que ocorrem no modelo, pode-se dizer que o valor de cálculo da resistência, obtida a partir do modelo, é conservador o suficiente.

\section{- Conclusões}

O método recomendado pelo EC2 superestimou a resistência média ao cisalhamento de todos os tipos de lajes ensaiadas. A resistência das lajes com 200 mm de espessura foi bastante superestimada (em mais de 10\%). Quando as resistências experimentais foram comparadas com as resistências características calculadas, o ajuste foi melhor, mas ainda ocorreu uma considerável falta de segurança para as lajes de $200 \mathrm{~mm}$.

A resistência característica calculada com o método de Yang foi de $89 \%$ a $98 \%$ da resistência experimental, para casos problemáticos como o das lajes de $200 \mathrm{~mm}$ e as lajes com nervuras finas. Com base nos resultados, o método de Yang para projetos em que se considera ruptura por cisalhamento da nervura pode substituir o método recomendado pelo EC2, pois proporciona um melhor ajuste com os resultados experimentais e porque é teoricamente mais correto. Entretanto, de acordo com Pajari (2005), não é aceitável adotar um método de projeto que superestima a resistência característica de algum tipo de produto em 10\%, como o método de Yang parece fazer. Se este for realmente o caso, é ainda uma questão em aberto, pois o número de ensaios foi pequeno, e devido à natureza dos tipos de ensaios realizados, algumas amostras ensaiadas podem ter sido mais fracas do que as lajes típicas da produção normal. Essa questão pode ser respondida pela realização de ensaios dos tipos de lajes mais suscetíveis à tensão de cisalhamento devida à transferência da força de protensão. Tais lajes correspondem às de menor altura e com nervuras estreitas.

A aplicabilidade do método recomendado pelo EC2 deveria sempre ser verificada numérica ou experimentalmente, antes de ser utilizado.

\subsection{TKALCIC ET AL. (2007)}

No Laboratório Estrutural do Departamento de Estruturas de Concreto e Alvenaria do Instituto de Engenharia Civil da Croácia, foram realizados ensaios para a determinação da resistência ao cisalhamento em diversos tipos de lajes alveolares. Os ensaios foram desenvolvidos de acordo com a norma europeia EN 1168:2005. Todas as lajes ensaiadas apresentavam $120 \mathrm{~cm}$ de largura, com altura e comprimento variados, dependendo do tipo de peça. As lajes tinham sete nervuras (seis alvéolos), e foram produzidas com concreto das classes C50/60, pré-tracionado com fios de aço em zonas superiores e inferiores. 
De acordo com as recomendações da EN 1168:2005, foi necessário verificar a resistência à compressão e as propriedades geométricas de cada peça, antes do ensaio. Corpos de prova cilíndricos foram extraídos das lajes para ser submetidos à compressão, os quais ensaiados tinham $50 \mathrm{~mm}$ de diâmetro e $56 \mathrm{~mm}$ de altura, de acordo com a EN 12504-1:2003. Além disso, foram verificadas algumas propriedades geométricas tais como: altura da laje; espessura das nervuras e do flange inferior; comprimento e largura da laje; posição do aço pré-tracionado ou armaduras em zona de tração e cobrimento de concreto. Os valores medidos foram comparados com os fornecidos pelo fabricante.

Para o ensaio, a laje foi colocada em apoios de tal forma que ela atuasse como uma viga simplesmente apoiada. O apoio próximo da força aplicada foi executado como um apoio móvel (Figura 4.19 e Figura 4.20), de modo a evitar o aparecimento de força longitudinal devida ao movimento da laje no apoio.
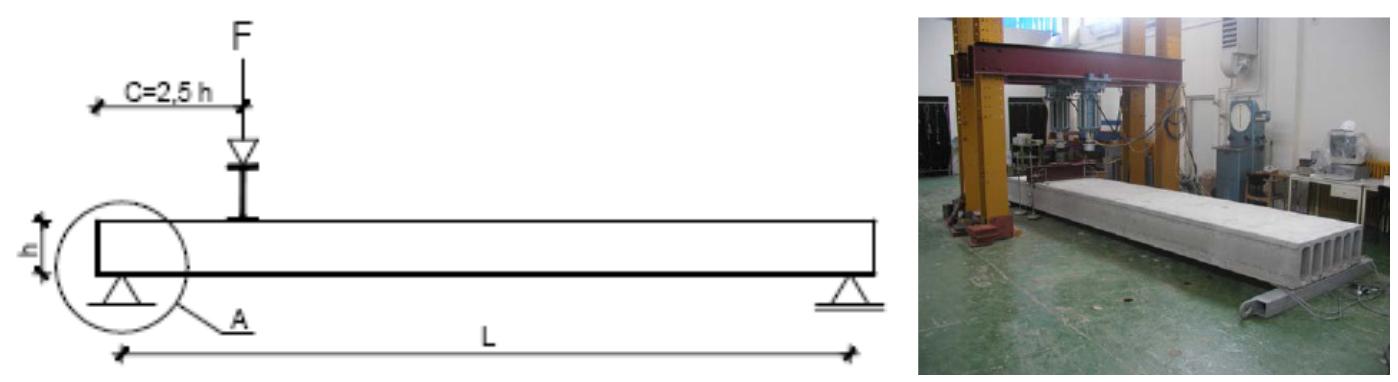

Figura 4.19: Arranjo do ensaio. [Tkalcic et al. (2007)]

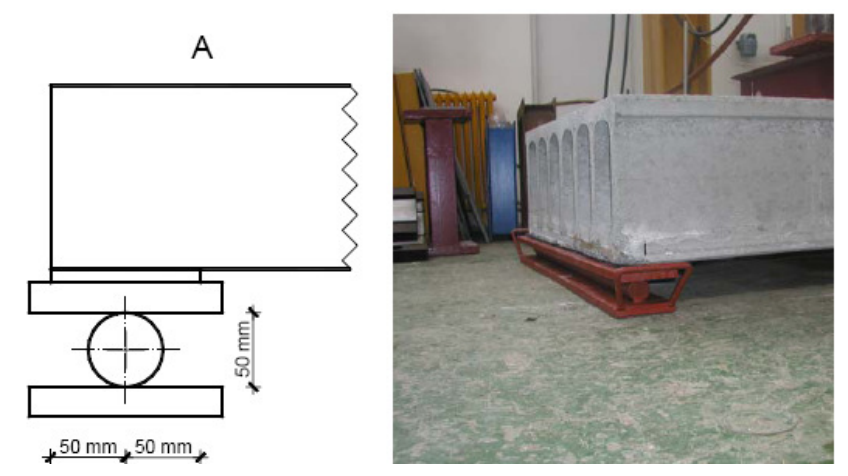

Figura 4.20: Arranjo do ensaio - detalhe do apoio (A). [Tkalcic et al. (2007)]

Uma camada de neoprene foi colocada entre a laje e o apoio e entre a laje e a viga metálica, usada para aplicar o carregamento (uma camada de argamassa ou gesso também pode ser aplicada), a fim de contrabalancear áreas laterais desiguais e aplicar forças de modo mais uniforme possível.

Segundo Tkalcic et al. (2007), nesse ensaio de cisalhamento, a força foi aplicada a uma distância de $2,5 \mathrm{~h}$, medida a partir da extremidade da laje, sendo $\mathrm{h}$ a altura de sua seção transversal (Figura 4.19). 
Além disso, as condições de apoio permitiam a distribuição uniforme da força ao longo de toda a largura da laje. Esses pesquisadores também esclarecem que, no ensaio, a força foi aplicada através de uma viga metálica, cuja rigidez foi suficientemente alta para permitir a distribuição uniforme do carregamento ao longo de toda a largura da laje.

De acordo com Tkalcic et al. (2007), a altura da viga metálica deve ser no mínimo de $150 \mathrm{~mm}$, se a força for aplicada por meio de duas vigas. Se for por apenas uma viga, a altura recomendada é de $250 \mathrm{~mm}$.

Durante os ensaios, foram aplicados carregamentos cíclicos, na velocidade de $1 / 10 \mathrm{da}$ força máxima teórica de ruptura, até atingir $70 \%$ do Estado Limite Último de cálculo. No décimo ciclo, os elementos foram carregados até a ruptura. A Figura 4.21 mostra a fissuração para um dos modelos ensaiados.

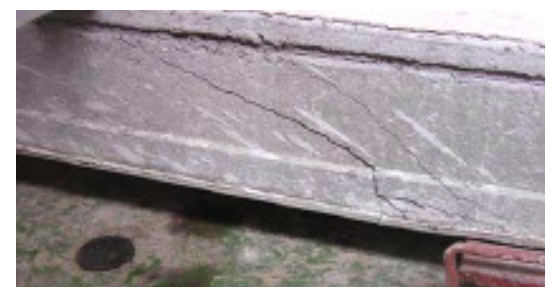

Figura 4.21: Fissuração de elemento de laje alveolar protendida, ensaiado por Tkalcic et al (2007).

Os elementos de laje alveolar ensaiados tinham comprimentos variando entre $4 \mathrm{~m}$ e $16 \mathrm{~m}$, e espessuras variando entre $0,15 \mathrm{~m}$ e $0,5 \mathrm{~m}$.

A partir dos resultados experimentais obtidos foi possível a comparação com os valores teóricos, aferindo a qualidade dos produtos ensaiados.

Segundo os autores, os resultados obtidos atenderam as especificações normativas.

\subsection{AJDUKIEWICZ ET AL. (2007)}

Ajdukiewicz et al. (2007) realizaram ensaios comparativos com o intuito de analisar o comportamento de elementos de laje com e sem capa, submetidos a carregamentos quase distribuídos. Foram empregados elementos de laje com pouca idade e com idades mais avançadas.

O objetivo geral dos ensaios foi comparar o comportamento de lajes com e sem capa, para as seguintes condições:

* carregamento linear de curta duração (instantâneo) até a ruptura, para elementos com processo avançado de perdas de protensão, com idade mínima de um ano;

* carregamento de longa duração, iniciando os ensaios pelos elementos relativamente novos, com idade de um a dois meses;

* após ensaios de longa duração (seis meses), submetidos a carregamento linear de curta duração, até a ruptura. 
Foram ensaiados quatro elementos de $7 \mathrm{~m}$ de comprimento e 0,32 $\mathrm{m}$ de espessura. Os modelos HCS1 e HCS2 foram expostos às condições ambientais normais antes dos ensaios, e suas resistências foram avaliadas no decorrer do tempo, por esclerômetro.

Os modelos HCS3 e HCS4 foram mantidos em condições de laboratório, com temperatura e umidade relativamente controladas, por quase dois meses, e posteriormente sob as mesmas condições, para os ensaios de avaliação ao longo do tempo.

Foram empregados dois diferentes modos de carregamento para cada grupo de elemento ensaiado. Os elementos HCS-1 (sem capa) e HCS-2 (com $50 \mathrm{~mm}$ de capa) foram submetidos a carregamento instantâneo linear até a ruptura, enquanto que HCS-3 (sem capa) e HCS-4 (com capa) foram submetidos a carregamento de longa duração. Finalmente eles também foram ensaiados até a ruptura, com carregamento instantâneo. Os elementos foram ensaiados como sendo simplesmente apoiados, com vão de 6,9 m. Para os ensaios de curta duração, o carregamento linear foi aplicado por quatro forças uniformemente distribuídas ao longo da largura da laje. A geometria da laje e o arranjo de carregamento estão apresentados na Figura 4.22. Para o ensaio de longa duração, o carregamento foi aplicado por 16 blocos de concreto, com $11 \mathrm{kN}$ cada (esquema da Figura 4.22b). Portanto, a carga uniforme empregada no ensaio de longa duração correspondeu a $21 \mathrm{kN} / \mathrm{m}^{2}$ (excluindo o peso próprio). A carga de longa duração correspondeu a $35 \%$ da força última e $58 \%$ da força de fissuração, quando se comparam os resultados para HCS-1.

a)

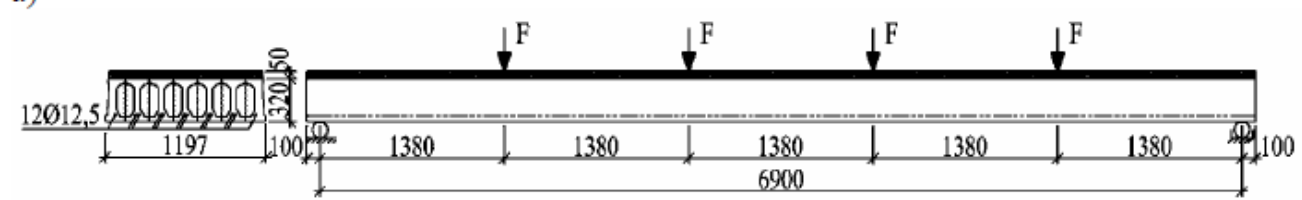

b)

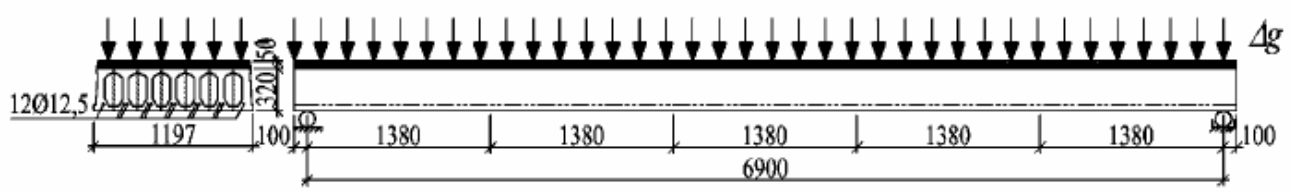

Figura 4.22: Geometria da laje e arranjo de carregamento: a) Carregamento de curta duração; b) Carregamento de longa duração. [Ajdukiewicz et al. (2007)]

Nos ensaios de curta duração, em cada incremento de força de $12,5 \mathrm{kN}$ foram registrados os seguintes dados: flechas das lajes e escorregamento das cordoalhas, por meio de medidor indutivo; deformação do concreto, por meio de medidor elétrico de resistência; localização e largura das fissuras, particularmente no nível das cordoalhas; e o comportamento da interface da laje com o concreto complementar (capa). 


\section{- Resultados e observações para os ensaios de curta duração}

A fissuração da laje HCS-1 (sem capa) apareceu aproximadamente no nível de força de $250 \mathrm{kN}$, que corresponde a um momento de fissuração de $306 \mathrm{kN} . \mathrm{m}$, enquanto que a fissuração da laje HCS-2 (com capa) apareceu no nível de força de 280 kN (345 kN.m).

A flecha da laje na fissuração foi estimada para HCS-1 como 1/468 do vão, e para HCS-2 (com capa), como $1 / 488$ do vão. Após a fissuração, o aumento da flecha na laje com capa foi muito menor, comparando com a da outra laje.

$\mathrm{Na}$ ruptura, foi observado repentino cisalhamento na região do apoio e posterior escorregamento das cordoalhas. A ruptura das lajes não foi precedida por fissuração nos apoios, mas foram observadas grandes fissuras no meio do vão. A ruptura da laje HCS-1 (sem capa) ocorreu para a força de $440 \mathrm{kN}$ (correspondendo a $502 \mathrm{kN} . \mathrm{m}$ ), enquanto que a ruptura da laje HCS-2 (com capa) ocorreu para a força de 540 kN (614 kN.m).

Até a ruptura, não foi observada qualquer delaminação (efeito de perda de aderência) ou fissuração na interface da laje pré-moldada (HCS-2) com a capa. Isto significa que a resistência ao cisalhamento na interface foi suficiente. A delaminação apareceu somente na ruptura, simultaneamente ao dano completo do elemento.

\section{- Resultados e observações para os ensaios de longa duração}

A carga de aproximadamente $21 \mathrm{kN} / \mathrm{m}^{2}$ foi aplicada na laje e mantida constante ao longo de seis meses. Os efeitos dependentes do tempo foram registrados durante todo o período de ensaio, o que significa resultados de fluência e retração do concreto e relaxação do aço. O desenvolvimento de flecha no tempo é apresentado na Figura 4.23. Não foi observada qualquer fissuração das lajes ou escorregamento das cordoalhas.

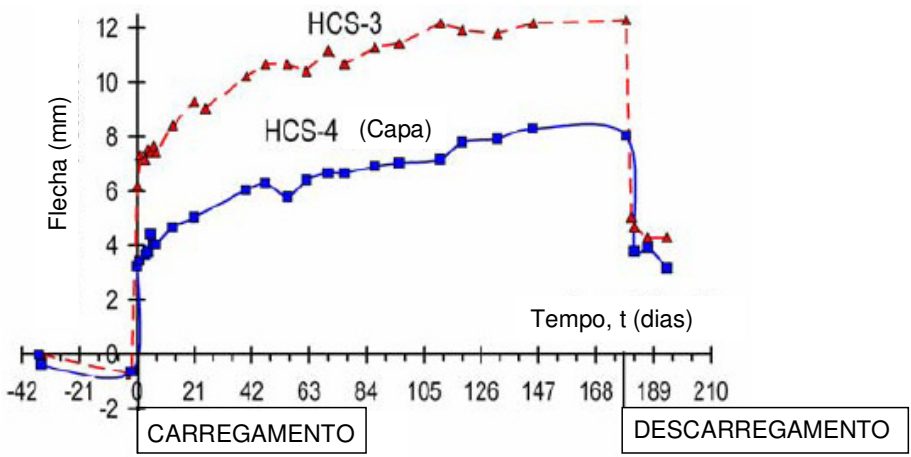

Figura 4.23: Desenvolvimento da flecha no tempo. [Ajdukiewicz et al. (2007)]

- Resultados e observações para os ensaios de curta duração realizados em elementos submetidos anteriormente a carregamento de longa duração.

As lajes HCS-3 e HCS-4, primeiramente submetidas a carregamento de longa duração, foram subsequentemente ensaiadas sob carregamento instantâneo até a ruptura. Os resultados dos dois grupos de elementos estão apresentados na Tabela 4.8. 
Tabela 4.8: Resultados de ensaios de curta duração (após carregamento de longa duração de HCS-3 e HCS-4). [Ajdukiewicz et al. (2007)]

\begin{tabular}{|c|c|c|c|c|c|c|}
\hline Símbolo da laje & $\mathbf{4} \mathbf{F}_{\mathbf{c r}} \mathbf{( k N )}$ & $\mathbf{4} \mathbf{F u}_{\mathbf{u}} \mathbf{( k N )}$ & $\begin{array}{c}\boldsymbol{\varepsilon}_{\mathbf{c , 4 0 0}} \\
(\mathbf{\%} \%)\end{array}$ & $\begin{array}{c}\boldsymbol{\varepsilon}_{\mathbf{c n}, \mathbf{4 0 0}} \\
\mathbf{( \% )}\end{array}$ & $\mathbf{a}_{\mathbf{4 0 0}} \mathbf{( \mathbf { m m } )}$ & $\mathbf{\Sigma} \mathbf{w}_{\mathbf{4 0 0}}(\mathbf{m m})$ \\
\hline $\mathbf{1}$ & $\mathbf{2}$ & $\mathbf{3}$ & $\mathbf{4}$ & $\mathbf{5}$ & $\mathbf{6}$ & $\mathbf{7}$ \\
\hline HCS-1 & 250 & 440 & 0,72 & - & 71,32 & 8,75 \\
\hline HCS-2 & 280 & 540 & 0,11 & 0,82 & 41,11 & 5,10 \\
\hline HCS-3 & 240 & 450 & 0,84 & - & 78,64 & 9,78 \\
\hline
\end{tabular}

Força da primeira fissura (4Fcr); força última $\left(4 \mathrm{~F}_{\mathrm{u}}\right)$; deformação no concreto $\left(\varepsilon_{c, 400}\right)$; deformação complementar do concreto $\left(\varepsilon_{\mathrm{cn}, 400}\right)$; flecha da laje no meio do vão $\left(\mathrm{a}_{400}\right)$; abertura de fissuras $\left(\Sigma \mathrm{w}_{400}\right)$, na força escolhida de $4 \mathrm{~F}=400 \mathrm{kN}$

Os resultados obtidos para as lajes HCS-3 e HCS-4 foram compatíveis com os alcançados para HCS-1 e HCS-2, as quais foram submetidas somente ao primeiro carregamento. Não houve escorregamento das cordoalhas, o que comprova que ocorreu boa aderência entre estas e o concreto. Alguns resultados dos ensaios estão apresentados na Figura 4.24: comparação da relação momento fletor versus flecha e desenvolvimento da largura das fissuras no nível das cordoalhas. Foi observada diminuição da rigidez para as lajes submetidas previamente ao carregamento de longa duração. Isso ocorreu devido à elevada perda de protensão após 6 meses do carregamento de longa duração, igual a $35 \%$ da força última e $58 \%$ da força de fissuração esperada para as lajes.
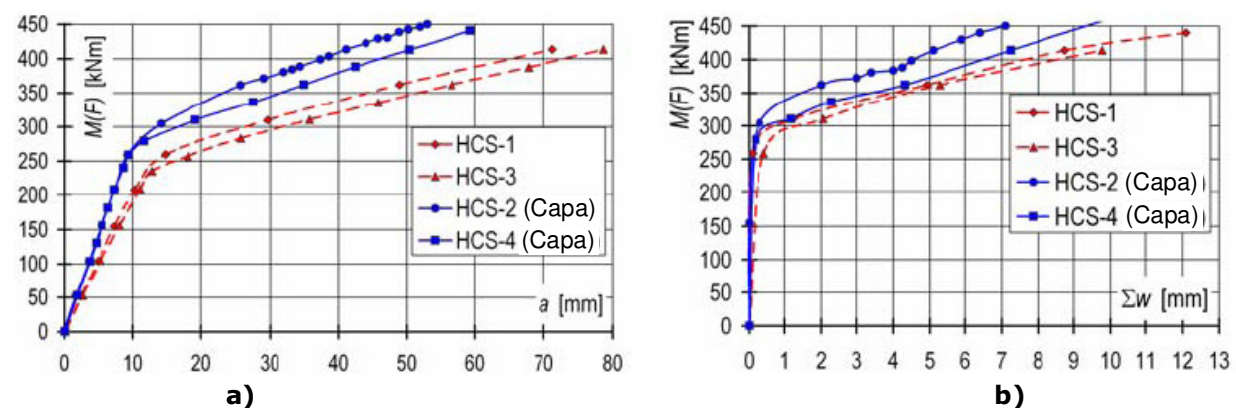

b)

Figura 4.24: a) Momento fletor versus flecha; b) Largura das fissuras. [Ajdukiewicz et al. (2007)]

Os gráficos de momento versus flecha, considerando os quatro elementos de laje ensaiados, podem ser observados na Figura 4.24a. O elemento de laje com a presença de capa e que ficou totalmente exposto às condições climáticas naturais, denominado HCS-2, apresentou o melhor desempenho. O elemento que apresentou pior desempenho correspondeu ao HSC-3. Comparando os resultados obtidos para HCS-2 (melhor resultado) e HCS-3 (pior resultado), pode-se observar uma diferença de $50 \mathrm{kN} . \mathrm{m}$ entre os elementos e que HCS-2 apresentou uma flecha em torno de $37,5 \%$ menor que HCS-3.

O modo de ruptura para as lajes HCS-3 (sem capa) e HCS-4 (com capa) foram compatíveis com o previsto. Foi observada repentina ruptura por cisalhamento na região do apoio, no nível das forças quase iguais para as lajes HCS-1 (sem capa) e HCS-2 (com capa). 
De acordo com Ajdukiewicz et al. (2007), os elementos ensaiados tiveram um comportamento similar na ruptura, apresentando como única diferença o efeito de perda de aderência (delaminação) entre a capa e a laje, para os elementos com capa. Todos os elementos apresentaram ruptura de adesão na interface do concreto com os cabos de protensão, na região próxima ao apoio.

\section{- Conclusões}

Os elementos foram ensaiados como simplesmente apoiados, o que corresponde a um arranjo estático típico para esses elementos na estrutura real.

A pesquisa desenvolvida por Ajdukiewicz et al. (2007) focou na trabalhabilidade das lajes e particularmente nas vantagens do emprego de lajes com seção composta (com 50 $\mathrm{mm}$ de capa).

Não foram empregadas armaduras transversais adicionais, foi feita somente uma preparação básica da superfície, com limpeza e molhagem.

Durante os ensaios, os elementos apresentaram comportamento próximo ao esperado. Houve aumento nas flechas observadas, perceptíveis especialmente para os dois primeiros meses de aplicação de força, como um resultado usual do fenômeno dependente do tempo.

Os seis meses de carregamento influenciaram o comportamento das lajes durante o ensaio final de curta duração, devido às perdas de protensão que ocasionaram uma rápida diminuição da rigidez das lajes.

Durante o ensaio de curta duração, sob carregamento instantâneo, não foi observado qualquer dano antecipado ou ruptura de adesão das cordoalhas.

O concreto complementar de apenas $50 \mathrm{~mm}$ de espessura demonstrou evidentemente ser vantajoso. Mesmo sem qualquer tratamento superficial adicional e sem armadura na interface, não foi observada fissuração ou delaminação entre a laje e a capa de concreto, até o nível de mais de $95 \%$ da força de ruptura.

As forças de fissuração e momentos fletores últimos para as lajes ensaiadas foram relativamente elevados. Comparando as lajes com e sem capa de concreto, foram obtidas as seguintes conclusões:

- As lajes com capa apresentaram aumento do momento fletor último superior a $22 \%$;

- As lajes com capa também apresentaram aumento do momento de fissuração, de quase $13 \%$ (as primeiras fissuras com abertura de $0,05 \mathrm{~mm}$ ).

Em geral, os ensaios provaram a elevada capacidade de carga, resistência à fissuração e rigidez à flexão das lajes alveolares protendidas. Foram observadas mais melhorias no desempenho estrutural geral dos elementos compostos com capa de concreto. 


\subsection{IBRAHIM ET AL. (2008)}

De acordo com Ibrahim et al. (2008), inúmeros problemas podem ocorrer quanto à execução de capas de concreto em lajes alveolares, como pode ser observado na Figura 4.25 .

A ruptura pode ser brusca, especialmente em pisos pré-moldados protendidos que tenham elevada relação resistência-rigidez.

$\mathrm{Na}$ Europa, milhões de libras são gastas em onerosos trabalhos de reparo, desperdícios e elevada espessura da capa de concreto, provenientes dos problemas quanto ao processo construtivo.

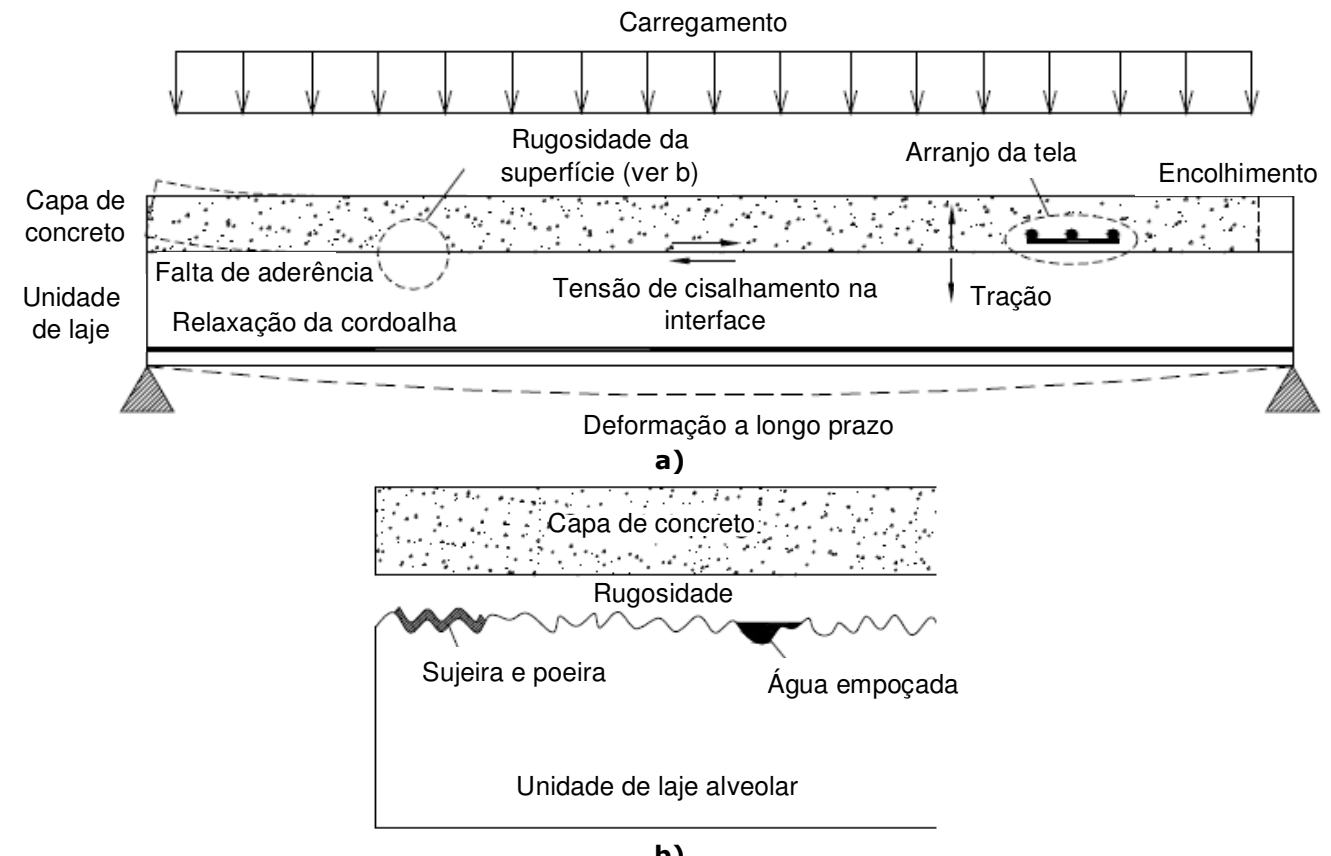

b)

Figura 4.25: Problemas relativos à construção das capas de concreto. a) Problemas globais; b) Problemas relativos à rugosidade da superfície. [IBRAHIM et al. (2008)]

Segundo Ibrahim et al. (2008), quando os poros da superfície estão totalmente tratados, essa superfície encontra-se em condições úmidas. Se a superfície pré-moldada foi deixada repousando ao ar livre, em condições ambientes (condições secas), antes do lançamento da capa de concreto, uma parte da água contida na unidade irá evaporar e será inferior à da peça saturada.

Para produzir uma superfície em condição extremamente seca, uma secagem prolongada em estufa ou em um complexo fechado quente iria reduzir o teor de umidade do concreto, até a secagem total. No entanto, essa condição não é alcançável para produção, em larga escala, de unidades pré-moldadas. As diferentes fases das condições da superfície são mostradas na Figura 4.26. 


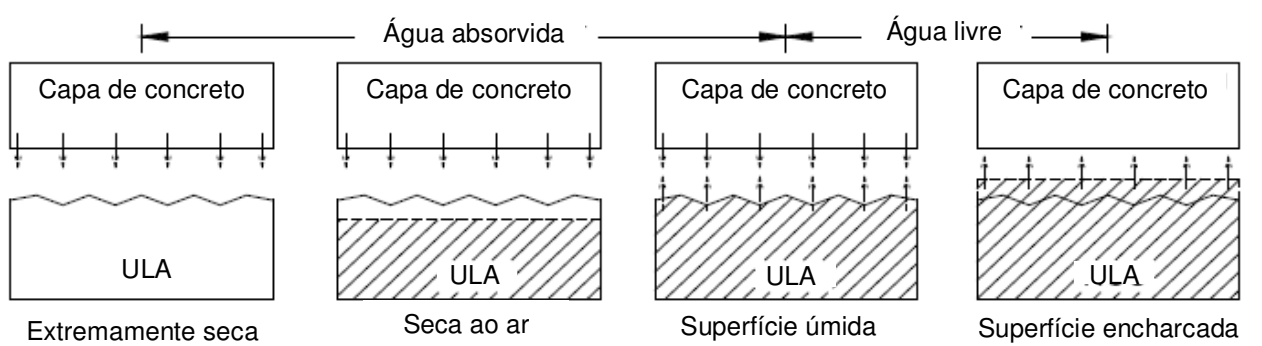

Figura 4.26: Interface com diferentes tipos de preparação de superfície. [IBRAHIM et al. (2008)]

Para uma condição extrema, a superfície encontra-se em condições saturadas. Se a superfície da unidade pré-moldada, antes do lançamento, estiver muito seca, ela irá absorver a água da capa de concreto, sendo a qualidade adjacente à interface regulada pela capacidade da interface. Em contrapartida, se a superfície for encharcada, a grande quantidade de água livre na superfície irá enfraquecer a aderência da interface, reduzindo, assim, a capacidade da laje composta.

Assim, Ibrahim et al. (2008) estudaram os efeito da rugosidade (rugosa ou lisa) e condições de superfície (encharcada e condições ótimas de umidade) na capacidade à flexão, de lajes alveolares protendidas, com capa de concreto moldado no local, por meio de diversos ensaios experimentais em escala real. O escorregamento da interface também foi medido durante o ensaio para observar o comportamento de seção composta, das amostras ensaiadas.

A geometria dos modelos pode ser observada na Figura 4.27.

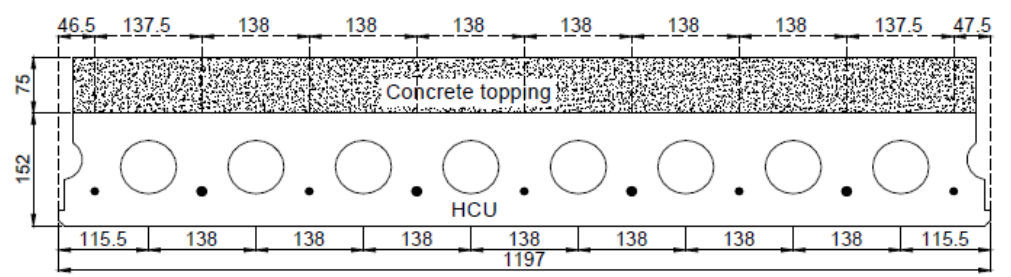

Figura 4.27: Seção transversal do modelo ensaiado à flexão. [Ibrahim et al. (2008)]

Foram analisados modelos considerando a superfície rugosa e lisa, variando, para cada uma dessas, as condições de umidade, podendo ser superfície encharcada ou em condições de umidade ótima. A rugosidade foi medida empregando um instrumento especial, que pode ser observado na Figura 4.28.

Esse instrumento é colocado em cima da laje para medir a rugosidade ao longo de um comprimento de $200 \mathrm{~mm}$. Uma vez que o instrumento está posicionado, o controle deslizante move-se livremente, sem deslocar o próprio instrumento.

A rugosidade foi medida em três locais na direção longitudinal: meio do vão e extremidades direita e esquerda da laje. Considerou-se a média dos três locais analisados. 
O esquema de ensaio à flexão pode ser observado na Figura 4.29.

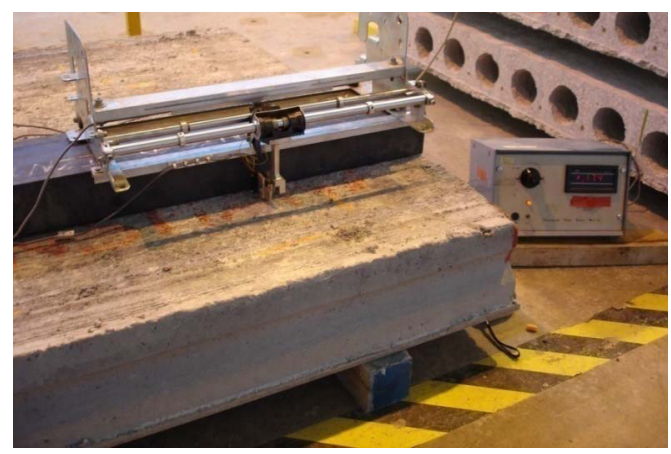

Figura 4.28: Instrumento para medir rugosidade superficial. [Ibrahim et al. (2008)]

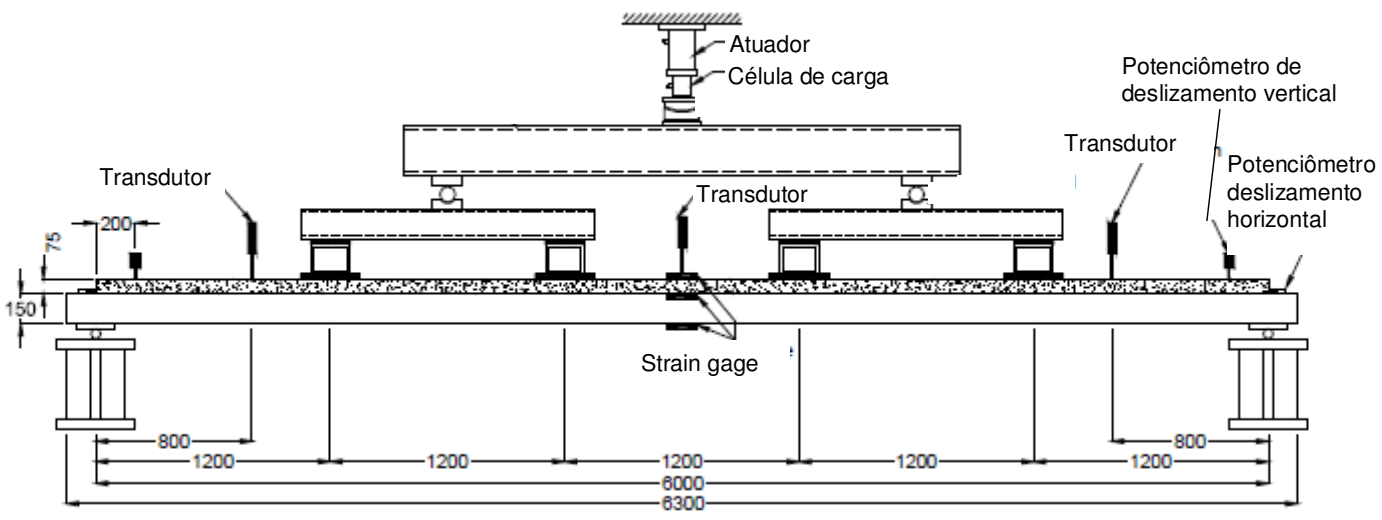

Figura 4. 29: Esquema do ensaio à flexão. [Ibrahim et al. (2008)]

Considerando superfícies lisas e rugosas, os resultados dos ensaios mostraram que a capacidade última à flexão para a condição encharcada foi de 3 a $5 \%$ menor do que para a condição de umidade ótima, apesar de apresentarem valores mais altos do que os calculados.

Os modelos com a superfície encharcada, para superfícies lisas e rugosas, não apresentaram redução quanto à capacidade ao momento fletor último, sendo tal momento $17 \%$ a $25 \%$ superior ao valor calculado. Somente foi observado um escorregamento da interface para os modelos com superfície encharcada e lisa, correspondendo a 0,08 $\mathrm{mm}$. Posteriormente, foi observado que, com a rugosidade da superfície superior da laje, esse escorregamento da interface pode ser eliminado.

\subsection{BERTAGNOLI \& MANCINI (2009)}

Uma interpretação mais cuidadosa, com relação ao cálculo ao cisalhamento de lajes alveolares, é apresentada por Bertagnoli \& Mancini (2009). Eles mostram que não há risco quanto à segurança, se essas lajes forem projetadas adequadamente. 


\section{- Aspectos gerais da pesquisa}

A racionalização do projeto de lajes alveolares ao cisalhamento é apresentada no estudo dos citados pesquisadores, que demonstam a necessidade de considerar quatro diferentes mecanismos resistentes, os quais podem governar o comportamento último da laje. Também é apresentada uma comparação entre os resultados do procedimento proposto por esses autores com o grande banco de dados de resultados experimentais. Tal comparação mostra que o projeto de lajes alveolares de acordo com as recomendações do Código Modelo 90 e do Eurocode é seguro, mas que projetistas e construtores deveriam checar todos os quatro mecanismos resistentes.

O comportamento de lajes alveolares submetidas predominantemente ao cisalhamento depende de diferentes fenômenos, denominados: dispersão da protensão, ancoragem das armaduras protendidas, valor do momento de fissuração em cada seção e, por último, mas não menos importante, resistência ao cisalhamento em região fissurada e em região não fissurada. Assim, uma estimativa correta da carga última pode ser alcançada somente com a consideração de todos esses fenômenos e de sua interação.

\section{- Descrição dos ensaios experimentais}

Os ensaios experimentais descritos no trabalho de Bertagnoli \& Mancini (2009) foram realizados pelo Centro de Pesquisa Técnica (VTT) da Finlândia, pelo Instituto Holandês de Pesquisas Científicas, TNO, pela Universidade de Áquila, na Itália, e pelo Instituto de Pesquisa M. Mancini, na Itália. Todos os esquemas de carregamento usados nos ensaios experimentais são ilustrados na Figura 4.30.
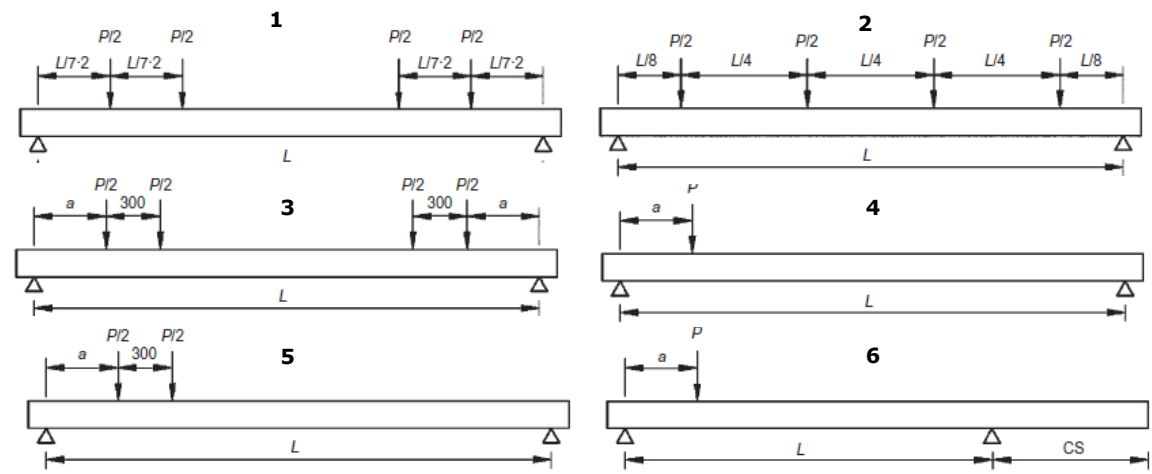

Figura 4.30: Esquemas de carregamento empregados. [Bertagnoli \& Mancini (2009)]

Todos os ensaios alcançaram um colapso frágil, na região entre o apoio e a área mais próxima da força. Na ruptura, todas as lajes apresentaram uma ou mais fissuras inclinadas entre o apoio e a área mais próxima da força aplicada, como pode ser observado na Figura 4.31. 

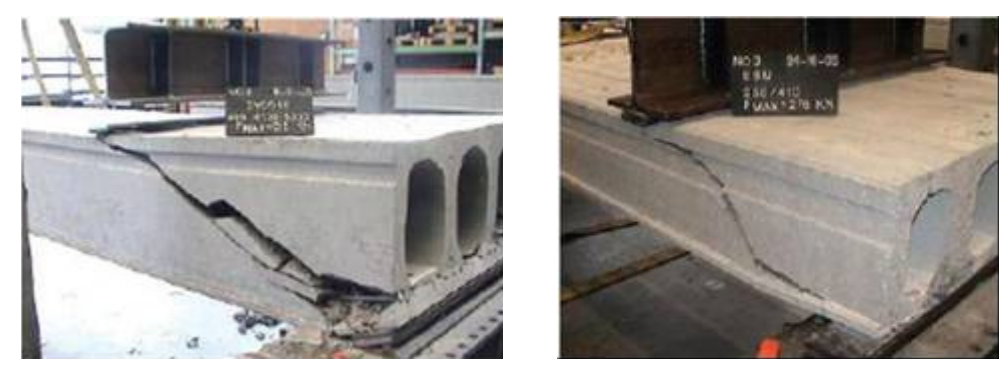

Figura 4.31: Exemplos de fissuras no colapso. [Bertagnoli \& Mancini (2009)]

Devido à imensa gama de dados, atribuiu-se maior atenção às peças com menores alturas. A Tabela 4.9 mostra propriedades das lajes com alturas de $151 \mathrm{~mm}$ a $260 \mathrm{~mm}$.

Tabela 4.9: Propriedades geométricas e mecânicas dos modelos. [Bertagnoli \& Mancini (2009)]

\begin{tabular}{|c|c|c|c|c|c|c|c|c|c|c|c|}
\hline$N^{\circ}$ & $\begin{array}{c}\mathrm{H} \\
(\mathrm{mm})\end{array}$ & $\begin{array}{c}\mathrm{A}_{\mathrm{C}} \\
\left(\mathrm{mm}^{2}\right)\end{array}$ & $\mathrm{I}\left(\mathrm{mm}^{4}\right)$ & $\mathrm{n}_{\mathrm{b} 1}$ & $\begin{array}{c}\phi_{\mathrm{b} 1} \\
(\mathrm{~mm})\end{array}$ & $\mathrm{n}_{\mathrm{b} 2}$ & $\begin{array}{c}\phi_{\mathrm{b} 2} \\
(\mathrm{~mm})\end{array}$ & $\mathrm{n}_{\mathrm{t}}$ & $\begin{array}{c}\phi_{\mathrm{t}} \\
(\mathrm{mm})\end{array}$ & $\begin{array}{c}\sigma_{\mathrm{b}} \\
(\mathrm{MPa})\end{array}$ & $\begin{array}{c}\sigma_{\mathrm{t}} \\
(\mathrm{MPa})\end{array}$ \\
\hline 1 & 200 & $1,19.10^{3}$ & $6,02 \cdot 10^{8}$ & 4 & 12,5 & 3 & 12,5 & 0 & ----- & 1100 & 0 \\
\hline 2 & 200 & $1,19.10^{3}$ & $6,03 \cdot 10^{8}$ & 4 & 12,5 & 3 & 12,5 & 0 & ----- & 1100 & 0 \\
\hline 3 & 200 & $1,26.10^{3}$ & $6,07 \cdot 10^{8}$ & 4 & 12,5 & 3 & 12,5 & 0 & ----- & 1100 & 0 \\
\hline 4 & 200 & $1,26.10^{3}$ & $6,18.10^{8}$ & 4 & 12,5 & 3 & 12,5 & 0 & ----- & 1000 & 0 \\
\hline 47 & 255 & $1,74.10^{3}$ & $1,40.10^{9}$ & 5 & 12,5 & 5 & 12,5 & 2 & 6,5 & 1302 & 1302 \\
\hline 48 & 255 & $1,74.10^{3}$ & $1,40.10^{9}$ & 5 & 12,5 & 5 & 12,5 & 2 & 6,5 & 1302 & 1302 \\
\hline 49 & 255 & $1,74.10^{3}$ & $1,40.10^{9}$ & 5 & 12,5 & 5 & 12,5 & 2 & 6,5 & 1302 & 1302 \\
\hline 62 & 260 & $1,86.10^{3}$ & $1,50.10^{9}$ & 5 & 12,5 & 5 & 12,5 & 0 & ----- & 930 & 930 \\
\hline 63 & 260 & $1,86 \cdot 10^{3}$ & $1,50.10^{9}$ & 5 & 12,5 & 5 & 12,5 & 0 & ----- & 930 & 930 \\
\hline 64 & 260 & $1,86.10^{3}$ & $1,50.10^{9}$ & 5 & 12,5 & 5 & 12,5 & 0 & ----- & 930 & 930 \\
\hline 68 & 260 & $1,81.10^{3}$ & $1,50.10^{9}$ & 5 & 12,5 & 5 & 12,5 & 2 & 9,3 & 1250 & 800 \\
\hline 69 & 260 & $1,81.10^{3}$ & $1,50.10^{9}$ & 5 & 12,5 & 5 & 12,5 & 2 & 9,3 & 1250 & 800 \\
\hline 70 & 260 & $1,81.10^{3}$ & $1,50.10^{9}$ & 5 & 12,5 & 5 & 12,5 & 2 & 9,3 & 1250 & 800 \\
\hline 77 & 260 & $1,78.10^{3}$ & $1,40.10^{9}$ & 12 & 12,5 & 4 & 12,5 & 10 & 5 & 1100 & 1100 \\
\hline 78 & 260 & $1,78.10^{3}$ & $1,40.10^{9}$ & 12 & 12,5 & 4 & 12,5 & 10 & 5 & 1100 & 1100 \\
\hline 79 & 260 & $1,78.10^{3}$ & $1,40.10^{9}$ & 12 & 12,5 & 4 & 12,5 & 10 & 5 & 1100 & 1100 \\
\hline 86 & 255 & $1,71.10^{3}$ & $1,35.10^{9}$ & 3 & 12,5 & 3 & 12,5 & 0 & ----- & 1300 & 0 \\
\hline 88 & 255 & $1,71.10^{3}$ & $1,35.10^{9}$ & 3 & 12,5 & 3 & 12,5 & 0 & ----- & 1300 & 0 \\
\hline 89 & 255 & $1,71.10^{3}$ & $1,35.10^{9}$ & 3 & 12,5 & 3 & 12,5 & 0 & ----- & 1300 & 0 \\
\hline 90 & 255 & $1,71.10^{3}$ & $1,35.10^{9}$ & 5 & 12,5 & 5 & 12,5 & 0 & ----- & 1300 & 0 \\
\hline 91 & 255 & $1,71.10^{3}$ & $1,35.10^{9}$ & 5 & 12,5 & 5 & 12,5 & 0 & ----- & 1300 & 0 \\
\hline 92 & 255 & $1,71.10^{3}$ & $1,35.10^{9}$ & 5 & 12,5 & 5 & 12,5 & 0 & ---- & 1300 & 0 \\
\hline 93 & 255 & $1,71.10^{3}$ & $1,35.10^{9}$ & 5 & 12,5 & 5 & 12,5 & 0 & ----- & 1300 & 0 \\
\hline 94 & 255 & $1,71.10^{3}$ & $1,35.10^{9}$ & 5 & 12,5 & 5 & 12,5 & 0 & ----- & 1300 & 0 \\
\hline 110 & 200 & $1,41.10^{3}$ & $6,57 \cdot 10^{8}$ & 3 & 9,3 & 7 & 9,3 & 2 & 6,5 & 956 & 956 \\
\hline 111 & 200 & $1,41.10^{3}$ & $6,57.10^{8}$ & 3 & 9,3 & 7 & 9,3 & 2 & 6,5 & 956 & 956 \\
\hline 112 & 200 & $1,41.10^{3}$ & $6,57 \cdot 10^{8}$ & 3 & 9,3 & 7 & 9,3 & 2 & 6,5 & 956 & 956 \\
\hline 116 & 162 & $1,34.10^{3}$ & $3,85 \cdot 10^{8}$ & 6 & 9,3 & 2 & 6,5 & 0 & ---- & 1362 & 0 \\
\hline 117 & 153 & $1,18.10^{3}$ & $3,12.10^{8}$ & 6 & 9,3 & 2 & 6,5 & 0 & ---- & 1264 & 0 \\
\hline 118 & 151 & $1,16.10^{3}$ & $2,99 \cdot 10^{8}$ & 2 & 9,3 & 6 & 6,5 & 0 & ----- & 1290 & 0 \\
\hline 119 & 203 & $1,34.10^{3}$ & $6,74.10^{8}$ & 4 & 9,3 & 3 & 12,5 & 0 & ----- & 1360 & 0 \\
\hline
\end{tabular}

No: número da laje ensaiada; $\mathrm{H}$ : altura da laje; $\mathrm{A}_{\mathrm{C}}$ : área da seção transversal; I: momento de inércia da seção de concreto; $\mathrm{n}_{\mathrm{b} 1}$ : número de cordoalhas na parte inferior da peça, com diâmetro nominal $\phi_{\mathrm{b} 1} ; \mathrm{n}_{\mathrm{b} 2}$ : número de cordoalhas na parte inferior da peça, com diâmetro nominal $\phi_{\mathrm{b} 2} ; \mathrm{n}_{\mathrm{t}}$ : número de cordoalhas na parte superior da peça, com diâmetro nominal $\phi_{t} ; \sigma_{b}$ :tensão de protensão das barras da parte inferior; $\sigma_{t}$ : tensão de protensão das barras da parte superior.

A resistência última nunca foi alcançada, ou seja, nenhuma laje rompeu por flexão. Nesse trabalho (Bertagnoli \& Mancini (2009)) foram analisados 129 modelos: 46 pelo Centro de Pesquisa Técnica (VTT), de 1991 a 2003, 39 pelo Instituto Holandês TNO, em 2005, 16 pela Universidade Tecnológica de Delft, em 1979, 14 pela Universidade de Áquila, de 1998 a 2003, e 14 pelo Instituto de Pesquisa M. Mancini, de 1995 a 2005. 
A Tabela 4.10 apresenta resultados e considerações sobre os modelos escolhidos.

Tabela 4.10: Ensaios experimentais: dados gerais. [Bertagnoli \& Mancini (2009)]

\begin{tabular}{|c|c|c|c|c|c|c|c|c|c|c|}
\hline $\mathrm{N}^{\circ}$ & $P$ & EE & NA & $\begin{array}{l}\mathrm{L} \\
(\mathrm{mm})\end{array}$ & $\begin{array}{l}\text { a } \\
(\mathrm{mm})\end{array}$ & $\begin{array}{l}\text { LP } \\
(\mathrm{mm})\end{array}$ & Idade & $\begin{array}{l}\mathrm{R}_{\mathrm{cm}} \\
(\mathrm{MPa})\end{array}$ & $\begin{array}{l}R_{\mathrm{ck}} \\
(\mathrm{MPa})\end{array}$ & $\begin{array}{l}F_{u, \exp } \\
(k N)\end{array}$ \\
\hline 1 & $\mathrm{~F}$ & 1 & 6 & 6603 & 917 & 40 & 49 & 54,8 & 48,5 & 80 \\
\hline 2 & $\mathrm{~F}$ & 1 & 6 & 4958 & 689 & 40 & 61 & 52,8 & 47,5 & 108 \\
\hline 3 & $\mathrm{~F}$ & 1 & 6 & 6217 & 863 & 40 & 29 & 76,5 & 70,2 & 95 \\
\hline 4 & $\mathrm{~F}$ & 1 & 6 & 3966 & 551 & 40 & 90 & 56,6 & 52,5 & 95 \\
\hline 47 & $\mathrm{H}$ & 4 & 5 & 3900 & 638 & 100 & 33 & 83,8 & 81,9 & 399 \\
\hline 48 & $\mathrm{H}$ & 4 & 5 & 3900 & 638 & 100 & 33 & 83,8 & 81,9 & 417 \\
\hline 49 & $\mathrm{H}$ & 4 & 5 & 3900 & 638 & 100 & 33 & 83,8 & 81,9 & 411 \\
\hline 62 & $\mathrm{H}$ & 4 & --- & 3900 & 650 & 100 & 33 & 101,4 & 81,1 & 416 \\
\hline 63 & $\mathrm{H}$ & 4 & --- & 3900 & 650 & 100 & 33 & 101,4 & 81,1 & 386 \\
\hline 64 & $\mathrm{H}$ & 4 & --- & 3900 & 650 & 100 & 33 & 101,4 & 81,1 & 376 \\
\hline 68 & $\mathrm{H}$ & 4 & 5 & 3900 & 650 & 100 & 30 & 91,1 & 88,7 & 415 \\
\hline 69 & $\mathrm{H}$ & 4 & 5 & 3900 & 650 & 100 & 30 & 91,1 & 88,7 & 402 \\
\hline 70 & $\mathrm{H}$ & 4 & 5 & 3900 & 650 & 100 & 30 & 91,1 & 88,7 & 424 \\
\hline 77 & $\mathrm{H}$ & 4 & 7 & 3900 & 650 & 100 & 28 & 81,5 & 81,3 & 302 \\
\hline 78 & $\mathrm{H}$ & 4 & 7 & 3900 & 650 & 100 & 28 & 81,5 & 81,3 & 300 \\
\hline 79 & $\mathrm{H}$ & 4 & 7 & 3900 & 650 & 100 & 28 & 81,5 & 81,3 & 295 \\
\hline 86 & $\mathrm{H}$ & 4 & 5 & 2295 & 805 & 150 & 28 & 62,7 & 61,4 & 353 \\
\hline 88 & $\mathrm{H}$ & 4 & 5 & 2312 & 805 & 150 & 28 & 62,7 & 61,4 & 370 \\
\hline 89 & $\mathrm{H}$ & 4 & 5 & 1945 & 460 & 150 & 28 & 62,7 & 61,4 & 364 \\
\hline 90 & $\mathrm{H}$ & 4 & 5 & 1939 & 460 & 150 & 28 & 62,7 & 61,4 & 367 \\
\hline 91 & $\mathrm{H}$ & 4 & 5 & 2299 & 805 & 150 & 28 & 62,7 & 61,4 & 405 \\
\hline 92 & $\mathrm{H}$ & 4 & 5 & 1933 & 460 & 150 & 28 & 62,7 & 61,4 & 370 \\
\hline 93 & $\mathrm{H}$ & 4 & 5 & 2645 & 1150 & 150 & 28 & 62,7 & 61,4 & 436 \\
\hline 94 & $\mathrm{H}$ & 4 & 5 & 2996 & 1500 & 150 & 28 & 62,7 & 61,4 & 414 \\
\hline 110 & I & 4 & 9 & 4000 & 600 & 100 & 30 & 55,7 & 55,7 & 165 \\
\hline 111 & I & 4 & 9 & 4000 & 600 & 100 & 30 & 55,7 & 55,7 & 166 \\
\hline 112 & I & 4 & 9 & 4000 & 600 & 100 & 30 & 55,7 & 55,7 & 195 \\
\hline 116 & I & 4 & 8 & 4000 & 375 & 200 & 28 & 59,2 & 58,1 & 181 \\
\hline 117 & I & 4 & 8 & 4000 & 375 & 200 & 28 & 59,2 & 58,1 & 177 \\
\hline 118 & I & 4 & 8 & 4000 & 375 & 200 & 28 & 59,2 & 58,1 & 157 \\
\hline 119 & I & 4 & 6 & 4000 & 500 & 200 & 28 & 59,2 & 58,1 & 258 \\
\hline
\end{tabular}

No: número da laje ensaiada; P: país (F: Finlândia, H: Holanda, I: Itália); EE: esquema de ensaio; NA: número de alvéolos; L: vão da laje; a: distância de aplicação da força; LP:Largura da placa do apoio; $R_{c m}$ : resistência cúbica média à compressão; $R_{c k}$ : resistência cúbica característica à compressão; $F_{\mathrm{u}, \exp }$ : resistência última experimental.

\section{- Modelo teórico}

A carga de ruptura da laje foi determinada de acordo com a fórmula proposta pela EN 1992-1-1:2004, considerando primeiramente os valores médios das propriedades dos materiais. Esse cálculo permite verificar se o modelo teórico usado para referência está correto, o que significa apresentar uma relação próxima de 1, entre a carga última calculada e a medida em ensaio. O modelo também pode ser considerado preciso se apresentar baixa dispersão.

Além disso, realizaram-se os mesmos cálculos considerando os valores de cálculo das propriedades dos materiais. Nesse caso, foi considerada a situação dos projetistas que não podem se referir a ensaios de laboratório. A carga de ruptura calculada nesse caso é claramente menor que aquela calculada anteriormente.

A relação $P_{u, m} / P_{u, d}$ entre a carga média obtida nos ensaios e o valor último de cálculo pode fornecer uma primeira medida indicativa do nível de segurança intrínseco ao modelo de projeto adotado. 
A resistência ao cisalhamento varia de acordo com a quantidade de força de protensão transmitida a partir da extremidade do elemento até a seção considerada. Além disso, o comprimento previsto de transmissão da protensão altera-se, quando as propriedades do material mudam, de valor médio para valor de cálculo.

\section{- Análise dos resultados}

Os valores da relação $F_{u m} / F_{\text {fail }}$ entre a carga média de ruptura calculada e a carga de ruptura experimental, considerando todas as peças ensaiadas, estão apresentados na Figura 4.32, enquanto que os valores da relação $F_{\text {ud }} / F_{\text {fail }}$ entre a carga de ruptura de projeto calculada e a carga de ruptura experimental estão apresentados na Figura 4.33.

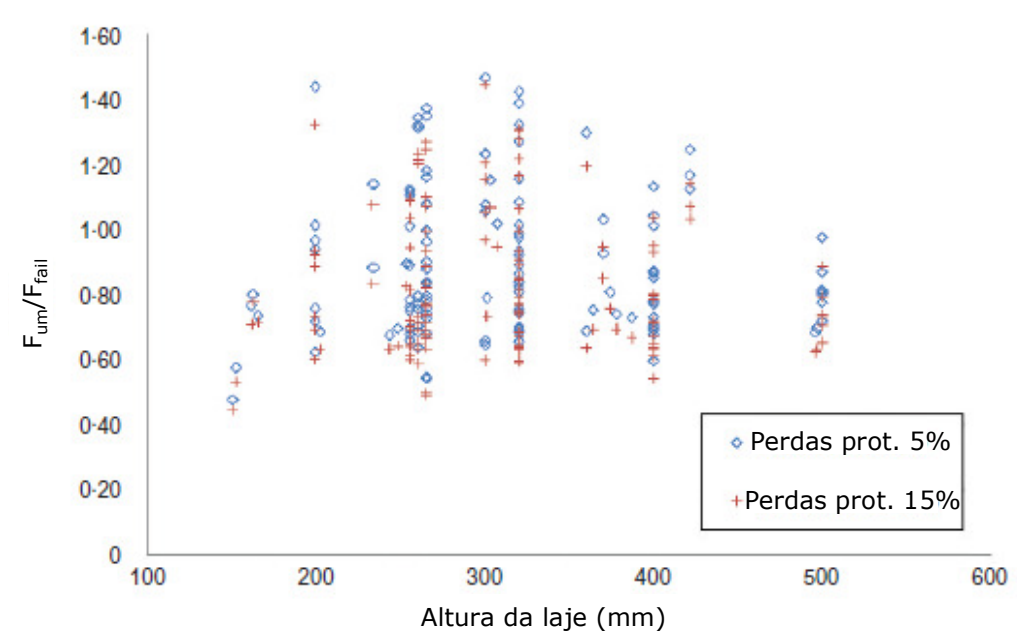

Figura 4.32: Relação $F_{u m} / F_{\text {fail, }}$ para todas as peças ensaiadas. [Bertagnoli \& Mancini (2009)]

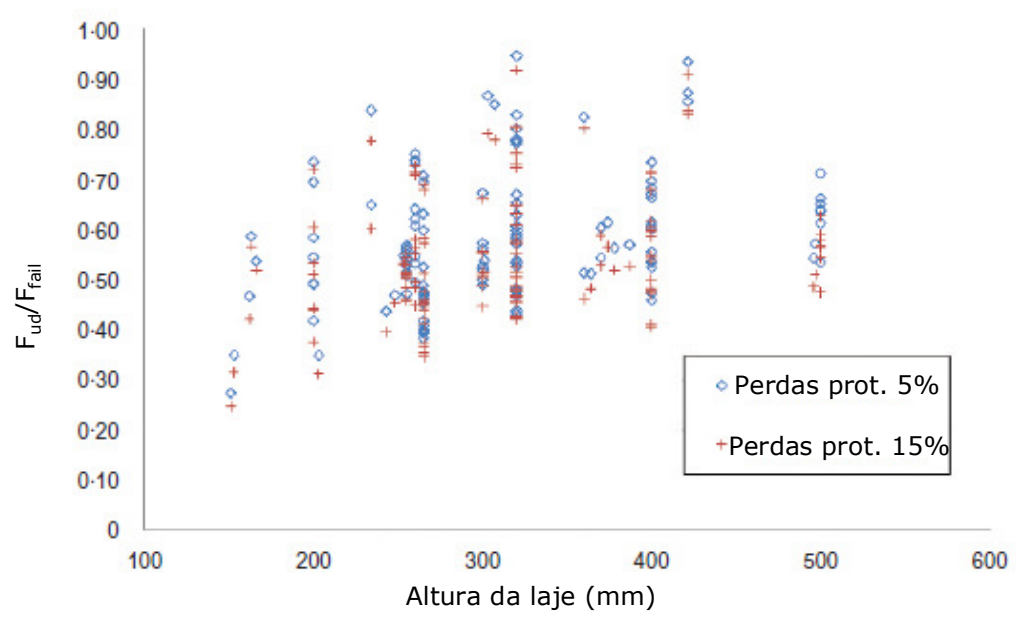

Figura 4.33: Relação $F_{u d} / F_{\text {failı }}$ para todas as peças ensaiadas. [Bertagnoli \& Mancini (2009)]

De acordo com Bertagnoli \& Mancini (2009), pode-se afirmar que todas as lajes, se modeladas corretamente, rompem com uma carga de projeto menor do que a experimental. O valor médio da relação $F_{\text {ud }} / F_{\text {fail }}$ varia entre 0,54 e 0,58. 
O estudo dos mecanismos de ruptura também se mostrou interessante. Todos os modelos analisados foram divididos, na Tabela 4.11, de acordo com os mecanismos de ruptura previstos pelos modelos teóricos.

Tabela 4.11: Mecanismos de ruptura. [Bertagnoli \& Mancini (2009)]

\begin{tabular}{|c|c|c|c|c|}
\hline $\begin{array}{c}\text { Mecanismo } \\
\text { de ruptura }\end{array}$ & \multicolumn{2}{|c|}{$\begin{array}{c}\text { Valor médio das } \\
\text { propriedades dos } \\
\text { materiais (\%) }\end{array}$} & \multicolumn{2}{c|}{$\begin{array}{c}\text { Valor de cálculo } \\
\text { das propriedades } \\
\text { dos materiais (\%) }\end{array}$} \\
\hline Perdas (\%) & $\mathbf{5}$ & $\mathbf{1 5}$ & $\mathbf{5}$ & $\mathbf{1 5}$ \\
\hline CRNF & 9 & 4 & 49 & 45 \\
\hline CRF & 5 & 6 & 2 & 2 \\
\hline FMF & 86 & 90 & 46 & 50 \\
\hline FA & 0 & 0 & 3 & 3 \\
\hline
\end{tabular}

CRNF: ruptura por cisalhamento em região não fissurada; CRF: ruptura por cisalhamento em região fissurada; FMF: ruptura por fissuração devida ao momento fletor; FA: ruptura por falha de ancoragem.

\section{- Conclusão}

Com a mudança das propriedades dos materiais de valor médio para valor de cálculo, houve a alteração do mecanismo de ruptura previsto, para um número considerável de modelos. Isso ocorre devido à diferença entre os coeficientes de segurança aplicados nos diferentes modelos de resistência.

Os valores adotados para as perdas de protensão apresentaram influência insignificante nos resultados, para todos os casos. Então, isso acaba por ser um parâmetro marginal para a interpretação do fenômeno.

O mecanismo de ruptura previsto para a grande maioria dos modelos, empregando valores médios, corresponde a ruptura por fissuração devida ao momento fletor (FMF). A resistência ao cisalhamento em região não fissurada permite que $\mathrm{o}$ momento de fissuração seja alcançado e ultrapassado, mas a laje entra em colapso logo que a seção fissura, devido ao fato de que a resistência ao cisalhamento em região fissurada é menor do que a tensão atuante, cuja força origina o momento de fissuração.

Todos os mecanismos de ruptura descritos pelos autores são frágeis e difíceis de serem vistos claramente em laboratório. Os autores dos estudos experimentais anteriores registraram que os modelos romperam repentinamente, com um forte estrondo. Tais autores não forneceram informações claras sobre o mecanismo de ruptura, ainda que a maioria deles acreditasse que as lajes romperam pelo modo CRNF (cisalhamento em região não fissurada).

De acordo com Bertagnoli e Mancini (2009), pode-se concluir que as lajes alveolares não apresentam problemas de segurança relacionados com cisalhamento em regiões não fissuradas, contanto que elas sejam corretamente projetadas. Uma recomendação final de projeto é a de escolher placas de apoio maiores, relacionando-as com a espessura da laje. Quanto maior é a placa do apoio, maior é a quantidade de protensão introduzida na laje antes das cargas originarem as ações relevantes quanto ao cisalhamento. 


\subsection{PESQUISAS REALIZADAS NO NETPRE}

No Núcleo de Estudos e Tecnologia em Pré-Moldados de Concreto (NETPRE) da Universidade Federal de São Carlos (UFSCar), os estudos sobre lajes alveolares foram iniciados em 2006, englobando pesquisas relacionadas à padronização de ensaios e à descrição de procedimentos experimentais. Tais pesquisas foram descritas por Fernandes (2007) e Costa (2009).

No trabalho de Fernandes (2007) foram definidos procedimentos de ensaio para estudo do cisalhamento em elementos de laje alveolar de concreto protendido, por meio do ensaio de apoio padrão, estabelecendo critérios de padronização dos procedimentos de ensaio. Assim, foi possível implantar e avaliar um método de ensaio de cisalhamento, conforme as recomendações da FIB (CEB-FIP, 1992), para efeito de controle de qualidade, em elementos de laje alveolar pré-fabricados de concreto protendido.

Além disso, Fernandes (2007) apresentou resultados de ensaios experimentais realizados conforme as prescrições contidas nos boletins da FIB (CEB-FIP, 1992) e da EN 1168:2005, analisando o comportamento de elementos de lajes alveolares pré-fabricados de concreto protendido, com diversas tipologias (sem e com capa e com alvéolos preenchidos), comparando esses ensaios com os modelos teóricos de cálculo, e assim, atestando a eficácia dos procedimentos e dos métodos utilizados.

Em Costa (2009) foram investigados procedimentos de ensaio para a avaliação de desempenho de lajes alveolares, com base em referências internacionais, encontradas nos boletins técnicos da FIB e na norma européia EN 1168:2005, sendo apresentadas possíveis recomendações para adequações e aplicações desses procedimentos na realidade brasileira. Nessa pesquisa foram abordadas metodologias experimentais para três finalidades distintas: ensaios para pesquisa, ensaios para avaliação do desempenho de produtos e ensaios para controle de qualidade de elementos de laje. Além disso, foram apresentados exemplos de aplicação desses procedimentos com base nos resultados referentes a ensaios de cisalhamento e flexão, em lajes sem e com capa e com alvéolos preenchidos. Tais resultados foram validados com base em comparações com resultados teóricos.

A partir dessas pesquisas, ficou clara a necessidade de um estudo mais aprofundado quanto ao comportamento mecânico das lajes de uso corrente no Brasil. Assim, esta pesquisa ora apresentada dá continuidade ao trabalho iniciado no NETPRE. 


\section{Características dos ensaios e dos modelos}

A parte experimental desta pesquisa faz parte de um programa mais amplo, desenvolvido pelo Núcleo de Estudos e Tecnologia em Pré-Moldados de Concreto (NETPRE) da Universidade Federal de São Carlos (UFSCar). A partir da co-orientação deste trabalho pelo coordenador do NETPRE, a presente pesquisa contou com a disponibilização de diversos resultados experimentais, além de diversos modelos para o acompanhamento e a execução de ensaios.

Entretanto é importante ressaltar que, apesar desta pesquisa ter obtido alguns dados de ensaios já realizados, houve um grande trabalho quanto ao levantamento e organização dos dados originais, inclusive de dados referentes aos materiais empregados, sendo feita a revisão de todos esses dados antes de sua utilização. A seguir serão descritos os ensaios realizados, a instrumentação e os modelos ensaiados.

\subsection{DESCRIÇÃO DOS ENSAIOS}

A maior parte dos ensaios realizados corresponderam ao ensaio padrão definido pela FIP (1992) (com aplicação da força a 2,5 h do apoio), descrito anteriormente, para a determinação da capacidade ao cisalhamento da laje alveolar. Além disso, também foram realizados ensaios à flexão e alguns ensaios exploratórios, considerando a variação do ponto de aplicação da força (força aplicada a $5 \mathrm{~h}$ e 5,75 h) e também o aumento do comprimento do apoio (ensaio com balanço de $1 \mathrm{~m}$ ). Esses ensaios exploratórios foram realizados com o intuito de verificar a influência da distância de aplicação da força no comportamento da laje e também visando analisar o desempenho da peça quando empregadas melhores condições de apoio, respectivamente.

As etapas de preparação e realização dos ensaios é descrita a seguir:

Para o início de um ensaio, primeiramente são realizadas as medições das diversas partes constituintes da laje, tais como: largura, altura da laje, altura da capa (quando possível), diâmetro dos alvéolos (medidas horizontais e verticais), largura das nervuras, distância das cordoalhas à parte inferior da laje, afundamento das cordoalhas e comprimento da laje. 
Em seguida, para o posicionamento da laje e do dispositivo de aplicação de carga, são feitas marcações na peça, com o auxílio de trena, esquadro e lápis de carpinteiro (Figura 5.1). As posições dos apoios e do carregamento são marcadas nas duas faces laterais e nas faces inferior e superior, nestas duas com auxílio de fio marcador de obra.
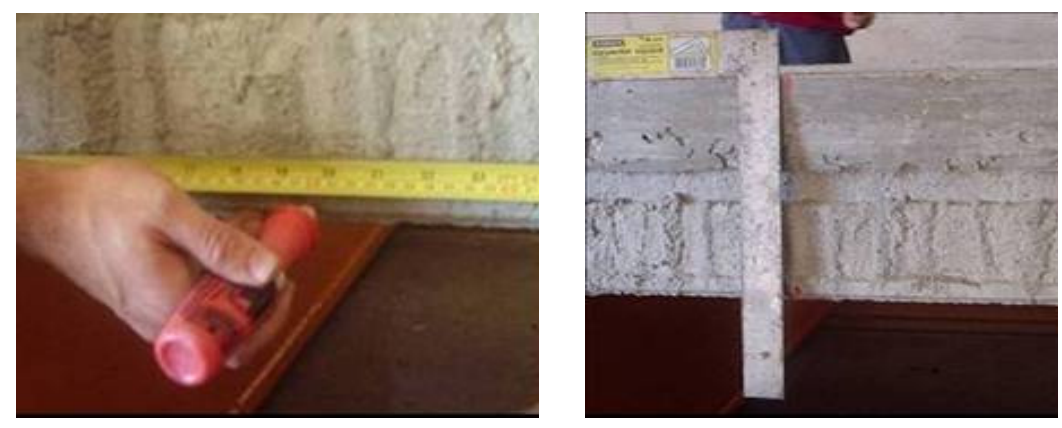

Figura 5.1: Medição e marcação nas faces da peça a ser ensaiada.

Para o apoio da laje, são empregadas vigas metálicas posicionadas na laje de reação. Para permitir a movimentação horizontal do modelo durante o ensaio, são empregados apoios móveis. Para a obtenção desses apoios, sobre a viga metálica é fixada uma chapa metálica, que por sua vez é coberta por uma camada de graxa, com espessura de cerca de $0,3 \mathrm{~cm}$ (Figura 5.2), sendo colocada outra chapa metálica sobre essa camada. 0 apoio é finalizado com o posicionamento de uma viga de madeira diretamente sobre a segunda chapa metálica. Para compensar possíveis irregularidades da face inferior da laje, entre ela e a viga de madeira é fixada uma tira de borracha, com dureza shore igual a 50, espessura de $1,5 \mathrm{~cm}$, largura de $5 \mathrm{~cm}$ e comprimento igual à largura da laje.
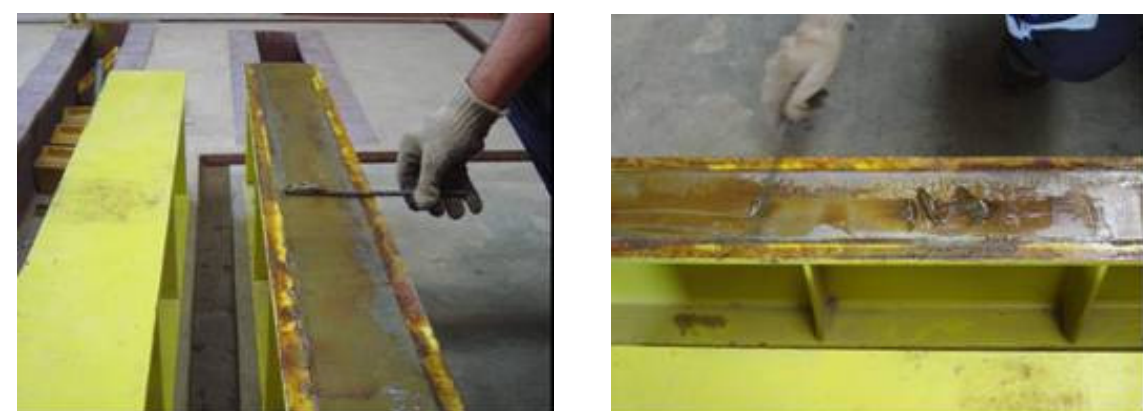

Figura 5.2: Aplicação de camada de graxa sobre os apoios.

Após a preparação dos apoios, eles são posicionados. Primeiramente, realizam-se as marcações na laje de reação do laboratório e nas partes constituintes dos apoios, para o correto posicionamento do modelo, e em seguida, com o auxílio de um esquadro, um dos apoios é posicionado de forma a permanecer perpendicular aos trilhos do pórtico de carregamento. 
Após o posicionamento do primeiro apoio, é verificado seu nivelamento transversal. Em seguida, é medida a distância necessária entre os apoios, conforme o vão do elemento a ser ensaiado.

Para o posicionamento do segundo apoio, toma-se como referência os centros das extremidades das barras de centralização de cada um dos apoios de reação. Após o posicionamento do segundo apoio, realiza-se o seu nivelamento transversal.

Os dois apoios são fixados à laje de reação com o emprego de dispositivos metálicos. Detalhe do apoio fixado à laje de reação pode ser observado na Figura 5.3.

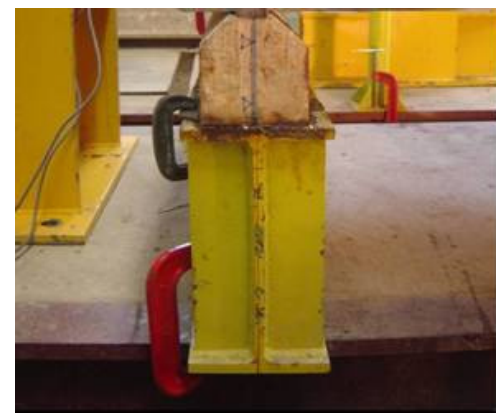

Figura 5.3: Apoio fixado à laje de reação.

Após a fixação dos apoios, realiza-se o adequado posicionamento do modelo, a partir das marcações previamente realizadas na laje e nos apoios. Para o correto posicionamento da laje, são verificados os níveis transversais da peça, o alinhamento das marcações relativas ao centro de cada apoio e, com o auxílio de um prumo de centro, alinha-se o centro do pistão do atuador hidráulico com o centro da laje, a uma distância do apoio previamente definida e marcada. A etapa de posicionamento da laje sobre os apoios pode ser observada na Figura 5.4.

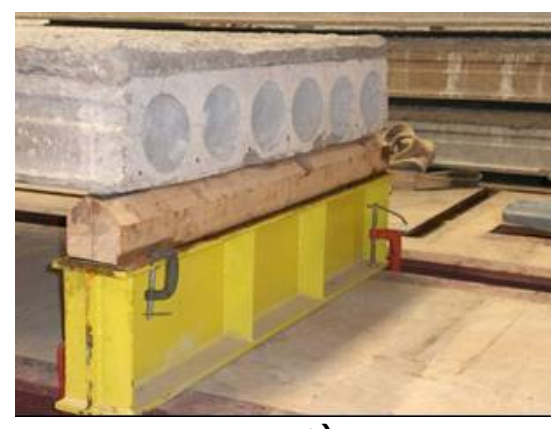

a)

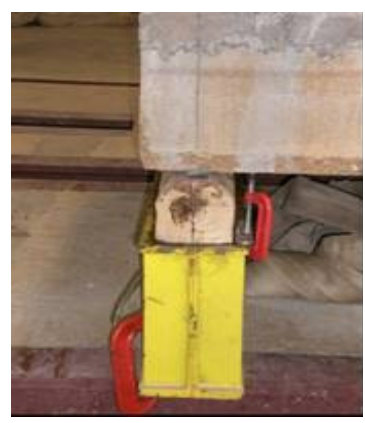

b)

Figura 5.4: a) Posicionamento de laje sobre um dos apoios; b) Detalhe da extremidade da laje sobre o apoio.

Após o adequado posicionamento da laje, realiza-se a limpeza de sua parte superior. Em seguida, inicia-se o posicionamento da viga de transferência de força sobre tiras de borracha (do mesmo tipo empregado nos apoios), com espessura aproximada de $1,5 \mathrm{~cm}$, posicionadas na superfície da laje, com o intuito de eliminar possíveis irregularidades. 
Então, alinha-se o pistão de aplicação de força com o eixo da viga de transferência, sendo realizado o posicionamento de uma rótula sobre placas metálicas posicionadas sobre a viga. Com isso, realiza-se o posicionamento da célula de carga sobre a rótula, sendo feito o abaixamento do pistão do atuador hidráulico, para garantir a correta centralização do sistema. O posicionamento da viga de transferência e da célula de carga podem ser observados na Figura 5.5.

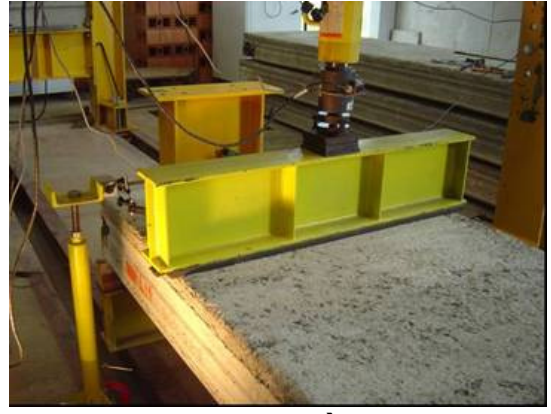

a)

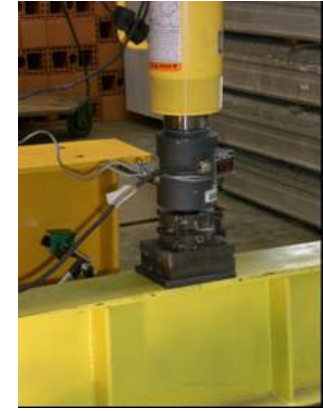

b)

Figura 5.5: a) Posicionamento da viga de transferência de força e da célula de carga; b) Detalhe da célula de carga.

A partir dessa etapa, realiza-se a preparação da superfície para o posterior posicionamento dos transdutores. Com o auxílio de massa plástica, são fixadas pequenas chapas metálicas sobre a superfície da laje, próximas à viga de transferência de força. Então, os transdutores são posicionados sobre essas chapas e fixados à laje de reação, em cada lado da peça. Após o posicionamento dos instrumentos de medição, célula de carga e transdutores, realiza-se a ligação deles ao sistema de aquisição de dados, com a marcação e anotação adequada dos canais correspondentes a cada equipamento.

Com a realização de todos os procedimentos descritos, inicia-se o ensaio com a aplicação do carregamento por meio de um atuador hidráulico alimentado por uma bomba manual, sendo controlada manualmente a taxa de carregamento, que foi adotada em torno de $40 \mathrm{kN} / \mathrm{min}$. A aplicação de força é interrompida a partir do instante que não há aumento de força, mesmo com o acionamento do atuador hidráulico. Durante o ensaio, são feitos dois registros a cada segundo, com o intuito de obter maior confiabilidade nas medidas. Para os ensaios à flexão e os ensaios exploratórios, são realizados os mesmos procedimentos, alterando o posicionamento dos apoios e a aplicação da força. Da mesma forma, nesses são utilizados transdutores na região de aplicação da força, para medir os deslocamentos verticais.

\subsection{INSTRUMENTAÇÃO}

Nesta pesquisa, realizou-se a investigação experimental de diversos modelos, compostos por variados tipos de lajes alveolares protendidas. Nos ensaios foram medidos os valores da força aplicada (em kN) e os deslocamentos verticais. 
Nos modelos, aplicou-se um carregamento incremental monotônico de curta duração, por meio de um atuador hidráulico da marca Enerpac com capacidade de 500 kN, alimentado por uma bomba manual. Para a medição da força aplicada, foi utilizada uma célula de carga (CC) da marca MSI (Micro Sensores Industrial), e para a obtenção dos deslocamentos foram utilizados transdutores LVDT (Linear Variable Differential).

Os esquemas gerais com a instrumentação dos ensaios ao cisalhamento e à flexão podem ser observados na Figura 5.6 e na Figura 5.7, respectivamente.

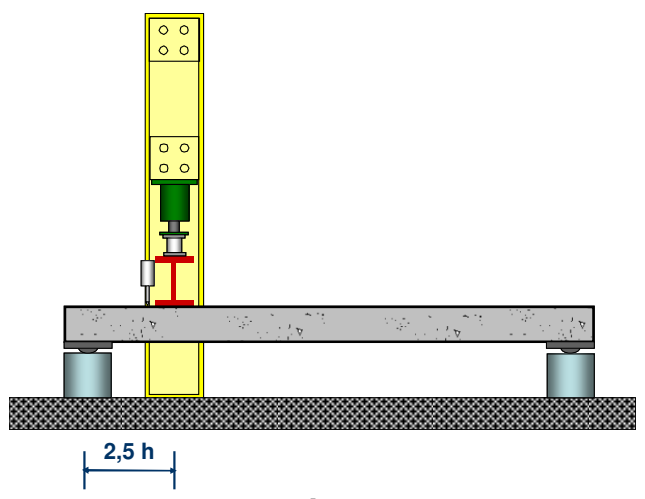

a)

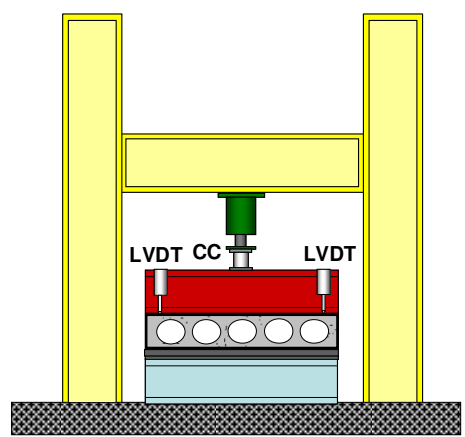

b)

Figura 5.6: a) Esquema do ensaio de cisalhamento; b) Esquema da vista frontal.

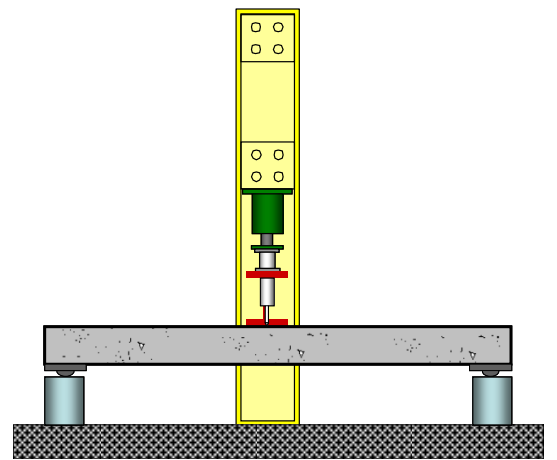

a)

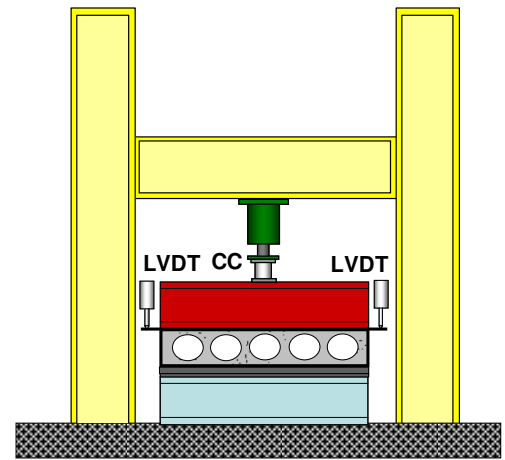

b)

Figura 5.7: a) Esquema do ensaio à flexão; b) Esquema da vista frontal.

\subsection{DESCRIÇÃO DOS MODELOS ENSAIADOS}

Para melhor compreender o comportamento das lajes alveolares protendidas, foram realizados diversos ensaios de flexão e, principalmente, de cisalhamento.

Esses ensaios foram realizados de acordo com as recomendações da FIB (CEP-FIP, 1992), sendo empregadas as recomendações da NBR 6118:2003 para os cálculos, quanto ao cisalhamento e à flexão, das unidades ensaiadas.

Uma parte dos modelos aqui descritos foi ensaiada durante o desenvolvimento desta pesquisa, e outra parte foi ensaiada anteriormente, havendo o cuidado quanto ao trabalho de levantamento, revisão e organização dos dados originais. 
As lajes protendidas, que constituíram os modelos ensaiados, foram fabricadas por quatro diferentes empresas brasileiras, compondo quatro lotes, aqui denominados de lote $X, Y, Z$ e W. Dessa forma, a parte dos modelos cujos ensaios foram realizados durante 0 desenvolvimento desta pesquisa engloba os lotes $X, Y$ e $W$. Os modelos pertencentes ao lote $Z$ foram ensaiados anteriormente, dentro do programa experimental desenvolvido pelo NETPRE, seguindo as mesmas recomendações descritas para os demais modelos.

Todas as peças ensaiadas foram selecionadas pelas empresas, de forma a representar os tipos mais produzidos por elas. A empresa $Y$, em especial, realizou uma pesquisa para descobrir qual o tipo de laje que apresentou maior demanda durante 0 período de um ano de produção. Tais lajes selecionadas apresentaram grande emprego em obras destinadas à construção de supermercados e edificações industriais. Assim, a partir desta pesquisa, a empresa $Y$ identificou os tipos de laje com maior interesse na análise de seus comportamentos.

Para a descrição dos modelos, serão consideradas as tipologias das unidades alveolares. Então, para as unidades sem capa, foram realizados 30 ensaios de cisalhamento e 11 de flexão, com as características na Tabela 5.1.

Tabela 5.1: Caracterização dos modelos sem capa.

\begin{tabular}{|c|c|c|c|}
\hline Especificação & Tipo de laje & Armadura & Ensaio \\
\hline \multirow{2}{*}{ L-S-15-6D9,5_lote X } & \multirow{2}{*}{$\begin{array}{l}\text { Sem capa (altura } 15 \mathrm{~cm} \\
\text { comprimento } 6,5 \mathrm{~m} \text { e protensão } \\
\text { inicial } 1423,42 \mathrm{MPa} \text { ) }\end{array}$} & \multirow{2}{*}{$6 \phi 9,5 \mathrm{~mm}$} & 1 Cis. (força a $2,5 \mathrm{~h}$ do apoio) \\
\hline & & & 2 Flexão \\
\hline \multirow{2}{*}{ L-S-20-8D12,7_lote X } & \multirow{2}{*}{$\begin{array}{l}\text { Sem capa (altura } 20 \mathrm{~cm} \\
\text { comprimento } 6,5 \mathrm{~m} \text { e protensão } \\
\text { inicial } 1425,05 \mathrm{MPa} \text { ) }\end{array}$} & \multirow{2}{*}{$8 \phi 12,7 \mathrm{~mm}$} & 1 Cis. (força a $2,5 \mathrm{~h}$ do apoio) \\
\hline & & & 2 Flexão \\
\hline L-S-20-6D12,7_lote Y & $\begin{array}{c}\text { Sem capa (altura } 20 \mathrm{~cm} \\
\text { comprimento } 4,00 \mathrm{~m} \text { e protensão } \\
\text { inicial } 1429,98 \mathrm{MPa} \text { ) }\end{array}$ & $6 \phi 12,7 \mathrm{~mm}$ & 3 Cis. (força a $2,5 \mathrm{~h}$ do apoio) \\
\hline \multirow{3}{*}{ L-S-20-7D9,5_lote Y } & $\begin{array}{c}\text { Sem capa (altura } 20 \mathrm{~cm} \\
\text { comprimentos } 4,15 \mathrm{~m} \text { e protensão } \\
\text { inicial } 1351,35 \mathrm{MPa} \text { ) }\end{array}$ & $7 \phi 9,5$ mm & 3 Cis. (força a $2,5 \mathrm{~h}$ do apoio) \\
\hline & \multirow{2}{*}{$\begin{array}{l}\text { Sem capa (altura } 20 \mathrm{~cm} \\
\text { comprimento } 4,65 \mathrm{~m} \text { e protensão } \\
\text { inicial } 1351,35 \mathrm{MPa} \text { ) }\end{array}$} & \multirow{2}{*}{$7 \phi 9,5 \mathrm{~mm}$} & 1 Cis. (força a $2,5 \mathrm{~h}$ do apoio) \\
\hline & & & 2 Cis.(a 5,75 h do apoio) \\
\hline \multirow{3}{*}{ L-S-20-5D12,7_lote Z } & \multirow{2}{*}{$\begin{array}{c}\text { Sem capa (altura } 20 \mathrm{~cm}, \\
\text { comprimento } 3,1 \mathrm{~m} \text { e protensão } \\
\text { inicial } 1140 \mathrm{MPa} \text { ) }\end{array}$} & \multirow{2}{*}{$5 \phi 12,7 \mathrm{~mm}$} & 5 Cis. (força a 2,5 h do apoio) \\
\hline & & & 5 Flexão \\
\hline & $\begin{array}{c}\text { Sem capa (altura } 20 \mathrm{~cm}, \\
\text { comprimento } 6,10 \mathrm{~m} \text { e protensão } \\
\text { inicial } 1140 \mathrm{MPa} \text { ) }\end{array}$ & $5 \phi 12,7 \mathrm{~mm}$ & 1 Flexão \\
\hline \multirow{3}{*}{ L-S-21-7D9,5_lote W } & \multirow{3}{*}{$\begin{array}{c}\text { Sem capa (altura } 21 \mathrm{~cm} \\
\text { comprimento } 4,0 \mathrm{~m} \text { e protensão } \\
\text { inicial } 1460 \mathrm{MPa} \text { ) }\end{array}$} & \multirow{3}{*}{$7 \phi 9,5 \mathrm{~mm}$} & 2 Cis. (força a 2,5 h do apoio) \\
\hline & & & 3 Cis. (força a 5,0 h do apoio) \\
\hline & & & 1 Flexão \\
\hline \multirow{2}{*}{ L-S-16-5D9,5_lote W } & \multirow{2}{*}{$\begin{array}{c}\text { Sem capa (altura } 16 \mathrm{~cm} \\
\text { comprimento } 4,0 \mathrm{~m} \text { e protensão } \\
\text { inicial } 1460 \mathrm{MPa} \text { ) }\end{array}$} & \multirow{2}{*}{$5 \phi 9,5 \mathrm{~mm}$} & 2 Cis. (força a 2,5 h do apoio) \\
\hline & & & 3 Cis. (força a 5,0 h do apoio) \\
\hline \multirow{3}{*}{ L-S-26-9D12,7_lote W } & \multirow{3}{*}{$\begin{array}{c}\text { Sem capa (altura } 26 \mathrm{~cm}, \\
\text { comprimento } 4,0 \mathrm{~m} \text { e protensão } \\
\text { inicial } 1460 \mathrm{MPa} \text { ) }\end{array}$} & \multirow{3}{*}{$9 \phi 12,7 \mathrm{~mm}$} & 2 Cis. (força a $2,5 \mathrm{~h}$ do apoio) \\
\hline & & & 1 Cis. (força a 5,0 h do apoio) \\
\hline & & & $\begin{array}{c}1 \text { Cis. (balanço de } 1 \mathrm{~m} \text { e força } \\
\text { a } 2,5 \mathrm{~h} \text { do apoio) }\end{array}$ \\
\hline
\end{tabular}

Obs: Cis. $\rightarrow$ Corresponde a Cisalhamento. 
As tipologias das unidades alveolares sem a presença de capa estrutural podem ser observadas na Figura 5.8 e na Figura 5.9, sendo indicados os respectivos códigos empregados para diferenciá-las.

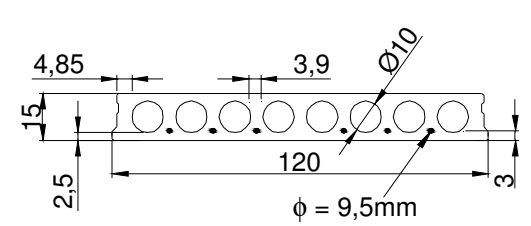

L-S-15-6D9,5_lote X

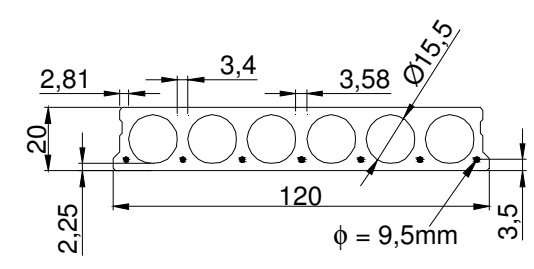

L-S-20-7D9,5_lote $Y$

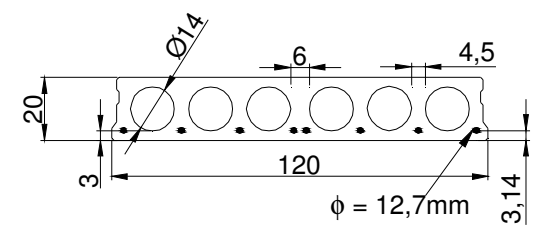

L-S-20-8D12,7_lote X

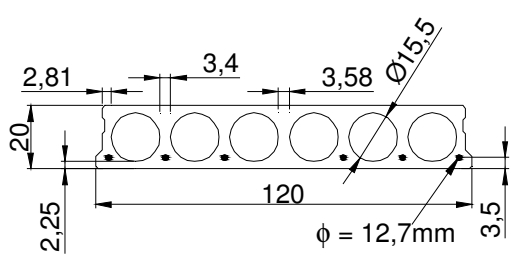

L-S-20-6D12,7_lote Y

Figura 5.8: Tipologia das lajes sem capa pertencentes aos lotes $X$ e $Y$, com suas respectivas identificações.

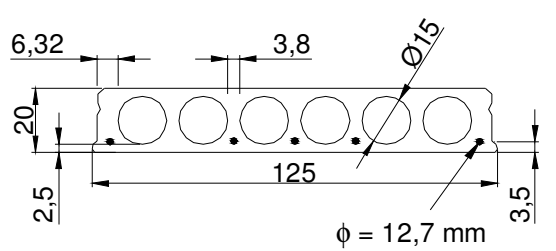

L-S-20-5D12,7_loteZ

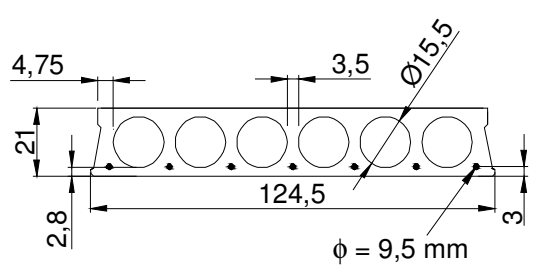

L-S-21-7D9,5_loteW

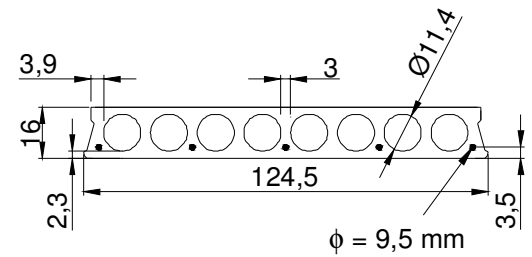

L-S-16-5D9,5_loteW

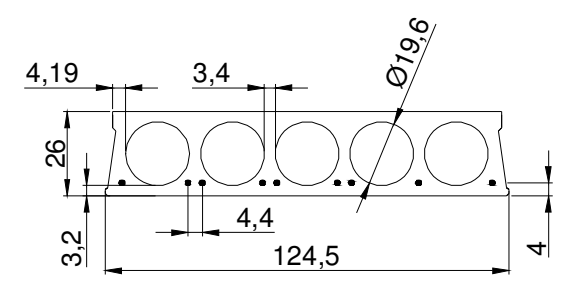

L-S-26-9D12,7_loteW

Figura 5.9: Tipologia das lajes sem capa pertencentes aos lotes $Z$ eW, com suas respectivas identificações.

Considerando as unidades alveolares com capa estrutural, foram realizados 17 ensaios de cisalhamento e 14 de flexão, variando o tipo de laje, como pode ser observado na Tabela 5.2. Para as lajes com capa, todos os ensaios foram feitos com aplicação da força a 2,5 h com relação ao eixo do apoio.

Vale ressaltar que para a execução das capas de concreto, nas lajes pertencentes às empresas $X$ e $Y$, não foi feita a limpeza das faces superiores e as superfícies permaneceram lisas. 
Entretanto, diferentemente das demais, as lajes do lote $\mathrm{Z}$ tiveram suas faces superiores escarificadas, tornando-se rugosas, e limpas com aspersão de água. As tipologias das lajes com a presença de capa estrutural podem ser observadas na Figura 5.10, sendo indicados os códigos que caracterizam cada uma delas.

Tabela 5.2: Caracterização dos modelos com capa.

\begin{tabular}{|c|c|c|c|}
\hline Especificação & $\begin{array}{c}\text { Tipo de laje } \\
\end{array}$ & Armadura & Ensaio \\
\hline L-C-20-6D9,5_lote X & $\begin{array}{l}\text { Com capa, interface lisa e empoeirada } \\
\text { (altura total } 20 \mathrm{~cm} \text {, comprimento } 6,5 \mathrm{~m} \\
\text { e protensão inicial } 1423,42 \mathrm{MPa} \text { ) }\end{array}$ & $6 \phi 9,5 \mathrm{~mm}$ & $\begin{array}{l}2 \text { Cisalhamento } \\
2 \text { Flexão }\end{array}$ \\
\hline L-C-25-8D12,7_lote X & $\begin{array}{l}\text { Com capa, interface lisa e empoeirada } \\
\text { (altura total } 25 \mathrm{~cm} \text {, comprimento } 6,5 \mathrm{~m} \\
\text { e protensão inicial } 1425,05 \mathrm{MPa} \text { ) }\end{array}$ & $8 \phi 12,7 \mathrm{~mm}$ & $\begin{array}{c}1 \text { Cisalhamento } \\
1 \text { Flexão }\end{array}$ \\
\hline L-C-25-6D12,7_lote Y & $\begin{array}{c}\text { Com capa, interface laje-capa lisa e } \\
\text { empoeirada (altura total } 25 \mathrm{~cm}, \\
\text { comprimento } 4,15 \mathrm{~m} \text { e protensão inicial } \\
1429,98 \mathrm{MPa} \text { ) }\end{array}$ & $6 \phi 12,7 \mathrm{~mm}$ & 1 Cisalhamento \\
\hline L-C-25-7D9,5_lote Y & $\begin{array}{c}\text { Com capa, com interface lisa e } \\
\text { empoeirada (altura total } 25 \mathrm{~cm} \text {, } \\
\text { comprimento } 4,15 \mathrm{~m} \text { e protensão inicial } \\
1351,35 \mathrm{MPa} \text { ) }\end{array}$ & $7 \phi 9,5 \mathrm{~mm}$ & 3 Cisalhamento \\
\hline \multirow{2}{*}{ L-C-25-5D12,7_lote Z } & $\begin{array}{c}\text { Com capa, tela soldada, interface rugosa } \\
\text { e limpa (altura total } 25 \mathrm{~cm}, \\
\text { comprimento } 3,1 \mathrm{~m} \text { e protensão inicial } \\
1140 \mathrm{MPa} \text { ) }\end{array}$ & $5 \phi 12,7 \mathrm{~mm}$ & $\begin{array}{c}5 \text { Cisalhamento } \\
5 \text { Flexão }\end{array}$ \\
\hline & $\begin{array}{c}\text { Com capa, tela soldada, interface rugosa } \\
\text { e limpa (altura total } 25 \mathrm{~cm}, \\
\text { comprimento } 6,10 \mathrm{~m} \text { e protensão inicial } \\
1140 \mathrm{MPa} \text { ) }\end{array}$ & $5 \phi 12,7 \mathrm{~mm}$ & 1 Flexão \\
\hline L-CF-25-5D12,7_lote Z & $\begin{array}{c}\text { Com capa e fibras metálicas, interface } \\
\text { rugosa e limpa (altura total } 25 \mathrm{~cm}, \\
\text { comprimento } 3,1 \mathrm{~m} \text { e protensão inicial } \\
1140 \mathrm{MPa} \text { ) }\end{array}$ & $5 \phi 12,7 \mathrm{~mm}$ & $\begin{array}{c}5 \text { Cisalhamento } \\
5 \text { Flexão }\end{array}$ \\
\hline
\end{tabular}

Todos os modelos foram ensaiados com aplicação da força a 2,5 h com relação ao eixo do apoio.

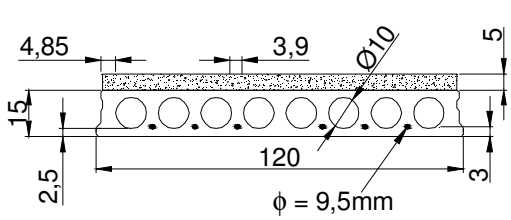

L-C-20-6D9,5 lote X

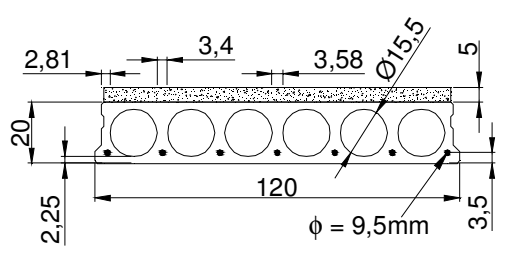

L-C-25-7D9,5_lote $Y$

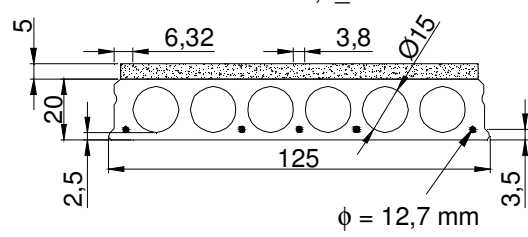

L-C-25-5D12,7_loteZ

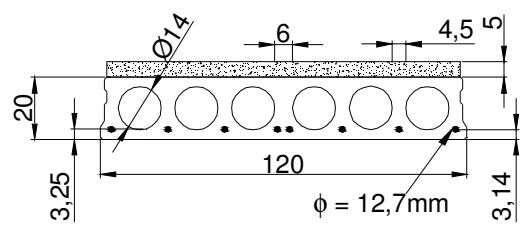

L-C-25-8D12,7 lote X

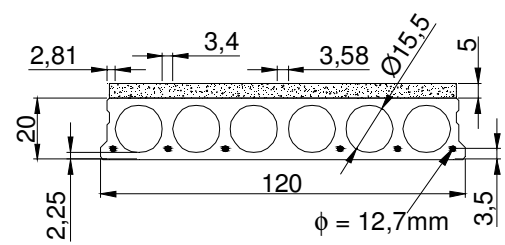

L-C-25-6D12,7_lote $Y$

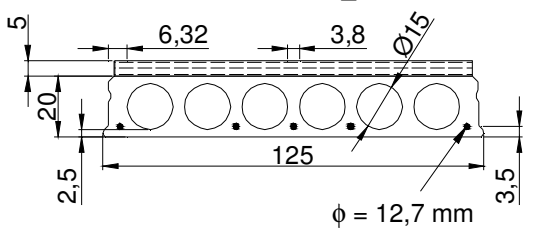

L-CF-25-5D12,7_loteZ

Figura 5.10: Tipologia das lajes com capa estrutural, com suas respectivas identificações. 
Considerando as unidades alveolares com alvéolos preenchidos, foram realizados 18 ensaios de cisalhamento e 6 de flexão, como pode ser observado na Tabela 5.3.

Para as lajes com alvéolos preenchidos, todos os ensaios foram feitos com aplicação da força a 2,5 h com relação ao eixo do apoio. Além disso, os alvéolos foram preenchidos juntamente com a moldagem das lajes, antes da liberação dos cabos pré-tracionados.

Tabela 5.3: Caracterização dos modelos ensaiados com a presença de alvéolos preenchidos.

\begin{tabular}{|c|c|c|c|}
\hline Especificação & $\begin{array}{c}\text { Tipo de laje } \\
\end{array}$ & Armadura & Ensaio \\
\hline L-2P-20-6D12,7_lote Y & $\begin{array}{c}\text { Sem capa estrutural e com } 2 \text { alveolos } \\
\text { preenchidos (altura de } 20 \mathrm{~cm} \text {, comprimento } \\
\text { de } 4,15 \mathrm{~m} \text { e protensão inicial de } 1429,98 \mathrm{MPa} \text { ) }\end{array}$ & $6 \phi 12,7 \mathrm{~mm}$ & 3 Cisalhamento \\
\hline L-2P-20-7D9,5_lote Y & $\begin{array}{c}\text { Sem capa estrutural e com } 2 \text { alveolos } \\
\text { preenchidos (altura de } 20 \mathrm{~cm} \text {, comprimento } \\
\text { de } 4,15 \mathrm{~m} \text { e protensão inicial de } 1351,35 \mathrm{MPa} \text { ) }\end{array}$ & $7 \phi 9,5 \mathrm{~mm}$ & 3 Cisalhamento \\
\hline L-2PF-20-5D12,7_lote Z & $\begin{array}{c}\text { Sem capa estrutural e } 2 \text { alvéolos preenchidos } \\
\text { com concreto reforçado com fibras (altura de } \\
20 \mathrm{~cm} \text {, comprimento de } 3,1 \mathrm{~m} \text { e protensão } \\
\text { inicial de } 1140 \mathrm{MPa} \text { ) }\end{array}$ & $5 \phi 12,7 \mathrm{~mm}$ & $\begin{array}{c}6 \text { Cisalhamento } \\
3 \text { Flexão }\end{array}$ \\
\hline L-4PF-20-5D12,7_lote Z & $\begin{array}{c}\text { Sem capa estrutural e } 4 \text { alvéolos preenchidos } \\
\text { com concreto reforçado com fibras (altura de } \\
20 \mathrm{~cm} \text {, comprimento de } 3,1 \mathrm{~m} \text { e protensão } \\
\text { inicial de } 1140 \mathrm{MPa} \text { ) }\end{array}$ & $5 \phi 12,7 \mathrm{~mm}$ & $\begin{array}{c}6 \text { Cisalhamento } \\
3 \text { Flexão }\end{array}$ \\
\hline
\end{tabular}

Todos os modelos foram ensaiados com aplicação da força a 2,5 h com relação ao eixo do apoio.

Somente nas lajes da empresa $Z$, o preenchimento dos alvéolos foi realizado com concreto reforçado com fibras. As tipologias das lajes com alvéolos preenchidos podem ser observadas na Figura 5.11, sendo indicados os respectivos códigos definidos.

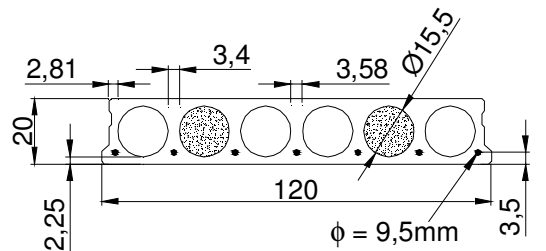

L-2P-20-7D9,5_lote Y

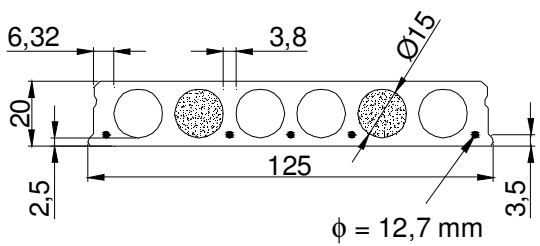

L-2PF-20-5D12,7_loteZ

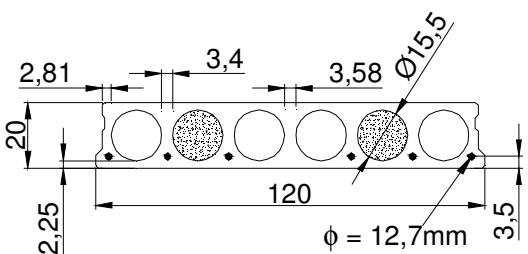

L-2P-20-6D12,7_lote Y

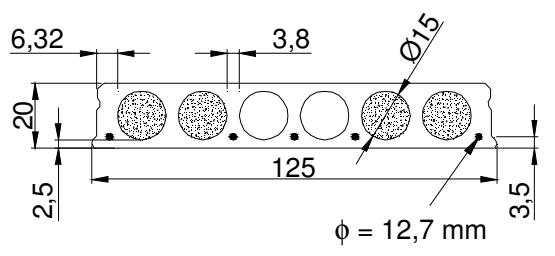

L-4PF-20-5D12,7_loteZ

Figura 5.11: Tipologia das lajes com alvéolos preenchidos, com suas respectivas identificações.

O comprimento de preenchimento dos alvéolos, à partir da extremidade da laje, foi de $80 \mathrm{~cm}$ para as lajes do lote $Y$ e de $100 \mathrm{~cm}$ para as do lote $Z$.

\subsection{CARACTERÍSTICAS GEOMÉTRICAS DAS LAJES}

As características geométricas das unidades alveolares sem capa podem ser observadas na Tabela 5.4 . 
Tabela 5.4: Características geométricas das unidades sem capa estrutural.

\begin{tabular}{|c|c|c|c|c|c|c|c|c|c|}
\hline Laje & $\begin{array}{c}H_{L A} \\
(\mathrm{~cm})\end{array}$ & $\begin{array}{c}\mathrm{L} \\
(\mathrm{cm})\end{array}$ & $\begin{array}{c}\text { b } \\
(\mathrm{cm})\end{array}$ & $\begin{array}{c}\phi_{\text {alv }} \\
(\mathrm{cm})\end{array}$ & $\begin{array}{c}A_{c} \\
\left(\mathrm{~cm}^{2}\right)\end{array}$ & $\begin{array}{c}I_{C} \\
\left(\mathrm{~cm}^{4}\right)\end{array}$ & $\begin{array}{c}\Sigma \mathbf{b}_{\mathrm{w}} \\
(\mathbf{m m})\end{array}$ & $\begin{array}{c}d^{\prime} \\
(\mathrm{cm})\end{array}$ & $\begin{array}{c}d \\
(\mathrm{~cm})\end{array}$ \\
\hline L1- S-15-6D9,5-X_C & 15,00 & 650 & 120,0 & 8,81 & 1312,36 & $3,14.10^{4}$ & 463,50 & 3,38 & 11,52 \\
\hline L2-S-20-8D12,7-X_C & 20,00 & 650 & 120,0 & 12,14 & 1705,03 & $7,36.10^{4}$ & 411,50 & 3,29 & 16,71 \\
\hline L3-S-20-6D12,7-Y_C & 20,30 & 400 & 121,0 & 14,49 & 1356,85 & $6,76.10^{4}$ & 250,15 & 3,35 & 16,95 \\
\hline L4-S-20-6D12,7-Y_C & 19,99 & 400 & 120,0 & 14,43 & 1324,00 & $6,40.10^{4}$ & 269,30 & 2,51 & 17,48 \\
\hline L5-S-20-6D12,7-Y_C & 19,80 & 401 & 121,0 & 14,28 & 1326,10 & $6,25.10^{4}$ & 268,95 & 2,96 & 16,84 \\
\hline L6-S-20-7D9,5-Y_C & 19,97 & 414 & 120,0 & 14,54 & 1305,53 & $6,33.10^{4}$ & 262,35 & 3,41 & 16,56 \\
\hline L7-S-20-7D9,5-Y_C & 20,19 & 415 & 121,0 & 14,37 & 1365,72 & $6,69.10^{4}$ & 268,70 & 3,72 & 16,47 \\
\hline L8-S-20-7D9,5-Y_C & 20,24 & 415 & 120,0 & 14,52 & 1340,24 & $6,66.10^{4}$ & 263,85 & 3,50 & 16,75 \\
\hline L9-S-20-7D9,5-Y_C & 20,43 & 465 & 120,0 & 14,52 & 1356,66 & $6,87 \cdot 10^{4}$ & 267,90 & 3,52 & 16,92 \\
\hline L10-S-20-7D9,5-Y_C & 19,75 & 465 & 120,0 & 14,52 & 1279,65 & $6,08.10^{4}$ & 265,95 & 3,54 & 16,21 \\
\hline L11-S-20-7D9,5-Y_C & 19,75 & 464 & 120,0 & 14,56 & 1277,61 & $6,07.10^{4}$ & 258,45 & 3,54 & 16,20 \\
\hline $\begin{array}{c}\text { L12-S-20-5D12,7-Z_C } \\
a \\
\text { L16-S-20-5D12,7-Z_C }\end{array}$ & 20,00 & 310 & 125,0 & 15,00 & 1377,95 & $6,71 \cdot 10^{4}$ & 320,00 & 3,50 & 16,5 \\
\hline L17-S-21-7D9,5-W_C & 20,30 & 399 & 124,0 & 14,24 & 1460,64 & $7,09 \cdot 10^{4}$ & 312,50 & 3,16 & 17,14 \\
\hline L18-S-21-7D9,5-W_C & 20,39 & 400 & 124,5 & 14,37 & 1459,48 & $7,17.10^{4}$ & 307,00 & 3,10 & 17,29 \\
\hline L19-S-21-7D9,5-W_C & 20,39 & 395 & 124,4 & 14,56 & 1432,44 & $7,10.10^{4}$ & 299,50 & 3,06 & 17,33 \\
\hline L20-S-21-7D9,5-W_C & 20,20 & 394 & 124,0 & 14,34 & 1438,58 & $6,94.10^{4}$ & 304,50 & 2,94 & 17,26 \\
\hline L21-S-21-7D9,5-W_C & 20,48 & 396 & 124,5 & 14,67 & 1427,96 & $7,17.10^{4}$ & 295,50 & 2,73 & 17,75 \\
\hline L22-S-16-5D9,5-W_C & 16,15 & 399 & 124,5 & 9,77 & 1340,09 & $3,86.10^{4}$ & 357,50 & 2,72 & 13,43 \\
\hline L23-S-16-5D9,5-W_C & 16,31 & 400 & 124,5 & 10,35 & 1279,94 & $3,88.10^{4}$ & 324,50 & 2,89 & 13,42 \\
\hline L24-S-16-5D9,5-W_C & 16,34 & 400 & 123,8 & 9,98 & 1334,55 & $3,97.10^{4}$ & 352,50 & 2,62 & 13,72 \\
\hline L25-S-16-5D9,5-W_C & 16,03 & 399 & 124,2 & 10,22 & 1264,49 & $3,68.10^{4}$ & 323,50 & 2,57 & 13,46 \\
\hline L26-S-16-5D9,5-W_C & 16,01 & 399 & 124,0 & 9,99 & 1290,85 & $3,71.10^{4}$ & 346,50 & 2,45 & 13,57 \\
\hline L27-S-26-9D12,7-W_C & 25,60 & 398 & 124,2 & 18,53 & 1711,55 & $13,82.10^{4}$ & 235,00 & 2,71 & 22,89 \\
\hline L28-S-26-9D12,7-W_C & 25,73 & 395 & 124,2 & 18,83 & 1699,76 & $13,97.10^{4}$ & 232,00 & 2,89 & 22,84 \\
\hline L29-S-26-9D12,7-W_C & 25,56 & 397 & 124,3 & 18,87 & 1669,93 & $13,59.10^{4}$ & 230,00 & 2,96 & 22,60 \\
\hline L30-S-26-9D12,7-W_C & 25,50 & 403 & 124,0 & 18,32 & 1750,22 & $13,86.10^{4}$ & 261,00 & 3,97 & 21,53 \\
\hline L1-S-15-6D9,5-X_F & 15,00 & 650 & 120,0 & 8,81 & 1312,36 & $3,14.10^{4}$ & 399,20 & 3,23 & 11,77 \\
\hline L2-S-15-6D9,5-X_F & 15,00 & 650 & 120,0 & 8,81 & 1312,36 & & 408,30 & 3,78 & 11,22 \\
\hline L3-S-20-8D12,7-X_F & 20,00 & 650 & 120,0 & 12,14 & 1705,03 & $7,36.10^{4}$ & 411,50 & 3,29 & 16,71 \\
\hline L4-S-20-8D12,7-X_F & 20,00 & 650 & 120,0 & 12,14 & 1705,03 & & 411,50 & 3,29 & 16,71 \\
\hline $\begin{array}{c}\text { L5-S-20-5D12,7-Z_F } \\
a \\
\text { L9-S-20-5D12,7-Z_F }\end{array}$ & 20,00 & 310 & 125,0 & 15,00 & 1377,95 & $6,71.10^{4}$ & 320,00 & 3,50 & 16,5 \\
\hline L10-S-20-5D12,7-Z_F & 20,00 & 610 & 125,0 & 15,00 & 1377,95 & $6,71.10^{4}$ & 320,00 & 3,50 & 16,5 \\
\hline L11-S-21-7D9,5-W_F & 20,35 & 400 & 124,3 & 14,38 & 1448,78 & $7,10.10^{4}$ & 306,00 & 2,98 & 17,37 \\
\hline
\end{tabular}

$\mathrm{H}_{\mathrm{LA}}$ : altura da laje;

$\mathrm{H}_{\text {Tот }}$ : altura total considerando laje e capa, quando houver;

L: comprimento da laje;

b: largura da laje;

$\phi_{\text {alv }}$ : diâmetro dos alvéolos;

$A_{c}$ : área da laje alveolar sem considerar a capa e alvéolos preenchidos;

$I_{C}$ : momento de inércia da laje, sem considerar capa e alvéolos preenchidos;

$\Sigma \mathrm{b}_{\mathrm{w}}$ : soma das larguras das nervuras da laje na região central, onde seu valor é mínimo;

d: altura útil da seção transversal da laje;

$d^{\prime}$ : distância entre o centro das cordoalhas e a face inferior da laje. 
As características geométricas das lajes que receberam capa e tiveram alvéolos preenchidos estão na Tabela 5.5 e na Tabela 5.6, respectivamente.

Tabela 5.5: Características geométricas das unidades que receberam capa estrutural.

\begin{tabular}{|c|c|c|c|c|c|c|c|c|c|c|}
\hline Laje & $\begin{array}{c}\mathbf{H}_{\mathrm{LA}} \\
(\mathbf{c m})\end{array}$ & $\begin{array}{l}\mathbf{H}_{\text {тот }} \\
(\mathrm{cm})\end{array}$ & $\begin{array}{c}\mathrm{L} \\
(\mathrm{cm})\end{array}$ & $\begin{array}{c}\text { b } \\
(\mathrm{cm})\end{array}$ & $\begin{array}{c}\phi_{\text {alv }} \\
(\mathrm{cm})\end{array}$ & $\begin{array}{c}A_{c} \\
\left(\mathrm{~cm}^{2}\right)\end{array}$ & $\begin{array}{c}I_{C} \\
\left(\mathrm{~cm}^{4}\right)\end{array}$ & $\begin{array}{c}\Sigma \mathbf{b}_{\mathrm{w}} \\
(\mathrm{mm})\end{array}$ & $\begin{array}{c}d^{\prime} \\
(\mathrm{cm})\end{array}$ & $\begin{array}{c}\text { d } \\
(\mathrm{cm})\end{array}$ \\
\hline L1-C-20-6D9,5-X_C & 15,00 & 20,00 & 650 & 120 & 9,19 & 1269,17 & $3,09.10^{4}$ & 380,90 & 3,06 & 16,94 \\
\hline L2-C-20-6D9,5-X_C & 15,00 & 20,00 & 650 & 120 & 9,19 & 1269,17 & $3,09 \cdot 10^{4}$ & 400,10 & 3,06 & 16,94 \\
\hline L3-C-25-8D12,7-X_C & 20,00 & 25,00 & 650 & 120 & 12,04 & 1717,21 & $7,38.10^{4}$ & 453,90 & 3,29 & 21,71 \\
\hline L4-C-25-7D9,5-Y_C & 19,60 & 25,37 & 415 & 120 & 14,67 & 1246,35 & $5,87.10^{4}$ & 254,50 & 3,53 & 21,84 \\
\hline L5-C-25-7D9,5-Y_C & 19,78 & 25,68 & 415 & 120 & 14,61 & 1266,49 & $6,07 \cdot 10^{4}$ & 239,00 & 3,77 & 21,92 \\
\hline L6-C-25-6D12,7-Y_C & 19,87 & 25,34 & 415 & 120 & 14,61 & 1282,02 & $6,18 \cdot 10^{4}$ & 253,50 & 3,41 & 21,93 \\
\hline L7-C-25-7D9,5-Y_C & 19,93 & 25,35 & 415 & 121 & 14,74 & 1279,47 & $6,24.10^{4}$ & 243,50 & 3,67 & 21,68 \\
\hline $\begin{array}{c}\text { L8-C-25-5D12,7-Z_C } \\
a \\
\text { L12-C-25-5D12,7-Z_C }\end{array}$ & 20,00 & 25,00 & 310 & 125 & 15,00 & 1377,95 & $6,71.10^{4}$ & 320,00 & 3,50 & 21,50 \\
\hline $\begin{array}{c}\text { L13-CF-25-5D12,7-Z_C } \\
a \\
\text { L17-CF-25-5D12,7-Z_C }\end{array}$ & 20,00 & 25,00 & 310 & 125 & 15,00 & 1377,95 & $6,71.10^{4}$ & 320,00 & 3,50 & 21,50 \\
\hline L1-C-20-6D9,5-X_F & 15,00 & 20,00 & 650 & 120 & 9,19 & 1269,17 & $3,09.10^{4}$ & 400,10 & 3,06 & 16,94 \\
\hline L2-C-20-6D9,5-X_F & 15,00 & 20,00 & 650 & 120 & 9,19 & 1269,17 & $3,09.10^{4}$ & 424,10 & 3,38 & 16,62 \\
\hline L3-C-25-8D12,7-X_F & 20,00 & 25,00 & 650 & 120 & 12,04 & 1717,21 & $7,38.10^{4}$ & 453,90 & 3,29 & 21,71 \\
\hline $\begin{array}{c}\text { L4-C-25-5D 12,7-Z_F } \\
a \\
\text { L8-C-25-5D12,7-Z_F }\end{array}$ & 20,00 & 25,00 & 310 & 125 & 15,00 & 1377,95 & $6,71.10^{4}$ & 320,00 & 3,50 & 21,50 \\
\hline L9-C-25-5D12,7-Z_F & 20,00 & 25,00 & 610 & 125 & 15,00 & 1377,95 & $6,71 \cdot 10^{4}$ & 320,00 & 3,50 & 21,50 \\
\hline $\begin{array}{c}\text { L10-CF-25-5D12,7-Z_F } \\
a \\
\text { L14-CF-25-5D12,7-Z F }\end{array}$ & 20,00 & 25,00 & 310 & 125 & 15,00 & 1377,95 & $6,71.10^{4}$ & 320,00 & 3,50 & 21,50 \\
\hline
\end{tabular}

Tabela 5.6: Características geométricas das unidades que tiveram alvéolos preenchidos.

\begin{tabular}{|c|c|c|c|c|c|c|c|c|c|}
\hline Laje & $\begin{array}{c}\mathbf{H}_{\mathrm{LA}} \\
(\mathbf{c m})\end{array}$ & $\begin{array}{c}\mathrm{L} \\
(\mathrm{cm})\end{array}$ & $\begin{array}{c}\text { b } \\
(\mathrm{cm})\end{array}$ & $\begin{array}{c}\phi_{\text {alv }} \\
(\mathrm{cm})\end{array}$ & $\begin{array}{c}A_{c} \\
\left(\mathrm{~cm}^{2}\right)\end{array}$ & $\begin{array}{c}I_{c} \\
\left(\mathrm{~cm}^{4}\right)\end{array}$ & $\begin{array}{c}\Sigma \mathbf{b}_{\mathrm{w}} \\
(\mathbf{m m})\end{array}$ & $\begin{array}{c}d^{\prime} \\
(\mathrm{cm})\end{array}$ & $\begin{array}{c}\mathrm{d} \\
(\mathrm{cm})\end{array}$ \\
\hline L1-2P-20-6D12,7-Y_C & 20,06 & 415 & 120 & 14,42 & 1326,77 & $6,46.10^{4}$ & 261,25 & 3,41 & 16,65 \\
\hline L2-2P-20-6D12,7-Y_C & 20,02 & 415 & 120 & 14,34 & 1331,16 & $6,43.10^{4}$ & 262,25 & 3,49 & 16,52 \\
\hline L3-2P-20-6D12,7-Y_C & 19,94 & 415 & 120 & 14,52 & 1308,98 & $6,32.10^{4}$ & 257,75 & 3,51 & 16,44 \\
\hline L4-2P-20-7D9,5-Y_C & 19,87 & 415 & 121 & 14,48 & 1309,76 & $6,27.10^{4}$ & 252,00 & 3,21 & 16,66 \\
\hline L5-2P-20-7D9,5-Y_C & 19,91 & 415 & 120 & 14,47 & 1308,24 & $6,29.10^{4}$ & 257,75 & 3,03 & 16,88 \\
\hline L6-2P-20-7D9,5-Y_C & 19,94 & 414 & 120 & 14,96 & 1227,82 & $6,08 \cdot 10^{4}$ & 253,55 & 3,43 & 16,50 \\
\hline $\begin{array}{c}\text { L7-2PF-20-5D12,7-Z_C } \\
a \\
\text { L12-2PF-20-5D12,7-Z_C }\end{array}$ & 20,00 & 310 & 125 & 15,00 & 1377,95 & $6,71 \cdot 10^{4}$ & 320,00 & 3,50 & 16,50 \\
\hline $\begin{array}{c}\text { L13-4PF-20-5D12,7-Z_C } \\
a \\
\text { L18-4PF-20-5D12,7-Z_C }\end{array}$ & 20,00 & 310 & 125 & 15,00 & 1377,95 & $6,71 \cdot 10^{4}$ & 320,00 & 3,50 & 16,50 \\
\hline $\begin{array}{c}\text { L1-2PF-20-5D 12,7-Z_F } \\
a \\
\text { L3-2PF-20-5D12,7-Z_F }\end{array}$ & 20,00 & 310 & 125 & 15,00 & 1377,95 & $6,71 \cdot 10^{4}$ & 320,00 & 3,50 & 16,50 \\
\hline $\begin{array}{c}\text { L4-4PF-20-5D12,7-Z_F } \\
a \\
\text { L6-4PF-20-5D12,7-Z_F }\end{array}$ & 20,00 & 310 & 125 & 15,00 & 1377,95 & $6,71 \cdot 10^{4}$ & 320,00 & 3,50 & 16,50 \\
\hline
\end{tabular}




\subsection{CARACTERÍSTICAS DO CONCRETO}

As características do concreto das lajes foram fornecidas pelas respectivas empresas fabricantes.

Com o intuito de garantir maior confiabilidade a esses valores, foram feitas análises e comparações a partir de resultados obtidos por meio de ensaios de flexão das unidades. Então, para os lotes $\mathrm{X}, \mathrm{Z}$ e $\mathrm{W}$ foram tomadas as providências relatadas a seguir.

No caso da empresa $X$ a confiabilidade foi garantida com a comparação entre os módulos de elasticidade do concreto determinados por meio das flechas verificadas nos ensaios de flexão das lajes e os módulos determinados por meio das resistências do concreto à compressão, obtidas nos ensaios de corpos de prova. Para os lotes Z e W foram feitas comparações entre as resistências do concreto à tração e à compressão, respectivamente, relativas aos ensaios de caracterização, e as resistências obtidas a partir de valores experimentais do momento de fissuração, determinados nos ensaios de flexão da laje. Tais comparações podem ser observadas mais adiante, no capítulo 6, item 6.2.5.

\section{- Lajes sem capa}

As características do concreto das lajes sem capa estão apresentadas: na Tabela 5.7, para o lote $X$; na Tabela 5.8, lote $Y$, na Tabela 5.9, lote $Z$ e na Tabela 5.10, lote W.

Tabela 5.7: Características do concreto das lajes sem capa, do lote $X$.

\begin{tabular}{|c|c|c|c|}
\hline Laje & $\begin{array}{c}\mathbf{f}_{\text {cm }} \text { laje } \\
\mathbf{( 2 8 ~ d ) ~} \\
\mathbf{( M P a )}\end{array}$ & $\begin{array}{c}\mathbf{f}_{\mathrm{cj}} \text { laje } \\
\text { (Iib. pr.) } \\
(\mathbf{M P a})\end{array}$ & $\begin{array}{c}\mathbf{f}_{\mathbf{c j}} \text { laje } \\
(\mathbf{e n s a i o}) \\
\text { (MPa) }\end{array}$ \\
\hline L1-S-15-6D9,5-X_C & 52,63 & 31,58 & 55,94 \\
\hline L2-S-20-8D12,7-X_C & 45,65 & 27,40 & 48,40 \\
\hline L1-S-15-6D9,5-X_F & 52,63 & 31,58 & 56,02 \\
\hline L2-S-15-6D9,5-X_F & 52,63 & 31,58 & 55,97 \\
\hline L3-S-20-8D12,7-X_F & 45,65 & 27,40 & 48,27 \\
\hline L4-S-20-8D12,7-X_F & 45,65 & 27,40 & 48,40 \\
\hline
\end{tabular}

d: dias; lib.pr.: liberação da protensão

Tabela 5.8: Características do concreto das lajes sem capa, do lote $Y$.

\begin{tabular}{|c|c|c|c|c|c|c|}
\hline Laje & $\begin{array}{c}f_{\text {cm }} \text { laje } \\
(28 \mathrm{~d}) \\
(\mathrm{MPa})\end{array}$ & $\begin{array}{c}\mathbf{f}_{\mathrm{cj}} \text { laje } \\
\text { (lib. pr.) } \\
(\mathrm{MPa})\end{array}$ & $\begin{array}{c}\mathbf{f}_{\mathrm{cj}} \text { laje } \\
\text { (ensaio) } \\
(\mathrm{MPa})\end{array}$ & $\begin{array}{c}E_{c} \\
(14 d) \\
(G P a)\end{array}$ & $\begin{array}{c}E_{c} \\
(28 d) \\
(G P a)\end{array}$ & $\begin{array}{c}f_{\mathrm{tm}} \\
(28 \mathrm{~d}) \\
(\mathrm{MPa})\end{array}$ \\
\hline L3-S-20-6D12,7-Y_C & 50,2 & 27,80 & 53,28 & 32,1 & 36,6 & 4,2 \\
\hline L4-S-20-6D12,7-Y_C & 50,2 & 27,80 & 53,45 & 32,1 & 36,6 & 4,2 \\
\hline L5-S-20-6D12,7-Y_C & 50,2 & 27,80 & 53,45 & 32,1 & 36,6 & 4,2 \\
\hline L6-S-20-7D9,5-Y_C & 50,2 & 29,87 & 53,53 & 32,1 & 36,6 & 4,2 \\
\hline L7-S-20-7D9,5-Y_C & 50,2 & 29,87 & 53,53 & 32,1 & 36,6 & 4,2 \\
\hline L8-S-20-7D9,5-Y_C & 50,2 & 29,87 & 53,54 & 32,1 & 36,6 & 4,2 \\
\hline L9-S-20-7D9,5-Y_C & 50,2 & 29,87 & 53,54 & 32,1 & 36,6 & 4,2 \\
\hline L10-S-20-7D9,5-Y_C & 50,2 & 29,87 & 53,58 & 32,1 & 36,6 & 4,2 \\
\hline L11-S-20-7D9,5-Y_C & 50,2 & 29,87 & 53,59 & 32,1 & 36,6 & 4,2 \\
\hline
\end{tabular}

d: dias; lib.pr.: liberação da protensão 
Tabela 5.9: Características do concreto das lajes sem capa, do lote Z.

\begin{tabular}{|c|c|c|c|c|c|c|c|}
\hline Laje & $\begin{array}{c}f_{\text {cm }} \text { laje } \\
(28 \mathrm{~d}) \\
(\mathrm{MPa})\end{array}$ & $\begin{array}{c}\mathbf{f}_{\mathrm{cj}} \text { laje } \\
(\mathrm{lib} . \mathrm{pr} .) \\
(\mathrm{MPa})\end{array}$ & $\begin{array}{c}\mathbf{f}_{\mathrm{cj}} \text { laje } \\
\text { (ensaio) } \\
\text { (MPa) }\end{array}$ & $\begin{array}{c}E_{c} \\
(10 \mathrm{~d}) \\
(\mathrm{GPa})\end{array}$ & $\begin{array}{c}E_{c} \\
(28 \mathrm{~d}) \\
(\mathrm{GPa})\end{array}$ & $\begin{array}{c}f_{\mathrm{tm}} \\
(28 \mathrm{~d}) \\
(\mathrm{MPa})\end{array}$ & $\begin{array}{c}\mathbf{f}_{\mathrm{tj}} \\
\text { (ensaio) } \\
(\mathrm{MPa})\end{array}$ \\
\hline $\begin{array}{l}\text { L12-S-20-5D12,7Z_C a } \\
\text { L16-S-20-5D12,7-Z_C }\end{array}$ & 50,4 & 30 & 40 & 28,5 & 29,2 & 5,6 & 4,09 \\
\hline $\begin{array}{c}\text { L5-S-20-5D12,7-Z_F a } \\
\text { L9-S-20-5D12,7-Z_F }\end{array}$ & 50,4 & 30 & 40 & 28,5 & 29,2 & 5,6 & 4,09 \\
\hline L10-S-20-5D12,7-Z_F & 50,4 & 30 & 40 & 28,5 & 29,2 & 5,6 & 4,09 \\
\hline
\end{tabular}

d: dias; lib.pr.: liberação da protensão

Tabela 5.10: Características do concreto das lajes sem capa, do lote W.

\begin{tabular}{|c|c|c|}
\hline Laje & $\begin{array}{c}\mathbf{f}_{\text {cj laje }} \\
\text { (lib. pr.) } \\
\text { (MPa) }\end{array}$ & $\begin{array}{c}\mathbf{f}_{\text {cj Iaje }} \\
\text { (ensaio) } \\
\text { (MPa) }\end{array}$ \\
\hline $\begin{array}{c}\text { L17-S-21-7D9,5-W_C a } \\
\text { L21-S-21-7D9,5-W_C }\end{array}$ & 28,2 & 47 \\
\hline $\begin{array}{c}\text { L22-S-16-5D9,5-W_C a } \\
\text { L26-S-16-5D9,5-W_C }\end{array}$ & 28,2 & 47 \\
\hline $\begin{array}{c}\text { L27-S-26-9D12,7-W_C a } \\
\text { L30-S-26-9D12,7-W_C }\end{array}$ & 28,0 & 50 \\
\hline L11-S-21-7D9,5-W_F & 28,2 & 47 \\
\hline
\end{tabular}

lib.pr.: liberação da protensão

\section{- Lajes com capa}

As características do concreto das lajes com de capa podem ser observados: na Tabela 5.11, para o lote X; na Tabela 5.12, para o lote Y e na Tabela 5.13, para o lote Z.

Tabela 5.11: Características do concreto das lajes com capa, do lote $X$.

\begin{tabular}{|c|c|c|c|c|c|}
\hline Laje & $\begin{array}{r}f_{\text {cm laje }} \\
(28 \mathrm{~d}) \\
(\mathrm{MPa})\end{array}$ & $\begin{array}{c}f_{\mathrm{cm}} \text { capa } \\
(28 \mathrm{~d}) \\
(\mathrm{MPa})\end{array}$ & $\begin{array}{c}\mathbf{f}_{\mathrm{cj}} \text { laje } \\
\text { (lib. pr.) } \\
(\mathrm{MPa})\end{array}$ & $\begin{array}{c}f_{c j} \text { laje } \\
\text { (ensaio) } \\
\text { (MPa) }\end{array}$ & $\begin{array}{c}\mathbf{f}_{\mathrm{cj}} \text { capa } \\
\text { (ensaio) } \\
\text { (MPa) }\end{array}$ \\
\hline L1-C-20-6D9,5-X_C & 52,63 & 33,67 & 31,58 & 55,87 & 28,74 \\
\hline L2-C-20-6D9,5-X_C & 52,63 & 33,67 & 31,58 & 55,73 & 33,05 \\
\hline L3-C-25-8D 12,7-X_C & 45,65 & 33,67 & 27,40 & 48,36 & 34,63 \\
\hline L1-C-20-6D9,5-X_F & 52,63 & 33,67 & 31,58 & 55,75 & 33,16 \\
\hline L2-C-20-6D9,5-X_F & 52,63 & 33,67 & 31,58 & 55,86 & 33,74 \\
\hline L3-C-25-8D12,7-X_F & 45,65 & 33,67 & 27,40 & 48,39 & 34,69 \\
\hline
\end{tabular}

d: dias; lib.pr.: liberação da protensão

Tabela 5.12: Características do concreto das lajes com capa, do lote $Y$.

\begin{tabular}{|c|c|c|c|c|c|c|c|}
\hline Laje & $\begin{array}{c}f_{c m} \text { laje } \\
(28 \mathrm{~d}) \\
(\mathrm{MPa})\end{array}$ & $\begin{array}{c}\mathbf{f}_{\mathrm{cj}} \text { laje } \\
\text { (lib. pr.) } \\
(\mathrm{MPa})\end{array}$ & $\begin{array}{c}\mathbf{f}_{\mathrm{cj}} \text { laje } \\
\text { (ensaio) } \\
\text { (MPa) }\end{array}$ & $\begin{array}{c}\mathbf{f}_{\mathrm{cj}} \\
\text { capa } \\
(\mathrm{MPa})\end{array}$ & $\begin{array}{c}E_{c} \\
(14 d) \\
(G P a)\end{array}$ & $\begin{array}{c}E_{c} \\
(28 d) \\
(G P a)\end{array}$ & $\begin{array}{c}f_{\mathrm{tm}} \\
(28 \mathrm{~d}) \\
(\mathrm{MPa})\end{array}$ \\
\hline L4-C-25-7D9,5-Y_C & 50,2 & 29,87 & 54,61 & 27,87 & 32,1 & 36,6 & 4,2 \\
\hline L5-C-25-7D9,5-Y_C & 50,2 & 29,87 & 54,61 & 28,41 & 32,1 & 36,6 & 4,2 \\
\hline L6-C-25-6D12,7-Y_C & 50,2 & 27,80 & 54,61 & 28,41 & 32,1 & 36,6 & 4,2 \\
\hline L7-C-25-7D9,5-Y_C & 50,2 & 29,87 & 54,61 & 28,41 & 32,1 & 36,6 & 4,2 \\
\hline
\end{tabular}

d: dias; lib.pr.: liberação da protensão 
Tabela 5.13: Características do concreto das lajes com capa, do lote Z.

\begin{tabular}{|c|c|c|c|c|c|c|c|c|}
\hline Laje & $\begin{array}{c}\mathbf{f}_{\mathrm{cm}} \\
\text { laje } \\
(28 \mathrm{~d}) \\
(\mathrm{MPa})\end{array}$ & $\begin{array}{c}\mathbf{f}_{\mathrm{cj}} \\
\text { laje } \\
\text { (lib. pr.) } \\
(\mathrm{MPa})\end{array}$ & $\begin{array}{c}f_{c j} \\
\text { laje } \\
(10 \mathrm{~d}) \\
(\mathrm{MPa})\end{array}$ & $\begin{array}{c}\mathbf{f}_{\mathrm{cj}} \\
\text { capa } \\
(\mathrm{MPa})\end{array}$ & $\begin{array}{c}E_{c} \\
(10 \mathrm{~d}) \\
(\mathrm{GPa})\end{array}$ & $\begin{array}{c}E_{c} \\
(28 d) \\
(G P a)\end{array}$ & $\begin{array}{c}\mathbf{f}_{\mathrm{tm}} \\
(28 \mathrm{~d}) \\
(\mathrm{MPa})\end{array}$ & $\begin{array}{c}\mathbf{f}_{\mathrm{tj}} \\
(\mathbf{M P a})\end{array}$ \\
\hline $\begin{array}{l}\text { L8-C-25-5D12,7-Z_C a } \\
\text { L12-C-25-5D12,7-Z_C }\end{array}$ & 50,4 & 30 & 40 & 33 & 28,5 & 29,2 & 5,6 & 4,09 \\
\hline $\begin{array}{l}\text { L13-CF-25-5D12,7-Z_C a } \\
\text { L17-CF-25-5D12,7-Z_C }\end{array}$ & 50,4 & 30 & 40 & 33 & 28,5 & 29,2 & 5,6 & 4,09 \\
\hline $\begin{array}{c}\text { L4-C-25-5D12,7-Z_F a } \\
\text { L8-C-25-5D 12,7-Z_F }\end{array}$ & 50,4 & 30 & 40 & 33 & 28,5 & 29,2 & 5,6 & 4,09 \\
\hline L9-C-25-5D12,7-Z_F & 50,4 & 30 & 40 & 33 & 28,5 & 29,2 & 5,6 & 4,09 \\
\hline $\begin{array}{c}\text { L10-CF-25-5D12,7-Z_F a } \\
\text { L14-CF-25-5D12,7-Z_F }\end{array}$ & 50,4 & 30 & 40 & 33 & 28,5 & 29,2 & 5,6 & 4,09 \\
\hline
\end{tabular}

d: dias; lib.pr.: liberação da protensão

\section{- Lajes com alvéolos preenchidos}

As características do concreto das lajes com alvéolos preenchidos podem ser observadas: na Tabela 5.14, para o lote Y e na Tabela 5.15, para o lote $Z$.

Tabela 5.14: Características do concreto das lajes com alvéolos preenchidos, do lote Y.

\begin{tabular}{|c|c|c|c|c|c|c|}
\hline Laje & $\begin{array}{c}\mathbf{f}_{\mathrm{cm}} \text { laje } \\
\text { (28 d) } \\
(\mathrm{MPa})\end{array}$ & $\begin{array}{c}\text { f }_{\mathrm{cj}} \text { laje } \\
\text { (lib. pr.) } \\
\text { (MPa) }\end{array}$ & $\begin{array}{c}\mathbf{f}_{\mathrm{cj}} \text { laje } \\
\text { (ensaio) } \\
\text { (MPa) }\end{array}$ & $\begin{array}{c}E_{c} \\
(14 d) \\
(G P a)\end{array}$ & $\begin{array}{c}E_{c} \\
(28 d) \\
(G P a)\end{array}$ & $\begin{array}{c}f_{\mathrm{tm}} \\
(28 \mathrm{~d}) \\
(\mathrm{MPa})\end{array}$ \\
\hline L1-2P-20-6D12,7-Y_C & 50,2 & 27,80 & 53,19 & 32,1 & 36,6 & 4,2 \\
\hline L2-2P-20-6D12,7-Y_C & 50,2 & 27,80 & 53,47 & 32,1 & 36,6 & 4,2 \\
\hline L3-2P-20-6D12,7-Y_C & 50,2 & 27,80 & 53,54 & 32,1 & 36,6 & 4,2 \\
\hline L4-2P-20-7D9,5-Y_C & 50,2 & 29,87 & 53,53 & 32,1 & 36,6 & 4,2 \\
\hline L5-2P-20-7D9,5-Y_C & 50,2 & 29,87 & 53,53 & 32,1 & 36,6 & 4,2 \\
\hline L6-2P-20-7D9,5-Y_C & 50,2 & 29,87 & 53,52 & 32,1 & 36,6 & 4,2 \\
\hline
\end{tabular}

d: dias; lib.pr.: liberação da protensão

Tabela 5.15: Características do concreto das lajes com alvéolos preenchidos, do lote Z.

\begin{tabular}{|c|c|c|c|c|c|c|c|c|}
\hline Laje & $\begin{array}{l}f_{\text {cm }} \text { laje } \\
(28 \mathrm{~d}) \\
(\mathrm{MPa})\end{array}$ & $\begin{array}{l}f_{c j} \text { laje } \\
\text { (lib. pr.) } \\
(\mathrm{MPa})\end{array}$ & $\begin{array}{l}f_{c j} \text { laje } \\
(10 \mathrm{~d}) \\
(\mathrm{MPa})\end{array}$ & $\begin{array}{l}f_{c j} \text { alv. } \\
(10 \mathrm{~d}) \\
(\mathrm{MPa})\end{array}$ & $\begin{array}{c}E_{c} \\
(10 \mathrm{~d}) \\
(\mathrm{GPa})\end{array}$ & $\begin{array}{c}E_{c} \\
(28 \mathrm{~d}) \\
(\mathrm{GPa})\end{array}$ & $\begin{array}{c}f_{\mathrm{tm}} \\
(28 \mathrm{~d}) \\
(\mathrm{MPa})\end{array}$ & $\begin{array}{c}\mathbf{f}_{\mathrm{tj}} \\
(\mathbf{M P a})\end{array}$ \\
\hline $\begin{array}{l}\text { L1-2PF-20-5D12,7-Z_F a } \\
\text { L3-2PF-20-5D12,7-Z_F }\end{array}$ & 50,4 & 30 & 40 & 40 & 28,5 & 29,2 & 5,6 & 4,09 \\
\hline $\begin{array}{c}\text { L4-4PF-20-5D12,7-Z_F a } \\
\text { L6-4PF-20-5D 12,7-Z_F }\end{array}$ & 50,4 & 30 & 40 & 40 & 28,5 & 29,2 & 5,6 & 4,09 \\
\hline $\begin{array}{l}\text { L7-2PF-20-5D12,7-Z_C a } \\
\text { L12-2PF-20-5D12,7-Z_C }\end{array}$ & 50,4 & 30 & 40 & 40 & 28,5 & 29,2 & 5,6 & 4,09 \\
\hline $\begin{array}{c}\text { L13-4PF-20-5D12,7-Z_C } \\
\text { a } \\
\text { L18-4PF-20-5D12,7-Z_C }\end{array}$ & 50,4 & 30 & 40 & 40 & 28,5 & 29,2 & 5,6 & 4,09 \\
\hline
\end{tabular}

d: dias; alv.: alvéolos; lib.pr.: liberação da protensão

\subsection{CARACTERÍSTICAS DA ARMADURA}

Todos os valores referentes às características das armaduras foram fornecidos pelos fabricantes de cada unidade. Na Tabela 5.16 constam as características das armaduras das peças sem capa, na Tabela 5.17, das peças com capa e na Tabela 5.18, das peças com alvéolos preenchidos. 
A NBR 7483:2004 recomenda para o cálculo estrutural a utilização do valor nominal da área da armadura ativa. Assim, os cálculos foram realizados considerando essa área nominal, fornecida pelos respectivos fabricantes.

Tabela 5.16: Características das armaduras de protensão das peças sem capa.

\begin{tabular}{|c|c|c|c|c|c|c|}
\hline Laje & $\begin{array}{l}N^{\circ} \text { de } \\
\text { cordoalhas }\end{array}$ & $\begin{array}{l}\phi \text { cordoalhas } \\
(\mathbf{m m})\end{array}$ & $\begin{array}{l}\mathbf{F}_{\mathrm{p}} \text { por } \\
\text { cabo } \\
(\mathbf{k N})\end{array}$ & $\begin{array}{l}F_{p} \text { total } \\
(\mathbf{k N})\end{array}$ & $\underset{\left(\mathbf{m m}^{2}\right)}{A_{p}}$ & $\begin{array}{c}\sigma_{\mathrm{p}} \\
(\mathrm{MPa})\end{array}$ \\
\hline L1- S-15-6D9,5-X_C & 6 & 9,5 & 79 & 474 & 333 & 1423,42 \\
\hline L2-S-20-8D12,7-X_C & 8 & 12,7 & 144,5 & 1156 & 811,2 & 1425,05 \\
\hline L1-S-15-6D9,5-X_F & 6 & 9,5 & 79 & 474 & 333 & 1423,42 \\
\hline L2-S-15-6D9,5-X_F & 6 & 9,5 & 79 & 474 & 333 & 1423,42 \\
\hline L3-S-20-8D12,7-X_F & 8 & 12,7 & 144,5 & 1156 & 811,2 & 1425,05 \\
\hline L4-S-20-8D12,7-X_F & 8 & 12,7 & 144,5 & 1156 & 811,2 & 1425,05 \\
\hline $\begin{array}{l}\text { L3-S-20-6D12,7-Y_C a } \\
\text { L5-S-20-6D 12,7-Y_C }\end{array}$ & 6 & 12,7 & 145 & 870 & 608,4 & 1429,98 \\
\hline $\begin{array}{l}\text { L6-S-20-7D9,5-Y_C a } \\
\text { L11-S-20-7D9,5-Y_C }\end{array}$ & 7 & 9,5 & 75 & 525 & 388,5 & 1351,35 \\
\hline $\begin{array}{c}\text { L12-S-20-5D12,7-Z_C a } \\
\text { L16-S-20-5D12,7-Z_C }\end{array}$ & 5 & 12,7 & 114 & 570 & 500 & 1140 \\
\hline $\begin{array}{l}\text { L17-S-21-7D9,5-W_C a } \\
\text { L21-S-21-7D9,5-W_C }\end{array}$ & 7 & 9,5 & 81,03 & 567,21 & 388,5 & 1460 \\
\hline $\begin{array}{l}\text { L22-S-16-5D9,5-W_C a } \\
\text { L26-S-16-5D9,5-W_C }\end{array}$ & 5 & 9,5 & 81,03 & 405,15 & 277,5 & 1460 \\
\hline $\begin{array}{c}\text { L27-S-26-9D12,7-W_C } \\
\text { a } \\
\text { L30-S-26-9D 12,7-W_C }\end{array}$ & 9 & 12,7 & 148,04 & 1332,40 & 912,6 & 1460 \\
\hline $\begin{array}{c}\text { L5-S-20-5D 12,7-Z_F a } \\
\text { L9-S-20-5D12,7-Z_F }\end{array}$ & 5 & 12,7 & 114 & 570 & 500 & 1140 \\
\hline L10-S-20-5D12,7-Z_F & 5 & 12,7 & 114 & 570 & 500 & 1140 \\
\hline L11-S-21-7D9,5-W_F & 7 & 9,5 & 81,03 & 567,21 & 388,5 & 1460 \\
\hline
\end{tabular}

Tabela 5.17: Características das armaduras das peças com capa.

\begin{tabular}{|c|c|c|c|c|c|c|}
\hline Laje & $\begin{array}{c}\mathbf{N}^{\circ} \text { de } \\
\text { cordoalhas }\end{array}$ & $\begin{array}{l}\phi \text { cordoalhas } \\
(\mathbf{m m})\end{array}$ & $\begin{array}{c}\mathbf{F}_{\mathrm{p}} \text { por } \\
\text { Cabo } \\
(\mathbf{k N})\end{array}$ & $\begin{array}{l}\mathbf{F}_{\mathrm{p}} \text { total } \\
\quad(\mathbf{k N})\end{array}$ & $\begin{array}{c}A_{p} \\
\left(\mathbf{m m}^{2}\right)\end{array}$ & $\begin{array}{c}\sigma_{\mathrm{p}} \\
(\mathrm{MPa})\end{array}$ \\
\hline L1-C-20-6D9,5-X_C & 6 & 9,5 & 79 & 474 & 333 & 1423,42 \\
\hline L2-C-20-6D9,5-X_C & 6 & 9,5 & 79 & 474 & 333 & 1423,42 \\
\hline L3-C-25-8D12,7-X_C & 8 & 12,7 & 144,5 & 1156 & 811,2 & 1425,05 \\
\hline L1-C-20-6D9,5-X_F & 6 & 9,5 & 79 & 474 & 333 & 1423,42 \\
\hline L2-C-20-6D9,5-X_F & 6 & 9,5 & 79 & 474 & 333 & 1423,42 \\
\hline L3-C-25-8D12,7-X_F & 8 & 12,7 & 144,5 & 1156 & 811,2 & 1425,05 \\
\hline L4-C-25-7D9,5-Y_C & 7 & 9,5 & 75 & 525 & 388,5 & 1351,35 \\
\hline L5-C-25-7D9,5-Y_C & 7 & 9,5 & 75 & 525 & 388,5 & 1351,35 \\
\hline L6-C-25-6D12,7-Y_C & 6 & 12,7 & 145 & 870 & 608,4 & 1429,98 \\
\hline L7-C-25-7D9,5-Y_C & 7 & 9,5 & 75 & 525 & 388,5 & 1351,35 \\
\hline $\begin{array}{l}\text { L8-C-25-5D12,7-Z_C a } \\
\text { L12-C-25-5D 12,7-Z_C }\end{array}$ & 5 & 12,7 & 114 & 570 & 500 & 1140 \\
\hline $\begin{array}{l}\text { L4-C-25-5D12,7-Z_F a } \\
\text { L8-C-25-5D } 12,7-\bar{Z} \text { F }\end{array}$ & 5 & 12,7 & 114 & 570 & 500 & 1140 \\
\hline L9-C-25-5D12,7-Z_F & 5 & 12,7 & 114 & 570 & 500 & 1140 \\
\hline $\begin{array}{l}\text { L13-CF-25-5D12,7-Z_C a } \\
\text { L17-CF-25-5D12,7-Z_C }\end{array}$ & 5 & 12,7 & 114 & 570 & 500 & 1140 \\
\hline $\begin{array}{l}\text { L10-CF-25-5D12,7-Z_F a } \\
\text { L14-CF-25-5D12,7-Z_F }\end{array}$ & 5 & 12,7 & 114 & 570 & 500 & 1140 \\
\hline
\end{tabular}


Tabela 5.18: Características das armaduras das peças com alvéolos preenchidos.

\begin{tabular}{|c|c|c|c|c|c|c|}
\hline Laje & $\begin{array}{c}\mathbf{N}^{\circ} \text { de } \\
\text { cordoalhas }\end{array}$ & $\begin{array}{c}\phi \text { cordoalhas } \\
(\mathrm{mm})\end{array}$ & $\begin{array}{c}F_{p} \text { por } \\
\text { cabo } \\
(k N)\end{array}$ & $\begin{array}{l}\mathbf{F}_{\mathrm{p}} \text { total } \\
(\mathbf{k N})\end{array}$ & $\begin{array}{c}A_{p} \\
\left(\mathrm{~mm}^{2}\right)\end{array}$ & $\begin{array}{c}\sigma_{p} \\
(M P a)\end{array}$ \\
\hline L1-2P-20-6D12,7-Y_C & 6 & 12,7 & 145 & 870 & 608,4 & 1429,98 \\
\hline L2-2P-20-6D12,7-Y_C & 6 & 12,7 & 145 & 870 & 608,4 & 1429,98 \\
\hline L3-2P-20-6D12,7-Y_C & 6 & 12,7 & 145 & 870 & 608,4 & 1429,98 \\
\hline L4-2P-20-7D9,5-Y_C & 7 & 9,5 & 75 & 525 & 388,5 & 1351,35 \\
\hline L5-2P-20-7D9,5-Y_C & 7 & 9,5 & 75 & 525 & 388,5 & 1351,35 \\
\hline L6-2P-20-7D9,5-Y_C & 7 & 9,5 & 75 & 525 & 388,5 & 1351,35 \\
\hline $\begin{array}{l}\text { L7-2PF-20-5D12,7-Z_C a } \\
\text { L12-2PF-20-5D12,7-Z_C }\end{array}$ & 5 & 12,7 & 114 & 570 & 500 & 1140 \\
\hline $\begin{array}{c}\text { L1-2PF-20-5D12,7-Z_F a } \\
\text { L3-2PF-20-5D12,7-Z_F }\end{array}$ & 5 & 12,7 & 114 & 570 & 500 & 1140 \\
\hline $\begin{array}{c}\text { L13-4PF-20-5D12,7-Z_C a } \\
\text { L18-4PF-20-5D12,7-Z_C }\end{array}$ & 5 & 12,7 & 114 & 570 & 500 & 1140 \\
\hline $\begin{array}{c}\text { L4-4PF-20-5D12,7-Z_F a } \\
\text { L6-4PF-20-5D12,7-Z_F }\end{array}$ & 5 & 12,7 & 114 & 570 & 500 & 1140 \\
\hline
\end{tabular}

Nos modelos em que a capa foi executada com tela soldada, utilizou-se uma malha com $\phi 5 \mathrm{~mm}$ e espaçamento de $200 \mathrm{~mm}$. Para os modelos em que foi empregado concreto com fibras, utilizaram-se fibras metálicas com comprimento de $50 \mathrm{~mm}$, na dosagem especificada pelo fabricante, com $30 \mathrm{~kg}$ de fibra por metro cúbico de concreto.

De acordo com a NBR 6118:2003, devem ser considerados valores limites para a operação de protensão. De acordo com o item 9.6.1.2.1 dessa Norma, em casos de armadura pré-tracionada, a tensão de protensão inicial $\left(\sigma_{\mathrm{pi}}\right)$ na saída do aparelho de tração deve respeitar, para aços de baixa relaxação, os limites $0,77 . f_{\text {ptk }}$ e $0,85 . f_{\text {pyk }}$.

Considerando aço CP190RB, a tensão de protensão na saída do aparelho não deve ultrapassar os seguintes valores:

$\sigma_{\mathrm{pi}} \leq\left\{\begin{array}{l}0,77 \cdot 1900=1463 \mathrm{MPa} \\ 0,85 \cdot 1710=1453,5 \mathrm{MPa}\end{array} \quad \rightarrow \sigma_{\mathrm{pi}}=1453,5 \mathrm{MPa}\right.$

No lote $X$, a protensão empregada correspondeu a $98 \%$ desse limite recomendado. Para o lote $Y$, a protensão empregada nas peças com $6 \phi 12,7 \mathrm{~mm}$ foi de $98 \%$ e nas peças de $7 \phi 9,5$ correspondeu a $93 \%$. No caso do lote $Z$, a protensão empregada correspondeu a $78,4 \%$ do limite. Considerando o lote $W$, a protensão empregada nas peças apresentou um pequeno acréscimo de $0,45 \%$ em relação ao limite especificado pela NBR 6118:2003, sendo aplicada uma tensão inicial de $1460 \mathrm{MPa}$.

\subsection{ESQUEMAS DOS ENSAIOS}

Foram realizados diversos ensaios, variando o ponto de aplicação da força. $\mathrm{Na}$ Tabela 5.19 é possível observar o esquema de ensaio para cada laje sem capa. 
Tabela 5.19: Esquemas dos ensaios para as peças sem capa.

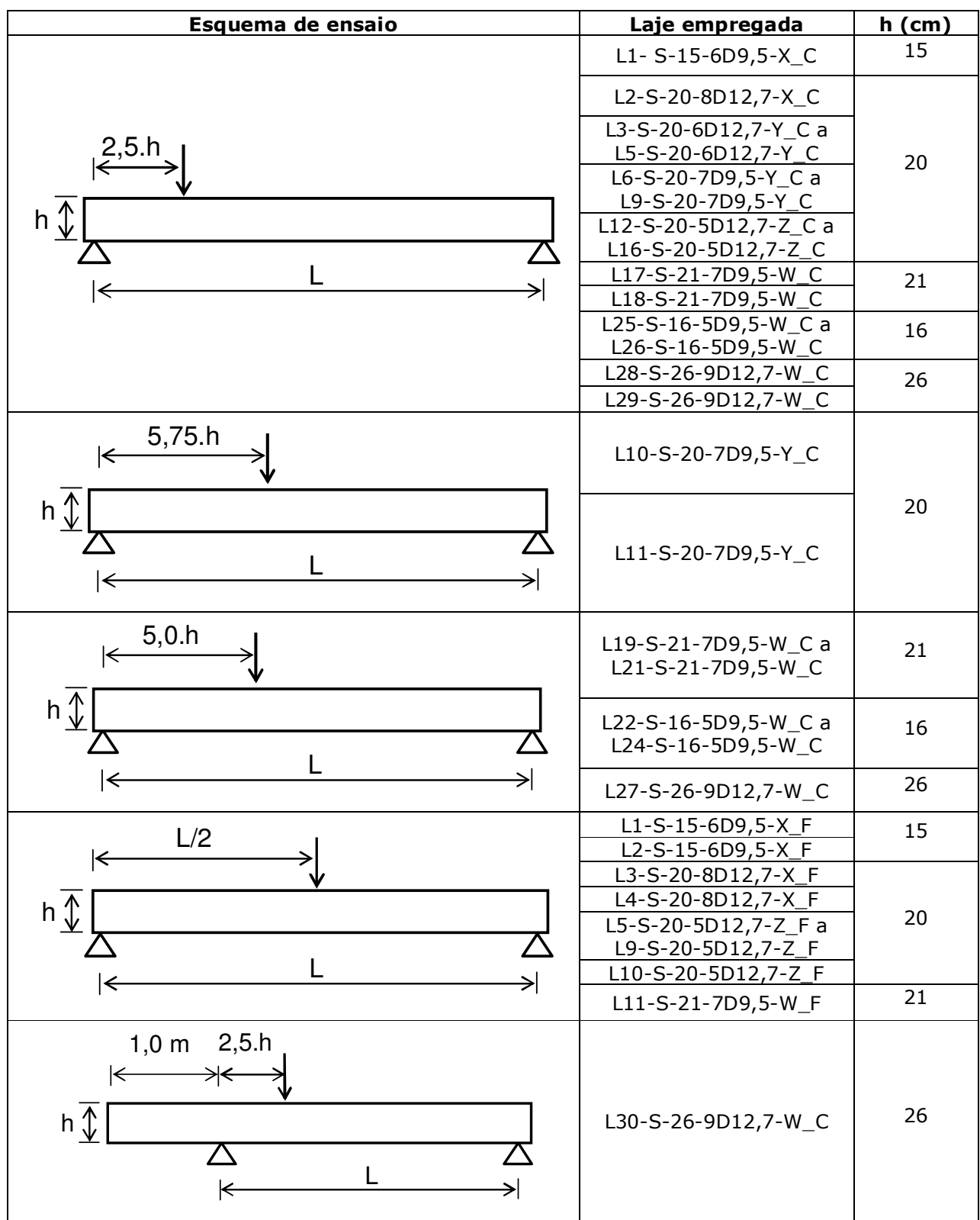

Na Tabela 5.20 é possível observar o esquema de ensaio para cada laje com a presença de capa.

E na Tabela 5.21, encontram-se o esquema relativo às lajes com alvéolos parcialmente preenchidos. 
Tabela 5.20: Esquemas dos ensaios para as peças com capa.

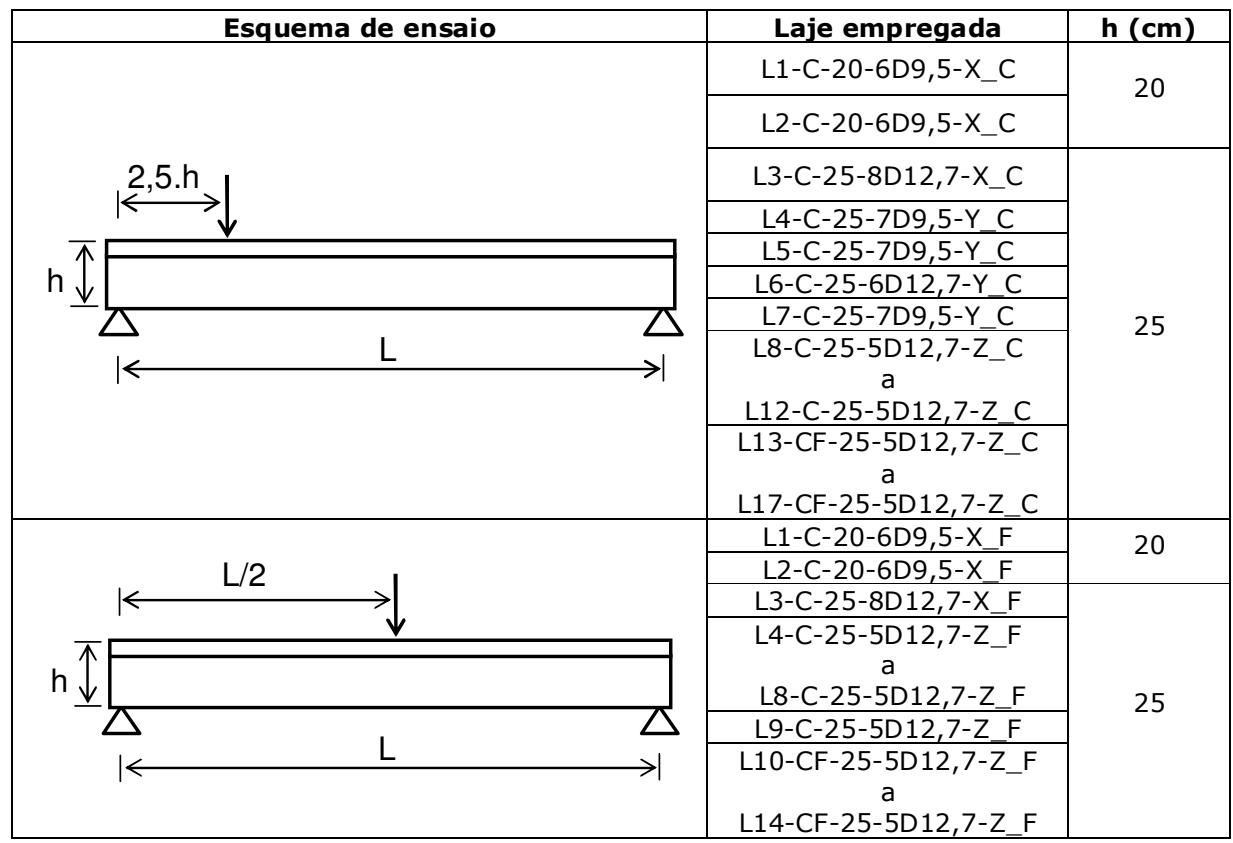

Tabela 5.21: Esquemas dos ensaios para as peças com alvéolos preenchidos.

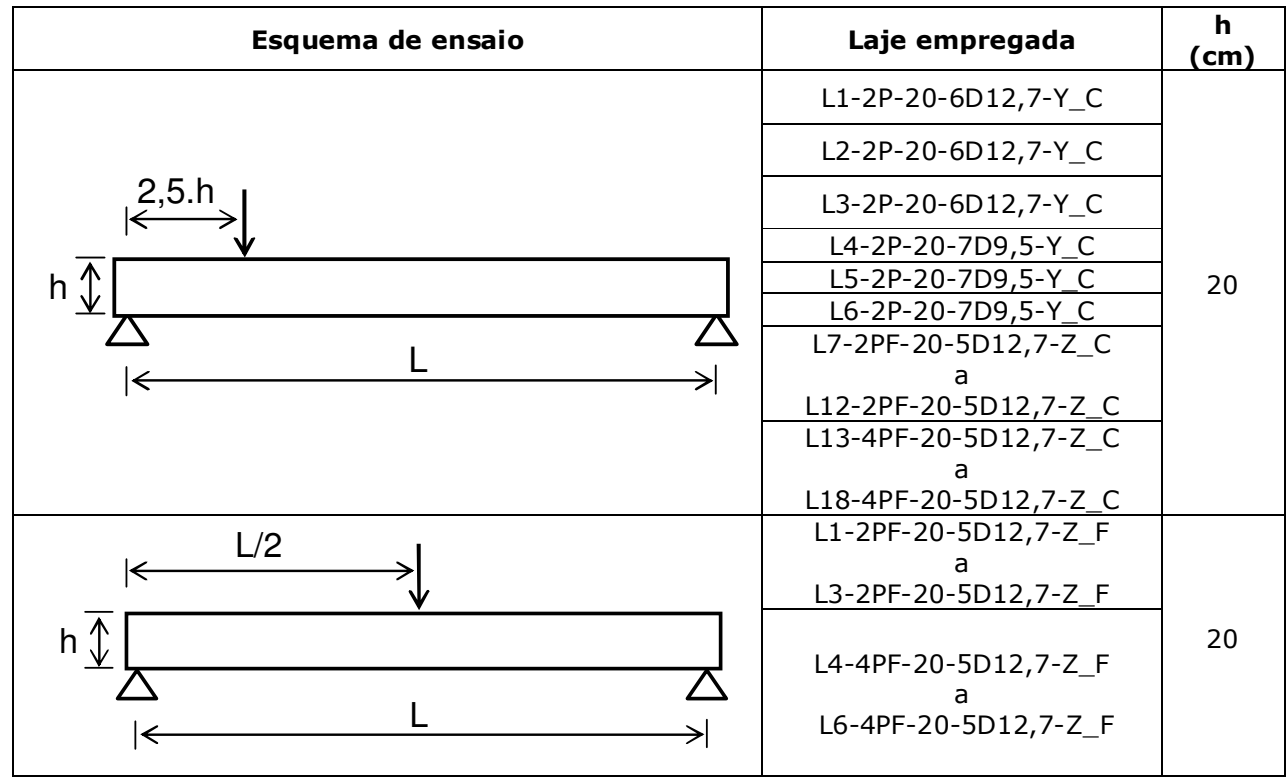




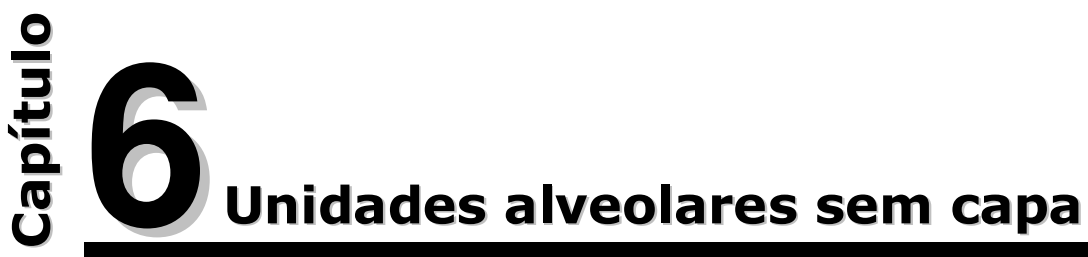

\subsection{RESULTADOS}

Os gráficos de força cortante devida à força do atuador versus deslocamento, obtidos nos ensaios ao cisalhamento e à flexão, para cada laje sem capa, estão apresentados no Apêndice D. A seguir serão apresentados os principais resultados obtidos nos ensaios realizados.

\subsubsection{Ensaios ao cisalhamento}

Os valores correspondentes à força cortante última e momento fletor último obtidos nos ensaios, considerando o peso próprio da unidade, estão indicados na Tabela 6.1.

Tabela 6.1: Resultados para as lajes sem capa ensaiadas ao cisalhamento.

\begin{tabular}{|c|c|c|c|c|c|}
\hline Laje & $\begin{array}{c}\mathrm{V}_{\mathrm{u}, \exp } \\
\text { (kN) }\end{array}$ & $\begin{array}{c}\mathrm{M}_{\mathrm{u}, \exp } \\
\text { (kN.m) }\end{array}$ & Laje & $\begin{array}{c}\mathrm{V}_{\mathrm{u}, \exp } \\
(\mathbf{k N})\end{array}$ & $\begin{array}{l}M_{\mathrm{u}, \exp } \\
\text { (kN.m) }\end{array}$ \\
\hline L1-S-15-6D9,5-X_C & 134,46 & 50,42 & L16-S-20-5D12,7-Z_C & 87,53 & 43,76 \\
\hline L2-S-20-8D 12,7-X_C & 222,39 & 111,19 & L17-S-21-7D9,5-W_C & 136,16 & 69,78 \\
\hline L3-S-20-6D12,7-Y C & 125,14 & 62,57 & L18-S-21-7D9,5-W C & 168,80 & 86,51 \\
\hline L4-S-20-6D12,7-Y_C & 163,46 & 81,73 & L19-S-21-7D9,5-W_C ${ }^{2}$ & 97,40 & 99,84 \\
\hline L5-S-20-6D12,7-Y_C & 144,51 & 72,25 & L20-S-21-7D9,5-W_C $C^{2}$ & 86,86 & 89,03 \\
\hline L6-S-20-7D9,5-Y_C & 121,71 & 60,85 & L21-S-21-7D9,5-W_C $C^{2}$ & 90,03 & 92,28 \\
\hline L7-S-20-7D9,5-Y_C & 137,04 & 68,52 & L22-S-16-5D9,5-W_C ${ }^{2}$ & 94,46 & 75,57 \\
\hline L8-S-20-7D9,5-Y_C & 142,17 & 71,08 & L23-S-16-5D9,5-W_C ${ }^{2}$ & 96,90 & 77,52 \\
\hline L9-S-20-7D9,5-Y_C & 135,44 & 67,72 & L24-S-16-5D9,5-W_C ${ }^{2}$ & 94,89 & 75,91 \\
\hline L10-S-20-7D9,5-Y_C $C^{1}$ & 68,09 & 78,30 & L25-S-16-5D9,5-W_C & 111,07 & 44,43 \\
\hline L11-S-20-7D9,5-Y_C ${ }^{1}$ & 68,40 & 78,66 & L26-S-16-5D9,5-W_C & 144,05 & 57,62 \\
\hline L12-S-20-5D12,7-Z_C & 121,39 & 60,69 & L27-S-26-9D12,7-W_C & 150,80 & 196,04 \\
\hline L13-S-20-5D12,7-Z_C & 120,78 & 60,39 & L28-S-26-9D12,7-W_C & 195,08 & 126,80 \\
\hline L14-S-20-5D12,7-Z_C & 141,16 & 70,58 & L29-S-26-9D12,7-W_C & 226,85 & 147,45 \\
\hline L15-S-20-5D12,7-Z_C & 111,85 & 55,93 & L30-S-26-9D12,7-W_C & 320,89 & 208,58 \\
\hline
\end{tabular}

Valores obtidos nos ensaios, considerando o peso próprio

${ }^{1}$ Nas lajes L10 e L11, a distância da aplicação da força foi de 5,75 h do apoio

${ }^{2}$ Nas lajes L19 a L24 e L27, a força foi aplicada à distância de 5 h do apoio.

$\mathrm{V}_{\mathrm{u}, \mathrm{exp}}$ : força cortante última obtida no ensaio (valor retirado do gráfico, somando o peso próprio);

$\mathrm{M}_{\mathrm{u}, \exp }$ : momento fletor último obtido no ensaio, correspondente $a \mathrm{~V}_{\mathrm{u}, \exp }$, (somando o momento correspondente ao peso próprio). 


\subsubsection{Ensaios à flexão}

Os valores correspondentes ao momento fletor último e ao momento de fissuração obtidos nos ensaios, considerando o peso próprio, estão indicados na Tabela 6.2 .

Tabela 6.2: Resultados para as lajes sem capa ensaiadas à flexão.

\begin{tabular}{|c|c|c|}
\hline Laje & $\begin{array}{c}M_{u, \exp } \\
(\mathbf{k N . m})\end{array}$ & $\begin{array}{c}M_{\text {r,exp }} \\
(\mathbf{k N . m})\end{array}$ \\
\hline L1-S-15-6D9,5-X_F & 79,89 & 64,43 \\
\hline L2-S-15-6D9,5-X_F & 78,16 & 59,07 \\
\hline L3-S-20-8D12,7-X_F & 224,19 & 131,82 \\
\hline L4-S-20-8D12,7-X_F & 245,92 & 142,19 \\
\hline L5-S-20-5D12,7-Z_F & 109,70 & 101,22 \\
\hline L6-S-20-5D12,7-Z_F & 125,30 & 107,00 \\
\hline L7-S-20-5D12,7-Z_F & 102,42 & 99,80 \\
\hline L8-S-20-5D12,7-Z_F & 97,17 & 97,17 \\
\hline L9-S-20-5D12,7-Z_F & 100,40 & 86,15 \\
\hline L10-S-20-5D12,7-Z_F & 135,65 & 95,00 \\
\hline L11-S-21-7D9,5-W_F & 154,85 & 100,73 \\
\hline
\end{tabular}

$M_{r, \text { exp }}$ : momento de fissuração experimental, na seção do meio do vão, determinado pelo gráfico de momento fletor versus deslocamento, obtido com o ensaio de flexão.

\subsection{ANÁLISE DOS RESULTADOS}

A seguir serão apresentadas as análises dos resultados, pela comparação dos valores experimentais com os teóricos e pela descrição dos mecanismos resistentes observados em cada tipo de laje ensaiada. Como critério para interpretação dos resultados de ensaios em lajes alveolares, a nova proposta de revisão da EN 1168:2005 (Apêndice 2009) estabelece que o modelo de projeto confiável seja confirmado se forem cumpridos os seguintes requisitos:

$$
\mathrm{V}_{\text {ensaio }} / \mathrm{V}_{\text {calc }} \geq 0,95
$$

para cada ensaio;

Média de $\left(\mathrm{V}_{\text {ensaio }} / \mathrm{V}_{\text {calc }}\right) \geq 1,00$ para o valor médio de três ensaios.

$V_{\text {calc }}:$ força cortante última calculada para cada elemento;

$V_{\text {ensaio}}$ : força cortante última obtida no ensaio de cada elemento.

\subsubsection{Análise dos ensaios de cisalhamento}

$\mathrm{Na}$ Tabela 6.3 é possível observar as forças cortantes experimentais e teóricas, considerando cisalhamento em região fissurada por flexão (Flexural Shear Capacity) e em região não fissurada por flexão (Tension Shear Capacity).

$\mathrm{Na}$ Tabela 6.4 estão apresentados os valores experimentais e teóricos quanto à flexão, sendo determinado o momento fletor resistente característico, o momento de fissuração, as perdas de protensão e a força de protensão na seção, descontando as perdas. 
Os valores de resistência à flexão e ao cisalhamento foram determinados seguindo as recomendações da NBR 6118:2003.

Tabela 6.3: Forças cortantes experimentais e teóricas para as lajes sem capa ensaiadas ao cisalhamento.

\begin{tabular}{|c|c|c|c|c|c|c|}
\hline Laje & $\begin{array}{c}V_{u, \exp } \\
(\mathbf{k N})\end{array}$ & $\begin{array}{l}\mathrm{V}_{\mathrm{Rk}} * \\
(\mathbf{k N})\end{array}$ & $\frac{V_{\mathrm{u}, \exp }}{\mathrm{V}_{\mathrm{RK}}}$ & $\begin{array}{c}\mathrm{V}_{\mathrm{S}, \text { máx }} \\
(\mathbf{k N})\end{array}$ & $\begin{array}{c}\mathrm{V}_{\mathrm{Rk}, \mathrm{C}^{* *}} \\
(\mathbf{k N})\end{array}$ & $\frac{\mathrm{V}_{\mathrm{u}, \exp }}{\mathrm{V}_{\mathrm{RK}, \mathrm{C}}}$ \\
\hline L1-S-15-6D9,5-X_C & 134,46 & 113,11 & 1,19 & 62,78 & 257,48 & 0,52 \\
\hline L2-S-20-8D12,7-X_C & 222,39 & 169,20 & 1,31 & 97,41 & 336,79 & 0,66 \\
\hline L3-S-20-6D12,7-Y_C & 125,14 & 112,04 & 1,12 & 63,70 & 239,69 & 0,52 \\
\hline L4-S-20-6D 12,7-Y_C & 163,46 & 121,27 & 1,35 & 69,11 & 254,28 & 0,64 \\
\hline L5-S-20-6D12,7-Y_C & 144,51 & 118,40 & 1,22 & 67,44 & 250,74 & 0,58 \\
\hline L6-S-20-7D9,5-Y_C & 121,71 & 94,28 & 1,29 & 52,57 & 221,80 & 0,55 \\
\hline L7-S-20-7D9,5-Y_C & 137,04 & 94,97 & 1,44 & 52,84 & 224,69 & 0,61 \\
\hline L8-S-20-7D9,5-Y_C & 142,17 & 95,03 & 1,50 & 52,93 & 224,05 & 0,63 \\
\hline L9-S-20-7D9,5-Y_C & 135,44 & 96,72 & 1,40 & 53,86 & 228,99 & 0,59 \\
\hline L10-S-20-7D9,5-Y_C ${ }^{1}$ & 68,09 & 94,45 & 0,72 & 52,73 & ------- & ------- \\
\hline L11-S-20-7D9,5-Y_C ${ }^{1}$ & 68,40 & 92,24 & 0,74 & 51,48 & ------- & -------- \\
\hline L12-S-20-5D12,7-Z_C & 121,39 & 102,17 & 1,19 & 57,99 & 241,00 & 0,50 \\
\hline L13-S-20-5D12,7-Z_C & 120,78 & 102,17 & 1,18 & 57,99 & 241,00 & 0,50 \\
\hline L14-S-20-5D12,7-Z_C & 141,16 & 102,17 & 1,38 & 57,99 & 241,00 & 0,58 \\
\hline L15-S-20-5D12,7-Z_C & 111,85 & 102,17 & 1,09 & 57,99 & 241,00 & 0,46 \\
\hline L16-S-20-5D12,7-Z_C & 87,53 & 102,17 & 0,86 & 57,99 & --------- & -------- \\
\hline L17-S-21-7D9,5-W_C & 136,16 & 104,80 & 1,30 & 58,95 & 243,57 & 0,56 \\
\hline L18-S-21-7D9,5-W_C & 168,80 & 103,91 & 1,62 & 58,44 & 241,23 & 0,70 \\
\hline L19-S-21-7D9,5-W_C ${ }^{2}$ & 97,40 & 102,42 & 0,95 & 57,66 & -------- & ------- \\
\hline L20-S-21-7D9,5-W_C ${ }^{2}$ & 86,86 & 103,35 & 0,84 & 58,17 & ------- & ------- \\
\hline L21-S-21-7D9,5-W_C $C^{2}$ & 90,03 & 103,02 & 0,87 & 58,00 & -------- & -------- \\
\hline L22-S-16-5D9,5-W_C $C^{2}$ & 94,46 & 88,04 & 1,07 & 48,83 & -------- & -------- \\
\hline L23-S-16-5D9,5-W_C ${ }^{2}$ & 96,90 & 81,67 & 1,19 & 45,38 & 187,42 & 0,52 \\
\hline L24-S-16-5D9,5-W_C & 94,89 & 88,49 & 1,07 & 49,10 & -------- & ------- \\
\hline L25-S-16-5D9,5-W_C & 111,07 & 81,76 & 1,36 & 45,45 & 182,90 & 0,61 \\
\hline L26-S-16-5D9,5-W_C & 144,05 & 86,95 & 1,66 & 48,31 & 192,43 & 0,75 \\
\hline L27-S-26-9D12,7-W_C & 150,80 & 145,51 & 1,04 & 83,78 & 294,32 & 0,51 \\
\hline L28-S-26-9D12,7-W_C & 195,08 & 144,22 & 1,35 & 83,05 & 294,94 & 0,66 \\
\hline L29-S-26-9D12,7-W_C & 226,85 & 143,04 & 1,58 & 82,42 & 293,17 & 0,77 \\
\hline L30-S-26-9D12,7-W_C ${ }^{3}$ & $320,89^{a}$ & 151,73 & 2,11 & 87,45 & 322,66 & 0,99 \\
\hline
\end{tabular}

*Considerando região fissurada por flexão. **Considerando região não fissurada.

${ }^{1}$ Força aplicada a 5,75 h do apoio. ${ }^{2}$ Força a $5 \mathrm{~h}$ do apoio. ${ }^{3}$ Balanço de $1 \mathrm{~m}$ e força a 2,5 h do apoio. ${ }^{a}$ Não corresponde ao valor último, pois o ensaio foi encerrado antes da ruptura da laje.

$\mathrm{V}_{\mathrm{u}, \exp }$ : força cortante última obtida no ensaio (somando o peso próprio), na seção de aplicação da força;

$\mathrm{V}_{\mathrm{RK}}$ : força cortante resistente característica, calculada para zona fissurada à flexão (força cortante resistente da seção, sem nenhum coeficiente de ponderação);

$\mathrm{V}_{\mathrm{s}, \text { máx }}$ : força cortante máxima de serviço, correspondente a $\mathrm{V}_{\mathrm{rd} 1} / 1,4$;

$\mathrm{V}_{\mathrm{rd} 1}$ : força cortante de cálculo;

$\mathrm{V}_{\mathrm{Rk}, \mathrm{C}}$ : força cortante característica, calculada para zona não fissurada à flexão, (força cortante resistente da seção, sem nenhum coeficiente de ponderação).

Comparando os valores da Tabela 6.3, considerando cisalhamento em zona fissurada à flexão, pode-se observar que a maioria das peças apresentou valores superiores aos previstos pela equação da NBR 6118:2003, correspondendo a resultados coerentes com as recomendações da norma empregada. 
Somente a peça $\mathrm{L} 30$ apresentou resistência muito próxima ao valor previsto considerando região não fissurada (Tension Shear Capacity). A determinação da força cortante característica, considerando zona não fissurada à flexão, foi feita empregando a equação recomendada pelo EC2 (2004), descrita anteriormente no item referente aos modelos de cálculo.

Os casos cujos resultados não atenderam ao previsto teoricamente corresponderam às lajes em que foi observada elevada interferência de mecanismos como flexão (com força aplicada a 5 h e 5,75 h do apoio) e torção, sendo elas: L10, L11, L16, L20 e L21. Nas peças L10, L11, L20 e L21 foi possível verificar forte influência da flexão, sendo constatada uma elevada relação de momento experimental e teórico (Tabela 6.4), quando comparada com a relação entre força cortante experimental e teórica (Tabela 6.3). As lajes L10 e L11 apresentaram 72\% e 74\% da força cortante prevista, respectivamente, e ambas apresentaram 74\% do momento fletor previsto. As lajes L20 e L21 apresentaram $84 \%$ e $87 \%$ da força cortante prevista, respectivamente, e ambas $79 \%$ do momento fletor previsto.

Assim, nota-se que a flexão não só esteve presente, como apresentou relação de momento fletor experimental e teórico próxima ou igual (para L11) à obtida para a força cortante, sendo capaz de prejudicar o desempenho das peças e contribuir para que elas não alcançassem suas máximas capacidades ao cisalhamento.

A laje L16 apresentou forte influência da torção, que comprometeu seu desempenho ao cisalhamento.

Com a Tabela 6.4 foi possível observar que, para as peças ensaiadas com a aplicação da força a $5 \mathrm{~h}$ e $5,75 \mathrm{~h}$, os momentos fletores últimos (obtidos nos ensaios) foram próximos aos valores referentes aos momentos de fissuração, sendo em alguns casos superiores (L22, L23 e L24). Com isso, constatou-se a maior influência da flexão nesse tipo de ensaio, quando comparado com o ensaio com força aplicada a 2,5h do apoio.

Melhor análise quanto à interação dos mecanismos está apresentada mais adiante, no item 6.2.6.

Os cálculos para a determinação da força de protensão (Tabela 6.3), com as respectivas perdas (indicadas na Tabela 6.4) foram realizados sem a consideração de qualquer redução devida ao comprimento necessário para transferência de protensão na seção de concreto. Assim, a correção da tensão de protensão é prevista pelo fator $0,15 \sigma_{c p}$, presente na equação recomendada pela NBR 6118:2003, para determinar a força cortante de cálculo.

Ao longo deste capítulo, será realizada a descrição dos mecanismos relativos à ruptura das peças, justamente com o intuito de verificar a presença ou não de fissuras de flexão e adequar a peça à equação que melhor a representa. 
Tabela 6.4: Resultados experimentais e teóricos, referentes à flexão, para as lajes sem capa ensaiadas ao cisalhamento.

\begin{tabular}{|c|c|c|c|c|c|c|c|}
\hline Laje & $\begin{array}{l}M_{u, \exp } \\
(\mathbf{k N} \cdot \mathbf{m})\end{array}$ & $\begin{array}{c}M_{r} \\
\text { (kN.m) }\end{array}$ & $\begin{array}{c}M_{\mathrm{Rk}} \\
\text { (kN.m) }\end{array}$ & $\frac{M_{u, \exp }}{M_{R K}}$ & $\begin{array}{l}\text { Idade } \\
\text { (dias) }\end{array}$ & $\begin{array}{c}\text { Perdas } \\
\text { totais } \\
(\%)\end{array}$ & $\begin{array}{c}F_{p, \text { seção }} \\
(\mathbf{k N})\end{array}$ \\
\hline L1-S-15-6D9,5-X_C & 50,42 & 57,30 & 64,26 & 0,78 & 118 & 14,06 & 407,37 \\
\hline L2-S-20-8D12,7-X_C & 111,19 & 145,31 & 218,58 & 0,51 & 108 & 22,29 & 898,27 \\
\hline L3-S-20-6D12,7-Y_C & 62,57 & 124,22 & 170,28 & 0,37 & 112 & 21,40 & 683,83 \\
\hline L4-S-20-6D12,7-Y_C & 81,73 & 124,94 & 175,80 & 0,46 & 125 & 23,58 & 664,83 \\
\hline L5-S-20-6D12,7-Y_C & 72,25 & 120,89 & 169,12 & 0,43 & 125 & 22,63 & 673,11 \\
\hline L6-S-20-7D9,5-Y_C & 60,85 & 91,68 & 108,14 & 0,56 & 132 & 16,46 & 438,57 \\
\hline L7-S-20-7D9,5-Y_C & 68,52 & 92,93 & 107,57 & 0,64 & 132 & 15,73 & 442,42 \\
\hline L8-S-20-7D9,5-Y_C & 71,08 & 93,79 & 109,36 & 0,65 & 133 & 16,17 & 440,12 \\
\hline L9-S-20-7D9,5-Y_C & 67,72 & 95,34 & 110,51 & 0,61 & 133 & 16,01 & 440,95 \\
\hline L10-S-20-7D9,5-Y_C ${ }^{1}$ & 78,30 & 89,42 & 105,80 & 0,74 & 137 & 16,09 & 440,54 \\
\hline L11-S-20-7D9,5-Y_C ${ }^{1}$ & 78,66 & 89,34 & 105,73 & 0,74 & 138 & 16,11 & 440,39 \\
\hline L12-S-20-5D12,7-Z_C & 60,69 & 93,41 & 135,64 & 0,45 & 10 & 12,33 & 499,70 \\
\hline L13-S-20-5D12,7-Z_C & 60,39 & 93,41 & 135,64 & 0,45 & 10 & 12,33 & 499,70 \\
\hline L14-S-20-5D12,7-Z_C & 70,58 & 93,41 & 135,64 & 0,52 & 10 & 12,33 & 499,70 \\
\hline L15-S-20-5D12,7-Z_C & 55,93 & 93,41 & 135,64 & 0,41 & 10 & 12,33 & 499,70 \\
\hline L16-S-20-5D12,7-Z_C & 43,76 & 93,41 & 135,64 & 0,32 & 10 & 12,33 & 499,70 \\
\hline L17-S-21-7D9,5-W_C & 69,78 & 99,45 & 111,88 & 0,62 & 30 & 13,97 & 487,98 \\
\hline L18-S-21-7D9,5-W_C & 86,51 & 100,43 & 112,90 & 0,77 & 30 & 14,04 & 487,54 \\
\hline L19-S-21-7D9,5-W_C ${ }^{2}$ & 99,84 & 100,44 & 113,17 & 0,88 & 30 & 14,03 & 487,64 \\
\hline L20-S-21-7D9,5-W_C ${ }^{2}$ & 89,03 & 99,46 & 112,69 & 0,79 & 33 & 14,31 & 486,06 \\
\hline L21-S-21-7D9,5-W_C ${ }^{2}$ & 92,28 & 102,39 & 116,00 & 0,79 & 33 & 14,61 & 484,32 \\
\hline L22-S-16-5D9,5-W_C & 75,57 & 60,37 & 62,85 & 1,20 & 29 & 11,94 & 356,77 \\
\hline L23-S-16-5D9,5-W_C $C^{2}$ & 77,52 & 60,40 & 62,79 & 1,23 & 29 & 12,09 & 356,15 \\
\hline L24-S-16-5D9,5-W_C $C^{2}$ & 75,91 & 61,78 & 64,25 & 1,18 & 30 & 12,16 & 355,90 \\
\hline L25-S-16-5D9,5-W_C & 44,43 & 59,63 & 62,99 & 0,71 & 28 & 12,62 & 354,03 \\
\hline L26-S-16-5D9,5-W_C & 57,62 & 60,10 & 63,47 & 0,91 & 28 & 12,61 & 354,07 \\
\hline L27-S-26-9D12,7-W_C $C^{2}$ & 196,04 & 233,54 & 342,18 & 0,57 & 87 & 25,52 & 992,34 \\
\hline L28-S-26-9D12,7-W_C & 126,80 & 233,43 & 341,51 & 0,37 & 87 & 25,53 & 992,26 \\
\hline L29-S-26-9D12,7-W_C & 147,45 & 229,97 & 337,66 & 0,44 & 87 & 25,67 & 990,29 \\
\hline L30-S-26-9D12,7-W_C ${ }^{3}$ & $208,58^{a}$ & 223,14 & 320,83 & 0,65 & 87 & 23,35 & 1021,29 \\
\hline
\end{tabular}

${ }^{1}$ Força aplicada a 5,75 h do apoio. ${ }^{2}$ Força a $5 \mathrm{~h}$ do apoio. ${ }^{3}$ Balanço de $1 \mathrm{~m}$ e força a 2,5 h do apoio. ${ }^{a}$ Não corresponde ao valor último, pois o ensaio foi encerrado antes da ruptura da laje.

$M_{u, \exp }$ : momento fletor último obtido no ensaio, correspondente a $v_{u, e x p}$, (somando a parte correspondente ao peso próprio);

$M_{r}$ : $\quad$ momento de fissuração (considerando a seção do ponto de aplicação da força);

$\mathrm{M}_{\mathrm{Rk}}$ : momento fletor resistente característico (calculado considerando a seção do ponto de aplicação da força, sem nenhum coeficiente de segurança);

$F_{p, s e c ̧ a ̃ o ~}$ : força de protensão existente na seção do ponto de aplicação da força, descontando todas as perdas (empregada no cálculo do cisalhamento).

Para melhor análise dos resultados, realizou-se a separação dos tipos de laje ensaiados e criaram-se gráficos de $V_{\exp } / V_{R K}$ versus deslocamento vertical para cada laje, sendo $V_{\exp }$ a força cortante obtida no ensaio, na seção da aplicação da força.

Com a Figura 6.1 é possível observar que as lajes sem capa, pertencentes ao lote $X$, tanto a de $15 \mathrm{~cm}$ de altura com armadura longitudinal de 6 क 9,5 mm quanto a laje de $20 \mathrm{~cm}$ de altura e $8 \phi 12,7$, apresentaram resultados satisfatórios, sendo os experimentais superiores aos previstos teoricamente. 


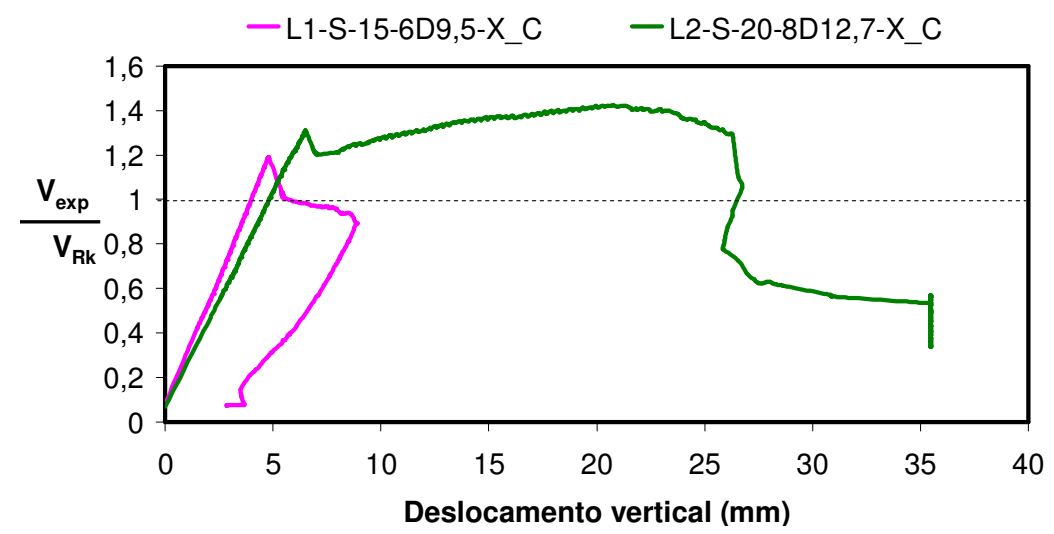

Figura 6.1: Gráficos $V_{\exp } / V_{R K}$ versus deslocamento vertical, obtidos a partir dos ensaios das lajes sem capa do lote $X$.

Além disso, a laje com maior altura e maior área de armadura longitudinal, mas com tensão de protensão semelhante $-\mathrm{L} 1\left(\sigma_{\mathrm{p}}=1423,42 \mathrm{MPa}\right)$ e $\mathrm{L} 2\left(\sigma_{\mathrm{p}}=1425,05 \mathrm{MPa}\right)-$, apresentou maior resistência ao cisalhamento do que a outra laje sem capa, como esperado teoricamente.

$\mathrm{Na}$ Figura 6.2, pode-se observar a configuração da fissuração para a laje L1- S-15-6D9,5-X_C. Nessa laje é possível observar a forte influência do mecanismo de flexão e compressão da borda superior. Essa laje atingiu na ruptura um valor de momento fletor equivalente a $78 \%$ do momento resistente característico.

Nessa figura e nas subsequentes, as faces laterais das lajes serão denominadas face frontal e face oposta, relativas à posição do observador e do sistema de aquisição de dados.

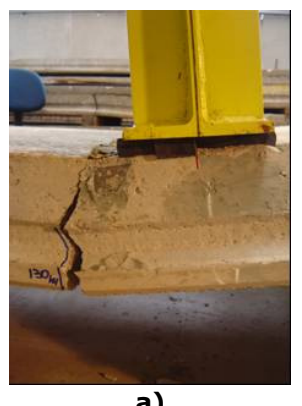

a)

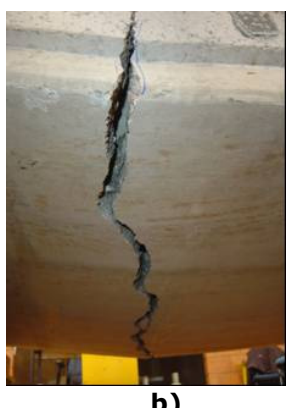

b)

Figura 6.2: Fissuração da laje L1- S-15-6D9,5-X_C. a) Face oposta; b) Face frontal e inferior.

$\mathrm{Na}$ Figura 6.3, pode-se observar a configuração da fissuração para a laje L2-S-20-8D12,7-X_C, que apresentou uma combinação de fissuras de cisalhamento com efeito da flexão, fendilhamento com falha de ancoragem, resultando em esmagamento da borda superior da laje. Esse comportamento pode ser observado a partir das fissuras horizontais presentes na região do posicionamento das cordoalhas. 


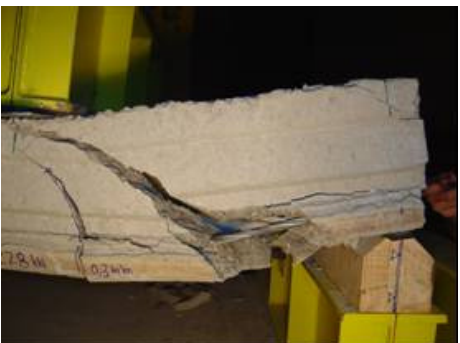

a)

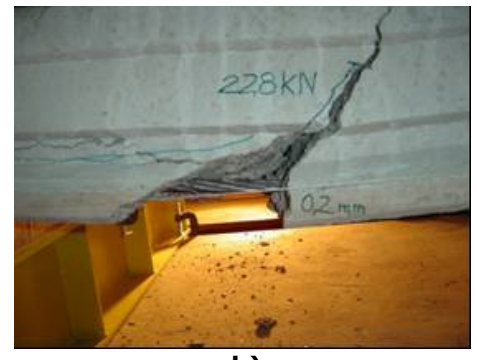

b)

Figura 6.3: Configuração de fissuração da laje L2-S-20-8D12,7-X C.

a) Fissuração da face oposta; b) Fissuração da face frontal.

A Figura 6.4 apresenta os resultados obtidos para as lajes sem capa, com 6 \$ 12,7 mm e comprimento de cerca de $4 \mathrm{~m}$, fabricadas pela empresa Y. A partir dos gráficos, é possível observar que todas as lajes desse tipo descrito ultrapassaram as resistências previstas teoricamente. Essas lajes apresentaram configurações de fissuração semelhantes.

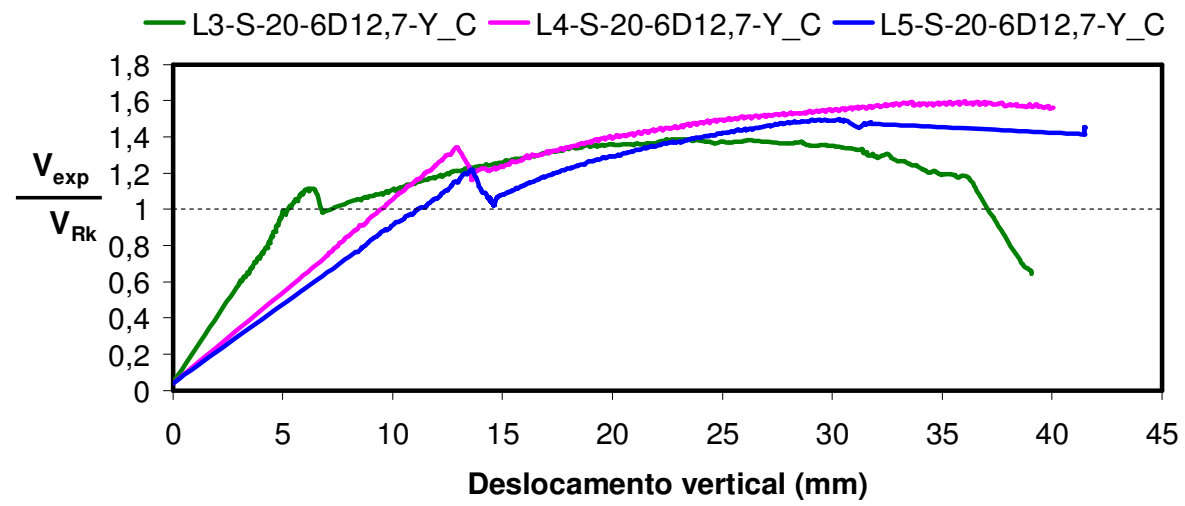

Figura 6.4: Gráficos $V_{\exp } / V_{R K}$ versus deslocamento vertical obtidos a partir dos ensaios das lajes sem capa com 6 12,7 e comprimento de cerca de $400 \mathrm{~cm}$, pertencentes ao lote $Y$.

Na Figura 6.5a e na Figura 6.5b observa-se a fissuração da laje L4-S-20-6D12,7-Y_C, que apresentou uma combinação de fissuras de cisalhamento com efeito da flexão, fendilhamento com falha de ancoragem e esmagamento da borda superior.

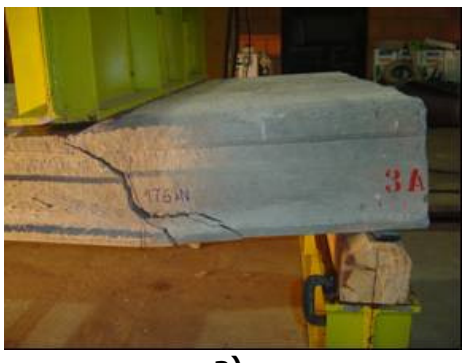

a)

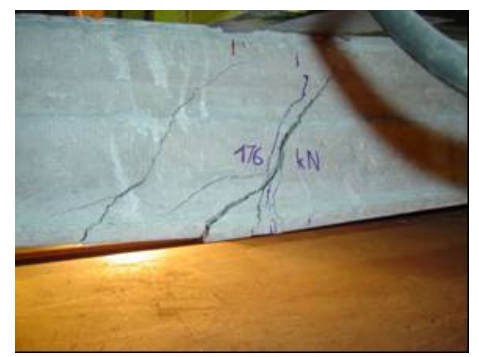

b)

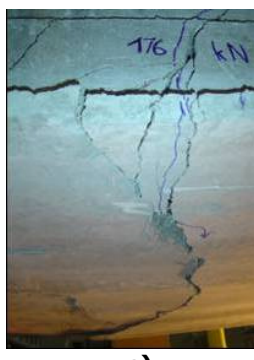

c)

Figura 6.5: Configuração de fissuração da laje L4-S-20-6D12,7-Y C. a) Fissuração da face oposta; b) Fissuração da face frontal; c) Fissuração da face inferior da laje.

Lajes Alveolares Protendidas: Cisalhamento em Região Fissurada por Flexão 
A falha de ancoragem pode ser observada a partir da fissura horizontal presente na região do posicionamento das cordoalhas, ilustrada na Figura 6.5a. Na Figura 6.5c podese observar a fissuração na face inferior da laje.

Na Figura 6.6a e na Figura 6.6b observa-se a fissuração da laje L5-S-20-6D12,7-Y_C, que também apresentou uma combinação de fissuras de cisalhamento com efeito da flexão, fendilhamento com falha de ancoragem e esmagamento da borda superior. $\mathrm{O}$ encontro da fissura de cisalhamento, sob efeito da flexão, e da fissura horizontal, devida ao fendilhamento do concreto, forma um triângulo na face inferior da laje, sendo possível observar o descolamento do concreto nessa região.

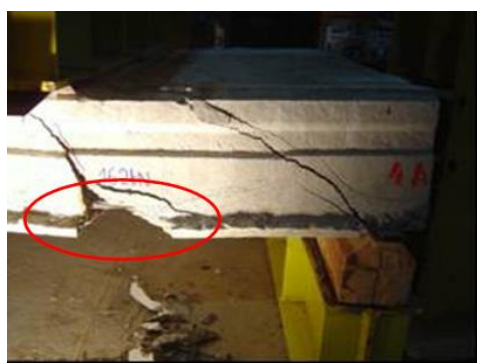

a)

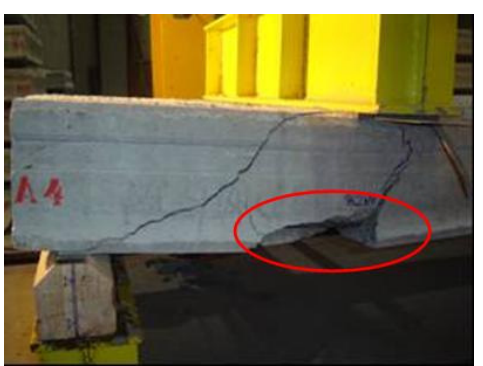

b)

Figura 6.6: Configuração de fissuração da laje L5-S-20-6D12,7-Y_C.

a) Fissuração da face oposta; b) Fissuração da face frontal.

Na Figura 6.7 estão apresentados os resultados referentes às lajes sem capa, com 7 ф 9,5 mm e comprimento de 4,15 m, do lote Y. Além disso, estão apresentados os resultados para a laje semelhante, mas com comprimento de 4,65 m (L9). Tais lajes também apresentaram valores satisfatórios, com os resultados experimentais ultrapassando os valores previstos teoricamente.

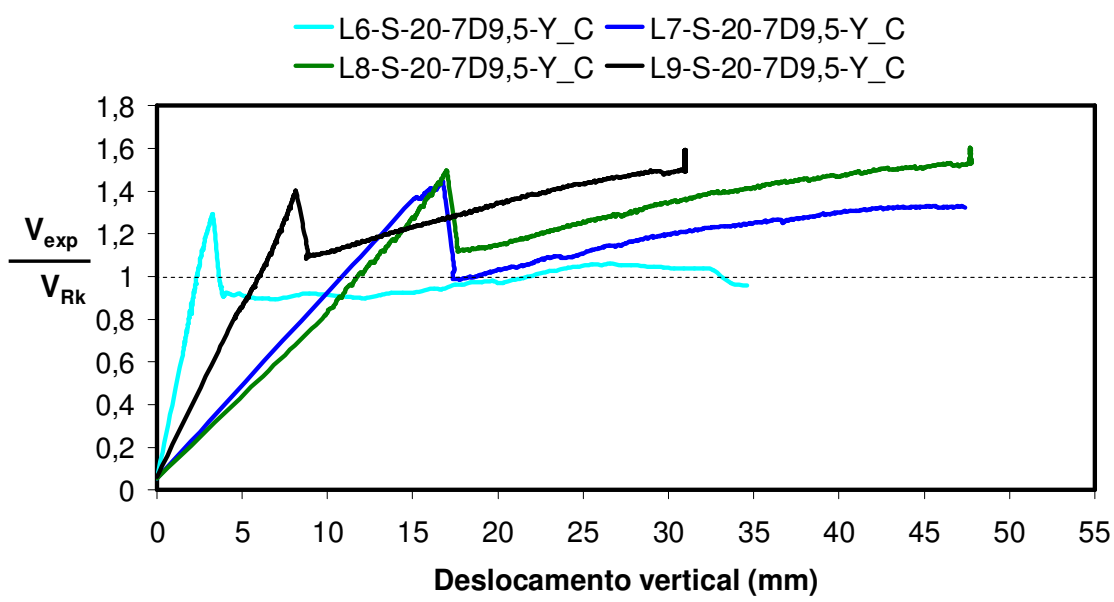

Figura 6.7: Gráficos $\mathrm{V}_{\exp } / \mathrm{V}_{\mathrm{RK}}$ versus deslocamento vertical obtidos a partir dos ensaios das lajes sem capa com $7 \phi$ 9,5 e comprimentos de $415 \mathrm{~cm}$ e $465 \mathrm{~cm}$ (L9), pertencentes ao lote $Y$. 
Na Figura 6.8a observa-se a fissuração da face lateral da laje L6-S-20-7D9,5-Y_C (face oposta), que apresentou uma típica fissura de cisalhamento, a qual se estende do ponto de aplicação de força ao apoio. Na Figura 6.8b observa-se a fissuração na face frontal da laje, que apresentou uma fissura de cisalhamento com forte efeito da flexão.

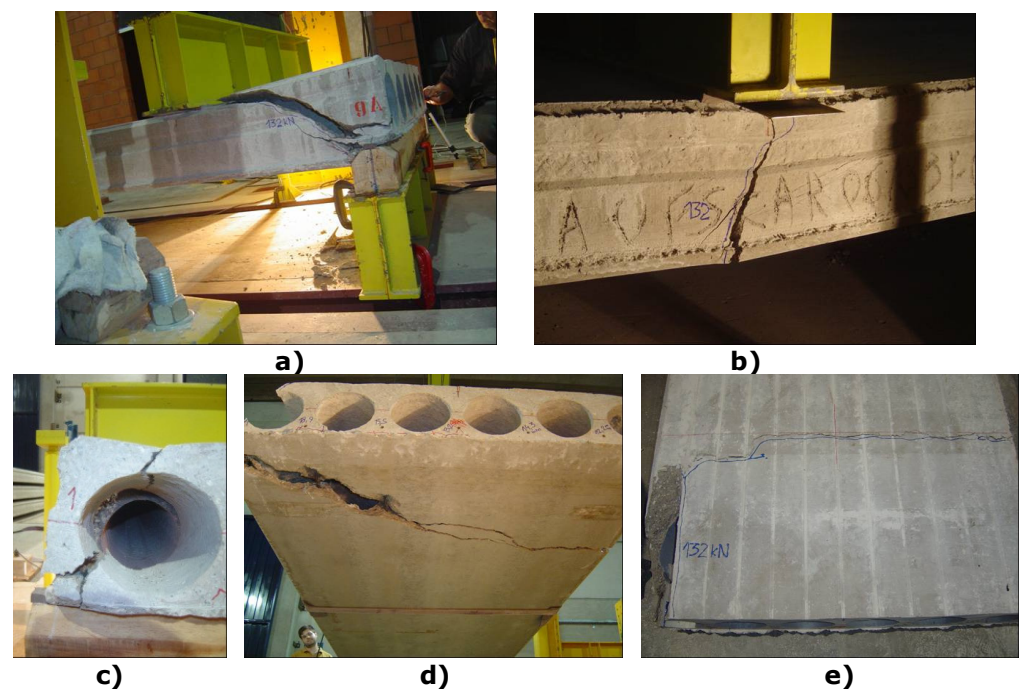

Figura 6.8: Configuração de fissuração da laje L6-S-20-7D9,5-Y_C. a) Fissuração da face oposta b) Fissuração da face frontal; c) Detalhe da região do alvéolo; d) Fissuração da face superior da laje.

$\mathrm{Na}$ Figura 6.8c pode-se observar a fissuração na borda superior do alvéolo e a fissuração em torno da cordoalha de protensão, ocasionada pelo seu deslizamento. $\mathrm{Na}$ Figura 6.8d está apresentada a fissuração da face inferior da laje, sendo possível observar a ocorrência do mecanismo de torção. Nos dois lados da peça observou-se também o esmagamento de sua borda superior, que garantiu a abertura de uma fissura ao longo de toda a largura da peça, como indicado na Figura 6.8e.

$\mathrm{Na}$ Figura 6.9a é possível observar a fissuração na face lateral da laje L7-S-20-7D9,5-Y_C (face oposta) com a presença de cisalhamento, flexão, falha de ancoragem e esmagamento da borda superior.

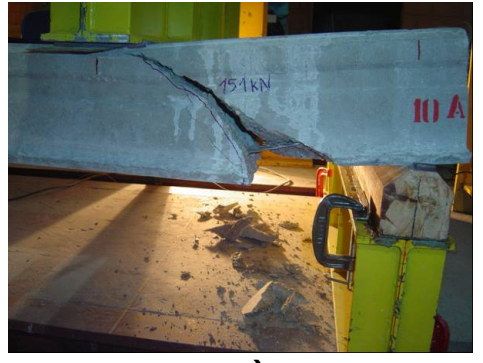

a)

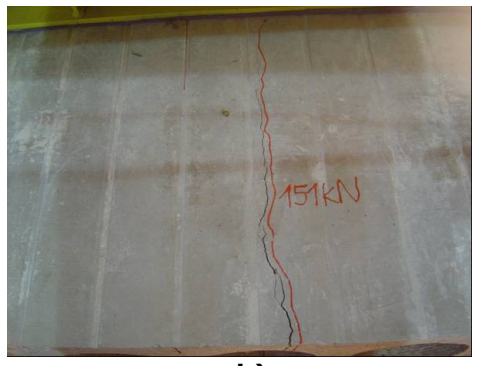

b)

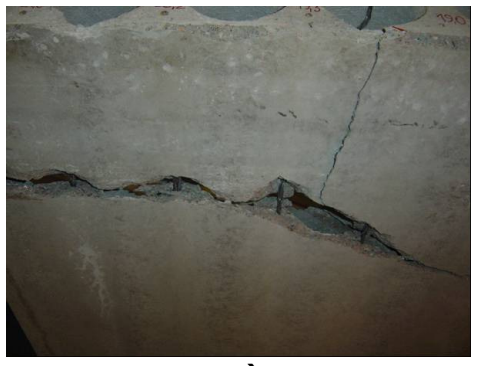

c)

a) Face oposta; b) Fissura longitudinal na face superior da laje; c) Face inferior da laje. 
$\mathrm{Na}$ Figura 6.9b pode-se observar a fissuração da face superior da laje, que apresentou uma fissura longitudinal ao longo de um alvéolo, ocorrida devido à tração no concreto após a abertura de fissura na borda superior da laje. Finalmente a Figura 6.9c ilustra a fissuração da face inferior da laje.

Na Figura 6.10 observa-se a fissuração da laje L9-S-20-7D9,5-Y_C, que apresentou fissuras de flexão na face oposta e fissura de cisalhamento com flexão na face frontal, com presença do mecanismo de torção (Figura 6.10c) e esmagamento da borda superior.

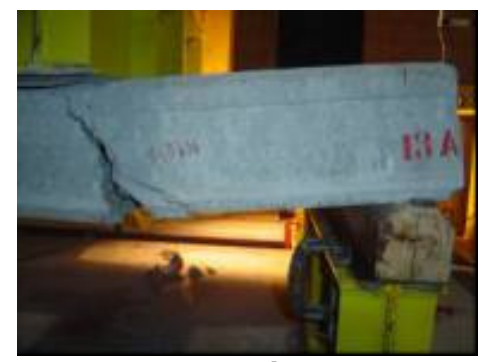

a)

Figura 6.10: Configuração de fissuração da laje L9-S-20-7D9,5-Y_C.

a) Face oposta; b) Face frontal; c) Face inferior da laje.

Na Figura 6.11, estão apresentados os resultados para as lajes sem capa do lote $Y$, com $7 \phi 9,5 \mathrm{~mm}$ e comprimento de 4,65 m. Nesses ensaios foi feita a aplicação da força a $5,75 \mathrm{~h}$ do apoio (correspondente a $1,15 \mathrm{~m}$ do apoio). Por meio dos gráficos é possível notar que as lajes L10 e L11 não alcançaram os valores previstos.

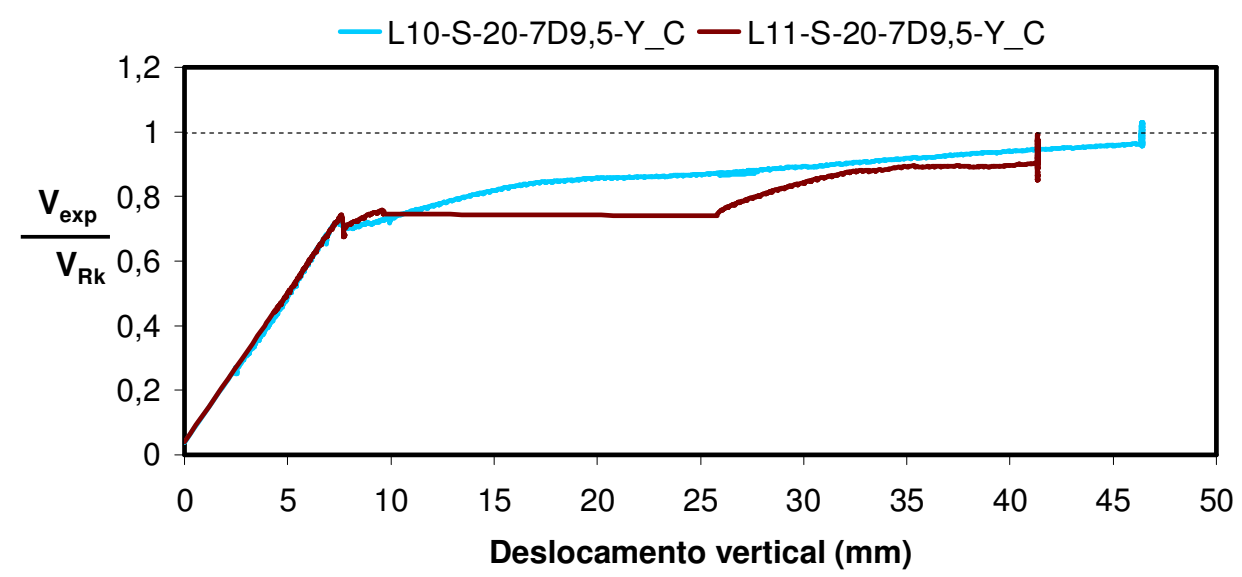

Figura 6.11: Gráficos $V_{\exp } / V_{R K}$ versus deslocamento vertical para lajes sem capa, $7 \phi$ 9,5, comprimento de $465 \mathrm{~cm}$ e força a 5,75 h, do lote $Y$.

Na Figura 6.12 está ilustrada a fissuração da laje L10-S-20-7D9,5-Y_C. A partir da Figura 6.12 a é possível observar que a distância de aplicação da força, com relação ao apoio, foi maior que nos demais ensaios. 
Neste ensaio, observou-se uma forte influência da flexão e compressão da borda superior. Houve a predominância da fissura de flexão, sendo observada uma relação $M_{u, \text { exp }} / M_{R K}$ que correspondeu a $74 \%$ para as lajes $L 10$ e L11. No caso da peça L10, esse valor foi superior à relação $V_{\mathrm{u}, \exp } / \mathrm{V}_{\mathrm{RK}}$, equivalente a $72 \%$.

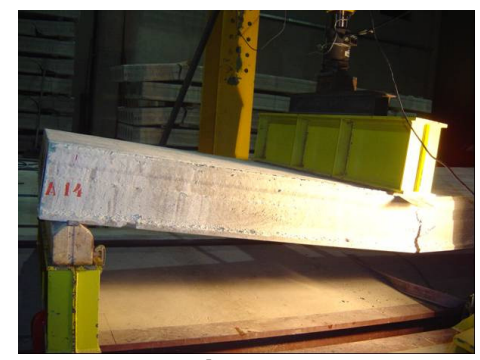

a)

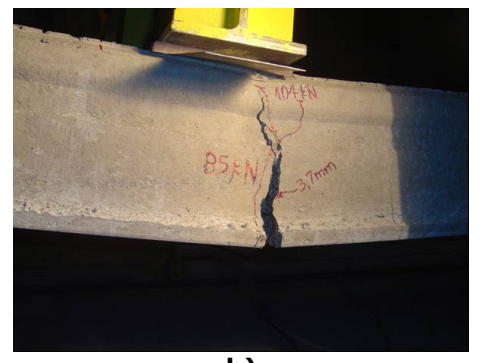

b)

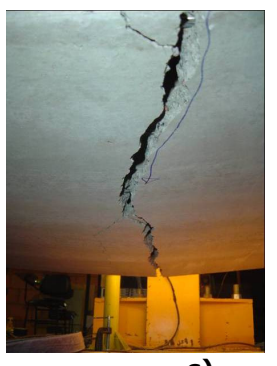

c)

Figura 6.12: Configuração de fissuração da laje L10-S-20-7D9,5-Y C. a) Aplicação de força na laje a 5,75 h do apoio; b) Fissuração na face frontal; c) Fissuração da face inferior da laje.

Assim como na L10, na laje L11-S-20-7D9,5-Y_C a força foi aplicada a 5,75 h do apoio. A fissuração da laje L11 pode ser observada na Figura 6.13. Na face oposta da laje L11 pode-se observar a ocorrência de fissuras de flexão, enquanto que na face frontal ocorreram fissuras de cisalhamento com flexão. Na ruína da laje L11, foi constatado que as relações $M_{u, \exp } / M_{R K}$ foram iguais às de $V_{u, \exp } / V_{R K}$, equivalentes a $74 \%$ (como pode ser observado na Tabela 6.3). Houve grande influência das fissuras de flexão, sendo constatada a interação de cisalhamento e flexão. Também observou-se fissuras de falha de ancoragem. Dessa forma, foi possível notar que, assim como recomendado pela FIP (1982), é possível obter ruptura da laje pela interação de cisalhamento e flexão, a partir de um tipo de ensaio com a aplicação de apenas uma força a cerca de 1,00 m do apoio (para as lajes L10 e L11, foi empregada uma distância de 1,15 m).

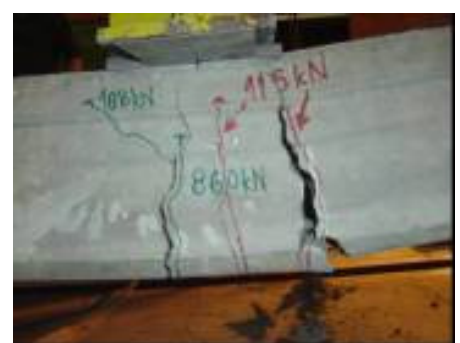

a)

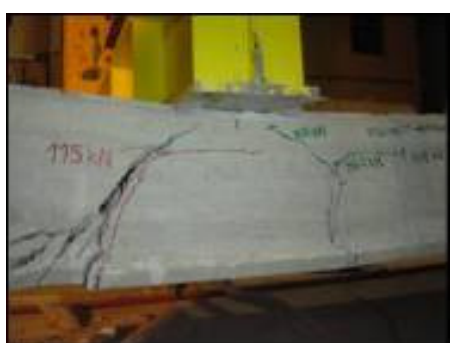

b)

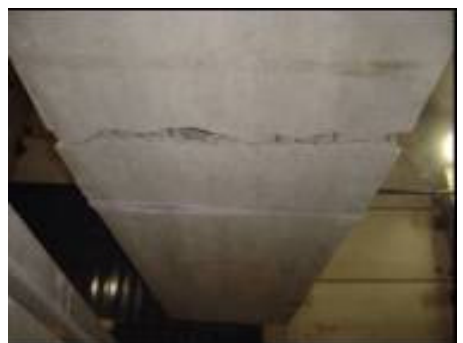

c)

Figura 6.13: Configuração de fissuração da laje L11-S-20-7D9,5-Y C.

a) Fissuração da face oposta; b) Fissuração da face frontal; c) Fissuração da face inferior da laje.

Os resultados para as lajes sem capa, pertencentes ao lote $Z$, podem ser observados na Figura 6.14, na qual é possível observar que a maior parte das lajes ensaiadas apresentou valores experimentais superiores aos valores teóricos, apenas uma não atendeu ao previsto (L16). 


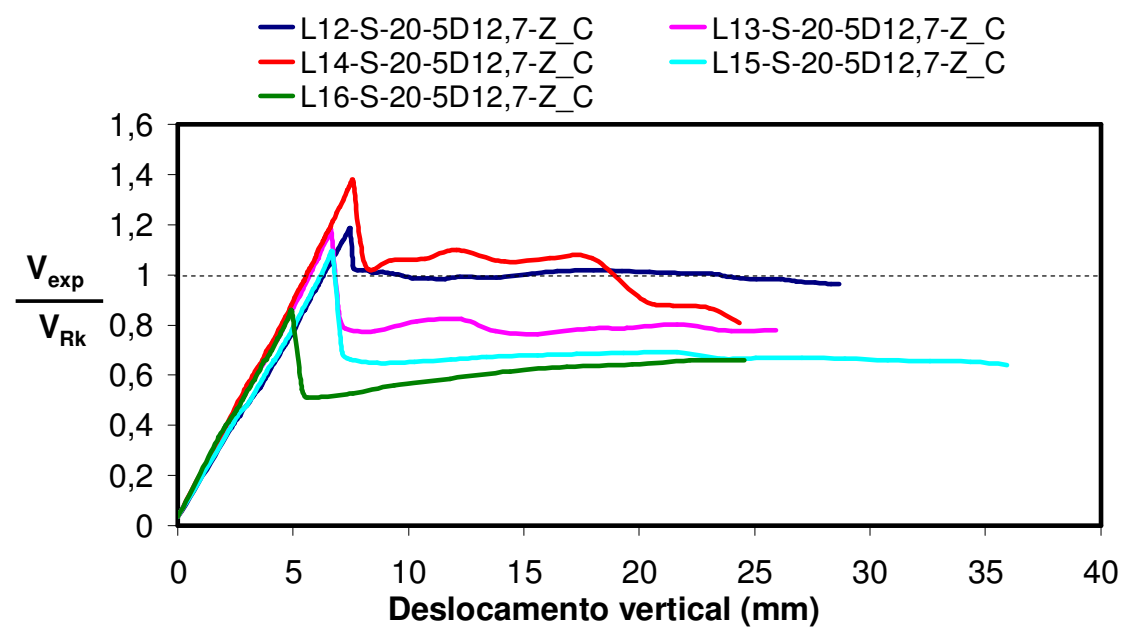

Figura 6.14: Gráficos $V_{\text {exp }} / V_{R K}$ versus deslocamento vertical para lajes sem capa, com $5 \phi 12,7$ e comprimento de $310 \mathrm{~cm}$, do lote $Z$.

As lajes sem capa apresentaram comportamento semelhante, com a interação de flexão e cisalhamento, sendo que apenas uma laje rompeu por mecanismo combinado de cisalhamento, flexão e torção. As peças apresentaram esmagamento na borda superior. Na Figura 6.15, pode-se observar a fissuração da lateral e da face inferior de uma laje sem capa, com flexão e cisalhamento, e a fissuração de uma laje com a influência da torção (L16).

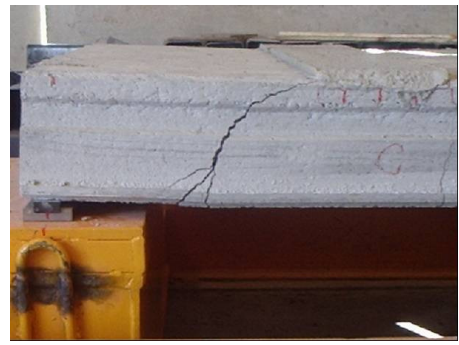

a)

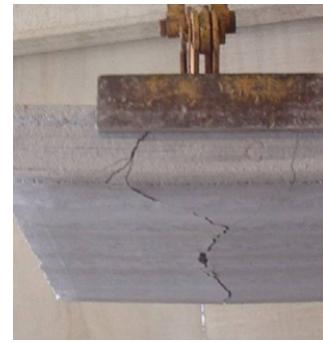

b)

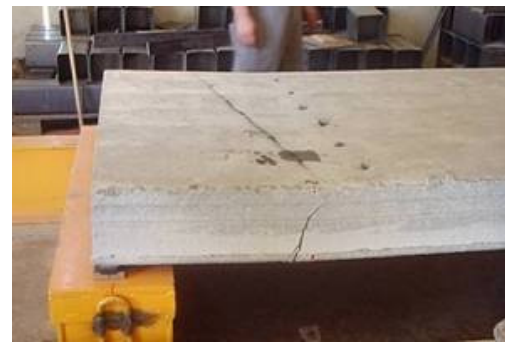

c)

Figura 6.15: Exemplo de configuração de fissuração de laje sem capa do lote $Z$. a)Vista lateral; b) Vista inferior; c)Vista lateral, com influência da torção (L16).

Os resultados para as lajes sem capa, pertencentes ao lote W, com aplicação da força a $2,5 \mathrm{~h}$ podem ser observados na Figura 6.16. Eles apresentaram valores experimentais bem superiores aos valores previstos teoricamente.

Na laje L17 foram inicialmente observadas fissuras de flexão, que se estenderam sob o efeito do cisalhamento, apresentando certa inclinação, como ilustrado na Figura 6.17. Tais fissuras se estenderam até o topo da laje, resultando no esmagamento da borda superior. Na face oposta, também foi observada falha de ancoragem, com o escorregamento das cordoalhas. 


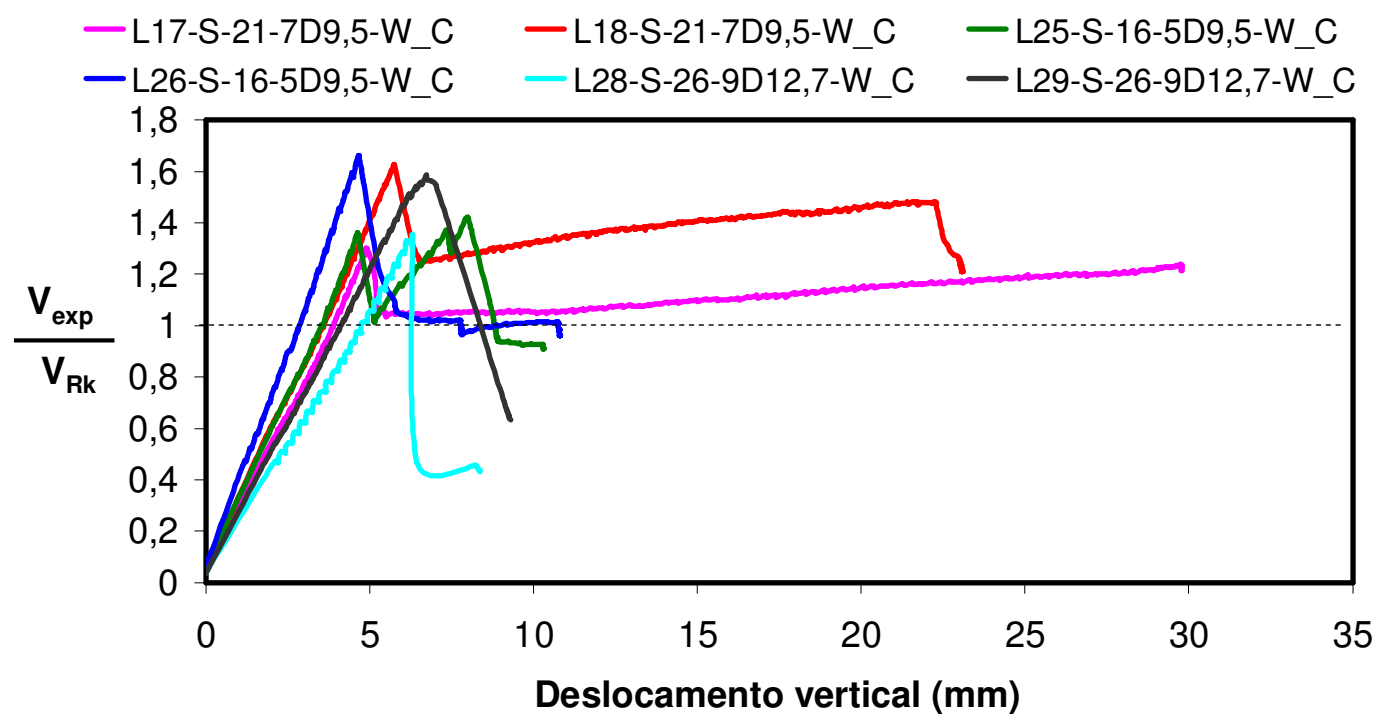

Figura 6.16: Gráficos $V_{e x p} / V_{R K}$ versus deslocamento vertical para lajes sem capa, com $5 \phi 9,5$ e 7 $\phi 9,5$, altura de $16 \mathrm{~cm}$ e $21 \mathrm{~cm}$ e comprimento de $400 \mathrm{~cm}$, do lote $W$.

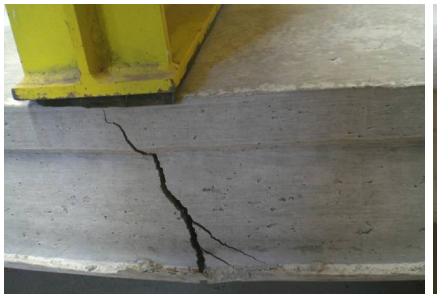

a)

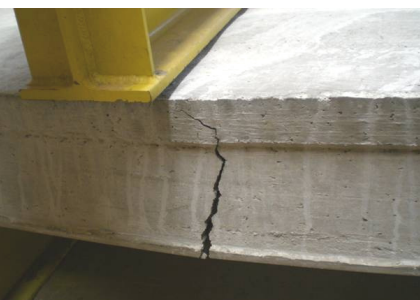

b)

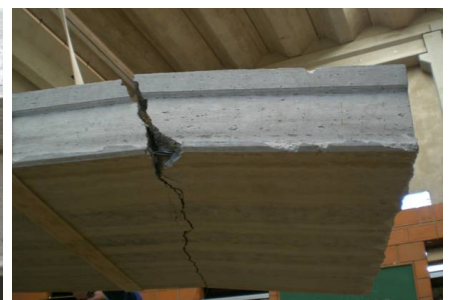

c)

Figura 6.17: Fissuração da laje L17-S-21-7D9,5-W_C. a) Vista da face oposta; b) Vista da face frontal; c) Vista lateral e inferior da peça ensaiada.

Na laje L18 também foram observadas fissuras de flexão com cisalhamento e falha de ancoragem, e posterior esmagamento da borda superior da laje. Além disso, ocorreu fissuração longitudinal ao longo do segundo alvéolo, em relação à face frontal da peça, de acordo com a Figura 6.18d.

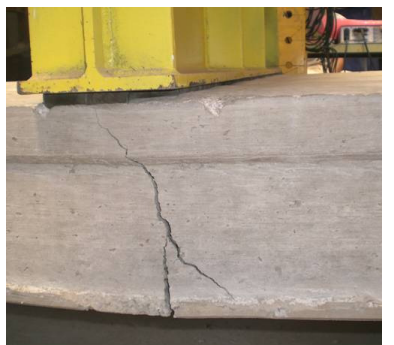

a)

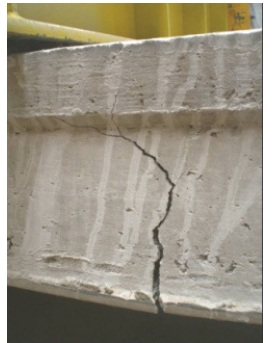

b)

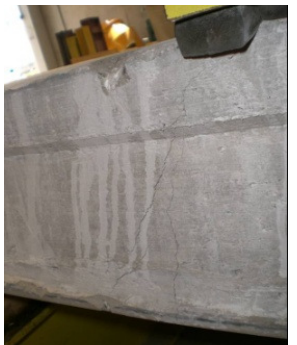

c)

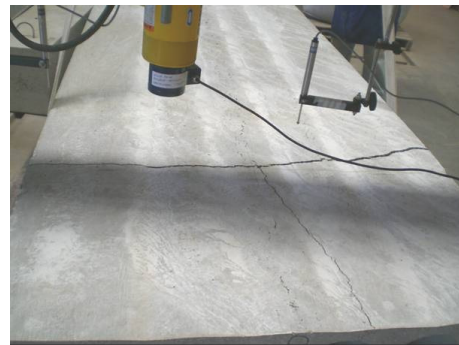

d)

Figura 6.18: Fissuração da laje L18-S-21-7D9,5-W_C. a) Vista da face oposta; b) Vista da face frontal; c) Vista da face frontal; d)Vista superior.

A laje L25 apresentou fissuras de flexão com cisalhamento (Figura 6.19). 


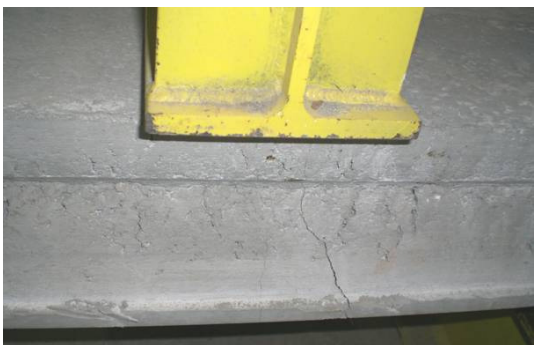

a)

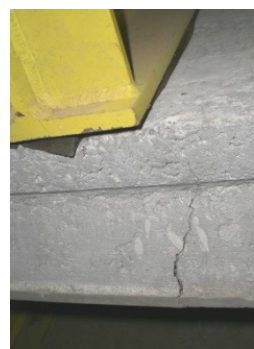

b)

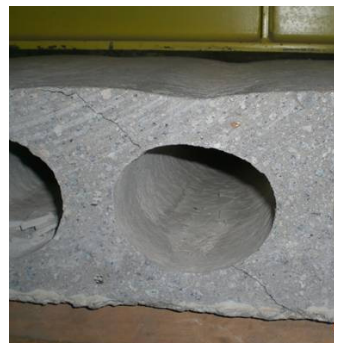

c)

Figura 6.19: Fissuração da laje L25-S-16-5D9,5-W_C. a) Vista da face oposta; b) Vista da face frontal; c) Fissuração nas proximidades do segundo alvéolo, em relação a face frontal.

A laje L26 apresentou fissuras de flexão com cisalhamento e falha de ancoragem, observada na face oposta da peça, como pode ser observado na Figura 6.20.

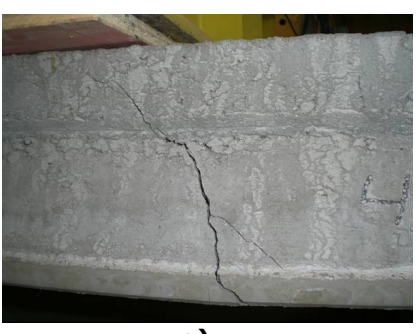

a)

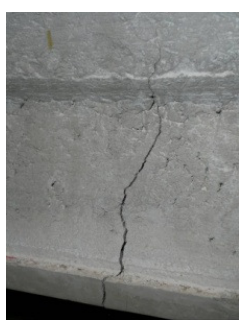

b)

Figura 6.20: Fissuração da laje L26-S-16-5D9,5-W_C. a) Face oposta; b) Face frontal.

A laje L28 apresentou fissuras de flexão com forte influência do cisalhamento e falha de ancoragem, como pode ser observado na Figura 6.21.
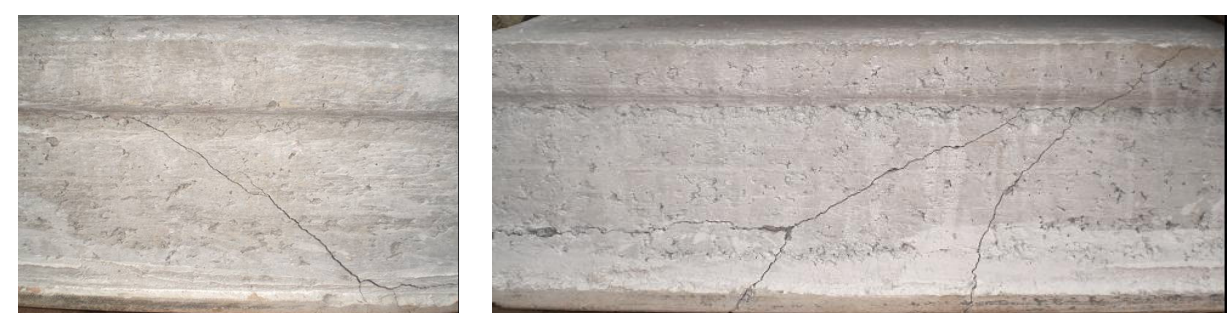

Figura 6.21: Fissuração da laje L28-S-26-9D9,5-W_C. a) Face oposta; b) Face frontal.

A laje L29 apresentou fissuras típicas de cisalhamento. Em um dos lados também foram observadas fissuras referentes a falha de ancoragem (Figura 6.22).

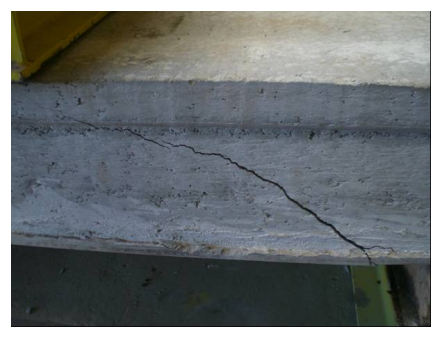

a)

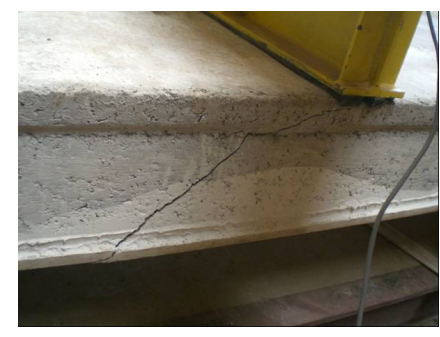

b)

Figura 6.22: Fissuração da laje L29-S-26-9D12,7-W_C. a) Face oposta; b) Face frontal. 
Os resultados para as lajes sem capa, pertencentes ao lote $W$, com aplicação da força a 5,0 h podem ser observados na Figura 6.23. Com esses resultados é possível observar que duas peças ( $L 20$ e L21) não alcançaram as resistências previstas teoricamente.

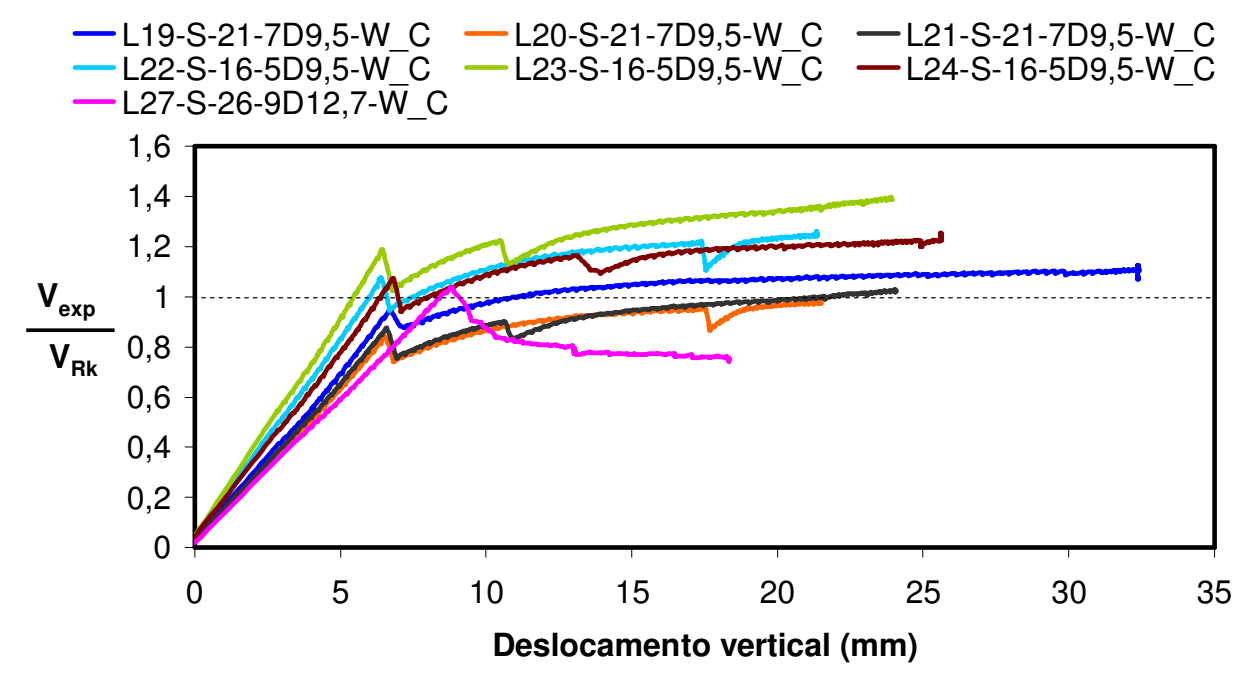

Figura 6.23: Gráficos $V_{e x p} / V_{R K}$ versus deslocamento vertical para lajes sem capa, força a 5,0 $\mathbf{h}$ do apoio, lote $\mathbf{W}$.

As peças L19 e L20 apresentaram comportamentos semelhantes, com fissuras de cisalhamento com forte influência da flexão e falha de ancoragem, como pode ser observado na Figura 6.24 e na Figura 6.25. A laje L21 também apresentou forte influência de flexão com cisalhamento (Figura 6.26).

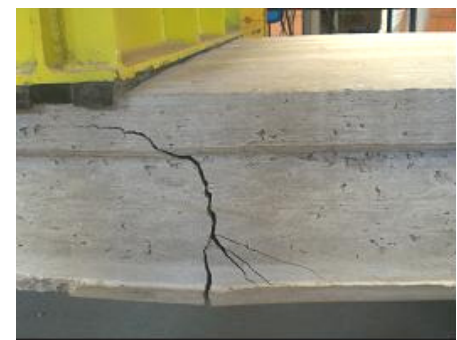

a)

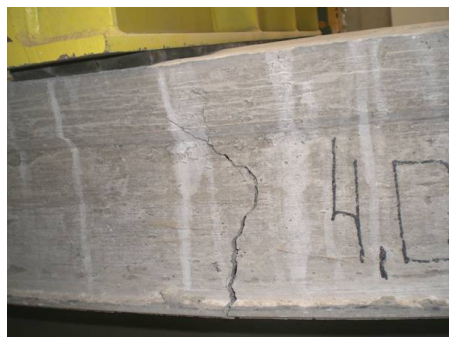

b)

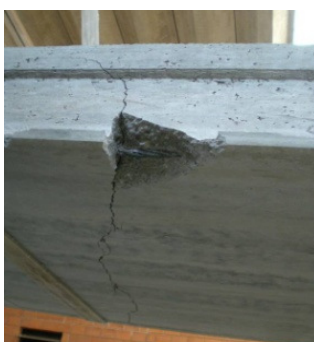

c)

a) Vista face oposta; b) Vista face frontal; c) Vista da face inferior.

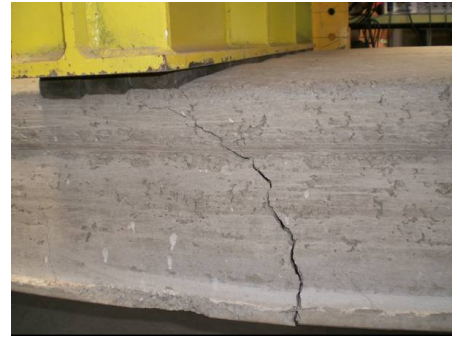

a)

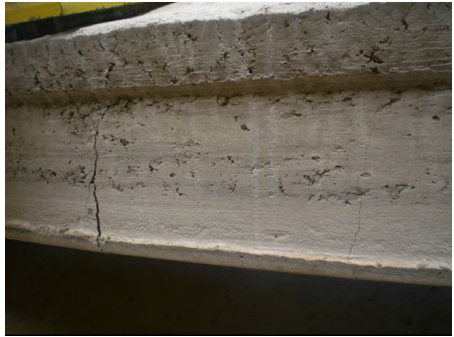

b)

Figura 6.25: Fissuração da laje L20-S-21-7D9,5-W_C. a) Face oposta; b) Face frontal. 


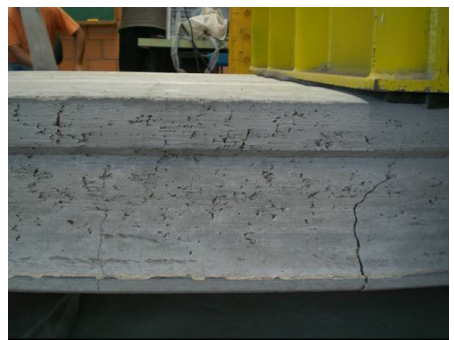

a)

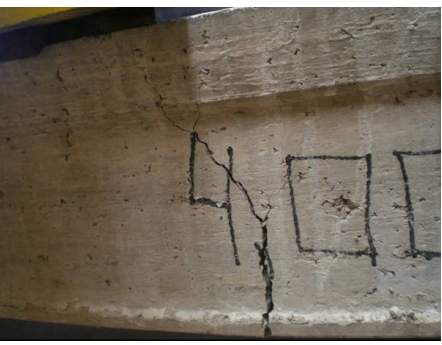

b)

Figura 6.26: Fissuração da laje L21-S-21-7D9,5-W_C. a) Face oposta; b) Face frontal.

As unidades com altura de $16 \mathrm{~cm}$ e força a 5,0 h apresentaram comportamentos muito semelhantes. Houve fissuras de cisalhamento com forte influência da flexão, como pode ser observado na Figura 6.27 e na Figura 6.28.

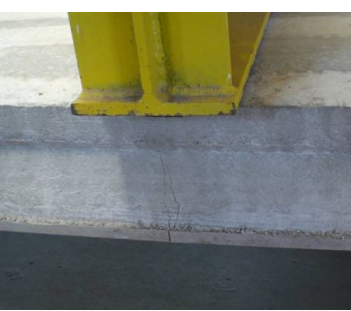

a)

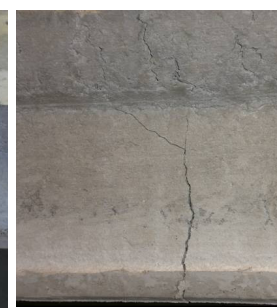

b)

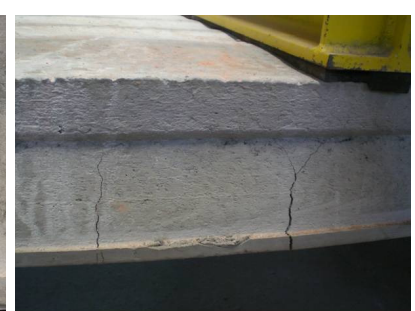

c)

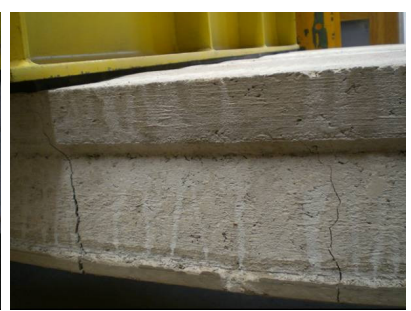

d)

Figura 6.27: Fissuração. a) e b) Peça L22-S-16-5D9,5-W_C, vista lateral (face oposta e frontal, respectivamente); c) e d) Peça L23-S-16-5D9,5-W_C, vista lateral (face oposta e frontal, respectivamente).

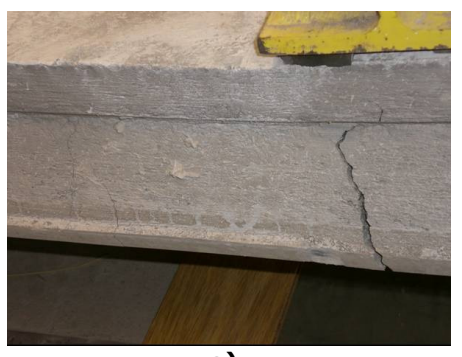

a)

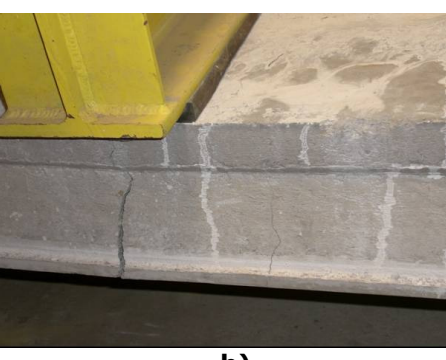

b)

Figura 6.28: Fissuração da laje L24-S-16-5D9,5-W_C. a) Face oposta; b) Face frontal.

A laje L27 apresentou fissuras de flexão com forte influência de cisalhamento, havendo também fissuras por falha de ancoragem em um dos lados, como pode ser observado na Figura 6.29.
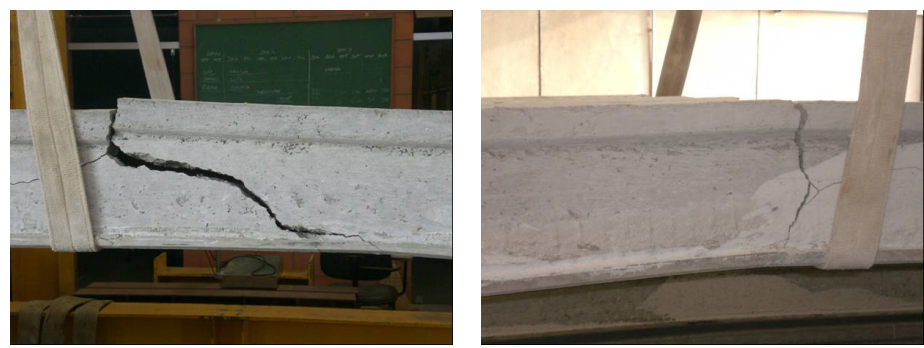

Figura 6.29: Fissuração da laje L27-S-26-9D12,7-w_C. a) Face oposta; b) Face frontal. 
A laje L30 apresentou comportamento diferente das demais lajes, com resistência ao cisalhamento muito próxima à prevista considerando Tension Shear Capacity, ou seja, resistência ao cisalhamento em região não fissurada por flexão $\left(V_{R k, C}\right)$. Vale ressaltar que o ensaio foi finalizado antes da ruptura da laje, devido à capacidade do atuador, não sendo obtido o valor último de resistência. O resultado para a laje L30, com $1 \mathrm{~m}$ de balanço e força aplicada a 2,5 h do apoio, pode ser observado na Figura 6.30.

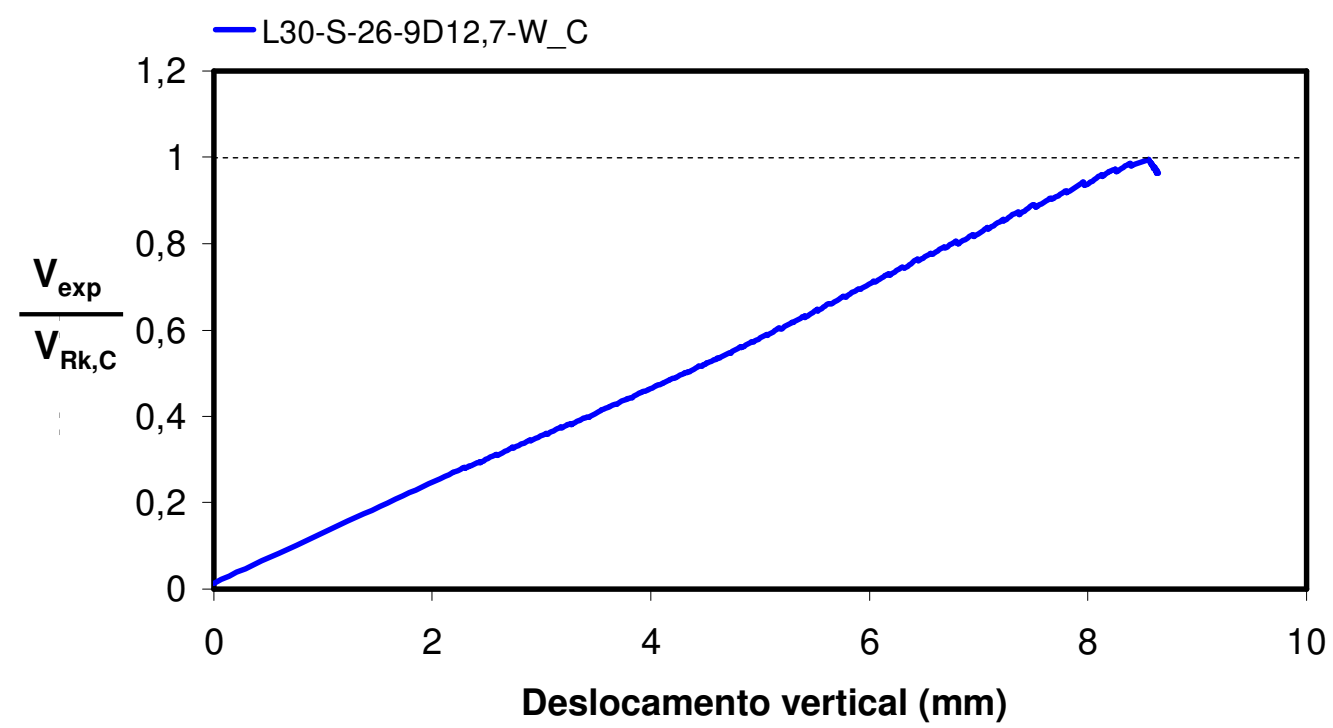

Figura 6.30: Gráfico $V_{\text {exp }} / V_{R K, C}$ versus deslocamento vertical para laje sem capa, balanço de 1 m e força a $2,5 \mathrm{~h}$ do apoio, lote $\mathrm{W}$.

O ensaio da L30 pode ser observado na Figura 6.31.

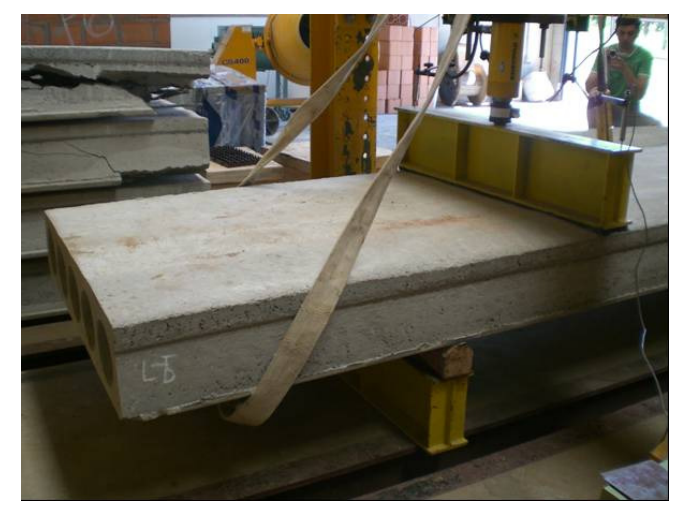

Figura 6.31: Ensaio da laje L30-S-26-9D12,7-W_C, $1 \mathrm{~m}$ de balanço e força aplicada a 2,5 h do apoio.

\subsubsection{Considerações sobre lajes sem capa ensaiadas ao cisalhamento}

Para melhor comparação entre os resultados, determinou-se a resistência média ao cisalhamento para cada tipo de laje ensaiada. As características e os resultados encontram-se na Tabela 6.5 e na Tabela 6.6. 
De acordo com a Tabela 6.5 e a Tabela 6.6, é possível observar que a maioria das peças sem a presença de capa apresentou resultados satisfatórios.

O tipo de peça que apresentou maior resistência ao cisalhamento correspondeu à laje do lote W (L30), com 1 m de balanço e força aplicada a 2,5 h do apoio, com $9 \phi 12,7$ $\mathrm{mm}$, altura de $26 \mathrm{~cm}$, comprimento de $4 \mathrm{~m}$ e protensão inicial de $1460 \mathrm{MPa}$, seguida pela laje do lote W (L29) com $9 \phi 12,7$, altura de $26 \mathrm{~cm}$, comprimento de $4 \mathrm{~m}$ e protensão inicial de $1460 \mathrm{MPa}$.

Tabela 6.5: Resistência média ao cisalhamento das lajes sem capa (parte 1).

\begin{tabular}{|c|c|c|c|c|c|c|c|c|}
\hline Descrição das peças & Força & Laje & $\begin{array}{l}V_{u, \exp } \\
(\mathbf{k N})\end{array}$ & $\begin{array}{l}\mathrm{V}_{\mathrm{u}, \exp , \mathrm{m}} \\
(\mathbf{k N})\end{array}$ & $\begin{array}{l}\mathrm{V}_{\mathrm{Rk}} \\
(\mathbf{k N})\end{array}$ & $\begin{array}{l}\mathrm{V}_{\mathrm{Rk}, \mathrm{m}} \\
(\mathbf{k N})\end{array}$ & $\frac{\mathrm{V}_{\mathrm{u}, \mathrm{exp}, \mathrm{m}}}{\mathrm{V}_{\mathrm{RK}, \mathrm{m}}}$ & $\begin{array}{c}\text { Mecanismos } \\
\text { presentes na } \\
\text { ruptura }\end{array}$ \\
\hline $\begin{array}{c}\text { Sem capa, com } 6 \phi 9,5, \\
\mathrm{~h}=15 \mathrm{~cm}, \mathrm{~L}=6,5 \mathrm{~m} \text { e } \\
\sigma_{\mathrm{pi}}=1423,42 \mathrm{MPa} \\
\left(\mathrm{L}-\mathrm{S}-15-6 \mathrm{D} 9,5-\mathrm{X} \_\mathrm{C}\right)\end{array}$ & $2,5 \mathrm{~h}$ & L1 & 134,46 & ---- & 113,11 & ----- & 1,19 & $\begin{array}{l}\text { Cis. com forte } \\
\text { influência de } \\
\text { Fl. e CBS }\end{array}$ \\
\hline $\begin{array}{c}\text { Sem capa, com } 8 \phi \\
12,7, \mathrm{~h}=20 \mathrm{~cm}, \mathrm{~L}=6,5 \mathrm{~m} \\
\text { e } \sigma_{\mathrm{pi}}=1425,05 \mathrm{MPa} \\
\left(\mathrm{L}-\mathrm{S}-20-8 \mathrm{D} 12,7-\mathrm{X} \_\mathrm{C}\right)\end{array}$ & $2,5 \mathrm{~h}$ & L2 & 222,39 & ----- & 169,20 & ---- & 1,31 & $\begin{array}{l}\text { Cis., } \mathrm{Fl} ., \mathrm{FA} \text { e } \\
\text { CBS }\end{array}$ \\
\hline \multirow{3}{*}{$\begin{array}{c}\text { Sem capa, com } 6 \phi \\
12,7, \mathrm{~h}=20 \mathrm{~cm}, \mathrm{~L}=4 \mathrm{~m} \\
\text { e } \sigma_{\mathrm{pi}}=1429,98 \mathrm{MPa} \\
\left(\mathrm{L}-\mathrm{S}-20-6 \mathrm{D} 12,7-\mathrm{Y} \_\mathrm{C}\right)\end{array}$} & \multirow{3}{*}{$2,5 \mathrm{~h}$} & L3 & 125,14 & \multirow{3}{*}{144,37} & 112,04 & \multirow{3}{*}{117,24} & \multirow{3}{*}{1,23} & \multirow{3}{*}{$\begin{array}{l}\text { Cis., } \mathrm{Fl} ., \mathrm{FA} \mathrm{e} \\
\text { CBS }\end{array}$} \\
\hline & & L4 & 163,46 & & 121,27 & & & \\
\hline & & L5 & 144,51 & & 118,40 & & & \\
\hline \multirow{3}{*}{$\begin{array}{c}\text { Sem capa, com } 7 \phi 9,5 \\
\text { h=20 cm, L=4,15 m e } \\
\sigma_{\mathrm{pi}}=1351,35 \mathrm{MPa} \\
\left(\mathrm{L}-\mathrm{S}-20-7 \mathrm{D} 9,5-Y_{-} \mathrm{C}\right)\end{array}$} & \multirow[t]{3}{*}{$2,5 \mathrm{~h}$} & L6 & 121,71 & \multirow[t]{3}{*}{133,64} & 94,28 & \multirow[t]{3}{*}{94,76} & \multirow[t]{3}{*}{1,41} & $\begin{array}{l}\text { Predomínio } \\
\text { Cis. com Fl., } \\
\text { Tor. e CBS } \\
\end{array}$ \\
\hline & & $\mathrm{L} 7$ & 137,04 & & 94,97 & & & Cis., Fl., FA e \\
\hline & & L8 & 142,17 & & 95,03 & & & CBS \\
\hline $\begin{array}{c}\text { Sem capa, com } 7 \phi 9,5, \\
\text { h=20 cm, L=4,65 m e } \\
\sigma_{\mathrm{pi}}=1351,35 \mathrm{MPa} \\
\left(\mathrm{L}-\mathrm{S}-20-7 \mathrm{D} 9,5-\mathrm{Y}_{-} \mathrm{C}\right)\end{array}$ & $2,5 \mathrm{~h}$ & L9 & 135,44 & ----- & 96,72 & ---- & 1,40 & $\begin{array}{l}\text { Cis., } \mathrm{Fl.,} \mathrm{Tor.} \mathrm{e} \\
\text { CBS }\end{array}$ \\
\hline \multirow{2}{*}{$\begin{array}{c}\text { Sem capa, com } 7 \phi 9,5 \\
\mathrm{~h}=20 \mathrm{~cm}, \mathrm{~L}=4,65 \mathrm{~m} \text { e } \\
\sigma_{\mathrm{pi}}=1351,35 \mathrm{MPa} \\
\left(\mathrm{L}-\mathrm{S}-20-7 \mathrm{D} 9,5-Y_{-} \mathrm{C}\right)\end{array}$} & \multirow{2}{*}{$5,75 \mathrm{~h}$} & L10 & 68,09 & \multirow{2}{*}{68,24} & 94,45 & \multirow{2}{*}{93,34} & \multirow{2}{*}{0,73} & $\begin{array}{c}\text { Cis. forte } \\
\text { influência de } \\
\text { Fl. e CBS }\end{array}$ \\
\hline & & L11 & 68,40 & & 92,24 & & & $\begin{array}{c}\text { Cis. forte } \\
\text { influência de } \\
\text { Fl., FA. e CBS }\end{array}$ \\
\hline \multirow{5}{*}{$\begin{array}{c}\text { Sem capa, com } 5 \phi \\
12,7, \mathrm{~h}=20 \mathrm{~cm}, \mathrm{~L}=3,10 \\
\mathrm{~m} \mathrm{e} \\
\sigma_{\mathrm{pi}}=1140 \mathrm{MPa} \\
\left(\mathrm{L}-\mathrm{S}-20-5 \mathrm{D} 12,7-\mathrm{Z} \_\mathrm{C}\right)\end{array}$} & \multirow{5}{*}{$2,5 \mathrm{~h}$} & L12 & 121,39 & \multirow{5}{*}{116,54} & 102,17 & \multirow{5}{*}{102,17} & \multirow{5}{*}{1,14} & \multirow{4}{*}{$\begin{array}{l}\text { Cis., } \mathrm{Fl} ., \mathrm{FA} \text { e } \\
\text { CBS }\end{array}$} \\
\hline & & L13 & 120,78 & & 102,17 & & & \\
\hline & & L14 & 141,16 & & 102,17 & & & \\
\hline & & L15 & 111,85 & & 102,17 & & & \\
\hline & & L16 & 87,53 & & 102,17 & & & $\begin{array}{l}\text { Cis., Fl., Tor., } \\
\text { FA e CBS }\end{array}$ \\
\hline \multirow{2}{*}{$\begin{array}{c}\text { Sem capa, com } 7 \phi 9,5 \\
\text { h=21 cm, L=4 m e } \\
\sigma_{\mathrm{pi}}=1460 \mathrm{MPa} \\
\text { (L-S-21-7D9,5-W_C) }\end{array}$} & \multirow{2}{*}{$2,5 \mathrm{~h}$} & L17 & 136,16 & \multirow{2}{*}{152,48} & 104,80 & \multirow{2}{*}{104,35} & \multirow{2}{*}{1,46} & \multirow{2}{*}{$\begin{array}{c}\text { Cis., } \mathrm{Fl} ., \mathrm{FA} \text { e } \\
\text { CBS }\end{array}$} \\
\hline & & L18 & 168,80 & & 103,91 & & & \\
\hline
\end{tabular}

$\mathrm{V}_{\mathrm{RK}}$ : resistência ao cisalhamento em zona fissurada à flexão. $\mathrm{V}_{\mathrm{RK}, \mathrm{m}}$ : resistência média ao cisalhamento. $\mathrm{V}_{\mathrm{u}, \mathrm{exp}, \mathrm{m}}$ : resistência experimental média ao cisalhamento.

h:altura da laje; L: comprimento da peça e $\sigma_{\mathrm{pi}}$ : protensão inicial.

Cis.: cisalhamento; FI.: flexão; Tor.: torção; FA: falha de ancoragem; CBS: compressão da borda superior. 
Tabela 6.6: Resistência média ao cisalhamento das lajes sem capa (parte 2).

\begin{tabular}{|c|c|c|c|c|c|c|c|c|}
\hline Descrição das peças & Força & Laje & $\begin{array}{c}\mathrm{V}_{\mathrm{u}, \exp } \\
(\mathbf{k N})\end{array}$ & $\begin{array}{l}\mathrm{V}_{\mathrm{u}, \exp , \mathrm{m}} \\
(\mathbf{k N})\end{array}$ & $\begin{array}{c}\mathrm{V}_{\mathrm{Rk}} \\
(\mathbf{k N})\end{array}$ & $\begin{array}{l}\mathrm{V}_{\mathrm{Rk}, \mathrm{m}} \\
(\mathbf{k N})\end{array}$ & $\frac{\mathrm{V}_{\mathrm{u}, \exp , \mathrm{m}}}{\mathrm{V}_{\mathrm{RK}, \mathrm{m}}}$ & $\begin{array}{c}\text { Mecanismos } \\
\text { presentes na } \\
\text { ruptura }\end{array}$ \\
\hline \multirow{3}{*}{$\begin{array}{c}\text { Sem capa, com } 7 \phi 9,5 \\
\mathrm{~h}=21 \mathrm{~cm}, \mathrm{~L}=4 \mathrm{~m} \mathrm{e} \\
\sigma_{\mathrm{pi}}=1460 \mathrm{MPa} \\
\left(\mathrm{L}-\mathrm{S}-21-7 \mathrm{D} 9,5-\mathrm{W}_{-} \mathrm{C}\right)\end{array}$} & \multirow{3}{*}{$5,0 \mathrm{~h}$} & L19 & 97,40 & \multirow{3}{*}{91,43} & 102,42 & \multirow{3}{*}{102,93} & \multirow{3}{*}{0,89} & \multirow{2}{*}{$\begin{array}{c}\text { Cis., forte } \\
\text { influência de } \\
\text { Fl. e FA }\end{array}$} \\
\hline & & L20 & 86,86 & & 103,35 & & & \\
\hline & & L21 & 90,03 & & 103,02 & & & $\begin{array}{c}\text { Cis. e forte } \\
\text { influência de } \\
\text { Fl. }\end{array}$ \\
\hline \multirow{3}{*}{$\begin{array}{c}\text { Sem capa, com } 5 \phi 9,5, \\
\mathrm{~h}=16 \mathrm{~cm}, \mathrm{~L}=4 \mathrm{~m} \mathrm{e} \\
\sigma_{\mathrm{pi}}=1460 \mathrm{MPa} \\
\left(\mathrm{L}-\mathrm{S}-16-5 \mathrm{D} 9,5-\mathrm{W} \_\mathrm{C}\right)\end{array}$} & \multirow{3}{*}{$5,0 \mathrm{~h}$} & L22 & 94,46 & \multirow{3}{*}{95,42} & 88,04 & \multirow{3}{*}{86,07} & \multirow{3}{*}{1,11} & \multirow{3}{*}{$\begin{array}{l}\text { Cis. com forte } \\
\text { influência de } \\
\text { Fl. }\end{array}$} \\
\hline & & L23 & 96,90 & & 81,67 & & & \\
\hline & & L24 & 94,89 & & 88,49 & & & \\
\hline \multirow{2}{*}{$\begin{array}{c}\text { Sem capa, com } 5 \phi 9,5 \\
\mathrm{~h}=16 \mathrm{~cm}, \mathrm{~L}=4 \mathrm{~m} \text { e } \\
\sigma_{\mathrm{pi}}=1460 \mathrm{MPa} \\
\left(\mathrm{L}-\mathrm{S}-16-5 \mathrm{D} 9,5-\mathrm{W} \_\mathrm{C}\right)\end{array}$} & \multirow{2}{*}{$2,5 \mathrm{~h}$} & L25 & 111,07 & \multirow{2}{*}{127,56} & 81,76 & \multirow{2}{*}{84,35} & \multirow{2}{*}{1,51} & Cis. e Fl. \\
\hline & & L26 & 144,05 & & 86,95 & & & Cis., Fl. e FA \\
\hline $\begin{array}{c}\text { Sem capa, com } 9 \phi 12,7 \\
\mathrm{~h}=26 \mathrm{~cm}, \mathrm{~L}=4 \mathrm{~m} \text { e } \\
\sigma_{\mathrm{pi}}=1460 \mathrm{MPa} \\
\left(\mathrm{L}-\mathrm{S}-26-9 \mathrm{D} 12,7-\mathrm{W} \_\mathrm{C}\right)\end{array}$ & $5,0 \mathrm{~h}$ & L27 & 150,80 & ------- & 145,51 & ------- & 1,04 & $\begin{array}{l}\text { FI. com forte } \\
\text { influência de } \\
\text { Cis e FA. }\end{array}$ \\
\hline \multirow{2}{*}{$\begin{array}{c}\text { Sem capa, com } 9 \phi 12,7 \\
\mathrm{~h}=26 \mathrm{~cm}, \mathrm{~L}=4 \mathrm{~m} \text { e } \\
\sigma_{\mathrm{pi}}=1460 \mathrm{MPa} \\
\left(\mathrm{L}-\mathrm{S}-26-9 \mathrm{D} 12,7-\mathrm{W} \_\mathrm{C}\right)\end{array}$} & \multirow[t]{2}{*}{$2,5 \mathrm{~h}$} & L28 & 195,08 & \multirow[t]{2}{*}{210,96} & 144,22 & \multirow[t]{2}{*}{143,63} & \multirow[t]{2}{*}{1,47} & $\begin{array}{c}\text { FI. com forte } \\
\text { influência de } \\
\text { Cis e FA. }\end{array}$ \\
\hline & & L29 & 226,85 & & 143,04 & & & $\begin{array}{c}\text { Cis e FA. e } \\
\text { CBS }\end{array}$ \\
\hline $\begin{array}{c}\text { Sem capa, com } 9 \phi 12,7 \text {, } \\
\text { h=26 cm, L=4 m e } \\
\sigma_{\text {pi }}=1460 \mathrm{Mpa} . \\
\text { Balanço de } 1 \mathrm{~m} \\
\left(\mathrm{~L}-\mathrm{S}-26-9 \mathrm{D} 12,7-\mathrm{W} \_\mathrm{C}\right)\end{array}$ & $2,5 \mathrm{~h}$ & L30 & $320,89^{a} * *$ & ------- & $322,66 *$ & ------- & $0,99 *$ & ------- \\
\hline
\end{tabular}

$\mathrm{V}_{\mathrm{RK}}$ : resistência ao cisalhamento em zona fissurada à flexão. $\mathrm{V}_{\mathrm{RK}, \mathrm{m}}$ : resistência média ao cisalhamento;

$\mathrm{V}_{\mathrm{u}, \mathrm{exp}, \mathrm{m}}$ : resistência experimental média ao cisalhamento;

h:altura da laje; L: comprimento da peça e $\sigma_{\mathrm{pi}}$ : protensão inicial;

Cis.: cisalhamento. FI.: flexão; Tor.: torção; FA: falha de ancoragem; CBS: compressão da borda superior; *Valor referente à resistência ao cisalhamento em zona não fissurada à flexão $\left(\mathrm{V}_{\mathrm{RK}, \mathrm{c}}\right)$;

** Não corresponde a máxima capacidade, pois o ensaio foi finalizado antes da ruptura da laje.

${ }^{a}$ Não corresponde ao valor último, pois o ensaio foi encerrado antes da ruptura da laje.

Considerando a laje L30, observou-se que o balanço de $1 \mathrm{~m}$ possibilitou isolar o efeito desfavorável da zona de transmissão para a aderência da cordoalha junto ao apoio, diminuindo, assim, o efeito da flexão, o que permitiu o alcançe de elevada resistência ao cisalhamento $(320,89 \mathrm{kN})$.

Comparando as lajes L28 e L29, observou-se que a peça que apresentou menor influência da flexão (L29), verificada pela configuração de fissuração, alcançou maior resistência.

Assim, as peças com maior altura, maior número de cordoalhas e maior nível de protensão apresentaram maiores resistências.

Analisando as demais lajes, observou-se que maior altura garante maior resistência, considerando peças com protensão semelhante.

De uma forma geral, lajes com maior nível de protensão apresentam melhor desempenho ao cisalhamento. 
Considerando peças com níveis de protensão e diâmetros de armadura semelhantes, um maior número de cordoalhas garante melhor desempenho ao cisalhamento, uma vez que maior quantidade de cordoalhas corresponde a maior superfície de aço aderente ao concreto, o que potencializa o efeito de pino, e consequentemente retarda a falha de ancoragem.

Devido à grande variedade de tipologia de peças ensaiadas, pode-se observar que são muitos os fatores que afetam a resistência ao cisalhamento da laje.

Analisando os resultados dos ensaios, nota-se que a resistência é aumentada com o aumento de fatores como: nível de protensão, altura da peça, diâmetro de cordoalhas, número de cordoalhas, comprimento e melhoria das condições de ancoragem.

Assim, pode-se dizer que o comportamento das unidades alveolares depende de diversos fatores e é extremamente influenciado por outros mecanismos, como a flexão e a torção. Isso pode ser observado, por exemplo, analisando as unidades com comprimento de 4,65 m (L9, L10 e L11).

Apesar de possuírem características geométricas semelhantes, mesmo nível de protensão e mesmo número de cordoalhas, a mudança do posicionamento da força aplicada (L10 e L11) contribuiu para uma forte influência da flexão, o que permitiu um menor desempenho das peças quanto ao cisalhamento. Da mesma forma, a laje L16 apresentou resistência bem inferior as demais peças semelhantes (L12, L13, L14 e L15) devido a influência prejudicial da torção.

As peças L19, L20 e L21 também apresentaram forte influência da flexão, que acabou prejudicando o alcance de suas máximas capacidades resistentes.

Acredita-se que as peças L10, L11, L19, L20 e L21, com aplicação da força a 5,75 h e $5 \mathrm{~h}$, apresentaram valores inferiores aos previstos devido não somente à interação dos mecanismos de cisalhamento e flexão, como também devido ao escorregamento das cordoalhas. As fissuras de flexão e o escorregamento das cordoalhas afetam o comprimento de transferência, tornando-o maior e prejudicando a ancoragem das barras. Com isso, ocorre uma perda do efeito da protensão, o que afeta consideravelmente o desempenho da laje. Diante disso, novos estudos são necessário com o emprego de melhores condições de ancoragem justamente para analisar melhor os equacionamentos, considerando esses casos (força a $5 \mathrm{~h}$ e $5,75 \mathrm{~h}$ ).

Analisando as peças de diferentes alturas, pode-se dizer que com o aumento da altura tem-se uma alteração do mecanismo de ruptura, que passa a sofrer menor influência da flexão, predominando o cisalhamento. Tal efeito pode ser constatado a partir da análise da configuração de fissuração para as lajes com diversas alturas, variando de $15 \mathrm{~cm}$ a $26 \mathrm{~cm}$. Pode-se observar um aumento gradativo da influência do cisalhamento e consequente diminuição do efeito da flexão à medida que a altura da laje é aumentada. 
A partir dessa análise fica evidente a alteração do mecanismo de ruptura, sendo observado que as lajes de menores alturas apresentaram maior influência do mecanismo de flexão, quando comparadas com as demais de alturas superiores.

Mesmo que algumas peças, principalmente do lote $W$, apresentaram valores experimentais bem superiores aos previstos teoricamente, considerando cisalhamento em região fissurada à flexão, ficou evidente a presença de fissuras de flexão na seção considerada para cada peça, a partir da observação da configuração de fissuração.

\subsubsection{Análise dos ensaios de flexão}

Os resultados experimentais e os teóricos podem ser observados na Tabela 6.7.

Tabela 6.7: Resultados experimentais e teóricos para as lajes sem capa ensaiadas à flexão.

\begin{tabular}{|c|c|c|c|c|c|c|}
\hline Laje & $\begin{array}{c}M_{u, e x p} \\
(\mathbf{k N . m})\end{array}$ & $\begin{array}{c}\mathbf{M}_{\mathrm{Rk}} \\
\mathbf{( k N . m )}\end{array}$ & $\frac{\mathrm{M}_{\mathrm{u}, \exp }}{\mathrm{M}_{\mathrm{RK}}}$ & $\begin{array}{c}\mathrm{M}_{\mathrm{r}, \exp } \\
\mathbf{( k N . m )}\end{array}$ & $\begin{array}{c}\mathrm{M}_{\mathrm{r}} \\
\mathbf{( k N . m )}\end{array}$ & $\begin{array}{c}\text { Idade } \\
\mathbf{( d i a s )}\end{array}$ \\
\hline L1-S-15-6D9,5-X_F & 79,89 & 65,73 & 1,21 & 64,43 & 58,97 & 124 \\
\hline L2-S-15-6D9,5-X_F & 78,16 & 62,54 & 1,25 & 58,34 & 56,70 & 120 \\
\hline L3-S-20-8D12,7-X_F & 224,19 & 218,58 & 1,02 & 125,28 & 147,56 & 99 \\
\hline L4-S-20-8D12,7-X_F & 245,92 & 218,62 & 1,12 & 129,82 & 147,36 & 108 \\
\hline L5-S-20-5D12,7-Z_F & 109,70 & 135,64 & 0,81 & 101,22 & 93,53 & 10 \\
\hline L6-S-20-5D12,7-Z_F & 125,30 & 135,64 & 0,92 & 107,00 & 93,53 & 10 \\
\hline L7-S-20-5D12,7-Z_F & 102,42 & 135,64 & 0,75 & 99,80 & 93,53 & 10 \\
\hline L8-S-20-5D12,7-Z_F & 97,17 & 135,64 & 0,72 & 97,17 & 93,53 & 10 \\
\hline L9-S-20-5D12,7-Z_F & 100,40 & 135,64 & 0,74 & 86,15 & 93,53 & 10 \\
\hline L10-S-20-5D12,7-Z_F & 135,65 & 135,65 & 1,00 & 95,00 & 94,37 & 10 \\
\hline L11-S-21-7D9,5-W_F & 154,85 & 113,44 & 1,36 & 100,73 & 100,71 & 33 \\
\hline
\end{tabular}

Como pode ser observado na Tabela 6.7, a maior parte das peças apresentou resultados satisfatórios quanto à flexão (valores experimentais superiores aos previstos). As pertencentes ao lote $Z$, cujos resultados em geral foram inferiores aos previstos, apresentaram interação de mecanismos, como pode ser observado a partir da configuração de fissuração, descrita a seguir. Melhor análise desse efeito está apresentada no item 6.2.6.

Da mesma forma que para os ensaios de cisalhamento, nos ensaios para determinação da resistência à flexão realizou-se a separação dos tipos de laje e criaramse gráficos de $M_{\exp } / M_{R K}$ versus deslocamento vertical para cada laje, sendo $M_{\exp }$ correspondente ao momento fletor obtido na seção do meio do vão.

Na Figura 6.32 podem ser observados os gráficos de $M_{\exp } / M_{R K}$ versus deslocamento vertical para as lajes sem capa pertencentes ao lote $X$, com variações quanto à altura e à área de armadura.

As lajes sem capa e com altura de 15 cm (L1_X e L2_X) apresentaram comportamento diferente das demais (com um pico bem definido no gráfico) e alcançaram resistência à flexão superior à esperada teoricamente. 


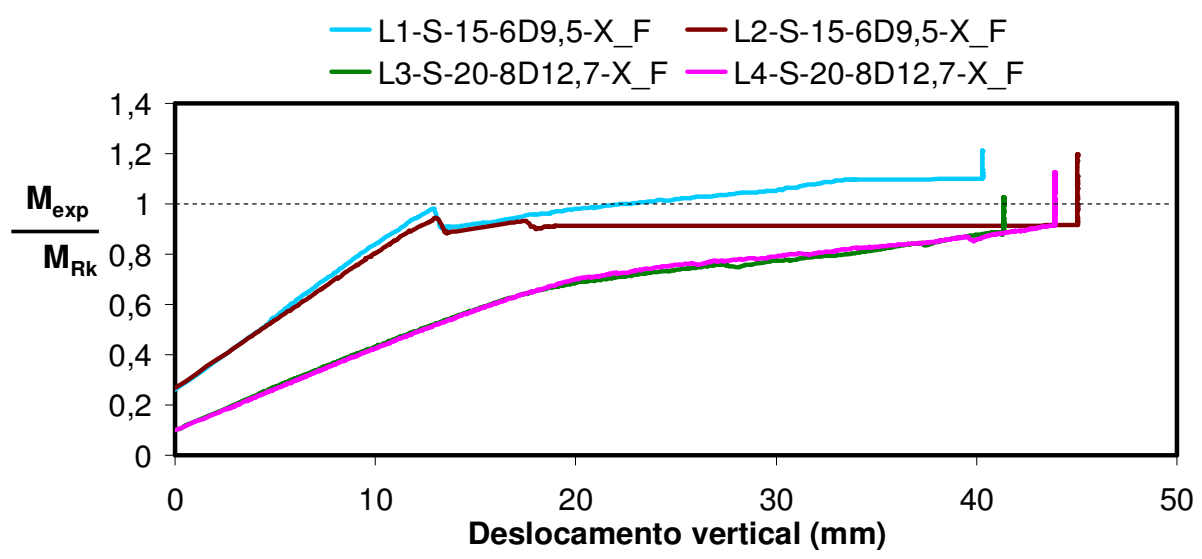

Figura 6.32: Gráficos $M_{\exp } / M_{R k}$ versus deslocamento vertical obtidos a partir dos ensaios das lajes sem capa, com $8 \phi 12,7$ e $6 \phi 9,5$, pertencentes ao lote $X$.

As lajes com altura de $20 \mathrm{~cm}$ ( L3_X e L4_X) também alcançaram valores satisfatórios e apresentaram um comportamento mais dúctil com relação às lajes menores (identificado pelos gráficos sem picos definidos).

Na Figura 6.33 é possível observar a fissuração da laje L2-S-15-6D9,5-X_F e da laje L4-S-20-8D12,7-X_F, submetidas ao ensaio de flexão.

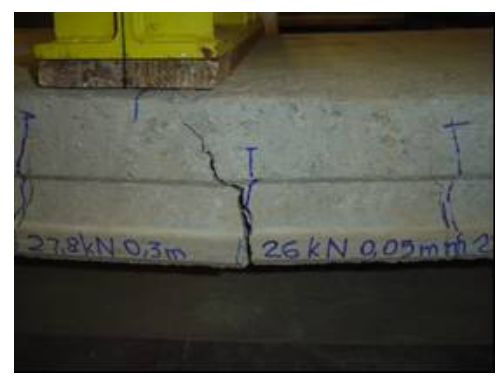

a)

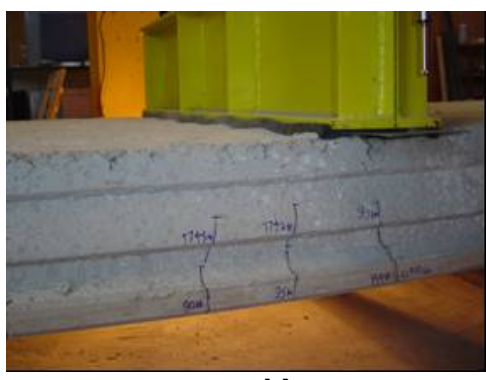

b)

Figura 6.33: a) Fissuração da região central da laje L2-S-15-6D9,5-X_F; b) Fissuração da região central da laje L4-S-20-8D12,7-X_F.

Na Figura 6.34 estão ilustrados os gráficos de $M_{\exp } / M_{R k}$ versus deslocamento vertical para as lajes sem capa, pertencentes ao lote Z. Nessas lajes foi realizado o ensaio de flexão padrão, descrito no item 3.6.2. Nesse ensaio é realizada a aplicação da força no meio do vão, sendo aumentada até o início da fissuração, em seguida é feito o descarregamento e o posterior carregamento da peça até a ruptura. Com esses gráficos, é possível observar que todas as lajes apresentaram valores experimentais inferiores aos previstos.

Na Figura 6.35 é possível observar a fissuração de uma das lajes ensaiadas à flexão. $\mathrm{Na}$ face oposta da peça, indicada pela letra "a", pode-se notar a presença de fissura de flexão, e na face frontal, indicada na letra " $b$ ", pode-se observar a presença de fissura de flexão com cisalhamento e fendilhamento horizontal junto à armadura. 


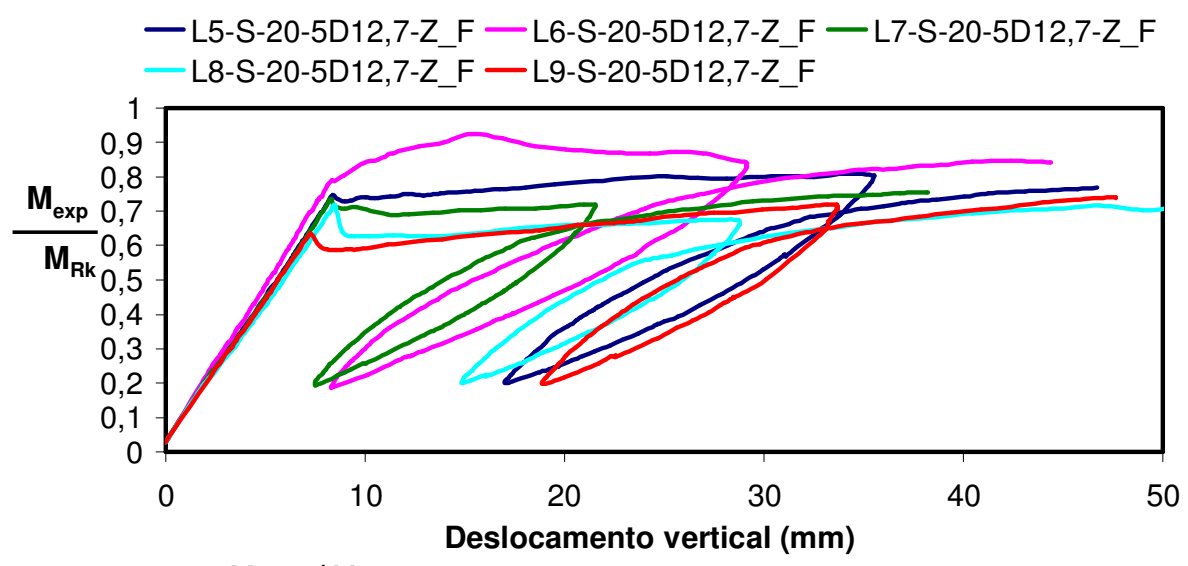

Figura 6.34: Gráficos $M_{\exp } / M_{k K}$ versus deslocamento vertical obtidos a partir dos ensaios das lajes sem capa, com 5 \$ 12,7 e $310 \mathrm{~cm}$ de comprimento, pertencentes ao lote $Z$.

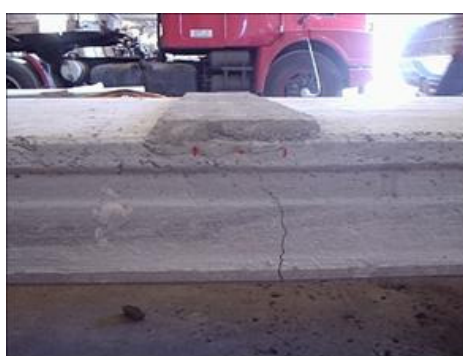

a)

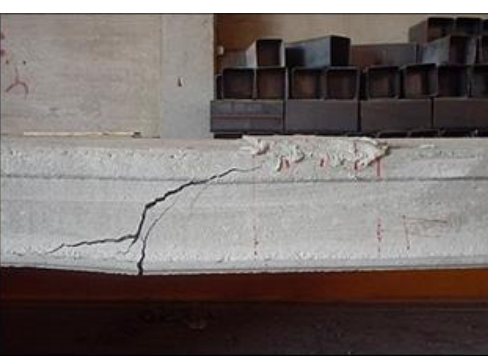

b)

Figura 6.35: Configuração de fissuração para laje de $3 \mathbf{m}$ de vão, submetida a ensaio de flexão. a) Fissuração da face oposta; b) Fissuração da face frontal.

Como todas as lajes não atenderam aos valores previstos, um novo ensaio foi realizado para o mesmo tipo de peça, mas aumentando o seu comprimento (sendo ensaiada uma laje do mesmo tipo com $6 \mathrm{~m}$ de vão). Assim, a laje de maior comprimento apresentou valor experimental satisfatório, igual ao previsto (Figura 6.36.), porém com flecha elevada, acima de $10 \mathrm{~cm}$.

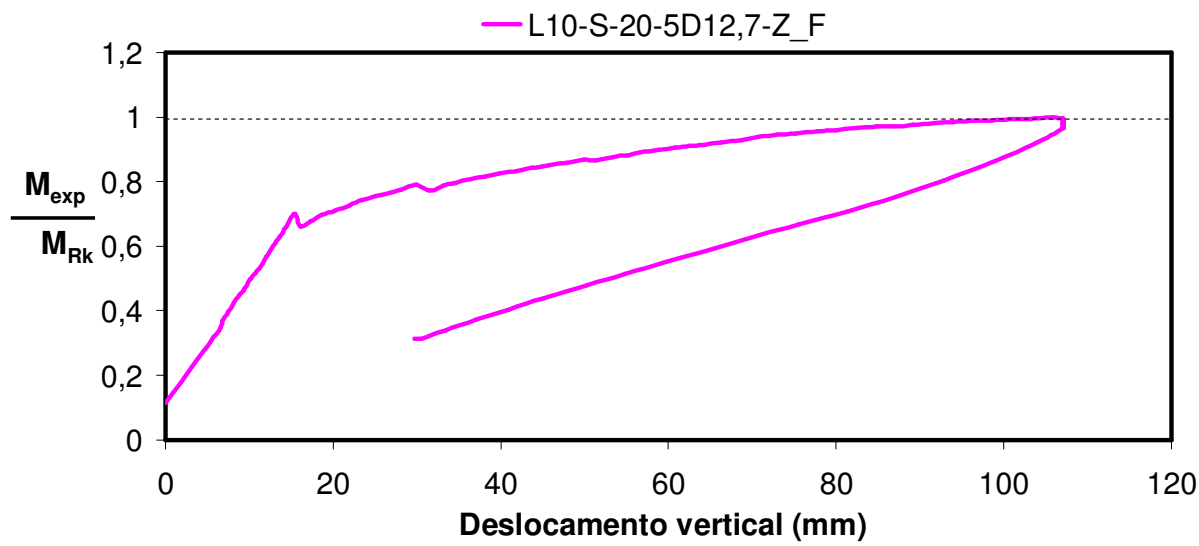

Figura 6.36: Gráfico $M_{\exp } / M_{R k}$ versus deslocamento vertical, obtido a partir do ensaio da laje sem capa L10, com 5 \$12,7 e $610 \mathrm{~cm}$ de comprimento, pertencente ao lote $Z$. 
Na Figura 6.37 estão ilustrados os resultados do ensaio da laje L11, do lote W.

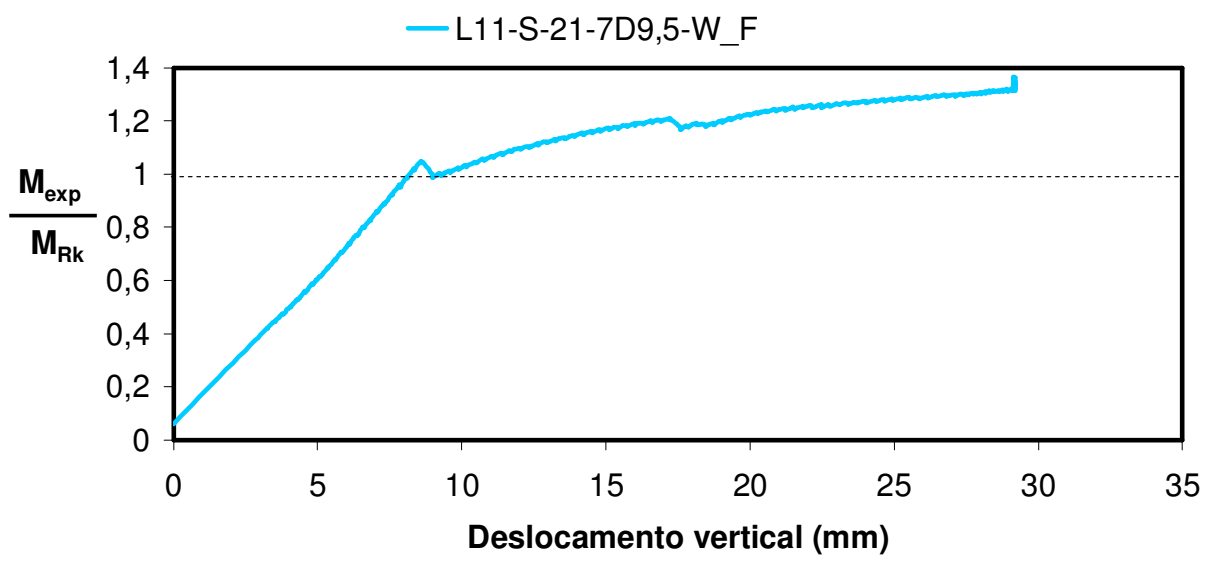

Figura 6.37: Gráficos $M_{\text {exp }} / M_{R k}$ versus deslocamento vertical para a laje sem capa L11-S-21-7D9,5-W_F, com $7 \phi 9,5$ e $400 \mathrm{~cm}$ de comprimento, pertencente ao lote $W$.

Na Figura 6.38 pode-se observar a fissuração da laje L11 em ensaio de flexão.

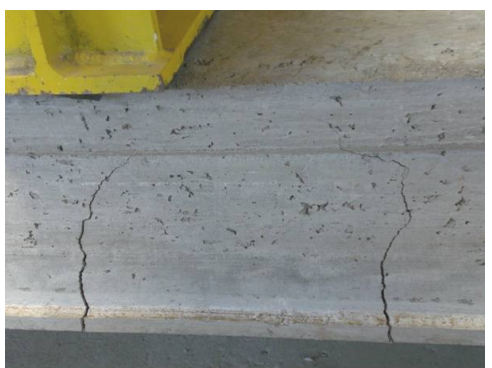

Figura 6.38: Fissuração da laje L11-S-21-7D9,5-W_F, vão de 4 m, submetida ao ensaio de flexão.

\subsubsection{Considerações sobre as unidades sem capa ensaiadas à flexão}

Para melhor comparação dos resultados, foram determinadas as resistências médias à flexão para cada tipo de laje ensaiada. Esses dados estão ilustrados na Tabela 6.8.

A partir da comparação dos resultados é possível notar que, assim como esperado teoricamente, o tipo de laje com maior comprimento, maior número de cordoalhas e elevada protensão apresentou melhor desempenho à flexão.

Entretanto, as lajes sem capa com $3 \mathrm{~m}$ de vão apresentaram resultados experimentais inferiores aos obtidos teoricamente. Além disso, essas lajes (lajes L5, L6, L7, L8 e L9) apresentaram o valor do momento último próximo ao do momento de fissuração indicado na tabela anterior (Tabela 6.7), o que não era esperado nos cálculos teóricos. Essa situação é explicada como sendo a ruptura devida à interação dos mecanismos de cisalhamento e flexão, em região próxima ao apoio. Essa interação desaparece quando a capacidade resistente da laje ao cisalhamento é aumentada, por meio do aumento do comprimento, do preenchimento dos alvéolos ou do acréscimo de capa, ocorrendo nesse caso ruptura devida apenas à flexão. 
Tabela 6.8: Resistência média à flexão das lajes sem capa.

\begin{tabular}{|c|c|c|c|c|c|c|c|}
\hline Descrição & Laje & $\begin{array}{l}M_{u, \exp } \\
(\mathbf{k N} \cdot \mathbf{m})\end{array}$ & $\begin{array}{c}\mathrm{M}_{\mathrm{u}, \mathrm{exp}, \mathrm{m}} \\
(\mathbf{k N} \mathbf{m})\end{array}$ & $\begin{array}{c}M_{\mathrm{Rk}} \\
\text { (kN.m) }\end{array}$ & $\begin{array}{l}M_{\mathrm{Rk}, \mathrm{m}} \\
(\mathbf{k N} \cdot \mathbf{m})\end{array}$ & $\frac{M_{\mathrm{u}, \exp , \mathrm{m}}}{M_{\mathrm{Rk}, \mathrm{m}}}$ & $\begin{array}{l}\text { Mecanismos } \\
\text { presentes } \\
\text { na ruptura }\end{array}$ \\
\hline \multirow{2}{*}{$\begin{array}{c}\text { Sem capa, } 6 \phi 9,5, \\
\mathrm{~h}=15 \mathrm{~cm}, \mathrm{~L}=6,5 \mathrm{~m} \text { e } \\
\sigma_{\text {pi }}=1423,42 \mathrm{MPa} \\
\left(\mathrm{L}-\mathrm{S}-15-6 \mathrm{D} 9,5-\mathrm{X} \_\mathrm{F}\right)\end{array}$} & L1 & 79,89 & \multirow{2}{*}{79,02} & 65,73 & \multirow{2}{*}{64,13} & \multirow{2}{*}{1,23} & \multirow{2}{*}{ Flexão } \\
\hline & L2 & 78,16 & & 62,54 & & & \\
\hline \multirow{2}{*}{$\begin{array}{c}\text { Sem capa, } 8 \phi 12,7, \\
\mathrm{~h}=20 \mathrm{~cm}, \mathrm{~L}=6,5 \mathrm{~m} \mathrm{e} \\
\sigma_{\text {pi }}=1425,05 \mathrm{MPa} \\
\left(\mathrm{L}-\mathrm{S}-20-8 \mathrm{D} 12,7-\mathrm{X} \_\mathrm{F}\right)\end{array}$} & L3 & 224,19 & \multirow{2}{*}{235,05} & 218,58 & \multirow{2}{*}{218,60} & \multirow{2}{*}{1,07} & \multirow{2}{*}{ Flexão } \\
\hline & L4 & 245,92 & & 218,62 & & & \\
\hline \multirow{5}{*}{$\begin{array}{c}\text { Sem capa, } 5 \text { \$ } 12,7 \text {, } \\
\mathrm{h}=20 \mathrm{~cm}, \mathrm{~L}=3,10 \mathrm{~m} \mathrm{e} \\
\sigma_{\mathrm{pi}}=1140 \mathrm{MPa} \\
\left(\mathrm{L}-\mathrm{S}-20-5 \mathrm{D} 12,7-\mathrm{Z} \_\mathrm{F}\right)\end{array}$} & L5 & 109,70 & \multirow{5}{*}{107,00} & 135,64 & \multirow{5}{*}{135,64} & \multirow{5}{*}{0,79} & \multirow{5}{*}{$\begin{array}{l}\text { Flexão com } \\
\text { cisalhamento } \\
\text { e falha de } \\
\text { ancoragem }\end{array}$} \\
\hline & L6 & 125,30 & & 135,64 & & & \\
\hline & L7 & 102,42 & & 135,64 & & & \\
\hline & L8 & 97,17 & & 135,64 & & & \\
\hline & L9 & 100,40 & & 135,65 & & & \\
\hline $\begin{array}{c}\text { Sem capa, } 5 \phi 12,7, \\
\mathrm{~h}=20 \mathrm{~cm}, \mathrm{~L}=6,10 \mathrm{~m} \mathrm{e} \\
\sigma_{\mathrm{pi}}=1140 \mathrm{MPa} \\
\left(\mathrm{L}-\mathrm{S}-20-5 \mathrm{D} 12,7-\mathrm{Z} \_\mathrm{F}\right)\end{array}$ & L10 & 135,65 & ----- & 135,67 & ----- & 1,00 & Flexão \\
\hline $\begin{array}{c}\text { Sem capa, } 7 \phi 9,5 \\
\mathrm{~h}=21 \mathrm{~cm}, \mathrm{~L}=4,0 \mathrm{~m} \mathrm{e} \\
\sigma_{\mathrm{pi}}=1460 \mathrm{MPa} \\
\mathrm{L}-\mathrm{S}-21-7 \mathrm{D} 9,5-\mathrm{W} / \mathrm{F}\end{array}$ & L11 & 154,85 & ----- & 113,44 & ----- & 1,36 & Flexão \\
\hline
\end{tabular}

h:altura da laje; L: comprimento da peça e $\sigma_{\mathrm{pi}}$ : protensão inicial.

Além disto, para as lajes sem capa com vãos de $3 \mathrm{~m}$, notou-se que, além da combinação da flexão com cisalhamento, a força última foi alcançada quando ocorreu uma falha de ancoragem.

Como o objetivo desse ensaio era justamente medir a capacidade resistente das lajes alveolares à flexão, foi realizado outro ensaio de laje com vão de $6 \mathrm{~m}$ a fim de não haver interferência de cisalhamento na ruptura. A laje sem capa, de $6 \mathrm{~m}$ de vão, apresentou melhor desempenho à flexão, sendo o valor de momento último experimental próximo ao do valor teórico.

Dessa forma, pode-se observar que o ensaio à flexão empregando unidades com vãos de $3 \mathrm{~m}$ não é adequado para avaliar a resistência última à flexão. Isso pode ser afirmado devido à identificação da interação combinada dos mecanismos de flexão e cisalhamento nos ensaios à flexão, realizados com unidades alveolares de pequenos vãos, sendo, nesse caso, necessária uma elevada relação $\mathrm{V} / \mathrm{M}$ para atingir o momento último, e consequentemente alcançar o máximo desempenho.

\subsubsection{Resistência do concreto à tração e módulo de elasticidade}

A resistência do concreto à tração e o módulo de elasticidade podem ser obtidos a partir dos ensaios das unidades alveolares. 


\section{- Determinação da resistência do concreto à tração - lote Z}

Para garantir maior confiabilidade quanto aos valores de resistência do concreto à tração obtidos a partir dos ensaios de corpos de prova, foram determinados valores de resistência do concreto à tração a partir de valores de momento de fissuração determinados por meio dos ensaios das unidades alveolares. A partir da equação empregada para determinar o momento de fissuração, determinou-se o valor da resistência média do concreto à tração, com a seguinte expressão:

$f_{c t m}=\frac{\left[\frac{N_{p}}{A_{c, \text { hom }}}+\frac{N_{p} \cdot e_{p} \cdot y_{t, \text { hom }}}{I_{\text {hom }}}-\frac{M_{r, \text { exp }} \cdot y_{t, \text { hom }}}{I_{\text {hom }}}\right]}{\alpha_{f}}$

$M_{r, \text { exp }}$ : momento de fissuração relativo à força aplicada pelo atuador, no instante da primeira fissura (considerando o peso próprio da laje);

$\mathrm{N}_{\mathrm{p}}$ : força de protensão na data do ensaio (descontando as perdas calculadas para essa data);

$\mathrm{A}_{\mathrm{c}, \text { hom }}$ : área de concreto da seção homogeneizada;

$I_{\text {hom }}$ momento de inércia da seção homogeneizado;

$\mathrm{y}_{\mathrm{t} \text {, hom }}$ : distância do centro de gravidade até a borda mais tracionada da seção;

$\mathrm{e}_{\mathrm{p}}$ : excentricidade efetiva (valor médio para as posições das cordoalhas);

$\alpha_{f}: \quad$ coeficiente equivalente a 1,5 .

Os valores para o cálculo da resistência média do concreto à tração, determinados a partir dos valores de momento de fissuração obtidos com os ensaios, e os respectivos valores dessa resistência podem ser observados na Tabela 6.9.

Tabela 6.9: Determinação da resistência média do concreto à tração, a partir do momento de fissuração experimental, e comparação com o valor experimental.

\begin{tabular}{|c|c|c|c|c|c|c|c|}
\hline Laje & $\begin{array}{l}M_{r, \exp } \\
\text { (kN.m) }\end{array}$ & $\begin{array}{c}\mathrm{N}_{\mathrm{p}} \\
(\mathbf{k N})\end{array}$ & $\begin{array}{c}A_{c, \text { hom }} \\
\left(\mathbf{m}^{2}\right)\end{array}$ & $\begin{array}{c}\mathrm{Y}_{\mathrm{t}, \mathrm{hom}} \\
(\mathbf{m})\end{array}$ & $\begin{array}{l}I_{\text {hom }} \\
\left(\mathbf{m}^{\mathbf{4}}\right)\end{array}$ & $\begin{array}{c}e_{p} \\
(\mathbf{m})\end{array}$ & $\begin{array}{c}\mathrm{f}_{\mathrm{ctm}} \\
(\mathbf{M P a})\end{array}$ \\
\hline L5-S-20-5D12,7-Z_F & 101,22 & 500,79 & 0,140451 & 0,098771 & $6,82208.10^{4}$ & 0,065 & 4,251 \\
\hline L6-S-20-5D12,7-Z_F & 107,00 & 500,79 & 0,140451 & 0,098771 & $6,82208.10^{4}$ & 0,065 & 4,809 \\
\hline L7-S-20-5D12,7-Z_F & 99,80 & 500,79 & 0,140451 & 0,098771 & $6,82208.10^{4}$ & 0,065 & 4,114 \\
\hline L8-S-20-5D12,7-Z_F & 97,17 & 500,79 & 0,140451 & 0,098771 & $6,82208.10^{4}$ & 0,065 & 3,860 \\
\hline L10-S-20-5D12,7-Z_F & 95,00 & 508,15 & 0,140451 & 0,098771 & $6,82208 \cdot 10^{4}$ & 0,065 & 3,570 \\
\hline Média & & & & & & & 4,121 \\
\hline $\mathrm{f}_{\mathrm{ct}, \exp }(\mathbf{M P a})$ & \multicolumn{6}{|c|}{ (determinação por meio de ensaios de tração por compressão diametral) } & 4,093 \\
\hline
\end{tabular}

Nessa tabela verifica-se que o valor médio da resistência do concreto à tração, determinado a partir de ensaios de corpos de prova cilíndricos, correspondeu a 4,093 MPa, sendo muito próximo ao valor médio determinado considerando os valores experimentais de momento de fissuração (4,121 MPa). 
A partir dessa comparação é possível garantir confiabilidade aos valores de resistência do concreto à tração, obtidos pela empresa em questão.

\section{- Determinação do módulo de elasticidade do concreto - lote $\mathbf{X}$}

Para outro grupo de lajes foram determinados valores de módulo de elasticidade do concreto $\left(E_{c}\right)$ a partir das flechas obtidas com os ensaios à flexão das unidades alveolares.

Tais valores de módulo, proveniente de flechas, foram comparados com os módulos determinados a partir das resistências à compressão obtidas com ensaios de corpos de prova.

Tal procedimento foi empregado com o intuito de garantir maior confiabilidade quanto aos valores experimentais de resistência do concreto, empregados nesta pesquisa. A determinação do módulo de elasticidade a partir de valores de flecha obtidos por meio de ensaios experimentais pode ser realizada com a seguinte expressão:

$E_{c}=\left[\frac{F_{\text {exp }} \cdot L^{3}}{48 \cdot I_{\text {hom }} \cdot a_{\text {exp }}}\right]$

$F_{\text {exp }}$ força aplicada no ensaio;

L : $\quad$ valor do vão;

$I_{\text {hom }}$ : momento de inércia da seção homogeneizada;

$a_{\text {exp }}$ : flecha experimental.

O valor do módulo de elasticidade secante do concreto, quando não se tem o valor experimental, pode ser calculado por meio da expressão normativa $\left(E_{c s}=0,85.5600 \cdot \sqrt{f_{c k}}\right)$ que fornece esse valor a partir da resistência do concreto à compressão obtida com corpos de prova. De acordo com a NBR 6118:2003, para idades maiores ou iguais a 7 dias, o módulo de elasticidade pode ser calculado substituindo $f_{c k}$ por $\mathrm{f}_{\mathrm{cj}}$.

Os valores de módulo de elasticidade determinados estão indicados na Tabela 6.10.

Tabela 6.10: Determinação dos módulos de elasticidade do concreto.

\begin{tabular}{|c|c|c|c|c|c|c|c|}
\hline Laje & $\begin{array}{l}F_{\text {exp }} \\
\text { (kN) }\end{array}$ & $\underset{(\mathrm{mm})}{\mathrm{L}}$ & $\begin{array}{l}\mathrm{I}_{\mathrm{hom}} \\
\left(\mathbf{m m}^{4}\right)\end{array}$ & $\begin{array}{l}a_{\exp } \\
(\mathbf{m m})\end{array}$ & $\begin{array}{c}\mathrm{f}_{\mathrm{cj}} \\
\text { (MPa) }\end{array}$ & $\begin{array}{c}E_{c} \\
\text { (a partir de } \\
\left.a_{\text {exp }}\right) \\
\left(\mathbf{k N} / \mathbf{m m}^{2}\right)\end{array}$ & $\begin{array}{c}E_{c s} \\
\begin{array}{c}\text { (a partir de } \\
\left.\mathbf{f}_{\mathrm{cj}}\right) \\
\left(\mathbf{k N} / \mathbf{m m}^{\mathbf{2}}\right)\end{array}\end{array}$ \\
\hline L2-S-15-6D9,5-X_F & 25,9659 & 6400 & $3,1582.10^{8}$ & 12,3589 & 55,97 & 36,3310 & 35,6110 \\
\hline L3-S-20-8D12,7-X_F & 64,6591 & 6400 & $7,5289.10^{8}$ & 14,2393 & 48,27 & 32,9386 & 33,0709 \\
\hline L4-S-20-8D12,7-X_F & 67,5000 & 6400 & $7,5286.10^{8}$ & 14,8491 & 48,40 & 32,9750 & 33,1154 \\
\hline Média & & & & & & 34,0815 & 33,9324 \\
\hline
\end{tabular}


Os gráficos de força no atuador versus flecha, necessários para a identificação das flechas e respectivas forças das unidades alveolares ensaiadas, podem ser observados na Figura 6.39.

Comparando os valores dos módulos de elasticidade, foi possível observar a proximidade dos valores obtidos, garantindo a confiabilidade dos valores experimentais empregados nesta pesquisa, que por sua vez foram fornecidos pelos respectivos fabricantes das unidades alveolares.
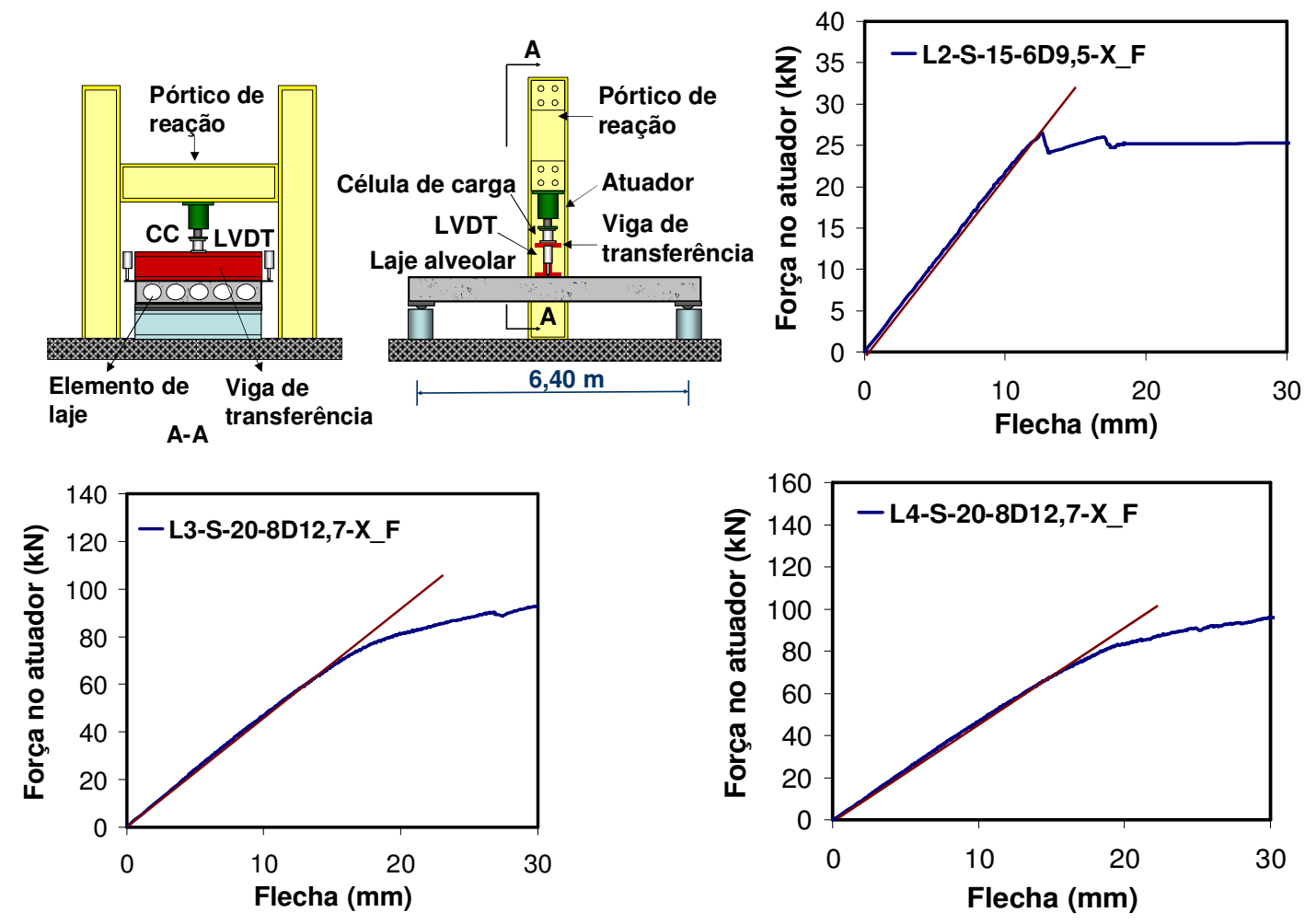

Figura 6.39: Gráficos de força no atuador versus flecha para as lajes sem capa do lote $X$.

\section{- Determinação da resistência do concreto à compressão - lote $\mathbf{W}$}

Com a mesma finalidade, de fornecer maior confiabilidade aos resultados de resistência fornecidos pelo fabricante, procedeu-se a determinação da resistência do concreto à compressão considerando o momento de fissuração experimental (semelhante ao procedimento já realizado para a determinação da resistência do concreto à tração das peças do lote $Z$, no início deste item), sendo feita posterior comparação de tal resultado com o valor de ensaio fornecido pela empresa fabricante $\mathrm{W}$.

Assim, determinou-se a resistência do concreto à tração a partir do momento de fissuração experimental obtido no ensaio à flexão da laje, como já descrito. Então, com a resistência à tração, determinou-se a resistência à compressão (Tabela 6.11). 
Tabela 6.11 - Determinação da resistência do concreto à compressão a partir do momento de fissuração experimental e comparação com o valor experimental.

\begin{tabular}{|c|c|c|c|c|c|c|c|c|}
\hline Laje & $\begin{array}{l}M_{r, \exp } \\
\text { (kN.m) }\end{array}$ & $\begin{array}{c}\mathrm{N}_{\mathrm{p}} \\
(\mathbf{k N})\end{array}$ & $\begin{array}{c}A_{c, \text { hom }} \\
\left(\mathbf{m}^{2}\right)\end{array}$ & $\begin{array}{c}y_{t, h o m} \\
(\mathbf{m})\end{array}$ & $\begin{array}{l}I_{\text {hom }} \\
\left(\mathrm{m}^{4}\right)\end{array}$ & $\begin{array}{c}e_{p} \\
(\mathbf{m})\end{array}$ & $\begin{array}{c}\mathrm{f}_{\mathrm{ctm}} \\
(\mathbf{M P a})\end{array}$ & $\begin{array}{c}f_{c k} \\
(\mathbf{M P a})\end{array}$ \\
\hline L11-S-21-7D9,5-W_F & 100,73 & 488,10 & 0,14675 & 0,10083 & $7,19939 \cdot 10^{4}$ & 0,07195 & 3,9088 & 47,031 \\
\hline$f_{c k, \exp }(\mathbf{M P a})$ & \multicolumn{7}{|c|}{ (determinação por meio de ensaios de compressão axial) } & 47,00 \\
\hline
\end{tabular}

Assim, pode-se garantir a confiabilidade do valor fornecido pelo fabricante (47 MPa), uma vez que ele é muito próximo ao determinado pelo ensaio experimental da laje.

\subsubsection{Interação cisalhamento-flexão}

\section{- Influência do cisalhamento em ensaios de flexão}

Como descrito anteriormente, as unidades alveolares ensaiadas à flexão, do lote $Z$, apresentaram influência do cisalhamento, o que reduziu a capacidade resistente da laje à flexão, sendo esse efeito notado a partir do aparecimento de fissuras de cisalhamento. Assim, com o intuito de comprovar a presença da interação dos mecanismos de flexão e cisalhamento, foi empregada a equação recomendada por Lindström (2009) (equação 3.35). Os resultados alcançados, considerando os valores teóricos determinados pela equação da NBR 6118:2003, estão indicados na Tabela 6.12.

Tabela 6.12: Verificação da interação de cisalhamento e flexão.

\begin{tabular}{|c|c|c|c|c|c|c|}
\hline Laje & $\begin{array}{c}M_{\text {atuante }} \\
(\mathbf{k N} \mathbf{m})\end{array}$ & $\begin{array}{c}M_{\text {resistido }} \\
(\mathbf{k N} \cdot \mathbf{m})\end{array}$ & $\frac{M_{\text {atuante }}}{M_{\text {resistido }}}$ & $\begin{array}{c}\mathrm{V}_{\text {atuante }} \\
\text { (kN) }\end{array}$ & $\begin{array}{c}V_{\text {resistido }} \\
(\mathbf{k N})\end{array}$ & $\frac{V_{\text {atuante }}}{V_{\text {resistido }}}$ \\
\hline L5-S-20-5D1 2,7-Z_F & 109,70 & 135,64 & 0,81 & 73,13 & 102,24 & 0,71 \\
\hline L7-S-20-5D12,7-Z_F & 102,43 & 135,64 & 0,76 & 68,28 & 102,24 & 0,67 \\
\hline L8-S-20-5D1 2,7-Z_F & 97,18 & 135,64 & 0,72 & 64,78 & 102,24 & 0,63 \\
\hline L9-S-20-5D12,7-Z_F & 100,40 & 135,64 & 0,74 & 66,93 & 102,24 & 0,65 \\
\hline Média & 102,43 & 135,64 & 0,76 & 68,28 & 102,24 & 0,67 \\
\hline \multirow{2}{*}{ Laje } & \multicolumn{6}{|c|}{ Resultados da Eq.3.35* } \\
\hline & \multicolumn{2}{|l|}{$\mathbf{n}=\mathbf{2}$} & \multicolumn{2}{|c|}{$n=3$} & \multicolumn{2}{|c|}{$n=4$} \\
\hline L5-S-20-5D1 2,7-Z_F & \multicolumn{2}{|l|}{1,08} & \multicolumn{2}{|c|}{0,96} & \multicolumn{2}{|c|}{0,91} \\
\hline L7-S-20-5D1 2,7-Z_F & \multicolumn{2}{|l|}{1,01} & \multicolumn{2}{|c|}{0,90} & \multicolumn{2}{|c|}{0,85} \\
\hline L8-S-20-5D12,7-Z_F & \multicolumn{2}{|l|}{0,96} & \multicolumn{2}{|c|}{0,85} & \multicolumn{2}{|c|}{0,81} \\
\hline L9-S-20-5D12,7-Z_F & \multicolumn{2}{|l|}{0,99} & \multicolumn{2}{|c|}{0,88} & \multicolumn{2}{|c|}{0,83} \\
\hline Média & \multicolumn{2}{|l|}{1,01} & \multicolumn{2}{|c|}{0,90} & \multicolumn{2}{|c|}{0,85} \\
\hline
\end{tabular}

Com o intuito de analisar melhor a distribuição dos resultados e sua proximidade com as curvas das respectivas equações, foram desenvolvidos gráficos de $M_{\text {atuante/ }} M_{\text {resisitdo }}$ versus $\mathrm{V}_{\text {atuante }} / \mathrm{V}_{\text {resisitdo, ilustrados na Figura 6.40. }}$ 
Assim, é possível observar que todos os resultados, considerando $\mathrm{n}$ variando de 2 a 4 ) se encontram dentro dos limites estabelecidos pela equação $(\leq 1)$, o que comprova a existência da interação cisalhamento-flexão. Nesses ensaios, o cisalhamento foi capaz de prejudicar o desempenho da peça à flexão, fazendo com que as proporções entre os valores experimentais e teóricos fossem próximas para os dois tipos de solicitação.

Comparando flexão e cisalhamento, nota-se que mesmo correspondendo a ensaios de flexão, o cisalhamento esteve presente em elevadas proporções.

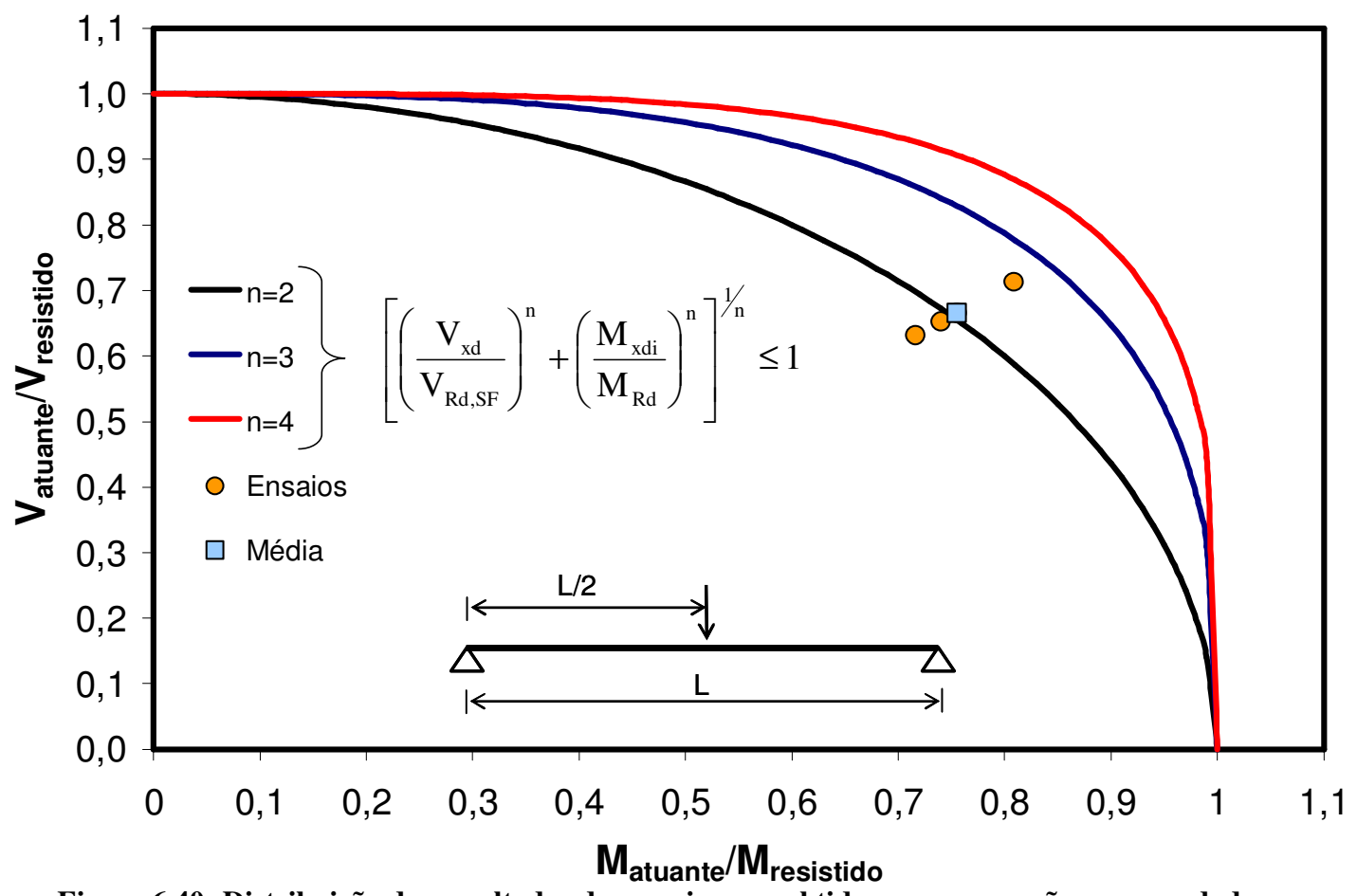

Figura 6.40: Distribuição dos resultados dos ensaios e os obtidos com a equação recomendada por Lindström (2009).

A partir da Figura 6.40 é possível observar que a equação $3.35 \mathrm{com} n=3$ fornece os resultados mais satisfatórios, atendendo todos os valores de ensaio.

\section{- Influência da flexão em ensaios de cisalhamento}

Realizou-se a análise das unidades ensaiadas ao cisalhamento que apresentaram forte influência da flexão, identificadas a partir de suas configurações de fissuração. Os resultados alcançados podem ser observados na Tabela 6.13.

A distribuição dos resultados e sua proximidade com as curvas das respectivas equações podem ser observadas na Figura 6.41. De acordo com essa figura é possível observar que todos os resultados se encontram dentro dos limites estabelecidos pela equação 3.35 (com n variando de 2 a 4), como previsto em Lindström (2009). 
Assim, pode-se comprovar numericamente a existência da interação de cisalhamento e flexão nos ensaios de cisalhamento realizados nas respectivas peças analisadas.

Tabela 6.13: Verificação da interação de cisalhamento e flexão em peças ensaiadas ao cisalhamento.

\begin{tabular}{|c|c|c|c|c|c|c|}
\hline Laje & $\begin{array}{l}M_{\text {atuante }} \\
\text { (kN.m) }\end{array}$ & $\begin{array}{c}M_{\text {resistido }} \\
\text { (kN.m) }\end{array}$ & $\frac{M_{\text {atuante }}}{M_{\text {resistido }}}$ & $\begin{array}{c}\mathrm{V}_{\text {atuante }} \\
\text { (kN) }\end{array}$ & $\begin{array}{c}V_{\text {resistido }} \\
(\mathbf{k N})\end{array}$ & $\frac{V_{\text {atuante }}}{V_{\text {resistido }}}$ \\
\hline L10-S-20-7D9,5-Y_C & 78,30 & 105,80 & 0,74 & 68,09 & 94,45 & 0,72 \\
\hline L11-S-20-7D9,5-Y_C & 78,66 & 105,74 & 0,74 & 68,40 & 92,24 & 0,74 \\
\hline L20-S-21-7D9,5-W_C & 89,03 & 112,69 & 0,79 & 86,86 & 103,35 & 0,84 \\
\hline L21-S-21-7D9,5-W_C & 92,28 & 116,00 & 0,80 & 90,03 & 103,02 & 0,87 \\
\hline Média & 84,57 & 110,06 & 0,77 & 78,35 & 98,27 & 0,79 \\
\hline \multirow{2}{*}{ Laje } & \multicolumn{6}{|c|}{ Resultados da Eq.3.35* } \\
\hline & \multicolumn{2}{|c|}{$\mathbf{n}=\mathbf{2}$} & \multicolumn{2}{|c|}{$n=3$} & \multicolumn{2}{|c|}{$n=4$} \\
\hline L10-S-20-7D9,5-Y_C & \multicolumn{2}{|c|}{1,03} & \multicolumn{2}{|c|}{0,92} & \multicolumn{2}{|c|}{0,87} \\
\hline L11-S-20-7D9,5-Y_C & \multicolumn{2}{|c|}{1,05} & \multicolumn{2}{|c|}{0,94} & \multicolumn{2}{|c|}{0,88} \\
\hline L20-S-21-7D9,5-W_C & \multicolumn{2}{|c|}{1,15} & \multicolumn{2}{|c|}{1,03} & \multicolumn{2}{|c|}{0,97} \\
\hline L21-S-21-7D9,5-W_C & \multicolumn{2}{|c|}{1,18} & \multicolumn{2}{|c|}{1,05} & \multicolumn{2}{|c|}{1,00} \\
\hline Média & \multicolumn{2}{|c|}{1,10} & \multicolumn{2}{|c|}{0,98} & \multicolumn{2}{|c|}{0,93} \\
\hline
\end{tabular}

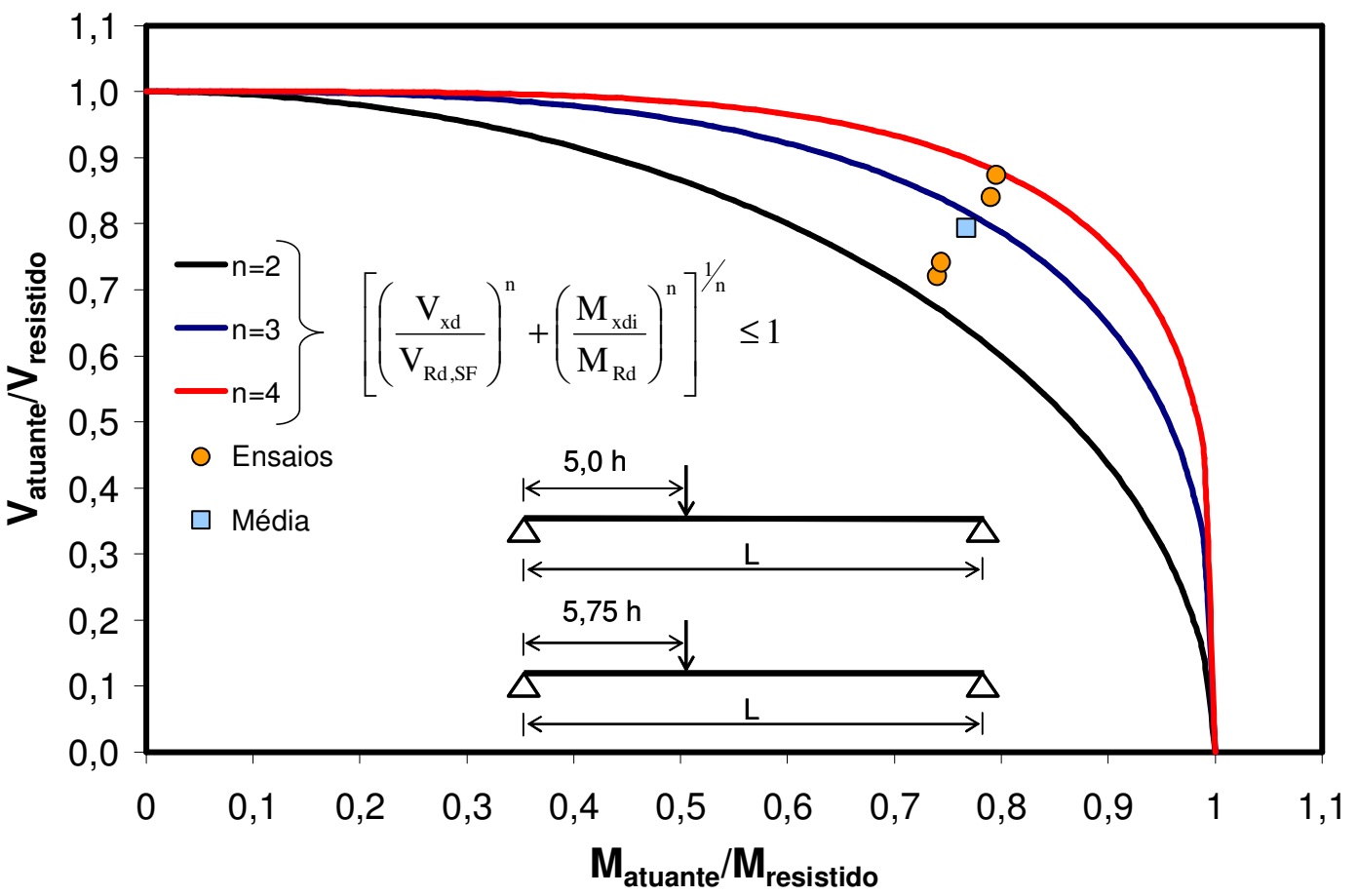

Figura 6.41: Distribuição dos resultados dos ensaios e os obtidos com a equação recomendada por Lindström (2009).

Considerando as análises para as peças ensaiadas à flexão e ao cisalhamento, observou-se que a equação $3.35 \mathrm{com} n=4$ permite que todos os valores de ensaio atendam ao limite estabelecido ( $\leq 1)$. Assim essa equação é a mais eficiente para representar todos os casos. 
De uma forma geral pode-se notar que a equação 3.35 (condição de interação) (com n variando de 2 a 4), recomendada por Lindström (2009), é válida para representar o comportamento de peças que apresentam a interferência prejudicial de um mecanismo sobre o outro, seja flexão afetando o cisalhamento ou vice-versa.

$\mathrm{Em}$ alguns casos, geralmente quando se empregam peças de pequeno comprimento ( $3 \mathrm{~m}$ ) para ensaios de flexão ou quando se aplica força a maiores distâncias ( 5 h) para ensaios de cisalhamento, ocorre a interação dos mecanismos de cisalhamento e flexão.

Assim, um mecanismo afeta o outro que, por sua vez, não consegue se desenvolver totalmente, de forma que ambos resultam em proporções (entre valores experimentais e teóricos) muito próximas e às vezes iguais. Tal efeito corresponde a um comportamento complexo e difícil de ser previsto, pois a peça realmente possui a capacidade de alcançar resistências superiores quanto ao determinado mecanismo (cisalhamento ou flexão), mas seu desempenho é afetado pelo outro mecanismo que pode passar a controlar o desempenho da laje.

Considerando a utilização dessa verificação, para projeto técnico seria interessante o emprego da condição de interação de Lindström (2009), com $n=2$, que permite a obtenção de valores mais conservadores e, portanto, a favor da segurança.

\subsubsection{Correlações entre valores experimentais e teóricos}

Com o intuito de analisar outros equacionamentos expressos na literatura, também foram determinados valores teóricos a partir das equações recomendadas pelo EC2:2004 e pelo ACI-318:2008. As comparações desses valores com os anteriormente determinados pela equação da NBR 6118:2003 podem ser observadas na Tabela 6.14.

Com os valores teóricos obtidos, foi possível observar que todas as equações empregadas forneceram, em sua maioria, valores satisfatórios, ou seja, valores teóricos inferiores aos experimentais.

De um modo geral, a equação recomendada pelo EC2:2004 forneceu resultados mais conservadores para lajes com aplicação de força a 2,5 h, enquanto que o ACI forneceu valores mais conservadores para as peças com aplicação da força a $5 \mathrm{~h}$.

Assim, não é intuito da presente pesquisa identificar a melhor equação, mas analisar qual delas é capaz de representar, de forma mais precisa, o comportamento das unidades ensaiadas, inclusive quanto aos mecanismos verificados na ruptura.

Cabe ressaltar que as peças ensaiadas correspondem às de uso corrente no Brasil, apresentando características muito distintas das utilizadas em outros países e, portanto, necessitam da definição de critérios para sua avaliação compatíveis com suas características, sendo inviável a avaliação desses elementos da mesma forma que para as peças produzidas em outros países. 
Tabela 6.14: Valores teóricos obtidos por diferentes equações, recomendadas por NB1, EC2 e ACI.

\begin{tabular}{|c|c|c|c|c|c|c|c|}
\hline Laje & $\begin{array}{c}\mathrm{V}_{\mathrm{RK}} * \\
\text { (NB1) } \\
\text { (kN) }\end{array}$ & $\begin{array}{l}\frac{\mathrm{V}_{\mathrm{u}, \exp }}{\mathrm{V}_{\mathrm{RK}}} \\
\text { (NB1) }\end{array}$ & $\begin{array}{l}\mathrm{V}_{\mathrm{RK}} * * \\
\text { (EC2) } \\
(\mathbf{k N}) \\
\end{array}$ & $\begin{array}{l}\frac{\mathrm{V}_{\mathrm{u}, \exp }}{\mathrm{V}_{\mathrm{RK}}} \\
\text { (EC2) }\end{array}$ & $\begin{array}{l}\mathrm{V}_{\mathrm{RK}} * * \\
(\mathbf{A C I}) \\
(\mathbf{k N})\end{array}$ & $\begin{array}{c}\frac{V_{\mathrm{u}, \exp }}{\mathrm{V}_{\mathrm{RK}}} \\
\text { (ACI) }\end{array}$ & $\begin{array}{c}\mathrm{V}_{\mathrm{u}, \exp } \\
(\mathbf{k N})\end{array}$ \\
\hline L1-S-15-6D9,5-X_C & 113,11 & 1,19 & 87,67 & 1,53 & 95,45 & 1,41 & 134,46 \\
\hline L2-S-20-8D12,7-X_C & 169,20 & 1,31 & 149,66 & 1,48 & 151,26 & 1,47 & 222,39 \\
\hline L3-S-20-6D12,7-Y_C & 112,04 & 1,12 & 96,84 & 1,29 & 130,06 & 0,96 & 125,14 \\
\hline L4-S-20-6D12,7-Y_C & 121,27 & 1,35 & 104,99 & 1,56 & 127,17 & 1,28 & 163,46 \\
\hline L5-S-20-6D12,7-Y_C & 118,40 & 1,22 & 102,25 & 1,41 & 125,61 & 1,15 & 144,51 \\
\hline L6-S-20-7D9,5-Y_C & 94,28 & 1,29 & 78,68 & 1,55 & 103,84 & 1,17 & 121,71 \\
\hline L7-S-20-7D9,5-Y_C & 94,97 & 1,44 & 79,00 & 1,73 & 106,48 & 1,29 & 137,04 \\
\hline L8-S-20-7D9,5-Y_C & 95,03 & 1,50 & 79,21 & 1,79 & 106,41 & 1,34 & 142,17 \\
\hline L9-S-20-7D9,5-Y_C & 96,72 & 1,40 & 80,52 & 1,68 & 108,34 & 1,25 & 135,44 \\
\hline L10-S-20-7D9,5-Y_C ${ }^{1}$ & 94,45 & 0,72 & 78,78 & 0,86 & 51,82 & 1,31 & 68,09 \\
\hline L11-S-20-7D9,5-Y_C1 & 92,24 & 0,74 & 77,07 & 0,89 & 51,35 & 1,33 & 68,40 \\
\hline L12-S-20-5D 12,7-Z__C & 102,17 & 1,19 & 92,56 & 1,31 & 106,70 & 1,14 & 121,39 \\
\hline L13-S-20-5D 12,7-Z_C & 102,17 & 1,18 & 92,56 & 1,30 & 106,70 & 1,13 & 120,78 \\
\hline L14-S-20-5D 12,7-Z_C & 102,17 & 1,38 & 92,56 & 1,52 & 106,70 & 1,32 & 141,16 \\
\hline L15-S-20-5D 12,7-Z_C & 102,17 & 1,09 & 92,56 & 1,21 & 106,70 & 1,05 & 111,85 \\
\hline L16-S-20-5D 12,7-Z_C & 102,17 & 0,86 & 92,56 & 0,94 & 106,70 & 0,82 & 87,53 \\
\hline L17-S-21-7D9,5-W_C & 104,80 & 1,30 & 89,36 & 1,52 & 109,35 & 1,24 & 136,16 \\
\hline L18-S-21-7D9,5-W_C & 103,91 & 1,62 & 88,74 & 1,90 & 109,86 & 1,54 & 168,80 \\
\hline L19-S-21-7D9,5-W_C ${ }^{2}$ & 102,42 & 0,95 & 87,73 & 1,11 & 62,18 & 1,57 & 97,40 \\
\hline L20-S-21-7D9,5-W_C ${ }^{2}$ & 103,35 & 0,84 & 88,37 & 0,98 & 61,63 & 1,41 & 86,86 \\
\hline L21-S-21-7D9,5-W_C & 103,02 & 0,87 & 88,34 & 1,02 & 62,53 & 1,44 & 90,03 \\
\hline L22-S-16-5D9,5-W_C ${ }^{2}$ & 88,04 & 1,07 & 71,13 & 1,33 & 51,33 & 1,84 & 94,46 \\
\hline L23-S-16-5D9,5-W_C & 81,67 & 1,19 & 66,86 & 1,45 & 50,42 & 1,92 & 96,90 \\
\hline L24-S-16-5D9,5-W_C & 88,49 & 1,07 & 71,56 & 1,33 & 52,10 & 1,82 & 94,89 \\
\hline L25-S-16-5D9,5-W_C & 81,76 & 1,36 & 66,97 & 1,66 & 85,57 & 1,30 & 111,07 \\
\hline L26-S-16-5D 9,5-W_C & 86,95 & 1,66 & 70,59 & 2,04 & 86,65 & 1,66 & 144,05 \\
\hline L27-S-26-9D 12,7-W_C $C^{2}$ & 145,51 & 1,04 & 129,09 & 1,17 & 93,52 & 1,61 & 150,80 \\
\hline L28-S-26-9D12,7-W_C & 144,22 & 1,35 & 127,93 & 1,52 & 173,56 & 1,12 & 195,08 \\
\hline L29-S-26-9D12, 7-W_C & 143,04 & 1,58 & 126,94 & 1,79 & 171,59 & 1,32 & 226,85 \\
\hline
\end{tabular}

*Valores obtidos com emprego de $\mathrm{f}_{\mathrm{ctk}, \text { inf }} ; * *$ Valores obtidos com emprego de $\mathrm{f}_{\mathrm{cj}}$

${ }^{1}$ Força aplicação a 5,75 h do apoio. ${ }^{2}$ Força aplicada a $5 \mathrm{~h}$ do apoio.

Para melhor análise dos resultados, na Figura 6.42, pode-se observar a relação entre os resultados experimentais e os teóricos para as lajes sem capa com aplicação da força a 2,5 h do apoio, considerando todas as equações empregadas.

Com essa figura é possível notar que os resultados obtidos com a equação da NBR 6118:2003 garantem o melhor ajuste dos dados, quando considerada uma linha de tendência linear.

Nesse caso foram consideradas peças sem capa, em que não houve a forte interferência de outros mecanismos como a flexão e a torção.

As lajes com aplicação da força a 5,0 h (L19 a L24 e L27) e 5,75 h (L10 e L11) do apoio apresentaram comportamento diferente das demais peças ensaiadas, o que foi observado pela configuração de fissuração descrita anteriormente. A partir da análise dos mecanismos resistentes dessas peças ficou claro que elas foram extremamente influenciadas pela flexão que, em alguns casos, passou a controlar o comportamento da peça. 
$\circ$ EC2 $\triangle \mathrm{ACl} \diamond \mathrm{NB1}--$ Linear (ACl) ---Linear (NB1) ---Linear (EC2)

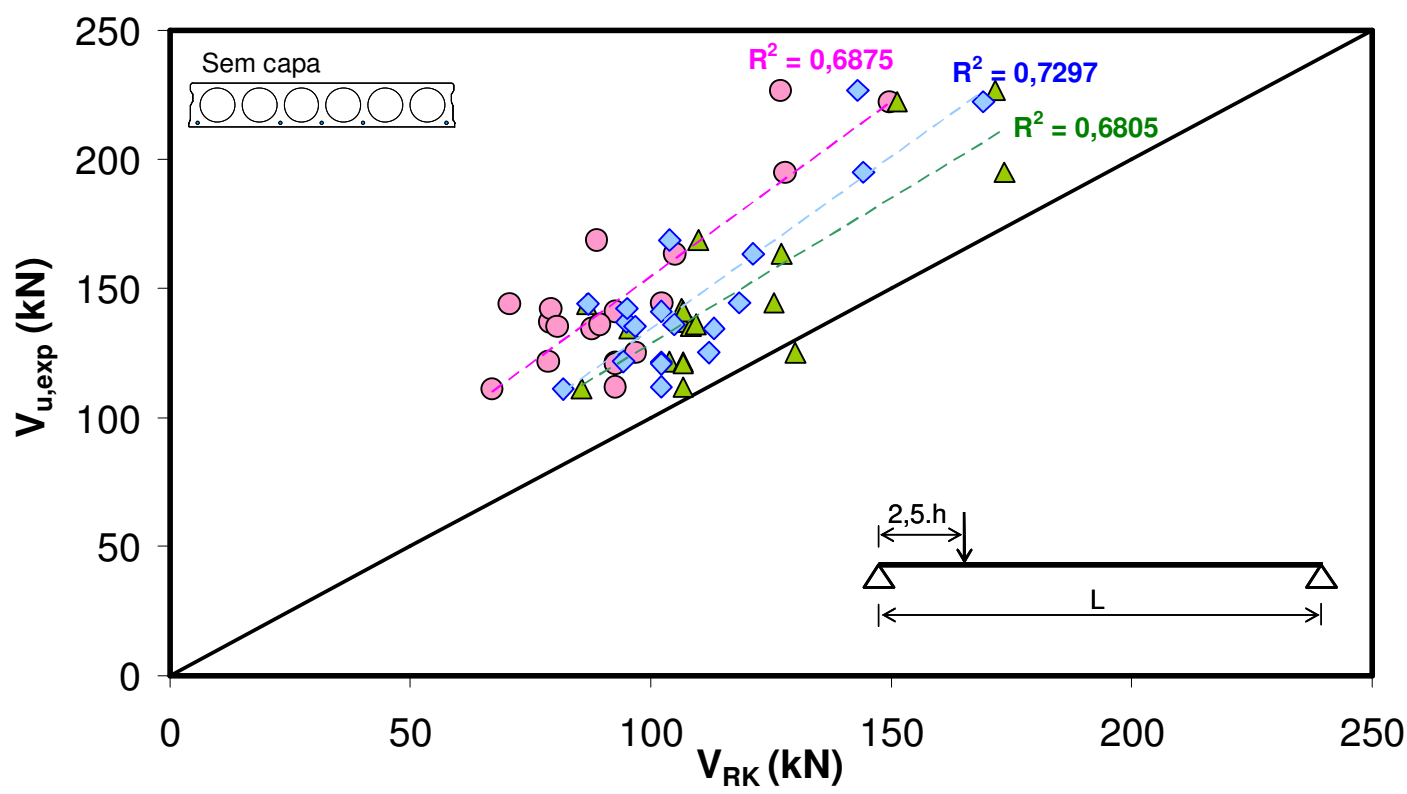

Figura 6.42: Relação entre $V_{u, \exp }$ e $V_{R k}$ considerando as peças sem capa estrutural, com força a plicada a 2,5 h do apoio e com indicação do ajuste dos dados a uma reta.

Na Figura 6.43 estão ilustradas as relações entre os resultados experimentais e teóricos, considerando somente as peças sem capa com aplicação da força a 5,0 h e 5,75 h. Pode-se observar que a equação que melhor considera o efeito da flexão no comportamento ao cisalhamento da laje corresponde à equação recomendada pelo ACI (2008).

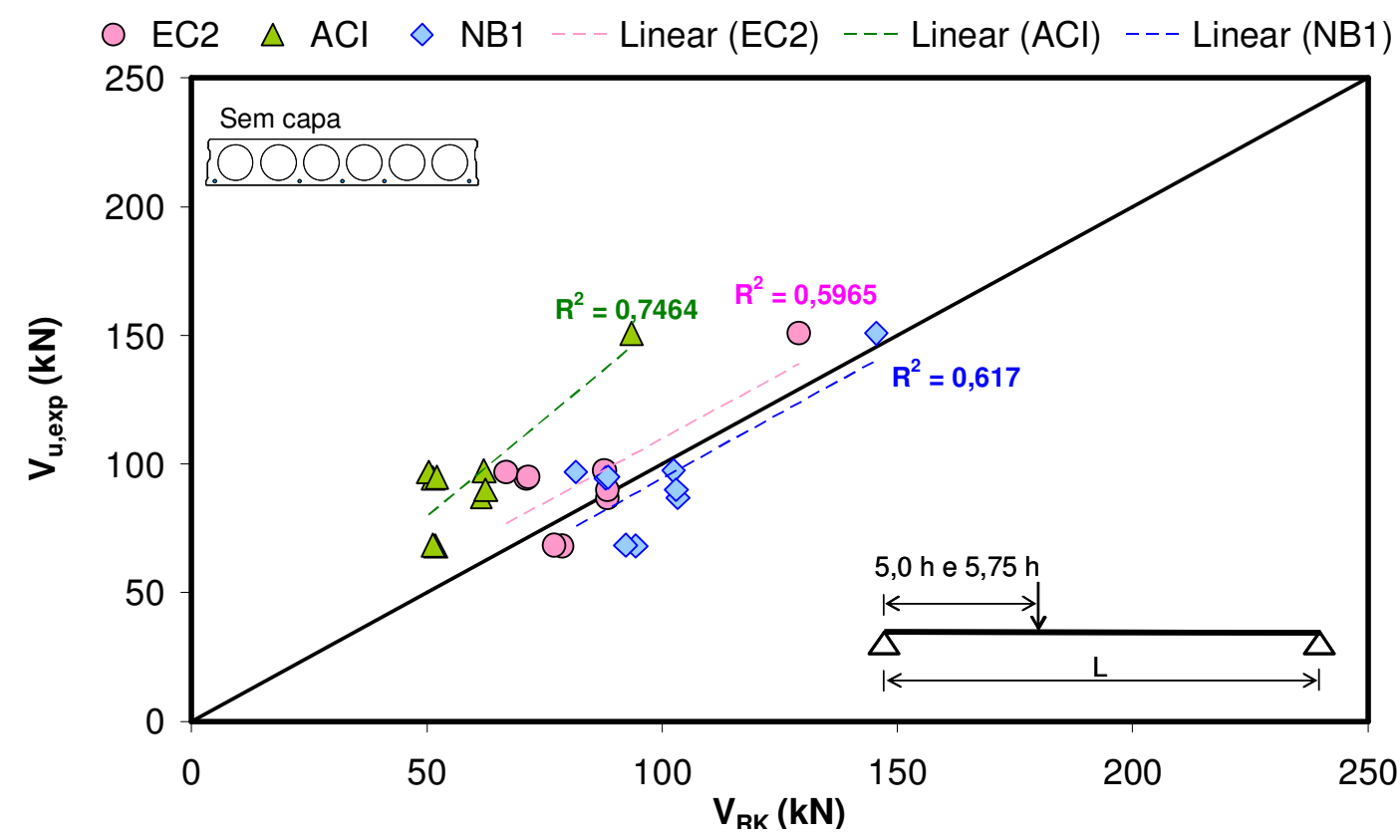

Figura 6.43: Relação entre $V_{u, e x p}$ versus $V_{R k}$ considerando as peças sem capa, com força aplicada a 5 h e 5,75 h, com indicação do ajuste dos dados a uma reta. 
Na Figura 6.44 estão ilustradas as relações entre os resultados experimentais e teóricos, considerando todas as peças sem capa, com aplicação da força a 2,5 h, 5,0 h e 5,75 h. Com a introdução dos resultados das lajes com aplicação da força a 5,0 h e $5,75 \mathrm{~h}$ do apoio, pode-se observar que a equação que garante o melhor ajuste dos dados corresponde a equação recomendada pelo ACI (2008).

Cabe ressaltar que nesta pesquisa foi empregado um tipo de laje, com alvéolos circulares, protensão variando de $1140 \mathrm{MPa}$ a $1460 \mathrm{MPa}$, espessuras variando de $15 \mathrm{~cm}$ a $26 \mathrm{~cm}$, concreto com resistência à compressão de $40 \mathrm{MPa}$ a $55 \mathrm{MPa}$, sendo todas as peças produzidas pelo método da extrusão.

Assim, a partir desta pesquisa pode-se identificar as equações que fornecem resultados satisfatórios para esse tipo de laje estudada, que por sua vez possui características bem distintas das utilizadas na Europa e nos Estados Unidos.

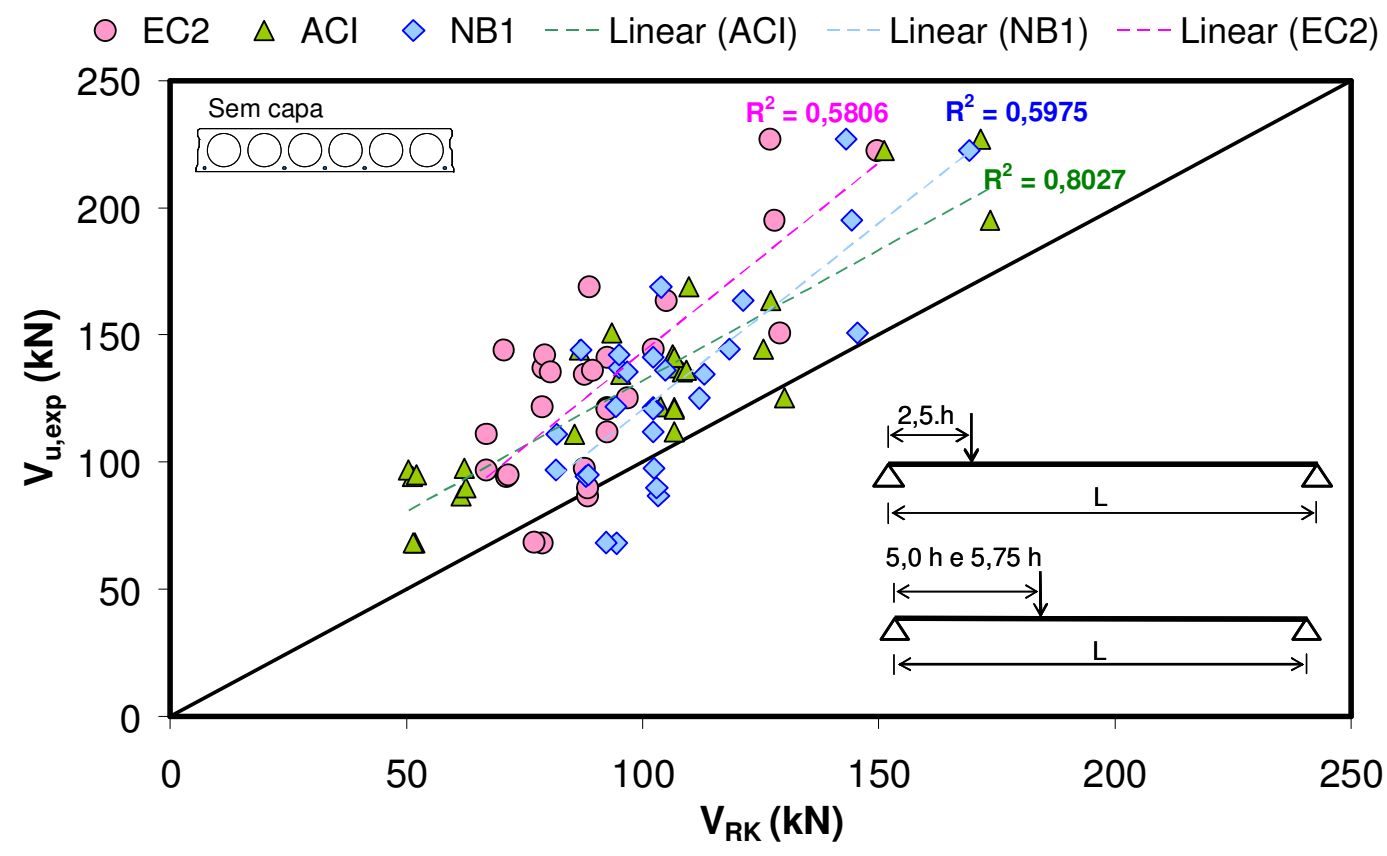

Figura 6.44: Relação entre $V_{u, e x p}$ e $V_{R k}$ considerando todas as peças sem capa estrutural, com indicação do ajuste dos dados a uma reta.

É importante observar que determinada equação pode representar melhor o comportamento de um tipo de laje do que outro, como é o caso da equação recomendada pela NBR 6118:2003, que forneceu resultados satisfatórios para as lajes brasileiras ensaiadas e, por sua vez, é criticada por não representar satisfatoriamente o comportamento de unidades utilizadas na Europa (que empregam concreto de maior resistência à compressão, com maiores alturas, menores níveis de protensão e com seções compostas por alvéolos mais ovais e trapezoidais). 
Então, como contribuição à revisão da norma brasileira NBR 14861, esta pesquisa sugere que os cálculos para determinar a resistência ao cisalhamento em zona fissurada por flexão para lajes sem capa sejam feitos considerando a equação recomendada pela NBR 6118:2003.

Para o caso de peças com aplicação de força a maiores distâncias, como $5 \mathrm{~h}$ do apoio, recomenda-se a verificação da interação de cisalhamento e flexão a partir do emprego da equação recomendada por Lindström (2009), a qual permite a identificação da máxima força cortante que pode atuar na seção sem que ocorra forte influência da flexão. 


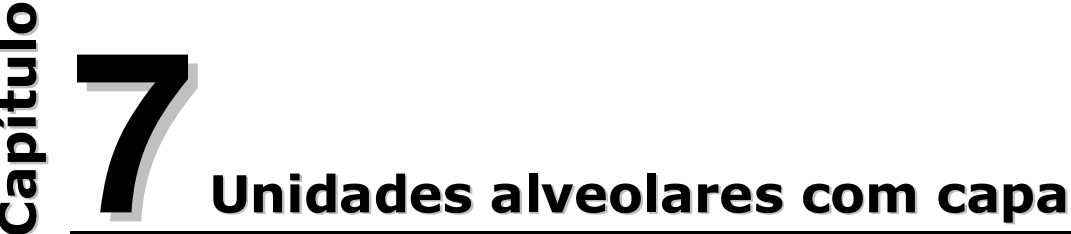

\subsection{RESULTADOS}

Os gráficos com os resultados dos ensaios ao cisalhamento e à flexão, para cada laje com capa, estão apresentados no Apêndice D. A seguir serão apresentados os valores últimos obtidos nos ensaios.

\subsubsection{Ensaios ao cisalhamento}

Os valores correspondentes a cortante última e momento fletor último, obtidos nos ensaios de cisalhamento, considerando o peso próprio dos modelos com capa, estão indicados na Tabela 7.1.

Tabela 7.1: Resultados para as lajes com capa ensaiadas ao cisalhamento.

\begin{tabular}{|c|c|c|}
\hline Laje & $\begin{array}{c}\mathrm{V}_{\mathrm{u}, \exp } \\
\mathbf{( k N )}\end{array}$ & $\begin{array}{c}\mathrm{M}_{\mathrm{u}, \exp } \\
\mathbf{( k N . m )}\end{array}$ \\
\hline L1-C-20-6D9,5-X_C & 95,01 & 47,50 \\
\hline L2-C-20-6D9,5-X_C & 118,17 & 59,08 \\
\hline L3-C-25-8D12,7-X_C & 215,89 & 134,93 \\
\hline L4-C-25-7D9,5-Y_C & 113,45 & 70,91 \\
\hline L5-C-25-7D9,5-Y_C & 125,25 & 78,28 \\
\hline L6-C-25-6D12,7-Y_C & 140,80 & 88,00 \\
\hline L7-C-25-7D9,5-Y_C & 118,35 & 73,97 \\
\hline L8-C-25-5D12,7-Z_C & 133,29 & 83,30 \\
\hline L9-C-25-5D12,7-Z_C & 125,33 & 78,33 \\
\hline L10-C-25-5D12,7-Z_C & 193,49 & 120,93 \\
\hline L11-C-25-5D12,7-Z_C & 193,23 & 120,77 \\
\hline L12-C-25-5D12,7-Z_C & 154,11 & 96,32 \\
\hline L13-CF-25-5D12,7-Z_C & 196,11 & 122,57 \\
\hline L14-CF-25-5D12,7-Z_C & 196,29 & 122,68 \\
\hline L15-CF-25-5D12,7-Z_C & 191,65 & 119,78 \\
\hline L16-CF-25-5D12,7-Z_C & 199,35 & 124,59 \\
\hline L17-CF-25-5D12,7-Z_C & 199,61 & 124,76 \\
\hline
\end{tabular}

Valores obtidos por meio dos ensaios acrescentando o peso próprio da laje

\subsubsection{Ensaios à flexão}

Os valores correspondentes ao momento fletor último e ao momento de fissuração obtidos nos ensaios à flexão, considerando o peso próprio da laje, estão indicados na Tabela 7.2 . 
Tabela 7.2: Resultados para as lajes com capa ensaiadas à flexão.

\begin{tabular}{|c|c|c|}
\hline Laje & $\begin{array}{c}\mathrm{M}_{\mathrm{u}, \exp } \\
(\mathbf{k N . m )}\end{array}$ & $\begin{array}{c}\mathrm{M}_{\mathrm{r}, \exp } \\
(\mathbf{k N . m )}\end{array}$ \\
\hline L1-C-20-6D9,5-X_F & 99,73 & 94,56 \\
\hline L2-C-20-6D9,5-X_F & 103,94 & 91,50 \\
\hline L3-C-25-8D12,7-X_F & 267,30 & 157,66 \\
\hline L4-C-25-5D12,7-Z_F & 184,73 & 127,81 \\
\hline L5-C-25-5D12,7-Z_F & 189,23 & 124,13 \\
\hline L6-C-25-5D12,7-Z_F & 181,96 & 135,68 \\
\hline L7-C-25-5D12,7-Z_F & 186,76 & 133,43 \\
\hline L8-C-25-5D12,7-Z_F & 184,73 & 127,81 \\
\hline L9-C-25-5D12,7-Z_F & 183,48 & 114,03 \\
\hline L10-CF-25-5D12,7-Z_F & 186,31 & 132,83 \\
\hline L11-CF-25-5D12,7-Z_F & 184,96 & 128,48 \\
\hline L12-CF-25-5D12,7-Z_F & 185,41 & 132,76 \\
\hline L13-CF-25-5D12,7-Z_F & 186,23 & 130,36 \\
\hline L14-CF-25-5D12,7-Z_F & 188,93 & 130,73 \\
\hline
\end{tabular}

\subsection{ANÁLISE DOS RESULTADOS}

A seguir serão apresentadas as análises dos resultados, com a comparação dos valores teóricos e experimentais, levando em conta os mecanismos resistentes observados em cada tipo de laje ensaiada. Assim como para as lajes sem a presença de capa, para interpretação dos resultados dos ensaios das lajes com capa serão considerados os critérios estabelecidos pela proposta da nova revisão da EN 1168:2005.

\subsubsection{Análise dos ensaios de cisalhamento}

Neste item serão comparados os resultados para as lajes com capa ensaiadas ao cisalhamento e, também, descritos seus mecanismos resistentes.

A comparação dos resultados experimentais e teóricos pode ser observada na Tabela 7.3, considerando o cisalhamento, e na Tabela 7.4, considerando a flexão.

Tabela 7.3: Resultados experimentais e teóricos, referentes ao cisalhamento, para as lajes com capa ensaiadas ao cisalhamento.

\begin{tabular}{|c|c|c|c|c|c|c|}
\hline Laje & $\begin{array}{c}\mathrm{V}_{\mathrm{u}, \exp } \\
\mathbf{( k N )}\end{array}$ & $\begin{array}{c}\mathrm{V}_{\mathrm{Rk}} \\
\mathbf{( k N )}\end{array}$ & $\begin{array}{c}\mathrm{V}_{\mathrm{u}, \exp } \\
\mathrm{V}_{\mathrm{Rk}}\end{array}$ & $\begin{array}{c}\mathrm{V}_{\mathrm{s}, \text { máx }} \\
\mathbf{( k N )}\end{array}$ & $\begin{array}{c}\text { Idade } \\
\text { laje } \\
\text { (dias) }\end{array}$ & $\begin{array}{c}\text { Idade } \\
\mathbf{c a p a} \\
\text { (dias) }\end{array}$ \\
\hline L1-C-20-6D9,5-X_C & 95,01 & 130,76 & 0,73 & 73,07 & 112 & 29 \\
\hline L2-C-20-6D9,5-X_C & 118,17 & 136,43 & 0,87 & 76,28 & 104 & 21 \\
\hline L3-C-25-8D12,7-X_C & 215,89 & 223,55 & 0,96 & 130,04 & 105 & 48 \\
\hline L4-C-25-7D9,5-Y_C & 113,45 & 114,62 & 0,99 & 64,35 & 328 & 7 \\
\hline L5-C-25-7D9,5-Y_C & 125,25 & 108,64 & 1,15 & 60,90 & 329 & 7 \\
\hline L6-C-25-6D12,7-Y_C & 140,80 & 137,40 & 1,02 & 78,85 & 329 & 7 \\
\hline L7-C-25-7D9,5-Y_C & 118,35 & 109,18 & 1,08 & 61,16 & 329 & 7 \\
\hline L8-C-25-5D12,7-Z_C & 133,29 & 124,94 & 1,07 & 71,44 & 10 & 8 \\
\hline L9-C-25-5D12,7-Z_C & 125,33 & 124,94 & 1,00 & 71,44 & 10 & 8 \\
\hline L10-C-25-5D12,7-Z_C & 193,49 & 124,94 & 1,55 & 71,44 & 10 & 8 \\
\hline L11-C-25-5D12,7-Z_C & 193,23 & 124,94 & 1,55 & 71,44 & 10 & 8 \\
\hline L12-C-25-5D12,7-Z_C & 154,11 & 124,94 & 1,23 & 71,44 & 10 & 8 \\
\hline L13-CF-25-5D12,7-Z_C & 196,11 & 124,94 & 1,57 & 71,44 & 10 & 8 \\
\hline L14-CF-25-5D12,7-Z_C & 196,29 & 124,94 & 1,57 & 71,44 & 10 & 8 \\
\hline L15-CF-25-5D12,7-Z_C & 191,65 & 124,94 & 1,53 & 71,44 & 10 & 8 \\
\hline L16-CF-25-5D12,7-Z_C & 199,35 & 124,94 & 1,59 & 71,44 & 10 & 8 \\
\hline L17-CF-25-5D12,7-Z_C & 199,61 & 124,94 & 1,60 & 71,44 & 10 & 8 \\
\hline
\end{tabular}


Tabela 7.4: Resultados experimentais e teóricos, referentes à flexão, para as lajes com capa ensaiadas ao cisalhamento.

\begin{tabular}{|c|c|c|c|c|c|c|}
\hline Laje & $\begin{array}{l}M_{\mathrm{u}, \exp } \\
\text { (kN.m) }\end{array}$ & $\begin{array}{c}M_{r} \\
\text { (kN.m) }\end{array}$ & $\begin{array}{c}M_{\mathrm{Rk}} \\
\text { (kN.m) }\end{array}$ & $\frac{M_{u, \exp }}{M_{R K}}$ & $\begin{array}{c}\text { Perdas } \\
\text { totais } \\
(\%)\end{array}$ & $\begin{array}{c}\mathrm{F}_{\mathrm{p} \text {, seção }} \\
(\mathbf{k N})\end{array}$ \\
\hline L1-C-20-6D9,5-X_C & & 92,82 & 94,04 & 0,50 & 13,83 & 408,44 \\
\hline L2-C-20-6D9,5-X_C & 59,08 & 92,57 & 93,95 & 0,63 & 13,85 & 408,34 \\
\hline L3-C-25-8D12,7-X_C & 134,93 & 210,31 & 282,34 & 0,48 & & 909,97 \\
\hline L4-C-25-7D9,5-Y_C & 70,91 & 126,59 & 140,33 & 0,50 & 18,07 & 430,13 \\
\hline L5-C-25-7D9,5-Y_C & & & & 0,55 & & \\
\hline L6-C-25-6D12,7-Y_C & 88,00 & 165,98 & 214,85 & 0,41 & 21 & 659,40 \\
\hline L7-C-25-7D9,5-Y_C & 73,97 & 126,77 & 139,45 & 0,53 & 71 & 432,00 \\
\hline L8-C-25-5D12,7-Z_C & 83,30 & 134,58 & 177,44 & 0,47 & 11,65 & 503,57 \\
\hline L9-C-25-5D12,7-Z_C & 78,33 & 134,58 & 177,44 & 0,44 & & 503,57 \\
\hline L10-C-25-5D12,7-Z_C & & & 177,44 & 0,68 & & \\
\hline L11-C-25-5D12,7-Z_C & 120,77 & 134,58 & 177,44 & 0,68 & & 503,57 \\
\hline L12-C-25-5D12,7-Z_C & & 134,58 & 177,44 & 0,54 & & 503,57 \\
\hline L13-CF-25-5D12,7-Z_C & 122,57 & 134,58 & 177,44 & 0,69 & 11,65 & 503,57 \\
\hline L14-CF-25-5D12,7-Z_C & 122,68 & 134,58 & 177,44 & 0,69 & 11,65 & 503,57 \\
\hline L15-CF-25-5D12,7-Z_C & 119,78 & 134,58 & 177,44 & 0,67 & 11,65 & 503,57 \\
\hline L16-CF-25-5D12,7-Z_C & 124,59 & 134,58 & 177,44 & 0,70 & 11,65 & 503,57 \\
\hline L17-CF-25-5D12,7-Z_C & 124,76 & 134,58 & 177,44 & 0,70 & 11,65 & 503,57 \\
\hline
\end{tabular}

Com a Tabela 7.3 é possível observar que a maior parte dos resultados experimentais foram coerentes com os obtidos por meio da equação recomendada da NBR 6118:2003, considerando a peça com capa estrutural.

Com a Tabela 7.3 é possível observar que algumas peças apresentaram baixa resistência ao cisalhamento (menor que a prevista teoricamente). Tal efeito permitiu constatar que essas lajes não trabalharam como seção composta.

Além disso, com os resultados (Tabela 7.3 e Tabela 7.4), observou-se que quando é empregada capa com concreto reforçado com fibras, tem-se um aumento significativo da resistência à força cortante e ao momento fletor, o que contribui para um melhor desempenho da laje.

De acordo com os gráficos da Figura 7.1, relativos a ensaios ao cisalhamento, a maioria das lajes com capa, pertencentes ao lote $X$, apresentaram valores experimentais inferiores aos previstos teoricamente. Somente a laje L3, a de maior altura $(25 \mathrm{~cm})$, apresentou a relação $V_{\exp } / V_{R k}$ equivalente a 0,96 , sendo aceitável para esse caso, de acordo com o critério da nova revisão da EN 1168:2005. Como esperado teoricamente, a laje com maior altura e maior área de armadura longitudinal apresentou resistência superior às das demais lajes.

Na Figura 7.2 é possível observar a fissuração da laje L1-C-20-6D9,5-X_C, que apresentou predominância do mecanismo de flexão, sendo observada a presença de fissura horizontal na interface laje-capa, configurando o descolamento da capa. As peças L1 e L2 apresentaram comportamento semelhante, sendo observado, em ambas, o descolamento da capa. 


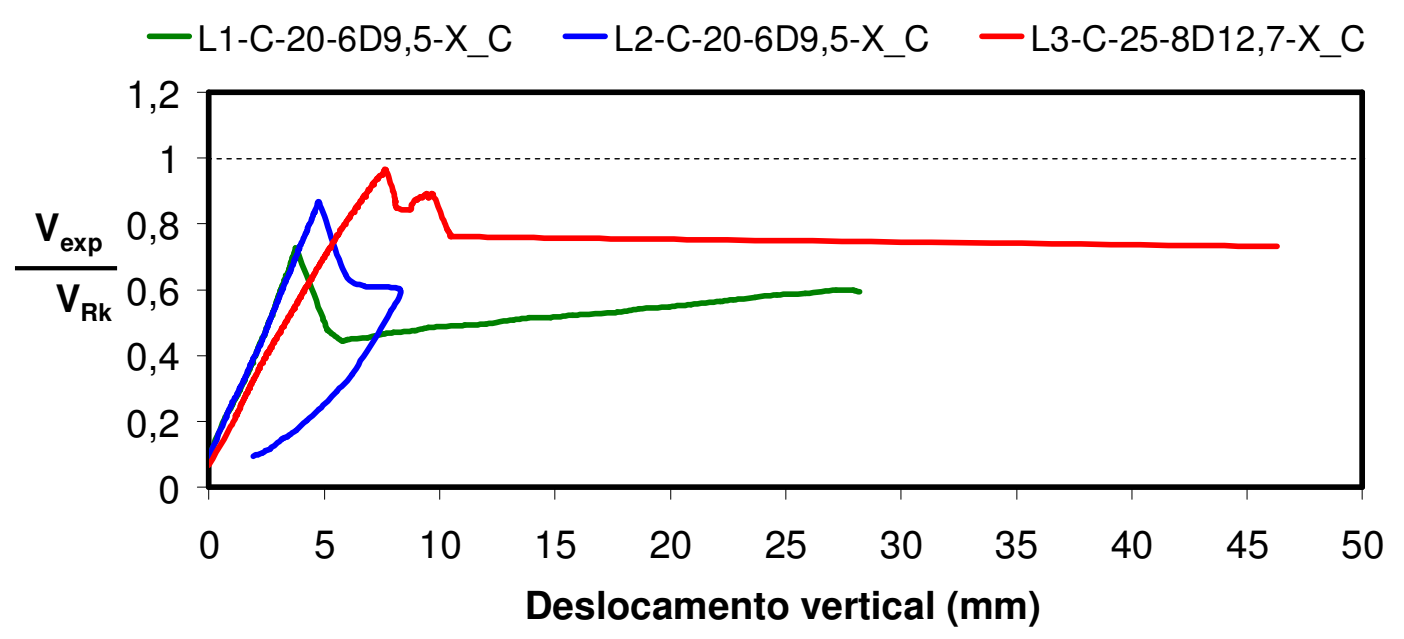

Figura 7.1: Gráficos $V_{\text {exp }} / V_{R k}$ versus deslocamento vertical para ensaios ao cisalhamento das lajes com capa pertencentes ao lote $X$.
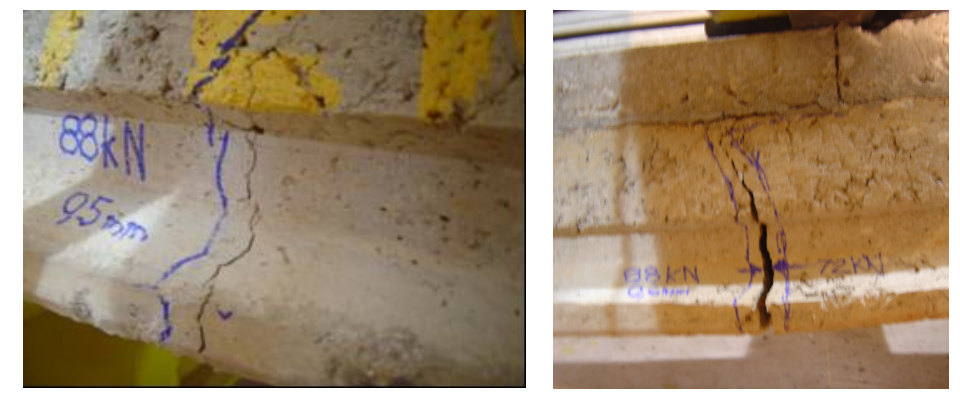

Figura 7.2: Configuração de fissuração da laje L1-C-20-6D9,5-X_C.

Na Figura 7.3, é possível observar a fissuração da laje L3-C-25-8D12,7-X_C, que apresentou, na ruína, predomínio de cisalhamento e fendilhamento com falha de ancoragem. Além disso, na Figura 7.3b é possível observar uma fissura ao longo da cordoalha de protensão, na face inferior da laje, evidenciando a perda da aderência da armadura ativa e o seu consequente escorregamento. Também se pode observar na Figura 7.3c o descolamento da capa e a fissuração acima do alvéolo.

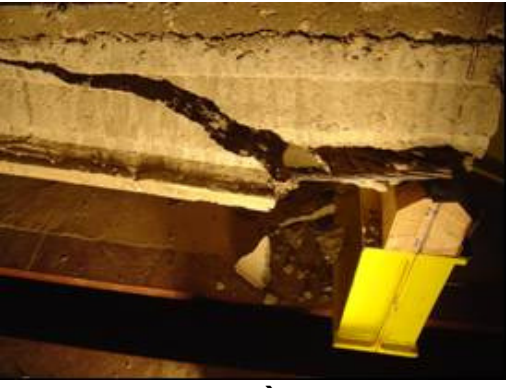

a)

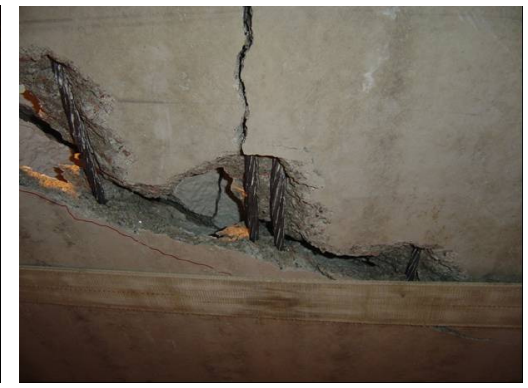

b)

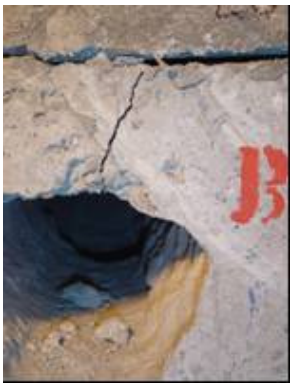

c)

Figura 7.3: Configuração de fissuração da laje L3-C-25-8D12,7-X_C. a) Fissuração na face oposta; b) Fissuração da face inferior; c) Vista da extremidade esquerda da laje. 
Na Figura 7.4 estão apresentados os resultados para as lajes com capa do lote $Y$ (altura total de $25 \mathrm{~cm}$ e comprimento de 4,15 m) com $6 \phi 12,7$ e $7 \phi 9,5$. Todas as lajes apresentaram resultados satisfatórios (com as relações $V_{\text {exp }} / V_{R k}$ superiores a 0,95).

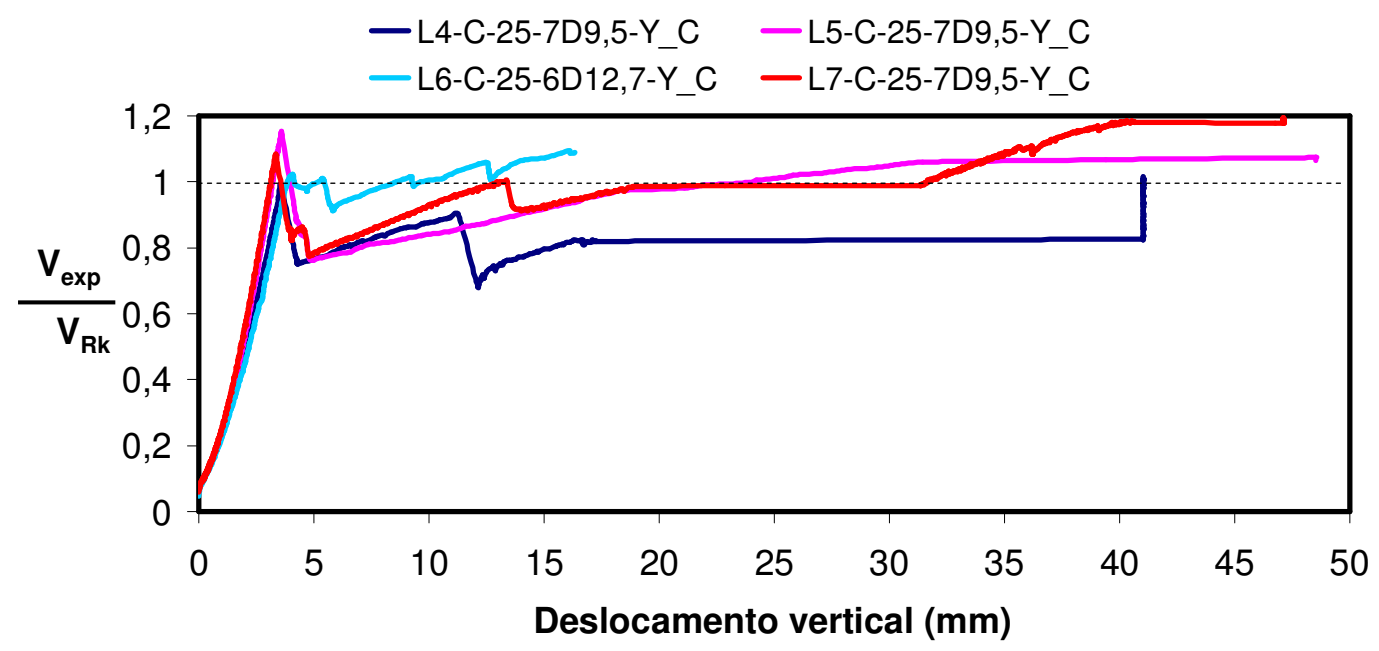

Figura 7.4: Gráficos $V_{\text {exp }} / V_{R k}$ versus deslocamento vertical para ensaios ao cisalhamento das lajes com capa e comprimento de cerca de $415 \mathrm{~cm}$, pertencentes ao lote $Y$.

As lajes L4-C-25-7D9,5-Y_C, L5-C-25-7D9,5-Y_C e L7-C-25-7D9,5-Y_C apresentaram comportamento muito semelhante, ilustrado na Figura 7.5, que mostra a fissuração da L5. Todas apresentaram fissuras de flexão com cisalhamento na face frontal e fissura de cisalhamento com efeito da flexão e falha de ancoragem na face oposta, ocorrendo, também, esmagamento na face superior das peças. Além disso, foi notado o descolamento da capa.

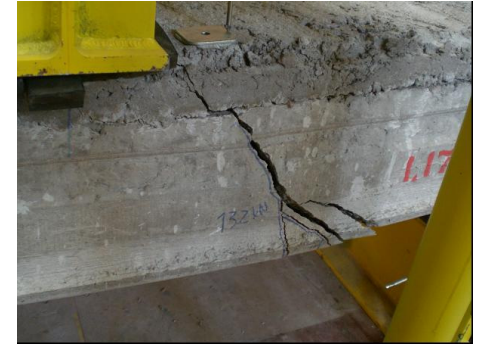

a)

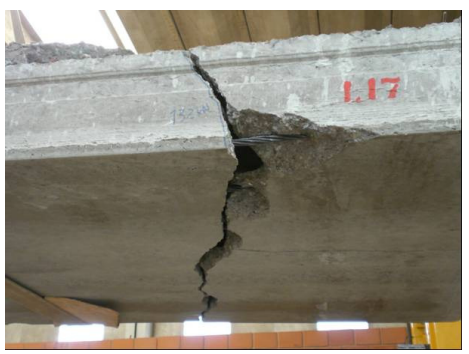

c)

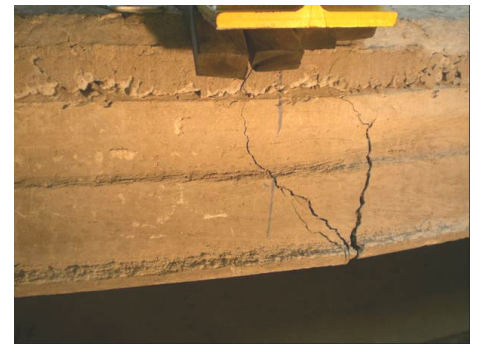

b)

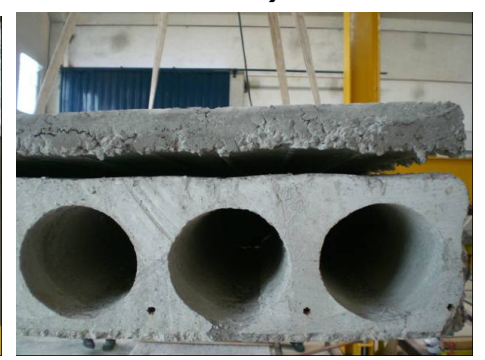

d)

Figura 7.5: Configuração da fissuração da laje L5-C-25-7D9,5-Y_C. a) Fissuração da face oposta; b) Fissuração da face frontal; c) Fissuração da face inferior; d) Descolamento da capa. 
Na L6-C-25-6D12,7-Y_C, no inicio apareceram fissuras de flexão com cisalhamento próximo ao ponto de aplicação da força. Na ruína, houve fissuração típica do mecanismo de cisalhamento, com fissuras inclinadas partindo do ponto de aplicação da força indo até o apoio (caracterizando ruptura por tração devida ao cisalhamento), sendo observado o descolamento da capa a partir da fissuração horizontal existente na intersecção da laje com a capa. A Figura 7.6 ilustra o comportamento dessa laje. Em região próxima ao ponto de aplicação da força também ocorreu esmagamento da borda superior da peça.
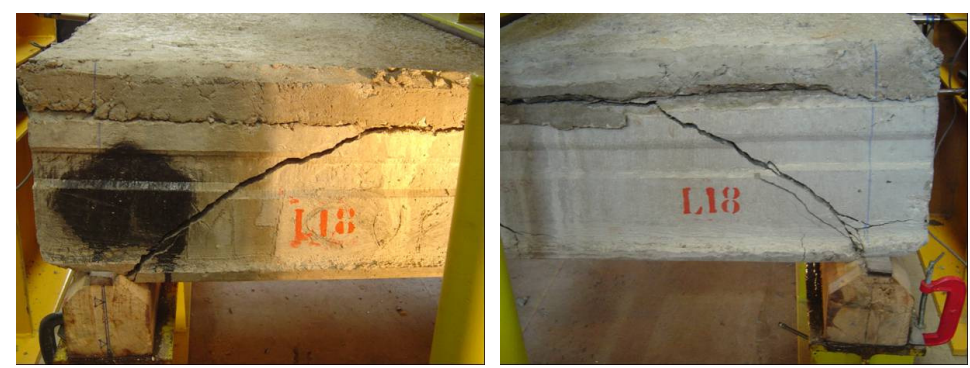

Figura 7.6: Fissuração da laje L6-C-25-6D12,7-Y_C.

A Figura 7.7 permite comparar os resultados experimentais com os teóricos para as lajes com capa e tela, pertencentes ao lote $Z$. A partir dos gráficos indicados nessa figura, é possível observar que todas as lajes com capa e tela apresentaram resultados satisfatórios, sendo os valores experimentais superiores aos previstos teoricamente.

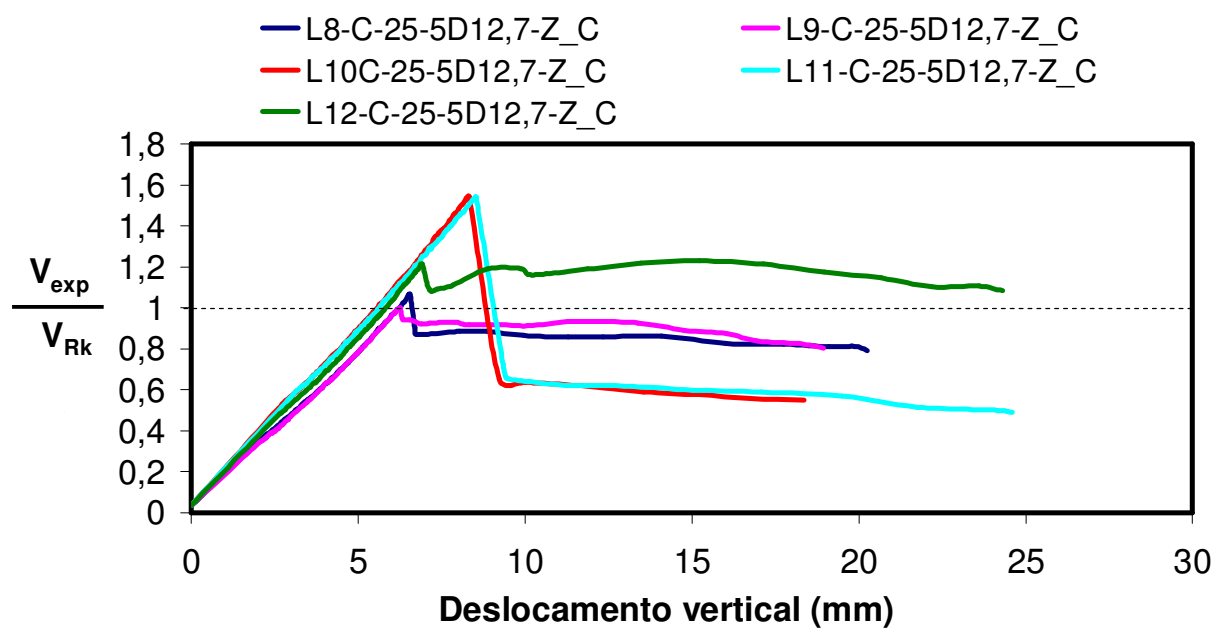

Figura 7.7: Gráficos $V_{\text {exp }} / V_{R k}$ versus deslocamento vertical para ensaios ao cisalhamento das lajes com capa e tela, 5 \$ 12,7 e comprimento de $310 \mathrm{~cm}$, pertencentes ao lote $Z$.

É importante ressaltar que nas lajes provenientes da empresa $Z$ foram realizadas ranhuras longitudinais, tornando a superfície rugosa, e realizou-se a limpeza da superfície, com água, antes da execução da capa de concreto moldado no local. 
A Figura 7.8 apresenta vista lateral e inferior de uma das lajes ensaiadas, com capa de concreto e tela. Na Figura 7.8a é possível observar a interação dos mecanismos de cisalhamento e flexão, com escorregamento das cordoalhas e esmagamento da borda superior da peça. Em uma das lajes com capa e tela, além da combinação de flexão e cisalhamento, também foi observada a presença da torção.

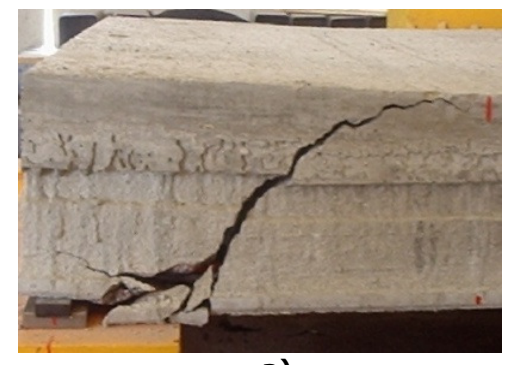

a)

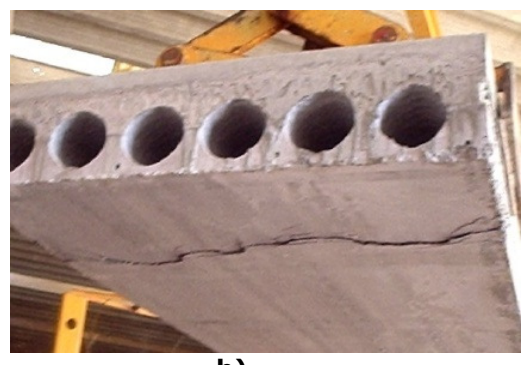

b)

Figura 7.8: Exemplo de configuração de fissuração de laje com capa, do lote $Z$. a)Vista lateral; b) Vista inferior.

Na Figura 7.9 estão apresentadas as comparações entre os resultados experimentais e os teóricos, das lajes com capa de concreto reforçado com fibras. Nessa figura é possível observar que todas as lajes com capa de concreto reforçado com fibras apresentaram valores experimentais bem superiores aos previstos teoricamente.

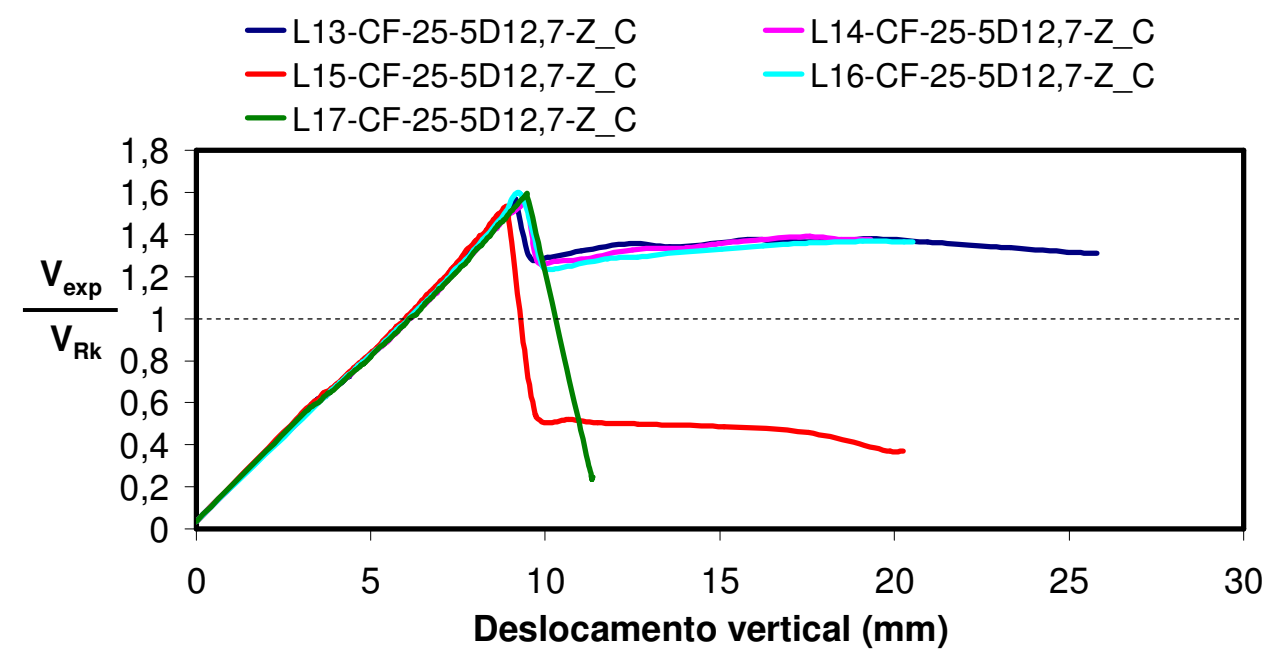

Figura 7.9: Gráficos $V_{\text {exp }} / V_{R k}$ versus deslocamento vertical para ensaios ao cisalhamento das lajes com capa de concreto reforçado com fibras, $5 \phi 12,7$ e comprimento de $310 \mathrm{~cm}$, do lote $Z$.

A Figura 7.10 mostra vistas lateral e inferior de uma das lajes ensaiadas, com capeamento de concreto reforçado com fibras. A configuração da fissuração dessa laje apresenta a interação de cisalhamento e flexão, com efeito de torção e de esmagamento na borda superior. 


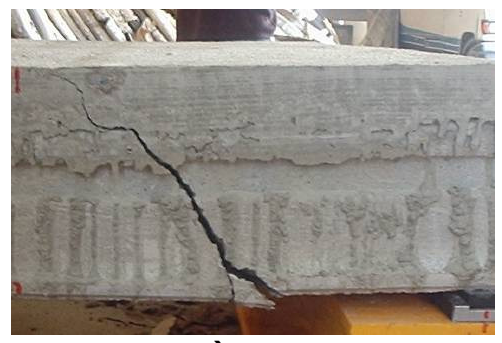

a)

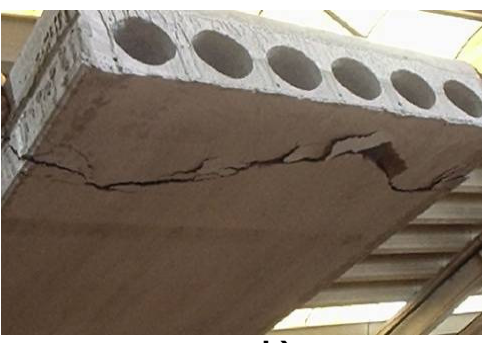

b)

Figura 7.10: Exemplo de configuração de fissuração de laje com capa de concreto reforçado com fibras, proveniente do lote $Z$. a)Vista lateral; b) Vista inferior.

\subsubsection{Considerações sobre lajes com capa ensaiadas ao cisalhamento}

Para melhor comparação entre os resultados, determinou-se a resistência média ao cisalhamento para cada tipo de laje ensaiada, como ilustrado na Tabela 7.5.

Tabela 7.5: Resistência média ao cisalhamento das lajes com capa.

\begin{tabular}{|c|c|c|c|c|c|c|c|}
\hline Descrição & Laje & $\begin{array}{l}\mathrm{V}_{\mathrm{u}, \exp } \\
(\mathbf{k N})\end{array}$ & $\begin{array}{l}\mathrm{V}_{\mathrm{u}, \exp , \mathrm{m}} \\
(\mathbf{k N})\end{array}$ & $\begin{array}{l}\mathrm{V}_{\mathrm{Rk}} \\
(\mathbf{k N})\end{array}$ & $\begin{array}{l}\mathrm{V}_{\mathrm{Rk}, \mathrm{m}} \\
(\mathbf{k N})\end{array}$ & $\frac{V_{\mathrm{u}, \exp , \mathrm{m}}}{\mathrm{V}_{\mathrm{Rk}, \mathrm{m}}}$ & $\begin{array}{l}\text { Mecanismos } \\
\text { presentes na } \\
\text { ruptura }\end{array}$ \\
\hline \multirow{2}{*}{$\begin{array}{c}\text { Com capa, } 6 \phi 9,5, \\
\mathrm{~h}_{\text {total }}=20 \mathrm{~cm}, \mathrm{~L}=6,5 \mathrm{~m} . . \\
\sigma_{\mathrm{pi}}=1423,42 \mathrm{MPa} . \underline{\mathrm{UST}} \\
\left(\mathrm{L}-\mathrm{C}-20-6 \mathrm{D} 9,5-\mathrm{X} \_\mathrm{C}\right)\end{array}$} & L1 & 95,01 & \multirow{2}{*}{106,59} & 130,76 & \multirow{2}{*}{133,59} & \multirow{2}{*}{0,80} & \multirow{2}{*}{$\begin{array}{c}\text { Cis. com forte } \\
\text { influência de FI. } \\
\text { Descolamento capa } \\
\end{array}$} \\
\hline & L2 & 118,17 & & 136,43 & & & \\
\hline $\begin{array}{c}\text { Com capa, } 8 \phi 12,7 \text {, } \\
\mathrm{h}_{\text {total }}=25 \mathrm{~cm}, \mathrm{~L}=6,5 \mathrm{~m} . \\
\sigma_{\mathrm{pi}}=1425,05 \mathrm{MPa} . \underline{\mathrm{UST}} \\
(\mathrm{L}-\mathrm{C}-25-8 \mathrm{D} 12,7-\mathrm{X}=\mathrm{C})\end{array}$ & L3 & 215,89 & ----- & 223,55 & ------ & 0,97 & $\begin{array}{l}\begin{array}{c}\text { Predomínio de Cis. } \\
\text { e FA }\end{array} \\
\text { Descolamento capa } \\
\end{array}$ \\
\hline $\begin{array}{c}\text { Com capa, } 6 \phi 12,7 \\
\mathrm{~h}_{\text {total }}=25 \mathrm{~cm}, \mathrm{~L}=4,15 \mathrm{~m} . \\
\sigma_{\mathrm{p}}=1429,98 \mathrm{MPa} . \underline{\mathrm{UST}} \\
\left(\mathrm{L}-\mathrm{C}-25-6 \mathrm{D} 12,7-\mathrm{Y} \_\mathrm{C}\right)\end{array}$ & L6 & 140,80 & ---- & 137,40 & ------ & 1,02 & $\begin{array}{l}\text { Predomínio de Cis. } \\
\text { Descolamento capa }\end{array}$ \\
\hline \multirow{3}{*}{$\begin{array}{c}\text { Com capa, } 7 \phi 9,5, \\
\mathrm{~h}_{\text {total }}=25 \mathrm{~cm}, \mathrm{~L}=4,15 \mathrm{~m} . \\
\sigma_{\mathrm{pi}}=1351,35 \mathrm{MPa} \text {. UST } \\
\left(\mathrm{L}-\mathrm{C}-25-7 \mathrm{D} 9,5-\mathrm{Y} \_\mathrm{C}\right)\end{array}$} & L4 & 113,45 & \multirow{3}{*}{119,02} & 114,62 & \multirow{3}{*}{110,81} & \multirow{3}{*}{1,07} & \multirow{3}{*}{$\begin{array}{l}\text { Cis. FI. FA. e EBS } \\
\text { Descolamento capa }\end{array}$} \\
\hline & L5 & 125,25 & & 108,64 & & & \\
\hline & L7 & 118,35 & & 109,18 & & & \\
\hline \multirow{5}{*}{$\begin{array}{c}\text { Com capa e tela, } 5 \phi \\
12,7, h_{\text {total }}=25 \mathrm{~cm}, \\
L=3,10 \mathrm{~m} . \\
\sigma_{\mathrm{pi}}=1140 \mathrm{MPa} . \underline{\mathrm{UCT}} \\
\left(\mathrm{L}-\mathrm{C}-25-5 \mathrm{D} 12,7-\mathrm{Z}_{-} \mathrm{C}\right)\end{array}$} & L8 & 133,29 & \multirow{5}{*}{159,89} & 124,94 & \multirow{5}{*}{124,94} & \multirow{5}{*}{1,28} & Cis. Fl.e FA e EBS \\
\hline & L9 & 125,33 & & 124,94 & & & Cis. FI. Tor. e EBS \\
\hline & L10 & 193,49 & & 124,94 & & & Predomínio de Cis. \\
\hline & L11 & 193,23 & & 124,94 & & & e EBS \\
\hline & L12 & 154,11 & & 124,94 & & & Cis. FI. FA e EBS \\
\hline \multirow{5}{*}{$\begin{array}{c}\text { Com capa e fibra, } 5 \phi \\
12,7, h_{\text {total }}=25 \mathrm{~cm}, \\
L=3,10 \mathrm{~m} . \\
\sigma_{\text {pi }}=1140 \mathrm{MPa} . \mathrm{UCT} \\
\left(\mathrm{L}-\mathrm{CF}-25-5 \mathrm{D} 12,7-\mathrm{Z}_{-} \mathrm{C}\right)\end{array}$} & L13 & 196,11 & \multirow{5}{*}{196,60} & 124,94 & \multirow{5}{*}{124,94} & \multirow{5}{*}{1,57} & \multirow{2}{*}{ Cis. FI. FA e EBS } \\
\hline & L14 & 196,29 & & 124,94 & & & \\
\hline & L15 & 191,65 & & 124,94 & & & $\begin{array}{l}\text { Predomínio de Cis. } \\
\text { com FI. Tor. e EBS }\end{array}$ \\
\hline & L16 & 199,35 & & 124,94 & & & Cis. FI. FA e EBS \\
\hline & L17 & 199,61 & & 124,94 & & & $\begin{array}{c}\text { Predomínio de Cis. } \\
\text { e EBS }\end{array}$ \\
\hline
\end{tabular}

Cis.: cisalhamento. Fl.: flexão; Tor.: torção; FA: falha de ancoragem. EBS: esmagamento da borda superior. 
Por meio dos resultados e da análise dos mecanismos resistentes, fica clara a influência da aderência laje-capa no bom desempenho da peça. As unidades do lote $Z$, apesar de possuírem menores níveis de protensão e menores comprimentos, apresentaram maiores resistências ao cisalhamento e à flexão, em relação aos respectivos valores previstos teoricamente (maiores relações $V_{u \text {,exp }} / V_{R k}$ e $M_{u, \exp } / M_{R k}$ ).

Vale ressaltar que nas peças do lote $Z$ foi realizado um tratamento da face superior da laje, como descrito anteriormente, que garantiu boa aderência entre a laje e a capa. Nos ensaios de tais unidades, não houve o descolamento da capa, sendo observado que a fissura se estendeu através da interface, diferentemente das peças sem qualquer tratamento, que apresentaram fissuras horizontais na interface, as quais se ampliaram consideravelmente até o descolamento da capa.

Nas peças do lote $X$, foi observado o descolamento prematuro da capa, o que prejudicou, e muito, o desempenho das unidades. Estas apresentaram forte influência da flexão, uma vez que, devido à má aderência laje-capa, trabalharam como peças de seções simples, porém submetidas a maiores momentos fletores, devido à aplicação da força a uma distância superior à das peças sem capa (distância do apoio de 2,5 h, sendo h a altura total). Assim, como as solicitações nas unidades não foram resistidas por seções compostas, as elevadas flexões, nas então seções simples, permitiram o aparecimento de fissuras que prejudicaram a resistência das unidades ao cisalhamento.

De uma forma geral, nos casos das lajes com capa (com tela e com fibra metálica), considerando as peças com boa aderência laje-capa, observou-se que os resultados experimentais foram bem superiores aos estimados teoricamente. Acredita-se que este fato ocorreu devido à mudança de mecanismo de ruptura por causa do aumento da altura da laje, ficando mais próximo ao mecanismo de ruptura por cisalhamento puro, em que a tensão principal de tração na nervura excede a resistência do concreto à tração. Entretanto, observa-se que, se por um lado a capacidade resistente ao cisalhamento tenha aumentado, houve uma redução da ductilidade da peça.

Da mesma forma que para as peças sem capa, observou-se, nas peças com capa, a maior influência da flexão em elementos de menores alturas, como é o caso das lajes de $20 \mathrm{~cm}$ (sendo $15 \mathrm{~cm}$ a altura da laje e $5 \mathrm{~cm}$ a da capa). As peças de alturas menores apresentaram comportamentos diferenciados daquelas com alturas maiores, sendo evidente a forte influência do mecanismo de flexão.

\subsubsection{Análise dos ensaios de flexão}

Neste item serão comparados os resultados para as lajes com capa ensaiadas à flexão e, também, descritos seus mecanismos resistentes. Os resultados experimentais juntamente com os teóricos podem ser observados na Tabela 7.6. 
Tabela 7.6: Resultados experimentais e teóricos para as lajes com capa ensaiadas à flexão.

\begin{tabular}{|c|c|c|c|c|c|c|c|}
\hline Laje & $\begin{array}{l}M_{\mathrm{u}, \exp } \\
\text { (kN.m) }\end{array}$ & $\begin{array}{c}M_{\mathrm{Rk}} \\
\text { (kN.m) }\end{array}$ & $\frac{M_{u, \exp }}{M_{R k}}$ & $\begin{array}{l}M_{r, \exp } \\
\text { (kN.m) }\end{array}$ & $\begin{array}{c}M_{r} \\
\text { (kN.m) }\end{array}$ & $\begin{array}{l}\text { Idade } \\
\text { laje } \\
\text { (dias) }\end{array}$ & $\begin{array}{c}\text { Idade } \\
\text { capa } \\
\text { (dias) }\end{array}$ \\
\hline L1-C-20-6D9,5-X_F & 99,73 & 93,99 & 1,06 & 94,56 & 93,71 & 105 & 22 \\
\hline L2-C-20-6D9,5-X_F & 103,94 & 92,21 & 1,13 & 91,50 & 91,91 & 112 & 29 \\
\hline L3-C-25-8D12,7-X_F & 267,30 & 282,45 & 0,95 & 157,66 & 213,75 & 107 & 50 \\
\hline L4-C-25-5D12,7-Z_F & 184,73 & 177,44 & 1,04 & 127,81 & 134,76 & 10 & 8 \\
\hline L5-C-25-5D12,7-Z_F & 189,23 & 177,44 & 1,07 & 124,13 & 134,76 & 10 & 8 \\
\hline L6-C-25-5D12,7-Z_F & 181,96 & 177,44 & 1,02 & 135,68 & 134,76 & 10 & 8 \\
\hline L7-C-25-5D12,7-Z_F & 186,76 & 177,44 & 1,05 & 133,43 & 134,76 & 10 & 8 \\
\hline L8-C-25-5D12,7-Z_F & 184,73 & 177,44 & 1,04 & 127,81 & 134,76 & 10 & 8 \\
\hline L9-C-25-5D12,7-Z_F & 183,48 & 177,47 & 1,03 & 114,03 & 136,28 & 10 & 8 \\
\hline L10-CF-25-5D12,7-Z_F & 186,31 & 177,44 & 1,05 & 132,83 & 134,76 & 10 & 8 \\
\hline L11-CF-25-5D12,7-Z_F & 184,96 & 177,44 & 1,04 & 128,48 & 134,76 & 10 & 8 \\
\hline L12-CF-25-5D12,7-Z_F & 185,41 & 177,44 & 1,04 & 132,76 & 134,76 & 10 & 8 \\
\hline L13-CF-25-5D12,7-Z_F & 186,23 & 177,44 & 1,05 & 130,36 & 134,76 & 10 & 8 \\
\hline L14-CF-25-5D12,7-Z_F & 188,93 & 177,44 & 1,06 & 130,73 & 134,76 & 10 & 8 \\
\hline
\end{tabular}

A partir da Tabela 7.6 é possível observar que todas as peças com capa apresentaram bom desempenho à flexão.

Na Figura 7.11 é possível observar os resultados para as lajes com capa pertencentes ao lote $\mathrm{X}$, com variações quanto à altura e a área de armadura.

As lajes com $15 \mathrm{~cm}$ de altura (altura total de $20 \mathrm{~cm}$ ) e 6 9 9,5 (L1_X e L2_X) apresentaram comportamentos semelhantes e valores superiores aos obtidos teoricamente. A laje com altura de $20 \mathrm{~cm}$ (totalizando $25 \mathrm{~cm}$ com a presença da capa) e 8 \& 12,7 (L3_X) apresentou resistência inferior ao esperado, sendo observado o descolamento da capa, próximo a ruptura da peça. Da mesma forma que para as lajes sem capa, a laje com capa de maior altura apresentou um comportamento mais dúctil (considerando flexão) com relação às de altura menores.

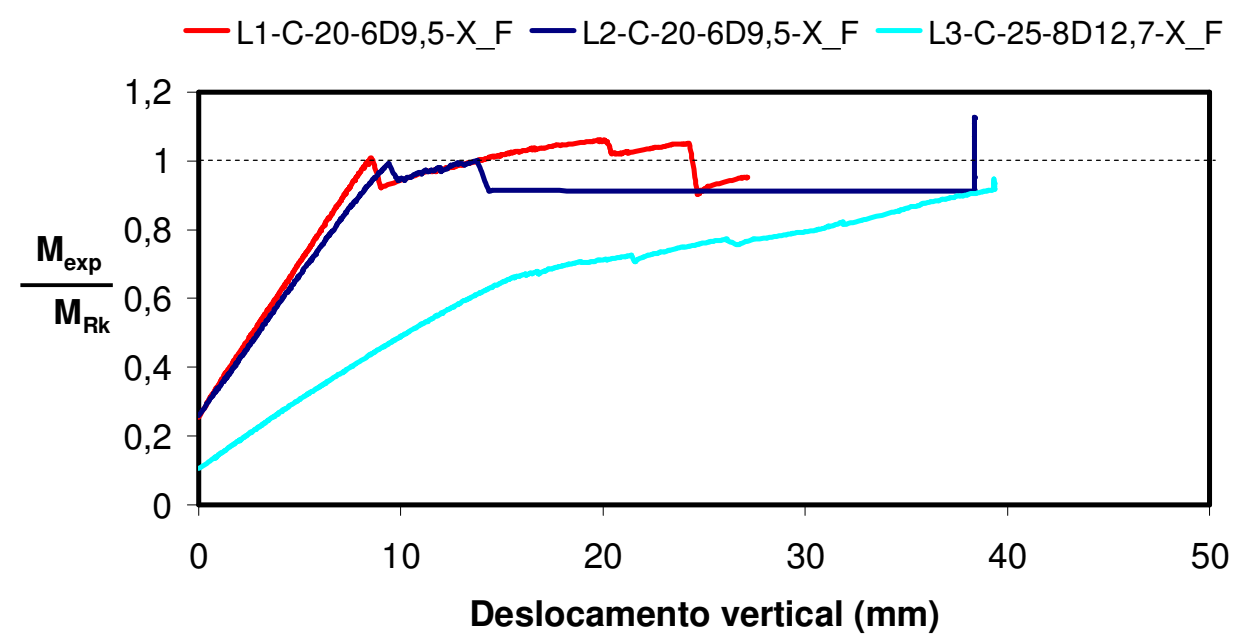

Figura 7.11: Gráficos $M_{\exp } / M_{R k}$ versus deslocamento vertical obtidos nos dos ensaios das lajes com capa, com 8 12,7 e $6 \phi 9,5$, pertencentes ao lote $X$. 
$\mathrm{Na}$ Figura 7.12a é possível observar a fissuração da face lateral da laje L2-C-20-6D9,5-X_F, e na Figura 7.12b e c, o descolamento da capa ocorrido durante o ensaio de flexão.

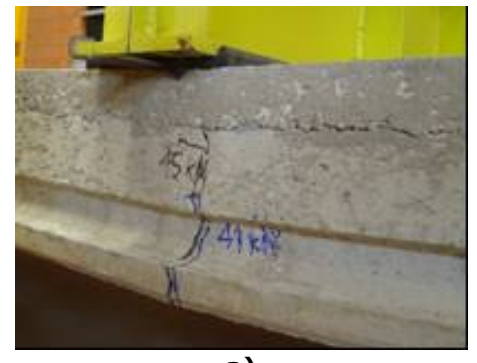

a)

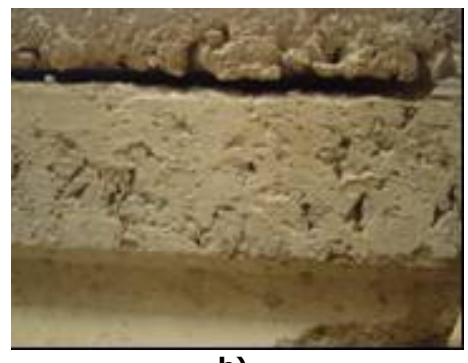

b)

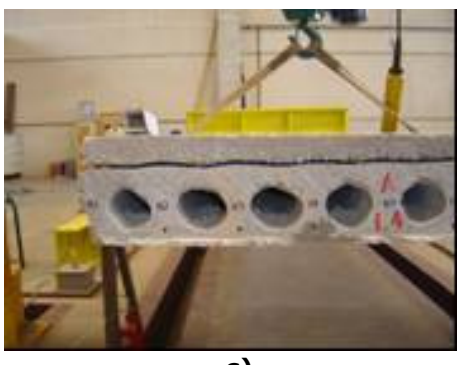

c)

Figura 7.12: Configuração de fissuração da laje L2-C-20-6D9,5-X_F. a) Face lateral; b) Descolamento da capa (vista lateral); c) Descolamento da capa (seção transversal).

Na Figura 7.13 é possível observar os gráficos de $M_{\exp } / M_{R k}$ versus deslocamento vertical para as lajes com capa e tela, pertencentes ao lote $\mathbf{Z}$.

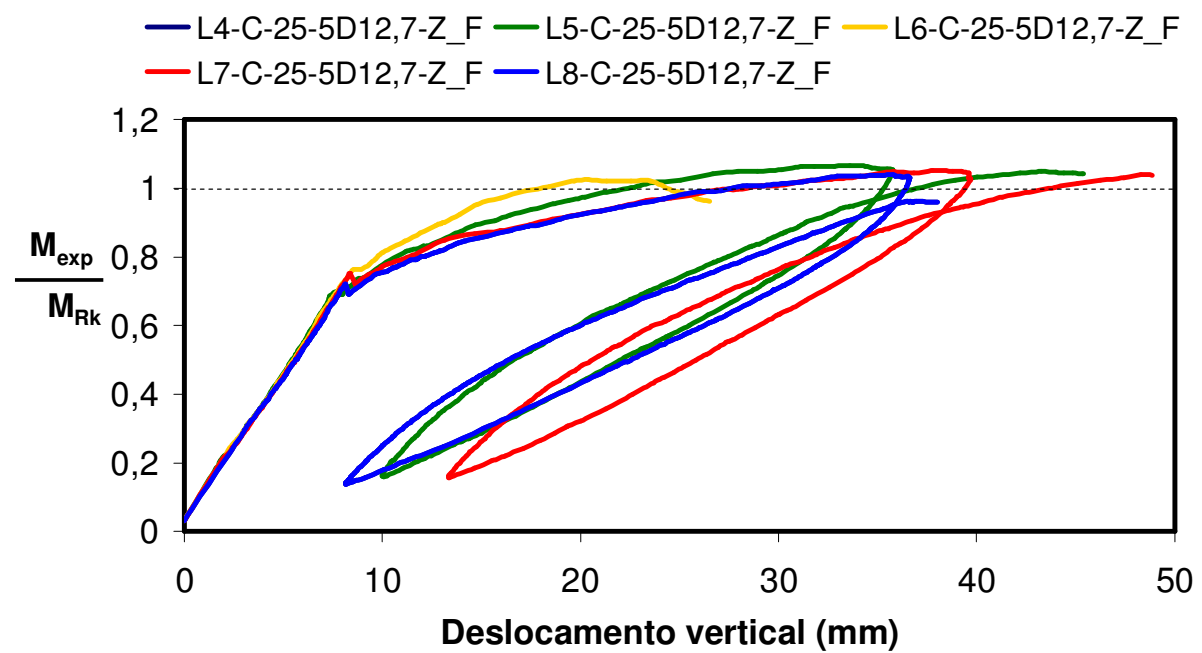

Figura 7.13: Gráficos $M_{\text {exp }} / M_{R k}$ versus deslocamento vertical obtidos nos ensaios das lajes com capa e tela, com $5 \phi 12,7$ e $310 \mathrm{~cm}$ de comprimento, pertencentes ao lote $Z$.

Com esses gráficos, é possível observar que todas as lajes apresentaram valores experimentais superiores aos previstos teoricamente.

Também foi realizado ensaio à flexão em uma laje com capa e tela, de vão igual a 6,0 m. Da mesma forma que para a laje sem capa, essa laje com capa e tela apresentou resultado experimental satisfatório, como pode ser observado na Figura 7.14.

Na Figura 7.15 é possível observar a comparação entre os resultados teóricos e experimentais para as unidades de laje com capa de concreto reforçado com fibras. A partir desses resultados é possível observar que todas as peças apresentaram resultados satisfatórios, com os valores experimentais superiores aos previstos. 


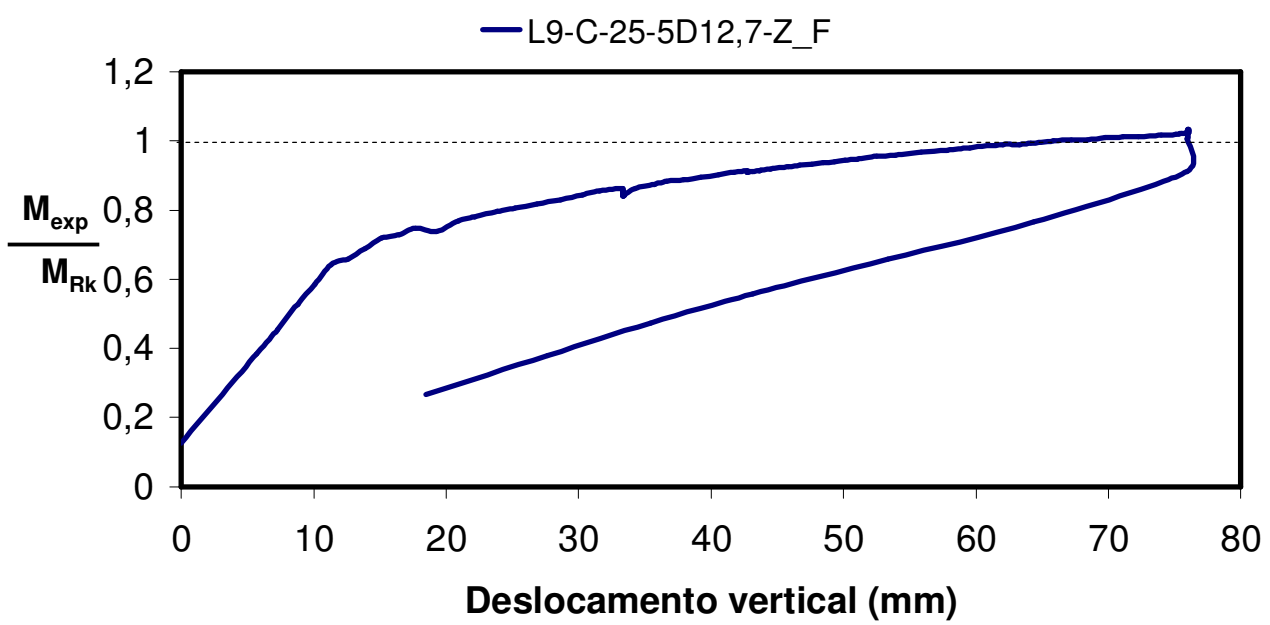

Figura 7.14: Gráfico $M_{\exp } / M_{R k}$ versus deslocamento vertical obtido no ensaio da laje com capa e tela, com $5 \phi 12,7$ e $600 \mathrm{~cm}$ de comprimento, pertencente ao lote $Z$.

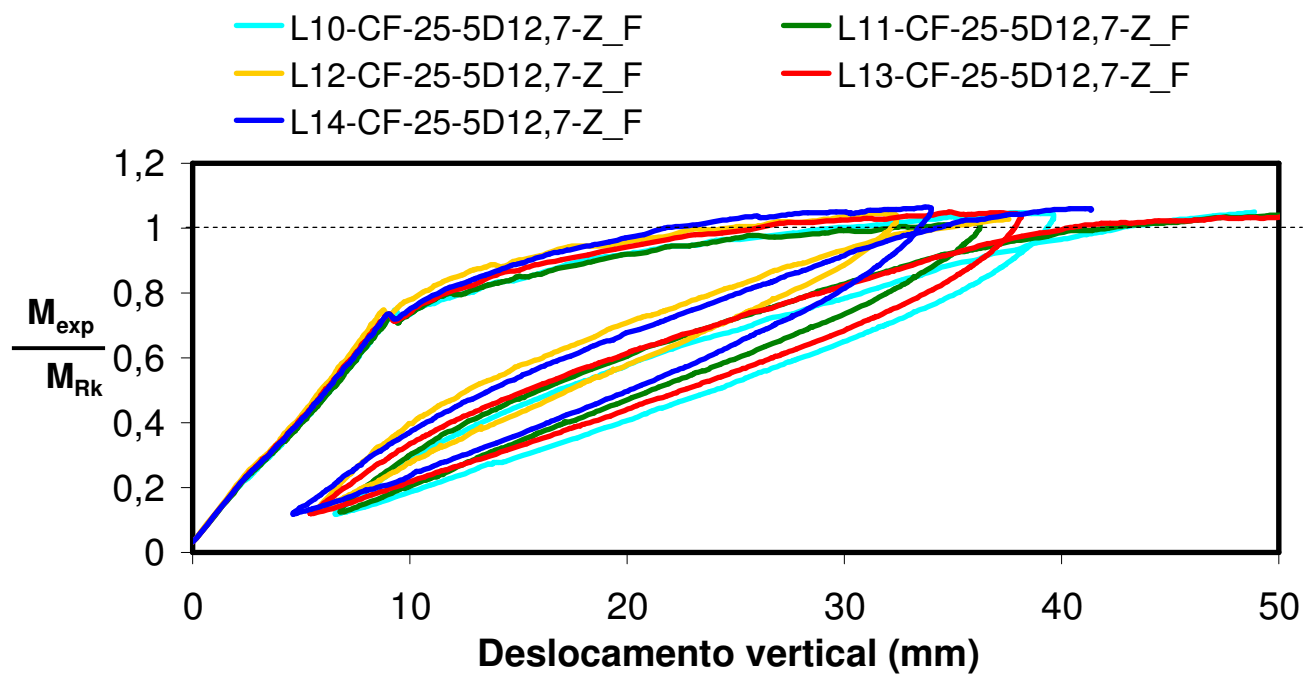

Figura 7.15: Gráficos $M_{\text {exp }} / M_{R k}$ versus deslocamento vertical obtidos nos ensaios das lajes com capa de concreto reforçado com fibra, com $5 \phi 12,7$ e $310 \mathrm{~cm}$ de comprimento, do lote $Z$.

\subsubsection{Considerações sobre as lajes com capa ensaiadas à flexão}

Para melhor comparação dos resultados, foram determinadas as resistências médias à flexão para cada tipo de laje com capa de concreto (Tabela 7.7).

De uma forma geral, todas as peças com capa ensaiadas à flexão apresentaram bons resultados, sendo possível observar que a presença da capa, com boa aderência, contribui para o aumento da capacidade resistente à flexão, das lajes alveolares protendidas.

Para as lajes pertencentes ao lote $X$, em alguns casos, foi observado o descolamento da capa. Entretanto, como isso ocorreu próximo à ruptura da laje, a capa contribuiu para aumentar a capacidade resistente da unidade à flexão. 
Tabela 7.7: Resistência média à flexão das lajes com capa.

\begin{tabular}{|c|c|c|c|c|c|c|c|}
\hline Descrição & Laje & $\begin{array}{l}M_{\mathrm{u}, \exp } \\
(\mathbf{k N} \cdot \mathbf{m})\end{array}$ & $\begin{array}{l}\mathrm{M}_{\mathrm{u}, \mathrm{exp}, \mathrm{m}} \\
(\mathbf{k N} \mathbf{m})\end{array}$ & $\begin{array}{c}\mathrm{M}_{\mathrm{Rk}} \\
\text { (kN.m) }\end{array}$ & $\begin{array}{l}M_{R k, m} \\
(\mathbf{k N} \cdot \mathbf{m})\end{array}$ & $\frac{M_{\mathrm{u}, \mathrm{exp}, \mathrm{m}}}{\mathrm{M}_{\mathrm{Rk}, \mathrm{m}}}$ & $\begin{array}{l}\text { Mecanismos } \\
\text { presentes na } \\
\text { ruptura }\end{array}$ \\
\hline \multirow{2}{*}{$\begin{array}{c}\text { Com capa, } 6 \phi 9,5, \\
\mathrm{~h}_{\text {total }}=20 \mathrm{~cm}, \mathrm{~L}=6,5 \mathrm{~m} . \\
\sigma_{\mathrm{pi}}=1423,42 \mathrm{MPa} . \underline{\mathrm{UST}} \\
(\mathrm{L}-\mathrm{C}-20-6 \mathrm{D} 9,5-\mathrm{X} \text { F })\end{array}$} & L1 & 99,73 & \multirow{2}{*}{101,83} & 93,99 & \multirow{2}{*}{93,10} & \multirow{2}{*}{1,09} & Flexão \\
\hline & L2 & 103,94 & & 92,21 & & & $\frac{\text { Descolamento }}{\text { capa }}$ \\
\hline $\begin{array}{c}\text { Com capa, } 8 \phi 12,7, \\
\mathrm{~h}_{\text {total }}=25 \mathrm{~cm}, \mathrm{~L}=6,5 \mathrm{~m} . \\
\sigma_{\mathrm{pi}}=1425,05 \mathrm{MPa} . \underline{\mathrm{UST}} \\
\left(\mathrm{L}-\mathrm{C}-25-8 \mathrm{D} 12,7-\mathrm{X} \_\mathrm{F}\right)\end{array}$ & L3 & 267,30 & ----- & 282,45 & ----- & 0,95 & $\begin{array}{c}\text { Flexão } \\
\frac{\text { Descolamento }}{\underline{\text { capa }}}\end{array}$ \\
\hline \multirow{5}{*}{$\begin{array}{c}\text { Capa e tela, } 5 \phi 12,7 \\
\mathrm{~h}_{\text {total }}=25 \mathrm{~cm}, \mathrm{~L}=3,10 \mathrm{~m} . \\
\sigma_{\mathrm{pi}}=1140 \mathrm{MPa} . \underline{\mathrm{UCT}} \\
\left(\mathrm{L}-\mathrm{C}-25-5 \mathrm{D} 12,7-\mathrm{Z}_{-} \mathrm{F}\right)\end{array}$} & L4 & 184,73 & \multirow{5}{*}{185,48} & 177,44 & \multirow{5}{*}{177,44} & \multirow{5}{*}{1,04} & \multirow{5}{*}{ Flexão } \\
\hline & L5 & 189,23 & & 177,44 & & & \\
\hline & L6 & 181,96 & & 177,44 & & & \\
\hline & L7 & 186,76 & & 177,44 & & & \\
\hline & L8 & 184,73 & & 177,44 & & & \\
\hline $\begin{array}{c}\text { Capa e tela, } 5 \phi 12,7, \\
\mathrm{~h}_{\text {total }}=25 \mathrm{~cm}, \mathrm{~L}=6,10 \mathrm{~m} . \\
\sigma_{\mathrm{pi}}=1140 \mathrm{MPa} . \underline{\mathrm{UCT}} \\
\left(\mathrm{L}-\mathrm{C}-25-5 \mathrm{D} 12,7-\mathrm{Z}_{-} \mathrm{F}\right)\end{array}$ & L9 & 183,48 & ---- & 177,47 & ---- & 1,03 & Flexão \\
\hline \multirow{5}{*}{$\begin{array}{c}\text { Capa e fibra, } 5 \phi 12,7 \\
\mathrm{~h}_{\text {total }}=25 \mathrm{~cm}, \mathrm{~L}=3,10 \mathrm{~m} . \\
\sigma_{\mathrm{pi}}=1140 \mathrm{MPa} . \mathrm{UCT} \\
\left(\mathrm{L}-\mathrm{CF}-25-5 \mathrm{D} 12,7-\mathrm{Z} \_\mathrm{F}\right)\end{array}$} & L10 & 186,31 & \multirow{5}{*}{186,37} & 177,44 & \multirow{5}{*}{177,44} & \multirow{5}{*}{1,05} & \multirow{5}{*}{ Flexão } \\
\hline & L11 & 184,96 & & 177,44 & & & \\
\hline & L12 & 185,41 & & 177,44 & & & \\
\hline & L13 & 186,23 & & 177,44 & & & \\
\hline & L14 & 188,93 & & 177,44 & & & \\
\hline
\end{tabular}

UST: unidade sem tratamento da face superior (Iisa e empoeirada).

UCT: unidade com tratamento da face superior (rugosa e limpa).

$h_{\text {total }}$ : altura total da peça; L: comprimento da laje; $\sigma_{\mathrm{pi}}$ : protensão inicial.

Nas peças com capa, pertencentes ao lote $Z$, foi comprovada a boa adesão entre 0 concreto da capa e o da laje, pois constatou-se que os momentos últimos experimentais foram superiores aos valores teóricos correspondentes, os quais foram calculados considerando a seção sendo composta integralmente de capa e laje (a capa e a laje trabalhando como um único elemento). Além disso, não foi observado o descolamento da capa.

A partir dos resultados obtidos para cada modelo ensaiado, é possível observar que a presença da capa garante um aumento tanto no valor do momento de fissuração quanto no do momento último. Por outro lado, também é possível verificar a semelhança dos resultados das lajes com capa, pertencentes ao lote $Z$, que foram moldadas com fibras metálicas, e as que foram moldadas com tela soldada. Assim, pode-se dizer que, considerando a resistência à flexão, é viável a substituição da armadura de tela soldada por fibras metálicas incorporadas à matriz do concreto.

\subsubsection{Correlações dos valores experimentais com os teóricos}

Para melhor analisar os resultados experimentais, empregou-se, para as lajes com capa, além da equação da NBR 6118:2003, as equações recomendadas pelo EC2:2004 e o ACI: 2008. Os valores obtidos podem ser observados na Tabela 7.8. 
Tabela 7.8: Valores teóricos determinados por equações recomendadas pela NB1, EC2 e ACI.

\begin{tabular}{|c|c|c|c|c|c|c|c|}
\hline Laje & $\begin{array}{c}\mathrm{V}_{\mathrm{RK}} * \\
\mathbf{( N B 1 )} \\
(\mathbf{k N})\end{array}$ & $\begin{array}{c}\frac{\mathrm{V}_{\mathrm{u}, \exp }}{\mathrm{V}_{\mathrm{Rk}}} \\
\mathbf{( N B 1 )}\end{array}$ & $\begin{array}{c}\mathrm{V}_{\mathrm{Rk}} * * \\
\mathbf{( E C 2 )} \\
\mathbf{( k N )}\end{array}$ & $\begin{array}{c}\frac{\mathrm{V}_{\mathrm{u}, \exp }}{\mathrm{V}_{\mathrm{Rk}}} \\
\mathbf{( E C 2 )}\end{array}$ & $\begin{array}{c}\mathrm{V}_{\mathrm{Rk}} * * \\
\mathbf{( A C I}) \\
\mathbf{( k N )}\end{array}$ & $\begin{array}{c}\frac{\mathrm{V}_{\mathrm{u}, \exp }}{\mathrm{V}_{\mathrm{Rk}}} \\
(\mathbf{A C I})\end{array}$ & $\begin{array}{c}\mathrm{V}_{\mathrm{u}, \exp } \\
\text { (kN) }\end{array}$ \\
\hline L1-C-20-6D9,5-X_C & 130,76 & 0,73 & 102,38 & 0,93 & 112,84 & 0,84 & 95,01 \\
\hline L2-C-20-6D9,5-X_C & 136,43 & 0,87 & 106,25 & 1,11 & 113,79 & 1,04 & 118,17 \\
\hline L3-C-25-8D12,7-X_C & $\mathbf{2 2 3 , 5 5}$ & 0,96 & 197,02 & 1,09 & 180,82 & 1,19 & 215,89 \\
\hline L4-C-25-7D9,5-Y_C & 114,62 & 0,99 & 94,69 & 1,20 & 117,93 & 0,96 & 113,45 \\
\hline L5-C-25-7D9,5-Y_C & 108,64 & 1,15 & 90,14 & 1,39 & 119,18 & 1,05 & 125,25 \\
\hline L6-C-25-6D12,7-Y_C & 137,40 & 1,02 & 119,17 & 1,18 & 143,09 & 0,98 & 140,80 \\
\hline L7-C-25-7D9,5-Y_C & 109,18 & 1,08 & 90,54 & 1,31 & 117,51 & 1,01 & 118,35 \\
\hline L8-C-25-5D12,7-Z_C & 124,94 & 1,07 & 112,52 & 1,18 & 104,87 & 1,27 & 133,29 \\
\hline L9-C-25-5D12,7-Z_C & 124,94 & 1,00 & 112,52 & 1,11 & 104,87 & 1,19 & 125,33 \\
\hline L10-C-25-5D12,7-Z_C & 124,94 & 1,55 & 112,52 & 1,72 & 104,87 & 1,84 & 193,49 \\
\hline L11-C-25-5D12,7-Z_C & 124,94 & 1,55 & 112,52 & 1,72 & 104,87 & 1,84 & 193,23 \\
\hline L12-C-25-5D12,7-Z_C & 124,94 & 1,23 & 112,52 & 1,37 & 104,87 & 1,47 & 154,11 \\
\hline L13-CF-25-5D12,7-Z_C & 124,94 & 1,57 & 112,52 & 1,74 & 104,87 & 1,87 & 196,11 \\
\hline L14-CF-25-5D12,7-Z_C & 124,94 & 1,57 & 112,52 & 1,74 & 104,87 & 1,87 & 196,29 \\
\hline L15-CF-25-5D12,7-Z_C & 124,94 & 1,53 & 112,52 & 1,70 & 104,87 & 1,83 & 191,65 \\
\hline L16-CF-25-5D12,7-Z_C & 124,94 & 1,59 & 112,52 & 1,77 & 104,87 & 1,90 & 199,35 \\
\hline L17-CF-25-5D12,7-Z_C & 124,94 & 1,60 & 112,52 & 1,77 & 104,87 & 1,90 & 199,61 \\
\hline
\end{tabular}

*Valores obtidos com emprego de $\mathrm{f}_{\mathrm{ctk}, \mathrm{inf}} ; * *$ Valores obtidos com emprego de $\mathrm{f}_{\mathrm{cj}}$

A partir da Tabela 7.8, pode-se observar que a equação da NBR 6118:2003 fornece resultados mais próximos dos experimentais, considerando as unidades alveolares com a presença de capa estrutural. Além disso, no caso das peças $L 1$ e $L 2$, ficou evidente o não funcionamento conjunto laje-capa, observado por meio da configuração de fissuração e do descolamento prematuro da capa. Entretanto, tal comportamento não foi previsto pelas equações do EC2 e do ACI, uma vez que tais equações fornecem resultados mais conservadores, garantindo elevadas relações $V_{u, \text { exp }} / V_{R k}$ mesmo para os casos em que houve o descolamento da capa.

Então, como contribuição à revisão da norma brasileira NBR 14861, esta pesquisa recomenda que os cálculos para determinar a resistência ao cisalhamento em zona fissurada por flexão para lajes com capa sejam feitos considerando a mesma equação empregada para peças sem capa, substituindo o valor de $d$ por $d_{\text {tot }}$ calculado considerando a altura da capa, da seguinte forma: $d_{t o t}=d+h_{t}$, sendo $h_{t}$ a altura da capa

Da mesma forma, os valores de $k$ e $\rho$ devem ser determinados considerando $d_{\text {tot }}$. 


\section{Unidades com alvéolos preenchidos}

\subsection{RESULTADOS}

Os gráficos com os resultados experimentais dos ensaios ao cisalhamento e à flexão, para cada laje com alvéolos parcialmente preenchidos, estão apresentados no Apêndice D. A seguir serão apresentados os principais resultados experimentais obtidos com os ensaios realizados.

\subsubsection{Ensaios ao cisalhamento}

Os valores correspondentes à cortante última e ao momento último obtidos nos ensaios de cisalhamento, considerando o peso próprio, estão indicados na Tabela 8.1.

Tabela 8.1: Resultados para as lajes com alvéolos preenchidos ensaiadas ao cisalhamento.

\begin{tabular}{|c|c|c|}
\hline Laje & $\begin{array}{c}\mathrm{V}_{\mathrm{u}, \exp } \\
\mathbf{( k N )}\end{array}$ & $\begin{array}{c}\mathrm{M}_{\mathrm{u}, \exp } \\
\mathbf{( k N . m )}\end{array}$ \\
\hline L1-2P-20-6D12,7-Y_C & 142,67 & 71,33 \\
\hline L2-2P-20-6D12,7-Y_C & 122,86 & 61,43 \\
\hline L3-2P-20-6D12,7-Y_C & 128,01 & 64,00 \\
\hline L4-2P-20-7D9,5-Y_C & 110,78 & 55,39 \\
\hline L5-2P-20-7D9,5-Y_C & 111,92 & 55,96 \\
\hline L6-2P-20-7D9,5-Y_C & 128,70 & 64,35 \\
\hline L7-2PF-20-5D12,7-Z_C & 147,76 & 73,88 \\
\hline L8-2PF-20-5D12,7-Z_C & 189,73 & 94,86 \\
\hline L9-2PF-20-5D12,7-Z_C & 168,11 & 84,06 \\
\hline L10-2PF-20-5D12,7-Z_C & 156,30 & 78,15 \\
\hline L11-2PF-20-5D12,7-Z_C & 163,56 & 81,78 \\
\hline L12-2PF-20-5D12,7-Z_C & 173,63 & 86,81 \\
\hline L13-4PF-20-5D12,7-Z_C & 173,19 & 86,59 \\
\hline L14-4PF-20-5D12,7-Z_C & 181,33 & 90,66 \\
\hline L15-4PF-20-5D12,7-Z_C & 176,34 & 88,17 \\
\hline L16-4PF-20-5D12,7-Z_C & 178,44 & 89,22 \\
\hline L17-4PF-20-5D12,7-Z_C & 172,75 & 86,38 \\
\hline L18-4PF-20-5D12,7-Z_C & 170,91 & 85,46 \\
\hline
\end{tabular}

\subsubsection{Ensaios à flexão}

Os valores correspondentes ao momento fletor último e ao momento de fissuração obtidos nos ensaios de flexão, considerando o peso próprio, estão indicados na Tabela 8.2 . 
Tabela 8.2: Resultados para as lajes com alvéolos preenchidos ensaiadas à flexão.

\begin{tabular}{|c|c|c|}
\hline Laje & $\begin{array}{c}\mathrm{M}_{\mathrm{u}, \exp } \\
\mathbf{( k N . m )}\end{array}$ & $\begin{array}{c}\mathrm{M}_{\text {r,exp }} \\
(\mathbf{k N . m})\end{array}$ \\
\hline L1-2PF-20-5D12,7-Z_F & 141,52 & 99,15 \\
\hline L2-2PF-20-5D12,7-Z_F & 140,40 & 103,12 \\
\hline L3-2PF-20-5D12,7-Z_F & 142,87 & 97,72 \\
\hline L4-4PF-20-5D12,7-Z_F & 141,40 & 99,02 \\
\hline L5-4PF-20-5D12,7-Z_F & 135,55 & 100,00 \\
\hline L6-4PF-20-5D12,7-Z_F & 139,75 & 98,27 \\
\hline
\end{tabular}

\subsection{ANÁLISE DOS RESULTADOS}

Neste item serão comparados os resultados e indicados os mecanismos resistentes para cada tipo de ensaio.

\subsubsection{Análise dos ensaios de cisalhamento}

A comparação entre os resultados experimentais e teóricos pode ser observada na Tabela 8.3, considerando o cisalhamento, e na Tabela 8.4, considerando a flexão, incluindo valores referentes à protensão.

Os valores de resistência à flexão e ao cisalhamento foram determinados de acordo com as recomendações da NBR 6118:2003, sendo considerado que o preenchimento dos alvéolos foi realizado antes da liberação da pré-tração dos cabos, ou seja, preenchimento executado na fábrica, o que de fato ocorreu para as peças ensaiadas. Melhor análise quanto a essa consideração pode ser observada mais adiante, no item 8.2.5.

Na Figura 8.1 podem ser observados os gráficos referentes às lajes sem capa, lote $Y$, com dois alvéolos parcialmente preenchidos, 6 ф 12,7 e comprimento de 4,15 m. Todas as lajes desse tipo não alcançaram as resistências previstas teoricamente, sendo observado que os alvéolos preenchidos não contribuíram como esperado.

Tabela 8.3: Resultados experimentais e teóricos, referentes ao cisalhamento, para as lajes com alvéolos preenchidos ensaiadas ao cisalhamento.

\begin{tabular}{|c|c|c|c|c|c|}
\hline Laje & $\begin{array}{c}\mathrm{V}_{\mathrm{u}, \exp } \\
(\mathbf{k N})\end{array}$ & $\begin{array}{l}\mathrm{V}_{\mathrm{Rk}} \\
(\mathbf{k N})\end{array}$ & $\frac{V_{\mathrm{u}, \exp }}{\mathrm{V}_{\mathrm{Rk}}}$ & $\begin{array}{c}\mathrm{V}_{\mathrm{S}, \text { máx }} \\
(\mathbf{k N})\end{array}$ & $\begin{array}{c}\text { Idade } \\
\text { laje } \\
\text { (dias) }\end{array}$ \\
\hline L1-2P-20-6D12,7-Y_C & 142,67 & 201,53 & 0,71 & 114,80 & 106 \\
\hline L2-2P-20-6D12,7-Y_C & 122,86 & 199,88 & 0,61 & 113,81 & 127 \\
\hline L3-2P-20-6D12,7-Y_C & 128,01 & 199,85 & 0,64 & 113,80 & 133 \\
\hline L4-2P-20-7D9,5-Y_C & 110,78 & 169,32 & 0,65 & 93,93 & 132 \\
\hline L5-2P-20-7D9,5-Y_C & 111,92 & 172,66 & 0,65 & 95,81 & 132 \\
\hline L6-2P-20-7D9,5-Y_C & 128,70 & 172,48 & 0,75 & 95,91 & 131 \\
\hline L7-2PF-20-5D12,7-Z_C & 147,76 & 170,97 & 0,86 & 96,45 & 10 \\
\hline L8-2PF-20-5D12,7-Z_C & 189,73 & 170,97 & 1,11 & 96,45 & 10 \\
\hline L9-2PF-20-5D12,7-Z_C & 168,11 & 170,97 & 0,98 & 96,45 & 10 \\
\hline L10-2PF-20-5D12,7-Z_C & 156,30 & 170,97 & 0,91 & 96,45 & 10 \\
\hline L11-2PF-20-5D12,7-Z_C & 163,56 & 170,97 & 0,96 & 96,45 & 10 \\
\hline L12-2PF-20-5D12,7-Z_C & 173,63 & 170,97 & 1,01 & 96,45 & 10 \\
\hline L13-4PF-20-5D12,7-Z_C & 173,19 & 234,68 & 0,74 & 131,27 & 10 \\
\hline L14-4PF-20-5D12,7-Z_C & 181,33 & 234,68 & 0,77 & 131,27 & 10 \\
\hline L15-4PF-20-5D12,7-Z_C & 176,34 & 234,68 & 0,75 & 131,27 & 10 \\
\hline L16-4PF-20-5D12,7-Z_C & 178,44 & 234,68 & 0,76 & 131,27 & 10 \\
\hline L17-4PF-20-5D12,7-Z_C & 172,75 & 234,68 & 0,74 & 131,27 & 10 \\
\hline L18-4PF-20-5D12,7-Z_C & 170,91 & 234,68 & 0,73 & 131,27 & 10 \\
\hline
\end{tabular}


Tabela 8.4: Resultados experimentais e teóricos, referentes à flexão, para as lajes com alvéolos preenchidos ensaiadas ao cisalhamento.

\begin{tabular}{|c|c|c|c|c|c|c|}
\hline Laje & $\begin{array}{l}M_{\mathrm{u}, \exp } \\
\text { (kN.m) }\end{array}$ & $\begin{array}{c}M_{r} \\
\text { (kN.m) }\end{array}$ & $\begin{array}{c}\mathrm{M}_{\mathrm{Rk}} \\
\text { (kN.m) }\end{array}$ & $\frac{M_{\mathrm{u}, \exp }}{M_{\mathrm{Rk}}}$ & $\begin{array}{c}\text { Perdas } \\
\text { totais } \\
(\%)\end{array}$ & $\begin{array}{c}\mathrm{F}_{\mathrm{p}, \text { seção }} \\
(\mathbf{k N})\end{array}$ \\
\hline L1-2P-20-6D12,7-Y_C & 71,33 & 121,46 & 167,08 & 0,43 & 18,71 & 707,19 \\
\hline L2-2P-20-6D12,7-Y_C & 61,43 & 120,34 & 165,85 & 0,37 & 18,96 & 705,01 \\
\hline L3-2P-20-6D12,7-Y_C & 64,00 & 119,39 & 164,80 & 0,39 & 19,11 & 703,71 \\
\hline L4-2P-20-7D9,5-Y_C & 55,39 & 92,62 & 108,87 & 0,51 & 14,69 & 447,90 \\
\hline L5-2P-20-7D9,5-Y_C & 55,96 & 93,53 & 110,32 & 0,51 & 14,90 & 446,77 \\
\hline L6-2P-20-7D9,5-Y_C & 64,35 & 91,01 & 107,83 & 0,60 & 14,78 & 447,41 \\
\hline L7-2PF-20-5D12,7-Z_C & 73,88 & 93,47 & 135,66 & 0,54 & 10,57 & 509,75 \\
\hline L8-2PF-20-5D12,7-Z_C & 94,86 & 93,47 & 135,66 & 0,70 & 10,57 & 509,75 \\
\hline L9-2PF-20-5D12,7-Z_C & 84,06 & 93,47 & 135,66 & 0,62 & 10,57 & 509,75 \\
\hline L10-2PF-20-5D12,7-Z_C & 78,15 & 93,47 & 135,66 & 0,58 & 10,57 & 509,75 \\
\hline L11-2PF-20-5D12,7-Z_C & 81,78 & 93,47 & 135,66 & 0,60 & 10,57 & 509,75 \\
\hline L12-2PF-20-5D12,7-Z_C & 86,81 & 93,47 & 135,66 & 0,64 & 10,57 & 509,75 \\
\hline L13-4PF-20-5D12,7-Z_C & 86,59 & 94,46 & 135,68 & 0,64 & 9,17 & 517,73 \\
\hline L14-4PF-20-5D12,7-Z_C & 90,66 & 94,46 & 135,68 & 0,67 & 9,17 & 517,73 \\
\hline L15-4PF-20-5D12,7-Z_C & 88,17 & 94,46 & 135,68 & 0,65 & 9,17 & 517,73 \\
\hline L16-4PF-20-5D12,7-Z_C & 89,22 & 94,46 & 135,68 & 0,66 & 9,17 & 517,73 \\
\hline L17-4PF-20-5D12,7-Z_C & 86,38 & 94,46 & 135,68 & 0,64 & 9,17 & 517,73 \\
\hline L18-4PF-20-5D12,7-Z_C & 85,46 & 94,46 & 135,68 & 0,63 & 9,17 & 517,73 \\
\hline
\end{tabular}

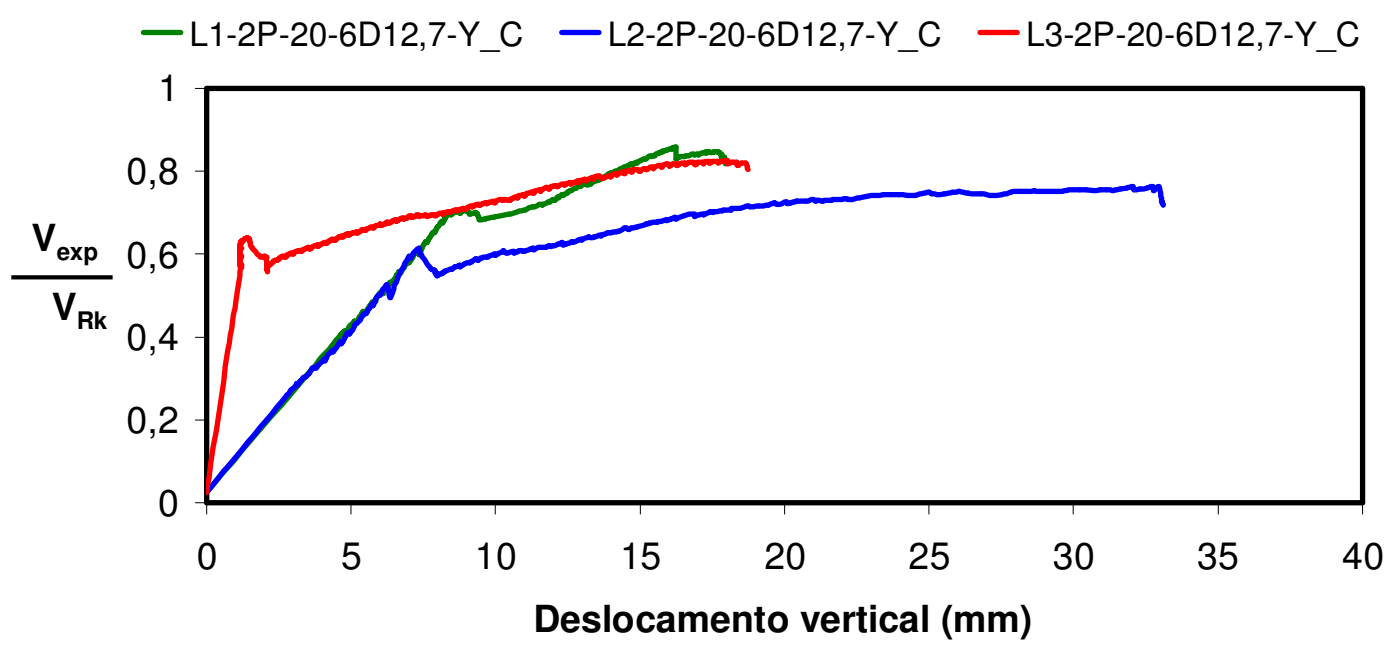

Figura 8.1: Gráficos $V_{\text {exp }} / V_{R K}$ versus deslocamento vertical obtidos nos ensaios das lajes sem capa com dois alvéolos preenchidos, 6 12,7 e comprimento de $415 \mathrm{~cm}$, do lote $Y$.

Na Figura 8.2 pode-se observar a fissuração da laje L2-2P-20-6D12,7-Y_C. Nessa figura é possível observar a presença de fissuras de cisalhamento com efeito da flexão e fendilhamento com falha de ancoragem, nas faces laterais da laje (Figura 8.2a e Figura 8.2b). Além disso, houve o aparecimento de fissuras longitudinais na face superior da laje, ao longo de um alvéolo não preenchido, na região central (Figura 8.2c) e fissuras na região da cordoalha (Figura $8.2 \mathrm{~d}$ ).

Na Figura 8.3 está ilustrada a fissuração da laje L3-2P-20-6D12,7-Y_C. Assim como na L2, a laje L3-2P-20-6D12,7-Y_C apresentou a fissuração da face superior, ao longo de um alvéolo não preenchido, localizado na região central (Figura 8.3c). 


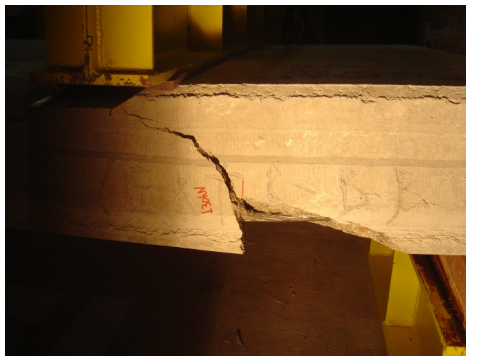

a)

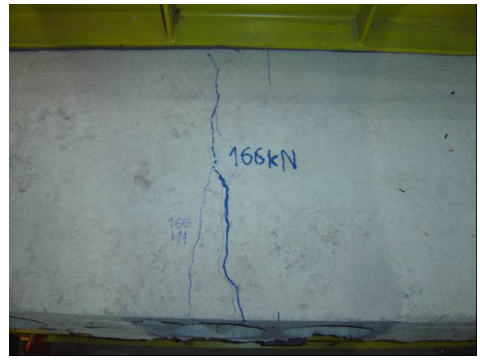

c)

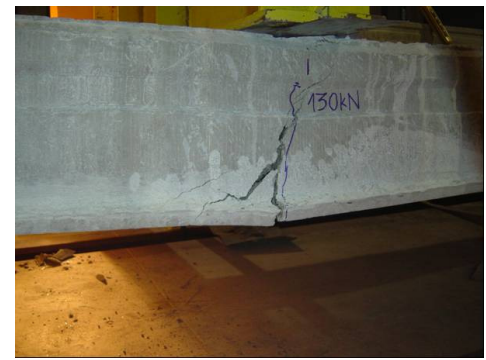

b)

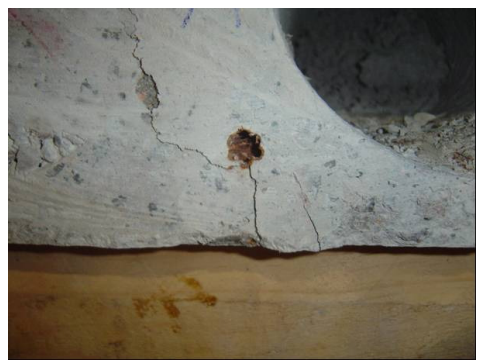

d)

Figura 8.2: Configuração de fissuração da laje L2-2P-20-6D12,7-Y_C.

a) Face oposta; b) Face frontal; c) Face superior; d) Fissuração próxima à cordoalha.

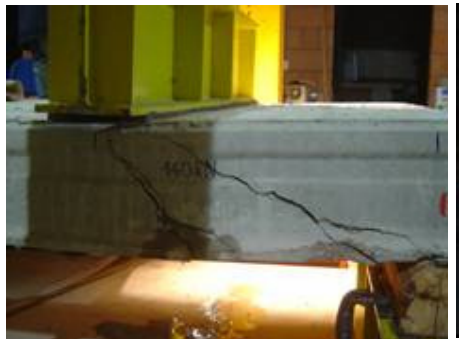

a)

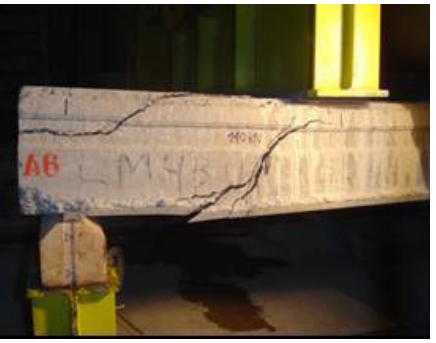

b)

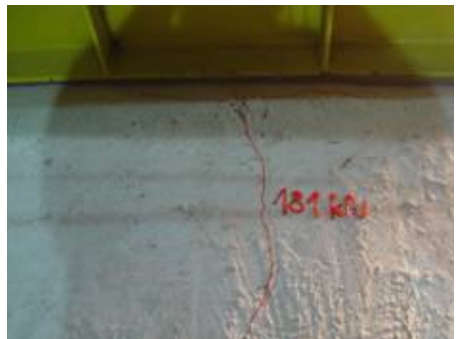

c)

Figura 8.3: Configuração de fissuração da laje L3-2P-20-6D12,7-Y C.

a) Face oposta; b) Face frontal; c) Fissuração da face superior da laje.

Na Figura 8.4 estão ilustrados os resultados obtidos para as lajes sem capa do lote $Y$, com dois alvéolos preenchidos, $7 \phi$ 9,5 e comprimento de 4,15 m. Esse tipo de laje também não alcançou a resistência prevista teoricamente. Da mesma forma que para o tipo descrito anteriormente, os alvéolos não contribuíram como era esperado.

As lajes L4-2P-20-7D9,5-Y_C e L5-2P-20-7D9,5-Y_C apresentaram comportamento bem semelhante. A fissuração da laje L5-2P-20-7D9,5-Y_C pode ser observada na Figura 8.5. Essa laje apresentou fissuras de flexão, na face frontal (Figura 8.5c), e fissura de cisalhamento com flexão e fendilhamento do concreto com falha de ancoragem, na face oposta (Figura 8.5b). Além disso, próximo da extremidade, foi observado o aparecimento de fissuras longitudinais nas faces superior e inferior da laje, ao longo de um alvéolo da região central (Figura 8.5d e Figura 8.5e). Tal comportamento foi identificado em várias lajes com alvéolos preenchidos. Na Figura 8.5f, é possível observar o aparecimento de fissuras ao redor da cordoalha, devido ao seu escorregamento. 


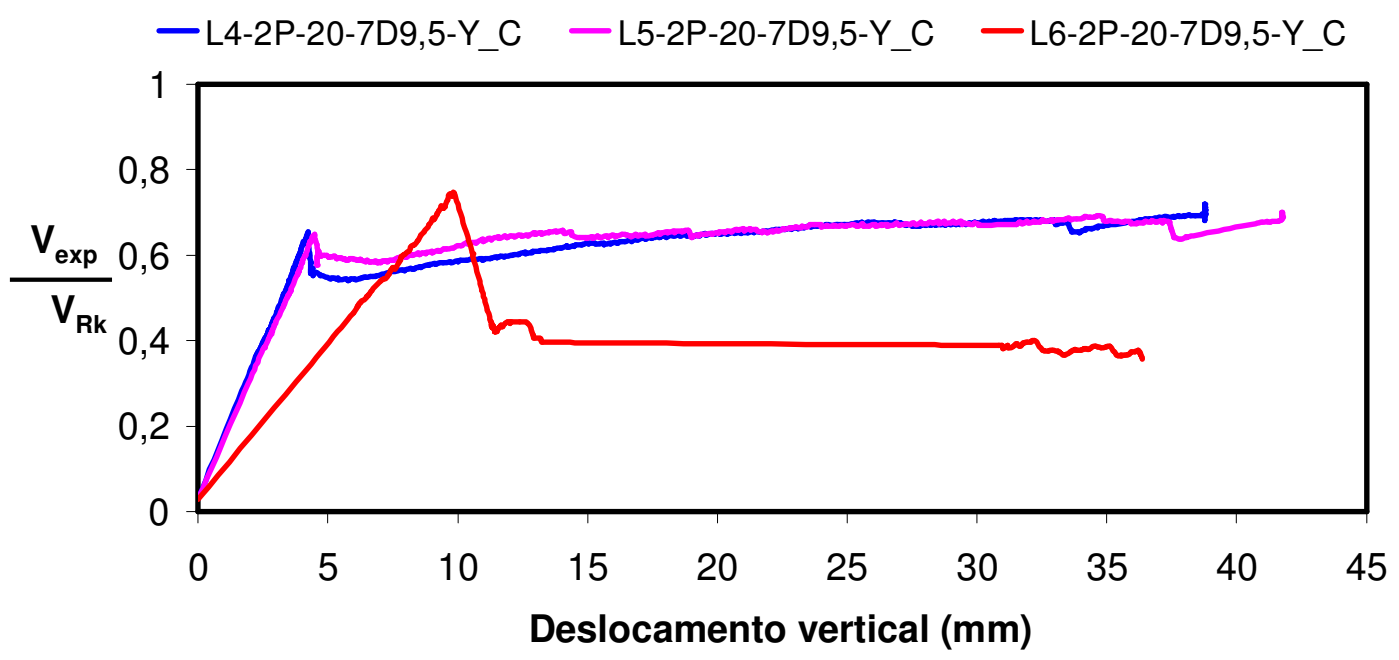

Figura 8.4: Gráficos $V_{\text {exp }} / V_{R k}$ versus deslocamento vertical obtidos nos ensaios das lajes sem capa com dois alvéolos preenchidos, $7 \phi 9,5$ e comprimento de $415 \mathrm{~cm}$, pertencentes ao lote $Y$.

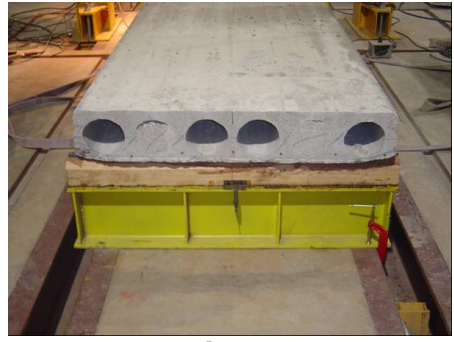

a)

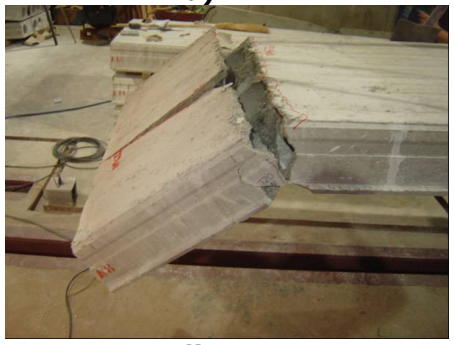

d)

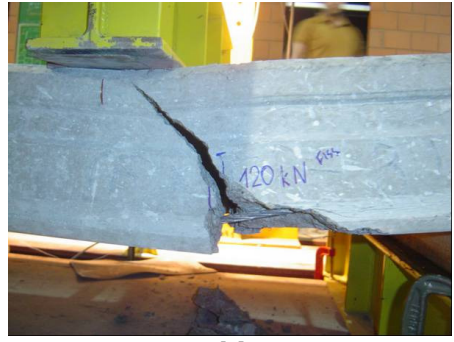

b)

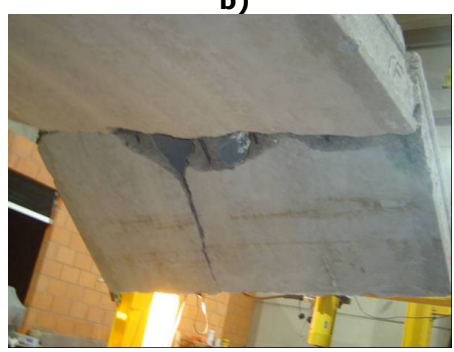

e)
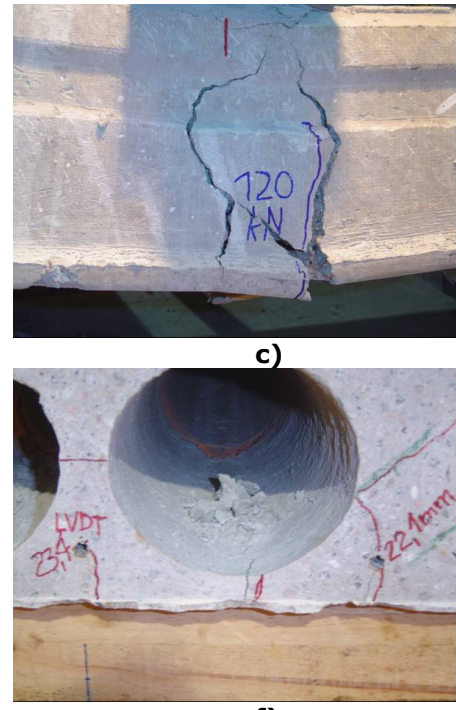

f)

Figura 8.5: Configuração de fissuração da laje L5-2P-20-7D9,5-Y_C. a) Laje com dois alvéolos preenchidos; b) Face oposta; c) Face frontal; d) e e) Laje após sua ruptura; f) Detalhe da fissuração ao redor das cordoalhas de protensão.

A laje L6-2P-20-7D9,5-Y_C apresentou comportamento diferente das demais lajes desse tipo (com alvéolos preenchidos), ocorrendo torção juntamente com os mecanismos de cisalhamento e flexão. Esse comportamento pode ser observado na Figura 8.6.

Com a Figura 8.7 é possível observar que a maior parte das lajes com dois alvéolos preenchidos, pertencentes ao lote $\mathbf{Z}$, apresentaram resultados satisfatórios (valores de $\mathrm{V}_{\exp } / \mathrm{V}_{\mathrm{Rk}}$ superiores a 0,95$)$. 


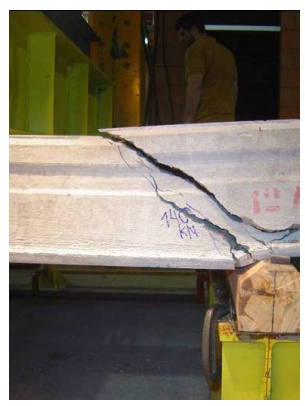

a)

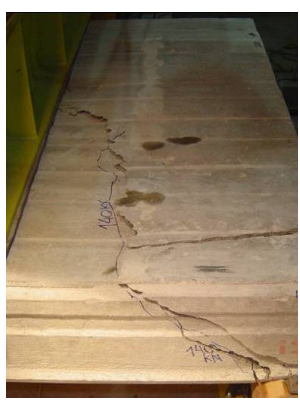

b)

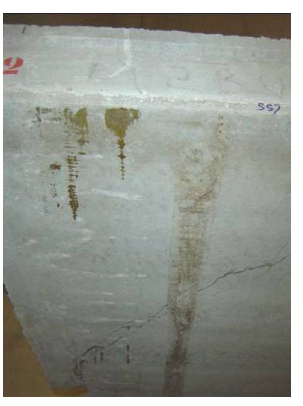

c)

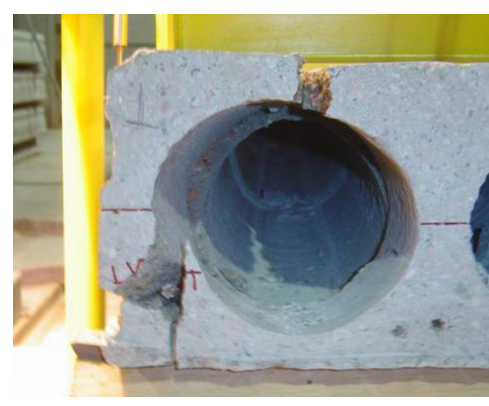

d)

Figura 8.6: Configuração da fissuração da laje L6-2P-20-7D9,5-Y_C. a) Face oposta; b) Face superior; c) Face inferior; d) Ruptura da face superior, junto ao alvéolo de extremidade.

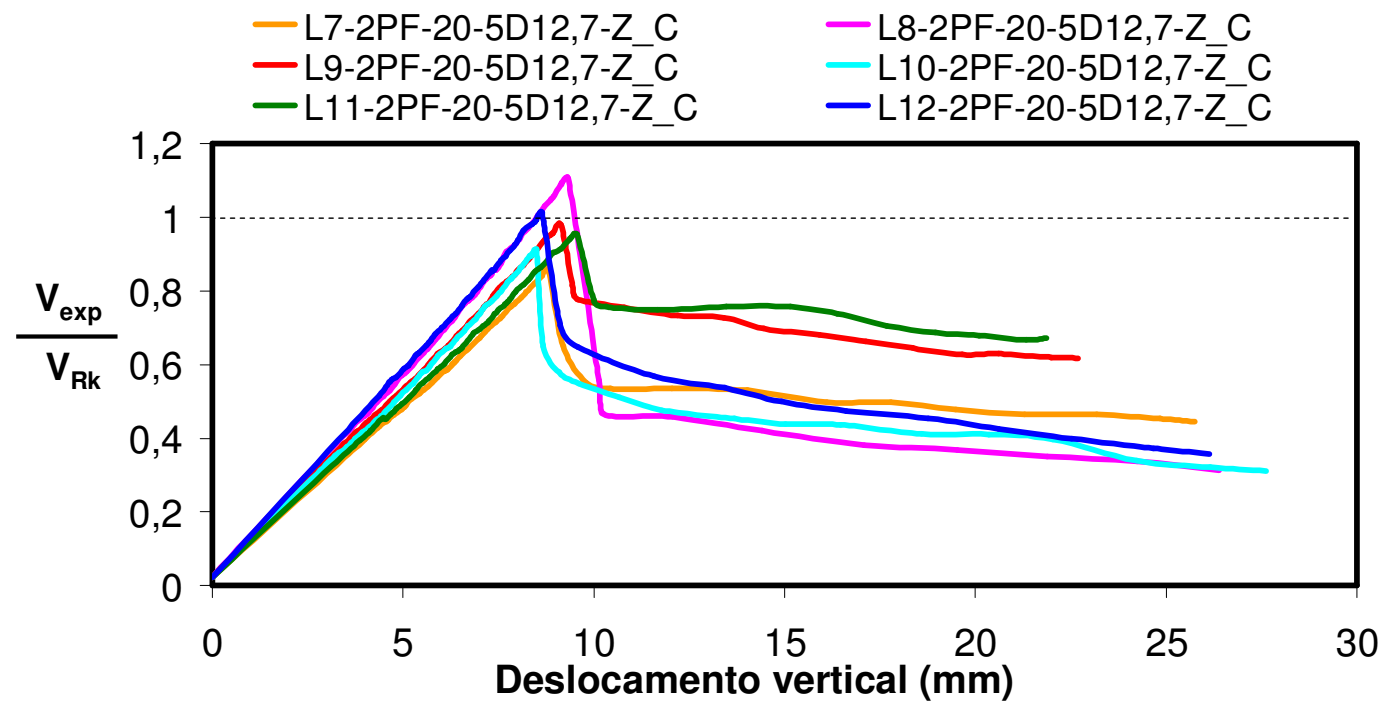

Figura 8.7: Gráficos $V_{\text {exp }} / V_{R k}$ versus deslocamento vertical obtidos nos ensaios das lajes sem capa com dois alvéolos preenchidos, com 5 \$ 12,7 e comprimento de $310 \mathrm{~cm}$, do lote $Z$.

A Figura 8.8 mostra a extremidade, a configuração de fissuração das duas faces laterais e da face inferior, para uma das lajes com dois alvéolos preenchidos, do lote $Z$.

Pode-se notar, na Figura 8.8d, a abertura de fissuras longitudinais na borda de um dos alvéolos centrais.

Com a Figura 8.8b é possível observar a presença dos mecanismos de cisalhamento e flexão, podendo verificar o fendilhamento do concreto (fissura horizontal na região do posicionamento das cordoalhas) devido à falha de ancoragem da armadura ativa.

Com a Figura 8.9 é possível verificar que todas as lajes com quatro alvéolos preenchidos, do lote $Z$, apresentaram valores experimentais inferiores aos previstos teoricamente. 


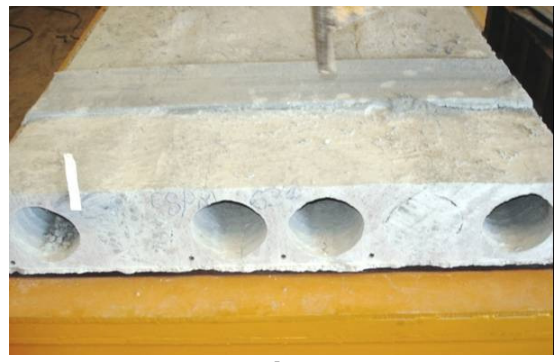

a)

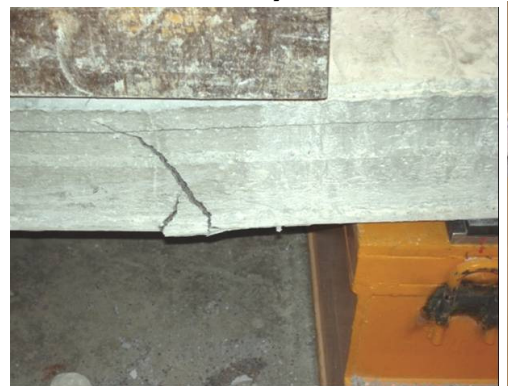

c)

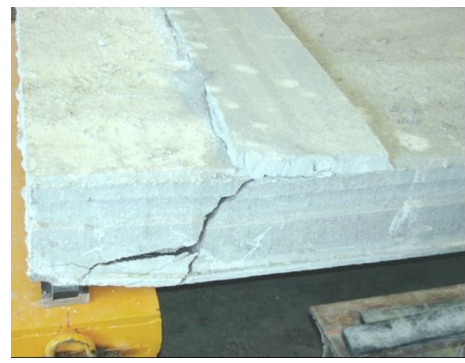

b)

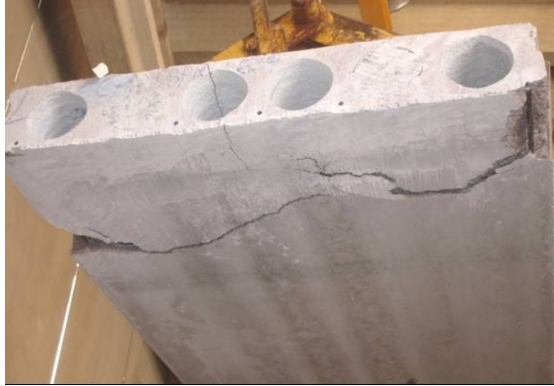

d)

Figura 8.8: Exemplo de configuração das fissuras de laje com dois alvéolos preenchidos, proveniente do lote Z. a) Extremidade; b) Face frontal; c) Face oposta; d) Face inferior.

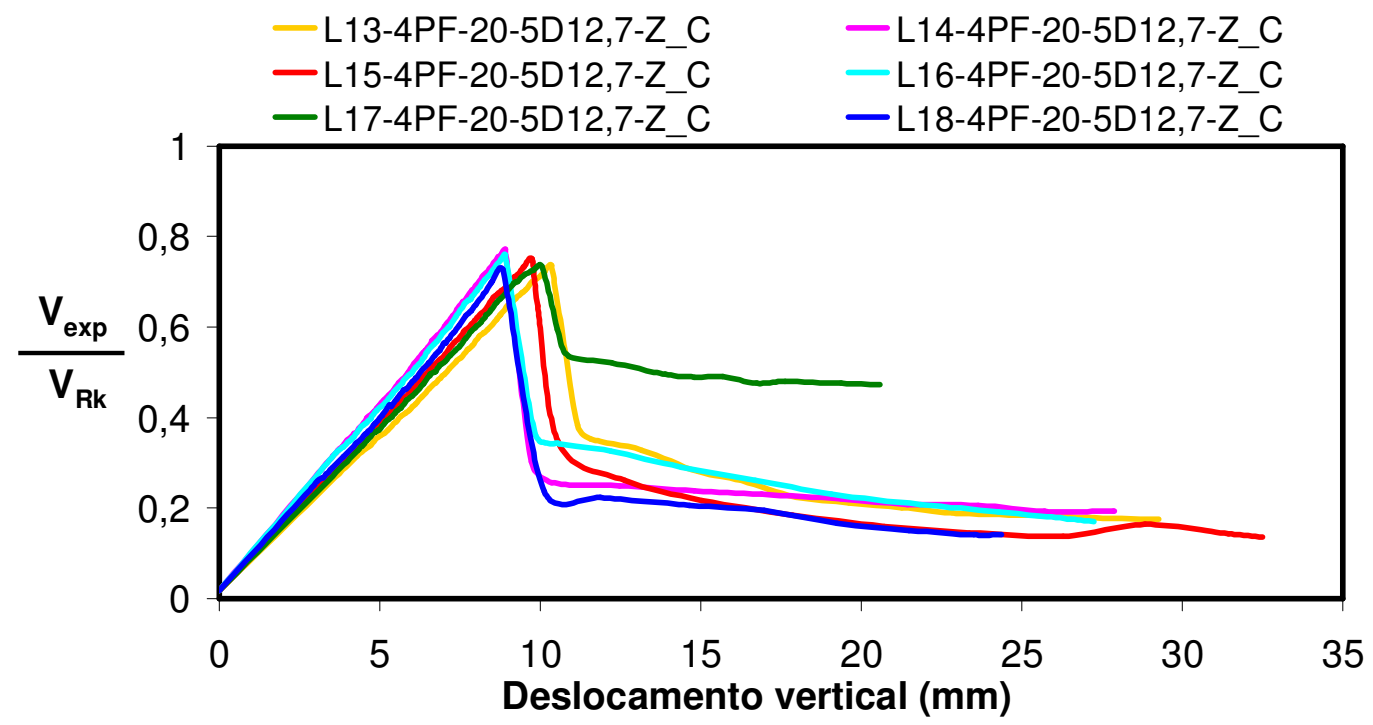

Figura 8.9: Gráficos $V_{\text {exp }} / V_{R k}$ versus deslocamento vertical obtidos nos ensaios das lajes sem capa com quatro alvéolos preenchidos, com 5 \$12,7 e comprimento de $310 \mathrm{~cm}$, do lote $Z$.

As lajes com quatro alvéolos preenchidos se comportaram de forma semelhante. A Figura 8.10a mostra a vista da extremidade de um elemento de laje alveolar com quatro alvéolos preenchidos, as figuras com letras " $b$ " e " $c$ " ilustram a fissuração das faces laterais oposta e frontal, respectivamente. A partir da configuração da fissuração das laterais da peça, é possível observar que a laje apresentou a interação de flexão e cisalhamento, com perda de ancoragem da armadura ativa, podendo ser observado o fendilhamento do concreto. 
A figura com letra " $d$ " ilustra a fissuração da face inferior da peça, e a com letra " $e$ " mostra uma fissura longitudinal num dos alvéolos vazios, por tração no concreto, após a abertura da fissura na nervura interna.

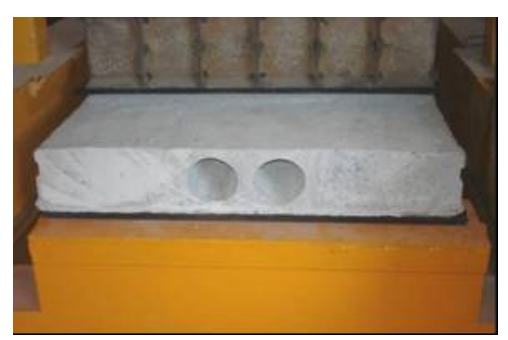

a)

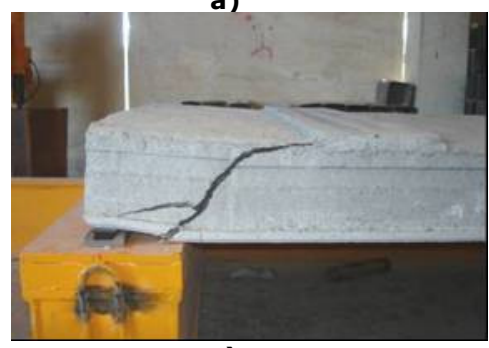

c)

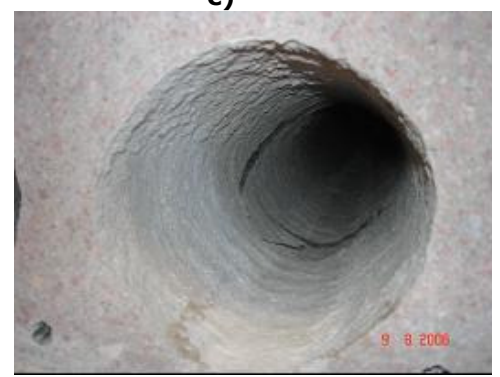

e)

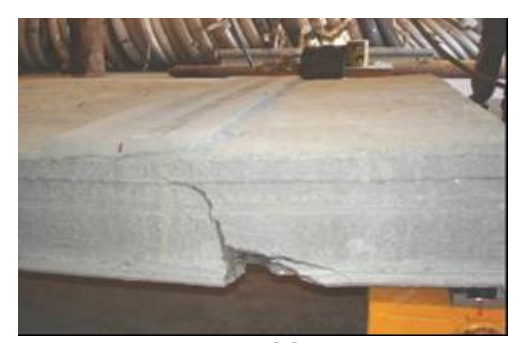

b)

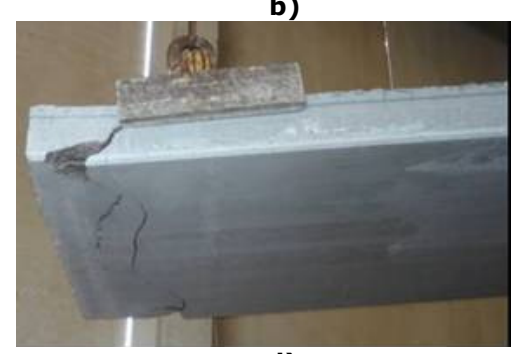

d)

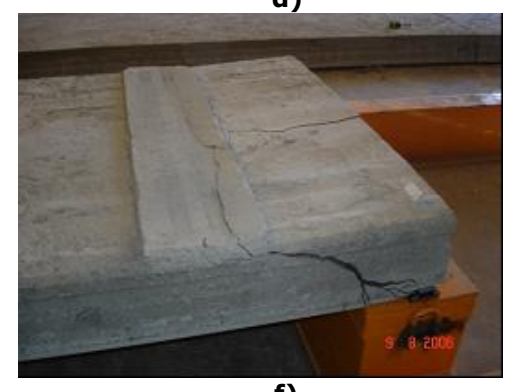

f)

Figura 8.10: Exemplo de configuração das fissuras de laje com quatro alvéolos preenchidos, proveniente do lote $Z$. a) Extremidade; b) Face oposta; c) Face frontal; d) Face inferior; e) Início da fissuração nas nervuras; f) Fissuração longitudinal do alvéolo central.

\subsubsection{Lajes com alvéolos preenchidos ensaiadas ao cisalhamento}

Para possibilitar melhor comparação e análise dos resultados, foram determinadas as resistências médias ao cisalhamento para cada tipo de laje ensaiada, como pode ser observado na Tabela 8.5. Como já foi dito anteriormente, o preenchimento dos alvéolos das peças do lote $Y$ correspondeu a $80 \mathrm{~cm}$ a partir da extremidade, enquanto que das peças do lote $Z$, tal preenchimento correspondeu a $100 \mathrm{~cm}$.

Todas as peças com alvéolos parcialmente preenchidos, pertencentes ao lote $Y$, não atenderam ao previsto, indicando a falta de aderência entre o preenchimento dos alvéolos e a laje. Com a observação visual das peças antes dos ensaios, foi possível notar que os alvéolos não se encontravam adequadamente preenchidos, o que acabou comprometendo o desempenho do modelo. Com a Figura 8.11 é possível observar o preenchimento não completo dos alvéolos. 
Tabela 8.5: Resistência média ao cisalhamento das lajes com alvéolos preenchidos.

\begin{tabular}{|c|c|c|c|c|c|c|c|}
\hline Descrição & Laje & $\begin{array}{c}\mathrm{V}_{\mathrm{u}, \exp } \\
(\mathbf{k N})\end{array}$ & $\begin{array}{l}\mathrm{V}_{\mathrm{u}, \exp , \mathrm{m}} \\
\quad(\mathbf{k N})\end{array}$ & $\begin{array}{l}\mathrm{V}_{\mathrm{Rk}} \\
(\mathbf{k N})\end{array}$ & $\begin{array}{l}\mathrm{V}_{\mathrm{Rk}, \mathrm{m}} \\
(\mathbf{k N})\end{array}$ & $\frac{\mathrm{V}_{\mathrm{exp}, \mathrm{m}}}{\mathrm{V}_{\mathrm{Rk}, \mathrm{m}}}$ & $\begin{array}{l}\text { Mecanismos } \\
\text { presentes na } \\
\text { ruptura }\end{array}$ \\
\hline \multirow{3}{*}{$\begin{array}{c}\text { Com } 2 \text { AP }(80 \mathrm{~cm}), 6 \phi \\
12,7, \mathrm{~h}=20 \mathrm{~cm}, \mathrm{~L}=4,15 \mathrm{~m} \\
\text { e } \sigma_{\mathrm{pi}}=1429,98 \mathrm{MPa} . \\
\left(\mathrm{L}-2 \mathrm{P}-20-6 \mathrm{D} 12,7-\mathrm{Y} \_\mathrm{C}\right)\end{array}$} & L1 & 142,67 & \multirow{3}{*}{131,18} & 201,53 & \multirow{3}{*}{200,42} & \multirow{3}{*}{0,65} & Cis., FI. e FA \\
\hline & L2 & 122,86 & & 199,88 & & & Cis Fl FA e FNC* \\
\hline & L3 & 128,01 & & 199,85 & & & \\
\hline \multirow{3}{*}{$\begin{array}{c}\text { Com } 2 \text { AP }(80 \mathrm{~cm}), 7 \phi \\
9,5, \mathrm{~h}=20 \mathrm{~cm}, \mathrm{~L}=4,15 \mathrm{~m} \text { e } \\
\sigma_{\mathrm{pi}}=1351,35 \mathrm{MPa} . \\
\left(\mathrm{L}-2 \mathrm{P}-20-7 \mathrm{D} 9,5-Y_{-} \mathrm{C}\right)\end{array}$} & L4 & 110,78 & \multirow{3}{*}{117,13} & 169,32 & \multirow{3}{*}{171,49} & \multirow{3}{*}{0,68} & Cis., FI. e FA \\
\hline & L5 & 111,92 & & 172,66 & & & Cis., FI., FA. e FNC* \\
\hline & L6 & 128,70 & & 172,48 & & & $\begin{array}{c}\text { Predomínio de Cis., } \\
\text { com Fl., Tor. e } \\
\underline{\text { FAE** }^{*}}\end{array}$ \\
\hline \multirow{6}{*}{$\begin{array}{c}\text { Com } 2 \text { APF }(100 \mathrm{~cm}), 5 \phi \\
12,7, \mathrm{~h}=20 \mathrm{~cm}, \mathrm{~L}=3,10 \mathrm{~m} \\
\text { e } \sigma_{\mathrm{pi}}=1140 \mathrm{MPa} . \\
\left(\mathrm{L}-2 \mathrm{PF}-20-5 \mathrm{D} 12,7-\mathrm{Z}_{-} \mathrm{C}\right)\end{array}$} & L7 & 147,76 & \multirow{6}{*}{166,51} & 170,97 & \multirow{6}{*}{170,97} & \multirow{6}{*}{0,97} & $\begin{array}{c}\text { Cis. e forte } \\
\text { influência de Fl. e } \\
\text { FNC* }\end{array}$ \\
\hline & L8 & 189,73 & & 170,97 & & & Cis., Fl. e FA \\
\hline & L9 & 168,11 & & 170,97 & & & $\begin{array}{c}\text { Predomínio de Cis., } \\
\text { com Fl. e } \underline{\text { FNC* }}\end{array}$ \\
\hline & L10 & 156,30 & & 170,97 & & & \\
\hline & L11 & 163,56 & & 170,97 & & & Cis., Fl., FA. e FNC* \\
\hline & L12 & 173,63 & & 170,97 & & & $\begin{array}{c}\text { Predomínio de Cis., } \\
\text { com Fl. e } \underline{\mathrm{FAE}^{* *}}\end{array}$ \\
\hline \multirow{6}{*}{$\begin{array}{c}\text { Com } 4 \text { APF }(100 \mathrm{~cm}), 5 \phi \\
12,7, \mathrm{~h}=20 \mathrm{~cm}, \mathrm{~L}=3,10 \mathrm{~m} \\
\text { e } \sigma_{\mathrm{pi}}=1140 \mathrm{MPa} . \\
\left(\mathrm{L}-4 \mathrm{PF}-20-5 \mathrm{D} 12,7-\mathrm{Z} \_\mathrm{C}\right)\end{array}$} & L13 & 173,19 & \multirow{6}{*}{175,49} & 234,68 & \multirow{6}{*}{234,68} & \multirow{6}{*}{0,75} & Cis., FI., FA. e FNC* \\
\hline & L14 & 181,33 & & 234,68 & & & $\begin{array}{l}\text { Predomínio de Cis., } \\
\text { com Fl., FA. e FNC* }\end{array}$ \\
\hline & L15 & 176,34 & & 234,68 & & & Cis., FI. e FNC* \\
\hline & L16 & 178,44 & & 234,68 & & & $\begin{array}{l}\text { Predomínio de Cis., } \\
\text { com Fl., FA. e FNC* }\end{array}$ \\
\hline & $\mathrm{L} 17$ & 172,75 & & 234,68 & & & Cis., FI., FA. e FNC* \\
\hline & L18 & 170,91 & & 234,68 & & & Cis., Fl. e FNC* \\
\hline
\end{tabular}

AP: alvéolos parcialmente preenchidos (comprimento entre parênteses); APF: alvéolos parcialmente preenchidos com concreto reforçado com fibras (comprimento entre parênteses).

$\mathrm{h}_{\text {total }}$ : altura total da peça; L: comprimento da laje; $\sigma_{\mathrm{pi}}$ : protensão inicial.

* FNC - Fissuração próxima à nervura central, FAE** - Fissuração no alvéolo de extremidade Cis.: cisalhamento. FI.: flexão; Tor.: torção; FA: falha de ancoragem.

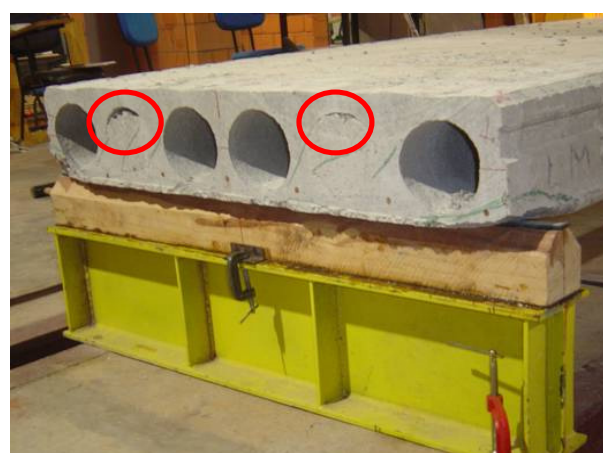

Figura 8.11: Preenchimento inadequado dos alvéolos (L5-2P-20-7D9,5-Y_C) 
Nos casos das lajes com preenchimento dos alvéolos pertencentes ao lote $Z$, as resistências experimentais não acompanharam proporcionalmente o aumento das resistências teóricas, calculadas com base no aumento das seções dos alvéolos preenchidos (considerando a contribuição de toda área do alvéolo preenchido). Os resultados apresentaram uma boa aproximação para o caso do preenchimento de dois alvéolos.

Porém, não se conseguiu o mesmo resultado para o caso de quatro alvéolos preenchidos, uma vez que a resistência experimental pouco variou para as situações com dois ou com quatro preenchimentos. Esse efeito está relacionado com a disposição desses alvéolos (como pode ser observado na Figura 8.12).

Por meio dos ensaios, identificou-se a presença de pontos fracos nas unidades parcialmente preenchidas, como ilustrado na Figura 8.12.

No caso de dois alvéolos preenchidos, apresentaram-se como pontos fracos os alvéolos de extremidade e a nervura central, que, por sua vez, permaneceu como ponto fraco nas unidades com quatro preenchimentos.

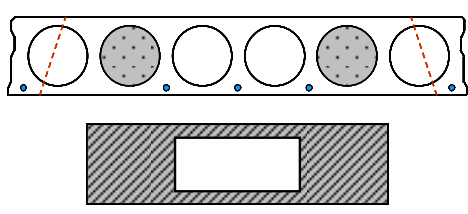

a)

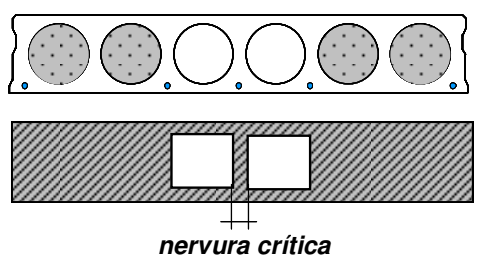

b)

Figura 8.12: Preenchimento dos alvéolos das lajes do lote Z. a) Lajes com dois alvéolos preenchidos; b) Lajes com quatro alvéolos preenchidos.

Tal fato pode ser confirmado observando a presença de fissuração próxima à nervura central, para quase todas as unidades com dois e quatro alvéolos parcialmente preenchidos, e fissuração nos alvéolos de extremidade em algumas peças com dois preenchimentos.

Assim, mesmo com quatro alvéolos preenchidos, a nervura central permaneceu igual ao caso com dois alvéolos, sendo que o ponto mais fraco é que determina a resistência global da laje.

Considerando o lote $Z$, pode-se observar que mesmo não funcionando como esperado, o preenchimento melhorou a capacidade das unidades à flexão, o que garantiu menor influência desse mecanismo e, consequentemente, melhor resistência ao cisalhamento, em comparação com peças semelhantes sem a presença de qualquer preenchimento.

No item 8.2.5 são feitas novas análises com relação à contribuição integral da área preenchida, sendo apresentadas novas considerações de cálculo. 


\subsubsection{Análise dos ensaios de flexão}

Neste item serão comparados os resultados das lajes com alvéolos preenchidos ensaiadas à flexão e, também, descritos seus mecanismos resistentes.

Os resultados experimentais e teóricos podem ser observados na Tabela 8.6.

Tabela 8.6: Resultados experimentais e teóricos para as lajes com alvéolos preenchidos ensaiadas à flexão.

\begin{tabular}{|c|c|c|c|c|c|c|}
\hline Laje & $\begin{array}{c}M_{\mathrm{u}, \exp } \\
\mathbf{( k N . m )}\end{array}$ & $\begin{array}{c}M_{\mathrm{Rk}} \\
\mathbf{( k N . m )}\end{array}$ & $\frac{M_{\mathrm{u}, \exp }}{M_{\mathrm{Rk}}}$ & $\begin{array}{c}M_{r, \exp } \\
\mathbf{( k N . m )}\end{array}$ & $\begin{array}{c}M_{r} \\
\mathbf{( k N . m )}\end{array}$ & $\begin{array}{c}\text { Idade } \\
\text { (dias) }\end{array}$ \\
\hline L1-2PF-20-5D12,7-Z_F & 141,52 & 135,64 & 1,04 & 99,15 & 93,72 & 10 \\
\hline L2-2PF-20-5D12,7-Z_F & 140,40 & 135,64 & 1,03 & 103,12 & 93,72 & 10 \\
\hline L3-2PF-20-5D12,7-Z_F & 142,87 & 135,64 & 1,05 & 97,72 & 93,72 & 10 \\
\hline L4-4PF-20-5D12,7-Z_F & 141,40 & 135,65 & 1,04 & 99,02 & 93,96 & 10 \\
\hline L5-4PF-20-5D12,7-Z_F & 135,55 & 135,65 & 1,00 & 100,00 & 93,96 & 10 \\
\hline L6-4PF-20-5D12,7-Z_F & 139,75 & 135,65 & 1,03 & 98,27 & 93,96 & 10 \\
\hline
\end{tabular}

Da mesma forma que para os demais casos, realizou-se a separação dos tipos de laje ensaiados e criaram-se gráficos de $M_{\exp } / M_{R k}$ versus deslocamento vertical para cada laje, sendo $M_{\exp }$ correspondente ao momento atuante, obtido por meio do ensaio, na seção do meio do vão.

Na Figura 8.13 estão ilustrados os resultados referentes às unidades de laje alveolar sem capa e com dois alvéolos parcialmente preenchidos. Todas as peças apresentaram resultados satisfatórios.

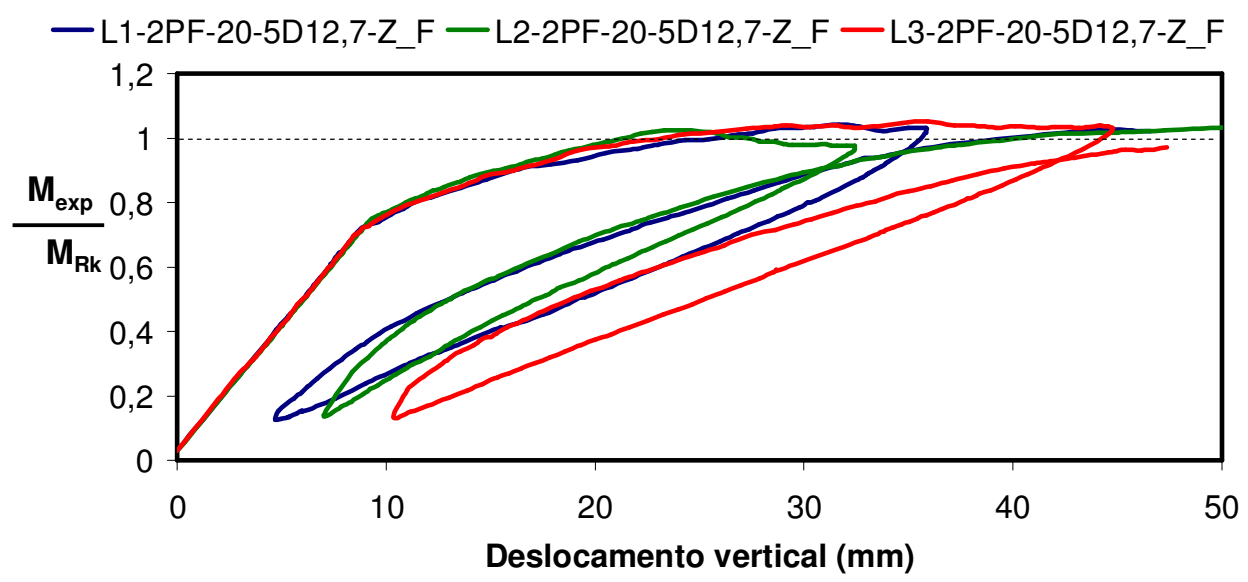

Figura 8.13: Gráficos $M_{\text {exp }} / M_{R k}$ versus deslocamento vertical obtidos nos ensaios das lajes sem capa com dois alvéolos preenchidos, com 5 \$12,7 e $310 \mathrm{~cm}$ de comprimento, do lote $Z$.

Na Figura 8.14, é possível observar que todas as unidades de laje sem capa e com quatro alvéolos parcialmente preenchidos apresentaram valores experimentais superiores aos previstos teoricamente. 


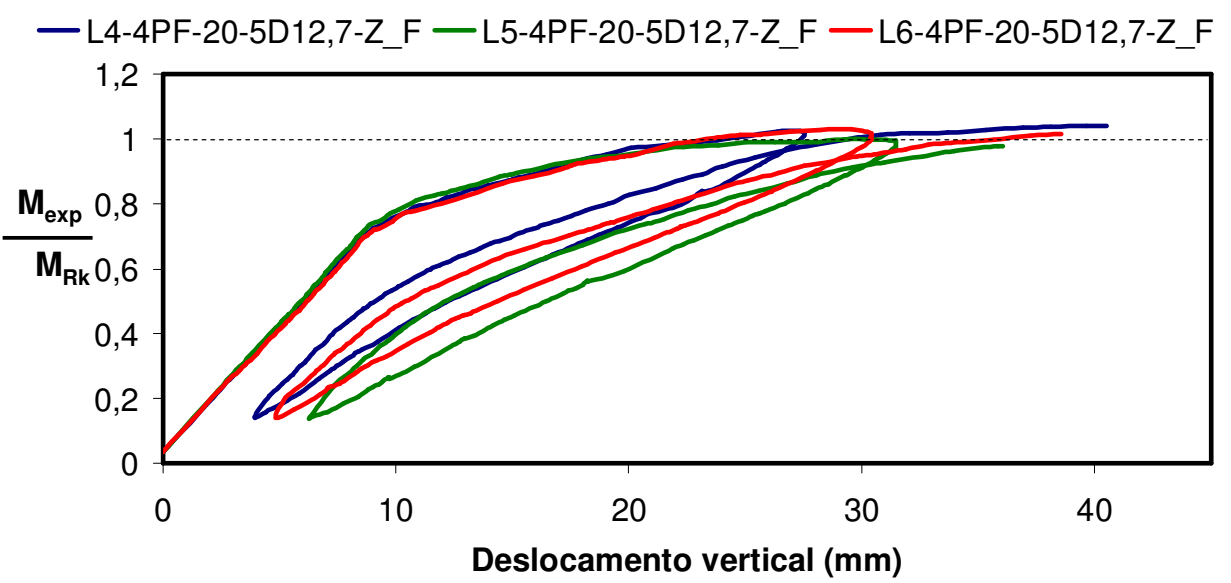

Figura 8.14: Gráficos $M_{\exp } / M_{R k}$ versus deslocamento vertical obtidos nos ensaios das lajes sem capa com quatro alvéolos preenchidos, com $5 \phi 12,7$ e $310 \mathrm{~cm}$ de comprimento, do lote $Z$.

\subsubsection{Lajes com alvéolos preenchidos ensaiadas à flexão}

Para melhor comparar os resultados obtidos nos ensaios das lajes com alvéolos parcialmente preenchidos, foram determinados os valores médios das resistências à flexão experimentais e teóricas, como pode ser observado na Tabela 8.7.

Tabela 8.7: Resistência média à flexão das lajes com alvéolos preenchidos.

\begin{tabular}{|c|c|c|c|c|c|c|c|}
\hline Descrição & Laje & $\begin{array}{l}M_{u, \exp } \\
(\mathbf{k N} \cdot \mathbf{m})\end{array}$ & $\begin{array}{c}M_{\mathrm{u}, \exp , \mathrm{m}} \\
(\mathbf{k N} \mathbf{m})\end{array}$ & $\begin{array}{c}\mathrm{M}_{\mathrm{Rk}} \\
(\mathbf{k N} \cdot \mathbf{m})\end{array}$ & $\begin{array}{l}M_{R k, m} \\
(\mathbf{k N} . \mathbf{m})\end{array}$ & $\frac{M_{u, e x p, m}}{M_{R k, m}}$ & $\begin{array}{c}\text { Mecanismos } \\
\text { presentes } \\
\text { na ruptura }\end{array}$ \\
\hline \multirow{3}{*}{$\begin{array}{c}2 \operatorname{APF}(100 \mathrm{~cm}), 5 \phi 12,7 \\
\mathrm{~h}=20 \mathrm{~cm}, \mathrm{~L}=3,10 \mathrm{~m} \mathrm{e} \\
\sigma_{\mathrm{pi}}=1140 \mathrm{MPa} . \\
\left(\mathrm{L}-2 \mathrm{PF}-20-5 \mathrm{D} 12,7-\mathrm{Z}_{-} \mathrm{F}\right)\end{array}$} & L1 & 141,52 & \multirow{3}{*}{141,60} & 135,64 & \multirow{3}{*}{135,64} & \multirow{3}{*}{1,04} & \multirow{3}{*}{ Flexão } \\
\hline & L2 & 140,40 & & 135,64 & & & \\
\hline & L3 & 142,87 & & 135,64 & & & \\
\hline \multirow{3}{*}{$\begin{array}{c}4 \text { APF }(100 \mathrm{~cm}), 5 \phi 12,7 \\
\mathrm{~h}=20 \mathrm{~cm}, \mathrm{~L}=3,10 \mathrm{~m} \mathrm{e} \\
\sigma_{\mathrm{pi}}=1140 \mathrm{MPa} . \\
\left(\mathrm{L}-4 \mathrm{PF}-20-5 \mathrm{D} 12,7-\mathrm{Z} \_\mathrm{F}\right)\end{array}$} & L4 & 141,40 & \multirow{3}{*}{138,90} & 135,65 & \multirow{3}{*}{135,65} & \multirow{3}{*}{1,02} & \multirow{3}{*}{ Flexão } \\
\hline & L5 & 135,55 & & 135,65 & & & \\
\hline & L6 & 139,75 & & 135,65 & & & \\
\hline
\end{tabular}

APF: alvéolos parcialmente preenchidos com concreto reforçado com fibras (comprimento entre parênteses). $\mathrm{h}_{\text {total }}$ : altura total da peça; $\mathrm{L}$ : comprimento da laje; $\sigma_{\mathrm{pi}}$ :protensão inicial.

Considerando os ensaios à flexão realizados nos modelos com alvéolos parcialmente preenchidos e comprimento de 3,10 m, foram obtidos valores próximos entre o momento último de ensaio e o calculado, ocorrendo uma fissuração típica de flexão (fissuras verticais), pois nesses casos as tensões de cisalhamento atuantes são de baixa intensidade, devido ao preenchimento dos alvéolos.

Para os casos de lajes sem capa com alvéolos parcialmente preenchidos, como a resistência ao cisalhamento é mais elevada, foi possível avaliar a resistência última à flexão, mesmo em peças com 3 m de vão. 
Com os resultados, é possível observar que as resistências das peças com quatro alvéolos preenchidos foram inferiores às das peças com dois preenchimentos. Assim, mesmo alcançando os valores previstos, os quatro preenchimentos não contribuíram para aumentar a resistência à flexão, comparando com as unidades de dois preenchimentos.

Diante disso, para melhorar a resistência à flexão de unidades alveolares empregando o preenchimento de alvéolos, o mais interessante é preencher apenas dois alvéolos, que fornece maiores vantagens, tanto nos quesitos de custo e tempo como no aumento da capacidade resistente da peça à flexão, quando se compara com o preenchimento de quatro alvéolos.

\subsubsection{Variações no cálculo das unidades com alvéolos preenchidos}

Com o intuito de identificar a melhor maneira de calcular, quanto ao cisalhamento, as lajes com alvéolos parcialmente preenchidos, foram realizados cálculos empregando diferentes considerações, sendo feitas comparações entre os resultados teóricos e os experimentais. Assim, além da maneira de cálculo já empregada, com a equação recomendada pela NBR 6118:2003 (considerando contribuição total dos alvéolos preenchidos e preenchimento antes da liberação da pré-tração dos cabos), também foram feitos cálculos considerando apenas $2 / 3$ da contribuição dos alvéolos preenchidos, como recomendado pela norma EN1168:2005, e considerando que os alvéolos foram preenchidos após a liberação dos cabos pré-tracionados. Além disso, também empregouse a NBR 6118:2003, sem considerar os preenchimentos no cálculo da taxa de armadura e da tensão de protensão.

Assim, foram determinados cinco casos de cálculo, em que foi empregada a equação da NB1 (NBR 6118:2003) com diferentes considerações, como descrito a seguir:

- Caso 1: NB1, considerando os alvéolos totalmente preenchidos, ou seja, contribuição de toda área dos alvéolos preenchidos, sendo o preenchimento realizado após a liberação da pré-tração dos cabos. Nesse caso os preenchimentos são considerados apenas no primeiro termo da equação recomendada pela NB1.

$\mathrm{V}_{\mathrm{Rk}}=0,25 \cdot \mathrm{f}_{\mathrm{ctd}} \cdot \mathrm{b}_{\mathrm{w}}{ }_{\mathrm{w}} \cdot \mathrm{d} \cdot \mathrm{k} \cdot\left(1,2+40 \rho_{1}^{\prime}\right)+0,15 \cdot \sigma_{\mathrm{cp}} \cdot \mathrm{b}_{\mathrm{w}} \cdot \mathrm{d}$

$b^{\prime}{ }_{w}=b_{w}+n \cdot b_{c} \cdot \frac{E_{c}}{E_{p}} \quad \rho_{1}^{\prime}=\frac{A_{s t}}{b^{\prime}{ }_{w} \cdot d}$

- Caso 2: NB1, considerando contribuição de $2 / 3$ dos alvéolos preenchidos e preenchimento após a liberação da pré-tração dos cabos. Os preenchimentos também são considerados apenas no primeiro termo da equação da NB1. É empregada a mesma equação do caso 1 , porém considerando, no cálculo do $\mathrm{b}^{\prime}{ }_{\mathrm{w}}$, contribuição de apenas $2 / 3$ dos alvéolos preenchidos. 
$b^{\prime}{ }_{w}=b_{w}+\frac{2}{3} n \cdot b_{c} \cdot \frac{E_{c}}{E_{p}}$

- Caso 3: NB1, considerando contribuição total dos alvéolos e preenchimento antes da aplicação da protensão. Nesse caso os preenchimentos são considerados nos dois termos da equação recomendada pela NB1.

$\left.V_{R k}=0,25 \cdot f_{c t d} \cdot k \cdot\left(1,2+40 \rho_{1}^{\prime}\right)+0,15 \cdot \sigma_{c p}^{\prime}\right] \cdot b^{\prime}{ }_{w} \cdot d$

$\mathrm{b}^{\prime}{ }_{\mathrm{w}}=\mathrm{b}_{\mathrm{w}}+\mathrm{n} \cdot \mathrm{b}_{\mathrm{c}} \cdot \frac{\mathrm{E}_{\mathrm{c}}}{\mathrm{E}_{\mathrm{p}}} \quad \rho_{1}^{\prime}=\frac{\mathrm{A}_{\mathrm{st}}}{\mathrm{b}^{\prime}{ }_{\mathrm{w}} \cdot \mathrm{d}} \quad \sigma_{\mathrm{cp}}^{\prime}=\frac{\mathrm{N}_{\mathrm{sd}}}{\mathrm{A}_{\text {total }}}$

$A_{\text {total }}$ : área total da seção transversal, considerando os alvéolos preenchidos;

$E_{c} / E_{p}$ : relação entre os módulos de elasticidade dos concretos da laje e dos alvéolos.

- Caso 4: NB1, considerando contribuição de 2/3 do alvéolo e preenchimento antes da aplicação da protensão.

É empregada a mesma equação que no caso 3, porém considerando tanto no cálculo do $b^{\prime}{ }_{w}$ como no $\sigma_{c p}^{\prime}$ contribuição de apenas $2 / 3$ dos alvéolos preenchidos.

$\mathrm{b}^{\prime}{ }_{\mathrm{w}}=\mathrm{b}_{\mathrm{w}}+\frac{2}{3} \mathrm{n} \cdot \mathrm{b}_{\mathrm{c}} \cdot \frac{\mathrm{E}_{\mathrm{c}}}{\mathrm{E}_{\mathrm{p}}} \quad \sigma_{\mathrm{cp}}=\frac{\mathrm{N}_{\mathrm{sd}}}{\mathrm{A}_{2 / 3 \mathrm{AP}}}$

$A_{2 / 3 A P}$ : área da seção transversal, considerando $2 / 3$ dos alvéolos preenchidos.

- Caso 5: NB1, sem considerações de preenchimento de alvéolos no cálculo da taxa de armadura e da tensão de protensão.

Nesse caso é empregada a equação da NBR 6118:2003, mas usando $b^{\prime}{ }_{w}$, sem considerar os alvéolos preenchidos no cálculo da taxa de armadura $(\rho)$ e da tensão de protensão $\left(\sigma_{\mathrm{cp}}\right)$, como indicado na seguinte expressão:

$$
\begin{aligned}
& \mathrm{V}_{\mathrm{Rk}}=\left[0,25 \cdot \mathrm{f}_{\mathrm{ctd}} \cdot \mathrm{k} \cdot\left(1,2+40 \rho_{1}\right)+0,15 \cdot \sigma_{\mathrm{cp}}\right] \cdot \mathrm{b}^{\prime}{ }_{\mathrm{w}} \cdot \mathrm{d} \\
& \mathrm{b}^{\prime}{ }_{\mathrm{w}}=\mathrm{b}_{\mathrm{w}}+\mathrm{n} \cdot \mathrm{b}_{\mathrm{c}} \cdot \frac{\mathrm{E}_{\mathrm{c}}}{\mathrm{E}_{\mathrm{p}}}
\end{aligned}
$$

Os resultados considerando todos os cinco casos estão indicados na Tabela 8.8, na qual é possível notar que os valores mais conservadores são obtidos empregando a equação recomendada pela NBR 6118:2003 e considerando a contribuição de 2/3 dos alvéolos preenchidos (caso 2 ).

Além disso, com a Tabela 8.8, pode-se observar que, para todos os casos, as lajes do lote $Y$ não atenderam ao previsto, até mesmo para o caso mais conservador (caso 2 contribuição de $2 / 3$ dos alvéolos), o que comprova a falta de aderência entre o concreto da laje e o dos alvéolos, proporcionada pelo processo de fabricação. 
Comparando as peças com dois e quatro alvéolos preenchidos e analisando o caso mais conservador (caso 2 ), pode-se observar que era esperado um aumento de $25,7 \%$ da resistência ao cisalhamento, com o preenchimento de quatro alvéolos ao invés de dois. Entretanto, com os ensaios, foi obtido um acréscimo de somente 3,06\%.

Assim, fica evidente a pouca melhoria obtida com o preenchimento de quatro alvéolos, quando comparado com dois alvéolos preenchidos.

Com isso, para o emprego de quatro preenchimentos é necessário um estudo mais aprofundado quanto ao melhor posicionamento dos alvéolos preenchidos, evitando a concentração de tensões em certos pontos da unidade.

Tabela 8.8: Variações no cálculo da resistência ao cisalhamento de lajes com alvéolos preenchidos.

\begin{tabular}{|c|c|c|c|c|c|c|c|}
\hline Laje & $\begin{array}{l}\mathrm{V}_{\mathrm{u}, \exp } \\
(\mathbf{k N})\end{array}$ & $\begin{array}{l}\mathrm{V}_{\mathrm{Rk}}{ }^{(1)} \\
(\mathbf{k N})\end{array}$ & $\frac{V_{u, \exp }}{V_{k K}^{(1)}}$ & $\begin{array}{c}\mathrm{V}_{\mathrm{Rk}}{ }^{(2)} \\
\text { (kN) }\end{array}$ & $\frac{V_{u, \exp }}{V_{R k}^{(2)}}$ & $\begin{array}{l}\mathrm{V}_{\mathrm{Rk}}{ }^{(3)} \\
(\mathbf{k N})\end{array}$ & $\frac{V_{u, \exp }}{V_{R k}^{(3)}}$ \\
\hline L1-2P-20-6D12,7-Y_C & 142,67 & 177,59 & 0,80 & 157,14 & 0,91 & 201,53 & 0,71 \\
\hline L2-2P-20-6D12,7-Y_C & 122,86 & 176,30 & 0,70 & 156,11 & 0,79 & 199,88 & 0,61 \\
\hline L3-2P-20-6D12,7-Y_C & 128,01 & 176,02 & 0,73 & 155,57 & 0,82 & 199,85 & 0,64 \\
\hline L4-2P-20-7D9,5-Y_C & 110,78 & 153,87 & 0,72 & 133,25 & 0,83 & 169,32 & 0,65 \\
\hline L5-2P-20-7D9,5-Y_C & 111,92 & 157,14 & 0,71 & 136,29 & 0,82 & 172,66 & 0,65 \\
\hline L6-2P-20-7D9,5-Y_C & 128,70 & 156,59 & 0,82 & 135,46 & 0,95 & 172,48 & 0,75 \\
\hline L7-2PF-20-5D12,7-Z_C & 147,76 & 155,09 & 0,95 & 137,65 & 1,07 & 170,97 & 0,86 \\
\hline L8-2PF-20-5D12,7-ZC & 189,73 & 155,09 & 1,22 & 137,65 & 1,38 & 170,97 & 1,11 \\
\hline L9-2PF-20-5D12,7-Z_C & 168,11 & 155,09 & 1,08 & 137,65 & 1,22 & 170,97 & 0,98 \\
\hline L10-2PF-20-5D12,7-Z_C & 156,30 & 155,09 & 1,01 & 137,65 & 1,13 & 170,97 & 0,91 \\
\hline L11-2PF-20-5D12,7-Z_C & 163,56 & 155,09 & 1,05 & 137,65 & 1,19 & 170,97 & 0,95 \\
\hline L12-2PF-20-5D12,7-Z_C & 173,63 & 155,09 & 1,12 & 137,65 & 1,26 & 170,97 & 1,01 \\
\hline L13-4PF-20-5D12,7-Z_C & 173,19 & 207,89 & 0,83 & 173,00 & 1,00 & 234,68 & 0,74 \\
\hline L14-4PF-20-5D 12,7-Z_C & 181,33 & 207,89 & 0,87 & 173,00 & 1,05 & 234,68 & 0,77 \\
\hline L15-4PF-20-5D12,7-Z_C & 176,34 & 207,89 & 0,85 & 173,00 & 1,02 & 234,68 & 0,75 \\
\hline L16-4PF-20-5D12,7-Z C & 178,44 & 207,89 & 0,86 & 173,00 & 1,03 & 234,68 & 0,76 \\
\hline L17-4PF-20-5D12,7-Z_C & 172,75 & 207,89 & 0,83 & 173,00 & 1,00 & 234,68 & 0,74 \\
\hline L18-4PF-20-5D12,7-Z_C & 170,91 & 207,89 & 0,82 & 173,00 & 0,99 & 234,68 & 0,73 \\
\hline Laje & $\begin{array}{l}\mathrm{V}_{\mathrm{u}, \exp } \\
\text { (kN) }\end{array}$ & $\begin{array}{l}\mathrm{V}_{\mathrm{Rk}}{ }^{(4)} \\
\text { (kN) }\end{array}$ & $\frac{V_{u, \exp }}{V_{R k}{ }^{(4)}}$ & $\begin{array}{l}\mathrm{V}_{\mathrm{Rk}}{ }^{(5)} \\
(\mathbf{k N})\end{array}$ & $\frac{V_{u, \exp }}{V_{R k}{ }^{(5)}}$ & & \\
\hline L1-2P-20-6D12,7-Y_C & 142,67 & 173,78 & 0,82 & 244,60 & 0,58 & & \\
\hline L2-2P-20-6D12,7-Y_C & 122,86 & 172,48 & 0,71 & 242,30 & 0,51 & & \\
\hline L3-2P-20-6D12,7-Y_C & 128,01 & 172,14 & 0,74 & 243,89 & 0,52 & & \\
\hline L4-2P-20-7D9,5-Y $=$ & 110,78 & 144,00 & 0,77 & 197,70 & 0,56 & & \\
\hline L5-2P-20-7D9,5-Y_C & 111,92 & 147,09 & 0,76 & 200,78 & 0,56 & & \\
\hline L6-2P-20-7D9,5-Y_C & 128,70 & 146,57 & 0,88 & 203,20 & 0,63 & & \\
\hline L7-2PF-20-5D12,7-Z_C & 147,76 & 148,64 & 0,99 & 199,08 & 0,74 & & \\
\hline L8-2PF-20-5D12,7-Z_C & 189,73 & 148,64 & 1,28 & 199,08 & 0,95 & & \\
\hline L9-2PF-20-5D12,7-Z_C & 168,11 & 148,64 & 1,13 & 199,08 & 0,84 & & \\
\hline L10-2PF-20-5D12,7-Z_C & 156,30 & 148,64 & 1,05 & 199,08 & 0,78 & & \\
\hline L11-2PF-20-5D12,7-Z_C & 163,56 & 148,64 & 1,10 & 199,08 & 0,82 & & \\
\hline L12-2PF-20-5D12,7-Z_C & 173,63 & 148,64 & 1,17 & 199,08 & 0,87 & & \\
\hline L13-4PF-20-5D12,7-Z_C & 173,19 & 192,35 & 0,90 & 296,73 & 0,58 & & \\
\hline L14-4PF-20-5D12,7-Z_C & 181,33 & 192,35 & 0,94 & 296,73 & 0,61 & & \\
\hline L15-4PF-20-5D12,7-Z_C & 176,34 & 192,35 & 0,92 & 296,73 & 0,59 & & \\
\hline L16-4PF-20-5D12,7-Z_C & 178,44 & 192,35 & 0,93 & 296,73 & 0,60 & & \\
\hline L17-4PF-20-5D12,7-Z_C & 172,75 & 192,35 & 0,90 & 296,73 & 0,58 & & \\
\hline L18-4PF-20-5D12,7-Z_C & 170,91 & 192,35 & 0,89 & 296,73 & 0,57 & & \\
\hline
\end{tabular}


Na Figura 8.15 estão apresentadas as relações $V_{\mathrm{u}, \text { exp }} / V_{\mathrm{Rk}}$ somente para as peças do lote $Z$, com dois alvéolos preenchidos, sendo eliminados os modelos em que foi comprovada a má aderência entre a laje e os alvéolos e os com quatro alvéolos preenchidos, que apresentaram pouca melhoria com relação aos dois preenchimentos.

\section{$\square$ Caso $1 \quad \square$ Caso $2 \quad 0$ Caso $3 \quad$ Caso $4 \quad \Delta$ Caso 5 \\ * Média Caso $1 \times$ Média Caso $2 \diamond$ Média Caso 3 OMédia Caso $4 \Delta$ Média Caso 5}

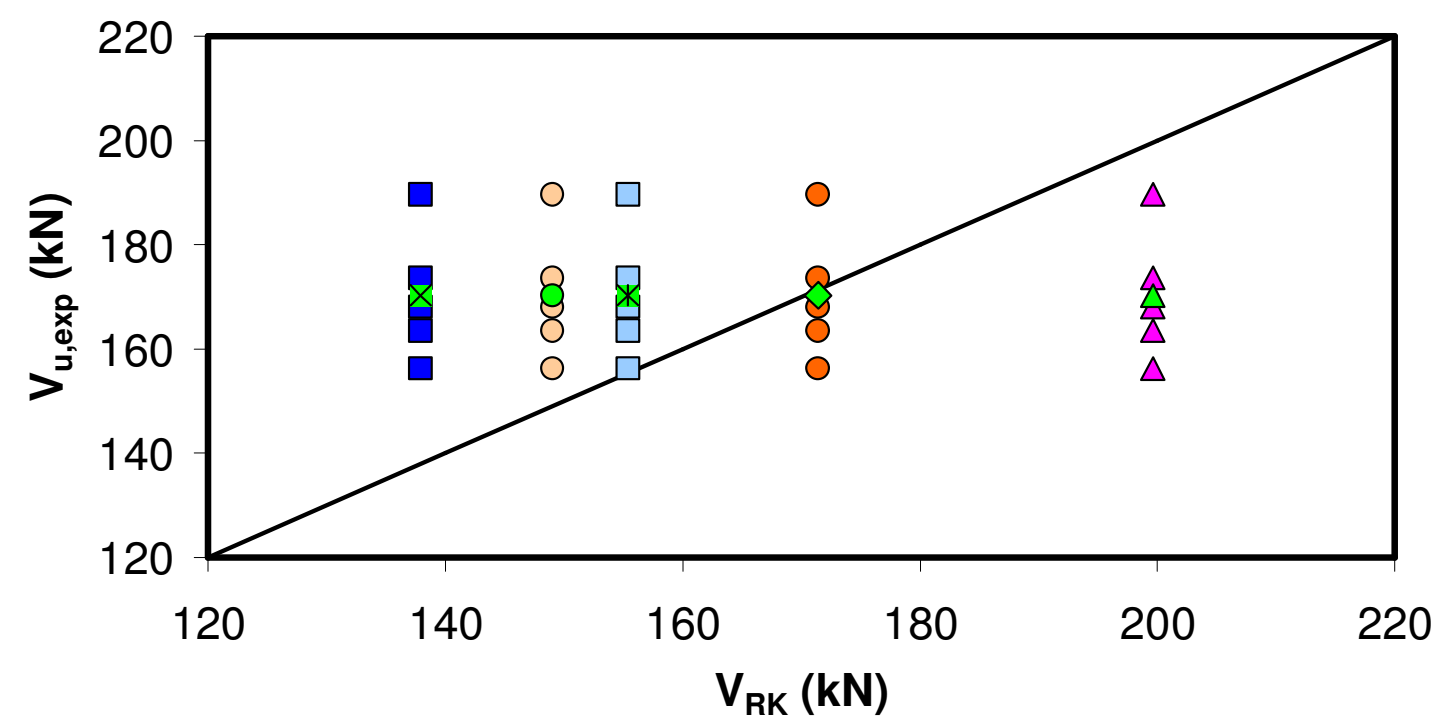

Figura 8.15: Relação $\mathrm{V}_{\mathrm{U}, \exp }$ e $\mathrm{V}_{\mathrm{RK}}$, considerando os cinco casos de cálculo.

Com a Figura 8.15 nota-se que, considerando a contribuição total e preenchimento executado antes da liberação da pré-tração (caso 3), o valor experimental médio se encontra mais próximo do previsto.

Apesar do caso 1 apresentar bons resultados, todos os valores experimentais superiores aos teóricos, ele não representa a realidade, pois de fato os alvéolos foram preenchidos antes da liberação da pré-tração dos cabos, algo que não é considerado nesse caso.

Já o caso 3 permite utilizar a máxima contribuição dos alvéolos preenchidos, no cálculo da resistência da laje alveolar ao cisalhamento, sendo que nos demais casos (1, 2 e 4) boa parte da contribuição fornecida pelos preenchimentos acaba sendo desprezada, pela consideração de valores teóricos mais conservadores.

Os resultados dessas lajes com dois alvéolos preenchidos, do lote $Z$, considerando 0 caso 3, e os respectivos valores médios estão apresentados na Tabela 8.9.

Com base nos dados analisados, pode-se notar que a relação entre a resistência experimental média e o valor médio previsto corresponde a 0,996, apresentando um desvio máximo de apenas $8 \%$ com relação à média. 
Tabela 8.9: Resistência ao cisalhamento considerando contribuição total dos alvéolos e preenchimento antes da protensão.

\begin{tabular}{|c|c|c|c|}
\hline Laje & $\begin{array}{c}\mathrm{V}_{\mathrm{u}, \exp } \\
\mathbf{( k N )}\end{array}$ & $\begin{array}{c}\mathrm{V}_{\mathrm{Rk}} \\
\left(\begin{array}{c}\text { Caso } \\
(\mathbf{k N})\end{array}\right.\end{array}$ & $\frac{\mathrm{V}_{\mathrm{u}, \exp }}{\mathrm{V}_{\mathrm{Rk}}}$ \\
\hline L8 & 189,73 & 170,97 & 1,11 \\
\hline L9 & 168,11 & 170,97 & 0,98 \\
\hline L10 & 156,30 & 170,97 & 0,91 \\
\hline L11 & 163,56 & 170,97 & 0,95 \\
\hline L12 & 173,63 & 170,97 & 1,01 \\
\hline Média & $\mathbf{1 7 0 , 2 7}$ & $\mathbf{1 7 0 , 9 7}$ & $\mathbf{0 , 9 9 6}$ \\
\hline
\end{tabular}

Vale ressaltar que, no Brasil, os projetos de laje alveolar geralmente consideram a presença de capa, o que permite aumentar sua resistência ao cisalhamento. Além disso, as unidades com preenchimentos ensaiadas correspondem a uma situação crítica, pois apresentam baixos níveis de protensão $\left(\sigma_{\mathrm{pi}}=1140 \mathrm{MPa}\right)$. Elementos com maiores níveis de protensão, comumente utilizados no Brasil, possuem maior capacidade ao cisalhamento.

Tendo em vista esses aspectos e o fato de que os valores de projeto levam em consideração os coeficientes de segurança, pode-se dizer que a consideração da contribuição total dos alvéolos, com o preenchimento antes da liberação da pré-tração (caso 3), corresponde à melhor maneira de representar o comportamento das lajes ensaiadas, com alvéolos preenchidos.

Analisando o caso em que não foram feitas considerações quanto ao preenchimento dos alvéolos, no cálculo da taxa de armadura, $\rho_{1}$, e da força de protensão, $\sigma_{\mathrm{cp}}$, (caso 5), observou-se a obtenção de valores muito elevados, os quais não foram atendidos pelos resultados experimentais. Assim, ficou clara a necessidade da realização de ajustes no cálculo de $\rho_{1}$ e $\sigma_{\mathrm{cp}}$, como empregado nos demais casos.

Além disso, com os ensaios das lajes com alvéolos preenchidos, observou-se a importância de uma aderência adequada entre a laje e o preenchimento dos alvéolos. A falta de aderência entre os concretos impede o trabalho da seção como composta e prejudica seu desempenho. O preenchimento dos alvéolos com concreto reforçado com fibras mostrou-se eficiente, garantindo o trabalho da seção composta.

$\mathrm{Na}$ análise dos ensaios, observou-se que o preenchimento dos alvéolos é uma atividade complexa, não havendo uma técnica padronizada que viabilize um adequado preenchimento. Então, quando for considerada a contribuição dos alvéolos preenchidos, no cálculo da resistência ao cisalhamento, deve-se atribuir atenção especial a esse procedimento. 
Alguns cuidados podem ser tomados como: garantir o preenchimento completo da seção, evitar a presença de detritos nas interfaces, que possam comprometer a aderência, verificar se o concreto não sofreu grande perda de água no instante do preenchimento, empregar concreto com características capazes de favorecer a aderência, como concreto reforçado com fibras, concreto de baixa retração etc.

Assim, fica evidente a dificuldade de garantir uma boa aderência entre a laje e o preenchimento dos alvéolos, quando esse procedimento for executado em obra, sem o controle de qualidade que ocorre em uma fábrica.

\subsubsection{Correlações dos valores experimentais e teóricos}

Para melhor analisar os resultados experimentais relativos às lajes com alvéolos parcialmente preenchidos, além da equação da NBR 6118:2003, empregaram-se, também, as equações recomendadas pelo EC2:2004.

Para ambas equações, os cálculos foram realizados considerando a contribuição total dos alvéolos preenchidos e preenchimento antes da aplicação da protensão, como pode ser observado na Tabela 8.10.

Tabela 8.10: Valores teóricos determinados por equações recomendadas pela NB1 e pelo EC2.

\begin{tabular}{|c|c|c|c|c|c|}
\hline Laje & $\begin{array}{c}\mathrm{V}_{\mathrm{Rk}} * \\
\mathbf{( N B 1 )} \\
\mathbf{( k N )}\end{array}$ & $\begin{array}{c}\mathrm{V}_{\mathrm{u}, \exp } \\
\mathbf{( \mathbf { N B } 1 )}\end{array}$ & $\begin{array}{c}\mathrm{V}_{\mathrm{Rk}} * * \\
\mathbf{( E C 2 )} \\
\mathbf{( k N )}\end{array}$ & $\begin{array}{c}\mathrm{V}_{\mathrm{u}, \exp } \\
\mathbf{( E \mathbf { N }}\end{array}$ & $\begin{array}{c}\mathrm{V}_{\mathrm{u}, \exp } \\
\mathbf{( k N )}\end{array}$ \\
\hline L1-2P-20-6D12,7-Y_C & 201,53 & 0,71 & 166,86 & 0,85 & 142,67 \\
\hline L2-2P-20-6D12,7-Y_C & 199,88 & 0,61 & 165,48 & 0,74 & 122,86 \\
\hline L3-2P-20-6D12,7-Y_C & 199,85 & 0,64 & 165,27 & 0,77 & 128,01 \\
\hline L4-2P-20-7D9,5-Y_C & 169,32 & 0,65 & 129,42 & 0,86 & 110,78 \\
\hline L5-2P-20-7D9,5-Y_C & 172,66 & 0,65 & 131,69 & 0,85 & 111,92 \\
\hline L6-2P-20-7D9,5-Y_C & 172,48 & 0,75 & 131,85 & 0,98 & 128,70 \\
\hline L7-2PF-20-5D12,7-Z_C & 170,97 & 0,86 & 144,39 & 1,02 & 147,76 \\
\hline L8-2PF-20-5D12,7-Z_C & 170,97 & 1,11 & 144,39 & 1,31 & 189,73 \\
\hline L9-2PF-20-5D12,7-Z_C & 170,97 & 0,98 & 144,39 & 1,16 & 168,11 \\
\hline L10-2PF-20-5D12,7-Z_C & 170,97 & 0,91 & 144,39 & 1,08 & 156,30 \\
\hline L11-2PF-20-5D12,7-Z_C & 170,97 & 0,95 & 144,39 & 1,13 & 163,56 \\
\hline L12-2PF-20-5D12,7-Z_C & 170,97 & 1,01 & 144,39 & 1,20 & 173,63 \\
\hline L13-4PF-20-5D12,7-Z_C & 234,68 & 0,74 & 185,62 & 0,93 & 173,19 \\
\hline L14-4PF-20-5D12,7-Z_C & 234,68 & 0,77 & 185,62 & 0,98 & 181,33 \\
\hline L15-4PF-20-5D12,7-Z_C & 234,68 & 0,75 & 185,62 & 0,95 & 176,34 \\
\hline L16-4PF-20-5D12,7-Z_C & 234,68 & 0,76 & 185,62 & 0,96 & 178,44 \\
\hline L17-4PF-20-5D12,7-Z_C & 234,68 & 0,74 & 185,62 & 0,93 & 172,75 \\
\hline L18-4PF-20-5D12,7-Z_C & 234,68 & 0,73 & 185,62 & 0,92 & 170,91 \\
\hline
\end{tabular}

$*$ Valores obtidos com emprego de $\mathrm{f}_{\mathrm{ctk} \text {,inf }} ; * *$ Valores obtidos com emprego de $\mathrm{f}_{\mathrm{cj}}$

Cálculos considerando contribuição total dos alvéolos preenchidos e preenchimento antes da protensão.

Considerando as unidades com alvéolos preenchidos, pode-se dizer que a equação recomendada pela NBR 6118:2003 (com consideração total dos alvéolos preenchidos e preenchimento antes da aplicação da protensão - caso 3) fornece os resultados mais coerentes com o comportamento apresentado pelos elementos, quando comparada com a equação fornecida pelo EC2 (2004). 
Essa equação do EC2 fornece valores teóricos mais conservadores e, portanto, menores, chegando a satisfazer a maior parte dos casos, inclusive aqueles cujo desempenho mostrou-se deficiente, como: alguns casos para as peças com quatro alvéolos preenchidos, do lote $Z$, que apresentaram concentração de tensões em pontos da seção transversal, e um caso do lote $Y$, cujo preenchimento dos alvéolos mostrou-se inadequado, devido a falhas de preenchimento entre a laje e os alvéolos, o que tornou evidente a impossibilidade do funcionamento conjunto laje-alvéolos, típico de uma seção composta.

Então, como contribuição à revisão da norma brasileira NBR 14861, esta pesquisa recomenda que os cálculos para determinação da resistência ao cisalhamento em zona fissurada por flexão, para lajes com alvéolos preenchidos, sejam feitos: considerando a contribuição total dos alvéolos com preenchimento antes da aplicação da protensão, quando preenchidos em fábrica, mediante a realização de ensaios experimentais para garantir a qualidade dos preenchimentos. 


\subsection{CONSIDERAÇÕES QUANTO AO CISALHAMENTO}

Na Tabela 9.1 é possível observar os resultados considerando todos os tipos de unidades alveolares ensaiadas ao cisalhamento. Para as peças com alvéolos preenchidos, os valores foram obtidos por meio da equação da NBR 6118:2003, considerando contribuição total dos alvéolos preenchidos e preenchimento antes da aplicação da protensão.

Tabela 9.1: Resultados de todos os tipos de unidades ensaiadas ao cisalhamento.

\begin{tabular}{|c|c|c|c|}
\hline Descrição & $\begin{array}{l}\mathrm{V}_{\mathrm{u}, \exp , \mathrm{m}} \\
(\mathbf{k N})\end{array}$ & $\begin{array}{l}\mathrm{V}_{\mathrm{Rk}, \mathrm{m}} \\
(\mathbf{k N})\end{array}$ & $\frac{\mathrm{V}_{\mathrm{u}, \mathrm{exp}, \mathrm{m}}}{\mathrm{V}_{\mathrm{Rk}, \mathrm{m}}}$ \\
\hline L-S-15-6D9,5-X_C - L=6,5 m e $\sigma_{\text {pii }}=1423,42 \mathrm{MPa}$. (força a 2,5 h) & $134,46 *$ & $113,11^{*}$ & 1,19 \\
\hline L-S-20-8D12,7-X_C - L=6,5 m e $\sigma_{\mathrm{pi}}=1425,05 \mathrm{MPa}$. (força a 2,5 h) & $222,39 *$ & $169,20 *$ & 1,31 \\
\hline L-S-20-6D12,7-Y_C - L=4,00 $\mathrm{m}$ e $\sigma_{\mathrm{pi}}=1429,98 \mathrm{MPa}$. (força a $2,5 \mathrm{~h}$ ) & 144,37 & 117,24 & 1,23 \\
\hline L-S-20-7D9,5-Y_C - L=4,15 m e $\sigma_{p i}=1351,35 \mathrm{MPa}$. (força a 2,5 h) & 133,64 & 94,76 & 1,41 \\
\hline L-S-20-7D9,5-Y_C - L=4,65 m e $\sigma_{p i}=1351,35 \mathrm{MPa}$. (força a $2,5 \mathrm{~h}$ ) & $135,44 *$ & $96,72 *$ & 1,40 \\
\hline L-S-20-7D9,5-Y_C - L=4,65 m e $\sigma_{p i}=1351,35 \mathrm{MPa}$. ( força a 5,75 h) & 68,24 & 93,34 & 0,73 \\
\hline L-S-20-5D12,7-Z_C - L=3,10 m e $\sigma_{\mathrm{pi}}=1140 \mathrm{MPa}$. (força a $2,5 \mathrm{~h}$ ) & 116,54 & 102,17 & 1,14 \\
\hline L-S-21-7D9,5-W_C-L=4,0 m e $\sigma_{\text {pii }}=1460 \mathrm{MPa}$. (força a 2,5 h) & 152,48 & 104,35 & 1,46 \\
\hline L-S-21-7D9,5-W_C- L=4,0 m e $\sigma_{\text {pii }}=1460 \mathrm{MPa}$. (força a 5,0 h) & 91,43 & 102,93 & 0,89 \\
\hline L-S-16-5D9,5-W_C - L=4,0 m e $\sigma_{\text {pii }}=1460 \mathrm{MPa}$. (força a 5,0 h) & 95,42 & 86,07 & 1,11 \\
\hline L-S-16-5D9,5-W_C - L=4,0 m e $\sigma_{\text {pii }}=1460 \mathrm{MPa}$. (força a 2,5 h) & 127,56 & 84,35 & 1,51 \\
\hline L-S-26-9D12,7-W_C - L=4,0 m e $\sigma_{p i i}=1460 \mathrm{MPa}$. (força a 5,0 h) & $150,80 *$ & $145,51 *$ & 1,04 \\
\hline L-S-26-9D12,7-W_C - L=4,0 m e $\sigma_{\text {pii }}=1460 \mathrm{MPa}$. (força a 2,5 h) & 210,96 & 143,63 & 1,47 \\
\hline $\begin{array}{c}\text { L-S-26-9D12,7-W_C - L=4,0 } \mathrm{m} \text { e } \sigma_{\text {pii }}=1460 \mathrm{MPa} .(1 \mathrm{~m} \text { de balanço e } \\
\text { força a } 2,5 \mathrm{~h} \text { ) }\end{array}$ & $320,89 *^{a}$ & $322,66 * 1$ & $0,99^{1}$ \\
\hline L-C-20-6D9,5-X_C - L=6,5 $\mathrm{m} \mathrm{e} \sigma_{\mathrm{pi}}=1423,42 \mathrm{MPa}$. (força a 2,5 h) & 106,59 & 133,59 & 0,80 \\
\hline L-C-25-8D12,7-X_C - L=6,5 m e $\sigma_{p i}=1425,05 \mathrm{MPa}$. (força a $2,5 \mathrm{~h}$ ) & $215,89 *$ & $223,55 *$ & 0,97 \\
\hline L-C-25-6D12,7-Y_C - L=4,15 m e $\sigma_{p i}=1429,98 \mathrm{MPa}$. (força a 2,5 h) & $140,80 *$ & $137,40 *$ & 1,02 \\
\hline L-C-25-7D9,5-Y_C - L=4,15 $\mathrm{m}$ e $\sigma_{\mathrm{pi}}=1351,35 \mathrm{MPa}$. (força a 2,5 h) & 119,02 & 110,81 & 1,07 \\
\hline L-C-25-5D12,7-Z_C - L=3,10 m e $\sigma_{p i}=1140 \mathrm{MPa}$. (força a $2,5 \mathrm{~h}$ ) & 159,89 & 124,94 & 1,28 \\
\hline L-CF-25-5D12,7-Z_C - L=3,10 m e $\sigma_{\mathrm{pi}}=1140 \mathrm{MPa}$. (força a 2,5 h) & 196,60 & 124,94 & 1,57 \\
\hline L-2P-20-6D12,7-Y_C - L=4,15 m e $\sigma_{p i}=1429,98 \mathrm{MPa}$. (força a 2,5 h) & 131,18 & 200,42 & 0,65 \\
\hline L-2P-20-7D9,5-Y_C - L=4,15 m e $\sigma_{p i}=1351,35 \mathrm{MPa}$. (força a $2,5 \mathrm{~h}$ ) & 117,13 & 171,49 & 0,68 \\
\hline L-2PF-20-5D12,7-Z_C - L=3,10 m e $\sigma_{\mathrm{pi}}=1140 \mathrm{MPa}$. (força a $2,5 \mathrm{~h}$ ) & 170,27 & 171,39 & 0,99 \\
\hline L-4PF-20-5D12,7-Z_C - L=3,10 m e $\sigma_{p i}=1140 \mathrm{MPa}$. (força a 2,5 h) & 175,49 & 235,13 & 0,75 \\
\hline
\end{tabular}

Somente as lajes do lote $Z$ receberam tratamento da face superior.

Ex: L-S-15-6D9,5-X_C $\rightarrow$ sem capa, altura $15 \mathrm{~cm}, 6$ cordoalhas de $9,5 \mathrm{~mm}$, lote $X$ e ensaio ao cisalhamento.

*Valor referente a um ensaio, não correspondendo a valor médio

${ }^{1}$ Valor determinado considerando região não fissurada por flexão (Tension Shear Capacity)

${ }^{a}$ Não corresponde ao valor último, pois o ensaio foi encerrado antes da ruptura da laje.

$\sigma_{\mathrm{pi}}$ - protensão inicial; $L$ - comprimento da unidade alveolar 
Com a presente pesquisa, considerando a grande quantidade de resultados para diversas tipologias de lajes, pode-se observar que inúmeros são os fatores que afetam a resistência ao cisalhamento, alguns com menor ou maior influência, mas cada qual com sua parcela acaba por tornar mais difícil a análise do comportamento de tais peças.

Os principais parâmetros que garantem alterações nas resistências das lajes são: características geométricas, resistência do concreto, nível de protensão, taxa de armadura, número e diâmetro de cordoalhas, posição da força e condições de apoio.

Constatou-se que um maior comprimento é capaz de aumentar a resistência ao cisalhamento, considerando peças com as mesmas características geométricas, protensão e armaduras. Além disso, o aumento da protensão garante maior resistência, comparando peças em que as demais características são semelhantes. Considerando peças com semelhantes níveis de protensão e diâmetros de armadura, um maior número de cordoalhas garante melhor desempenho ao cisalhamento.

Também foi observado que um aumento na altura da peça e no número de cordoalhas, mantendo o mesmo nível de protensão e o mesmo comprimento, garante um aumento significativo na resistência da peça ao cisalhamento e promove uma alteração no mecanismo de funcionamento próximo ao colapso.

Além disso, observou-se que é possível a obtenção de elevada resistência ao cisalhamento quando a aplicação da força é feita em seção distante da zona de transmissão da força de protensão, como é o caso da peça ensaiada com balanço de $1 \mathrm{~m}$ e força a 2,5 h do apoio.

Para diferentes situações de projeto, espera-se que peças com capa e com alvéolos preenchidos apresentem resistências superiores às daquelas sem capa. Entretanto, a partir dos resultados observou-se que isso não se concretizou para todos os casos.

De uma forma geral, é possível notar que as peças sem capa pertencentes aos lotes $\mathrm{X}$ e $\mathrm{Y}$ apresentaram resultados ao cisalhamento superiores aos obtidos pelas peças semelhantes, com a presença de capa. Assim, diferentemente do esperado, a presença da capa prejudicou o desempenho da unidade ao cisalhamento. Isso pode ser explicado pela falta de aderência entre a capa e a laje, uma vez que propositadamente não houve qualquer tratamento da face superior da laje, quanto à rugosidade ou limpeza antes da concretagem da capa, justamente nas peças pertencentes aos lotes $X$ e $Y$. A falta de aderência entre a capa e a laje acaba prejudicando o desempenho da unidade, pois quando a capa é considerada tem-se um aumento do peso próprio e da distância da aplicação de força (pois o considerado é $2,5 \mathrm{~h}$, sendo $\mathrm{h}$ a altura total do modelo), causando um aumento do momento fletor na seção considerada. Então, sem a aderência entre as partes, a seção transversal que resistirá não será composta, mas apenas constituída pela laje, que terá seu desempenho afetado. 
As unidades com capa pertencentes ao lote $Y$, apesar de terem alcançado suas máximas capacidades previstas, não apresentaram o trabalho conjunto laje-capa, sendo verificado o descolamento da capa.

O mesmo ocorreu para as peças com alvéolos parcialmente preenchidos, pertencentes ao lote $Y$, que apresentaram resistências ao cisalhamento inferiores às das peças sem qualquer preenchimento. Nesse caso, ficou evidente a falta de aderência entre a laje e os alvéolos, que não foram totalmente preenchidos, como anteriormente ilustrado na Figura 8.11.

Analisando as peças que apresentaram boas condições de aderência, a partir do tratamento prévio da face superior das lajes (lote $Z$ ), pode-se notar que tanto o emprego de capa como o preenchimento parcial dos alvéolos correspondem a alternativas que garantem uma melhoria no desempenho das unidades ao cisalhamento. 0 emprego de capa estrutural garantiu um aumento de resistência de 37\%, com relação a peça semelhante sem a presença de capa. Um aumento superior foi alcançado com o emprego da capa de concreto reforçado com fibras, equivalente a $69 \%$ da resistência obtida para as peças sem capa. Assim, nota-se que quando existe boa aderência entre a laje e a capa, a seção é extremamente beneficiada quanto ao cisalhamento.

Ainda considerando os resultados para as unidades pertencentes ao lote $Z$, pode-se notar que entre as peças sem capa e com dois alvéolos preenchidos houve um aumento de $46 \%$ da resistência ao cisalhamento, o que corresponde a um aumento significativo de resistência, obtido com apenas dois preenchimentos em parte da unidade.

Comparando as peças com dois e quatro alvéolos preenchidos, houve um pequeno aumento de resistência ao cisalhamento, cerca de $3 \%$, o que indica ser pouco compensador o preenchimento de quatro alvéolos, nos modelos analisados.

A partir dos resultados observou-se que a variação do ponto de aplicação da força modificou significativamente o comportamento das unidades. A maior parte das peças em que a força foi aplicada a uma distância de $5 \mathrm{~h}$ (peças do lote $\mathrm{W}$ ) e $5,75 \mathrm{~h}$ (peças do lote $Z$ ) apresentou grande influência da flexão, que acabou prejudicando o desempenho das peças quanto ao cisalhamento.

\subsection{CONSIDERAÇõES RELATIVAS À FLEXÃo}

$\mathrm{Na}$ Tabela 9.2 é possível observar os resultados considerando todos os tipos de unidades alveolares ensaiadas à flexão.

As peças com capa, pertencentes ao lote $X$, apresentaram resultados satisfatórios, inclusive superiores aos das peças semelhantes, sem capa. Dessa forma, pode-se observar que, nesse caso, a capa contribuiu para aumentar a capacidade resistente das unidades alveolares à flexão. 
Tabela 9.2: Resultados de todos os tipos de unidades ensaiadas à flexão.

\begin{tabular}{|c|c|c|c|}
\hline Descrição & $\begin{array}{c}\mathrm{M}_{\mathrm{u}, \exp , \mathrm{m}} \\
\quad(\mathbf{k N})\end{array}$ & $\begin{array}{c}M_{\mathrm{Rk}, \mathrm{m}} \\
(\mathbf{k N})\end{array}$ & $\frac{M_{\mathrm{u}, \text { exp }, \mathrm{m}}}{M_{\mathrm{Rk}, \mathrm{m}}}$ \\
\hline L-S-15-6D9,5-X_F - L=6,5 m e $\sigma_{p i}=1423,42 \mathrm{MPa}$. & 79,02 & 64,13 & 1,23 \\
\hline L-S-20-8D12,7-X_F - L=6,5 m e $\sigma_{p i}=1425,05 \mathrm{MPa}$. & 235,05 & 218,60 & 1,07 \\
\hline $\mathrm{L}-\mathrm{S}-20-5 \mathrm{D} 12,7-\mathrm{Z}=\mathrm{F}-\mathrm{L}=3,10 \mathrm{~m}$ e $\sigma_{\mathrm{pi}}=1140 \mathrm{MPa}$ & 107,00 & 135,64 & 0,79 \\
\hline L-S-20-5D12,7-Z F - L=6,10 m e $\sigma_{\mathrm{pi}}=1140 \mathrm{MPa}$. & $135,65 *$ & $135,67 *$ & 1,00 \\
\hline L-S-21-7D9,5-W_F- L=4,0 m e $\sigma_{\mathrm{pi}}=1460 \mathrm{MPa}$ & $154,85 *$ & $113,44 *$ & 1,36 \\
\hline L-C-20-6D9,5-X_F - L=6,5 m e $\sigma_{p i}=1423,42 \mathrm{MPa}$. & 101,83 & 93,10 & 1,09 \\
\hline L-C-25-8D12,7-X_F - L=6,5 m e $\sigma_{p i}=1425,05 \mathrm{MPa}$. & $267,30 *$ & $282,45^{*}$ & 0,95 \\
\hline $\mathrm{L}-\mathrm{C}-25-5 \mathrm{D} 12,7-\bar{Z} \mathrm{~F}-\mathrm{L}=3,10 \mathrm{~m}$ e $\sigma_{\mathrm{pi}}=1140 \mathrm{MPa}$ & 185,48 & 177,44 & 1,04 \\
\hline L-C-25-5D 12,7-Z_F - L=6,10 $\mathrm{m}$ e $\sigma_{\mathrm{pi}}=1140 \mathrm{MPa}$. & $183,48^{*}$ & $177,47^{*}$ & 1,03 \\
\hline L-CF-25-5D12,7-Z_F - L=3,10 m e $\sigma_{p i}=1140 \mathrm{MPa}$. & 186,37 & 177,44 & 1,05 \\
\hline L-2PF-20-5D12,7-Z_F - L=3,10 m e $\sigma_{p i}=1140 \mathrm{MPa}$. & 141,60 & 135,66 & 1,04 \\
\hline L-4PF-20-5D12,7-Z_F - L=3,10 $\mathrm{m}$ e $\sigma_{\mathrm{pi}}=1140 \mathrm{MPa}$. & 138,90 & 135,67 & 1,02 \\
\hline
\end{tabular}

Lajes com capa do lote $X$ não receberam tratamento da face superior - As lajes do lote $Z$, sim.

Ex: L-S-15-6D9,5-X_F $\rightarrow$ sem capa, altura $15 \mathrm{~cm}, 6$ cordoalhas de $9,5 \mathrm{~mm}$, lote $X$ e ensaio à flexão. *Valor referente a um ensaio, não correspondendo a valor médio.

$\sigma_{\mathrm{pi}}$ - protensão inicial; $L$ - comprimento da unidade alveolar.

De maneira geral, tanto a presença de capa como a de alvéolos parcialmente preenchidos contribuem com o aumento da capacidade resistente à flexão.

É importante ressaltar que, propositadamente, não houve qualquer preocupação com relação à limpeza e à rugosidade superficial das lajes dos lotes $\mathrm{X}$ e $\mathrm{Y}$ antes da concretagem das capas, ou seja, as lajes apresentavam superfícies lisas e receberam as capas nas condições em que se encontravam no pátio da fábrica. Dessa forma, conclui-se que o maior problema encontrado quanto à falta de aderência entre a capa e a laje está relacionado ao procedimento construtivo empregado.

Da mesma forma, o preenchimento parcial de alvéolos corresponde a uma atividade complexa e difícil de ser realizada corretamente, não somente devido ao processo produtivo empregado, como também devido ao tipo de concreto utilizado, com baixa relação água-cimento, o que dificulta o adensamento e diminui a trabalhabilidade. Observou-se aderência adequada entre a laje e os alvéolos somente nas peças em que se empregou concreto reforçado com fibras, que se mostrou mais adequado para o preenchimento, devido à maior resistência à tração e ao controle da retração, proporcionado pelas fibras presentes no concreto.

Considerando as peças pertencentes ao lote $Z$, pode-se notar que, apesar do preenchimento de quatro alvéolos proporcionar um aumento da resistência à flexão, com relação às peças sem capa, não garantiu qualquer aumento quando se compara com as peças com dois alvéolos preenchidos. Diante de tais resultados, tornou-se mais compensador o preenchimento de apenas dois alvéolos, uma vez que se garante maior resistência à flexão, com menor tempo de execução e menor custo, em relação às unidades com quatro alvéolos preenchidos. 


\subsection{ADEQUABILIDADE DAS EQUAÇÕES UTILIZADAS}

Para melhor análise quanto à adequabilidade das equações empregadas, realizou-se a distribuição dos pontos correspondentes à relação $V_{u, \exp }$ versus $V_{R k}$ em um mesmo gráfico, considerando as peças sem capa e com capa e tela, as quais apresentaram: aplicação da força a $2,5 \mathrm{~h}$ do apoio, boa aderência laje-capa e ausência da influência prejudicial de outros mecanismos. Para este caso, observou-se que os resultados fornecidos pela equação da NBR 6118:2003 apresentaram o melhor ajuste dos dados, considerando uma linha de tendência linear (Figura 9.1.).

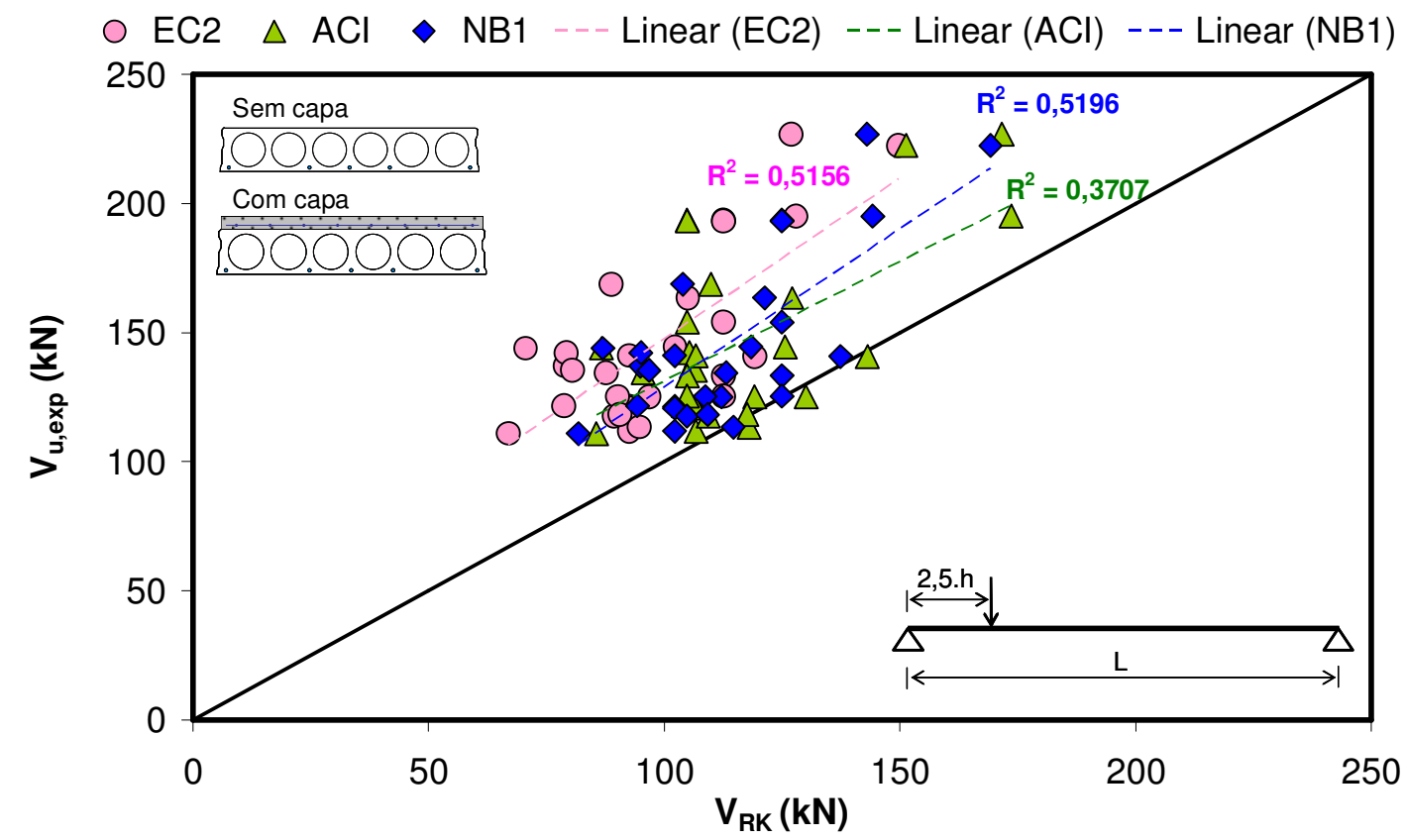

Figura 9.1: Correlação dos resultados obtidos, considerando as peças sem capa e com capa e tela, com aplicação da força a $2,5 \mathrm{~h}$ do apoio e com boa aderência laje-capa.

A Figura 9.2 mostra a distribuição dos pontos referentes à relação $V_{u, e x p}$ versus $V_{R k}$, considerando as peças: sem capa, com aplicação da força a 2,5 h, 5 h e 5,75 h do apoio e com capa e tela, com boa aderência laje-capa. Para este caso, com a consideração de peças submetidas a forte influência da flexão, observou-se que os resultados fornecidos pelas equações do ACI (2008) apresentaram o melhor ajuste linear dos dados.

$\mathrm{Na}$ Figura 9.3 é possível observar as correlações de $V_{u, \exp }$ e $V_{R k}$, para as lajes ensaiadas ao cisalhamento, com a distinção dos tipos de peças. Nessa figura estão apresentados somente os valores teóricos obtidos por meio dos equacionamentos recomendados pela NBR 6118:2003, considerando contribuição total dos alvéolos e preenchimento antes da aplicação da protensão. Além disso, são consideradas somente as peças com aplicação da força a 2,5 h do apoio e com boa aderência, para o caso dos elementos com seção composta (com capa e alvéolos preenchidos). 


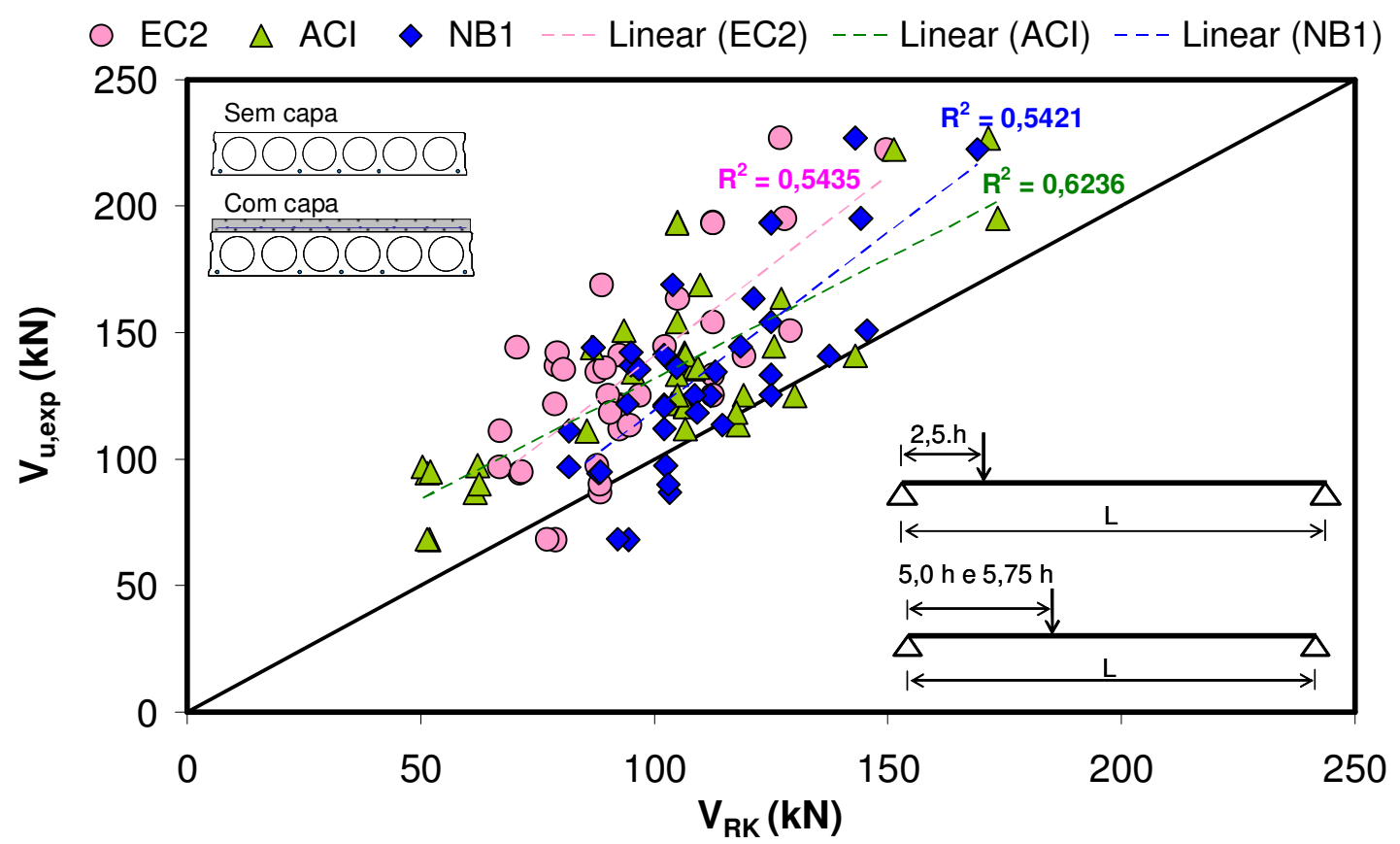

Figura 9.2: Correlação dos resultados obtidos, considerando as peças sem capa e com capa e tela, com aplicação da força a 2,5 h, 5 h e 5,75 h do apoio e com boa aderência laje-capa.

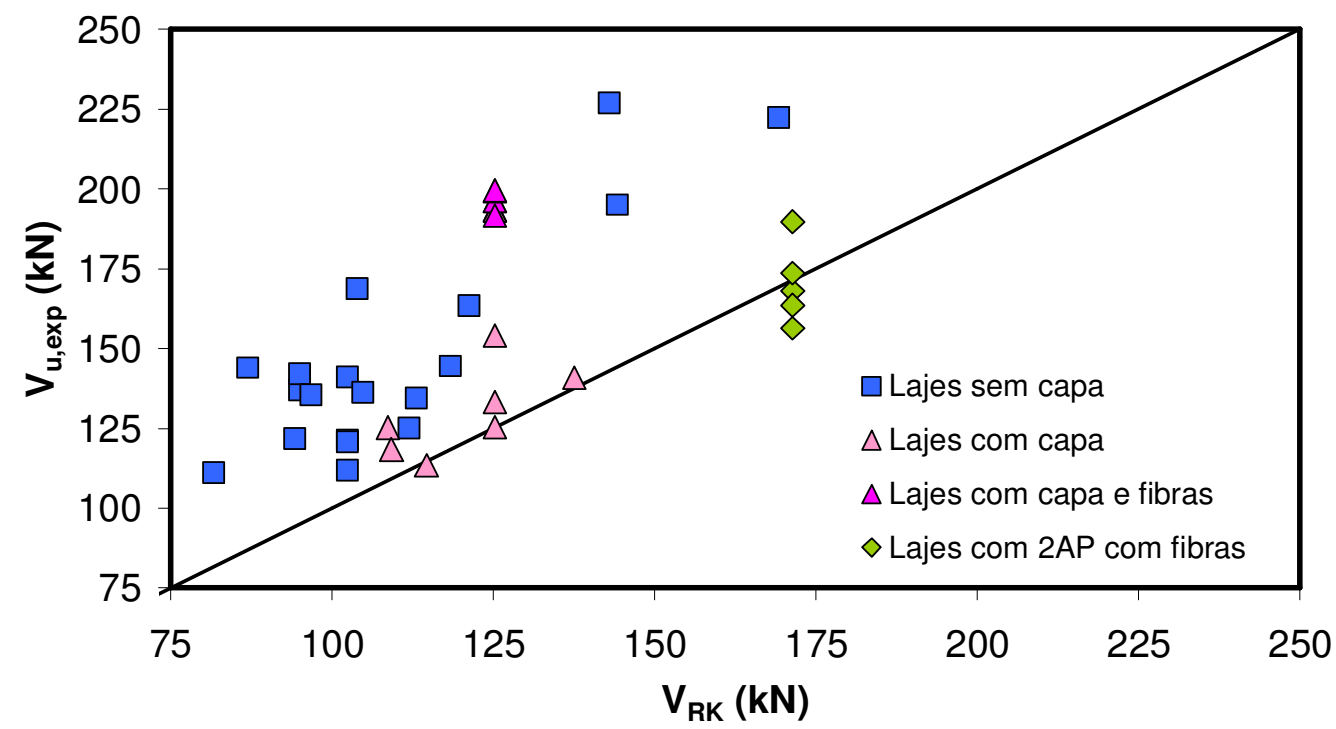

Figura 9.3: Correlação dos resultados obtidos nos ensaios realizados e os valores determinados pela equação da NBR 6118:2003, considerando as peças com força aplicada a 2,5 h.

Sendo assim, verificou-se uma boa consistência com os critérios de cálculo adotados para as diversas tipologias de laje estudadas, considerando o ensaio com aplicação da força a $2,5 \mathrm{~h}$ do apoio. 


\subsection{ANÁLISE DA RESISTÊNCIA DO CONCRETO À TRAÇÃO}

Aplicou-se a equação recomendada pela NBR 6118:2003, para diferentes resistências do concreto à tração, com o intuito de investigar qual dessas resistências é capaz de melhor representar o comportamento verificado nos ensaios das unidades alveolares.

De uma forma geral, foi possível constatar que, quando empregada a equação recomendada pela NBR 6118:2003, a resistência característica inferior à tração $\left(f_{c t k, i n f}\right)$ garante resultados mais consistentes, quando comparada com as resistências média e característica superior. $O$ emprego de $f_{c t k \text {,inf }}$ fornece melhores relações $V_{u, \text { exp }} / V_{R K}$, permitindo que um maior número de unidades alveolares alcance seus respectivos valores previstos, garantindo assim que um maior número de peças apresente resultados satisfatórios. Tal constatação pode ser observada na Figura 9.4.

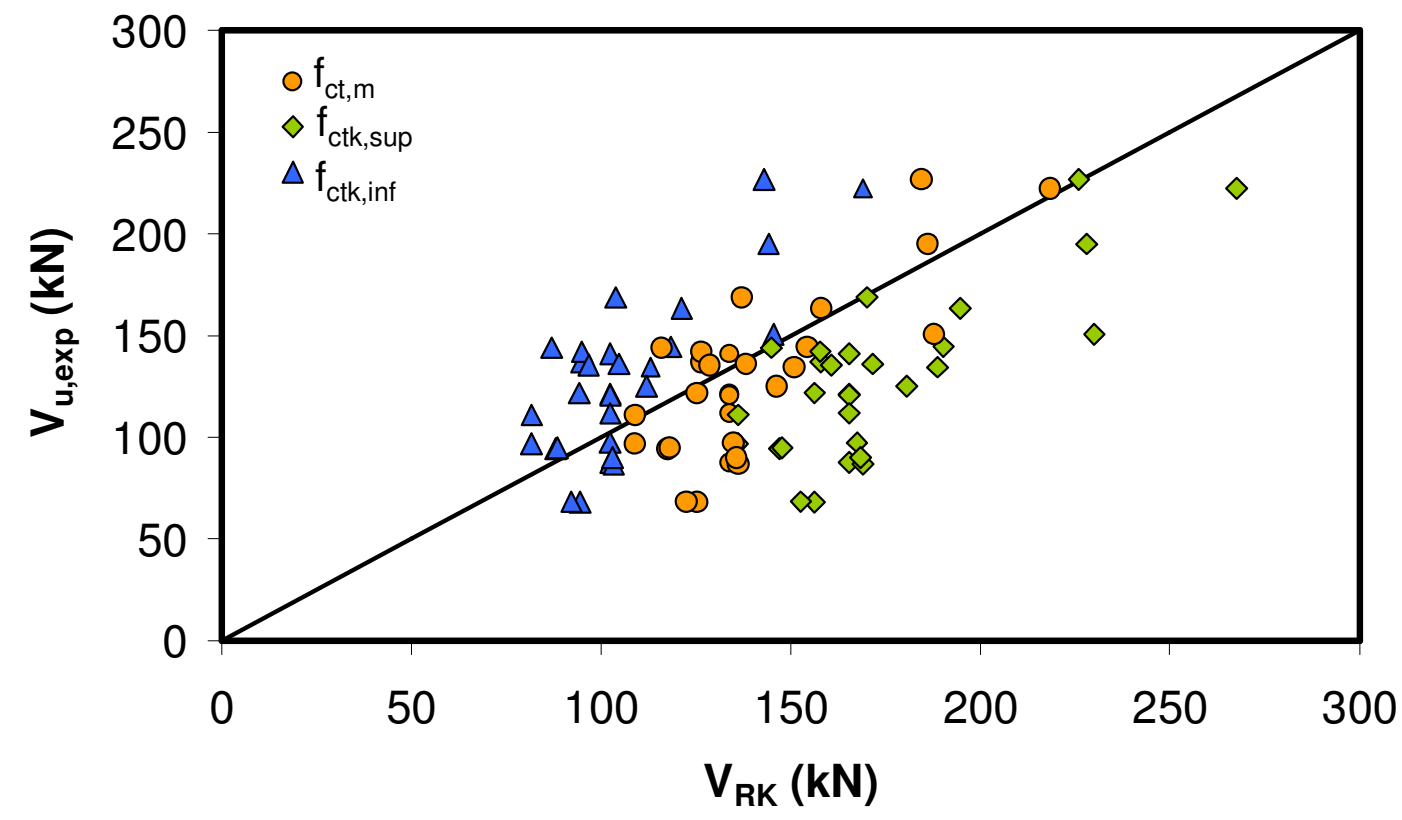

Figura 9.4: Relação entre resultados experimentais e teóricos considerando diferentes tipos de resistências do concreto à tração, para lajes sem capa.

\subsection{COMENTÁRIOS SOBRE AS CONFIGURAÇÕES DE FISSURAÇÃO}

Analisando de uma forma geral as configurações de fissuração para cada unidade ensaiada ao cisalhamento, constatou-se que lajes de $20 \mathrm{~cm}$, sem capa, nível de protensão variando entre $1140 \mathrm{MPa}$ a $1460 \mathrm{MPa}$, submetidas a uma força a 2,5 $\mathrm{h}$ do apoio, tendem a se comportar como indicado na Figura 9.5, podendo haver maior ou menor influência dos mecanismos de flexão e de torção.

Com a aplicação da força a 2,5 h do apoio, o mecanismo de cisalhamento tende a ocorrer em região fissurada à flexão. Para lajes sem capa ocorre maior influência das fissuras de flexão na capacidade resistente ao cisalhamento. 
Para uma unidade alveolar simplesmente apoiada, a primeira fissura de flexão tem início na região onde a tensão de tração na fibra inferior atingir a resistência do concreto à tração. A formação de uma fissura proporciona um súbito aumento da força de tração na armadura, pois as tensões de tração na seção transversal do concreto não fissurado acabam atravessando a fissura por meio da armadura. Assim, essa força adicional na armadura precisa ser totalmente ancorada para evitar uma falha brusca na formação da fissura. Um aumento adicional do carregamento deve resultar na formação de novas fissuras de flexão, mais próximas ao apoio.

Entretanto, se forças de cisalhamento estão presentes, com uma tensão de tração adicional nas nervuras, devida ao cisalhamento, a fissura de flexão resulta em uma típica fissura inclinada de cisalhamento com flexão. Além disso, essa fissura inclinada resulta em um aumento da força na armadura. Um menor ângulo entre a fissura inclinada e o eixo da laje resulta em um aumento adicional da força na armadura, assim como um aumento das fissuras de flexão na borda inferior. Devido ao fato das barras não serem totalmente ancoradas no apoio, a capacidade ao cisalhamento não pode ser efetivamente aumentada próximo à região do apoio da unidade alveolar, especialmente se essa região estiver fissurada por conta da flexão, causando um mecanismo final de falha de ancoragem.

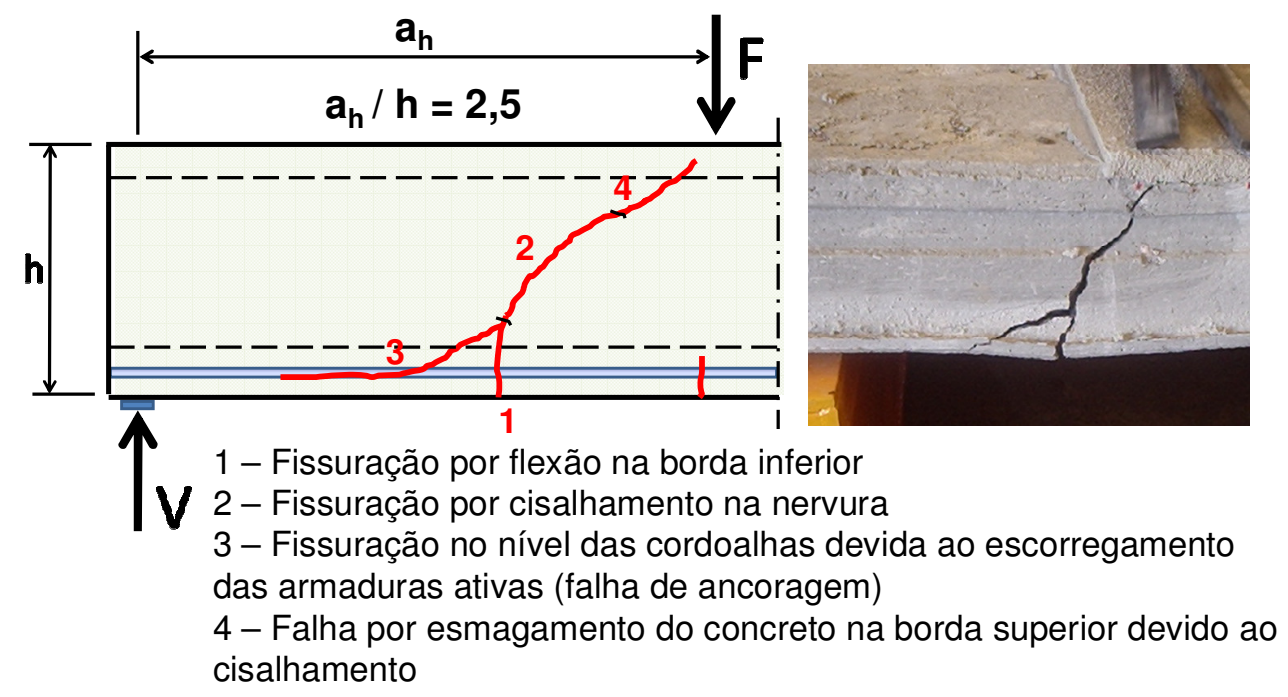

Figura 9.5: Mecanismos de comportamento das lajes sem capa.

Para as unidades alveolares com capa, a influência de outros mecanismos (como o de torção) é menos significante. Isto ocorre devido à mudança do mecanismo de ruptura, causada pelo aumento na altura da laje.

Com o aumento da altura da laje, devido à presença de capa, tem-se um aumento da capacidade à flexão, mas a seção continua crítica quanto ao cisalhamento, pois as nervuras permanecem estreitas. 
Dessa forma, considerando o ensaio com aplicação da força a $2,5 \mathrm{~h}$ do apoio, o mecanismo de ruptura tende a se aproximar daquele que ocorre quando a tensão de tração na nervura supera a resistência do concreto à tração, ou seja, ruptura por tração do concreto na nervura, devida ao cisalhamento. Diferentemente do caso anterior (lajes sem capa), nas peças com capa inicialmente ocorre a fissuração por cisalhamento, e em seguida, por flexão. Tais fissuras geram um aumento da tensão nas cordoalhas, afetando o equilíbrio da zona de trasnferência da força de protensão, aumentando o comprimento de transferência e, assim, possibilitando o escorregamento das armaduras, que é constatado pelo fendilhamento do concreto no nível das cordoalhas (falha de ancoragem).

Com os ensaios, pode-se dizer que peças de $20 \mathrm{~cm}$, com capa de $5 \mathrm{~cm}$, nível de protensão variando entre $1140 \mathrm{MPa}$ e $1429,98 \mathrm{MPa}$, submetidas a uma força a 2,5 h do apoio (sendo h a altura total), tendem a se comportar como indicado na Figura 9.6.

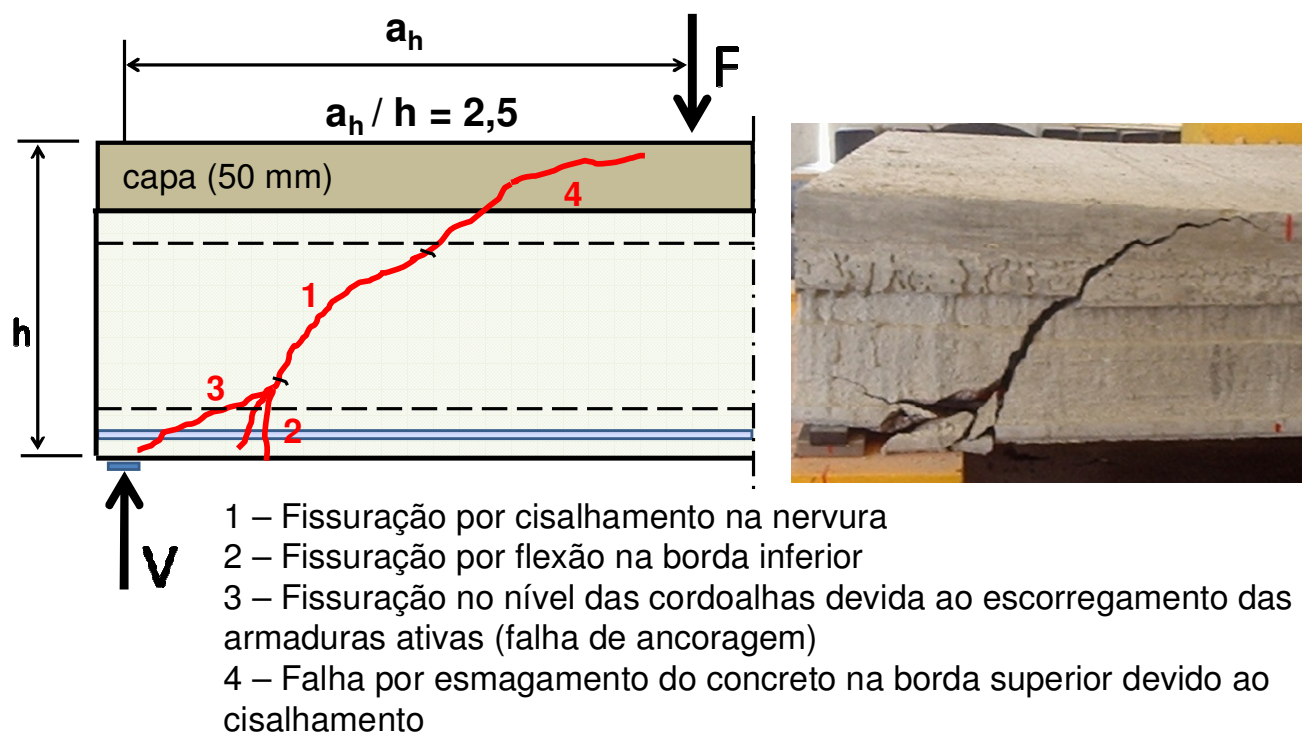

Figura 9.6: Mecanismos de comportamento para lajes com capa.

A partir dos ensaios realizados com elementos alveolares de $26 \mathrm{~cm}$ de altura, com força a 2,5 h do apoio, observou-se uma mudança no mecanismo de ruptura, que passou a apresentar maior influência do cisalhamento, rompendo de forma mais brusca. Os mecanismos típicos de comportamento presentes em peças de maiores alturas, quando estas se encontram próximas ao colapso, podem ser observados na Figura 9.7.

Assim, analisando todos os casos, pode-se dizer que, com o aumento da altura da laje, tem-se menor influência da flexão, com a presença de um mecanismo mais bem definido quanto ao cisalhamento e a tendência de uma ruptura mais brusca. 


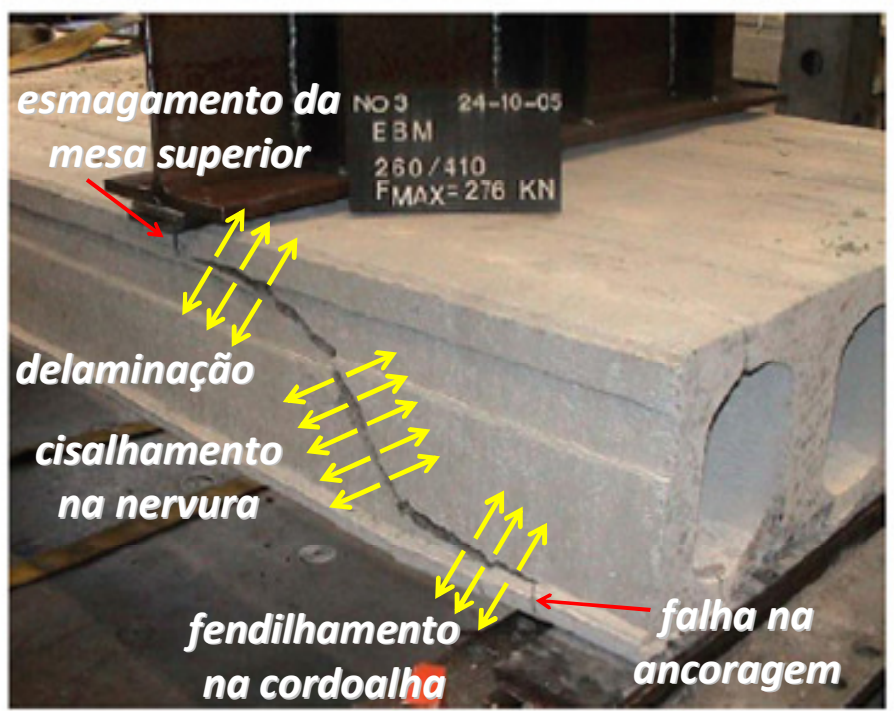

Figura 9.7: Mecanismos de comportamento para lajes de maior altura. [Bertagnoli \& Mancini (2009)] 


\section{0}

\subsection{CONSIDERAÇÕES FINAIS}

Considerando as lajes ensaiadas (com altura de $15 \mathrm{~cm}$ a $26 \mathrm{~cm}$ ), para a força aplicada a $2,5 \mathrm{~h}$ do apoio, os resultados experimentais e suas respectivas análises revelaram que o mecanismo de resistência ao cisalhamento pode ser afetado pela presença de fissuras de flexão, sendo que o mecanismo de ruptura na região do apoio passa a ser governado pela tensão de tração normal à armadura ativa (falha na ancoragem). Neste caso, o equacionamento recomendado pela NBR 6118:2003, que está de acordo com a norma europeia EN-1168:2005, considera essa hipótese, ou seja: Flexural Shear Capacity.

Com a análise dos resultados para as lajes sem capa foi possível concluir que, quando é isolado o efeito desfavorável da zona de transmissão, para a aderência das cordoalhas junto ao apoio, é possível diminuir o efeito da flexão e, assim, obter elevada resistência ao cisalhamento. Tal efeito foi constatado, melhorando as condições do apoio, a partir do ensaio de uma laje com $1 \mathrm{~m}$ em balanço e aplicação da força a 2,5 h do apoio. Assim, com a alteração das condições de ancoragem, tem-se uma mudança dos mecanismos de comportamento da laje, e novos estudos são necessários para verificar a validade das equações nesse caso, que apresenta diferentes condições de projeto, quando comparado com o ensaio padrão estudado nesta pesquisa.

O ensaio de flexão ( 3 m - lote $Z$ ), segundo o Manual da FIP (1992), pode ser utilizado para avaliação do ELS, fornecendo informações sobre a força efetiva na armadura de protensão, sobre a estimativa da resistência do concreto à tração e, consequentemente, permite identificar o momento de fissuração. Entretanto, empregando esse procedimento (com vão de $3 \mathrm{~m}$ ), não foi possível avaliar a flexão no ELU, devido à forte interação dos esforços de flexão e de cisalhamento.

Para a avaliação da resistência à flexão em lajes sem capa, verificou-se que o ensaio de flexão com três pontos (força concentrada) e com vão de $6 \mathrm{~m}$ (lote $\mathrm{Z}$ ) apresentou resultados experimentais compatíveis com os critérios de cálculo, sendo, portanto, um procedimento recomendado para ensaios de prova de carga e de investigação dos mecanismos de resistência à flexão. 
Foi possível constatar que, assim como recomendado pela FIP (1982), é possível obter ruptura da laje pela interação de cisalhamento e flexão, a partir de um tipo de ensaio, com a aplicação de apenas uma força a cerca de $1 \mathrm{~m}$ do apoio.

Analisando a ruína das lajes, em alguns ensaios ao cisalhamento foi observada a presença do mecanismo de torção. O sistema de ensaio permitia rotação apenas na direção longitudinal da lajes (empregou-se rótula somente em uma direção), sendo possível a ocorrência de torção, ocasionando a interação de mecanismos, o que prejudicou o desempenho da peça.

A partir da comparação dos gráficos para um mesmo tipo de laje, observou-se que a torção alterou o comportamento de alguns elementos, piorando seu desempenho. Com isso, é possível concluir que, além de observar resultados, é importante a identificação dos respectivos mecanismos, a partir da configuração das fissuras.

Além disso, quando ocorre a combinação de mecanismos, não compatíveis com as considerações feitas pelas equações empregadas, elas acabam não sendo válidas para representar o comportamento da unidade alveolar.

Dessa forma, para comparar resultados experimentais e teóricos, é importante verificar se o comportamento da unidade se encontra dentro das limitações das equações empregadas.

Com os ensaios foi possível observar que os resultados foram satisfatórios somente nos casos de preenchimento de alvéolos com concreto reforçado com fibras, devido à maior resistência à tração e ao controle da retração proporcionado pelas fibras.

Diante de todas as análises realizadas nesta pesquisa, fica evidente que o preenchimento de alvéolos corresponde a uma providência satisfatória quanto ao ganho de resistência à flexão e ao cisalhamento, uma vez que o preenchimento de dois alvéolos com concreto reforçado com fibras proporcionou aumento de $46 \%$ da resistência ao cisalhamento e de $32 \%$ da resistência à flexão, em relação aos valores obtidos para peça semelhante, sem capa.

Entretanto, para a distribuição dos alvéolos preenchidos empregada nas lajes ensaiadas, foi constatado que o melhor custo-benefício é obtido com o preenchimento de apenas dois alvéolos.

Para quatro alvéolos preenchidos, resulta maior gasto de material e maior tempo de execução, sem garantir grandes melhorias quanto às resistências ao cisalhamento e à flexão.

Comparando as resistências entre as peças com dois e quatro alvéolos preenchidos, notou-se que para a flexão houve uma pequena redução da resistência (cerca de apenas $2 \%$ ), e quanto ao cisalhamento houve um pequeno aumento, da ordem de $3 \%$. 
A consideração da melhoria da resistência da laje ao cisalhamento, mediante o preenchimento de alvéolos, deve ser feita com cautela, uma vez que é difícil garantir boa aderência entre a laje e o concreto de preenchimento. Consequentemente, é difícil garantir que a protensão seja transmitida da laje aos alvéolos como se constituíssem uma seção composta, quando o preenchimento é realizado antes da liberação da prétração dos cabos.

Assim, o cálculo para a determinação da resistência ao cisalhamento em zona fissurada por flexão, considerando a contribuição total dos alvéolos preenchidos e preenchimento antes da liberação da pré-tração dos cabos, deve ser feito somente quando existir um adequado controle de qualidade nas atividades de preenchimento dos alvéolos (comprovado por ensaios experimentais), sendo executados em fábrica.

Caso o preenchimento seja realizado em obra, esta pesquisa recomenda a realização de novos estudos, considerando, no cálculo, menor contribuição dos alvéolos preenchidos, com a validação a partir de resultados experimentais, a fim de garantir a segurança dos elementos, tendo em vista a dificuldade desse procedimento.

Assim, o preenchimento dos alvéolos, visando seu trabalho conjunto com a unidade alveolar, não corresponde a algo simples, e vários estudos são necessários, inclusive com o intuito de analisar o melhor material a ser empregado no preenchimento.

Nas demais unidades alveolares, em que os alvéolos foram preenchidos com o emprego de concreto sem fibras, esse preenchimento contribuiu para melhor definir o mecanismo de ruptura das unidades, apesar dos resultados experimentais serem bem inferiores aos obtidos teoricamente.

Por meio dos ensaios para determinar a capacidade resistente ao cisalhamento de lajes com capa de concreto moldado no local (lote $X$ e lote $Y$ ), pode-se concluir que a presença de capa, quando não estiver totalmente aderida à laje, pode prejudicar o desempenho quanto ao cisalhamento, resultando em resistências inferiores às obtidas pelas lajes do mesmo tipo, sem capa.

O adequado funcionamento da capa corresponde a um fator crítico, pois quando ela é executada sobre a unidade alveolar, tem-se um aumento do peso próprio e da distância de aplicação da força $(2,5 \mathrm{~h})$, gerando um acréscimo do momento fletor na seção considerada. Assim, tal momento deve ser resistido pela seção composta.

No entanto, sem a ação conjunta laje-capa, essa capa não irá contribuir na resistência do conjunto, e pode ocorrer maior fissuração de flexão no ensaio de cisalhamento.

Dessa forma, quando não são realizados procedimentos para garantir melhor aderência entre a laje e a capa de concreto, o alcance das máximas capacidades resistentes é inviabilizado. 
Comparando os resultados obtidos para as lajes compostas foi possível observar que os procedimentos empregados na concretagem da capa influenciam no desempenho da unidade alveolar.

A rugosidade superficial da face superior e a limpeza das peças antes da concretagem são essenciais para garantir a ação conjunta laje-capa. Dessa forma, a execução da capa corresponde a um aspecto de extrema importância na execução de estruturas de edifícios, principalmente quando essa capa é essencial para garantir o efeito diafragma, possibilitando o trabalho conjunto da estrutura.

Analisando os ensaios das peças com capa, concluiu-se que, quando a seção se comporta efetivamente como composta, é possível obter aumentos significativos nas resistências ao cisalhamento e à flexão, como foi observado nas peças do lote $Z$, que apresentaram um aumento de $37 \%$ ao cisalhamento e $73 \%$ à flexão, com relação à peça semelhante, sem capa, e um aumento de $69 \%$ da resistência ao cisalhamento e $74 \%$ à flexão, considerando a capa de concreto reforçado com fibras.

Quanto aos ensaios de flexão realizados nas lajes com capa, pertencentes ao lote $X$, pode-se dizer que a capa, mesmo não estando totalmente aderida à laje, contribuiu na melhoria do seu desempenho à flexão.

Dessa forma, o maior problema está relacionado com as condições de produção das lajes alveolares protendidas. Não existe uma tecnologia padronizada para preenchimento adequado dos alvéolos e execução da capa de concreto.

Diversos trabalhos estão sendo desenvolvidos na Universidade de Nottingham, na Inglaterra, com o intuito de descobrir a melhor maneira de executar a capa de concreto sobre a unidade alveolar.

Assim, com base nos estudos realizados, recomenda-se que seja feito um tratamento da face superior da laje antes da concretagem da capa, com a criação de ranhuras nessa face e posterior limpeza com jato de água.

Além disso, é muito importante a realização de ensaios periódicos para verificar a qualidade das peças e a eficiência dos preenchimentos e das capas, quando forem considerados no cálculo da resistência ao cisalhamento.

A partir da análise da configuração das fissuras para as lajes ensaiadas, foi possível observar que as lajes com altura de $15 \mathrm{~cm}$ (com ou sem capa) e de $16 \mathrm{~cm}$ alcançaram a ruptura com maior influência do mecanismo de flexão, quando comparadas com as lajes de $20 \mathrm{~cm}$ (com ou sem capa). Por sua vez, observou-se que as peças com $20 \mathrm{~cm}$ e 21 $\mathrm{cm}$ apresentaram maior influência da flexão do que aquelas com $26 \mathrm{~cm}$.

Assim, pode-se observar que o aumento da altura da peça conduz a uma alteração do mecanismo de ruptura, que passa a sofrer menor influência da flexão, predominando o cisalhamento. 
A partir das análises realizadas com as peças ensaiadas à flexão e ao cisalhamento, que apresentaram certa deficiência de desempenho, pode-se concluir que a equação recomendada por Lindström (2009) é eficaz para comprovar a existência da interação dos mecanismo de cisalhamento e flexão e para justificar casos em que um mecanismo interfere no outro e reduz sua máxima capacidade.

A partir dessa equação recomendada por Lindström (2009), pode-se determinar a máxima força cortante de cálculo com o intuito de evitar essa interação de mecanismos, capaz de prejudicar o desempenho da laje.

De uma forma geral, a expressão numérica que garantiu o atendimento ao limite estabelecido $(\leq 1)$ para todos os resultados de ensaio, considerando tanto os ensaios de flexão como os de cisalhamento, correspondeu à equação $3.35 \mathrm{com} n=4$, equação esta indicada em Lindström (2009).

Com as análises realizadas pode-se concluir que a equação recomendada pela NBR 6118:2003 fornece resultados satisfatórios quanto à determinação da resistência ao cisalhamento de peças com aplicação de força a $2,5 \mathrm{~h}$ do apoio, para as lajes alveolares com e sem capa.

Para outros casos, com diferentes condições de apoio, diferentes distâncias de aplicação da força, e mesmo os casos para lajes com alvéolos preenchidos, são necessárias outras considerações, as quais não foram pevistas por essa Norma.

Os resultados relativos à equação da NBR 6118:2003 apresentam melhor ajuste em comparação com os obtidos por meio das equações indicadas no EC2 (2004) e no ACI (2008). A equação recomendada pelo EC2 (2004) forneceu resultados mais conservadores, não considerando a interação de cisalhamento e flexão. A equação do ACI apresentou o pior ajuste dos resultados, considerando força aplicada a $2,5 \mathrm{~h}$ com relação ao eixo do apoio.

As peças com alvéolos preenchidos apresentaram resultados mais satisfatórios quando da consideração da contribuição total dos alvéolos preenchidos e do preenchimento antes da aplicação da protensão.

As peças com aplicação da força a $5 \mathrm{~h}$ e $5,75 \mathrm{~h}$ do apoio apresentaram forte influência da flexão, comprovada pela configuração de fissuração das respectivas peças. Com a análise dos resultados para esse tipo de laje, conclui-se que a equação que melhor considerou o efeito da flexão correspondeu à recomendada pelo ACI (2008).

Assim, quando a equação recomendada pela NBR 6118:2003 é empregada para determinar a resistência ao cisalhamento de peças com aplicação da força a 5 h e 5,75 h, é importante considerar a equação de interação de cisalhamento e flexão, recomendada por Lindström (2009), e verificar se esses elementos apresentam forte influência da flexão, capaz de reduzir consideravelmente o desempenho ao cisalhamento. 
Acredita-se que os resultados insatisfatórios (valores experimentais inferiores aos previstos) obtidos para algumas lajes com a força aplicada a 5 h e 5,75 h (L10, L11, L19, L20 e L21), foram ocasionados devido não somente a interação dos mecanismos de cisalhamento e flexão como também devido ao escorregamento das cordoalhas, visto que tanto as fissuras de flexão como o escorregamento das barras afetam o comprimento de transferência, o efeito favorável da protensão e, consequentemente, o desempenho da laje. Assim novos estudos são necessários para melhor analisar esse caso.

De acordo com o EC2-Comentary (2008), na equação da NBR 6118:2003, o papel da resistência do concreto não está correto, pois são obtidos grandes desvios quando empregado concreto de elevada resistência. Entretanto, as peças ensaiadas foram compostas por concretos com resistências à compressão variando de $40 \mathrm{MPa}$ a $55 \mathrm{MPa}$, o que corresponde a um nível relativamente baixo de resistência, quando comparado com o empregado pelos europeus.

Além disso, de acordo com o EC2-Comentary, outro problema é que a equação recomendada pela NBR 6118:2003 foi principalmente derivada de vigas, que rompem por cisalhamento com influência de flexão, e não é válida para elementos que geralmente rompem por tração devida ao cisalhamento.

Entretanto, as unidades ensaiadas nesta pesquisa não romperam tipicamente por tração devido ao cisalhamento (cisalhamento puro), havendo sim grande influência da flexão, por apresentarem menores alturas que as das unidades europeias.

Dessa forma, pode-se dizer que a equação da NBR 6118:2003 é apropriada para lajes de pequena altura e força aplicada a $2,5 \mathrm{~h}$ do apoio, pois representa satisfatoriamente 0 comportamento das unidades estudadas nesta pesquisa, que por sua vez correspondem às típicas lajes brasileiras (produzidas por quatro fabricantes).

Além disso, para as lajes sem capa, considerando o ensaio padrão, pode-se concluir que a correção da tensão de protensão é adequadamente prevista pelo fator $0,15 \sigma_{c p}$ presente na equação recomendada pela NBR 6118:2003, para determinar a força cortante de cálculo. Vale lembrar que essa análise foi feita considerando a resistência média à compressão do concreto presente na laje, determinado por meio de ensaio de corpo de prova.

Tais constatações sobre o emprego das equações, juntamente com o amplo estudo experimental realizado, além de fornecerem maior entendimento quanto ao comportamento das unidades ensaiadas, forneceram subsídios para a avaliação de tais peças, considerando as características peculiares dos elementos produzidos no Brasil e, assim, contribuíram com indicações que podem ser usadas na revisão da norma brasileira NBR 14861 (Laje pré-fabricada - Painel alveolar de concreto protendido). 


\subsection{SUGESTÕES PARA TRABALHOS FUTUROS}

Assim, como continuidade a esse trabalho são necessários novos estudos envolvendo a análise de diversos equacionamentos, com o intuito de refinar os cálculos, para peças com aplicação da força a $5 \mathrm{~h}$, e até mesmo determinar um coeficiente redutor da tensão de protensão, justamente para prever o efeito causado pelas fissuras de flexão e o escorregamento das barras.

Também como continuidade a esse trabalho é necessário um estudo mais aprofundado quanto às condições de ancoragem, com a realização de ensaios considerando melhores condições de ancoragem das lajes.

Com o intuito de verificar a adequabilidade das equações empregadas nesta pesquisa, seria muito importante um estudo de lajes alveolares protendidas com seções transversais variadas (alvéolos não circulares) e com maiores alturas. Tal estudo poderá verificar qual equação garante resultados satisfatórios para lajes alveolares protendidas com quaisquer seções transversais.

Pode-se realizar um estudo mais aprofundadado quanto às lajes com alvéolos preenchidos, visando garantir e padronizar um procedimento adequado de preenchimento e identificar a melhor distribuição dos alvéolos preenchidos, de forma a evitar pontos de concentração de tensões na seção.

Por meio da realização de ensaios, pode-se analisar o melhor posicionamento dos preenchimentos ao longo da seção transversal e verificar o melhor material a ser empregado nos alvéolos.

Muito importante seria um estudo das lajes alveolares considerando uma variação no comprimento dos apoios considerados nos ensaios, com o intuito de identificar a influência dessa variável no desempenho da laje alveolar.

A literatura carece de um estudo mais aprofundado quanto à fluência das lajes alveolares protendidas, com o intuito de definir critérios para o projeto de tais elementos.

Novos estudos são necessários em peças com alvéolos preenchidos, sendo tal preenchimento executado em obra (após a liberação da pré-tração dos cabos), com o intuito de verificar a contribuição dos alvéolos na resistência ao cisalhamento, sem a presença do controle de qualidade estabelecido em uma fábrica.

Além disso, é de extrema importância um estudo mais aprofundado quanto à determinação de melhores ajustes referentes à parcela da resistência ao cisalhamento atribuída à protensão $\left(0,15 \sigma_{\mathrm{cp} .}\right.$.b.d), para lajes com alvéolos preenchidos.

Esse preenchimento gera modificações na tensão de protensão e consequentemente no comprimento de transferência $\left(\mathrm{I}_{\mathrm{t}}\right)$, tornando mais complexo o comportamento da laje ao cisalhamento, o que justifica maiores estudos. 


\section{REFERÊNCIAS BIBLIOGRÁFICAS}

AJDUKIEWICZ, A.B.; KLISZCZEWICZ, A.T.; WEGLORZ, M. (2007). Behaviour of pretensioned hollow core slabs with in-situ concrete topping. In : CEB-FIB SYMPOSIUM, 2007, Dubrovnik. Proceedings... Dubrovnik, Croacia: FIB.

AMERICAN CONCRETE INSTITUTE - ACI Committee 318, Building code requirements for structural concrete (ACI 318-08) and commentary, Farmington Hills, MI.

ASSOCIAÇÃO BRASILEIRA DE NORMAS TÉCNICAS (2003). NBR 6118: Projeto de estruturas de concreto - Procedimento. Rio de Janeiro.

ASSOCIAÇÃO BRASILEIRA DE NORMAS TÉCNICAS (2002). NBR 14861: Laje préfabricada - painel alveolar de concreto protendido - Requisitos. Rio de Janeiro.

ASSOCIAÇÃO BRASILEIRA DA CONSTRUÇÃO INDUSTRIALIZADA - ABCI (1989). A história dos pré-fabricados e sua evolução no Brasil. São Paulo - SP.

ASSOCIATION OF MANUFACTURERS OF PRESTRESSED HOLLOW CORE FLOORS - ASSAP (2002). The hollow core floor design and applications.Verona - Italy.

ASTER, H.; KOCH, R. (1974). Untersuchungen an dicken stahlbetonplatten, Universität Stuttgart.

BERTAGNOLI, G.; MANCINI, G. (2009). Failure anlysis of hollow core slabs tested in shear. Structural Concrete, v.10, n.3, p.139-152, Sept.

BRITISH STANDARDS INSTITUTION. BS 8110-1:1997. Structural use of concrete. Code of practice for design and construction.

BROO, H.; LUNDGREN, K. (2002). Finite element analyses of hollow core units subjected to shear and torsion. Technical Report 1. Chalmers University, Sweden

CARVALHO, R.C. (2007). Estruturas em concreto armado. Universidade Federal de São Carlos. Notas de aula.

CARVALHO, R.C. (2008). Estruturas em concreto protendido: cálculo e detalhamento. Universidade Federal de São Carlos. Notas de aula.

COLLINS, M.P.; BENTZ, E.C.; SHERWOOD, E.G.; XIE, L. (2008). An adequate theory for the shear strength of reinforced concrete structures. Magazine of Concrete Research, v.60, n.9, 635-650.

COMITÉ EUROPÉEN DE NORMALISATION - CEN. EN 1991-1-1:2001. Eurocode 1 Actions on structures - Part 1-1: General Actions - Densities, self-weight, imposed loads for buildings. 
COMITÉ EUROPÉEN DE NORMALISATION - CEN. EN 1992-1-1:2004. Eurocode 2 Projeto de estruturas de betão - Parte 1-1: Regras gerais e regras para edifícios.

COMITÉ EUROPÉEN DE NORMALISATION - CEN. EN 1168:2005 - Precast concrete products - Hollow core slabs. (English version). Brussels: CEN, 2005.

COMITÉ EUROPÉEN DE NORMALISATION - CEN. EN 12504-1:2003. Testing concrete in structures. Cored specimens. Taking, examining and testing in compression structural use of concrete.

COSTA, O.O. (2010). Avaliação de desempenho de elementos de lajes alveolares protendidas pré-fabricadas. 132p. Dissertação (Mestrado) - Universidade Federal de São Carlos, São Carlos, 2010.

ELLIOTT, K.S. (2002). Precast concrete structures. 2.ed. London, England.

ELLIOTT, K.S. (2005). I Workshop Internacional: Design and construction of precast concrete structures. São Carlos, UFSCar - NETPRE.

ENGSTRÖM, B. (2005): Design and analysis of prestressed concrete structures. Chalmers University of Technology, Division of Structural Engineering, Göteborg, 144 pp.

EUROCODE 2 COMENTARY. (2008). European Concrete Platform ASBL. 2008.

FEDERATION INTERNATIONALE DE LA PRECONTRAINTE - FIP (1982). Guide to Good

Practice - Shear at the Interface of Precast and In-situ Concrete. Wrexham Springs.

FEDÉRATION INTERNATIONALE DE LA PRÉCONTRAINTE- FIP (1992). Guide to good practice: quality assurance of hollow core slab. London, England.

FEDERATION INTERNATIONALE DU BETON, FIB (CEB-FIB) (1990). Model Code. Thomas Telford Ltd., London, 1993.

FEDERATION INTERNATIONALE DU BETON - FIB (CEB-FIB) (2000). Guide to good practice: special design considerations for precast prestressed hollow core floors. Lausanne.

FEDERATION INTERNATIONALE DU BETON - FIB (CEB-FIB) (2007). Structural connections for precast concrete buildings. Draft.

FERNANDES, N.S (2007). Cisalhamento em lajes alveolares pré-fabricadas em concreto protendido: ensaio padrão de apoio para controle de qualidade. $124 p$. Dissertação (Mestrado) - Universidade Federal de São Carlos, São Carlos, 2007.

FERREIRA, M.A.; FERNANDES, N.S.; CARVALHO, R.C.; ORTENZI, A. (2007). Avaliação de desempenho da resistência ao cisalhamento em lajes alveolares pré-fabricadas em concreto protendido. Revista Concreto e Construções, São Paulo, n.48, p.46-51, out./dez. 
FUSCO, P.B. (1995). Técnica de armar as estruturas de concreto. 1.ed. São Paulo: Pini.

FUSCO, P.B. (2008). Estruturas de concreto - Solicitações tangenciais. 1.ed. São Paulo: Pini.

GIRHAMMAR, U.A. (1992). Design principles for simply supported prestressed hollow core slabs. Struct. Engrg. Rev., Oxford, England, 4(4), 301-316.

GIRHAMMAR, U.A.; PAJARI, M. (2008). Tests and analysis on shear of composite slabs of hollow core units and concrete topping. Construction and Building Materials. v.22, n.8, August, pp.1708-1722.

HEDMAN, O.; LOSBERG, A. (1978). Design of concrete structures with regard to shear forces, in shear and torsion. CEB Bulletin d' Information n.126. Paris.

IBRAHIM, I.S., ELLIOTT, K.S., COPELAND, S. Bending Capacity of Precast Prestressed Hollow Core Slabs with Concrete Toppings. Malaysian Journal of Civil Engineering. 20(2): $260-283,2008$.

INVELOP OY. www.invelopoy.com. Acesso em 10 abr. 2009.

KANI, G.N.J. (1966). Basic facts concerning shear failure. ACI Journal Proceedings. v.63, n.6, p.675-692, jun.

KONG, F.K.; EVANS, R.H. (2001). Reinforced and prestressed concrete. Spon Press, UK.

KÖNIG, G.; FISHER, J. (1995). Model uncertainties concerning design equations for shear capacity of concrete members without shear reinforcement. CEBBulletin 224, Model Unvertainties, pp.100.

LEONHARDT, F. (1983). Construções de concreto. v.5 - Concreto protendido. Interciência.

LEONHARDT, F.; MÖNNIG, E. (1977). Construções de concreto: princípios básicos

do dimensionamento de estruturas de concreto armado. v.1. Rio de Janeiro, Interciência.

LINDSTRÖM, G. (2007). FIB 2007. Draft.

LINDSTRÖM, G. (2009). FIB 2009. Draft.

MANUAL de produtos da Empresa Cassol Pré-Fabricados. (2010). Disponivel em: <http://www.arcomunicacao.com.br/cassol/php/produtos.php?id=16 >. Acesso em: 23 de out. 2010.

MELO, C.E.E. (2004). Manual Munte de projetos pré-fabricados de concreto. São Paulo: Pini.

Lajes Alveolares Protendidas: Cisalhamento em Região Fissurada por Flexão 
NATIONAL PRECAST CONCRETE ASSOCIATION AUSTRALIA - NPCAA (2003). Hollow core flooring technical manual. Melbourne.

PAJARI, M. (1989). Design of prestressed hollow core slabs. Technical Research Center of Finland, Espoo, Finland. Rep. 657.

PAJARI, M. (2004). Pure torsion tests on single hollow core slabs. VTT Technical Research Centre of Finland. Research Notes 2273.

PAJARI, M. (2005). Resistance of prestressed hollow core slabs against web shear failure. VTT Technical Research Centre of Finland. Research Notes 2292.

PAJARI, M.; YANG, L. (1994). Shear capacity of hollow core slabs on flexible supports. VTT Technical Research Centre of Finland. Research Notes 1587.

REAGAN, P. (1999). Ultimate limit states principles, in Structural Concrete vol. 2 - fib CEB-FIP bulletin n.2. Sttutgart.

RETTNE, L.; EDEKLING, K. (2006). Improved design method for web shear tension failure in hollow core units. 153p. Master's Thesis - Department of Civil and Environmental Engineering, Division of Structural Engineering, Chalmers University of Technology, Göteborg, Sweden, 2006.

TKALČIĆ, D.; BANIĆ D.; ZUPČIĆ M.; PERIĆ, Z. (2007). Prestressed hollow core slabs shear resistance test according to HRN EN 1168:2005. In: FIB SYMPOSIUM, 2007, Dubrovnik. Proceedings... Dubrovnik, Croacia: FIB.

TELFORD, T. (1988). Precast prestressed hollow core floors. FIP Recommendation. London, England.

VASCONCELOS, A.C. (1980). Manual prático para a correta utilização de aços no concreto protendido em obediência às normas atualizadas. Livros Técnicos e Científicos. Rio de Janeiro: Editora S.A.

WALRAVEN, J.C. (1978). The influence of depth on the shear strength of lightweight concrete beams without shear reinforcement, Report 5-78-4, Delft University of Technology.

WALRAVEN, J.C.; MERCX, W.P.M. (1983). The bearing capacity of prestressed hollow core slabs. HERON. Delft University of Technology. v.28, n.3, 1983.

YANG, L. (1994). Design of Prestressed Hollow core Slabs with Reference to Web Shear Failure. ASCE Journal of structural engineering. v.120, n.9, September, pp.26752696. 


\section{ANEXO A}

\section{DEFINIÇÕES E EQUAÇÕES RELATIVAS À ANCORAGEM}

É importante realizar uma distinção de quatro situações que, embora parecidas, exigem diferentes tratamentos nos modelos de cálculo, correspondendo a:

$>$ Comprimento de ancoragem básico $\left(\ell_{\mathrm{bp}}\right)$ : de maneira simplificada, pode ser considerado como o menor comprimento necessário para a ruptura ocorrer na armadura, situação em que ela deve se admitida com o maior esforço possível, e o concreto, em torno da armadura, com a menor resistência e fissurado;

> Comprimento de transferência ( $\left.\ell_{\mathrm{bpt}}\right)$ : comprimento necessário, em geral em serviço, para que o esforço de protensão se transfira, por aderência, da armadura ativa para o concreto;

$>$ Comprimento de ancoragem necessário $\left(\ell_{\mathrm{bpd}}\right)$ : comprimento para realizar 0 detalhamento da ancoragem real, usado para fazer o detalhamento de uma peça considerando as tensões atuantes e os comprimentos definidos anteriormente;

> Distância de regularização $\left(\ell_{\mathrm{p}}\right)$ : distância da extremidade da peça, a partir da qual é possível considerar o esforço de protensão atuando em toda a seção transversal, ou seja, é necessário um certo comprimento até que seja atingida uma distribuição retilínea das tensões no concreto.

Segundo a Norma Brasileira NBR 6118:2003, o comprimento de ancoragem básico de fios e cordoalhas (item 9.4.5) é de:

Para cordoalhas de sete fios $\rightarrow \quad \ell_{\mathrm{bp}}=\frac{7 \cdot \phi \cdot \mathrm{f}_{\mathrm{pyd}}}{36 \cdot \mathrm{f}_{\mathrm{bpd}}}$

$\ell_{\mathrm{bp}}:$ comprimento de ancoragem básico

$\mathrm{f}_{\text {pyd }}$ : valor de cálculo da resistência de escoamento da armadura de protensão

$\mathrm{f}_{\mathrm{bpd}}$ : resistência de aderência de cálculo entre armadura e concreto na ancoragem de armaduras ativas, pré-tracionadas

$\phi$ : diâmetro da barra

Antes de prosseguir, ressalta-se que no lugar de $f_{\text {pyd }}$ sugere-se o uso de $1,05 f_{\text {pyk }}$ (valor característico da resistência de escoamento de protensão), como recomenda Fusco (1995).

A resistência de aderência de cálculo $\left(f_{b p d}\right)$ pode ser obtida pela equação: 
$\mathrm{f}_{\mathrm{bpd}}=\eta_{\mathrm{p} 1} \cdot \eta_{\mathrm{p} 2} \cdot \mathrm{f}_{\mathrm{ctd}}$

$\eta_{\mathrm{p} 1}$ : igual a 1 para fios lisos, 1,2 para cordoalhas de três e sete fios e 1,4 para fios dentados

$\eta_{\mathrm{p} 2}$ : igual a 1 para situações de boa aderência e 0,7 para situações de má aderência

$\mathrm{f}_{\text {ctd }}$ : resistência de cálculo do concreto à tração

$\mathrm{f}_{\mathrm{ctd}}=\mathrm{f}_{\mathrm{ctk}, \mathrm{imf}} / \gamma_{\mathrm{c}}$

$\mathrm{f}_{\mathrm{ctk}, \text { imf }}$ : valor característico inferior da resistência do concreto à tração

$\gamma_{c}: \quad$ coeficiente de minoração da resistência do concreto

De acordo com a NBR 6118:2003, essa resistência $\left(f_{c t d}\right.$ ) deve ser calculada na idade de:

- aplicação da protensão, para o cálculo do comprimento de transferência;

- 28 dias, para o cálculo de comprimento de ancoragem.

Assim como no caso da pós-tração, também na pré-tração deve-se considerar que a introdução de protensão será efetivada a partir de um comprimento de transferência $\left(\ell_{\text {bpt }}\right.$ ) dado no item 9.4.5.2 da NBR 6118:2003.

Se no ato da protensão a liberação do dispositivo de tração é gradual, o comprimento de transferência, para cordoalhas de sete fios, deve ser calculado pela equação:

$\ell_{\mathrm{bpt}}=\frac{0,5 \cdot \ell_{\mathrm{bp}} \cdot \sigma_{\mathrm{pi}}}{\mathrm{f}_{\mathrm{pyd}}}$

Se no ato da protensão a liberação não é gradual, o comprimento de transferência, para cordoalhas de sete fios, deve ser calculado pela equação:

$\ell_{\text {bpt }}=\frac{0,625 \cdot \ell_{\mathrm{bp}} \cdot \sigma_{\mathrm{pi}}}{\mathrm{f}_{\mathrm{pyd}}}$

$\sigma_{\mathrm{pi}}$ : tensão na armadura ativa imediatamente após a aplicação da protensão

O comprimento de ancoragem necessário $\left(\ell_{\mathrm{bpd}}\right)$ pode ser obtido pela expressão:

$\ell_{\mathrm{bpd}}=\ell_{\mathrm{bpt}}+\ell_{\mathrm{bp}} \frac{\mathrm{f}_{\mathrm{pyd}}-\sigma_{\mathrm{pi}}}{\mathrm{f}_{\mathrm{pyd}}}$

Finalmente, no caso de elementos pré-tracionados, a distância de regularização $\left(\ell_{\mathrm{p}}\right)$ da força de protensão (que pode ser considerada variando linearmente ao longo do comprimento) pode ser calculada, para seções retangulares, pela equação:

$\ell_{\mathrm{p}}=\sqrt{\mathrm{h}^{2}+\left(0,6 \cdot \ell_{\mathrm{bpt}}\right)^{2}} \geq \ell_{\mathrm{bpt}}$

$\mathrm{h}$ : altura do elemento 


\section{APÊNDICE A}

\section{PERDAS DE PROTENSÃO}

A seguir são realizados exemplos numéricos para a determinação das perdas de protensão, considerando os diferentes tipos de lajes ensaiadas: sem a presença de capa estrutural, com capa e com alvéolos parcialmente preenchidos. Além disso, os exemplos são realizados considerando a seção do meio do vão e a seção a 2,5 h do apoio.

\section{Perdas de protensão para lajes sem capa e seção central}

Neste exemplo serão considerados os itens: dados gerais, perdas iniciais, perdas diferidas e perda total em relação à tensão inicial.

\subsection{DADOS GERAIS}

Os dados gerais incluem: características geométricas da seção, características mecânicas do concreto, dados relativos ao aço de protensão e dados complementares.

\subsubsection{Características geométricas da seção (seção sem capa)}

A seção transversal das lajes alveolares protendidas pode ser observada na Figura 1. Tais lajes serão descritas e caracterizadas a seguir.

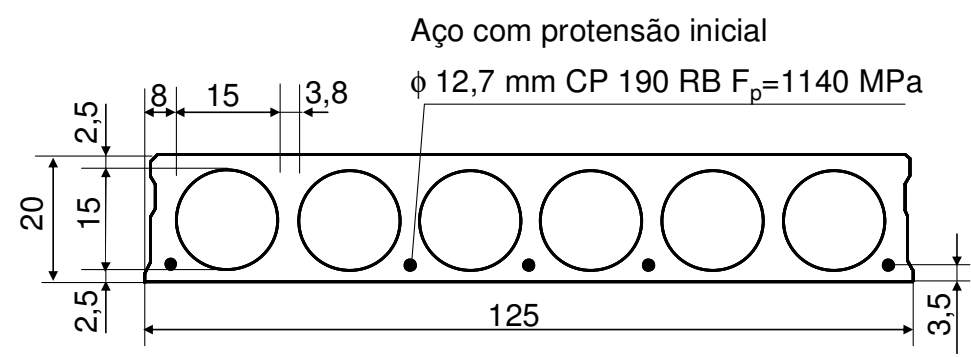

Figura 1 - Seção transversal da unidade alveolar.

$A=1377,95 \mathrm{~cm}^{2}-$ área da seção

$\mathrm{I}=67120 \mathrm{~cm}^{4}-$ momento de inércia da seção

$\mathrm{h}=20 \mathrm{~cm}-$ altura da seção

$\mathrm{d}^{\prime}=3,5 \mathrm{~cm}$ - distância da borda inferior ao centro da cordoalha

$\mathrm{d}=16,5 \mathrm{~cm}$ - distância do cg da armadura à fibra mais comprimida

$\phi_{\mathrm{alv}}=15 \mathrm{~cm}$ - diâmetro dos alvéolos

$b_{\text {laje }}=125 \mathrm{~cm}$ - largura da unidade alveolar

$\mathrm{L}=300 \mathrm{~cm}$ - comprimento da laje

$b_{w}=320 \mathrm{~mm}$ - soma das larguras das nervuras no eixo central da unidade alveolar 


\subsubsection{Características mecânicas do concreto}

$\mathrm{f}_{\mathrm{cj}}=30 \mathrm{MPa}$ resistência do concreto à compressão na data da efetivação da protensão.

$\mathrm{f}_{\mathrm{cj}}=40 \mathrm{MPa}$ resistência do concreto à compressão na data do ensaio, obtida com corpo de prova normalizado.

Foram considerados nos cálculos os valores médios de resistências determinados por ensaios de caracterização de corpos de prova.

\subsubsection{Dados relativos ao aço de protensão}

Aço categoria CP190RB

$\mathrm{E}_{\mathrm{p}}=190 \mathrm{GPa}$

Cordoalha de $12,7 \mathrm{~mm}$, com área de $1 \mathrm{~cm}^{2}$

$A_{p}=5 \mathrm{~cm}^{2}$ - área total da armadura de protensão da laje (cinco cordoalhas)

$\sigma_{\mathrm{pi}}=1140 \mathrm{MPa}$ - tensão inicial de protensão aplicada nas cordoalhas (valor abaixo do máximo permitido pela NBR6118:2003 - item 9.6.1.2.1).

Para aços da classe RB, a tensão na saída do aparelho deve atender aos limites:

$\sigma_{\mathrm{pi}} \leq\left\{\begin{array}{l}0,77 \cdot \mathrm{f}_{\mathrm{ptk}} \\ 0,85 \cdot f_{\mathrm{pyk}}\end{array}\right.$

$\mathrm{f}_{\mathrm{ptk}}=1900 \mathrm{MPa} \quad$ (resistência característica da armadura ativa à tração)

$\mathrm{f}_{\mathrm{pyk}}=1710 \mathrm{MPa}$ (resistência característica de escoamento da armadura ativa)

\subsubsection{Dados complementares}

Temperatura média de $20^{\circ} \mathrm{C}$

$\mathrm{t}=10$ dias - idade do concreto quando executado o ensaio

$\mathrm{U}_{\mathrm{r}}=70 \%$ - umidade relativa do ambiente

Cimento CP V-ARI

Abatimento do concreto menor que $4 \mathrm{~cm}$

\subsection{PERDAS INICIAIS}

Neste item serão consideradas: deformação por ancoragem, relaxação da armadura e deformação imediata do concreto.

\subsubsection{Deformação por ancoragem}

Sendo $\Delta \ell=0,6 \mathrm{~cm}$ e pista de $100 \mathrm{~m}$ :

$\Delta \sigma=\Delta \ell \times \mathrm{E}_{\mathrm{p}} \quad-->\Delta \sigma=0,6 \times 1,9 \times 10^{5} \quad \Delta \sigma=11,4 \mathrm{MPa}$ 


\subsubsection{Relaxação da armadura}

O cálculo da perda por relaxação da armadura pode ser feito com a expressão:

$\psi_{\left(\mathrm{t}, \mathrm{t}_{0}\right)}=\frac{\Delta \sigma_{\mathrm{pr}}\left(\mathrm{t}, \mathrm{t}_{\mathrm{o}}\right)}{\sigma_{\mathrm{pi}}}$

$\sigma_{\mathrm{pi}}:$ tensão da armadura de protensão no instante de seu estiramento.

Considerando a tensão na armadura retirando as perdas iniciais, tem-se:

$\sigma_{\mathrm{pi}}=1140-11,40=1128,6 \mathrm{MPa}$

$\Delta \sigma_{\mathrm{pr}}\left(t, t_{\mathrm{o}}\right)$ : perda de tensão por relaxação pura (com comprimento constante) desde o instante $t_{0}$ do estiramento da armadura até o instante $t$ considerado

A relaxação de fios e cordoalhas, após 1000 horas a $20^{\circ} \mathrm{C}\left(\Psi_{1000}\right)$ e para tensões variando de $0,5 f_{\text {ptk }}$ a $0,8 f_{p t k}$, obtida em ensaios descritos na NBR 7484, não deve ultrapassar os valores dados na NBR 7482 e na NBR 7483, respectivamente.

Para efeito de projeto, podem ser adotados os valores de $\Psi_{1000}$ da Tabela 8.3 da NBR 6118:2003. Essa tabela é reproduzida na Tabela 1.

Tabela 1 - Valores de $\Psi_{1000^{\prime}}$ em \% [Tabela 8.3 da NBR 6118:2003]

\begin{tabular}{|c|c|c|c|c|c|}
\hline & \multicolumn{2}{|c|}{ Cordoalhas } & \multicolumn{2}{|c|}{ Fios } & Barras \\
\hline Tensão inicial & RN & RB & RN & RB & \\
\hline $0,5 \mathrm{fptk}$ & 0 & 0 & 0 & 0 & 0 \\
\hline 0,6 fptk & 3,5 & 1,3 & 2,5 & 1,0 & 1,5 \\
\hline 0,7 fptk & 7 & 2,5 & 5 & 2 & 4 \\
\hline $0,8 \mathrm{fptk}$ & 12 & 3,5 & 8,5 & 3 & 7 \\
\hline
\end{tabular}

Assim, para o exemplo em questão, determinou-se a seguinte relação:

$r=\frac{\sigma_{p i}}{f_{p t k}}=\frac{1128,6}{1900}=0,594$

Então, consultando a Tabela 1, tem-se a situação indicada e o valor desejado k.

\begin{tabular}{|c|c|}
\hline $0,5 \mathrm{fptk}$ & 0 \\
\hline $0,594 \mathrm{fptk}$ & $\mathrm{k}$ \\
\hline $0,6 \mathrm{fptk}$ & 1,3 \\
\hline
\end{tabular}

Com interpolação linear, obtém-se:

$$
\frac{\mathrm{k}-0}{1,3-0}=\frac{0,594-0,5}{0,60-0,50} \rightarrow \mathrm{k}=\psi_{1000}=1,22 \%
$$

Os valores correspondentes a tempos diferentes de 1.000 horas, sempre a $20^{\circ} \mathrm{C}$, podem ser determinados a partir da expressão: 
$\psi_{\left(t, t_{0}\right)}=\psi_{1000} \cdot\left(\frac{t-t_{0}}{41,67}\right)^{0,15} \quad$ para $\left(t, t_{0}\right)$ em dias

Assim, considerando 1 dia, tem-se:

$\psi_{1}=1,222 .\left(\frac{1}{41,67}\right)^{0,15}=0,698 \%$

Como $\psi_{\left(t, t_{0}\right)}=\frac{\Delta \sigma_{p r}\left(t, t_{0}\right)}{\sigma_{p i}}$ tem-se:

$\Delta \sigma_{\mathrm{r}}=\frac{\psi_{1}}{100} \cdot \sigma_{\mathrm{i}} \quad \rightarrow \quad \Delta \sigma_{\mathrm{r}}=\frac{0,698}{100} \cdot 1128,6$

$\Delta \sigma_{\mathrm{r}}=7,88 \mathrm{MPa}$

\subsubsection{Deformação imediata do concreto}

A perda por deformação imediata do concreto pode ser obtida a partir da expressão:

$\Delta \sigma_{\mathrm{pd}}=\varepsilon_{7} \cdot \mathrm{E}_{\mathrm{p}}$

$\varepsilon_{7}$ : deformação específica da armadura de protensão devida à descompressão

\section{Determinação da deformação específica $\varepsilon_{\underline{Z}}$}

A deformação específica $\varepsilon_{7}$ pode ser determinada pela expressão:

$\varepsilon_{7}=\varepsilon_{\text {concreto }}=\frac{\sigma_{\mathrm{cg}, \text { cabos }}}{\mathrm{E}_{\mathrm{c}}}=\frac{7218}{30672000}=2,35.10^{-4}$

$E_{c}$ : módulo de elasticidade do concreto: $E_{c}=5600 \cdot \sqrt{f_{c j}}=5600 \cdot \sqrt{30}=30672 \mathrm{MPa}$

$\sigma_{c g, c a b o s}$ : tensão no concreto no nível do baricentro da armadura de protensão, devida à carga permanente modificada pela protensão ou simultaneamente aplicada com a protensão

$\sigma_{\mathrm{cg}, \text { cabos }}=\frac{\mathrm{N}_{\mathrm{p}}}{\mathrm{A}}+\frac{\mathrm{N}_{\mathrm{p}} \cdot \mathrm{e}_{\mathrm{p}}^{2}}{\mathrm{I}}-\frac{\mathrm{M}_{\mathrm{g} 1} \cdot \mathrm{e}_{\mathrm{p}}}{\mathrm{I}}=\frac{560,36}{0,137795}+\frac{560,36 \cdot 0,065^{2}}{6,712 \cdot 10^{-4}}-\frac{3,875 \cdot 0,065}{6,712 \cdot 10^{-4}}=7218 \frac{\mathrm{kN}}{\mathrm{m}^{2}}$

A, I: área e momento de inércia da seção transversal da peça

$\mathrm{N}_{\mathrm{p}}$ : força de protensão, descontando as perdas calculadas anteriormente

Como são cinco cabos: $A_{p}=5 \mathrm{~cm}^{2} \rightarrow N_{p}=5 .(114-1,14-0,788)=560,36 \mathrm{kN}$

$e_{p}:$ excentricidade da força de protensão: $e_{p}=\left(\frac{h}{2}-d^{\prime}\right)=\left(\frac{0,2}{2}-0,035\right)=0,065 m$

$M_{g 1:}$ momento do peso próprio da peça na sua retirada da pista

$M_{\mathrm{g} 1}=\left(\frac{\mathrm{pp} \cdot \mathrm{L}^{2}}{8}\right)=\left(\frac{3,44 \cdot 3^{2}}{8}\right)=3,875 \mathrm{kN} \cdot \mathrm{m}$ 
Com $p p=A_{c} \cdot \gamma_{c}=0,137795.25=3,44 \frac{k N}{m}$, tem-se:

$\Delta \sigma_{\mathrm{pd}}=\varepsilon_{7} \cdot \mathrm{E}_{\mathrm{p}}=2,35 \cdot 10^{-4} \cdot 1,9 \cdot 10^{5}=44,71 \mathrm{MPa}$

$\Delta \sigma_{\mathrm{pd}}=44,71 \mathrm{MPa}$

Logo após a retirada da pista, a armadura de protensão está submetida a:

$\sigma_{p}(t=1)=1140-11,40-7,88-44,71$

$\sigma_{\mathrm{p}}(\mathrm{t}=1)=1076 \mathrm{MPa}$

\subsection{PERDAS DIFERIDAS}

No cálculo das perdas diferidas, serão consideradas: retração do concreto, fluência do concreto e relaxação da armadura.

\subsubsection{Retração do concreto}

A expressão da perda devida à retração do concreto é dada por:

$\Delta \sigma_{\mathrm{p}, \mathrm{s}}\left(\mathrm{t}, \mathrm{t}_{0}\right)=\varepsilon_{\mathrm{cs}}\left(\mathrm{t}, \mathrm{t}_{0}\right) \cdot \mathrm{E}_{\mathrm{p}}$

$\varepsilon_{\mathrm{cs}}\left(\mathrm{t}, \mathrm{t}_{0}\right)$ : deformação por retração

\section{Determinação de $\varepsilon_{\mathrm{cs}}\left(t, t_{0}\right)$}

O valor de $\varepsilon_{c s}\left(t, t_{0}\right)$ pode ser obtido a partir da equação:

$\varepsilon_{\mathrm{cs}}\left(\mathrm{t}, \mathrm{t}_{0}\right)=\varepsilon_{\mathrm{cs} \infty} \cdot\left[\beta_{\mathrm{s}}(\mathrm{t})-\beta_{\mathrm{s}}\left(\mathrm{t}_{0}\right)\right]$

$\varepsilon_{\mathrm{cs} \infty}$ : valor final da retração

$\beta_{s}$ (t) ou $\beta_{s}\left(t_{0}\right)$ : coeficiente relativo à retração, no instante $t$ ou $t_{0}$ (Figura $A .3 d a$ NBR 6118:2003)

\section{$>$ Determinação de $\varepsilon_{\mathrm{cs} \infty}$}

$\varepsilon_{\mathrm{cs} \infty}=\varepsilon_{1 \mathrm{~s}} \cdot \varepsilon_{2 \mathrm{~s}} \rightarrow \varepsilon_{\mathrm{cs} \infty}=2,5 \cdot 10^{-4} \cdot 1,125=2,8125 \cdot 10^{-4}$

$\varepsilon_{1 \mathrm{~s}}$ : coeficiente dependente da umidade relativa do ambiente e da consistência do concreto (Tabela A1 da NBR 6118:2003)

$\varepsilon_{1 \mathrm{~s}}=2,5 \cdot 10^{-4} \rightarrow$ Para $70 \%$ de umidade e abatimento menor que $4 \mathrm{~cm}$

$\varepsilon_{2 s}$ : coeficiente dependente da espessura fictícia da peça

$\varepsilon_{2 \mathrm{~s}}=\frac{33+2 \mathrm{~h}_{\mathrm{fic}}}{20,8+3 \mathrm{~h}_{\mathrm{fic}}}=\frac{33+2 \cdot 6,977}{20,8+3 \cdot 6,977}=1,125$

$\mathrm{h}_{\text {fic }}$ : espessura fictícia em centímetros 
$\mathrm{h}_{\mathrm{fic}}=\gamma \frac{2 \mathrm{~A}_{\mathrm{c}}}{\mathrm{u}_{\mathrm{ar}}}=1,45 \cdot \frac{2 \cdot 1377,95}{572,74}=6,977 \mathrm{~cm}$

$\gamma=$ coeficiente dependente da umidade relativa do ambiente $\mathrm{U} \%$ (Tabela A1 da NBR 6118:2003)

$\gamma=1+\exp (-7,8+0,1 . U)=1+\exp (-7,8+0,1.70)=1,45$

$A_{c}$ : área da seção transversal da peça

$u_{a r}$ : parte do perímetro externo da seção transversal da peça em contato com o ar

$u_{a r}=2 \cdot(b+h)+6 \cdot(\pi \cdot \phi)$

$u_{a r}=2 \cdot(1,25+0,2)+6 \cdot(3,1415926 \cdot 0,15)$

$\mathrm{u}_{\mathrm{ar}}=5,7274 \mathrm{~m}=572,74 \mathrm{~cm}$

\section{$>$ Determinação de $\beta_{s}(t)$ e $\beta_{s}\left(t_{0}\right)$}

De acordo com a NBR 6118:2003, o coeficiente relativo à retração $\left(\beta_{s}(t)\right.$ ou $\left.\beta_{s}\left(t_{0}\right)\right)$ pode ser determinado através da seguinte expressão:

$\beta_{s}(t)=\frac{\left(\frac{t}{100}\right)^{3}+A \cdot\left(\frac{t}{100}\right)^{2}+B \cdot\left(\frac{t}{100}\right)}{\left(\frac{t}{100}\right)^{3}+C \cdot\left(\frac{t}{100}\right)^{2}+D \cdot\left(\frac{t}{100}\right)+E}$

t: idade fictícia do concreto no instante considerado, em dias, equivalente a

$\mathrm{t}=\alpha \sum_{\mathrm{i}} \frac{\mathrm{T}_{\mathrm{i}}+10}{30} \cdot \Delta \mathrm{t}_{\mathrm{ef}, \mathrm{i}} \rightarrow \mathrm{t}=1 \cdot \frac{50+10}{30} \cdot 10=20$ dias

$\alpha=1$ (para cimento ARI e retração) - coeficiente dependente da velocidade de endurecimento do cimento; na falta de dados experimentais a NBR 6118:2003 permite o emprego do valor indicado na Tabela A.2 da referida norma

$T_{i}=50^{\circ} \mathrm{C}$ (temperatura) - temperatura média diária do ambiente, para cura térmica

$\Delta \mathrm{t}_{\mathrm{ef}, \mathrm{i}}$ : período, em dias, durante o qual a temperatura média diária do ambiente, $\mathrm{T}_{\mathrm{i}}$, pode ser admitida constante

$t_{0}$ : idade fictícia do concreto ao ser feito o carregamento, em dias, equivalente a $\rightarrow$ $\mathrm{t}=1 . \frac{50+10}{30} \cdot 1=2$ dias

Considerando $\mathrm{h}=\mathrm{h}_{\text {fic }}=0,06977 \mathrm{~m}$, tem-se:

$\mathrm{A}=40$

$B=116 \cdot h^{3}-282 \cdot h^{2}+220 \cdot h-4,8 \rightarrow B=9,216$

$C=2,5 \cdot h^{3}-8,8 \cdot h+40,7 \rightarrow C=40,087$

$D=-75 \cdot h^{3}+585 \cdot h^{2}+496 \cdot h-6,8 \rightarrow D=30,628$ 
$E=-169 \cdot h^{4}+88 \cdot h^{3}+584 \cdot h^{2}-39 \cdot h+0,8 \rightarrow E=0,9477$

Para $t_{0}=2$ dia e $t=20$ dias, obtêm-se, respectivamente:

$$
\begin{aligned}
& \beta_{s}\left(t_{0}=2\right)=\frac{\left(\frac{2}{100}\right)^{3}+40 \cdot\left(\frac{2}{100}\right)^{2}+9,216 \cdot\left(\frac{2}{100}\right)}{\left(\frac{2}{100}\right)^{3}+40,087 \cdot\left(\frac{2}{100}\right)^{2}+30,628 \cdot\left(\frac{2}{100}\right)+0,9477}=0,127 \\
& \beta_{s}(t=20)=\frac{\left(\frac{20}{100}\right)^{3}+40 \cdot\left(\frac{20}{100}\right)^{2}+9,216 \cdot\left(\frac{20}{100}\right)}{\left(\frac{20}{100}\right)^{3}+40,087 \cdot\left(\frac{20}{100}\right)^{2}+30,628 \cdot\left(\frac{20}{100}\right)+0,9477}=0,397
\end{aligned}
$$

Logo:

$\varepsilon_{\mathrm{cS}}\left(\mathrm{t}, \mathrm{t}_{0}\right)=\varepsilon_{\mathrm{cS} \infty} \cdot\left[\beta_{\mathrm{s}}(\mathrm{t})-\beta_{\mathrm{s}}\left(\mathrm{t}_{0}\right)\right]=2,8125 \cdot 10^{-4} \cdot[0,397-0,127]=7,594 \cdot 10^{-5}$

$\Delta \sigma_{p s}\left(t, t_{0}\right)=\varepsilon_{c s}\left(t, t_{0}\right) \cdot E_{p} \quad \rightarrow \quad \Delta \sigma_{p s}\left(t, t_{0}\right)=7,594 \cdot 10^{-5} \cdot 190000$

$\Delta \sigma_{\mathrm{ps}}\left(\mathrm{t}, \mathrm{t}_{0}\right)=14,43 \mathrm{MPa}$

\subsubsection{Fluência do concreto}

A perda por fluência pode ser obtida pela expressão:

$\Delta \sigma_{p, s}\left(t, t_{0}\right)=\sigma_{c g p} \cdot \varphi\left(t, t_{0}\right) \cdot \alpha_{p}$

$\alpha_{p}$ : relação entre o módulo de elasticidade do aço protendido e o do concreto $\left(\frac{E_{p}}{E_{c}}\right)$.

$E_{p}=190 \frac{\mathrm{kN}}{\mathrm{mm}^{2}}$ e $E_{\mathrm{c}}=5600 \cdot \sqrt{\mathrm{f}_{\mathrm{ck}}}=5600 \cdot \sqrt{40}=35417 \mathrm{MPa}$

$\sigma_{\mathrm{cg}, \text { cabos }}$ : tensão que ocorre no concreto no nível do centro de gravidade da armadura de protensão e devido à ação das cargas permanentes inclusive a protensão;

$\sigma_{\mathrm{cg}, \text { cabos }}=\frac{\mathrm{N}_{\mathrm{p}}}{\mathrm{A}}+\frac{\mathrm{N}_{\mathrm{p}} \cdot \mathrm{e}_{\mathrm{p}}^{2}}{\mathrm{I}}-\frac{\mathrm{M}_{\mathrm{g} 1} \cdot \mathrm{e}_{\mathrm{p}}}{\mathrm{I}}=\frac{538,0}{0,137795}+\frac{538,0 \cdot 0,065^{2}}{6,712 \cdot 10^{-4}}-\frac{3,875 \cdot 0,065}{6,712 \cdot 10^{-4}}=6915,64 \frac{\mathrm{kN}}{\mathrm{m}^{2}}$

A, I: área e momento de inércia da seção transversal da peça

$\mathrm{N}_{\mathrm{p}}$ : força total de protensão, retirando as perdas iniciais.

Como $A_{p}=5 \mathrm{~cm}^{2}$, tem-se:

$N_{p}=5 .(114-1,14-0,788-4,471)=538,0 \mathrm{kN}$

$e_{p}$ : excentricidade da armadura protendida $e_{p}=0,065 \mathrm{~m}$

$M_{g 1:}$ momento de peso próprio para a peça na sua retirada da pista 


$$
\begin{aligned}
& M_{g 1}=\left(\frac{p p \cdot L^{2}}{8}\right)=\left(\frac{3,44 \cdot 3^{2}}{8}\right)=3,875 \mathrm{kN} \cdot \mathrm{m} \\
& \mathrm{pp}=\mathrm{A}_{\mathrm{c}} \cdot \gamma_{\mathrm{c}}=0,137795 \cdot 25=3,44 \frac{\mathrm{kN}}{\mathrm{m}}
\end{aligned}
$$

\section{Determinação de $\varphi\left(t, t_{0}\right)$}

$O$ coeficiente da fluência $\varphi\left(t, t_{0}\right)$ pode ser determinado pela equação:

$\varphi\left(t, t_{0}\right)=\varphi_{a}+\varphi_{f \infty}\left[\beta_{f}(t)-\left[\beta_{f}\left(t_{0}\right)\right]\right]+\varphi_{d \infty} \cdot \beta_{d}$

t: idade fictícia do concreto no instante considerado, em dias, equivalente a

$\mathrm{t}=\alpha \sum_{\mathrm{i}} \frac{\mathrm{T}_{\mathrm{i}}+10}{30} \cdot \Delta \mathrm{t}_{\mathrm{ef}, \mathrm{i}} \rightarrow \mathrm{t}=3 \cdot \frac{50+10}{30} \cdot 10=60$ dias

$\alpha=3 \quad$ (para cimento ARI) - coeficiente dependente da velocidade de endurecimento do cimento; na falta de dados experimentais a NBR 6118:2003 permite o emprego dos valores constantes na Tabela A. 2 da referida norma

$\mathrm{T}_{\mathrm{i}}=50^{\circ} \mathrm{C}$ (temperatura) - temperatura média diária do ambiente

$\Delta \mathrm{t}_{\mathrm{ef}, \mathrm{i}}$ : período, em dias, durante o qual a temperatura média diária do ambiente, $T_{\mathrm{i}}$, pode ser admitida constante.

$t_{0}$ : idade fictícia do concreto ao ser feito o carregamento, em dias, equivalente a $\rightarrow$ $\mathrm{t}=3 . \frac{50+10}{30} \cdot 1=6$ dias

$\varphi_{\mathrm{a}}: \quad$ coeficiente de fluência rápida equivalente a $\varphi_{\mathrm{a}}=0,8 \cdot\left[1-\frac{\mathrm{f}_{\mathrm{c}}\left(\mathrm{t}_{0}\right)}{\mathrm{f}_{\mathrm{c}}(\mathrm{t})}\right]$

$\phi_{a}=0,8 \cdot\left[1-\frac{f_{c}\left(t_{0}\right)}{f_{c}(t)}\right]=0,8 \cdot\left[1-\frac{0,79}{1,06}\right]=0,204$

$\frac{f_{c}\left(t_{o}\right)}{f_{c}(t)}$ : função de crescimento da resistência do concreto com a idade, que pode ser obtida usando a expressão de $\beta_{1}$ definida no item 12.3 da NBR 6118:2003, que correlaciona a resistência do concreto em um tempo t com o valor de $f_{c k}$, que é a resistência característica aos 28 dias $\quad-\quad \beta_{1}=\frac{f_{c j}}{f_{c k}}$

$$
\begin{aligned}
& \beta_{1}\left(\mathrm{t}_{\mathrm{o}}\right)=\exp \left\{\mathrm{s} \cdot\left[1-\left(\frac{28}{\mathrm{t}_{0}}\right)^{1 / 2}\right]\right\}=\exp \left\{0,2 \cdot\left[1-\left(\frac{28}{6}\right)^{1 / 2}\right]\right\}=0,79 \\
& \beta_{1}(\mathrm{t})=\exp \left\{\mathrm{s} \cdot\left[1-\left(\frac{28}{\mathrm{t}}\right)^{1 / 2}\right]\right\}=\exp \left\{0,2 \cdot\left[1-\left(\frac{28}{60}\right)^{1 / 2}\right]\right\}=1,06
\end{aligned}
$$


s: coeficiente que depende do tipo de cimento usado na produção do concreto

Segundo a NBR 6118:2003 (item 12.3.3), para cimento CPV-ARI $\rightarrow s=0,20$.

$\varphi_{f_{\infty}}:$ valor final do coeficiente de deformação lenta irreversível

$\varphi_{f_{\infty}}=\varphi_{1 c} \cdot \varphi_{2 c} \rightarrow \varphi_{f \infty}=1,5 \cdot 1,8155=2,723$

$\varphi_{1 c}$ : coeficiente dependente da umidade relativa do ambiente $U \%$ e da consistência do concreto, dado pela Tabela A1 da NBR 6118:2003

Neste caso, considerando $U=70 \%, \varphi_{1 c}=1,5$.

$\varphi_{2 c}$ : coeficiente dependente da espessura fictícia $\mathrm{h}_{\text {fic }}$ (em centímetros)

$\varphi_{2 \mathrm{c}}=\frac{42+\mathrm{h}_{\mathrm{fic}}}{20+\mathrm{h}_{\mathrm{fic}}} \rightarrow \varphi_{2 \mathrm{c}}=\frac{42+6,977}{20+6,977}=1,8155$

$\mathrm{h}_{\text {fic }}$ : espessura fictícia em centímetros, calculada como indicado no cálculo da perda por retração do concreto (item 1.3.1)

$\mathrm{h}_{\text {fic }}=6,977 \mathrm{~cm}$

$\beta_{\mathrm{f}}(\mathrm{t})$ ou $\beta_{\mathrm{f}}\left(\mathrm{t}_{\mathrm{o}}\right)$ : coeficiente relativo à deformação lenta irreversível, função da idade do concreto (definido no item A.2.2.3 da NBR 6118:2003)

Pode ser obtido pela expressão:

$\beta_{f}(t)=\frac{t^{2}+A \cdot t+B}{t^{2}+C . t+D}$

Considerando $\mathrm{h}=\mathrm{h}_{\text {fic }}=0,06977 \mathrm{~m}$, tem-se:

$A=42 \cdot h^{3}-350 \cdot h^{2}+588 \cdot h+113 \rightarrow A=152,33$

$B=768 \cdot h^{3}-3060 \cdot h^{2}+3234 \cdot h-23 \rightarrow B=188,00$

$C=-200 \cdot h^{3}+13 \cdot h^{2}+1090 \cdot h+183 \rightarrow C=259,04$

$D=7579 \cdot h^{3}-31916 \cdot h^{2}+35343 . h+1931 \rightarrow D=4244,09$

Assim:

$\beta_{f}\left(t_{0 \text { fic }}\right)=\frac{6^{2}+152,33 \cdot 6+188,00}{6^{2}+259,04 \cdot 6+4244,09}=0,195$

$\beta_{f}\left(t_{f} f i c=\frac{60^{2}+152,33.60+188,00}{60^{2}+259,04.60+4244,09}=0,553\right.$

$\varphi_{\mathrm{d} \infty}$ : valor final do coeficiente de deformação lenta reversível, considerado igual 0,4

$\beta_{d}$ : coeficiente relativo à deformação lenta reversível, função do tempo $\left(t-t_{0}\right)$ decorrido após o carregamento, equivalente a:

$\beta_{d}=\frac{t-t_{o}+20}{t-t_{o}+70} \rightarrow \beta_{d}=\frac{60-6+20}{60-6+70}=0,60$ 
Resulta:

$\varphi\left(t, t_{0}\right)=\varphi_{a}+\varphi_{f \infty}\left[\beta_{f}(t)-\beta_{f}\left(t_{0}\right)\right]+\varphi_{d \infty} \cdot \beta_{d}=0,204+2,723 \cdot(0,553-0,195)+0,4 \cdot 0,60=1,42$

Logo:

$\Delta \sigma_{p, s}\left(t, t_{0}\right)=\sigma_{c g p} \cdot \varphi\left(t, t_{0}\right) \cdot \alpha_{p}=6,9156 \cdot 1,42 \cdot \frac{190000}{35417}$

$\Delta \sigma_{p, s}\left(t, t_{0}\right)=52,68 \mathrm{MPa}$

\subsubsection{Relaxação da armadura}

O cálculo da perda por relaxação da armadura pode ser feito com a expressão:

$\psi_{\left(\mathrm{t}, \mathrm{t}_{0}\right)}=\frac{\Delta \sigma_{\mathrm{pr}}\left(\mathrm{t}, \mathrm{t}_{\mathrm{o}}\right)}{\sigma_{\mathrm{pi}}}$

$\sigma_{\mathrm{pi}}:$ tensão da armadura de protensão no instante de seu estiramento

Considerando a tensão na armadura retirando as perdas iniciais, tem-se:

$\sigma_{\mathrm{pi}}=1140-11,40-7,88-44,71=1076 \mathrm{MPa}$

$\Delta \sigma_{\mathrm{pr}}\left(\mathrm{t}, \mathrm{t}_{\mathrm{o}}\right)$ : perda de tensão por relaxação pura (com comprimento constante) desde o instante $t_{0}$ do estiramento da armadura até $o$ instante $t$ considerado

Assim, para o exemplo em questão, determinou-se a seguinte relação:

$r=\frac{\sigma_{p i}}{f_{p t k}}=\frac{1076}{1900}=0,566$

Então, consultando a Tabela 1, tem-se a situação indicada e o valor desejado é k.

\begin{tabular}{|c|c|}
\hline $0,5 \mathrm{fptk}$ & 0 \\
\hline $0,566 \mathrm{fptk}$ & $\mathrm{k}$ \\
\hline $0,6 \mathrm{fptk}$ & 1,3 \\
\hline
\end{tabular}

Interpolando, resulta:

$$
\frac{\mathrm{k}-0}{1,3-0}=\frac{0,566-0,5}{0,60-0,50} \rightarrow \mathrm{k}=\psi_{1000}=0,86 \%
$$

Os valores correspondentes a tempos diferentes de 1.000 horas, sempre a $20^{\circ} \mathrm{C}$, podem ser determinados a partir da expressão:

$\Psi_{\left(t, t_{0}\right)}=\psi_{1000} \cdot\left(\frac{t-t_{0}}{41,67}\right)^{0,15} \quad$ para $\left(t, t_{0}\right)$ em dias

Assim, tem-se:

$\psi_{10}=0,86 \cdot\left(\frac{10-1}{41,67}\right)^{0,15}=0,683 \%$ 
Como $\psi_{\left(\mathrm{t}, \mathrm{t}_{0}\right)}=\frac{\Delta \sigma_{\mathrm{pr}}\left(\mathrm{t}, \mathrm{t}_{\mathrm{o}}\right)}{\sigma_{\mathrm{pi}}}$ tem-se:

$\Delta \sigma_{\mathrm{pr}}=\frac{\psi_{\left(\mathrm{t}, \mathrm{t}_{0}\right)}}{100} \cdot \sigma_{\mathrm{i}} \quad \rightarrow \quad \Delta \sigma_{\mathrm{r}}=\frac{0,683}{100} \cdot 1076$

$\Delta \sigma_{\mathrm{r}}=7,35 \mathrm{MPa}$

\subsection{PERDA TOTAL EM RELAÇÃO À TENSÃO INICIAL}

Assim, após 10 dias, a tensão na armadura corresponde a:

$\sigma_{p}(t=10)=1076-14,43-52,68-7,35$

$\sigma_{\mathrm{p}}(\mathrm{t}=10)=1001,54 \mathrm{MPa}$

perdas $=1-\frac{1001,54}{1140}=12,14 \%$ (em relação à tensão inicial )

\section{Perdas de protensão para lajes com capa e seção central}

Neste exemplo serão considerados os itens: perdas iniciais, perdas diferidas e perda total em relação à tensão inicial.

\subsection{PERDAS INICIAIS}

Neste item serão consideradas: deformação por ancoragem, relaxação da armadura e deformação imediata do concreto.

\subsubsection{Deformação por ancoragem}

A perda devida à deformação por ancoragem é igual à calculada anteriormente para a laje sem a presença de capa (item 1.2.1), correspondendo a $\Delta \sigma=11,4 \mathrm{MPa}$.

\subsubsection{Relaxação da armadura}

Da mesma forma, o valor da perda por relaxação da armadura, já calculado anteriormente (item 1.2.2) corresponde a $\Delta \sigma_{r}=7,88 \mathrm{MPa}$.

\subsubsection{Deformação imediata do concreto}

A perda por deformação imediata do concreto, já determinada (item 1.2.3), corresponde a $\Delta \sigma_{\mathrm{pd}}=44,71 \mathrm{MPa}$. 
Assim, logo após a retirada da pista, a armadura de protensão está submetida a:

$\sigma_{p}(t=1)=1140-11,40-7,88-44,71$

$\sigma_{\mathrm{p}}(\mathrm{t}=1)=1076 \mathrm{MPa}$

\subsection{PERDAS DIFERIDAS}

No cálculo das perdas diferidas, serão consideradas: retração do concreto, fluência do concreto e relaxação da armadura.

\subsubsection{Retração do concreto}

A expressão da perda devida à retração do concreto é dada por:

$\Delta \sigma_{\mathrm{p}, \mathrm{s}}\left(\mathrm{t}, \mathrm{t}_{0}\right)=\varepsilon_{\mathrm{cs}}\left(\mathrm{t}, \mathrm{t}_{0}\right) \cdot \mathrm{E}_{\mathrm{p}}$

O valor de $\varepsilon_{\mathrm{cs}}\left(t, t_{0}\right)$ pode ser obtido a partir da equação:

$\varepsilon_{\mathrm{cs}}\left(\mathrm{t}, \mathrm{t}_{0}\right)=\varepsilon_{\mathrm{cs} \infty} \cdot\left[\beta_{\mathrm{s}}(\mathrm{t})-\beta_{\mathrm{s}}\left(\mathrm{t}_{0}\right)\right]$

Como a laje até um certo tempo permaneceu sem a presença de capa, passando a apresentar seção composta após determinado período de tempo, serão considerados dois valores de retração, sendo calculada posteriormente uma relação entre eles.

\section{Determinação de $\varepsilon_{c s}\left(t, t_{0}\right)_{s i m p l e s}$}

\section{$>$ Determinação de $\varepsilon_{\mathrm{cs} \infty}$ considerando seção simples}

$\varepsilon_{\mathrm{cs} \infty}:$ valor final da retração

$\varepsilon_{\mathrm{cs} \infty}=\varepsilon_{1 \mathrm{~s}} \cdot \varepsilon_{2 \mathrm{~s}} \rightarrow \varepsilon_{\mathrm{cs} \infty}=2,5 \cdot 10^{-4} \cdot 1,125=2,8125 \cdot 10^{-4}$

$\varepsilon_{1 s}$ : coeficiente dependente da umidade relativa do ambiente e da consistência do concreto (Tabela A1 da NBR 6118:2003)

$\varepsilon_{1 \mathrm{~s}}=2,5 \cdot 10^{-4} \rightarrow$ Para $70 \%$ de umidade e abatimento menor que $4 \mathrm{~cm}$

$\varepsilon_{2 \mathrm{~s}}$ : coeficiente dependente da espessura fictícia da peça

$\varepsilon_{2 \mathrm{~s}}=\frac{33+2 \mathrm{~h}_{\text {fic }}}{20,8+3 \mathrm{~h}_{\text {fic }}}=\frac{33+2 \cdot 6,977}{20,8+3 \cdot 6,977}=1,125$

$h_{\text {fic }}$ : espessura fictícia em centímetros

$\mathrm{h}_{\mathrm{fic}}=\gamma \frac{2 \mathrm{~A}_{\mathrm{c}}}{\mathrm{u}_{\mathrm{ar}}}=1,45 \cdot \frac{2 \cdot 1377,95}{572,74}=6,977 \mathrm{~cm}$

$\gamma=$ coeficiente dependente da umidade relativa do ambiente $\mathrm{U} \%$ (Tabela A1 da NBR 6118:2003) sendo:

$\gamma=1+\exp (-7,8+0,1 . U)=1+\exp (-7,8+0,1.70)=1,45$ 
$A_{c}$ : área da seção transversal da peça

$U_{\mathrm{ar}}$ : parte do perímetro externo da seção transversal da peça em contato com o ar

$\mathrm{u}_{\mathrm{ar}}=2 \cdot(\mathrm{b}+\mathrm{h})+6 \cdot(\pi \cdot \phi) \quad \rightarrow \quad \mathrm{u}_{\mathrm{ar}}=2 \cdot(1,25+0,2)+6 \cdot(3,1415926 \cdot 0,15)$

$u_{a r}=5,7274 \mathrm{~m}=572,74 \mathrm{~cm}$

\section{Determinação de $\beta_{s}(t)$ e $\beta_{s}\left(t_{0}\right)$ considerando a seção simples}

$\beta_{s}$ ( $t$ ) ou $\beta_{s}\left(t_{0}\right)$ : coeficiente relativo à retração, no instante $t$ ou $t_{0}$ (Figura $A .3$ da NBR 6118:2003)

De acordo com a NBR 6118:2003 o coeficiente relativo à retração ( $\beta$ s (t) ou $\beta s$ (to)) pode ser determinado através da expressão:

$\beta_{s}(t)=\frac{\left(\frac{t}{100}\right)^{3}+A \cdot\left(\frac{t}{100}\right)^{2}+B \cdot\left(\frac{t}{100}\right)}{\left(\frac{t}{100}\right)^{3}+C \cdot\left(\frac{t}{100}\right)^{2}+D \cdot\left(\frac{t}{100}\right)+E}$

Como já calculado anteriormente, no item 1.3.1, tem-se:

t: idade fictícia do concreto no instante considerado, em dias, equivalente a $\mathrm{t}=\alpha \sum_{\mathrm{i}} \frac{\mathrm{T}_{\mathrm{i}}+10}{30} \cdot \Delta \mathrm{t}_{\mathrm{ef}, \mathrm{i}} \rightarrow \mathrm{t}=1 \cdot \frac{50+10}{30} \cdot 2=4$ dias

$t_{0}$ : idade fictícia do concreto ao ser feito o carregamento, em dias, equivalente a:

$\mathrm{t}=1 . \frac{50+10}{30} \cdot 1=2$ dias

Considerando $\mathrm{h}=\mathrm{h}_{\text {fic }}=0,06977 \mathrm{~m}$, tem-se:

$\mathrm{A}=40$

$B=116 \cdot h^{3}-282 \cdot h^{2}+220 \cdot h-4,8 \rightarrow B=9,216$

$C=2,5 \cdot h^{3}-8,8 \cdot h+40,7 \rightarrow C=40,087$

$D=-75 \cdot h^{3}+585 \cdot h^{2}+496 \cdot h-6,8 \rightarrow D=30,628$

$E=-169 \cdot h^{4}+88 \cdot h^{3}+584 \cdot h^{2}-39 \cdot h+0,8 \rightarrow E=0,9477$

Para $\mathrm{t}_{0}=2$ dias e $\mathrm{t}=4$ dias, tem-se:

$\beta_{s}\left(t_{0}=2\right)=\frac{\left(\frac{2}{100}\right)^{3}+40 \cdot\left(\frac{2}{100}\right)^{2}+9,216 \cdot\left(\frac{2}{100}\right)}{\left(\frac{2}{100}\right)^{3}+40,087 \cdot\left(\frac{2}{100}\right)^{2}+30,628 \cdot\left(\frac{2}{100}\right)+0,9477}=0,127$ 
$\beta_{s}(t=4)=\frac{\left(\frac{4}{100}\right)^{3}+40 \cdot\left(\frac{4}{100}\right)^{2}+9,216 \cdot\left(\frac{4}{100}\right)}{\left(\frac{4}{100}\right)^{3}+40,087 \cdot\left(\frac{4}{100}\right)^{2}+30,628 \cdot\left(\frac{4}{100}\right)+0,9477}=0,193$

Assim, a deformação do concreto devida à retração, considerando seção simples, corresponde a:

$\varepsilon_{\mathrm{cs}}\left(t, t_{0}\right)_{\text {simples }}=\varepsilon_{\mathrm{cs} \infty} \cdot\left[\beta_{\mathrm{s}}(t)-\beta_{\mathrm{s}}\left(\mathrm{t}_{0}\right)\right]=2,8125 \cdot 10^{-4} \cdot[0,193-0,127]=1,856 \cdot 10^{-5}$

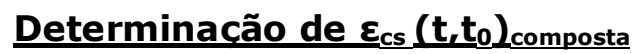

\section{$>$ Determinação de $\varepsilon_{\mathrm{cs} \infty}$ considerando a seção composta}

$\varepsilon_{\mathrm{CS} \infty}=\varepsilon_{1 \mathrm{~s}} \cdot \varepsilon_{2 \mathrm{~s}} \rightarrow \varepsilon_{\mathrm{cS} \infty}=2,5 \cdot 10^{-4} \cdot 1,0440=2,61 \cdot 10^{-4}$

$\varepsilon_{1 s}$ : coeficiente dependente da umidade relativa do ambiente e da consistência do concreto (Tabela A1 da NBR 6118:2003)

$\varepsilon_{1 \mathrm{~s}}=2,5 \cdot 10^{-4} \rightarrow$ Para $70 \%$ de umidade e abatimento menor que $4 \mathrm{~cm}$

$\varepsilon_{2 s}$ : coeficiente dependente da espessura fictícia da peça

$\varepsilon_{2 \mathrm{~s}}=\frac{33+2 \mathrm{~h}_{\mathrm{fic}}}{20,8+3 \mathrm{~h}_{\mathrm{fic}}}=\frac{33+2.9,96766}{20,8+3.9,96766}=1,0440$

$\mathrm{h}_{\text {fic }}$ : espessura fictícia em centímetros

$h_{\text {fic }}=\gamma \frac{2 A_{c}}{u_{a r}}=1,45 \cdot \frac{2 \cdot 2002,95}{582,74}=9,96766 \mathrm{~cm}$

$\gamma$ : coeficiente dependente da umidade relativa do ambiente $\mathrm{U} \%$ (Tabela A1 da NBR 6118:2003)

$\gamma=1+\exp (-7,8+0,1 . U)=1+\exp (-7,8+0,1.70)=1,45$

$A_{c}$ : área da seção transversal da peça, considerando a capa, equivalente a $A_{c}=2002,95 \mathrm{~cm}^{2}$

$U_{a r}$ : parte do perímetro externo da seção transversal da peça em contato com o ar

$\mathrm{u}_{\mathrm{ar}}=2 \cdot\left(\mathrm{b}+\mathrm{h}+\mathrm{h}_{\mathrm{capa}}\right)+6 \cdot(\pi \cdot \phi)$

$u_{a r}=2 \cdot(1,25+0,2+0,05)+6 \cdot(3,1415926 \cdot 0,15)$

$\mathrm{u}_{\mathrm{ar}}=5,8274 \mathrm{~m}=582,74 \mathrm{~cm}$

\section{$>$ Determinação de $\beta_{s}(t)$ e $\beta_{s}\left(t_{0}\right)$ considerando a seção composta}

$\beta_{s}(t)$ ou $\beta_{s}\left(t_{o}\right)$ : coeficiente relativo á retração, no instante t ou to (Figura A.3 da NBR 6118:2003) 
O coeficiente relativo à retração $\left(\beta_{s}(t)\right.$ ou $\beta_{s}\left(t_{0}\right)$ ) pode ser determinado com a expressão:

$$
\beta_{s}(t)=\frac{\left(\frac{t}{100}\right)^{3}+A \cdot\left(\frac{t}{100}\right)^{2}+B \cdot\left(\frac{t}{100}\right)}{\left(\frac{t}{100}\right)^{3}+C \cdot\left(\frac{t}{100}\right)^{2}+D \cdot\left(\frac{t}{100}\right)+E}
$$

t: idade fictícia do concreto no instante considerado, em dias, equivalente a $\mathrm{t}=\alpha \sum_{\mathrm{i}} \frac{\mathrm{T}_{\mathrm{i}}+10}{30} \cdot \Delta \mathrm{t}_{\mathrm{ef}, \mathrm{i}} \rightarrow \mathrm{t}=1 \cdot \frac{50+10}{30} \cdot 2=4$ dias

$t_{0}$ : idade fictícia do concreto ao ser feito o carregamento, em dias, equivalente a:

$\mathrm{t}=1 . \frac{50+10}{30} \cdot 10=20$ dias

Considerando $\mathrm{h}=\mathrm{h}_{\text {fic }}=0,0996766 \mathrm{~m}$, tem-se:

A $=40$

$B=116 \cdot h^{3}-282 \cdot h^{2}+220 \cdot h-4,8 \rightarrow B=14,4419$

$C=2,5 \cdot h^{3}-8,8 \cdot h+40,7 \quad \rightarrow \quad C=39,825$

$D=-75 \cdot h^{3}+585 \cdot h^{2}+496 \cdot h-6,8 \rightarrow D=48,3775$

$E=-169 \cdot h^{4}+88 \cdot h^{3}+584 \cdot h^{2}-39 \cdot h+0,8 \rightarrow E=2,785$

Para $t_{0}=4$ dias e $t=20$ dias, tem-se:

$\beta_{s}\left(t_{0}=4\right)=\frac{\left(\frac{4}{100}\right)^{3}+40 \cdot\left(\frac{4}{100}\right)^{2}+14,4419 \cdot\left(\frac{4}{100}\right)}{\left(\frac{4}{100}\right)^{3}+39,825 \cdot\left(\frac{4}{100}\right)^{2}+48,3775 \cdot\left(\frac{4}{100}\right)+2,785}=0,134$

$\beta_{s}(t=20)=\frac{\left(\frac{20}{100}\right)^{3}+40 \cdot\left(\frac{20}{100}\right)^{2}+14,4419 \cdot\left(\frac{20}{100}\right)}{\left(\frac{20}{100}\right)^{3}+39,825 \cdot\left(\frac{20}{100}\right)^{2}+48,3775 \cdot\left(\frac{20}{100}\right)+2,785}=0,320$

Assim, a deformação do concreto devido a retração, considerando seção composta, corresponde a:

$\varepsilon_{\mathrm{cs}}\left(\mathrm{t}, \mathrm{t}_{0}\right)_{\text {composta }}=\varepsilon_{\mathrm{cs} \infty} \cdot\left[\beta_{\mathrm{s}}(\mathrm{t})-\beta_{\mathrm{s}}\left(\mathrm{t}_{0}\right)\right]=2,61 \cdot 10^{-4} \cdot[0,320-0,134]=4,855 \cdot 10^{-5}$ 


\section{Determinação de $\varepsilon_{c s}\left(t, t_{0}\right)$ final}

Assim, com os valores correspondentes à deformação do concreto, devidos à retração, para a seção simples e a seção composta, pode-se determinar a retração total da seguinte forma:

$\varepsilon_{\mathrm{cS}}\left(\mathrm{t}, \mathrm{t}_{0}\right)=\frac{\varepsilon_{\mathrm{cs}}\left(\mathrm{t}, \mathrm{t}_{0}\right)_{\text {simples }} \cdot 10+\varepsilon_{\mathrm{cs}}\left(\mathrm{t}, \mathrm{t}_{0}\right)_{\text {composta }} \cdot 8}{10}=\frac{1,856 \cdot 10^{-5} \cdot 2+4,855 \cdot 10^{-5} \cdot 8}{10}=3,884 \cdot 10^{-5}$

$\Delta \sigma_{\mathrm{ps}}\left(\mathrm{t}, \mathrm{t}_{0}\right)=\varepsilon_{\mathrm{cs}}\left(\mathrm{t}, \mathrm{t}_{0}\right) \cdot \mathrm{E}_{\mathrm{p}} \rightarrow \Delta \sigma_{\mathrm{ps}}\left(\mathrm{t}, \mathrm{t}_{0}\right)=3,884 \cdot 10^{-5} \cdot 190000$

$\Delta \sigma_{\mathrm{ps}}\left(\mathrm{t}, \mathrm{t}_{0}\right)=7,38 \mathrm{MPa}$

\subsubsection{Fluência do concreto}

Assim como para a retração, no cálculo da perda por fluência deve ser considerado que a partir de certo momento a laje passa a apresentar capa. Dessa forma, a determinação da fluência para este caso pode ser realizada a partir da expressão:

$\Delta \sigma_{p, s}\left(t, t_{0}\right)=\alpha_{p} \cdot\left[\left(\frac{N_{p}}{A}+\frac{N_{p} \cdot e_{p}^{2}}{I}-\frac{M_{g 1} \cdot e_{p}}{I}\right) \cdot \varphi\left(t, t_{0}\right)_{\text {simples }}-\left(\frac{M_{g 2} \cdot e_{p}}{I}\right) \cdot \varphi\left(t, t_{0}\right)_{\text {composta }}\right]$

$\alpha_{p}$ : relação entre o módulo de elasticidade do aço protendido e o do concreto $\left(\frac{E_{p}}{E_{c}}\right)$

$E_{p}=190 \frac{\mathrm{kN}}{\mathrm{mm}^{2}}$ e $E_{\mathrm{c}}=5600 \cdot \sqrt{\mathrm{f}_{\mathrm{ck}}}=5600 \cdot \sqrt{40}=35417 \mathrm{MPa} ;$

A, I: área e momento de inércia da seção transversal inicial da peça, ou seja, sem capa.

$A=0,137795 \mathrm{~m}^{2}$ e $I=6,712 \cdot 10^{-4} \mathrm{~m}^{4}$

$\mathrm{N}_{\mathrm{p}}$ : Força total de protensão, retirando as perdas iniciais

Como são cinco cabos $\left(A_{p}=5 \mathrm{~cm}^{2}\right)$, tem-se:

$\mathrm{N}_{\mathrm{p}}=5 .(114-1,14-0,788-4,471)=538,0 \mathrm{kN}$

$e_{p}$ : excentricidade da força de protensão

$e_{p}=\left(\frac{0,2}{2}-0,035\right)=0,065 \mathrm{~m}$

$M_{g 1:}$ momento de peso próprio para a peça na sua retirada da pista, considerando a seção simples (sem capa) do meio do vão

Como calculado anteriormente, para laje sem capa considerando a seção do meio do vão (item 1.3.2):

$M_{g 1}=\left(\frac{p p \cdot L^{2}}{8}\right)=\left(\frac{3,44 \cdot 3^{2}}{8}\right)=3,875 \mathrm{kN} \cdot \mathrm{m}$ 
$\mathrm{M}_{\mathrm{g} 2 \text { : }}$ momento devido ao peso próprio da capa, considerando a seção composta no meio do vão

$M_{\mathrm{g} 2}=\left(\frac{\mathrm{pp} \cdot \mathrm{L}^{2}}{8}\right)=\left(\frac{1,5625.3^{2}}{8}\right)=1,7578 \mathrm{kN} \cdot \mathrm{m}$

pp : peso próprio da capa presente na seção composta

$\mathrm{pp}=\mathrm{A}_{\text {capa }} \cdot \gamma_{\mathrm{c}}=0,0625.25=1,5625 \frac{\mathrm{kN}}{\mathrm{m}}$

$A_{\text {capa }}$ : área da capa da seção composta, $A_{\text {capa }}=(1,25.0,05)=0,0625 \mathrm{~m}^{2}$

\section{Determinação de $\varphi\left(t, t_{0}\right)_{\text {simples }}$}

$\varphi\left(t, t_{0}\right)_{\text {simples }}$ : coeficiente da fluência, considerando a seção simples, ou seja, sem a presença de capa

Assim, como já calculado anteriormente, considerando a seção do meio do vão e a laje sem capa (no item 1.3.2), tem-se o coeficiente da fluência para a seção simples:

$\varphi\left(t, t_{0}\right)_{\text {simples }}=\varphi_{a}+\varphi_{f \infty}\left[\beta_{f}(t)-\left[\beta_{f}\left(t_{0}\right)\right]+\varphi_{d \infty} \cdot \beta_{d}\right.$

$\varphi\left(t, t_{0}\right)_{\text {simples }}=0,204+2,723 \cdot(0,553-0,195)+0,4 \cdot 0,6=1,42$

Logo, é possível determinar a fluência da seguinte maneira:

$$
\begin{aligned}
& \Delta \sigma_{p, s}\left(t, t_{0}\right)=\alpha_{p} \cdot\left[\left(\frac{N_{p}}{A}+\frac{N_{p} \cdot e_{p}^{2}}{I}-\frac{M_{g 1} \cdot e_{p}}{I}\right) \cdot \varphi\left(t, t_{0}\right)_{\text {simples }}-\left(\frac{M_{g 2} \cdot e_{p}}{I}\right) \cdot \varphi\left(t, t_{0}\right)_{\text {simples }}\right] \\
& \Delta \sigma_{p, s}\left(t, t_{0}\right)=\frac{190000}{35417} \cdot\left[\left(\frac{538,0}{0,137795}+\frac{538,0 \cdot 0,065^{2}}{6,712 \cdot 10^{-4}}-\frac{3,875 \cdot 0,065}{6,712 \cdot 10^{-4}}\right) \cdot 1,42-\left(\frac{1,7578 \cdot 0,065}{6,712 \cdot 10^{-4}}\right) \cdot 1,42\right] \\
& \Delta \sigma_{p, s}\left(t, t_{0}\right)=51385,24 \frac{\mathrm{kN}}{\mathrm{m}^{2}} \\
& \Delta \sigma_{p, s}\left(t, t_{0}\right)=51,38 \mathrm{MPa}
\end{aligned}
$$

\subsubsection{Relaxação da armadura}

Como já determinado anteriormente, considerando a laje sem capa (item 1.3.3), a perda ao longo do tempo por relaxação da armadura corresponde a

$\Delta \sigma_{\mathrm{r}}=7,35 \mathrm{MPa}$

\subsection{PERDA TOTAL EM RELAÇÃO À TENSÃO INICIAL}

Assim, após 10 dias, a tensão na armadura corresponde a:

$\sigma_{\mathrm{p}}(\mathrm{t}=10)=1076-7,38-51,38-7,35$ 
$\sigma_{\mathrm{p}}(\mathrm{t}=10)=1009,89 \mathrm{MPa}$

perdas $=1-\frac{1009,89}{1140}=11,41 \%$ (em relação à tensão inicial)

\section{Perdas para dois alvéolos preenchidos e seção central}

Neste exemplo de cálculo das perdas de protensão também serão considerados os itens: perdas iniciais, perdas diferidas e perda total em relação à tensão inicial.

\subsection{PERDAS INICIAIS}

Neste item serão consideradas: deformação por ancoragem, relaxação da armadura e deformação imediata do concreto.

\subsubsection{Deformação por ancoragem}

A perda devida à deformação por ancoragem é igual à calculada anteriormente para a laje sem a presença de capa (item 1.2.1), correspondendo a $\Delta \sigma=11,4 \mathrm{MPa}$.

\subsubsection{Relaxação da armadura}

A perda devida à relaxação da armadura é igual à calculada anteriormente para a laje sem a presença de capa (item 1.2.2), correspondendo a $\Delta \sigma_{r}=7,88 \mathrm{MPa}$.

\subsubsection{Deformação imediata do concreto}

A perda por deformação imediata do concreto pode ser obtida a partir da expressão: $\Delta \sigma_{\mathrm{pd}}=\varepsilon_{7}, \mathrm{E}_{\mathrm{p}}$.

\section{Determinação da deformação específica $\varepsilon_{7}$}

A deformação específica da armadura de protensão devida à descompressão $\left(\varepsilon_{7}\right)$ pode ser determinada da seguinte forma:

$\varepsilon_{7}=\varepsilon_{\text {concreto }}=\frac{\sigma_{\mathrm{cg}, \text { cabos }}}{\mathrm{E}_{\mathrm{c}}}=\frac{7177,50}{30672000}=2,34 \cdot 10^{-4}$

$E_{c}$ : módulo de elasticidade do concreto $\rightarrow E_{c}=5600 \cdot \sqrt{f_{c j}}=5600 \cdot \sqrt{30}=30672 \mathrm{MPa}$

$\sigma_{\mathrm{cg}, \text { cabos }}$ : tensão no concreto no nível do baricentro da armadura de protensão, devida à carga permanente modificada pela protensão ou simultaneamente aplicada com a protensão, que pode ser determinada através da expressão: 
$\sigma_{\mathrm{cg}, \text { cabos }}=\frac{N_{p}}{A}+\frac{N_{p} \cdot e_{p}^{2}}{I}-\frac{M_{g 1} \cdot e_{p}}{I}=\frac{560,36}{0,137795}+\frac{560,36 \cdot 0,065^{2}}{6,712 \cdot 10^{-4}}-\frac{4,30 \cdot 0,065}{6,712 \cdot 10^{-4}}=7177,50 \frac{\mathrm{kN}}{\mathrm{m}^{2}}$

A e I: área e momento de inércia da seção transversal considerada, que, neste caso, corresponde à seção do meio do vão da peça

$A=0,137795 \mathrm{~m}^{2}$ e $\mathrm{I}=0,0006712 \mathrm{~m}^{4}$.

$e_{p}$ : excentricidade da força de protensão $e_{p}=0,065 \mathrm{~m}$

$N_{p}=5 .(114-1,14-0,788)=560,36 \mathrm{kN}$ (força total de protensão)

$\mathrm{M}_{\mathrm{g} 1}$ : momento devido ao peso próprio para a peça na sua retirada da pista, considerando a seção do meio do vão da laje

\section{$>$ Determinação de $\mathbf{M}_{\mathbf{g 1}}$}

Para determinar $M_{g 1}$ na seção do meio do vão, é preciso considerar que existe um preenchimento parcial de dois alvéolos, próximo às extremidades, sendo o peso próprio da laje diferente para as regiões de extremidade e para a região central, como pode ser observado na Figura 2.

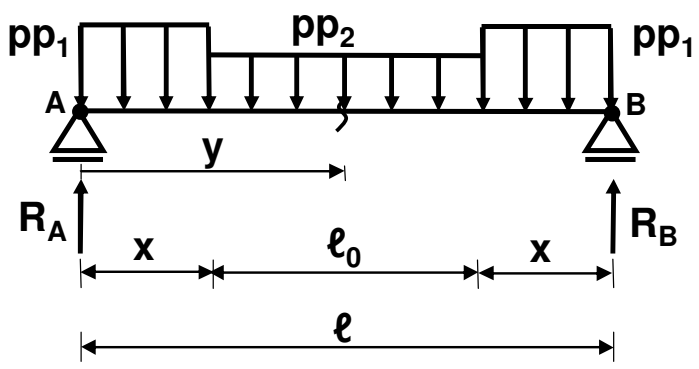

Figura 2 - Esquema para determinação do $M_{g 1}$ na seção do meio do vão.

Na Figura 2, tem-se:

$x$ : comprimento da região que possui dois alvéolos preenchidos, sendo $x=0,95 \mathrm{~m}$

$\ell_{0}$ : comprimento da região sem alvéolos preenchidos, sendo $\ell_{0}=1,1 \mathrm{~m}$

$\ell$ : comprimento do vão da laje, sendo $\ell=3 \mathrm{~m}$

y: distância, com relação ao apoio, da seção em que se pretende determinar o momento devido ao peso próprio $M_{\mathrm{g} 1}$, sendo neste caso $\mathrm{y}=1,5 \mathrm{~m}$

$\mathrm{pp}_{1}$ : peso próprio da laje, referente à região com alvéolos preenchidos

$\mathrm{pp}_{1}=\mathrm{A}_{\mathrm{c}, 1} \cdot \gamma_{\mathrm{c}}=0,173138.25=4,328 \frac{\mathrm{kN}}{\mathrm{m}}$

$A_{c, 1}$ : área de concreto referente à seção com alvéolos preenchidos, próximas às extremidades da peça, sendo $A_{c, 1}=0,173138 \mathrm{~m}^{2}$ 
$\mathrm{pp}_{2}$ : peso próprio da laje, referente à região sem alvéolos preenchidos

$\mathrm{pp}_{2}=\mathrm{A}_{\mathrm{c}, 2} \cdot \gamma_{\mathrm{c}}=0,137795.25=3,445 \frac{\mathrm{kN}}{\mathrm{m}}$

$A_{c, 2}$ : área de concreto referente à seção sem alvéolos preenchidos, na região central da

laje, sendo $A_{c, 2}=0,137795 \mathrm{~m}^{2}$

$R_{A}$ : reação de apoio no ponto $A$, sendo:

$\mathrm{R}_{\mathrm{A}}=\frac{\mathrm{pp}_{1} \cdot \mathrm{x} \cdot\left(\ell-\frac{\mathrm{x}}{2}\right)+\mathrm{pp}_{2} \cdot \ell_{0} \cdot\left(\ell-\mathrm{x}-\frac{\ell_{0}}{2}\right)+\mathrm{pp}_{1} \cdot \frac{\mathrm{x}^{2}}{2}}{\ell}$

$\mathrm{R}_{\mathrm{A}}=\frac{4,328 \cdot 0,95 \cdot\left(3,0-\frac{0,95}{2}\right)+3,445 \cdot 1,1 \cdot\left(3,0-0,95-\frac{1,1}{2}\right)+4,328 \cdot \frac{0,95^{2}}{2}}{3,0}$

$R_{A}=6,006 \mathrm{kN}$

Dessa forma, é possível determinar o momento devido ao peso próprio na seção do meio do vão:

$\mathrm{M}_{\mathrm{g} 1}=\mathrm{R}_{\mathrm{A}} \cdot \mathrm{y}-\left[\mathrm{pp}_{1} \cdot \mathrm{x} \cdot\left(\frac{\mathrm{x}}{2}+\frac{\ell_{0}}{2}\right)+\mathrm{pp}_{2} \cdot \frac{\ell_{0}}{2} \cdot \frac{\ell_{0}}{4}\right]$

$M_{g 1}=6,006 \cdot 1,5-\left[4,328 \cdot 0,95 \cdot\left(\frac{0,95}{2}+\frac{1,1}{2}\right)+3,445 \cdot \frac{1,1}{2} \cdot \frac{1,1}{4}\right]$

$M_{g 1}=4,30 \mathrm{kN} \cdot \mathrm{m}$

Logo, pode-se determinar a perda por deformação imediata do concreto.

$\Delta \sigma_{\mathrm{pd}}=\varepsilon_{7} \cdot \mathrm{E}_{\mathrm{p}}=2,34 \cdot 10^{-4} \cdot 1,9 \cdot 10^{5}$

$\Delta \sigma_{\mathrm{pd}}=44,46 \mathrm{MPa}$

Assim, logo após a retirada da laje da pista, a armadura de protensão está submetida a:

$\sigma_{\mathrm{p}}(\mathrm{t}=1)=1140-11,40-7,88-44,46$

$\sigma_{p}(t=1)=1076,26 \mathrm{MPa}$

\subsection{PERDAS DIFERIDAS}

No cálculo das perdas diferidas, serão consideradas: retração do concreto, fluência do concreto e relaxação da armadura. 


\subsubsection{Retração do concreto}

A expressão da perda devida à retração do concreto é dada por:

$\Delta \sigma_{\mathrm{p}, \mathrm{s}}\left(\mathrm{t}, \mathrm{t}_{0}\right)=\varepsilon_{\mathrm{cs}}\left(\mathrm{t}, \mathrm{t}_{0}\right) \cdot \mathrm{E}_{\mathrm{p}}$

\section{Determinação de $\varepsilon_{\underline{c s}}\left(t, t_{0}\right)$}

O valor de $\varepsilon_{\mathrm{cs}}\left(\mathrm{t}, \mathrm{t}_{0}\right)$ pode ser obtido a partir da equação:

$\varepsilon_{\mathrm{cs}}\left(\mathrm{t}, \mathrm{t}_{0}\right)=\varepsilon_{\mathrm{cs} \infty} \cdot\left[\beta_{\mathrm{s}}(\mathrm{t})-\beta_{\mathrm{s}}\left(\mathrm{t}_{0}\right)\right]$

$\varepsilon_{\mathrm{cs} \infty}$ : valor final da retração

$\beta_{s}(t)$ ou $\beta_{s}\left(t_{o}\right)$ : coeficiente relativo à retração, no instante t ou $t_{o}$

\section{$>$ Determinação de $\varepsilon_{\mathrm{cs} \infty}$}

$\varepsilon_{\mathrm{cs} \infty}$ : valor final da retração

$\varepsilon_{\mathrm{cs} \infty}=\varepsilon_{1 \mathrm{~s}} \cdot \varepsilon_{2 \mathrm{~s}} \rightarrow \varepsilon_{\mathrm{cs} \infty}=2,5 \cdot 10^{-4} \cdot 1,0839=2,71 \cdot 10^{-4}$

$\varepsilon_{1 \mathrm{~s}}$ : coeficiente dependente da umidade relativa do ambiente e da consistência do concreto (Tabela A1 da NBR 6118:2003)

$\varepsilon_{1 \mathrm{~s}}=2,5.10^{-4} \rightarrow$ Para $70 \%$ de umidade e abatimento menor que $4 \mathrm{~cm}$

$\varepsilon_{2 \mathrm{~s}}$ : coeficiente dependente da espessura fictícia da peça

$\varepsilon_{2 \mathrm{~s}}=\frac{33+2 \mathrm{~h}_{\mathrm{fic}}}{20,8+3 \mathrm{~h}_{\mathrm{fic}}}=\frac{33+2.8,351}{20,8+3.8,351}=1,0839$

$h_{\text {fic }}$ : espessura fictícia em centímetros. $h_{\text {fic }}=\gamma \frac{2 A_{c}}{u_{a r}}=1,45 \cdot \frac{2 \cdot 1377,95}{478,49}=8,351 \mathrm{~cm}$

$\gamma=$ coeficiente dependente da umidade relativa do ambiente $U \%$ (Tabela A1 da NBR 6118:2003)

$\gamma=1+\exp (-7,8+0,1 . U)=1+\exp (-7,8+0,1.70)=1,45$

$A_{c}$ : área da seção transversal da peça, para seção central. $A_{c}=0,137795 m^{2}$

$U_{\mathrm{ar}}$ : parte do perímetro externo da seção transversal da peça em contato com o ar.

Apesar do cálculo estar sendo feito para a seção do meio do vão, não serão considerados todos os perímetros das circunferências dos alvéolos, pois foi constatado, no ensaio, a presença de água contida no interior da laje, na região entre os alvéolos parcialmente preenchidos. Dessa forma, mesmo para a seção central serão considerados somente os perímetros de quatro alvéolos em contato com o ar.

$\mathrm{u}_{\mathrm{ar}}=2 \cdot(\mathrm{b}+\mathrm{h})+4 \cdot(\pi \cdot \phi)$

$u_{a r}=2 \cdot(1,25+0,2)+4 \cdot(3,1415926 \cdot 0,15)$

$\mathrm{u}_{\mathrm{ar}}=4,7849 \mathrm{~m}=478,49 \mathrm{~cm}$ 


\section{$>$ Determinação de $\beta_{s}(t)$ e $\beta_{s}\left(t_{0}\right)$}

$\beta_{s}$ (t) ou $\beta_{s}\left(t_{o}\right)$ : coeficiente relativo á retração, no instante $t$ ou to (Figura A.3 da NBR 6118:2003)

De acordo com a NBR 6118:2003, o coeficiente relativo à retração $\left(\beta_{s}(t)\right.$ ou $\left.\beta_{s}\left(t_{o}\right)\right)$ pode ser determinado através da expressão:

$\beta_{s}(t)=\frac{\left(\frac{t}{100}\right)^{3}+A \cdot\left(\frac{t}{100}\right)^{2}+B \cdot\left(\frac{t}{100}\right)}{\left(\frac{t}{100}\right)^{3}+C \cdot\left(\frac{t}{100}\right)^{2}+D \cdot\left(\frac{t}{100}\right)+E}$

t: idade fictícia do concreto no instante considerado, em dias, equivalente a

$\mathrm{t}=\alpha \sum_{\mathrm{i}} \frac{\mathrm{T}_{\mathrm{i}}+10}{30} \cdot \Delta \mathrm{t}_{\mathrm{ef}, \mathrm{i}} \rightarrow \mathrm{t}=1 \cdot \frac{50+10}{30} \cdot 1=2$ dias

$t_{0}$ : idade fictícia do concreto ao ser feito o carregamento, em dias, equivalente a:

$\mathrm{t}=1 . \frac{50+10}{30} \cdot 10=20$ dias

Considerando $\mathrm{h}=\mathrm{h}_{\text {fic }}=0,08351 \mathrm{~m}$, tem-se:

$A=40$

$B=116 \cdot h^{3}-282 \cdot h^{2}+220 \cdot h-4,8 \rightarrow B=11,67$

$\mathrm{C}=2,5 \cdot \mathrm{h}^{3}-8,8 \cdot \mathrm{h}+40,7 \rightarrow \mathrm{C}=39,97$

$\mathrm{D}=-75 \cdot \mathrm{h}^{3}+585 \cdot \mathrm{h}^{2}+496 \cdot \mathrm{h}-6,8 \rightarrow \mathrm{D}=38,66$

$E=-169 \cdot h^{4}+88 \cdot h^{3}+584 \cdot h^{2}-39 \cdot h+0,8 \rightarrow E=1,66$

Sendo $t_{0}=2$ dias e $t=20$ dias, tem-se:

$\beta_{s}\left(t_{0}=2\right)=\frac{\left(\frac{2}{100}\right)^{3}+40 \cdot\left(\frac{2}{100}\right)^{2}+11,67 \cdot\left(\frac{2}{100}\right)}{\left(\frac{2}{100}\right)^{3}+39,97 \cdot\left(\frac{2}{100}\right)^{2}+38,66 \cdot\left(\frac{2}{100}\right)+1,66}=0,102$

$\beta_{s}(t=20)=\frac{\left(\frac{20}{100}\right)^{3}+40 \cdot\left(\frac{20}{100}\right)^{2}+11,67 \cdot\left(\frac{20}{100}\right)}{\left(\frac{20}{100}\right)^{3}+39,97 \cdot\left(\frac{20}{100}\right)^{2}+38,66 \cdot\left(\frac{20}{100}\right)+1,66}=0,358$

$\varepsilon_{\mathrm{cs}}\left(\mathrm{t}, \mathrm{t}_{0}\right)=\varepsilon_{\mathrm{cs} \infty} \cdot\left[\beta_{\mathrm{s}}(\mathrm{t})-\beta_{\mathrm{s}}\left(\mathrm{t}_{0}\right)\right]=2,71 \cdot 10^{-4} \cdot[0,358-0,102]=6,938 \cdot 10^{-5}$

$\Delta \sigma_{\mathrm{ps}}\left(\mathrm{t}, \mathrm{t}_{0}\right)=\varepsilon_{\mathrm{cs}}\left(\mathrm{t}, \mathrm{t}_{0}\right) \cdot \mathrm{E}_{\mathrm{p}} \rightarrow \Delta \sigma_{\mathrm{ps}}\left(\mathrm{t}, \mathrm{t}_{0}\right)=6,938 \cdot 10^{-5} \cdot 190000$

$\Delta \sigma_{\mathrm{ps}}\left(\mathrm{t}, \mathrm{t}_{0}\right)=13,18 \mathrm{MPa}$ 


\subsubsection{Fluência do concreto}

A perda por fluência pode ser obtida pela expressão:

$\Delta \sigma_{p, s}\left(t, t_{0}\right)=\sigma_{c g p} \cdot \varphi\left(t, t_{0}\right) \cdot \alpha_{p}$

$\alpha_{p}$ : relação entre o módulo de elasticidade do aço protendido e o do concreto $\left(\frac{E_{p}}{E_{c}}\right)$

$E_{p}=190 \frac{\mathrm{kN}}{\mathrm{mm}^{2}}$ e $E_{c}=5600 \cdot \sqrt{f_{c k}}=5600 \cdot \sqrt{40}=35417 \mathrm{MPa}$

$\sigma_{\mathrm{cg}, \text { cabos }}$ : tensão que ocorre no concreto no nível do centro de gravidade da armadura de protensão e devido à ação das cargas permanentes, inclusive a protensão

$\sigma_{\mathrm{cg}, \text { cabos }}=\frac{N_{p}}{A}+\frac{N_{p} \cdot e_{p}^{2}}{I}-\frac{M_{g 1} \cdot e_{p}}{I}=\frac{538,13}{0,137795}+\frac{538,13 \cdot 0,065^{2}}{6,712 \cdot 10^{-4}}-\frac{4,30 \cdot 0,065}{6,712 \cdot 10^{-4}}=6876,24 \frac{\mathrm{kN}}{\mathrm{m}^{2}}$

$M_{g 1}$ : momento de peso próprio $M_{g 1}=4,30 \mathrm{kN} \cdot \mathrm{m}$ (Calculado no item 3.1.3)

A, I: área e momento de inércia da seção transversal do meio do vão da peça

$\mathrm{N}_{\mathrm{p}}$ : Força total de protensão, retirando as perdas iniciais

Como $\left(A_{p}=5 \mathrm{~cm}^{2}\right)$, tem-se:

$\mathrm{N}_{\mathrm{p}}=5 .(114-1,14-0,788-4,446)=538,13 \mathrm{kN}$

$e_{p}$ : excentricidade da armadura protendida $e_{p}=0,065 \mathrm{~m}$

\section{Determinação de $\varphi\left(t, t_{0}\right)$}

$\varphi\left(t, t_{0}\right)=\varphi_{a}+\varphi_{f \infty}\left[\beta_{f}(t)-\left[\beta_{f}\left(t_{0}\right)\right]\right]+\varphi_{d \infty} \cdot \beta_{d}$

$t_{0}$ : idade fictícia do concreto ao ser feito o carregamento $\rightarrow t=3 \cdot \frac{50+10}{30} \cdot 1=6$ dias

t: idade fictícia do concreto no instante considerado, em dias

$\mathrm{t}=\alpha \sum_{\mathrm{i}} \frac{\mathrm{T}_{\mathrm{i}}+10}{30} \cdot \Delta \mathrm{t}_{\mathrm{ef}, \mathrm{i}} \rightarrow \mathrm{t}=3 \cdot \frac{50+10}{30} \cdot 10=60$ dias

$\alpha=3$ (para cimento ARI)

$\mathrm{T}_{\mathrm{i}}=50^{\circ} \mathrm{C}$ (temperatura) - temperatura média diária do ambiente

$\Delta t_{e f, i}$ : período, em dias, durante o qual a temperatura média diária do ambiente, $T_{i}$, pode ser admitida constante

$\varphi_{a}$ : coeficiente de fluência rápida equivalente a $\varphi_{a}=0,8 .\left[1-\frac{f_{c}\left(t_{0}\right)}{f_{c}(t)}\right]$

$\phi_{a}=0,8 \cdot\left[1-\frac{f_{c}\left(t_{0}\right)}{f_{c}(t)}\right]=0,8 \cdot\left[1-\frac{0,79}{1,06}\right]=0,204$ 
$\frac{f_{c}\left(t_{o}\right)}{f_{c}(t)}$ : função de crescimento da resistência do concreto com a idade, que pode ser obtida usando a expressão $\beta_{1}=\frac{f_{c j}}{f_{c k}}$, com

$\beta_{1}\left(t_{0}\right)=\exp \left\{s \cdot\left[1-\left(\frac{28}{t_{0}}\right)^{1 / 2}\right]\right\}=\exp \left\{0,2 \cdot\left[1-\left(\frac{28}{6}\right)^{1 / 2}\right]\right\}=0,79$

$\beta_{1}(\mathrm{t})=\exp \left\{\mathrm{s} \cdot\left[1-\left(\frac{28}{\mathrm{t}}\right)^{1 / 2}\right]\right\}=\exp \left\{0,2 \cdot\left[1-\left(\frac{28}{60}\right)^{1 / 2}\right]\right\}=1,06$

$\mathrm{s}$ : coeficiente que depende do tipo de cimento usado no concreto. $s=0,2$

$\varphi_{f \infty}:$ valor final do coeficiente de deformação lenta irreversível equivalente

$\varphi_{f_{\infty}}=\varphi_{1 c} \cdot \varphi_{2 c} \rightarrow \varphi_{f \infty}=1,5 \cdot 1,776=2,664$

$\varphi_{1 \mathrm{c}}$ : coeficiente dependente da umidade relativa do ambiente e da consistência do concreto, $\varphi_{1 \mathrm{c}}=1,5$

$\varphi_{2 c}$ : coeficiente dependente da espessura fictícia $h_{\text {fic }}$ (em centímetro) da peça, definida

$$
\text { por } \varphi_{2 \mathrm{c}}=\frac{42+\mathrm{h}_{\mathrm{fic}}}{20+\mathrm{h}_{\mathrm{fic}}} \rightarrow \varphi_{2 \mathrm{c}}=\frac{42+8,351}{20+8,351}=1,776
$$

$\mathrm{h}_{\text {fic }}$ : espessura fictícia em centímetros, calculada como descrita na perda por retração do concreto (item 3.2.1) $-\mathrm{h}_{\text {fic }}=8,351 \mathrm{~cm}$

$\beta_{f}(t)$ ou $\beta_{f}\left(t_{0}\right)$ : coeficientes relativos à deformação lenta irreversível, função da idade do concreto (definido no item A.2.2.3 da NBR 6118:2003)

Podem ser obtidos pela seguinte expressão:

$\beta_{f}(t)=\frac{t^{2}+A \cdot t+B}{t^{2}+C \cdot t+D}$

Considerando $h=h_{\text {fic }}=0,08351 \mathrm{~m}$, tem-se:

$A=42 \cdot h^{3}-350 \cdot h^{2}+588 . h+113 \rightarrow A=159,69$

$B=768 \cdot h^{3}-3060 \cdot h^{2}+3234 \cdot h-23 \rightarrow B=226,18$

$C=-200 \cdot h^{3}+13 \cdot h^{2}+1090 \cdot h+183 \rightarrow C=274,00$

$D=7579 . h^{3}-31916 \cdot h^{2}+35343 \cdot h+1931 \rightarrow D=4664,33$

Assim:

$\beta_{f}\left(t_{0 \text { fic }}\right)=\frac{6^{2}+159,69.6+226,18}{6^{2}+274,00.6+4664,33}=0,1923$

$\beta_{f}\left(t_{f f i c}\right)=\frac{60^{2}+159,69 \cdot 60+226,18}{60^{2}+274,00 \cdot 60+4664,33}=0,5427$ 
$\varphi_{\mathrm{d} \infty}$ : valor final do coeficiente de deformação lenta reversível igual a 0,4

$\beta_{d}:$ coeficiente relativo à deformação lenta reversível função do tempo $\left(t-t_{0}\right)$

$\beta_{d}=\frac{t-t_{o}+20}{t-t_{o}+70} \rightarrow \beta_{d}=\frac{60-6+20}{60-6+70}=0,60$

$\varphi\left(t, t_{0}\right)=\varphi_{a}+\varphi_{f \infty}\left[\beta_{f}(t)-\beta_{f}\left(t_{0}\right)\right]+\varphi_{d \infty \infty} \cdot \beta_{d}=0,204+2,664 \cdot(0,5427-0,1923)+0,4 \cdot 0,6=1,377$

Logo:

$\Delta \sigma_{\mathrm{p}, \mathrm{s}}\left(\mathrm{t}, \mathrm{t}_{0}\right)=\sigma_{\mathrm{cgp}} \cdot \varphi\left(\mathrm{t}, \mathrm{t}_{0}\right) \cdot \alpha_{\mathrm{p}}=6,87624 \cdot 1,377 \cdot \frac{190000}{35417}$

$\Delta \sigma_{\mathrm{p}, \mathrm{s}}\left(\mathrm{t}, \mathrm{t}_{0}\right)=50,80 \mathrm{MPa}$

\subsubsection{Relaxação da armadura}

O cálculo da perda por relaxação da armadura pode ser feito através da expressão:

$\psi_{\left(\mathrm{t}, \mathrm{t}_{0}\right)}=\frac{\Delta \sigma_{\mathrm{pr}}\left(\mathrm{t}, \mathrm{t}_{\mathrm{o}}\right)}{\sigma_{\mathrm{pi}}}$

$\sigma_{\mathrm{pi}}:$ tensão da armadura de protensão no instante de seu estiramento

Considerando a tensão na armadura retirando as perdas iniciais, tem-se:

$\sigma_{\mathrm{pi}}=1140-11,40-7,88-44,46=1076,26 \mathrm{MPa}$

$\Delta \sigma_{p r}\left(t, t_{o}\right)$ : perda de tensão por relaxação pura (com comprimento constante) desde o instante $t_{0}$ do estiramento da armadura até o instante $t$ considerado

Assim, para o exemplo em questão, determinou-se a seguinte relação:

$r=\frac{\sigma_{\mathrm{pi}}}{\mathrm{f}_{\mathrm{ptk}}}=\frac{1076,26}{1900}=0,566$

Então, consultando a Tabela 1, tem-se a situação indicada e o valor desejado é k.

\begin{tabular}{|c|c|}
\hline $0,5 \mathrm{fptk}$ & 0 \\
\hline $0,566 \mathrm{fptk}$ & $\mathrm{k}$ \\
\hline $0,6 \mathrm{fptk}$ & 1,3 \\
\hline
\end{tabular}

Interpolando-se:

$$
\frac{\mathrm{k}-0}{1,3-0}=\frac{0,566-0,5}{0,60-0,50} \quad \rightarrow \quad \mathrm{k}=\psi_{1000}=0,86 \%
$$

Os valores correspondentes a tempos diferentes de 1.000 horas, sempre a $20^{\circ} \mathrm{C}$, podem ser determinados a partir da expressão:

$\psi_{\left(t, t_{0}\right)}=\psi_{1000} \cdot\left(\frac{t-t_{0}}{41,67}\right)^{0,15} \quad$ para $\left(t, t_{0}\right)$ em dias 
Assim, tem-se:

$$
\begin{aligned}
& \psi_{10}=0,86 \cdot\left(\frac{10-1}{41,67}\right)^{0,15}=0,683 \% \\
& \text { Como } \psi_{\left(\mathrm{t}, \mathrm{t}_{0}\right)}=\frac{\Delta \sigma_{\mathrm{pr}}\left(\mathrm{t}, \mathrm{t}_{\mathrm{o}}\right)}{\sigma_{\mathrm{pi}}} \text { tem-se: } \\
& \Delta \sigma_{\mathrm{pr}}=\frac{\psi_{\left(\mathrm{t}, \mathrm{t}_{0}\right)}}{100} \cdot \sigma_{\mathrm{i}} \quad \rightarrow \quad \Delta \sigma_{\mathrm{r}}=\frac{0,683}{100} \cdot 1076,26 \\
& \Delta \sigma_{\mathrm{r}}=7,35 \mathrm{MPa}
\end{aligned}
$$

\subsection{PERDA TOTAL EM RELAÇÃO À TENSÃO INICIAL}

Assim, após 10 dias, a tensão na armadura corresponde a:

$\sigma_{p}(t=10)=1076,26-13,18-50,80-7,35$

$\sigma_{\mathrm{p}}(\mathrm{t}=10)=1004,93 \mathrm{MPa}$

perdas $=1-\frac{1004,93}{1140}=11,85 \%$ (em relação à tensão inicial )

\section{Perdas em laje sem capa e seção a 2,5 h do apoio}

Neste exemplo de cálculo das perdas de protensão serão considerados os itens: perdas iniciais, perdas diferidas e perda total em relação à tensão inicial.

\subsection{PERDAS INICIAIS}

No cálculo das perdas iniciais serão consideradas: deformação por ancoragem, relaxação da armadura e deformação imediata do concreto.

\subsubsection{Deformação por ancoragem}

A perda devida à deformação por ancoragem é igual à calculada anteriormente para a laje sem capa (item 1.2.1), correspondendo a $\Delta \sigma=11,4 \mathrm{MPa}$.

\subsubsection{Relaxação da armadura}

A perda por relaxação da armadura é igual à calculada anteriormente para a laje sem capa (item 1.2.2), correspondendo a $\Delta \sigma_{r}=7,88 \mathrm{MPa}$. 


\subsubsection{Deformação imediata do concreto}

A perda por deformação imediata do concreto pode ser obtida a partir da expressão:

$\Delta \sigma_{\mathrm{pd}}=\varepsilon_{7} \cdot \mathrm{E}_{\mathrm{p}}$

\section{Determinação da deformação específica $\varepsilon_{7}$}

$\varepsilon_{7}=\varepsilon_{\text {concreto }}=\frac{\sigma_{\mathrm{cg}, \text { cabos }}}{\mathrm{E}_{\mathrm{c}}}$

$\varepsilon_{7}$ : deformação específica da armadura de protensão devida à descompressão

$e_{p}$ : excentricidade da força de protensão

$e_{p}=\left(\frac{h}{2}-d^{\prime}\right)=\left(\frac{0,2}{2}-0,035\right)=0,065 m$

$\mathrm{E}_{\mathrm{c}}$ : módulo de elasticidade do concreto recomendado pela NBR 6118:2003 para o cálculo das perdas de protensão.

$E_{c}=5600 \cdot \sqrt{f_{c j}}=5600 \cdot \sqrt{30}=30672 \mathrm{MPa}$

Como são cinco cabos: $A_{p}=5 \mathrm{~cm}^{2}$

$\mathrm{N}_{\mathrm{p}}$ : força de protensão, retirando as perdas iniciais

$N_{p}=5 .(114-1,14-0,788)=560,36 \mathrm{kN}$

$\sigma_{\mathrm{cg}, \text { cabos }}$ : tensão no concreto no nível do baricentro da armadura de protensão, devida à carga permanente modificada pela protensão ou simultaneamente aplicada com a protensão, que pode ser determinada, considerando a seção a $2,5 \mathrm{~h}$ do apoio, com a expressão:

$\sigma_{\text {cg,cabos }}=\frac{N_{p}}{A}+\frac{N_{p} \cdot e_{p}^{2}}{I}-\frac{M_{g 1} \cdot e_{p}}{I}=\frac{560,36}{0,137795}+\frac{560,36 \cdot 0,065^{2}}{6,712 \cdot 10^{-4}}-\frac{2,150 \cdot 0,065}{6,712 \cdot 10^{-4}}=7385,7 \frac{\mathrm{kN}}{\mathrm{m}^{2}}$

A, I: área e momento de inércia da seção transversal considerada

$\mathrm{M}_{\mathrm{g} 1}$ : momento do peso próprio para a peça na sua retirada da pista, considerando a seção a $2,5 \mathrm{~h}$ do apoio, que pode ser determinado através da Figura 3 , como indicado a seguir.

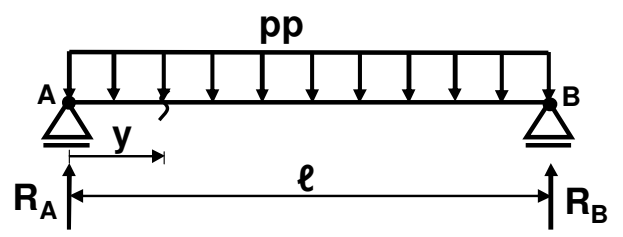

Figura 3 - Esquema para determinação do $M_{g 1}$ na seção a 2,5 h do apoio. 
pp : peso próprio da laje $\rightarrow \mathrm{pp}=\mathrm{A}_{\mathrm{c}} \cdot \gamma_{\mathrm{c}}=0,137795.25=3,44 \frac{\mathrm{kN}}{\mathrm{m}}$

y: distância da seção considerada ao apoio $\rightarrow y=2,5 \cdot h=2,5 \cdot 0,2=0,5 \mathrm{~m}$

$\mathrm{R}_{\mathrm{A}}$ : reação de apoio no ponto $A$

$\mathrm{R}_{\mathrm{A}}=\mathrm{R}_{\mathrm{B}}=\mathrm{pp} \cdot \frac{\ell}{2}=3,44 \cdot \frac{3}{2}=5,16 \mathrm{kN}$

Conhecidos esses valores, pode-se determinar o momento devido ao peso próprio:

$M_{g 1}=\left(R_{A} \cdot y\right)-\left(p p \cdot y \cdot \frac{y}{2}\right)=(5,16 \cdot 0,5)-\left(3,44 \cdot 0,5 \cdot \frac{0,5}{2}\right)=2,15 \mathrm{kN} \cdot \mathrm{m}$

Assim, tem-se:

$\varepsilon_{7}=\varepsilon_{\text {concreto }}=\frac{\sigma_{\text {cg,cabos }}}{\mathrm{E}_{\mathrm{c}}}=\frac{7385,7}{30672000}=2,41 \cdot 10^{-4}$

Logo:

$\Delta \sigma_{\mathrm{pd}}=\varepsilon_{7} \cdot \mathrm{E}_{\mathrm{p}}=2,41 \cdot 10^{-4} \cdot 1,9 \cdot 10^{5}=45,79 \mathrm{MPa}$

$\Delta \sigma_{\mathrm{pd}}=45,79 \mathrm{MPa}$

Portanto, logo após a retirada da pista, a armadura de protensão está submetida a:

$\sigma_{\mathrm{p}}(\mathrm{t}=1)=1140-11,40-7,88-45,79$

$\sigma_{\mathrm{p}}(\mathrm{t}=1)=1075 \mathrm{MPa}$

\subsection{PERDAS DIFERIDAS}

Do mesmo modo que nos exemplos anteriores, no cálculo das perdas diferidas, serão consideradas: retração do concreto, fluência do concreto e relaxação da armadura.

\subsubsection{Retração do concreto}

O cálculo considerando a seção a $2,5 \mathrm{~h}$ do apoio é igual ao realizado para determinar a retração da seção do meio do vão da laje (item 1.3.1): $\Delta \sigma_{\mathrm{ps}}\left(\mathrm{t}, \mathrm{t}_{0}\right)=14,43 \mathrm{MPa}$.

\subsubsection{Fluência do concreto}

A perda por fluência pode ser obtida com a expressão:

$\Delta \sigma_{\mathrm{p}, \mathrm{s}}\left(\mathrm{t}, \mathrm{t}_{0}\right)=\sigma_{\mathrm{cgp}} \cdot \varphi\left(\mathrm{t}, \mathrm{t}_{0}\right) \cdot \alpha_{\mathrm{p}}$

$\alpha_{p}$ : relação entre o módulo de elasticidade do aço protendido e o do concreto

$E_{p}=190 \frac{\mathrm{kN}}{\mathrm{mm}^{2}}$ e $E_{c}=5600 \cdot \sqrt{\mathrm{fck}_{\mathrm{c}}}=5600 \cdot \sqrt{40}=35417 \mathrm{MPa}$ 
$\sigma_{\mathrm{cg}, \text { cabos }}$ : tensão no concreto no nível do centro de gravidade da armadura de protensão, devida à ação das cargas permanentes, inclusive a protensão

$\sigma_{\mathrm{cg}, \text { cabos }}=\frac{\mathrm{N}_{\mathrm{p}}}{\mathrm{A}}+\frac{\mathrm{N}_{\mathrm{p}} \cdot \mathrm{e}_{\mathrm{p}}^{2}}{\mathrm{I}}-\frac{\mathrm{M}_{\mathrm{g} 1} \cdot \mathrm{e}_{\mathrm{p}}}{\mathrm{I}}=\frac{537,465}{0,137795}+\frac{537,465 \cdot 0,065^{2}}{6,712 \cdot 10^{-4}}-\frac{2,150 \cdot 0,065}{6,712 \cdot 10^{-4}}=7075,4 \frac{\mathrm{kN}}{\mathrm{m}^{2}}$

$\mathrm{N}_{\mathrm{p}}$ : força total de protensão, retirando as perdas iniciais

Como são cinco cabos $\left(A_{p}=5 \mathrm{~cm}^{2}\right)$, tem-se:

$\mathrm{N}_{\mathrm{p}}=5 .(114-1,14-0,788-4,579)=537,465 \mathrm{kN}$

$\mathrm{M}_{\mathrm{g} 1}$ : momento de peso próprio para a peça na sua retirada da pista, considerando a seção a 2,5.h do apoio. Calculado anteriormente, para deformação imediata do concreto (item 4.1.3), corresponde a $M_{g 1}=2,15 \mathrm{kN} . \mathrm{m}$

A, I: área e momento de inércia da seção transversal considerada

$\mathrm{e}_{\mathrm{p}}$ : excentricidade da força de protensão. $\mathrm{e}_{\mathrm{p}}=\left(\frac{0,2}{2}-0,035\right)=0,065 \mathrm{~m}$

Assim, como já calculado anteriormente, considerando a seção do meio do vão e a laje sem capa (item 1.3.2), tem-se o coeficiente da fluência $\varphi\left(t, t_{0}\right)$ :

$\varphi\left(t, t_{0}\right)=\varphi_{a}+\varphi_{f_{\infty}}\left[\beta_{f}(t)-\beta_{f}\left(t_{0}\right)\right]+\varphi_{d \infty} \cdot \beta_{d}=0,204+2,723 \cdot(0,553-0,195)+0,4 \cdot 0,6=1,42$

Logo:

$\Delta \sigma_{\mathrm{p}, \mathrm{s}}\left(\mathrm{t}, \mathrm{t}_{0}\right)=\sigma_{\mathrm{cgp}} \cdot \varphi\left(\mathrm{t}, \mathrm{t}_{0}\right) \cdot \alpha_{\mathrm{p}}=7,0754 \cdot 1,42 \cdot \frac{190000}{35417}$

$\Delta \sigma_{\mathrm{p}, \mathrm{s}}\left(\mathrm{t}, \mathrm{t}_{0}\right)=53,90 \mathrm{MPa}$

\subsubsection{Relaxação da armadura}

O cálculo da perda por relaxação da armadura pode ser feito com a expressão:

$\psi_{\left(\mathrm{t}, \mathrm{t}_{0}\right)}=\frac{\Delta \sigma_{\mathrm{pr}}\left(\mathrm{t}, \mathrm{t}_{\mathrm{o}}\right)}{\sigma_{\mathrm{pi}}}$

$\sigma_{\mathrm{pi}}$ : tensão da armadura ativa no instante da protensão, subtraindo as perdas iniciais

$\sigma_{\mathrm{pi}}=1140-11,40-7,88-45,79=1075 \mathrm{MPa}$

$\Delta \sigma_{\mathrm{pr}}\left(\mathrm{t}, \mathrm{t}_{\mathrm{o}}\right)$ : perda de tensão por relaxação pura (com comprimento constante) desde o instante $t_{o}$ aplicação da protensão até o instante $t$ considerado

Assim, para o exemplo em questão, determinou-se a seguinte relação:

$r=\frac{\sigma_{\mathrm{pi}}}{\mathrm{f}_{\mathrm{ptk}}}=\frac{1075}{1900}=0,566$

Então, consultando a Tabela 1, tem-se a situação indicada e o valor desejado é k. 


\begin{tabular}{|c|c|}
\hline $0,5 \mathrm{fptk}$ & 0 \\
\hline $0,566 \mathrm{fptk}$ & $\mathrm{k}$ \\
\hline $0,6 \mathrm{fptk}$ & 1,3 \\
\hline
\end{tabular}

Interpolação linear:

$$
\frac{\mathrm{k}-0}{1,3-0}=\frac{0,566-0,5}{0,60-0,50} \rightarrow \mathrm{k}=\psi_{1000}=0,86 \%
$$

Os valores correspondentes a tempos diferentes de 1.000 horas, sempre a $20^{\circ} \mathrm{C}$, podem ser determinados a partir da expressão:

$\psi_{\left(t, t_{0}\right)}=\psi_{1000} \cdot\left(\frac{t-t_{0}}{41,67}\right)^{0,15} \quad$ para $\left(t, t_{0}\right)$ em dias

Assim, para o décimo dia $(t=10)$, tem-se:

$\psi_{10}=0,86 \cdot\left(\frac{10-1}{41,67}\right)^{0,15}=0,683 \%$

Como $\psi_{\left(\mathrm{t}, \mathrm{t}_{0}\right)}=\frac{\Delta \sigma_{\mathrm{pr}}\left(\mathrm{t}, \mathrm{t}_{\mathrm{o}}\right)}{\sigma_{\mathrm{pi}}}$ tem-se:

$\Delta \sigma_{\mathrm{pr}}=\frac{\psi_{\left(\mathrm{t}, \mathrm{t}_{0}\right)}}{100} \cdot \sigma_{\mathrm{i}} \quad \rightarrow \quad \Delta \sigma_{\mathrm{r}}=\frac{0,683}{100} \cdot 1075 \quad \rightarrow \quad \Delta \sigma_{\mathrm{r}}=7,34 \mathrm{MPa}$

\subsection{PERDA TOTAL EM RELAÇÃO A TENSÃO INICIAL}

Assim, após 10 dias, a tensão na armadura corresponde a:

$\sigma_{p}(t=10)=1075-14,43-53,90-7,34 \rightarrow \sigma_{p}(t=10)=999,33 \mathrm{MPa}$

perdas $=1-\frac{999,33}{1140}=12,34 \%$ (em relação à tensão inicial)

\section{5 perdas em lajes com capa e seção a $2,5 \mathrm{~h}$ do apoio}

Neste exemplo de cálculo das perdas de protensão, também serão considerados os itens: perdas iniciais, perdas diferidas e perda total em relação à tensão inicial.

\subsection{PERDAS INICIAIS}

Do mesmo modo que nos exemplos anteriores, serão consideradas: deformação por ancoragem, relaxação da armadura e deformação imediata do concreto.

\subsubsection{Deformação por ancoragem}

O valor correspondente à perda por ancoragem é igual ao determinado para a mesma laje, sem a presença de capa (item 1.2.1): $\Delta \sigma=11,4 \mathrm{MPa}$. 


\subsubsection{Relaxação da armadura}

O valor correspondente à perda por relaxação da armadura é igual ao determinado para a mesma laje sem a presença de capa (item 4.1.2): $\Delta \sigma_{r}=7,88 \mathrm{MPa}$.

\subsubsection{Deformação imediata do concreto}

A perda por deformação imediata do concreto pode ser obtida a partir da expressão: $\Delta \sigma_{\mathrm{pd}}=\varepsilon_{7} \cdot \mathrm{E}_{\mathrm{p}}$

\section{Determinação da deformação específica $\varepsilon_{\bar{Z}}$}

$\varepsilon_{7}=\varepsilon_{\text {concreto }}=\frac{\sigma_{\mathrm{cg}, \text { cabos }}}{\mathrm{E}_{\mathrm{c}}}$

$\varepsilon_{7}$ : deformação específica da armadura de protensão devida à descompressão

$e_{p}$ : excentricidade da força de protensão

$\mathrm{e}_{\mathrm{p}}=\left(\frac{\mathrm{h}}{2}-\mathrm{d}^{\prime}\right)=\left(\frac{0,2}{2}-0,035\right)=0,065 \mathrm{~m}$

$\mathrm{E}_{\mathrm{c}}$ : módulo de elasticidade do concreto

$\mathrm{E}_{\mathrm{c}}=5600 \cdot \sqrt{\mathrm{f}_{\mathrm{cj}}}=5600 \cdot \sqrt{30}=30672 \mathrm{MPa}$

$\mathrm{N}_{\mathrm{p}}$ : força de protensão

$\mathrm{N}_{\mathrm{p}}=5 .(114-1,14-0,788)=560,36 \mathrm{kN}$

$\sigma_{\mathrm{cg}, \mathrm{cabos}}$ : tensão no concreto no nível do baricentro da armadura de protensão, devida à carga permanente modificada pela protensão ou simultaneamente aplicada com a protensão, que pode ser determinada, considerando a seção a 2,5 h do apoio, através da expressão:

$\sigma_{\mathrm{cg}, \text { cabos }}=\frac{N_{p}}{A}+\frac{N_{p} \cdot e_{p}^{2}}{I}-\frac{M_{g 1} \cdot e_{p}}{I}=\frac{560,36}{0,137795}+\frac{560,36 \cdot 0,065^{2}}{6,712 \cdot 10^{-4}}-\frac{2,55 \cdot 0,065}{6,712 \cdot 10^{-4}}=7346,97 \frac{\mathrm{kN}}{\mathrm{m}^{2}}$

A, I: área e momento de inércia da seção transversal considerada

$M_{\text {g1: }}$ momento do peso próprio para a peça na sua retirada da pista, considerando a seção a 2,5 h do apoio, que pode ser determinado com base na Figura 4.

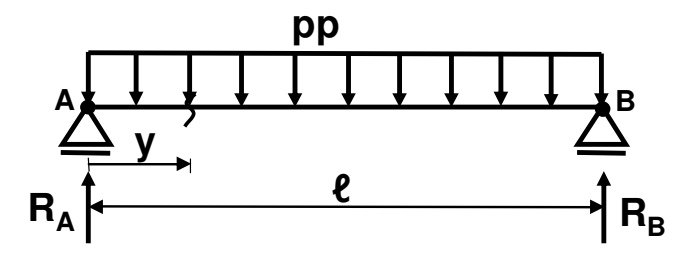

Figura 4 - Esquema para determinação de $M_{91}$ na seção a 2,5 h do apoio. 
pp : peso próprio da laje $\rightarrow \mathrm{pp}=\mathrm{A}_{\mathrm{c}} \cdot \gamma_{\mathrm{c}}=0,137795.25=3,44 \frac{\mathrm{kN}}{\mathrm{m}}$

y: distância da seção considerada ao apoio $\rightarrow y=2,5 \cdot h=2,5 \cdot 0,25=0,625 \mathrm{~m}$

$\mathrm{R}_{\mathrm{A}}$ : reação de apoio no ponto $A$

$\mathrm{R}_{\mathrm{A}}=\mathrm{R}_{\mathrm{B}}=\mathrm{pp} \cdot \frac{\ell}{2}=3,44 \cdot \frac{3}{2}=5,16 \mathrm{kN}$

$M_{g 1}=\left(R_{A} \cdot y\right)-\left(p p \cdot y \cdot \frac{y}{2}\right)=(5,16 \cdot 0,625)-\left(3,44 \cdot 0,625 \cdot \frac{0,625}{2}\right)=2,55 \mathrm{kN} \cdot \mathrm{m}$

Assim, tem-se:

$\varepsilon_{7}=\varepsilon_{\text {concreto }}=\frac{\sigma_{\mathrm{cg}, \text { cabos }}}{\mathrm{E}_{\mathrm{c}}}=\frac{7346,97}{30672000}=2,395 \cdot 10^{-4}$

Logo:

$\Delta \sigma_{\mathrm{pd}}=\varepsilon_{7} \cdot \mathrm{E}_{\mathrm{p}}=2,395 \cdot 10^{-4} \cdot 1,9 \cdot 10^{5}=45,505 \mathrm{MPa}$

$\Delta \sigma_{\mathrm{pd}}=45,505 \mathrm{MPa}$

Assim, logo após a retirada da pista a armadura de protensão está submetida a:

$\sigma_{p}(t=1)=1140-11,40-7,88-45,505$

$\sigma_{\mathrm{p}}(\mathrm{t}=1)=1075 \mathrm{MPa}$

\subsection{PERDAS DIFERIDAS}

Analogamente ao que foi feito nos exemplos anteriores, no cálculo das perdas diferidas serão consideradas: retração do concreto, fluência do concreto e relaxação da armadura.

\subsubsection{Retração do concreto}

Da mesma forma que já foi calculada anteriormente para a seção do meio do vão da laje com capa (item 2.2.1), a perda por retração corresponde a $\Delta \sigma_{p s}\left(t, t_{0}\right)=7,38 \mathrm{MPa}$.

\subsubsection{Fluência do concreto}

Assim como para a retração, no cálculo da perda por fluência deve ser considerado que a partir de certo momento a laje passa a apresentar capa. Dessa forma, a determinação da fluência para este caso pode ser realizada a partir da expressão:

$\Delta \sigma_{p, s}\left(t, t_{0}\right)=\alpha_{p} \cdot\left[\left(\frac{N_{p}}{A}+\frac{N_{p} \cdot e_{p}^{2}}{I}-\frac{M_{g 1} \cdot e_{p}}{I}\right) \cdot \varphi\left(t, t_{0}\right)_{\text {simples }}-\left(\frac{M_{g 2} \cdot e_{p}}{I}\right) \cdot \varphi\left(t, t_{0}\right)_{\text {composta }}\right]$

$\alpha_{p}$ : relação entre o módulo de elasticidade do aço protendido e o do concreto $\left(\frac{E_{p}}{E_{c}}\right)$ 
$E_{p}=190 \frac{\mathrm{kN}}{\mathrm{mm}^{2}}$ e $E_{c}=5600 \cdot \sqrt{\mathrm{f}_{\mathrm{ck}}}=5600 \cdot \sqrt{40}=35417 \mathrm{MPa}$

A, I: área e momento de inércia da seção transversal da peça inicial, ou seja, sem a presença de capa de concreto

$A=0,137795 \mathrm{~m}^{2}$ e $\mathrm{I}=6,712 \cdot 10^{-4} \mathrm{~m}^{4}$

$\mathrm{N}_{\mathrm{p}}$ : força total de protensão, retirando as perdas iniciais

Como são cinco cabos $\left(A_{p}=5 \mathrm{~cm} 2\right)$, tem-se:

$\mathrm{N}_{\mathrm{p}}=5 .(114-1,14-0,788-4,5505)=537,607 \mathrm{kN}$

$e_{\mathrm{p}}$ : excentricidade da força de protensão

$e_{p}=\left(\frac{0,2}{2}-0,035\right)=0,065 \mathrm{~m}$

$M_{g 1}$ momento de peso próprio para a peça na sua retirada da pista, a uma distância de $2,5 \mathrm{~h}$ do apoio

Como calculado anteriormente, para deformação imediata do concreto (item 5.1.3): $M_{g 1}=2,55 \mathrm{kN} \cdot \mathrm{m}$

$\mathrm{M}_{\mathrm{g} 2 \text { : }}$ momento devido ao peso próprio da capa, considerando a seção a uma distância de $2,5 \mathrm{~h}$ do apoio

O cálculo de $M_{\mathrm{g} 2:}$ pode ser feito de acordo com a Figura 3.

$\mathrm{pp}:$ peso próprio da capa $\rightarrow \mathrm{pp}=\mathrm{A}_{\text {capa }} \cdot \gamma_{\mathrm{c}}=(0,05 \cdot 1,25) \cdot 25=1,5625 \frac{\mathrm{kN}}{\mathrm{m}}$

y: distância da seção considerada ao apoio $\rightarrow y=2,5 \cdot h=2,5 \cdot 0,25=0,625 \mathrm{~m}$

$\mathrm{R}_{\mathrm{A}}$ : reação de apoio no ponto $A$

$\mathrm{R}_{\mathrm{A}}=\mathrm{pp} \cdot \frac{\ell}{2}=1,5625 \cdot \frac{3}{2}=2,34375 \mathrm{kN}$

$M_{g 2}=\left(R_{A} \cdot y\right)-\left(p p \cdot y \cdot \frac{y}{2}\right)=(2,34375 \cdot 0,625)-\left(1,5625 \cdot 0,625 \cdot \frac{0,625}{2}\right)=1,1597 \mathrm{kN} \cdot \mathrm{m}$

$\varphi\left(t, t_{0}\right)_{\text {simples }}$ : coeficiente da fluência para seção simples, ou seja, sem capa

Como já calculado anteriormente, considerando a seção do meio do vão e a laje sem capa (item 1.3.2), tem-se o coeficiente da fluência para a seção simples:

$\varphi\left(t, t_{0}\right)_{\text {simples }}=1,42$

Dessa forma, é possível determinar a fluência da seguinte maneira: 


$$
\begin{aligned}
& \Delta \sigma_{p, s}\left(t, t_{0}\right)=\alpha_{p} \cdot\left[\left(\frac{N_{p}}{A}+\frac{N_{p} \cdot e_{p}^{2}}{I}-\frac{M_{g 1} \cdot e_{p}}{I}\right) \cdot \varphi\left(t, t_{0}\right)_{\text {simples }}-\left(\frac{M_{g 2} \cdot e_{p}}{I}\right) \cdot \varphi\left(t, t_{0}\right)_{\text {simples }}\right] \\
& \Delta \sigma_{p, s}\left(t, t_{0}\right)=\frac{190000}{35417} \cdot\left[\left(\frac{537,607}{0,137795}+\frac{537,607 \cdot 0,065^{2}}{6,712 \cdot 10^{-4}}-\frac{2,55 \cdot 0,065}{6,712 \cdot 10^{-4}}\right) \cdot 1,42-\left(\frac{1,1597 \cdot 0,065}{6,712 \cdot 10^{-4}}\right) \cdot 1,42\right] \\
& \Delta \sigma_{p, s}\left(t, t_{0}\right)=52800,27 \frac{\mathrm{kN}}{\mathrm{m}^{2}} \\
& \Delta \sigma_{p, s}\left(t, t_{0}\right)=52,80 \mathrm{MPa}
\end{aligned}
$$

\subsubsection{Relaxação da armadura}

Como já determinada anteriormente para laje sem capa, considerando a seção a 2,5 h do apoio (item 4.2.3), a perda devida à relaxação da armadura corresponde a $\Delta \sigma_{\mathrm{r}}=7,34 \mathrm{MPa}$.

\subsection{PERDA TOTAL EM RELAÇÃO A TENSÃO INICIAL}

Assim, após 10 dias, a tensão na armadura corresponde a:

$\sigma_{p}(t=10)=1075-7,38-52,80-7,34$

$\sigma_{\mathrm{p}}(\mathrm{t}=10)=1007,48 \mathrm{MPa}$

perdas $=1-\frac{1007,48}{1140}=11,62 \%$ (em relação à tensão inicial )

\section{Dois alvéolos preenchidos e seção a 2,5 h do apoio}

Neste exemplo de cálculo das perdas de protensão também serão considerados os itens: perdas iniciais, perdas diferidas e perda total em relação à tensão inicial.

\subsection{PERDAS INICIAIS}

Analogamente ao que foi feito nos exemplos anteriores, serão consideradas: deformação por ancoragem, relaxação da armadura e deformação imediata do concreto.

\subsubsection{Deformação por ancoragem}

O cálculo é idêntico ao da laje sem de capa (item 1.2.1), resultando: $\Delta \sigma=11,4 \mathrm{MPa}$.

\subsubsection{Relaxação da armadura}

Como já determinada anteriormente, para laje com alvéolos parcialmente preenchidos e considerando seção do meio do vão (item 3.1.2), a perda inicial por relaxação da armadura corresponde a $\Delta \sigma_{\mathrm{r}}=7,88 \mathrm{MPa}$. 


\subsubsection{Deformação imediata do concreto}

A perda por deformação imediata do concreto pode ser obtida a partir da expressão: $\Delta \sigma_{p d}=\varepsilon_{7} \cdot E_{p}$.

A deformação específica da armadura de protensão devida à descompressão $\left(\varepsilon_{7}\right)$ pode ser determinada da seguinte forma:

$\varepsilon_{7}=\varepsilon_{\text {concreto }}=\frac{\sigma_{\mathrm{cg}, \text { cabos }}}{\mathrm{E}_{\mathrm{c}}}$

$\mathrm{E}_{\mathrm{c}}$ : módulo de elasticidade do concreto $\rightarrow \mathrm{E}_{\mathrm{c}}=5600 \cdot \sqrt{\mathrm{f}_{\mathrm{cj}}}=5600 \cdot \sqrt{30}=30672 \mathrm{MPa}$

$\sigma_{\text {cg,cabos }}$ : tensão no concreto no nível do baricentro da armadura de protensão, devida à carga permanente modificada pela protensão ou simultaneamente aplicada com a protensão, que pode ser determinada através da expressão:

$\sigma_{c g, \text { cabos }}=\frac{N_{p}}{A}+\frac{N_{p} \cdot e_{p}^{2}}{I}-\frac{M_{g 1} \cdot e_{p}}{I}=\frac{560,36}{0,173138}+\frac{560,36 \cdot 0,065^{2}}{7,20901 \cdot 10^{-4}}-\frac{2,462 \cdot 0,065}{7,20901 \cdot 10^{-4}}=6317,61 \frac{\mathrm{kN}}{\mathrm{m}^{2}}$

A, I: área e momento de inércia da seção transversal considerada, que, nesse caso, corresponde à seção situada a 2,5 h do apoio

Neste caso é considerada a seção com dois alvéolos preenchidos. Assim, tem-se: $A=0,173138 \mathrm{~m}^{2}$ e $I=0,000720901 \mathrm{~m}^{4}$.

$e_{p}$ : excentricidade da força de protensão

$\mathrm{e}_{\mathrm{p}}=\left(\frac{\mathrm{h}}{2}-\mathrm{d}^{\prime}\right)=\left(\frac{0,2}{2}-0,035\right)=0,065 \mathrm{~m}$

$\mathrm{N}_{\mathrm{p}}$ : força total de protensão considerando as perdas iniciais

$\mathrm{N}_{\mathrm{p}}=5 .(114-1,14-0,788)=560,36 \mathrm{kN}$

$M_{g 1}$ : momento devido ao peso próprio para a peça na sua retirada da pista, considerando a seção distante 2,5 h do apoio

\section{Determinação de $\mathbf{M}_{\mathrm{g} 1}$}

Para determinar $M_{g 1}$ na seção distante 2,5 h do apoio, é preciso considerar que existe um preenchimento parcial de dois alvéolos, próximo às extremidades, sendo o peso próprio da laje diferente para as regiões de extremidade e para a região central, como pode ser observado na Figura 5. 


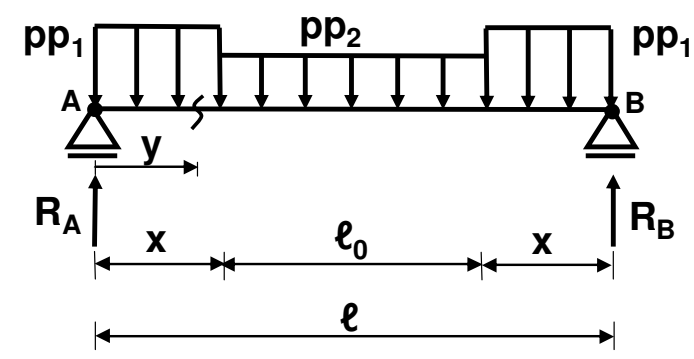

Figura 5 - Esquema para determinação do $M_{g 1}$ na seção distante 2,5 h do apoio.

$x$ : comprimento da região com dois alvéolos preenchidos, sendo $x=0,95 m$

$\ell_{0}$ : comprimento da região sem alvéolos preenchidos, sendo $\ell_{0}=1,1 \mathrm{~m}$

$\ell$ : comprimento do vão da laje, sendo $\ell=3 \mathrm{~m}$

y: distância, em relação ao apoio, da seção em que se pretende determinar o momento devido ao peso próprio $M_{g 1}$, sendo neste caso $y=2,5 \cdot h=0,5 \mathrm{~m}$

$\mathrm{pp}_{1}$ : peso próprio da laje, referente à região com alvéolos preenchidos

$\mathrm{pp}_{1}=\mathrm{A}_{\mathrm{c}, 1} \cdot \gamma_{\mathrm{c}}=0,173138.25=4,328 \frac{\mathrm{kN}}{\mathrm{m}}$

$A_{c, 1}$ : área de concreto referente à seção com alvéolos preenchidos, próxima à extremidade da peça, sendo $A_{c, 1}=0,173138 \mathrm{~m}^{2}$

$\mathrm{pp}_{2}$ : peso próprio da laje, referente à região sem alvéolos preenchidos

$\mathrm{pp}_{2}=\mathrm{A}_{\mathrm{c}, 2} \cdot \gamma_{\mathrm{c}}=0,137795.25=3,445 \frac{\mathrm{kN}}{\mathrm{m}}$

$A_{c, 2}$ : área de concreto referente à seção sem alvéolos preenchidos, na região central da laje, sendo $A_{c, 2}=0,137795 \mathrm{~m}^{2}$

$R_{A}$ : reação de apoio no ponto $A$

$\mathrm{R}_{\mathrm{A}}=\frac{\mathrm{pp}_{1} \cdot \mathrm{x} \cdot\left(\ell-\frac{\mathrm{x}}{2}\right)+\mathrm{pp}_{2} \cdot \ell_{0} \cdot\left(\ell-\mathrm{x}-\frac{\ell_{0}}{2}\right)+\mathrm{pp}_{1} \cdot \frac{\mathrm{x}^{2}}{2}}{\ell}$

$\mathrm{R}_{\mathrm{A}}=\frac{4,328 \cdot 0,95 \cdot\left(3,0-\frac{0,95}{2}\right)+3,445 \cdot 1,1 \cdot\left(3,0-0,95-\frac{1,1}{2}\right)+4,328 \cdot \frac{0,95^{2}}{2}}{3,0}$

$\mathrm{R}_{\mathrm{A}}=6,006 \mathrm{kN}$

Dessa forma, é possível determinar o momento devido ao peso próprio na seção distante 2,5 h do apoio, da seguinte forma:

$\mathrm{M}_{\mathrm{g} 1}=\mathrm{R}_{\mathrm{A}} \cdot \mathrm{y}-\mathrm{pp_{1 }} \cdot \mathrm{y} \cdot \frac{\mathrm{y}}{2}$ 
$M_{g 1}=6,006 \cdot 0,5-4,328 \cdot 0,5 \cdot \frac{0,5}{2}$

$M_{g 1}=2,462 \mathrm{kN} \cdot \mathrm{m}$

Assim, pode-se determinar o valor da deformação $\varepsilon_{7}$

$\varepsilon_{7}=\varepsilon_{\text {concreto }}=\frac{\sigma_{\text {cg,cabos }}}{E_{c}}=\frac{6317,61}{30672000}=2,06 \cdot 10^{-4}$

Logo, tem-se:

$\Delta \sigma_{\mathrm{pd}}=\varepsilon_{7} \cdot \mathrm{E}_{\mathrm{p}}=2,06 \cdot 10^{-4} \cdot 1,9 \cdot 10^{5} \rightarrow \Delta \sigma_{\mathrm{pd}}=39,14 \mathrm{MPa}$

Logo após a retirada da pista, a armadura de protensão está submetida a:

$\sigma_{p}(t=1)=1140-11,40-7,88-39,14$

$\sigma_{p}(\mathrm{t}=1)=1081,58 \mathrm{MPa}$

\subsection{PERDAS DIFERIDAS}

Como nos exemplos anteriores, no cálculo das perdas diferidas serão consideradas: retração do concreto, fluência do concreto e relaxação da armadura.

\subsubsection{Retração do concreto}

A expressão da perda devida à retração do concreto é dada por:

$\Delta \sigma_{\mathrm{p}, \mathrm{s}}\left(\mathrm{t}, \mathrm{t}_{0}\right)=\varepsilon_{\mathrm{cs}}\left(\mathrm{t}, \mathrm{t}_{0}\right) \cdot \mathrm{E}_{\mathrm{p}}$

\section{Determinação de $\varepsilon_{c \underline{s}}\left(t, t_{0}\right)$}

O valor de $\varepsilon_{\mathrm{cs}}\left(\mathrm{t}, \mathrm{t}_{0}\right)$ pode ser obtido a partir da equação:

$\varepsilon_{c s}\left(t, t_{0}\right)=\varepsilon_{c s \infty} \cdot\left[\beta_{s}(t)-\beta_{s}\left(t_{0}\right)\right]$

\section{$>$ Determinação de $\varepsilon_{\mathrm{cs} \infty}$}

$\varepsilon_{\mathrm{cs} \infty}:$ valor final da retração

$\varepsilon_{\mathrm{cs} \infty}=\varepsilon_{1 \mathrm{~s}} \cdot \varepsilon_{2 \mathrm{~s}} \rightarrow \varepsilon_{\mathrm{cs} \infty}=2,5 \cdot 10^{-4} \cdot 1,0327=2,582 \cdot 10^{-4}$

$\varepsilon_{1 \mathrm{~s}}$ : coeficiente dependente da umidade relativa do ambiente e da consistência do concreto (Tabela A1 da NBR 6118:2003)

$\varepsilon_{1 \mathrm{~s}}=2,5 \cdot 10^{-4} \rightarrow$ Para $70 \%$ de umidade e abatimento menor que $4 \mathrm{~cm}$

$\varepsilon_{2 s}$ : coeficiente dependente da espessura fictícia da peça

$\varepsilon_{2 s}=\frac{33+2 h_{\text {fic }}}{20,8+3 h_{\text {fic }}}=\frac{33+2 \cdot 10,49}{20,8+3 \cdot 10,49}=1,0327$

$\mathrm{h}_{\text {fic }}$ : espessura fictícia em centímetros 
$\mathrm{h}_{\mathrm{fic}}=\gamma \frac{2 \mathrm{~A}_{\mathrm{c}}}{\mathrm{u}_{\mathrm{ar}}}=1,45 \cdot \frac{2 \cdot 1731,38}{478,49}=10,49 \mathrm{~cm}$

$\gamma$ : coeficiente dependente da umidade relativa do ambiente U\% (Tabela A1 da NBR 6118:2003)

$\gamma=1+\exp (-7,8+0,1 . U)=1+\exp (-7,8+0,1.70)=1,45$

$A_{c}$ : área da seção transversal da peça, considerando a seção a 2,5 h do apoio

$A_{c}=0,173138 \mathrm{~m}^{2}$

$\mathrm{u}_{\mathrm{ar}}$ : parte do perímetro externo da seção transversal da peça em contato com o ar

A seção considerada (a 2,5 h do apoio) possui dois alvéolos preenchidos. A superfície em contato com o ar ao longo da superfície desses alvéolos também deve ser considerada no cálculo do perímetro, da seguinte forma:

$u_{a r}=2 \cdot(b+h)+4 .(\pi \cdot \phi)$

$u_{a r}=2 \cdot(1,25+0,2)+4 \cdot(3,1415926 \cdot 0,15)$

$\mathrm{u}_{\mathrm{ar}}=4,7849 \mathrm{~m}=478,49 \mathrm{~cm}$

\section{$>$ Determinação de $\beta_{s}(t)$ e $\beta_{s}\left(t_{0}\right)$}

$\beta_{\mathrm{s}}(\mathrm{t})$ ou $\beta_{\mathrm{s}}\left(\mathrm{t}_{\mathrm{o}}\right)$ : coeficientes relativos à retração, no instante $\mathrm{t}$ ou to (Figura $\mathrm{A} .3 \mathrm{da}$ NBR 6118:2003)

De acordo com a NBR 6118:2003 o coeficiente relativo à retração $\left(\beta_{\mathrm{s}}(\mathrm{t})\right.$ ou $\left.\beta_{\mathrm{s}}\left(\mathrm{t}_{\mathrm{o}}\right)\right)$ pode ser determinado através da expressão:

$\beta_{s}(t)=\frac{\left(\frac{t}{100}\right)^{3}+A \cdot\left(\frac{t}{100}\right)^{2}+B \cdot\left(\frac{t}{100}\right)}{\left(\frac{t}{100}\right)^{3}+C \cdot\left(\frac{t}{100}\right)^{2}+D \cdot\left(\frac{t}{100}\right)+E}$

t: idade fictícia do concreto no instante considerado, em dias, equivalente a

$\mathrm{t}=\alpha \sum_{\mathrm{i}} \frac{\mathrm{T}_{\mathrm{i}}+10}{30} \cdot \Delta \mathrm{t}_{\mathrm{ef}, \mathrm{i}} \rightarrow \mathrm{t}=1 \cdot \frac{50+10}{30} \cdot 1=2$ dias

$t_{0}$ : idade fictícia do concreto ao ser feito o carregamento, em dias, equivalente a:

$\mathrm{t}=1 . \frac{50+10}{30} \cdot 10=20$ dias

Considerando $\mathrm{h}=\mathrm{h}_{\text {fic }}=0,1049 \mathrm{~m}$, tem-se:

$$
\begin{aligned}
& A=40 \\
& B=116 \cdot h^{3}-282 \cdot h^{2}+220 \cdot h-4,8 \rightarrow B=15,31 \\
& C=2,5 \cdot h^{3}-8,8 \cdot h+40,7 \rightarrow C=39,78
\end{aligned}
$$


$D=-75 \cdot h^{3}+585 \cdot h^{2}+496 \cdot h-6,8 \rightarrow D=51,48$

$E=-169 \cdot h^{4}+88 \cdot h^{3}+584 \cdot h^{2}-39 \cdot h+0,8 \rightarrow E=3,22$

Para $\mathrm{t}_{0}=2$ dias e $\mathrm{t}=20$ dias, tem-se:

$\beta_{s}\left(t_{0}=2\right)=\frac{\left(\frac{2}{100}\right)^{3}+40 \cdot\left(\frac{2}{100}\right)^{2}+15,31 \cdot\left(\frac{2}{100}\right)}{\left(\frac{2}{100}\right)^{3}+39,78 \cdot\left(\frac{2}{100}\right)^{2}+51,48 \cdot\left(\frac{2}{100}\right)+3,22}=0,0755$

$\beta_{s}(t=20)=\frac{\left(\frac{20}{100}\right)^{3}+40 \cdot\left(\frac{20}{100}\right)^{2}+15,31 \cdot\left(\frac{20}{100}\right)}{\left(\frac{20}{100}\right)^{3}+39,78 \cdot\left(\frac{20}{100}\right)^{2}+51,48 \cdot\left(\frac{20}{100}\right)+3,22}=0,309$

Assim:

$\varepsilon_{\mathrm{cS}}\left(t, t_{0}\right)=\varepsilon_{\mathrm{cs} \infty} \cdot\left[\beta_{\mathrm{s}}(t)-\beta_{\mathrm{s}}\left(\mathrm{t}_{0}\right)\right]=2,582 \cdot 10^{-4} \cdot[0,309-0,0755]=6,029 \cdot 10^{-5}$

Logo:

$\Delta \sigma_{\mathrm{ps}}\left(\mathrm{t}, \mathrm{t}_{0}\right)=\varepsilon_{\mathrm{cs}}\left(\mathrm{t}, \mathrm{t}_{0}\right) \cdot \mathrm{E}_{\mathrm{p}} \rightarrow \Delta \sigma_{\mathrm{ps}}\left(\mathrm{t}, \mathrm{t}_{0}\right)=6,029 \cdot 10^{-5} \cdot 190000$

$\Delta \sigma_{\mathrm{ps}}\left(\mathrm{t}, \mathrm{t}_{0}\right)=11,45 \mathrm{MPa}$

\subsubsection{Fluência do concreto}

A perda por fluência pode ser obtida pela expressão:

$\Delta \sigma_{p, s}\left(t, t_{0}\right)=\sigma_{c g p} \cdot \varphi\left(t, t_{0}\right) \cdot \alpha_{p}$

$\sigma_{\mathrm{cg}, \text { cabos }}$ : tensão no concreto no nível do centro de gravidade da armadura de protensão e devido à ação das cargas permanentes, inclusive a protensão

$\sigma_{\text {cg, cabos }}=\frac{N_{p}}{A}+\frac{N_{p} \cdot e_{p}^{2}}{I}-\frac{M_{g 1} \cdot e_{p}}{I}=\frac{540,79}{0,173138}+\frac{540,79 \cdot 0,065^{2}}{7,20901 \cdot 10^{-4}}-\frac{2,462 \cdot 0,065}{7,20901 \cdot 10^{-4}}=6070,896 \frac{\mathrm{kN}}{\mathrm{m}^{2}}$

$M_{g 1:}$ momento de peso próprio $M_{g 1}=2,462 \mathrm{kN} \cdot \mathrm{m}$

A, I: área e momento de inércia da seção transversal a $2,5 \mathrm{~h}$ do apoio

$A_{c}=0,173138 \mathrm{~m}^{2}, I=7,20901 \cdot 10^{-4} \mathrm{~m}^{4}$

$N_{p}$ : força total de protensão, retirando as perdas iniciais

Como $A_{p}=5 \mathrm{~cm}^{2}$, tem-se:

$\mathrm{N}_{\mathrm{p}}=5 .(114-1,14-0,788-3,914)=540,79 \mathrm{kN}$ ；

$e_{p}$ : excentricidade da armadura protendida $e_{p}=0,065 \mathrm{~m}$

$\alpha_{p}$ : relação entre os módulos $\left(\frac{E_{p}}{E_{c}}\right) \cdot E_{p}=190 \frac{\mathrm{kN}}{\mathrm{mm}^{2}}$ e $E_{c}=35417 \mathrm{MPa}$ 


\section{Determinação de $\varphi\left(t, t_{0}\right)$}

$\varphi\left(t, t_{0}\right)=\varphi_{a}+\varphi_{f_{\infty}}\left[\beta_{f}(t)-\left[\beta_{f}\left(t_{0}\right)\right]\right]+\varphi_{d \infty} \cdot \beta_{d}$

t: idade fictícia do concreto no instante considerado, em dias, equivalente a $\mathrm{t}=\alpha \sum_{\mathrm{i}} \frac{\mathrm{T}_{\mathrm{i}}+10}{30} \cdot \Delta \mathrm{t}_{\mathrm{ef}, \mathrm{i}} \rightarrow \mathrm{t}=3 \cdot \frac{50+10}{30} \cdot 10=60$ dias

$\alpha=3$ (para cimento ARI) - coeficiente dependente da velocidade de endurecimento do cimento

$\mathrm{T}_{\mathrm{i}}=20^{\circ} \mathrm{C}$ (temperatura) - temperatura média diária do ambiente

$\Delta t_{e f, i}:$ período, em dias, durante o qual a temperatura média diária do ambiente, $T_{i}$, pode ser admitida constante

$t_{0}$ : idade fictícia do concreto ao ser feito o carregamento, em dias, equivalente a $\mathrm{t}=3 . \frac{50+10}{30} \cdot 1=6$ dias

$\varphi_{\mathrm{a}}: \quad$ coeficiente de fluência rápida, equivalente a $\varphi_{\mathrm{a}}=0,8 .\left[1-\frac{\mathrm{f}_{\mathrm{c}}\left(\mathrm{t}_{0}\right)}{\mathrm{f}_{\mathrm{c}}(\mathrm{t})}\right]$

$\phi_{a}=0,8 \cdot\left[1-\frac{f_{c}\left(t_{0}\right)}{f_{c}(t)}\right]=0,8 \cdot\left[1-\frac{0,79}{1,06}\right]=0,204$

$\frac{f_{c}\left(t_{o}\right)}{f_{c}(t)}$ : função de crescimento da resistência do concreto com a idade

$\beta_{1}\left(\mathrm{t}_{\mathrm{o}}\right)=\exp \left\{\mathrm{s} \cdot\left[1-\left(\frac{28}{\mathrm{t}_{0}}\right)^{1 / 2}\right]\right\}=\exp \left\{0,2 \cdot\left[1-\left(\frac{28}{6}\right)^{1 / 2}\right]\right\}=0,79$

$\beta_{1}(\mathrm{t})=\exp \left\{\mathrm{s} \cdot\left[1-\left(\frac{28}{\mathrm{t}}\right)^{1 / 2}\right]\right\}=\exp \left\{0,2 \cdot\left[1-\left(\frac{28}{60}\right)^{1 / 2}\right]\right\}=1,06$

s: coeficiente que depende do tipo de cimento usado no concreto, $s=0,2$

$\varphi_{f_{\infty}}$ : valor final do coeficiente de deformação lenta irreversível

$\varphi_{f_{\infty}}=\varphi_{1 \mathrm{c}} \cdot \varphi_{2 \mathrm{c}} \rightarrow \varphi_{f_{\infty}}=1,5 \cdot 1,7215=2,582$

$\varphi_{1 \mathrm{c}}$ : coeficiente dependente da umidade relativa do ambiente $U \%$ e da consistência do concreto dado pela Tabela A1 da NBR 6118:2003, neste caso considerando $\mathrm{U}=70 \%, \varphi_{1 \mathrm{c}}=1,5$

$\varphi_{2 c}$ : coeficiente dependente da espessura fictícia $h_{\text {fic }}$ (em centímetro) da peça

$\varphi_{2 \mathrm{c}}=\frac{42+\mathrm{h}_{\text {fic }}}{20+\mathrm{h}_{\mathrm{fic}}} \rightarrow \varphi_{2 \mathrm{c}}=\frac{42+10,49}{20+10,49}=1,7215$

$\mathrm{h}_{\text {fic }}$ : espessura fictícia em centímetros, obtida como no cálculo da perda por retração do concreto, $h_{\text {fic }}=10,49 \mathrm{~cm}$ 
$\beta_{f}(t)$ ou $\beta_{f}\left(t_{0}\right)$ : coeficiente relativo à deformação lenta irreversível, função da idade do concreto (definida no item A.2.2.3 da NBR 6118:2003)

$\beta_{f}(t)=\frac{t^{2}+A \cdot t+B}{t^{2}+C . t+D}$

Considerando $\mathrm{h}=\mathrm{h}_{\mathrm{fic}}=0,1049 \mathrm{~m}$, tem-se:

$A=42 \cdot h^{3}-350 \cdot h^{2}+588 \cdot h+113 \rightarrow A=170,88$

$B=768 \cdot h^{3}-3060 \cdot h^{2}+3234 \cdot h-23 \rightarrow B=283,46$

$C=-200 \cdot h^{3}+13 \cdot h^{2}+1090 \cdot h+183 \rightarrow C=297,25$

$D=7579 . h^{3}-31916 . h^{2}+35343 . h+1931 \rightarrow D=5296,02$

Assim:

$\beta_{f}\left(t_{0 \text { fic }}\right)=\frac{6^{2}+170,88.6+283,46}{6^{2}+297,25 \cdot 6+5296,02}=0,189$

$\beta_{f}\left(t_{f \text { fic }}\right)=\frac{60^{2}+170,88.60+283,46}{60^{2}+297,25.60+5296,02}=0,529$

$\varphi_{d \infty \infty}$ : valor final do coeficiente de deformação lenta reversível, igual a 0,4

$\beta_{d}$ : coeficiente relativo à deformação lenta reversível, função do tempo $\left(t-t_{0}\right)$

$\beta_{d}=\frac{t-t_{o}+20}{t-t_{o}+70} \rightarrow \beta_{d}=\frac{60-6+20}{60-6+70}=0,60$

Resulta:

$\varphi\left(t, t_{0}\right)=\varphi_{a}+\varphi_{f_{\infty}}\left[\beta_{f}(t)-\beta_{f}\left(t_{0}\right)\right]+\varphi_{d \infty} \cdot \beta_{d}=0,204+2,582 \cdot(0,529-0,189)+0,4 \cdot 0,6=1,32$

Logo:

$\Delta \sigma_{p, s}\left(t, t_{0}\right)=\sigma_{c g p} \cdot \varphi\left(t, t_{0}\right) \cdot \alpha_{p}=6,070896 \cdot 1,32 \cdot \frac{190000}{35417}$

$\Delta \sigma_{\mathrm{p}, \mathrm{s}}\left(\mathrm{t}, \mathrm{t}_{0}\right)=43,00 \mathrm{MPa}$

\subsubsection{Relaxação da armadura}

O cálculo da perda por relaxação da armadura pode ser feito através da expressão:

$\psi_{\left(\mathrm{t}, \mathrm{t}_{0}\right)}=\frac{\Delta \sigma_{\mathrm{pr}}\left(\mathrm{t}, \mathrm{t}_{\mathrm{o}}\right)}{\sigma_{\mathrm{pi}}}$

$\sigma_{\mathrm{pi}}:$ tensão da armadura ativa instante de protensão

Considerando a tensão na armadura subtraindo as perdas iniciais, tem-se:

$\sigma_{\mathrm{pi}}=1140-11,40-7,88-39,14=1081,58 \mathrm{MPa}$

$\Delta \sigma_{\mathrm{pr}}\left(\mathrm{t}, \mathrm{t}_{\mathrm{o}}\right)$ : perda de tensão por relaxação pura (com comprimento constante) desde o instante $t_{o}$ da aplicação da protensão até o instante $t$ considerado 
Assim, para o exemplo em questão, determinou-se a seguinte relação:

$r=\frac{\sigma_{\mathrm{pi}}}{\mathrm{f}_{\mathrm{ptk}}}=\frac{1081,58}{1900}=0,569$

Então, consultando a Tabela 1, tem-se a situação indicada e o valor desejado é k.

\begin{tabular}{|c|c|}
\hline $0,5 \mathrm{fptk}$ & 0 \\
\hline $0,569 \mathrm{fptk}$ & $\mathrm{k}$ \\
\hline $0,6 \mathrm{fptk}$ & 1,3 \\
\hline
\end{tabular}

Interpolando-se:

$$
\frac{\mathrm{k}-0}{1,3-0}=\frac{0,569-0,5}{0,60-0,50} \rightarrow \mathrm{k}=\psi_{1000}=0,897 \%
$$

Os valores correspondentes a tempos diferentes de 1.000 horas, sempre a $20^{\circ} \mathrm{C}$, podem ser determinados a partir da expressão:

$\psi_{\left(t, t_{0}\right)}=\psi_{1000} \cdot\left(\frac{t-t_{0}}{41,67}\right)^{0,15} \quad$ para $\left(t, t_{0}\right)$ em dias

Assim, para $\mathrm{t}=10$ dias, tem-se:

$\psi_{10}=0,897 \cdot\left(\frac{10-1}{41,67}\right)^{0,15}=0,7128 \%$

Como $\psi_{\left(\mathrm{t}, \mathrm{t}_{0}\right)}=\frac{\Delta \sigma_{\mathrm{pr}}\left(\mathrm{t}, \mathrm{t}_{\mathrm{o}}\right)}{\sigma_{\mathrm{pi}}}$, tem-se:

$\Delta \sigma_{\mathrm{pr}}=\frac{\psi_{\left(\mathrm{t}, \mathrm{t}_{0}\right)}}{100} \cdot \sigma_{\mathrm{i}} \quad \rightarrow \quad \Delta \sigma_{\mathrm{r}}=\frac{0,7128}{100} \cdot 1081,58$

$\Delta \sigma_{\mathrm{r}}=7,71 \mathrm{MPa}$

\subsection{PERDA TOTAL EM RELAÇÃO A TENSÃO INICIAL}

Assim, após 10 dias, a tensão na armadura corresponde a:

$\sigma_{p}(t=10)=1081,58-11,45-43,00-7,71$

$\sigma_{p}(t=10)=1019,42 \mathrm{MPa}$

perdas $=1-\frac{1019,42}{1140}=10,58 \%$ (em relação à tensão inicial) 


\section{APÊNDICE B}

\section{FLEXÃO EM LAJES PROTENDIDAS}

Serão apresentados exemplos numéricos para a análise da flexão, considerando os diferentes tipos de lajes ensaiadas: sem e com capa estrutural, sem preenchimento de alvéolos e com alguns parcialmente preenchidos. Além disso, há exemplos considerando a seção do meio do vão e outros que levam em conta a seção a $2,5 \mathrm{~h}$ do apoio. As características do tipo de laje a ser dimensionada se encontra no Apêndice A, item 1.1.1.

\section{Lajes sem capa e seção do meio do vão}

Este exemplo numérico considera flexão em lajes sem capa e seção do meio do vão. Será determinado o momento de fissuração e o momento resistente da seção transversal.

\subsection{MOMENTO DE FISSURAÇÃO}

A tensão na borda tracionada é dada por:

$\sigma_{\mathrm{i}}=\frac{\mathrm{N}}{\mathrm{A}}+\frac{\mathrm{M}_{\mathrm{p}} \cdot \mathrm{y}_{\mathrm{t}}}{\mathrm{I}}-\frac{\mathrm{M}_{\mathrm{r}} \cdot \mathrm{y}_{\mathrm{t}}}{\mathrm{I}}$

Igualando ao valor da tensão de tração que provoca a primeira fissura, tem-se:

$-\alpha \cdot f_{\mathrm{ctm}}=\frac{\mathrm{N}}{\mathrm{A}}+\frac{\mathrm{M}_{\mathrm{p}} \cdot \mathrm{y}_{\mathrm{t}}}{\mathrm{I}}-\frac{\mathrm{M}_{\mathrm{r}} \cdot \mathrm{y}_{\mathrm{t}}}{\mathrm{I}}$

Então, isolando o valor do momento de fissuração $\left(M_{r}\right)$ e considerando a homogeneização da seção, chega-se a:

$M_{r}=\left(\alpha \cdot f_{c t m}+\frac{N_{p}}{A_{\text {hom }}}\right) \cdot \frac{I_{\text {hom }}}{y_{t, \text { hom }}}+N_{p} \cdot e_{p}$

$N_{p}$ : Força normal de protensão na seção considerada

$N_{p}=\sigma_{p} \cdot A_{p}=(1001,54 \cdot 1000) \cdot(0,0005)=500,77 \mathrm{kN}\left(\sigma_{p}\right.$ calculado no apêndice $\left.A\right)$

$e_{p}$ : excentricidade da armadura protendida. $e_{p}=h / 2-d^{\prime}=0,1-0,035=0,065 m$

$\alpha$ : 1,2 para seções em forma de "T" ou duplo "T" e 1,5 para seções retangulares (NBR 6118:2003 - item 17.3.1)

Neste caso: $\alpha: 1,5$.

$\mathrm{f}_{\mathrm{ctm}}$ : resistência média do concreto à tração

$\mathrm{f}_{\mathrm{ctm}}=0,3 \cdot \mathrm{f}_{\mathrm{ck}} \frac{2}{3} \quad \rightarrow \quad \mathrm{f}_{\mathrm{ctm}}=0,3 \cdot(40)^{\frac{2}{3}}=3,508 \mathrm{MPa}=3508 \frac{\mathrm{kN}}{\mathrm{m}^{2}}$ 
$Y_{\text {hom }}$ : distância do centro de gravidade à fibra superior da seção homogeneizada

$y_{\text {hom }}=\frac{A \cdot y_{c g}+A_{p} \cdot\left(\alpha_{p}-1\right) \cdot d}{A_{\text {hom }}}$

$y_{\text {hom }}=\frac{0,137795 \cdot 0,1+0,0005 \cdot(6,31124-1) \cdot 0,165}{0,1404506}=0,1012$

$\mathrm{y}_{\mathrm{cg}}$ : distância do centro de gravidade à fibra superior da seção

$\mathrm{y}_{\mathrm{cg}}=0,1 \mathrm{~m}$

A : Área de concreto da seção transversal

$A=1377,95 \mathrm{~cm}^{2}=0,137795 \mathrm{~m}^{2}$

$A_{\text {hom }}$ : Área de concreto da seção transversal homogeneizada

$A_{\text {hom }}=A+A_{p} \cdot\left(\alpha_{p}-1\right)=0,137795+0,0005 \cdot(6,31124-1)=0,1404506 m^{2}$

$\alpha_{p}$ : relação entre os módulos de deformação longitudinal do aço $\left(E_{p}=190 \mathrm{GPa}\right)$ e do concreto $\left(E_{\mathrm{cs}}=0,85 \cdot 5600 \cdot \sqrt{40}=30105 \mathrm{MPa}\right)$

$\alpha_{p}=\frac{E_{p}}{E_{c s}}=\frac{190}{\frac{30105}{1000}}=6,31124$

I hom : momento de inércia da seção geométrica homogeneizada

Será empregado o momento de inércia da seção homogeneizada, que deve ser calculado da seguinte maneira:

$I_{\text {hom }}=I+A \cdot\left(y_{c g}-y_{\text {hom }}\right)^{2}+A_{p} \cdot\left(\alpha_{p}-1\right) \cdot\left(d-y_{\text {hom }}\right)^{2}$

I : momento de inércia da seção geométrica $\rightarrow \mathrm{I}=0,00067120 \mathrm{~m}^{4}$

$I_{\text {hom }}=0,00067120+0,137795 \cdot(0,10-0,1012)^{2}+0,0005 \cdot(6,31124-1) \cdot(0,165-0,1012)^{2}$

$\mathrm{I}_{\text {hom }}=0,000682208 \mathrm{~m}^{4}$

$\mathrm{y}_{\mathrm{t}, \text { hom }}$ : distância do centro de gravidade da seção homogeneizada à fibra mais tracionada

$\mathrm{y}_{\mathrm{t}, \mathrm{hom}}=\mathrm{h}-\mathrm{y}_{\mathrm{hom}}=0,2-0,1012=0,099 \mathrm{~m}$

Resulta:

$M_{r}=\left(\alpha . f_{c t m}+\frac{N_{p}}{A_{h o m}}\right) \cdot \frac{I_{\text {hom }}}{y_{t, h o m}}+N_{p} \cdot e_{p}$

$M_{r}=\left(1,5 \cdot 3508+\frac{500,77}{0,1404506}\right) \cdot \frac{0,000682208}{0,099}+500,77 \cdot 0,065$

$M_{r}=93,50 \mathrm{kN} \cdot \mathrm{m}$ 


\subsection{MOMENTO RESISTENTE NA SEÇÃO CENTRAL}

O momento resistente da seção (sem coeficientes de majoração de ações e de minoração da resistência dos materiais) é calculado com base na Figura 1.

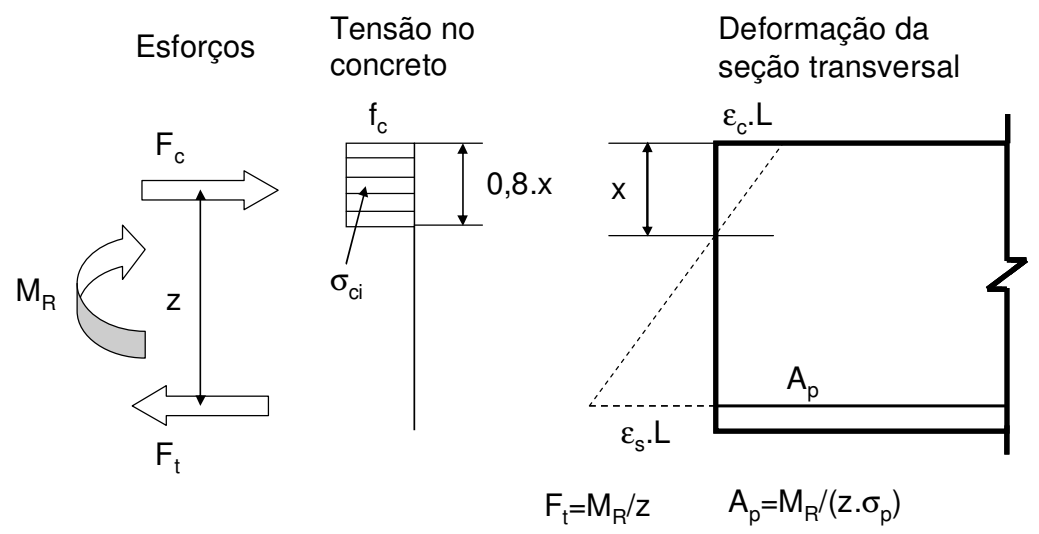

Figura 1 - Esquema para o cálculo do momento resistente da seção transversal

Inicialmente considera-se a peça no domínio 2 de deformação no ELU, sendo posteriormente feita a verificação. Essa verificação é feita variando os valores de deformação ou da posição da linha neutra até que seja garantido o equilíbrio entre as forças na armadura e no concreto, $F_{\mathrm{s}}$ e $F_{\mathrm{c}}$, respectivamente. Assim, para o domínio 2, tem-se: $\varepsilon_{\mathrm{s}}=1 \%$.

O valor do pré-alongamento $\left(\varepsilon_{\mathrm{p}}\right)$ fica definido a partir da tensão na armadura de protensão aos 10 dias (data do ensaio). Assim, a partir da lei de Hooke tem-se:

$\varepsilon_{\mathrm{p}}=\frac{\sigma_{\mathrm{p}}}{\mathrm{E}_{\mathrm{p}}}$

$\sigma_{\mathrm{p}}=1001,54 \mathrm{MPa}$ e $\mathrm{E}_{\mathrm{p}}=190 \mathrm{GPa}$

$\varepsilon_{\mathrm{p}}=\frac{1001,54}{190 \cdot 1000}=0,527 \%$

O valor da deformação correspondente à descompressão $\left(\varepsilon_{7}\right)$, já calculada nas perdas iniciais, é de $\varepsilon_{7}=0,0235 \%$. Assim, tem-se:

$\varepsilon_{\mathrm{t}}=\varepsilon_{\mathrm{p}}+\varepsilon_{7}+\varepsilon_{\mathrm{s}}=0,527+0,0235+1=1,5505 \%=15,505 \%$

Com o valor da deformação total é possível determinar a tensão no aço de protensão através da Tabela 1 (Vasconcelos (1980)). 
Tabela 1: Tensão no aço $\sigma_{\mathrm{pd}}(\mathrm{MPa})$ [Vasconcelos (1980)].

\begin{tabular}{|c|c|c|c|c|c|c|c|c|c|c|}
\hline$\varepsilon(\%$ & 5,25 & 6,794 & 7,438 & 8,167 & 9,000 & 9,962 & 10,00 & 12,50 & 15,00 & 17,5 \\
\hline CP175 & 1025 & 1264 & 1316 & 1344 & 1365 & 1368 & 1368 & 1378 & 1388 & 1397 \\
\hline CP190 & 1025 & 1314 & 1411 & 1459 & 1482 & 1486 & 1486 & 1496 & 1507 & 1517 \\
\hline$\varepsilon(\%$ & 20,00 & 22,50 & 25,00 & 27,5 & 30 , & & 50 & 35,00 & 37,50 & 40,00 \\
\hline CP175 & 1407 & 1416 & 1426 & 1436 & 144 & & & 1464 & 14,74 & 1484 \\
\hline CP190 & 1527 & 1538 & 15,48 & 1559 & 156 & & & 1590 & 1600 & 1611 \\
\hline
\end{tabular}

Determina-se o valor da tensão de projeto $\left(\sigma_{\mathrm{pd}}\right)$ realizando uma interpolação linear dos valores, da seguinte forma:

\begin{tabular}{lccc}
\hline$\varepsilon(\%)$ & 15,00 & 15,505 & 17,5 \\
CP190 & 1507 & $y$ & 1517 \\
\hline
\end{tabular}

$\frac{15,505-15,00}{y-1507}=\frac{17,5-15,00}{1517-1507} \rightarrow y=1509,02 \mathrm{MPa}$

O valor característico da tensão no aço $\left(\sigma_{\mathrm{pk}}\right)$ corresponde a:

$\sigma_{\mathrm{pk}}=\sigma_{\mathrm{pd}} \cdot 1,15=1509,02 \cdot 1,15=1735,37 \mathrm{MPa}=173,537 \frac{\mathrm{kN}}{\mathrm{cm}^{2}}$

Assim, a força resultante na armadura pode ser determinada da seguinte forma:

$F_{p}=A_{p} \sigma_{p}=5.173,537=867,685 \mathrm{kN}$

Igualando as expressões da força de tração e compressão, considerando o diagrama retangular simplificado, determina-se o valor da linha neutra $x$ dada por:

$x=\frac{F_{p}}{0,8 \cdot b_{\text {laje }} \cdot f_{c j}}=\frac{867,685}{0,8 \cdot 1,25 \cdot 40 \cdot 1000}=0,0217 \mathrm{~m}$

Através da determinação da posição da linha neutra (x), faz-se uma verificação se a peça realmente se encontra no domínio 2 , como considerado anteriormente.

No final do domínio 2, a posição da linha neutra corresponde a:

$x_{2}=0,259 \cdot d=0,259 \cdot 0,165=0,0427 m$

Dessa forma, como $x=0,0217<x_{2}=0,0427$, a peça encontra-se, de fato, no domínio 2 .

Momento resistente: $M_{R}=F_{p} \cdot(d-0,4 \cdot x)=867,685 \cdot(0,165-0,4 \cdot 0,0217)$

$M_{R}=135,64 \mathrm{kN} \cdot \mathrm{m}$ 


\section{Lajes com capa e seção do meio do vão}

Neste exemplo considera-se flexão em lajes com capa e seção do meio do vão. Como no exemplo anterior, será determinado o momento de fissuração e o momento resistente.

\subsection{MOMENTO DE FISSURAÇÃO}

A tensão na borda tracionada é dada por:

$$
\sigma_{i}=\frac{N_{p}}{A_{\text {hom, inicial }}}+\frac{N_{p} \cdot e_{p}}{W_{i, \text { hom, inicial }}}-\frac{M_{r}}{W_{i, \text { hom, final }}}
$$

Igualando-se ao valor da tensão de tração que provoca a primeira fissura, tem-se:

$-\alpha . f_{c t m}=\frac{N_{p}}{A_{\text {hom, inicial }}}+\frac{N_{p} \cdot e_{p}}{W_{i, \text { hom, inicial }}}-\frac{M_{r}}{W_{i, \text { hom, final }}}$

Isolando-se o valor do momento de fissuração $\left(M_{r}\right)$, chega-se a:

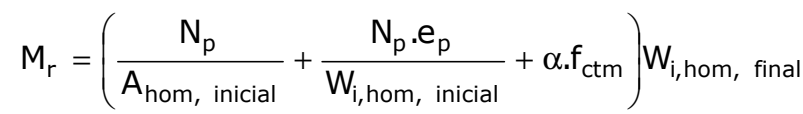

$\mathrm{N}_{\mathrm{p}}$ : força normal de protensão na seção considerada, descontadas todas as perdas calculadas anteriormente

$N_{p}=\sigma_{p} \cdot A_{p}=(1009,89 \cdot 1000) \cdot(0,0005)=504,945 \mathrm{kN} \quad\left(\sigma_{p}\right.$ calculado no apêndice $\left.A\right)$

$\mathrm{e}_{\mathrm{p}}$ : excentricidade da armadura protendida

$e_{p}=h / 2-d^{\prime}=0,1-0,035=0,065 m$

$\alpha$ : 1,2 para seções em forma de "T" ou duplo "T" e 1,5 para seções retangulares $($ NBR 6118:2003 - item 17.3.1) $\rightarrow \alpha=1,5$

$\mathrm{f}_{\mathrm{ctm}}$ : resistência à tração média do concreto $-\mathrm{f}_{\mathrm{ctm}}=0,3 \cdot \mathrm{f}_{\mathrm{ck}} \frac{2}{3}$

$f_{\mathrm{ctm}}=0,3 \cdot(40)^{\frac{2}{3}}=3,508 \mathrm{MPa}=3508 \frac{\mathrm{kN}}{\mathrm{m}^{2}}$

\section{Módulo de resistência à flexão da seção inicial homogeneizada}

$$
\begin{aligned}
& \mathrm{W}_{\mathrm{i}, \text { hom, inicial }}=\frac{\mathrm{I}_{\text {hom, inicial }}}{\mathrm{y}_{\mathrm{t}, \text { hom, inicial }}} \\
& \mathrm{W}_{\mathrm{i}, \text { hom, inicial }} \text { : módulo de resistência à flexão em relação à borda tracionada da laje } \\
& \text { (inferior), considerando a seção inicial homogeneizada, no caso, sem capa }
\end{aligned}
$$


I hom, inicial : momento de inércia da seção geométrica homogeneizada, considerando a seção inicial, ou seja, sem capa

Assim, é realizada a homogeneização do concreto com o aço:

$$
\begin{aligned}
& I_{\text {hom, inicial }}=I+A \cdot\left(y_{c g}-y_{\text {hom, inicial }}\right)^{2}+A_{p} \cdot\left(\alpha_{p}-1\right) \cdot\left(d-y_{\text {hom, inicial }}\right)^{2} \\
& I_{\text {hom, inicial }}=0,00067120+0,137795 \cdot(0,10-0,1012)^{2}+0,0005 \cdot(6,31124-1) \cdot(0,165-0,1012)^{2} \\
& I_{\text {hom, inicial }}=0,000682208 \mathrm{~m}^{4}
\end{aligned}
$$

A, I: área e momento de inércia da seção transversal da peça inicial, ou seja, sem a capa $A=0,137795 \mathrm{~m}^{2}$ e $I=6,712 \cdot 10^{-4} \mathrm{~m}^{4}$

$\mathrm{y}_{\mathrm{t}, \mathrm{hom} \text {, inicial }}$ : distância do centro de gravidade à fibra mais tracionada, considerando a seção homogeneizada inicial (sem capa)

$\mathrm{y}_{\mathrm{t}, \text { hom, inicial }}=\mathrm{h}_{\text {inicial }}-\mathrm{y}_{\text {hom, inicial }}=0,2-0,1012=0,099 \mathrm{~m}$

$Y_{\text {hom, inicial }}$ distância do centro de gravidade à fibra superior, considerando a seção homogeneizada inicial (sem capa)

$y_{\text {hom, inicial }}=\frac{A \cdot y_{c g}+A_{p} \cdot\left(\alpha_{p}-1\right) \cdot d}{A_{\text {hom, inicial }}}$

$\mathrm{y}_{\text {hom, inicial }}=\frac{0,137795 \cdot 0,1+0,0005 \cdot(6,31124-1) \cdot 0,165}{0,1404506}=0,1012 \mathrm{~m}$

$y_{c g}$ : distância do centro de gravidade à fibra superior da seção. $y_{c g}=0,1 \mathrm{~m}$

$A_{p}$ : armadura total na laje. $A_{p}=5 \mathrm{~cm}^{2}$

$\alpha_{p}$ : relação entre os módulos de deformação longitudinal do aço ( $E_{p}=190 \mathrm{GPa}$ ) e do concreto $\left(E_{c s}=0,85 \cdot 5600 \cdot \sqrt{40}=30105 \mathrm{MPa}\right) \quad \rightarrow \alpha_{p}=\frac{E_{p}}{E_{c}}=\frac{190}{\frac{30105}{1000}}=6,31124$

$A_{\text {hom, inicial }}$ área de concreto da seção transversal inicial, considerando homogeneização do concreto com o aço de protensão

$A_{\text {hom, inicial }}=A+A_{p} \cdot\left(\alpha_{p}-1\right)=0,137795+0,0005 \cdot(6,31124-1)=0,1404506 m^{2}$

Dessa forma, tem-se:

$W_{i, \text { hom, inicial }}=\frac{I_{\text {hom, inicial }}}{Y_{t, \text { hom, inicial }}}=\frac{0,000682208}{0,099}=0,0068910 \mathrm{~m}^{3}$ 


\section{Módulo de resistência à flexão da seção final homogeneizada}

$W_{i, \text { hom, final }}=\frac{I_{\text {hom, final }}}{y_{t, \text { hom, final }}}$

$\mathrm{W}_{\mathrm{i}, \text { hom, final }}$ : módulo de resistência à flexão na borda mais tracionada da laje (inferior), considerando a seção final homogeneizada, no caso, seção composta, com capa $I_{\text {hom, final }}$ : momento de inércia homogeneizado da seção final, com capa de concreto

Pode ser determinado com a equação, cujo cálculo das parcelas é detalhado em seguida:

$I_{\text {hom, final }}=I_{\text {capa }}+A_{c a p a}\left(Y_{\text {hom, final }}-Y_{c g, \text { capa }}\right)^{2}+I_{L A}+A_{L A} \cdot\left(Y_{\text {hom, final }}-Y_{c g, L A}\right)^{2}+A_{p} \cdot\left(\alpha_{p}-1\right) \cdot\left(y_{\text {hom, final }}-d_{\text {final }}\right)^{2}$

$I_{\text {hom, final }}=1,18229 \cdot 10^{-5}+0,0567 \cdot(0,1174-0,025)^{2}+6,712 \cdot 10^{-4}+0,137795 \cdot(0,1174-0,15)^{2}+$

$0,0005 \cdot(6,31124-1) \cdot(0,1174-0,215)^{2}$

$\mathrm{I}_{\text {hom, final }}=1,339.10^{-3} \mathrm{~m}^{4}$

$I_{\text {capa }}$ : momento de inércia da capa

$I_{\text {capa }}=\frac{b_{\text {capa }} \cdot h_{\text {capa }}{ }^{3}}{12}=\frac{1,135 \cdot 0,05^{3}}{12}=1,18229 \cdot 10^{-5} \mathrm{~m}^{4}$

$\mathrm{I}_{\mathrm{LA}}$ : momento de inércia da laje sem a presença da capa. $\mathrm{I}_{\mathrm{LA}}=6,712 \cdot 10^{-4} \mathrm{~m}^{4}$

$A_{L A}$ : área da laje sem a presença da capa. $A_{L A}=0,137795 \mathrm{~m}^{2}$

$\mathrm{Y}_{\mathrm{cg}, \mathrm{LA}}$ : distância do centro de gravidade da laje à fibra superior da seção composta

$\mathrm{Y}_{\mathrm{cg}, \mathrm{LA}}=0,1+0,05=0,15 \mathrm{~m}$

$\mathrm{d}_{\text {final }}$ : altura útil da seção final, ou seja, da laje com a presença de capa

$d_{\text {final }}=0,25-0,035=215 m$

$\mathrm{Y}_{\mathrm{cg} \text {, capa }}$ : distância do centro de gravidade da capa à fibra superior da seção

$\mathrm{y}_{\text {cg, capa }}=\frac{\mathrm{h}_{\text {capa }}}{2}=\frac{0,05}{2}=0,025 \mathrm{~m}$

$A_{\text {capa }}$ : Área da capa colocada sobre a unidade alveolar

$A_{\text {capa }}=b_{\text {capa }} \cdot h_{\text {capa }} \rightarrow A_{\text {capa }}=1,135 \cdot 0,05=0,0567 \mathrm{~m}^{2}$

$\mathrm{h}_{\text {capa }}$ : altura da capa de concreto colocada sobre a laje. $\mathrm{h}_{\text {capa }}=5 \mathrm{~cm}$

$\mathrm{b}_{\text {capa }}$ : largura da capa colocada sobre a laje, considerando a homogeneização entre os dois diferentes tipos de concreto, da laje e da capa

$\mathrm{b}_{\text {capa }}=\mathrm{b} \cdot \frac{\mathrm{f}_{\mathrm{cj}, \text { capa }}}{\mathrm{f}_{\mathrm{cj} \text {, laje }}}=1,25 \cdot \frac{\sqrt{33}}{\sqrt{40}}=1,135 \mathrm{~m}$

b: largura da laje. $b=1,25 \mathrm{~m}$

$\mathrm{f}_{\mathrm{cj} \text {, capa }}$ : resistência do concreto da capa à compressão, na data do ensaio 
$\mathrm{f}_{\mathrm{cj}, \text { capa }}=33 \mathrm{MPa}$

$\mathrm{f}_{\mathrm{cj} \text {, laje }}$ : resistência à compressão do concreto da laje na data do ensaio

$\mathrm{f}_{\mathrm{cj} \text {, laje }}=40 \mathrm{MPa}$

$Y_{\text {hom, final }}$ : distância do centro de gravidade à fibra superior, considerando a seção homogeneizada final (seção composta, com a presença de capa)

$y_{\text {hom, final }}=\frac{A_{\text {capa }} \cdot y_{c g, \text { capa }}+A_{L A} \cdot y_{c g, L A}+A_{p} \cdot\left(\alpha_{p}-1\right) \cdot d_{\text {final }}}{A_{\text {hom, final }}}$

$\mathrm{y}_{\text {hom, final }}=\frac{0,0567 \cdot 0,025+0,137795 \cdot(0,1+0,05)+0,0005 \cdot(6,31124-1) \cdot 0,215}{0,1971506}$

$\mathrm{Y}_{\text {hom, final }}=0,1149 \mathrm{~m}$

$A_{\text {hom, final }}$ : área de concreto da seção transversal final homogeneizada, considerando homogeneização de concreto com o aço de protensão

$A_{\text {hom, final }}=\left(A_{L A}+A_{\text {capa }}\right)+A_{p} \cdot\left(\alpha_{p}-1\right)$

$A_{\text {hom, final }}=(0,137795+0,0567)+0,0005 \cdot(6,31124-1)=0,1971506 \mathrm{~m}^{2}$

$\mathrm{y}_{\mathrm{t}, \mathrm{hom} \text {, final }}$ : distância do centro de gravidade à fibra mais tracionada, considerando a seção homogeneizada final (seção composta, com a presença de capa)

$y_{t, \text { hom, final }}=h_{\text {final }}-y_{\text {hom, final }}=0,25-0,1149=0,1351 m$

Dessa forma, tem-se:

$W_{i, \text { hom, final }}=\frac{I_{\text {hom, final }}}{y_{t, \text { hom, final }}}=\frac{0,001339}{0,1351}=0,0099112 \mathrm{~m}^{3}$

\section{Momento de fissuração}

$$
\begin{aligned}
& M_{r}=\left(\frac{N_{p}}{A_{\text {hom, inicial }}}+\frac{N_{p} \cdot e_{p}}{W_{i, \text { hom, inicial }}}+\alpha \cdot f_{c t m}\right) \cdot W_{i, \text { hom, final }} \\
& M_{r}=\left(\frac{504,945}{0,1404506}+\frac{504,945 \cdot 0,065}{0,0068910}+1,5 \cdot 3508\right) \cdot 0,0099112 \\
& M_{r}=134,99 \mathrm{kN} \cdot \mathrm{m}
\end{aligned}
$$

\subsection{MOMENTO RESISTENTE NA SEÇÃO CENTRAL}

O momento resistente é determinado de maneira semelhante à do exemplo anterior, considerando a seção sem a presença de capa, com apenas algumas alterações.

Considerando a peça no domínio 2, tem-se: $\varepsilon_{\mathrm{s}}=1 \%$. 
O valor do pré-alongamento $\left(\varepsilon_{\mathrm{p}}\right)$ fica definido a partir da tensão na armadura de protensão aos 10 dias (data do ensaio). Assim, com base na lei de Hooke tem-se:

$\varepsilon_{\mathrm{p}}=\frac{\sigma_{\mathrm{p}}}{\mathrm{E}_{\mathrm{p}}} \quad \mathrm{E}_{\mathrm{p}}=190 \mathrm{GPa}$

$\sigma_{\mathrm{p}}=1009,89 \mathrm{MPa}$

Assim:

$\varepsilon_{\mathrm{p}}=\frac{1009,89}{190.1000}=0,5315 \%$

O valor da deformação correspondente à descompressão $\left(\varepsilon_{7}\right)$, já calculada nas perdas iniciais, é de $\varepsilon_{7}=0,0235 \%$. Assim, tem-se:

$\varepsilon_{\mathrm{t}}=\varepsilon_{\mathrm{p}}+\varepsilon_{7}+\varepsilon_{\mathrm{s}}=0,5315+0,0235+1=1,555 \%=15,550 \%$ o

Com o valor da deformação total é possível determinar a tensão no aço de protensão através da Tabela 1, ilustrada anteriormente (item 1.2).

Determina-se o valor da tensão de projeto $\left(\sigma_{\mathrm{pd}}\right)$ com uma interpolação linear dos valores:

\begin{tabular}{llrr}
\hline $\boldsymbol{\varepsilon}(\%)$ & 15,00 & 15,55 & 17,5 \\
CP190 & 1507 & $y$ & 1517 \\
\hline
\end{tabular}

$\frac{15,55-15,00}{y-1507}=\frac{17,5-15,00}{1517-1507} \rightarrow y=1509,20 \mathrm{MPa}$

Valor característico da tensão no aço:

$\sigma_{\mathrm{pk}}=\sigma_{\mathrm{pd}} \cdot 1,15=1509,20.1,15=1735,58 \mathrm{MPa}=173,558 \frac{\mathrm{kN}}{\mathrm{cm}^{2}}$

Assim, a força na armadura pode ser determinada da seguinte forma:

$F_{p}=A_{p} \sigma_{p}=5.173,558=867,79 \mathrm{kN}$

Igualando as expressões da força de tração e compressão, considerando o diagrama retangular simplificado e admitindo que a linha neutra esteja na capa (até $5 \mathrm{~cm}$ da borda superior), determina-se o valor da linha neutra:

$\mathrm{x}=\frac{\mathrm{F}_{\mathrm{p}}}{0,8 \cdot \mathrm{b}_{\text {laje }} \cdot \mathrm{f}_{\mathrm{cj} \text {, capa }}}=\frac{867,79}{0,8 \cdot 1,25 \cdot 33 \cdot 1000}=0,02630 \mathrm{~m}$

Obtida a posição da linha neutra ( $x$ ), faz-se a verificação se a peça realmente se encontra no domínio 2, como considerado anteriormente.

No final do domínio 2 , a posição da linha neutra: $x_{2}=0,259 \cdot d=0,259 \cdot 0,215=0,055685 \mathrm{~m}$ 
Dessa forma, como $\mathrm{x}=0,02630<\mathrm{x}_{2}=0,055685$, a peça se encontra no domínio 2 .

Assim, obtém-se o momento resistente:

$M_{R}=F_{p} \cdot(d-0,4 \cdot x)=867,79 \cdot((0,25-0,035)-0,4 \cdot 0,02630) \rightarrow M_{R}=177,44 k N \cdot m$

\section{Lajes com dois alvéolos preenchidos e seção central}

Para flexão em lajes com dois alvéolos preenchidos, serão calculados o momento de fissuração e o momento resistente na seção central.

\subsection{MOMENTO DE FISSURAÇÃO NA SEÇÃO CENTRAL}

Como foi apresentado anteriormente, o momento de fissuração $\left(M_{r}\right)$ pode ser determinado da seguinte forma:

$M_{r}=\left(\alpha \cdot f_{c t m}+\frac{N_{p}}{A_{h o m}}\right) \cdot \frac{I_{\text {hom }}}{y_{t, h o m}}+N_{p} \cdot e_{p}$

$\mathrm{N}_{\mathrm{p}}$ : força normal de protensão na seção considerada, no caso, no meio do vão da laje

$N_{p}=\sigma_{p} \cdot A_{p}=(1004,93 \cdot 1000) \cdot(0,0005)=502,46 \mathrm{kN} \quad\left(\sigma_{p}\right.$ calculado apêndice $\left.A\right)$

$e_{p}$ : excentricidade da armadura protendida $\rightarrow \quad e_{p}=h / 2-d^{\prime}=0,1-0,035=0,065 m$

$\alpha: \quad 1,5$ para seções retangulares (NBR 6118:2003 - item 17.3.1). $\alpha=1,5$

$f_{c t m}$ : resistência média do concreto à tração. $f_{c t m}=0,3 \cdot f_{c k} \frac{2}{3}$

$\mathrm{f}_{\mathrm{ctm}}=0,3 \cdot(40)^{\frac{2}{3}}=3,508 \mathrm{MPa}=3508 \frac{\mathrm{kN}}{\mathrm{m}^{2}}$

$\mathrm{Y}_{\text {hom }}$ : distância do centro de gravidade à fibra superior da seção homogeneizada

$y_{\text {hom }}=\frac{A \cdot y_{c g}+A_{p} \cdot\left(\alpha_{p}-1\right) \cdot d}{A_{\text {hom }}}$

$\mathrm{y}_{\text {hom }}=\frac{0,137795 \cdot 0,1+0,0005 \cdot(6,31124-1) \cdot 0,165}{0,1404506}=0,1012$

$y_{c g}$ : distância do centro de gravidade à fibra superior da seção. $y_{c g}=0,1 m$

A : área de concreto da seção transversal $\rightarrow A=1377,95 \mathrm{~cm}^{2}=0,137795 \mathrm{~m}^{2}$

$A_{\text {hom }}$ : área de concreto da seção transversal homogeneizada

$A_{\text {hom }}=A+A_{p} \cdot\left(\alpha_{p}-1\right)=0,137795+0,0005 \cdot(6,31124-1)=0,1404506 m^{2}$

$\alpha_{p}$ : relação entre os módulos de deformação longitudinal do aço e do concreto 
$\alpha_{p}=\frac{E_{p}}{E_{c}}=\frac{190}{\frac{30105}{1000}}=6,31124$

I hom : momento de inércia da seção geométrica homogeneizada

$I_{\text {hom }}=I+A \cdot\left(y_{c g}-y_{h o m}\right)^{2}+A_{p} \cdot\left(\alpha_{p}-1\right) \cdot\left(d-y_{h o m}\right)^{2}$

$I_{\text {hom }}=0,00067120+0,137795 \cdot(0,10-0,1012)^{2}+0,0005 \cdot(6,31124-1) \cdot(0,165-0,1012)^{2}$

$\mathrm{I}_{\text {hom }}=0,000682208 \mathrm{~m}^{4}$

I : momento de inércia da seção geométrica $\rightarrow I=0,00067120 \mathrm{~m}^{4}$

$\mathrm{y}_{\mathrm{t}, \mathrm{hom}}$ : distância do centro de gravidade à fibra mais tracionada da seção homogeneizada

$\mathrm{y}_{\mathrm{t}, \mathrm{hom}}=\mathrm{h}-\mathrm{y}_{\mathrm{hom}}=0,2-0,1012=0,099 \mathrm{~m}$

Resulta:

$M_{r}=\left(\alpha_{t} f_{c t m}+\frac{N_{p}}{A_{h o m}}\right) \cdot \frac{I_{\text {hom }}}{y_{t, h o m}}+N_{p} \cdot e_{p}$

$M_{r}=\left(1,5.3508+\frac{502,46}{0,1404506}\right) \cdot \frac{0,000682208}{0,099}+502,46.0,065$

$M_{r}=93,57 \mathrm{kN} \cdot \mathrm{m}$

\subsection{MOMENTO RESISTENTE NO MEIO DO VÃO}

O cálculo do momento resistente (sem coeficientes de majoração das ações e de minoração da resistência dos materiais) é realizado da mesma forma que os casos anteriores.

Considerando a peça no domínio 2 de deformação, tem-se $\varepsilon_{\mathrm{s}}=1 \%$.

O valor do pré-alongamento $\left(\varepsilon_{\mathrm{p}}\right)$ fica definido a partir da tensão na armadura de protensão aos 10 dias (data do ensaio). Assim, com a lei de Hooke tem-se:

$\varepsilon_{\mathrm{p}}=\frac{\sigma_{\mathrm{p}}}{\mathrm{E}_{\mathrm{p}}}$

$\sigma_{\mathrm{p}}=1004,93 \mathrm{MPa} \quad \mathrm{E}_{\mathrm{p}}=190 \mathrm{GPa}$

Resulta: $\quad \varepsilon_{\mathrm{p}}=\frac{1004,93}{190.1000}=0,5289 \%$

O valor da deformação correspondente à descompressão $\left(\varepsilon_{7}\right)$ já calculado nas perdas iniciais é de $\varepsilon_{7}=0,0234 \%$. Assim, tem-se: 
$\varepsilon_{\mathrm{t}}=\varepsilon_{\mathrm{p}}+\varepsilon_{7}+\varepsilon_{\mathrm{s}}=0,5289+0,0234+1=1,5523 \%=15,523 \%$

Com o valor da deformação total é possível determinar a tensão no aço de protensão através da Tabela 1, ilustrada anteriormente (item 1.2).

Determina-se o valor da tensão de projeto $\left(\sigma_{\mathrm{pd}}\right)$ realizando uma interpolação linear dos valores, da seguinte forma:

\begin{tabular}{llcc}
\hline $\boldsymbol{\varepsilon}(\%)$ & $\mathbf{1 5 , 0 0}$ & $\mathbf{1 5 , 5 2 3}$ & $\mathbf{1 7 , 5}$ \\
$\mathrm{CP190}$ & 1507 & $\mathrm{y}$ & 1517 \\
\hline
\end{tabular}

$\frac{15,523-15,00}{y-1507}=\frac{17,5-15,00}{1517-1507} \rightarrow y=1509,09 \mathrm{MPa}$

O valor característico da tensão no aço $\left(\sigma_{\mathrm{pk}}\right)$ corresponde a:

$\sigma_{\mathrm{pk}}=\sigma_{\mathrm{pd}} \cdot 1,15=1509,09 \cdot 1,15=1735,45 \mathrm{MPa}=173,54 \frac{\mathrm{kN}}{\mathrm{cm}^{2}}$

Assim, a força na armadura resulta:

$F_{p}=A_{p} \sigma_{p}=5.173,54=867,70 \mathrm{kN}$

Igualando as expressões da força de tração e de compressão, considerando o diagrama retangular simplificado, determina-se a posição da linha neutra:

$x=\frac{F_{p}}{0,8 \cdot b_{\text {laje }} \cdot f_{c j}}=\frac{867,70}{0,8 \cdot 1,25 \cdot 40 \cdot 1000}=0,0217 \mathrm{~m}$

Com este valor, faz-se uma verificação se a peça realmente se encontra no domínio 2 , como considerado anteriormente.

No final do domínio 2, a posição da linha neutra corresponde a:

$x_{2}=0,259 \cdot d=0,259 \cdot 0,165=0,0427 m$

Dessa forma, como $x=0,0217<x_{2}=0,0427$, a peça se encontra no domínio 2 .

Assim, pode-se determinar o momento resistente:

$M_{R}=F_{p} \cdot(d-0,4 \cdot x)=867,70 \cdot(0,165-0,4 \cdot 0,0217)$

$M_{R}=135,64$ kN.m 


\section{Lajes sem capa e seção a 2,5 h do apoio}

De forma semelhante às realizadas nos exemplos anteriores, neste serão calculados o momento de fissuração e o momento resistente na seção a $2,5 \mathrm{~h}$ do apoio.

\subsection{MOMENTO DE FISSURAÇÃO A 2,5 h DO APOIO}

Como neste exemplo considera-se a seção a 2,5 h do apoio, para o cálculo do momento de fissuração, primeiramente é necessário verificar o comprimento de transferência da força de protensão. Esse comprimento é determinado de acordo com as recomendações da NBR 6118:2003.

\section{Comprimento de transferência}

Com o intuito de verificar a distância da extremidade da peça a partir da qual é possível considerar o esforço de protensão atuando em toda a seção transversal, deve-se determinar o comprimento de transferência $\left(\ell_{t}\right)$.

No caso de elementos pré-tracionados, o cálculo do comprimento de transferência $\left(\ell_{t}\right)$ da força de protensão (que pode ser considerada variando linearmente ao longo do comprimento) pode ser realizado pela equação:

$\ell_{\text {bpt }}=\frac{0,625 \cdot \ell_{\text {bp }} \cdot \sigma_{p}}{f_{\text {pyd }}}$

$\ell_{\text {bpt }}$ : comprimento de transferência, dado no item 9.4.5.2 da NBR 6118:2003

$\ell_{\mathrm{bp}}$ : comprimento de ancoragem básico. $\ell_{\mathrm{bp}}=\frac{7 \cdot \phi \cdot \mathrm{f}_{\mathrm{pyd}}}{36 \cdot \mathrm{f}_{\mathrm{bpd}}}$

Substituindo $\ell_{\mathrm{bp}}$ em $\ell_{\mathrm{bpt}}$, tem-se:

$\ell_{\mathrm{bpt}}=\frac{0,625 \cdot \ell_{\mathrm{bp}} \cdot \sigma_{\mathrm{p}}}{\mathrm{f}_{\mathrm{pyd}}}=\frac{0,625 \cdot 7 \cdot \phi \cdot \mathrm{f}_{\mathrm{pyd}} \cdot \sigma_{\mathrm{p}}}{36 \cdot \mathrm{f}_{\mathrm{bpd}} \cdot \mathrm{f}_{\mathrm{pyd}}} \rightarrow \quad \ell_{\mathrm{bpt}}=\frac{0,625 \cdot 7 \cdot \phi \cdot \sigma_{\mathrm{p}}}{36 \cdot \mathrm{f}_{\mathrm{bpd}}}$

$\phi$ : diâmetro da barra. $\phi=0,0127 \mathrm{~m}$

$\sigma_{\mathrm{p}}(\mathrm{t}=10$ dias $)=999,33 \mathrm{MPa}\left(\sigma_{\mathrm{p}}\right.$ calculado no item 4 do apêndice $\left.\mathrm{A}\right)$

$\mathrm{f}_{\mathrm{bpd}}$ : resistência de aderência de cálculo

$f_{b p d}=\eta_{p 1} \cdot \eta_{p 2} \cdot f_{c t d}=1,2 \cdot 1,0 \cdot 2,456=2,9472 \mathrm{MPa}$

$\eta_{\mathrm{p} 1}$ : igual a 1,2 para cordoalhas de três e sete fios

$\eta_{\mathrm{p} 2}$ : igual a 1 para situações de boa aderência

$\mathrm{f}_{\text {ctd }}$ : resistência de cálculo do concreto à tração 
$\mathrm{f}_{\mathrm{ctd}}=\frac{\mathrm{f}_{\mathrm{ctk}, \mathrm{inf}}}{\gamma_{\mathrm{c}}}=2,456 \mathrm{MPa}$

$\mathrm{f}_{\mathrm{ctk}, \text { inf }}$ : resistência característica inferior do concreto à tração

$\mathrm{f}_{\mathrm{ctk}, \mathrm{inf}}=0,21 .\left(\mathrm{f}_{\mathrm{cj}}\right)^{\frac{2}{3}}=0,21 \cdot(40)^{\frac{2}{3}}=2,456 \mathrm{MPa}$

$\gamma_{c}$ : coeficiente de minoração da resistência do concreto, sendo considerado igual a 1,0

Assim, pode-se determinar o comprimento de transferência $\ell_{\mathrm{bpt}}$ :

$\ell_{\mathrm{bpt}}=\frac{0,625 \cdot 7 \cdot \phi \cdot \sigma_{\mathrm{p}}}{36 \cdot \mathrm{f}_{\mathrm{bpd}}}=\frac{0,625 \cdot 7 \cdot 0,0127 \cdot 999,33}{36 \cdot 2,9472}$

$\ell_{\mathrm{bpt}}=0,52 \mathrm{~m}$

A seção considerada está a 2,5 h do apoio, ou seja, a 0,5 m (2,5.0,2), e a 0,55 m da extremidade (considerando $5 \mathrm{~cm}$ entre o eixo do apoio e a extremidade da laje). Dessa forma, de acordo com as recomendações da NBR 6118:2003, na seção considerada a força de protensão se encontra regularizada em toda seção transversal.

O momento de fissuração, considerando a homogeneização da seção, corresponde a:

$M_{r}=\left(\alpha \cdot f_{c t m}+\frac{N_{p}}{A_{h o m}}\right) \cdot \frac{I_{\text {hom }}}{y_{t, h o m}}+N_{p} \cdot e_{p}$

$N_{p}$ : força normal de protensão na seção considerada

$N_{p}=\sigma_{p} \cdot A_{p}=(999,33 \cdot 1000) \cdot(0,0005)=499,67 \mathrm{kN} \quad\left(\sigma_{p}\right.$ calculado apêndice $\left.A\right)$

$e_{p}$ : excentricidade da armadura protendida $\rightarrow \quad e_{p}=h / 2-d^{\prime}=0,1-0,035=0,065 m$

$\alpha: \quad$ 1,5 para seções retangulares (NBR 6118:2003 - item 17.3.1)

$\mathrm{f}_{\mathrm{ctm}}$ : resistência média do concreto à tração $\rightarrow \mathrm{f}_{\mathrm{ctm}}=0,3 \cdot(40)^{\frac{2}{3}}=3508 \frac{\mathrm{kN}}{\mathrm{m}^{2}}$

$\mathrm{Y}_{\text {hom }}$ : distância do centro de gravidade à fibra superior da seção homogeneizada

Como já determinado anteriormente, considerando a laje sem capa e a seção do meio do vão (item 1.1), tem-se: $y_{\text {hom }}=0,1012$

$A_{\text {hom }}$ : área de concreto da seção transversal, considerando homogeneização do concreto com o aço de protensão

Como calculado anteriormente, para laje sem capa e seção do meio do vão (item 1.1):

$A_{\text {hom }}=0,1404506 \mathrm{~m}^{2}$ 
$\mathrm{I}_{\text {hom }}$ : momento de inércia da seção homogeneizada

Como já determinado anteriormente, considerando a laje sem capa e a seção do meio do vão (item 1.1), tem-se: $\mathrm{I}=0,000682208 \mathrm{~m}^{4}$

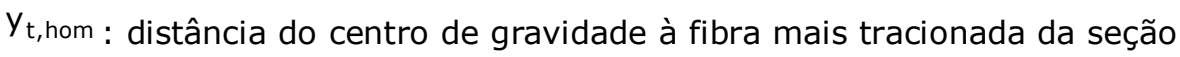
homogeneizada

$\mathrm{y}_{\mathrm{t}, \mathrm{hom}}=\mathrm{h}-\mathrm{y}_{\text {hom }}=0,2-0,1012=0,099 \mathrm{~m}$

Pode-se, então, calcular o momento de fissuração:

$M_{r}=\left(\alpha \cdot f_{c t m}+\frac{N_{p}}{A_{h o m}}\right) \cdot \frac{I_{\text {hom }}}{y_{t, h o m}}+N_{p} \cdot e_{p}$

$M_{r}=\left(1,5.3508+\frac{499,67}{0,1404506}\right) \cdot \frac{0,000682208}{0,099}+499,67 \cdot 0,065$

$M_{r}=93,25 \mathrm{kN} \cdot \mathrm{m}$

\subsection{MOMENTO RESISTENTE A 2,5 h DO APOIO}

Considerando a peça no domínio 2 , tem-se $\varepsilon_{\mathrm{s}}=1 \%$.

O valor do pré-alongamento $\left(\varepsilon_{\mathrm{p}}\right)$ fica definido a partir da tensão na armadura de protensão aos 10 dias (data do ensaio). Assim, a partir da lei de Hooke, tem-se:

$\varepsilon_{\mathrm{p}}=\frac{\sigma_{\mathrm{p}}}{\mathrm{E}_{\mathrm{p}}} \quad \sigma_{\mathrm{p}}=999,33 \mathrm{MPa} \quad \mathrm{E}_{\mathrm{p}}=190 \mathrm{GPa}$

$\varepsilon_{\mathrm{p}}=\frac{999,33}{190.1000}=0,5260 \%$

O valor da deformação correspondente à descompressão $\left(\varepsilon_{7}\right)$ já calculada nas perdas iniciais é de $\varepsilon_{7}=0,0241 \%$. Assim, tem-se:

$\varepsilon_{\mathrm{t}}=\varepsilon_{\mathrm{p}}+\varepsilon_{7}+\varepsilon_{\mathrm{s}}=0,5260+0,0241+1=1,5501 \%=15,50 \%$ o

Com o valor da deformação total é possível determinar a tensão no aço de protensão através da Tabela 1, ilustrada anteriormente (item 1.2).

Determina-se o valor da tensão de projeto $\left(\sigma_{\mathrm{pd}}\right)$ por interpolação linear:

\begin{tabular}{llcc}
\hline$\varepsilon(\% \circ)$ & $\mathbf{1 5 , 0 0}$ & $\mathbf{1 5 , 5 0}$ & $\mathbf{1 7 , 5}$ \\
CP190 & 1507 & $y$ & 1517 \\
\hline
\end{tabular}




$$
\frac{15,50-15,00}{y-1507}=\frac{17,5-15,00}{1517-1507} \rightarrow y=1509,00 \mathrm{MPa}
$$

O valor característico da tensão no aço $\left(\sigma_{\mathrm{pk}}\right)$ corresponde a:

$$
\sigma_{\mathrm{pk}}=\sigma_{\mathrm{pd}} \cdot 1,15=1509 \cdot 1,15=1735,35 \mathrm{MPa}=173,535 \frac{\mathrm{kN}}{\mathrm{cm}^{2}}
$$

Assim, a na armadura pode ser determinada da seguinte forma:

$\mathrm{F}_{\mathrm{p}}=\mathrm{A}_{\mathrm{p}} \sigma_{\mathrm{p}}=5.173,535=867,68 \mathrm{kN}$

Igualando as expressões da força de tração e de compressão, considerando o diagrama retangular simplificado, determina-se a posição da linha neutra:

$x=\frac{F_{p}}{0,8 \cdot b_{\text {laje }} \cdot f_{c j}}=\frac{867,68}{0,8 \cdot 1,25 \cdot 40 \cdot 1000}=0,0217 \mathrm{~m}$

Com este valor de $x$, pode-se verificar se a peça realmente se encontra no domínio 2, como considerado anteriormente. No limite do domínio 2, a posição da linha neutra é:

$x_{2}=0,259 \cdot d=0,259 \cdot 0,165=0,0427 \mathrm{~m}$

Como $\mathrm{x}=0,0217<\mathrm{x}_{2}=0,0427$, de fato a peça se encontra no domínio 2 .

Assim, pode-se determinar o momento resistente:

$M_{R}=F_{p} \cdot(d-0,4 \cdot x)=867,68 \cdot(0,165-0,4 \cdot 0,0217)$

$M_{R}=135,64 \mathrm{kN} \cdot \mathrm{m}$

\section{Lajes com capa e seção a $2,5 \mathrm{~h}$ do apoio}

Como nos exemplos anteriores, serão determinados o momento de fissuração e o momento resistente.

\subsection{MOMENTO DE FISSURAÇÃO A 2,5 h DO APOIO}

Assim como calculado anteriormente, para laje com capa, considerando a seção do meio do vão, pode-se determinar o momento de fissuração através da expressão:

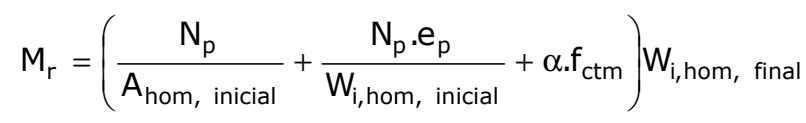

$\mathrm{N}_{\mathrm{p}}$ : força normal de protensão na seção considerada, descontadas todas as perdas

$N_{p}=\sigma_{p} \cdot A_{p}=(1007,48 \cdot 1000) \cdot(0,0005)=503,74 \mathrm{kN}\left(\sigma_{p}\right.$ calculado no apêndice $\left.A\right)$ 
$e_{p}$ : excentricidade da armadura protendida $\rightarrow e_{p}=h / 2-d^{\prime}=0,1-0,035=0,065 m$

$\alpha: \quad$ 1,5 para seções retangulares (NBR 6118:2003 - item 17.3.1)

$\mathrm{f}_{\mathrm{ctm}}$ : resistência média do concreto à tração $\rightarrow \mathrm{f}_{\mathrm{ctm}}=0,3 \cdot(40)^{\frac{2}{3}}=3508 \frac{\mathrm{kN}}{\mathrm{m}^{2}}$

$A_{\text {hom, inicial }}$ área de concreto da seção transversal inicial, considerando homogeneização do concreto com o aço de protensão

De acordo com cálculo anterior, para laje com capa e e seção do meio do vão (item 2.1):

$A_{\text {hom, inicial }}=0,1404506 \mathrm{~m}^{2}$

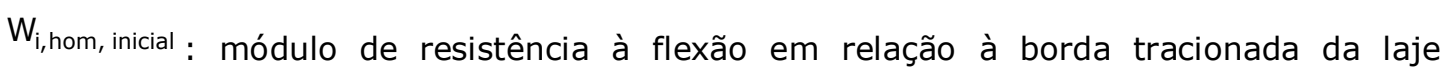
(inferior), considerando a seção inicial homogeneizada, no caso, sem capa

Como já calculado, para laje com capa e e seção do meio do vão (item 2.1), tem-se:

$\mathrm{W}_{\mathrm{i}, \text { hom, inicial }}=0,0068910 \mathrm{~m}^{3}$

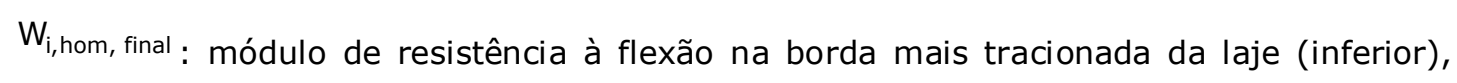
considerando a seção final homogeneizada, no caso, seção composta, com capa.

Conforme cálculo já realizado, para laje com capa e e seção do meio do vão (item 2.1):

$W_{i, \text { hom, final }}=0,0099112 \mathrm{~m}^{3}$

Dessa forma, tem-se:

$M_{r}=\left(\frac{N_{p}}{A_{\text {hom, inicial }}}+\frac{N_{p} \cdot e_{p}}{W_{i, \text { hom, inicial }}}+\alpha \cdot f_{c t m}\right) \cdot W_{i, \text { hom, final }}$

$M_{r}=\left(\frac{503,74}{0,1404506}+\frac{503,74 \cdot 0,065}{0,0068910}+1,5 \cdot 3508\right) \cdot 0,0099112$

$M_{r}=134,79 \mathrm{kN} \cdot \mathrm{m}$

\subsection{MOMENTO RESISTENTE A 2,5 h DO APOIO}

De modo análogo ao que foi feito nos itens anteriores, considerando a peça no domínio 2 , tem-se $\varepsilon_{\mathrm{s}}=1 \%$.

O valor do pré-alongamento $\left(\varepsilon_{\mathrm{p}}\right)$ fica definido a partir da tensão na armadura de protensão aos 10 dias (data do ensaio). Assim, a partir da lei de Hooke tem-se:

$\varepsilon_{\mathrm{p}}=\frac{\sigma_{\mathrm{p}}}{\mathrm{E}_{\mathrm{p}}} \quad \sigma_{\mathrm{p}}=1007,48 \mathrm{MPa} \quad \mathrm{E}_{\mathrm{p}}=190 \mathrm{GPa}$ 
Resulta: $\quad \varepsilon_{\mathrm{p}}=\frac{1007,48}{190.1000}=0,530 \%$

O valor da deformação correspondente à descompressão $\left(\varepsilon_{7}\right)$ já calculada nas perdas iniciais é de $\varepsilon_{7}=0,02395 \%$ (Apêndice $A$ item 5.1.3). Assim, tem-se:

$\varepsilon_{\mathrm{t}}=\varepsilon_{\mathrm{p}}+\varepsilon_{7}+\varepsilon_{\mathrm{s}}=0,530+0,02395+1=1,554 \%=15,54 \% \mathrm{o}$

Com o valor da deformação total é possível determinar a tensão no aço de protensão através da Tabela 1, ilustrada anteriormente (item 1.2).

Determina-se o valor da tensão de projeto $\left(\sigma_{p d}\right)$ realizando uma interpolação linear dos valores, da seguinte forma:

\begin{tabular}{llcc}
\hline $\boldsymbol{\varepsilon}(\% \circ)$ & 15,00 & $\mathbf{1 5 , 5 4}$ & $\mathbf{1 7 , 5}$ \\
CP190 & 1507 & $y$ & 1517 \\
\hline
\end{tabular}

$\frac{15,54-15,00}{y-1507}=\frac{17,5-15,00}{1517-1507} \rightarrow y=1509,16 \mathrm{MPa}$

O valor característico da tensão no aço $\left(\sigma_{\mathrm{pk}}\right)$ corresponde a:

$$
\sigma_{\mathrm{pk}}=\sigma_{\mathrm{pd}} \cdot 1,15=1509,16 \cdot 1,15=1735,53 \mathrm{MPa}=173,55 \frac{\mathrm{kN}}{\mathrm{cm}^{2}}
$$

Assim, a força na armadura pode ser determinada da seguinte forma:

$F_{p}=A_{p} \sigma_{p}=5.173,55=867,75 \mathrm{kN}$

Igualando as expressões da força de tração e de compressão, considerando o diagrama retangular simplificado e admitindo que a linha neutra está na capa (até $5 \mathrm{~cm}$ da borda superior), determina-se a posição da linha neutra $x$ dada por:

$\mathrm{x}=\frac{\mathrm{F}_{\mathrm{p}}}{0,8 \cdot \mathrm{b}_{\text {laje }} \cdot \mathrm{f}_{\mathrm{cj}, \text { capa }}}=\frac{867,75}{0,8 \cdot 1,25 \cdot 33 \cdot 1000}=0,02630 \mathrm{~m}$

Através da determinação da posição da linha neutra ( $\mathrm{x}$ ), faz-se uma verificação se a peça realmente se encontra no domínio 2 , como considerado anteriormente.

No final do domínio 2, a posição da linha neutra corresponde a:

$x_{2}=0,259 \cdot d=0,259 \cdot 0,215=0,05568 m$

Dessa forma, como $x=0,02630<x_{2}=0,05568$, a peça se encontra no domínio 2 .

Assim, o momento resistente resulta: $\quad M_{R}=F_{p} \cdot(d-0,4 \cdot x)=867,75 \cdot(0,215-0,4 \cdot 0,02630)$

$M_{R}=177,44 k N . m$ 


\section{Lajes com dois alvéolos preenchidos e seção a 2,5 h}

Para lajes com dois alvéolos preenchidos e seção a 2,5 h do apoio, de forma semelhante à dos exemplos anteriores, serão calculados o momento de fissuração e o momento resistente.

\subsection{MOMENTO DE FISSURAÇÃO A 2,5 h DO APOIO}

O momento de fissuração $\left(M_{r}\right)$ pode ser determinado da seguinte forma:

$M_{r}=\left(\alpha \cdot f_{c t m}+\frac{N_{p}}{A_{h o m}}\right) \cdot \frac{I_{\text {hom }}}{y_{t, h o m}}+N_{p} \cdot e_{p}$

$N_{p}$ : força normal de protensão na seção considerada, no caso, a 2,5 h do apoio

$N_{p}=\sigma_{p} \cdot A_{p}=(1019,42 \cdot 1000) \cdot(0,0005)=509,71 \mathrm{kN} \quad\left(\sigma_{p}\right.$ calculado no apêndice $\left.A\right)$

$e_{p}:$ excentricidade da armadura protendida $\rightarrow e_{p}=h / 2-d^{\prime}=0,1-0,035=0,065 m$

$\alpha: \quad$ 1,5 para seções retangulares (NBR 6118:2003 - item 17.3.1). $\alpha=1,5$

$\mathrm{f}_{\mathrm{ctm}}$ : resistência à tração média do concreto $\quad \mathrm{f}_{\mathrm{ctm}}=0,3 \cdot(40)^{\frac{2}{3}}=3508 \frac{\mathrm{kN}}{\mathrm{m}^{2}}$

$Y_{\text {hom }}$ : distância do centro de gravidade à fibra superior da seção homogeneizada

$y_{\text {hom }}=\frac{A \cdot y_{c g}+A_{p} \cdot\left(\alpha_{p}-1\right) \cdot d}{A_{\text {hom }}}$

$\mathrm{y}_{\text {hom }}=\frac{0,173138 \cdot 0,1+0,0005 \cdot(6,31124-1) \cdot 0,165}{0,1757936}=0,1010 \mathrm{~m}$

$\mathrm{y}_{\mathrm{cg}}$ : distância do centro de gravidade à fibra superior da seção. $\mathrm{y}_{\mathrm{cg}}=0,1 \mathrm{~m}$

$A_{p}$ : área da armadura de protensão. $A_{p}=5 \mathrm{~cm}^{2}$

$\alpha_{p}$ : relação entre os módulos de deformação longitudinal do aço e do concreto

$\alpha_{p}=\frac{E_{p}}{E_{c}}=\frac{190}{\frac{30105}{1000}}=6,31124$

A : área de concreto da seção a 2,5h do apoio. $A=0,173138 \mathrm{~m}^{2}$

$A_{\text {hom }}$ : área de concreto da seção transversal homogeneizada

$A_{\text {hom }}=A+A_{p} \cdot\left(\alpha_{p}-1\right)=0,173138+0,0005 \cdot(6,31124-1)=0,1757936 m^{2}$

$\mathrm{I}_{\text {hom }}$ : momento de inércia da seção geométrica homogeneizada 
Será empregado o momento de inércia da seção homogeneizada:

$I_{\text {hom }}=I+A \cdot\left(y_{c g}-y_{h o m}\right)^{2}+A_{p} \cdot\left(\alpha_{p}-1\right) \cdot\left(d-y_{h o m}\right)^{2}$

$I_{\text {hom }}=0,000720901+0,173138 \cdot(0,10-0,1010)^{2}+0,0005 \cdot(6,31124-1) \cdot(0,165-0,1010)^{2}$

$I_{\text {hom }}=0,0007319515 \mathrm{~m}^{4}$

I : momento de inércia da seção geométrica. $I=0,000720901 \mathrm{~m}^{4}$

$\mathrm{y}_{\mathrm{t}, \text { hom }}$ : distância do centro de gravidade à fibra mais tracionada da seção homogeneizada

$\mathrm{y}_{\mathrm{t}, \mathrm{hom}}=\mathrm{h}-\mathrm{y}_{\mathrm{hom}}=0,2-0,1010=0,099 \mathrm{~m}$

Resulta:

$M_{r}=\left(\alpha_{t} f_{c t m}+\frac{N_{p}}{A_{h o m}}\right) \cdot \frac{I_{\text {hom }}}{Y_{t, h o m}}+N_{p} \cdot e_{p}$

$M_{r}=\left(1,5.3508+\frac{509,71}{0,1757936}\right) \cdot \frac{0,0007319515}{0,099}+509,71 \cdot 0,065$

$M_{r}=93,47 \mathrm{kN} \cdot \mathrm{m}$

\subsection{MOMENTO RESISTENTE A 2,5 h DO APOIO}

O cálculo do momento resistente da seção (sem coeficientes parciais de segurança) é realizado da mesma forma que para os casos anteriores.

Considerando a peça no domínio 2 , tem-se $\varepsilon_{\mathrm{s}}=1 \%$.

O valor do pré-alongamento $\left(\varepsilon_{\mathrm{p}}\right)$ fica definido a partir da tensão na armadura de protensão aos 10 dias (data do ensaio). Assim, com a lei de Hooke tem-se:

$\varepsilon_{\mathrm{p}}=\frac{\sigma_{\mathrm{p}}}{\mathrm{E}_{\mathrm{p}}} \quad \sigma_{\mathrm{p}}=1019,42 \mathrm{MPa} \quad \mathrm{E}_{\mathrm{p}}=190 \mathrm{GPa} \quad \varepsilon_{\mathrm{p}}=\frac{1019,42}{190.1000}=0,5365 \%$

O valor da deformação correspondente à descompressão $\left(\varepsilon_{7}\right)$ já calculada nas perdas iniciais é de $\varepsilon_{7}=0,0206 \%$ (Apêndice $A$, item 6.1.3). Assim, tem-se:

$\varepsilon_{\mathrm{t}}=\varepsilon_{\mathrm{p}}+\varepsilon_{7}+\varepsilon_{\mathrm{s}}=0,5365+0,0206+1=1,5571 \%=15,571 \% \mathrm{o}$

Com o valor da deformação total é possível determinar a tensão no aço de protensão através da Tabela 1, ilustrada anteriormente (item 1.2).

Determina-se o valor da tensão de projeto $\left(\sigma_{\mathrm{pd}}\right)$ realizando uma interpolação linear:

\begin{tabular}{llcc}
\hline $\boldsymbol{\varepsilon}(\%)$ & $\mathbf{1 5}, 00$ & $\mathbf{1 5 , 5 7 1}$ & $\mathbf{1 7 , 5}$ \\
CP190 & 1507 & $y$ & 1517 \\
\hline
\end{tabular}




$$
\frac{15,571-15,00}{y-1507}=\frac{17,5-15,00}{1517-1507} \rightarrow y=1509,28 \mathrm{MPa}
$$

O valor característico da tensão no aço $\left(\sigma_{\mathrm{pk}}\right)$ corresponde a:

$$
\sigma_{\mathrm{pk}}=\sigma_{\mathrm{pd}} \cdot 1,15=1509,28 \cdot 1,15=1735,67 \mathrm{MPa}=173,567 \frac{\mathrm{kN}}{\mathrm{cm}^{2}}
$$

Assim, a força na armadura pode ser determinada da seguinte forma:

$\mathrm{F}_{\mathrm{p}}=\mathrm{A}_{\mathrm{p}} \sigma_{\mathrm{p}}=5.173,567=867,84 \mathrm{kN}$

Igualando as expressões da força de tração e de compressão, considerando o diagrama retangular simplificado, determina-se a posição da linha neutra:

$x=\frac{F_{p}}{0,8 \cdot b_{\text {laje }} \cdot f_{c j}}=\frac{867,84}{0,8 \cdot 1,25 \cdot 40 \cdot 1000}=0,0217 \mathrm{~m}$

Com este valor, faz-se uma verificação se a peça realmente se encontra no domínio 2, no final do qual a posição da linha neutra corresponde a:

$x_{2}=0,259 \cdot d=0,259 \cdot 0,165=0,0427 \mathrm{~m}$

Com $x=0,0217<x_{2}=0,0427$, como admitido, a peça se encontra no domínio 2 .

Assim, resulta o momento resistente: $M_{R}=F_{p} \cdot(d-0,4 \cdot x)=867,84 \cdot(0,165-0,4 \cdot 0,0217)$

$M_{R}=135,66 \mathrm{kN} \cdot \mathrm{m}$ 


\section{APÊNDICE C}

\section{CISALHAMENTO EM UNIDADES ALVEOLARES PROTENDIDAS}

Apresentam-se exemplos numéricos para a análise de cisalhamento em zona fissurada por flexão, considerando os diferentes tipos de lajes ensaiadas: sem e com capa estrutural e com alvéolos preenchidos. Esses exemplos consideram a seção a $2,5 \mathrm{~h}$ do apoio, sendo empregadas as equações recomendadas pela NBR 6118:2003 (lajes sem e com capa e com alvéolos preenchidos), pelo EC2:2004 (laje sem e com capa e com alvéolos preenchidos) e pelo ACI 318:2008 (laje sem e com capa), equações essas apresentadas na revisão bibliográfica. Também é apresentado exemplo da determinação da resistência ao cisalhamento considerando região não fissurada por flexão. As características do tipo de laje a ser dimensionada encontram-se no Apêndice $A$, item 1.1.1.

\section{Cisalhamento em lajes de acordo com a NBR 6118:2003}

Neste exemplo sobre a análise do cisalhamento em lajes alveolares, e nos subsequentes, serão determinados valores teóricos característicos, sem a consideração de coeficientes parciais de segurança, para melhor comparação com os valores experimentais obtidos nos ensaios. Nas situações de projeto, não previstas pela NBR 6118:2003, são feitas considerações para o cálculo dessas lajes.

\subsection{LAJE SEM CAPA E SEÇÃO A 2,5 h DO APOIO}

Para laje sem capa, a força cortante resistente em zona fissurada por flexão pode ser determinada como indicado a seguir:

$V_{R k}=\left[0,25 \cdot f_{c t k, \text { inf }} \cdot k \cdot\left(1,2+40 \rho_{1}\right)+0,15 \cdot \sigma_{c p}\right] \cdot b_{w} \cdot d$

$V_{R k}=[0,25 \cdot(2456,175) \cdot(1,435) \cdot(1,2+40 \cdot 0,00947)+0,15 \cdot(3626,184)] \cdot(0,32) \cdot(0,165)$

$\mathrm{V}_{\mathrm{Rk}}=102,17 \mathrm{kN}$

$V_{R k}$ : força cortante resistente em zona de flexão

$\mathrm{f}_{\mathrm{ctk} \text {, inf }}$ : resistência característica inferior do concreto pré-moldado à tração

$\mathrm{f}_{\mathrm{ctk}, \text { inf }}=0,7 \cdot \mathrm{f}_{\mathrm{ct}, \mathrm{m}}=0,7 \cdot\left(0,3 \cdot\left(\mathrm{f}_{\mathrm{cj}}\right)^{\frac{2}{3}}\right)=0,7 \cdot\left(0,3 \cdot(40)^{\frac{2}{3}}\right)=2,4561749 \mathrm{MPa}=2456,175 \frac{\mathrm{kN}}{\mathrm{m}^{2}}$

$\mathrm{f}_{\mathrm{ct}, \mathrm{m}}$ : resistência média do concreto à tração

$f_{c j}$ : resistência do concreto à compressão aos j dias (na data do ensaio) 
$b_{w}$ : largura total da nervura da laje alveolar, $b_{w}=0,32 m$

d: altura efetiva da seção transversal da laje alveolar, $d=0,2-0,035=0,165 \mathrm{~m}$

$\mathrm{k}$ : coeficiente correspondente a:

$k=1,6-d \geq 1 \Rightarrow k=1,6-0,165=1,435 \geq 1 \quad$ ( em metros)

$\rho_{1}$ : taxa geométrica da armadura da seção alveolar pré-moldada

$\rho_{1}=\frac{A_{p}}{b_{w} \cdot d}=\frac{0,0005}{0,32 \cdot 0,165}=0,00947$

$A_{p}$ : área da seção transversal da armadura protendida, $A_{p}=0,0005 \mathrm{~m}^{2}$

$\sigma_{\mathrm{cp}}$ : tensão de compressão no concreto devida à força de protensão

$\sigma_{\mathrm{cp}}=\frac{\mathrm{P}_{\infty}}{\mathrm{A}}=\frac{499,67}{0,137795}=3626,184 \frac{\mathrm{kN}}{\mathrm{m}^{2}}$

A : área da seção transversal da laje alveolar pré-moldada, $A=0,137795 \mathrm{~m}^{2}$

$\mathrm{P}_{\infty}$ : força de protensão final, depois de todas as perdas.

Como determinada anteriormente (no Apêndice A, item 4.3), a força final de protensão para laje sem capa e seção a $2,5 \mathrm{~h}$ do apoio corresponde a:

$P_{\infty}=N_{p}=\sigma_{p} \cdot A_{p}=(999,33 \cdot 1000) \cdot(0,0005)=499,67 \mathrm{kN}$

\subsection{LAJE COM CAPA E SEÇÃO A 2,5 h DO APOIO}

Para laje com capa, o cálculo da força cortante resistente em zona fissurada por flexão pode ser feito como indicado a seguir:

$\overline{V_{R k}}=\left[0,25 \cdot f_{c t k, \text { inf }} \cdot k^{\prime} \cdot\left(1,2+40 \rho_{1}^{\prime}\right)+0,15 \cdot \sigma_{c p}\right] \cdot b_{w} \cdot d^{\prime}$

$\overline{V_{R k}}=[0,25 \cdot(2456,175) \cdot(1,385) \cdot(1,2+40 \cdot 0,007267)+0,15 \cdot(3655,72)] \cdot(0,32) \cdot(0,215)$

$\overline{\mathrm{V}_{\mathrm{Rk}}}=124,95 \mathrm{kN}$

$\overline{\mathrm{V}_{\mathrm{RK}}}$ : força cortante resistente em zona de flexão de laje alveolar com capa

$d^{\prime}$ : $\quad$ altura efetiva da seção composta, $d^{\prime}=0,25-0,035=0,215 \mathrm{~m}$

$k^{\prime}$ : coeficiente considerando a seção composta ( $d^{\prime}$ em metros)

$k^{\prime}=1,6-d^{\prime}=1,6-0,215=1,385 \geq 1$

$\rho_{1}^{\prime}$ : taxa de armadura da seção composta, $\rho_{1}^{\prime}=\frac{A_{p}}{b_{w} \cdot d^{\prime}}=\frac{0,0005}{0,32 \cdot 0,215}=0,007267$

$\sigma_{\mathrm{cp}}$ : tensão de compressão no concreto devida à força de protensão

$\sigma_{\mathrm{cp}}=\frac{\mathrm{P}_{\infty}}{\mathrm{A}}=\frac{503,74}{0,137795}=3655,72 \frac{\mathrm{kN}}{\mathrm{m}^{2}}$

A : área da seção transversal da laje alveolar pré-moldada, $A=0,137795 \mathrm{~m}^{2}$

$\mathrm{P}_{\infty}$ : força de protensão final, depois de todas as perdas. 
Como determinada no Apêndice $A$, item 5.3, a força final de protensão para laje com capa e seção a 2,5 h do apoio corresponde a:

$\mathrm{P}_{\infty}=\mathrm{N}_{\mathrm{p}}=\sigma_{\mathrm{cp}} \cdot \mathrm{A}_{\mathrm{p}}=(1007,48 \cdot 1000) \cdot(0,0005)=503,74 \mathrm{kN}$

\subsection{DOIS ALVÉOLOS PREENCHIDOS E SEÇÃo A 2,5 h DO APOIO}

Para lajes com alvéolos preenchidos, a força cortante resistente em zona fissurada por flexão pode ser calculada considerando o preenchimento antes da aplicação da protensão (na fábrica) ou após (na obra), visto que no Brasil podem ser empregados esses dois procedimentos. São apresentados a seguir os cálculos para essas duas situações.

\section{- Preenchimento dos alvéolos antes da aplicação da protensão (na fábrica)}

Para preenchimento antes da aplicação da protensão e considerando a contribuição da área preenchida, a força cortante resistente em zona fissurada a flexão pode ser calculada da seguinte maneira:

$\mathrm{V}_{\mathrm{Rk}}^{\prime}=\left[0,25 \cdot \mathrm{f}_{\mathrm{ctk}, \text { inf }} \cdot \mathrm{k} \cdot\left(1,2+40 \rho^{\prime}{ }_{1}\right)+0,15 \cdot \sigma_{\mathrm{cp}}^{\prime}\right] \cdot \mathrm{b}_{\mathrm{w}}^{\prime} \cdot \mathrm{d}$

$\mathrm{V}_{\mathrm{Rk}}^{\prime}=[0,25 \cdot(2456,175) \cdot(1,435) \cdot(1,2+40 \cdot 0,004887)+0,15 \cdot(2943,95)] \cdot(0,62) \cdot(0,165)$

$\mathrm{V}_{\mathrm{Rk}}^{\prime}=170,97 \mathrm{kN}$

$\mathrm{V}_{\mathrm{Rk}}$ : força cortante resistente em zona de flexão de laje com alvéolos preenchidos

$f_{c t k, \text { inf }}$ : resistência característica inferior do concreto à tração, $f_{c t k, \text { inf }}=2456,175 \frac{\mathrm{kN}}{\mathrm{m}^{2}}$

$\mathrm{b}_{\mathrm{w}}$ : largura total da seção composta com alvéolos preenchidos

$b^{\prime}{ }_{w}=b_{w}+n b_{c} \frac{E_{c}}{E_{p}}=(0,32)+(2,00) \cdot(0,15) \cdot(1,00)=0,62 m$

$b_{w}$ : largura total das nervuras da laje alveolar, $b_{w}=0,32 m$

$\mathrm{n}$ : quantidade de alvéolos preenchidos, $\mathrm{n}=2$

$\mathrm{b}_{\mathrm{c}}$ : largura dos alvéolos preenchidos, $\mathrm{b}_{\mathrm{c}}=0,15 \mathrm{~m}$

$\frac{E_{c}}{E_{p}}$ : relação entre os módulos de elasticidade dos concretos da laje e dos alvéolos

Para a laje ensaiada, os alvéolos são preenchidos simultaneamente à moldagem das unidades, ou seja, é empregado o mesmo concreto para as lajes e para os alvéolos.

$$
\frac{\mathrm{E}_{\mathrm{C}}}{\mathrm{E}_{\mathrm{p}}}=1
$$

d: altura efetiva da seção transversal da laje alveolar, $d=0,2-0,035=0,165 \mathrm{~m}$

$\mathrm{k}$ : coeficiente correspondente a $\mathrm{k}=1,6-\mathrm{d} \geq 1 \Rightarrow \mathrm{k}=1,6-0,165=1,435 \geq 1$ 
$\rho_{1}^{\prime}:$ taxa de armadura da seção composta, $\rho_{1}=\frac{A_{p}}{b_{w}{ }^{\prime} \cdot d}=\frac{0,0005}{0,62 \cdot 0,165}=0,004887$

$\sigma_{\mathrm{cp}}$ : tensão de compressão do concreto devida à força de protensão

$\sigma_{\mathrm{cp}}=\frac{\mathrm{P}_{\infty}}{\mathrm{A}_{\text {tot }}}=\frac{509,71}{0,173138}=2943,95 \frac{\mathrm{kN}}{\mathrm{m}^{2}}$

$A_{\text {tot }}$ : área total da seção transversal da laje alveolar pré-moldada, considerando alvéolos preenchidos. $A_{\text {tot }}=0,173138 \mathrm{~m}^{2}$

$\mathrm{P}_{\infty}$ : força de protensão final, depois de todas as perdas

Como determinada anteriormente (no Apêndice A, item 6.3), a força final de protensão para lajes com alvéolos parcialmente preenchidos e seção a $2,5 \mathrm{~h}$ é:

$P_{\infty}=N_{p}=\sigma_{c p} \cdot A_{p}=(1019,42 \cdot 1000) \cdot(0,0005)=509,71 \mathrm{kN}$

\section{- Preenchimento dos alvéolos após a aplicação da protensão (na obra)}

Para preenchimento após a aplicação da protensão, a força cortante resistente em zona fissurada a flexão, considerando contribuição de toda a área preenchida, é dada por:

$\mathrm{V}_{\mathrm{Rk}}^{\prime}=0,25 \cdot \mathrm{f}_{\mathrm{ctk}, \mathrm{inf}} \cdot \mathrm{b}_{\mathrm{w}}^{\prime} \cdot \mathrm{d} \cdot \mathrm{k} \cdot\left(1,2+40 \rho_{1}^{\prime}\right)+0,15 \cdot \sigma_{\mathrm{cp}} \cdot \mathrm{b}_{\mathrm{w}} \cdot \mathrm{d}$

$\mathrm{V}_{\mathrm{Rk}}^{\prime}=0,25 \cdot(2456,175) \cdot(0,62) \cdot(0,165) \cdot(1,435) \cdot(1,2+40 \cdot 0,004887)+0,15 \cdot(3699,05) \cdot(0,32) \cdot(0,165)$

$\mathrm{V}_{\mathrm{Rk}}^{\prime}=155,09 \mathrm{kN}$

$\sigma_{\mathrm{cp}}$ : tensão de compressão do concreto devida à força de protensão

$\sigma_{\mathrm{cp}}=\frac{\mathrm{P}_{\infty}}{\mathrm{A}}=\frac{509,71}{0,137795}=3699,05 \frac{\mathrm{kN}}{\mathrm{m}^{2}}$

A : área da seção transversal da laje alveolar pré-moldada. $A=0,137795 \mathrm{~m}^{2}$

$P_{\infty}$ : força de protensão final, depois de todas as perdas

Como determinada anteriormente (no Apêndice A, item 6.3), a força de protensão final para lajes com alvéolos parcialmente preenchidos e seção a $2,5 \mathrm{~h}$ do apoio resulta:

$P_{\infty}=N_{p}=\sigma_{c p} \cdot A_{p}=(1019,42 \cdot 1000) \cdot(0,0005)=509,71 \mathrm{kN}$

\section{Cisalhamento em lajes alveolares segundo o EC2:2004}

Serão apresentados três exemplos da determinação da força cortante resistente, considerando lajes alveolares sem capa, com capa e com alvéolos preenchidos, de acordo com Eurocode 2 (EN 1992-1-1:2004), como foi visto na revisão bibliográfica.

Serão determinados valores teóricos característicos, ou seja, sem a consideração de coeficientes parciais de segurança. 


\subsection{LAJE SEM CAPA E SEÇÃO A 2,5 h DO APOIO}

Segundo o EN 1992-1-1:2004, para laje sem capa, a força cortante resistente em zona fissurada por flexão pode ser determinada como se indica a seguir:

$V_{R k}=\left|C_{R k} \cdot k \cdot\left(100 \cdot \rho_{1} \cdot f_{c j}\right)^{1 / 3}+0,15 \cdot \sigma_{c p}\right| b_{w} \cdot d$

$V_{R k}=\left[0,18 \cdot 2,0 \cdot(100 \cdot 0,00947 \cdot 40)^{1 / 3}+0,15 \cdot 3,63\right] \cdot 320 \cdot 165$

$\mathrm{V}_{\mathrm{Rk}}=92586,69 \mathrm{~N} \quad \mathrm{~V}_{\mathrm{Rk}}=92,59 \mathrm{kN}$

O valor mínimo deve ser:

$\mathrm{V}_{\mathrm{Rk}}=\left(0,035 \cdot \mathrm{k}^{3 / 2} \cdot \mathrm{f}_{\mathrm{cj}}{ }^{1 / 2}+0,15 \cdot \sigma_{\mathrm{cp}}\right) \cdot \mathrm{b}_{\mathrm{w}} \cdot \mathrm{d}$

$\mathrm{V}_{\mathrm{Rk}}=\left(0,035 \cdot 2,0^{3 / 2} \cdot 40^{1 / 2}+0,15 \cdot 3,63\right) \cdot 320 \cdot 165$

$\mathrm{V}_{\mathrm{Rk}}=61807,63 \mathrm{~N}=61,81 \mathrm{kN}$

$\mathrm{V}_{\mathrm{Rk}}$ : força cortante resistente característica $(\mathrm{em} \mathrm{N})$

$\mathrm{C}_{\mathrm{Rk}}$ : coeficiente correspondente a $\mathrm{C}_{\mathrm{Rk}}=0,18$

d: altura efetiva da seção transversal da laje alveolar, $d=200-35=165 \mathrm{~mm}$

$\mathrm{b}_{\mathrm{w}}$ : menor largura da seção transversal na área tracionada $(\mathrm{mm}), \mathrm{b}_{\mathrm{w}}=320 \mathrm{~mm}$

$f_{c j}$ : resistência do concreto à compressão na data do ensaio, $f_{c j}=40 \mathrm{MPa}$

$\mathrm{k}=1+\sqrt{\frac{200}{\mathrm{~d}}} \leq 2,0 \Rightarrow \mathrm{k}=1+\sqrt{\frac{200}{165}}=2,10 \Rightarrow \mathrm{k}=2,0 \quad(\mathrm{~d}$ em $\mathrm{mm})$

$\rho_{1}: \quad$ taxa de armadura longitudinal, $\rho_{1}=\frac{A_{s t}}{\left(b_{w} \cdot d\right)} \leq 0,02 \Rightarrow \rho_{1}=\frac{500}{(320.165)}=0,00947$

$\mathrm{A}_{\mathrm{st}}$ : área da armadura de tração, $\mathrm{A}_{\mathrm{st}}=500 \mathrm{~mm}^{2}$

$\sigma_{c p}$ : tensão devida à força de protensão, $\sigma_{c p}=\frac{N_{E}}{A_{c}}<0,2 . f_{c j}(\mathrm{MPa})$

$\sigma_{\mathrm{cp}}=\frac{N_{\mathrm{E}}}{\mathrm{A}_{\mathrm{c}}}=\frac{499670}{137795}=3,63 \mathrm{MPa}<0,2.40=8 \mathrm{MPa} \quad \Rightarrow \quad \sigma_{\mathrm{cp}}=3,63 \mathrm{MPa}$

$A_{C}$ : área da seção transversal de concreto $\left(\mathrm{mm}^{2}\right), A_{c}=137795 \mathrm{~mm}^{2}$

$\mathrm{N}_{\mathrm{E}}$ : força normal na seção devida às ações, inclusive protensão (em $\mathrm{N}$ )

$N_{E}=\sigma_{c p} \cdot A_{p}=(999,33 \cdot 1000) \cdot(0,0005)=499,67 \mathrm{kN}=499670 \mathrm{~N}$

\subsection{LAJE COM CAPA E SEÇÃO A 2,5 h DO APOIO}

De acordo com o EN 1992-1-1:2004, para laje com capa, a força cortante resistente em zona fissurada por flexão pode ser calculada da seguinte maneira:

$V_{R k}=\left[C_{R k} \cdot k^{\prime} \cdot\left(100 \cdot \rho^{\prime} \cdot f_{c j}\right)^{1 / 3}+0,15 \cdot \sigma_{c p}\right] b_{w} \cdot d^{\prime}$ 


$$
\begin{aligned}
& V_{R k}=\left[0,18 \cdot 1,96 \cdot(100 \cdot 0,007267 \cdot 40)^{1 / 3}+0,15 \cdot 3,65\right] \cdot 320 \cdot 215 \\
& V_{R k}=112299,48 \mathrm{~N} \\
& V_{R k}=112,30 \mathrm{kN}
\end{aligned}
$$

Deve ser respeitado um valor mínimo de:

$\mathrm{V}_{\mathrm{Rk}}=\left(0,035 \cdot \mathrm{k}^{13 / 2} \cdot \mathrm{f}_{\mathrm{cj}}{ }^{1 / 2}+0,15 \cdot \sigma_{\mathrm{cp}}\right) \cdot \mathrm{b}_{\mathrm{w}} \cdot \mathrm{d}^{\prime}$

$\mathrm{V}_{\mathrm{Rk}}=\left(0,035 \cdot 1,96^{3 / 2} \cdot 40^{1 / 2}+0,15 \cdot 3,65\right) \cdot 320 \cdot 215$

$\mathrm{V}_{\mathrm{Rk}}=79457,83 \mathrm{~N}=79,46 \mathrm{kN}$

$\mathrm{V}_{\mathrm{Rk}}$ : força cortante resistente característica (em N)

$C_{R k}$ : coeficiente correspondente a $C_{R k}=0,18$

$d^{\prime}$ : altura efetiva da seção transversal da laje alveolar, $d^{\prime}=250-35=215 \mathrm{~mm}$

$b_{w}$ : menor largura da seção transversal na área tracionada $(\mathrm{mm}), b_{w}=320 \mathrm{~mm}$

$f_{c j}$ : resistência do concreto à compressão na data do ensaio, $f_{c j}=40 \mathrm{MPa}$

$\mathrm{k}^{\prime}=1+\sqrt{\frac{200}{\mathrm{~d}^{\prime}}} \leq 2,0 \Rightarrow \mathrm{k}=1+\sqrt{\frac{200}{215}}=1,96 \Rightarrow \mathrm{k}=1,96$ (d em mm)

$\rho_{1}^{\prime}$ : taxa de armadura longitudinal, $\rho_{1}^{\prime}=\frac{A_{s t}}{\left(b_{w} \cdot d^{\prime}\right)} \leq 0,02 \Rightarrow \rho_{1}^{\prime}=\frac{500}{(320.215)}=0,007267$

$A_{s t}$ : área da armadura de tração, $A_{s t}=500 \mathrm{~mm}^{2}$

$\sigma_{\mathrm{cp}}$ : tensão devida à força de protensão, $\sigma_{\mathrm{cp}}=\frac{\mathrm{N}_{\mathrm{E}}}{\mathrm{A}_{\mathrm{c}}}<0,2 . \mathrm{f}_{\mathrm{cj}}(\mathrm{MPa})$

$\sigma_{\mathrm{cp}}=\frac{\mathrm{N}_{\mathrm{E}}}{\mathrm{A}_{\mathrm{c}}}=\frac{503740}{137795}=3,65 \mathrm{MPa}<0,2.40=8 \mathrm{MPa} \quad \Rightarrow \quad \sigma_{\mathrm{cp}}=3,65 \mathrm{MPa}$

$A_{c}$ : área da seção transversal de concreto $\left(\mathrm{mm}^{2}\right)-A_{c}=137795 \mathrm{~mm}^{2}$

$\mathrm{N}_{\mathrm{E}}$ : força normal na seção devida às ações aplicadas, inclusive protensão (em $\mathrm{N}$ );

$N_{E}=\sigma_{c p} \cdot A_{p}=(1007,48 \cdot 1000) \cdot(0,0005)=503,74 k N=503740 \mathrm{~N}$

\subsection{LAJE COM ALVÉOLO PREENCHIDO E SEÇÃO A 2,5 h DO APOIO}

Para laje com alvéolo preenchido, zona fissurada por flexão, contribuição de toda a área preenchida e preenchimento antes da aplicação da protensão, a força cortante resistente pode ser calculada da seguinte maneira:

$$
\begin{aligned}
& \left.V_{R k}=\mid C_{R k} \cdot k \cdot\left(100 \cdot \rho_{1}^{\prime} \cdot f_{C j}\right)^{1 / 3}+0,15 \cdot \sigma_{C p}^{\prime}\right\rfloor^{\prime}{ }^{\prime}{ }_{w} \cdot d \\
& V_{R k}=\left[0,18 \cdot 2 \cdot(100 \cdot 0,00489 \cdot 40)^{1 / 3}+0,15 \cdot 2,94\right] \cdot 620 \cdot 165 \\
& V_{R k}=144342,34 \mathrm{~N} \\
& V_{R k}=144,34 \mathrm{kN}
\end{aligned}
$$


Deve ser respeitado um mínimo de:

$v_{R k}=\left(0,035 \cdot k^{3 / 2} \cdot f_{c j}{ }^{1 / 2}+0,15 \cdot \sigma^{\prime}{ }_{c p}\right) \cdot b^{\prime}{ }_{w} \cdot d$

$\mathrm{V}_{\mathrm{Rk}}=\left(0,035 \cdot 2^{3 / 2} \cdot 40^{1 / 2}+0,15 \cdot 2,94\right) \cdot 620 \cdot 165$

$V_{\mathrm{Rk}}=109164,23 \mathrm{~N}=109,16 \mathrm{kN}$

$\mathrm{V}_{\mathrm{RK}}$ : força cortante resistente característica $(\mathrm{em} \mathrm{N})$

$\mathrm{C}_{\mathrm{RK}}$ : coeficiente correspondente a $\mathrm{C}_{\mathrm{RK}}=0,18$

d: altura efetiva da seção transversal da laje alveolar, $d=200-35=165 \mathrm{~mm}$

$b^{\prime}{ }_{w}$ : largura total da seção composta com alvéolos preenchidos

$b^{\prime}{ }_{w}=b_{w}+n b_{c} \frac{E_{c}}{E_{p}}=(0,32)+(2,00) \cdot(0,15) \cdot(1,00)=0,62 m$

$b_{w}$ : largura total da nervura da laje alveolar, $b_{w}=0,32 m$

$f_{c j}$ : resistência do concreto à compressão na data do ensaio, $f_{c j}=40 \mathrm{MPa}$

$\mathrm{k}=1+\sqrt{\frac{200}{\mathrm{~d}}} \leq 2,0 \Rightarrow \mathrm{k}=1+\sqrt{\frac{200}{165}}=2,10 \Rightarrow \mathrm{k}=2,0 \quad(\mathrm{~d}$ em $\mathrm{mm})$

$\rho_{1}^{\prime}$ : taxa de armadura longitudinal, $\rho_{1}^{\prime}=\frac{A_{s t}}{\left(b^{\prime}{ }_{w} \cdot d\right)} \leq 0,02 \Rightarrow \rho_{1}^{\prime}=\frac{500}{(620.165)}=0,00489$

$\mathrm{A}_{\mathrm{st}}$ : área da armadura de tração, $\mathrm{A}_{\mathrm{st}}=500 \mathrm{~mm}^{2}$

$\sigma_{c p}^{\prime}$ : tensão devida à força de protensão, $\sigma_{\mathrm{cp}}=\frac{N_{E}}{A_{\text {tot }}}<0,2 . f_{c j}(\mathrm{MPa})$

$\sigma_{\mathrm{cP}}^{\prime}=\frac{\mathrm{N}_{\mathrm{E}}}{\mathrm{A}_{\mathrm{tot}}}=\frac{509710}{173138}=2,94 \mathrm{MPa}<0,2.40=8 \mathrm{MPa} \quad \Rightarrow \quad \sigma_{\mathrm{cp}}^{\prime}=2,94 \mathrm{MPa}$

$A_{\text {tot }}$ : área da seção transversal composta, considerando os alvéolos preenchidos $\left(\mathrm{mm}^{2}\right)$

$A_{\text {tot }}=173138 \mathrm{~mm}^{2}$

$\mathrm{N}_{\mathrm{E}}$ : força normal na seção devida às ações aplicadas, inclusive protensão (em N);

$N_{E}=\sigma_{c p} \cdot A_{p}=(1019,42 \cdot 1000) \cdot(0,0005)=509,71 \mathrm{kN}=509710 \mathrm{~N}$

\section{Cisalhamento em lajes alveolares segundo o ACI 318:2008}

Apresentam-se a seguir dois exemplos da determinação da força cortante resistente, considerando unidades alveolares sem e com a presença de capa, segundo o ACI 318:2008, da maneira apresentada na revisão bibliográfica.

Da mesma forma que nos casos anteriores, serão determinados valores teóricos característicos, ou seja, sem a consideração de coeficientes parciais de segurança. 


\subsection{LAJE SEM CAPA E SEÇÃO A 2,5 h DO APOIO}

O valor característico da resistência à fissuração devida ao cisalhamento e à flexão $\left(V_{\mathrm{c}}\right)$ pode ser obtido através da expressão:

$\mathrm{V}_{\mathrm{ci}}=0,6 \cdot \sqrt{\mathrm{f}_{\mathrm{c}}} \cdot \mathrm{b}_{\mathrm{w}} \cdot \mathrm{d}_{\mathrm{p}}+\mathrm{V}_{\mathrm{d}}+\frac{\mathrm{V}_{\mathrm{i}} \cdot \mathrm{M}_{\mathrm{cre}}}{\mathrm{M}_{\max }}$

$\mathrm{V}_{\mathrm{ci}}$ : resistência ao cisalhamento nominal fornecida pelo concreto quando a fissuração diagonal resulta da combinação de momento fletor e cisalhamento (Ib);

$V_{i}$ : força cortante na seção devida ações externas, que ocorre junto com $M_{\text {máx }}(\mathrm{lb})$;

$M_{\text {máx }}$ : momento máximo na seção devido à aplicação de ações externas (Ib.in).

\section{Determinação de $\mathbf{V}_{\text {ie }} \mathbf{M}_{\text {máx }}$}

Não são conhecidas as ações externas a serem aplicadas, devido ao fato de corresponder justamente a uma investigação experimental. Assim, as variáveis $V_{i}$ e $M_{\text {máx }}$ são determinadas de forma literal, para melhor adaptação da equação empregada.

De acordo com a Figura 1, pode-se determinar a força cortante $V_{i}$ e o momento máximo devido às forças externas, considerando a seção a $2,5 \mathrm{~h}$ do apoio, da seguinte maneira:

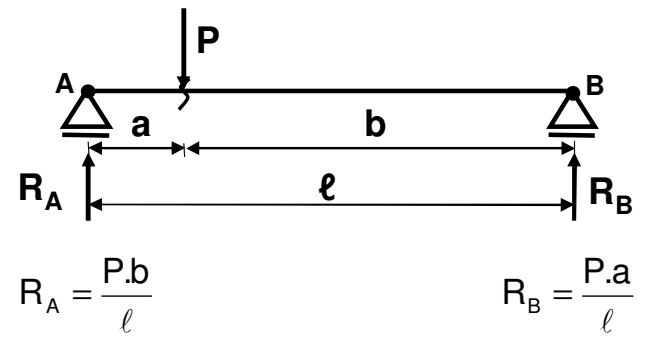

Figura 1 - Esquema para determinação de $V_{i}$ e $M_{\text {máx }}$ na seção a 2,5 h do apoio.

$\mathrm{V}_{\mathrm{i}}=\mathrm{R}_{\mathrm{A}}=\frac{\mathrm{P} \cdot \mathrm{b}}{\ell} ; \mathrm{M}_{\text {máx }}=\mathrm{R}_{\mathrm{A}} \cdot \mathrm{a}$

Assim, é possível determinar a seguinte relação: $\frac{V_{i}}{M_{\text {máx }}}=\frac{R_{A}}{R_{A} \cdot a}$

Então, tem-se: $\frac{V_{i}}{M_{\text {máx }}}=\frac{1}{a}$

Dessa forma, substituindo esta relação na equação para determinar a resistência à fissuração devida ao cisalhamento e à flexão, tem-se:

$\mathrm{V}_{\mathrm{ci}}=0,6 \cdot \sqrt{\mathrm{f}_{\mathrm{c}}{ }_{\mathrm{c}}} \cdot \mathrm{b}_{\mathrm{w}} \cdot \mathrm{d}_{\mathrm{p}}+\mathrm{V}_{\mathrm{d}}+\frac{\mathrm{M}_{\mathrm{cre}}}{\mathrm{a}}$

Considerações: 1 in $=25,4 \mathrm{~mm} ; 1 \mathrm{kN}=225 \mathrm{lbf} ; 1 \mathrm{Psi}=\frac{\mathrm{lbf}}{\mathrm{in}^{2}}=0,006894757 \mathrm{MPa}$

a : distância da carga aplicada ao apoio, $a=2,5 \mathrm{~h}=2,5 \cdot 0,2=0,5 \mathrm{~m}=19,685$ in

$b_{w}$ : largura total da nervura (in), $b_{w}=320 \mathrm{~mm}=12,598$ in 
$\mathrm{f}^{\prime}{ }_{\mathrm{c}}$ : resistência do concreto à compressão $(\mathrm{Psi}), \mathrm{f}^{\prime}{ }_{\mathrm{c}}=40 \mathrm{MPa}=5801,51 \mathrm{Psi}$

$d_{p}$ : distância da fibra mais comprimida ao centro da armadura protendida, que não pode ser menor que $0,8 \mathrm{~h}$ (in)

$d_{p}=165 \mathrm{~mm}=6,496$ in $>0,8 \cdot 200=160 \mathrm{~mm}=6,299$ in

Resulta:

$d_{p}=165 \mathrm{~mm}=6,496$ in

$V_{d}$ : força cortante na seção devida à carga permanente sem fator de segurança (Ib)

De acordo com a Figura 2, é possível determinar a força cortante na seção a $2,5 \mathrm{~h}$ do apoio.

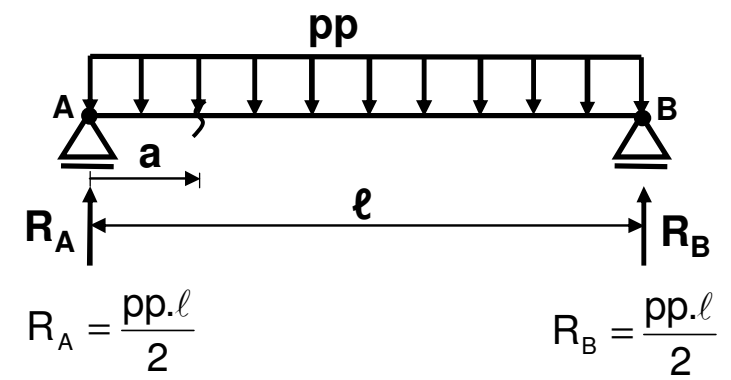

Figura 2 - Esquema para determinação de $V_{d}$ e $M_{g 1}$ na seção a 2,5 h do apoio.

$\mathrm{V}_{\mathrm{d}}=\mathrm{R}_{\mathrm{A}}-\mathrm{pp} \cdot \mathrm{a}=\frac{\mathrm{pp} \cdot \ell}{2}-\mathrm{pp} \cdot \mathrm{a}=\frac{3,449 \cdot 3,0}{2}-3,449 \cdot 0,5=3,449 \mathrm{kN}$

$V_{d}=3,449.225=776,025 \mathrm{lbf}$

$\mathrm{pp}=0,137795.25=3,449 \frac{\mathrm{kN}}{\mathrm{m}}$

$M_{c r e}:$ momento de fissuração da seção devido às ações externas (Ib.in)

$M_{c r e}=\left(\frac{I}{y_{t}}\right) \cdot\left(6 \cdot \sqrt{f^{\prime}{ }_{c}}+f_{p e}-f_{d}\right)$

$M_{\text {cre }}=\left(\frac{1612,56}{3,937}\right) \cdot(6 \cdot \sqrt{5801,51}+526,39-46,63)$

$M_{\text {cre }}=383690,92$ in.lb

I: momento de inércia da seção transversal da peça

$\mathrm{I}=6,712 \cdot 10^{-4} \mathrm{~m}^{4} \quad \Rightarrow \quad \mathrm{I}=\frac{6,712 \cdot 10^{-4}}{(0,0245)^{4}}=1612,56 \mathrm{in}^{4}$

$y_{t}$ : distância do eixo central da seção bruta à face tracionada. $y_{t}=\frac{0,1}{0,0254}=3,937$ in 
$f_{p e}$ : tensão de compressão no concreto devida ao efeito somente da força de protensão (após todas as perdas) na fibra extrema da seção, onde a tensão de tração é causada por ações aplicadas externamente (Psi)

$f_{p e}=\frac{N_{p}}{A_{c}}=\frac{112425,75}{213,58}=526,39$ Psi

$A_{c}$ : área da seção transversal de concreto. $A_{c}=137795 \mathrm{~mm}^{2}=213,58 \mathrm{in}^{2}$

$\mathrm{N}_{\mathrm{E}}$ : força de protensão após todas as perdas

$N_{E}=\sigma_{p} \cdot A_{p}=(999,33 \cdot 1000) \cdot(0,0005)=499,67 \mathrm{kN}$

$\mathrm{N}_{\mathrm{E}}=\sigma_{\mathrm{p}} \cdot \mathrm{A}_{\mathrm{p}}=499,67.225=112425,75 \mathrm{lbf}$

$f_{d}$ : tensão devida à carga permanente, sem fator parcial de segurança, na fibra extrema da seção, onde a tensão de tração é causada por ações externas (Psi)

$f_{d}=\frac{M_{g 1}}{W}=\frac{19098,425}{409,59}=46,63$ Psi

$\mathrm{M}_{\mathrm{g1}}$ : momento devido ao peso próprio, considerado a $2,5 \mathrm{~h}$ do apoio

$M_{g 1}=\frac{p p \cdot \ell}{2} \cdot a-p p \cdot a \cdot \frac{a}{2}=\frac{3,449 \cdot 3,0}{2} \cdot 0,5-3,449 \cdot 0,5 \cdot \frac{0,5}{2}=2,156 \mathrm{kN} \cdot \mathrm{m}$

$M_{g 1}=2,156 \cdot \frac{225}{0,0254}=19098,425 \mathrm{in.lbf}$

W : módulo de resistência da seção considerada $\rightarrow W=\frac{I}{y_{t}}=\frac{1612,56}{3,937}=409,59$ in $^{3}$

Logo, é possível determinar a resistência ao cisalhamento.

$\mathrm{V}_{\mathrm{ci}}=0,6 \cdot \sqrt{\mathrm{f}_{\mathrm{c}}{ }_{\mathrm{c}}} \cdot \mathrm{b}_{\mathrm{w}} \cdot \mathrm{d}_{\mathrm{p}}+\mathrm{V}_{\mathrm{d}}+\frac{\mathrm{M}_{\mathrm{cre}}}{\mathrm{a}}$

$\mathrm{V}_{\mathrm{ci}}=0,6 \cdot \sqrt{5801,51} \cdot 12,598 \cdot 6,496+776,025+\frac{383690,92}{19,685}$

$\mathrm{V}_{\mathrm{ci}}=24007,54 \mathrm{Psi} \quad \mathrm{V}_{\mathrm{ci}}=\frac{24007,54}{225}=106,70 \mathrm{kN}$

\subsection{LAJE COM CAPA E SEÇÃO A 2,5 h DO APOIO}

Para laje com capa, em zona fissurada por flexão, o valor característico da resistência à fissuração devida ao cisalhamento e à flexão $\left(V_{c i}\right)$ pode ser obtido com a equação:

$V_{c i}=0,6 \cdot \sqrt{f_{c}{ }_{c}} \cdot b_{w} \cdot d^{\prime}{ }_{p}+V^{\prime}{ }_{d}+\frac{M^{\prime}{ }_{c r e}}{a}$

Considerações: 1 in $=25,4 \mathrm{~mm} ; 1 \mathrm{kN}=225 \mathrm{lbf} ; 1 \mathrm{Psi}=\frac{\mathrm{lbf}}{\mathrm{in}^{2}}=0,006894757 \mathrm{MPa}$

a : distância da carga aplicada até o apoio, $a=2,5 \mathrm{~h}=2,5.0,25=0,625 \mathrm{~m}=24,61$ in

$b_{w}$ : largura total da nervura (in), $b_{w}=320 \mathrm{~mm}=12,598$ in 
$\mathrm{f}^{\prime}{ }_{\mathrm{c}}$ : resistência do concreto à compressão $(\mathrm{Psi}), \mathrm{f}^{\prime}{ }_{\mathrm{c}}=40 \mathrm{MPa}=5801,51 \mathrm{Psi}$

$d_{p}$ : distância da fibra mais comprimida ao centro da armadura protendida, que não pode ser menor que $0,8 \mathrm{~h}$ (in)

$\mathrm{d}_{\mathrm{p}}=215 \mathrm{~mm}=8,464$ in $>0,8.250=200 \mathrm{~mm}=7,874$ in

Resulta:

$\mathrm{d}_{\mathrm{p}}=215 \mathrm{~mm}=8,464$ in

$\mathrm{V}_{\mathrm{d}}{ }_{\mathrm{a}}$ : força cortante devida à carga permanente, sem fator parcial de segurança (Ib)

De acordo com a Figura 2, determina-se a força cortante na seção a 2,5 h do apoio.

$\mathrm{V}_{\mathrm{d}}=\mathrm{R}_{\mathrm{A}}-\mathrm{pp} \cdot \mathrm{a}=\frac{\mathrm{pp} \cdot \ell}{2}-\mathrm{pp} \cdot \mathrm{a}=\frac{5,007 \cdot 3,0}{2}-5,007 \cdot 0,625=4,381 \mathrm{kN}$

$\mathrm{V}_{\mathrm{d}}=4,381.225=985,725 \mathrm{lbf}$

$\mathrm{pp}=0,200295.25=5,007 \frac{\mathrm{kN}}{\mathrm{m}}$

$M^{\prime}{ }_{\text {cre }}$ : momento de fissuração na seção composta, devido às ações externas (Ib.in)

$M^{\prime}{ }_{\text {cre }}=\left(6 \cdot \sqrt{f^{\prime}{ }_{c}}+f_{p e}-f_{d}\right) \cdot W_{c c}$

$M_{\text {cre }}^{\prime}=(6 \cdot \sqrt{5801,51}+530,67-69,57) \cdot 473,13$

$M^{\prime}{ }_{\text {cre }}=434383,43 \mathrm{in} \cdot \mathrm{lb}$

$\mathrm{W}_{\mathrm{cc}}$ : módulo de resistência da seção com capa

$W_{c c}=\frac{I_{c c}}{y_{t, c c}}=\frac{2552,07}{5,394}=473,13 \mathrm{in}^{3}$

$I_{c c}$ : momento de inércia da seção transversal com capa

$I_{c c}=(0,25) \cdot(0,1135-0,025)^{2}+\left(1,18268 \cdot 10^{-5}\right)+\left(0,137795 \cdot(0,15-0,1135)^{2}+0,0006712\right)$

$\mathrm{I}_{\mathrm{cc}}=10,62251 \cdot 10^{-4} \mathrm{~m}^{4} \rightarrow \mathrm{I}_{\mathrm{cc}}=\frac{10,62251 \cdot 10^{-4}}{(0,0254)^{4}}=2552,07 \mathrm{in}^{4}$

$\mathrm{y}_{\mathrm{t}, \mathrm{cc}}$ : distância do eixo central da seção composta até a fibra mais tracionada (in)

$\mathrm{y}_{\mathrm{t}, \mathrm{cc}}=\mathrm{h}_{\mathrm{tot}}-\mathrm{y}_{\mathrm{cg}}=0,25-0,1135=0,137 \mathrm{~m}$

$\mathrm{y}_{\mathrm{t}, \mathrm{cc}}=0,137 / 0,0254=5,394$ in

$\mathrm{y}_{\mathrm{cg}}$ : distância do centro de gravidade da seção composta até a borda mais comprimida

$y_{c g}=\frac{A_{\text {capa }} \cdot y_{c g, \text { capa }}+A_{\text {laje }} \cdot y_{c g, \text { laje }}}{A_{\text {capa }}+A_{\text {laje }}}$

$y_{c g}=\frac{(1,135 \cdot 0,05) \cdot(0,05 / 2)+(0,137795 \cdot((0,2 / 2)+0,05)}{(1,135 \cdot 0,05)+(0,137795)}$

$\mathrm{y}_{\mathrm{cg}}=0,1135 \mathrm{~m}$ 
$\mathrm{Y}_{\mathrm{cg}, \text { capa }}$ : distância do centro de gravidade da capa até a borda mais comprimida

$b_{\text {capa }}$ : largura da capa considerando os diferentes concretos da laje e da capa

$b_{\text {capa }}=b_{\text {laje }} \cdot \frac{f_{\text {cj, capa }}}{f_{\text {cj, laje }}}=1,25 \cdot \frac{\sqrt{33}}{\sqrt{40}}=1,135 \mathrm{~m}$

$\mathrm{b}_{\text {laje }}$ : largura da laje alveolar, $\mathrm{b}_{\text {laje }}=1,25 \mathrm{~m}$

$f_{c j, l a j e}$ : resistência do concreto da laje, na data do ensaio, $f_{c j, l a j e}=40 \mathrm{MPa}$

$\mathrm{f}_{\mathrm{cj}, \text { capa }}$ : resistência do concreto da capa, na data do ensaio, $\mathrm{f}_{\mathrm{cj}, \text { capa }}=33 \mathrm{MPa}$

$\mathrm{f}_{\mathrm{pe}}$ : tensão de compressão no concreto devida à força de protensão (após todas as perdas) na fibra extrema da seção, onde a tensão de tração é causada por ações aplicadas externamente (Psi). $f_{p e}=\frac{N_{p}}{A_{c}}=\frac{113341,5}{213,58}=530,67$ Psi )

$$
\begin{aligned}
& N_{p}=\sigma_{p} \cdot A_{p}=(1007,48 \cdot 1000) \cdot(0,0005)=503,74 \mathrm{kN} \\
& N_{p}=503,74 \cdot 225=113341,5 \mathrm{lbf}
\end{aligned}
$$

$\mathrm{f}_{\mathrm{d}}$ : tensão devida à carga permanente, sem fator parcial de segurança, na fibra extrema da seção composta, onde a tensão de tração é causada pela aplicação de ações externas (Psi)

$f_{d}^{\prime}=\frac{M_{g 1}}{W_{c c}}=\frac{32917,32}{473,13}=69,57$ Psi

$\mathrm{M}_{\mathrm{g} 1}$ : momento devido ao peso próprio da seção composta, considerado a $2,5 \mathrm{~h}$ do apoio

$M_{g 1}=\frac{p p \cdot \ell}{2} \cdot a-p p \cdot a \cdot \frac{a}{2}=\frac{5,007 \cdot 3,0}{2} \cdot 0,625-5,007 \cdot 0,625 \cdot \frac{0,625}{2}=3,716 \mathrm{kN} \cdot \mathrm{m}$

$M_{g 1}=3,716 \cdot \frac{225}{0,0254}=32917,32 \mathrm{in.lbf}$

Logo, a resistência ao cisalhamento resulta:

$\mathrm{V}_{\mathrm{ci}}=0,6 \cdot \sqrt{\mathrm{f}^{\prime}{ }_{\mathrm{c}}} \cdot \mathrm{b}_{\mathrm{w}} \cdot \mathrm{d}_{\mathrm{p}}{ }_{\mathrm{p}}+\mathrm{V}^{\prime}{ }_{\mathrm{d}}+\frac{\mathrm{M}_{\mathrm{cre}}}{\mathrm{a}}$

$\mathrm{V}_{\mathrm{ci}}=(0,6 \cdot \sqrt{5801,51}) \cdot(12,598) \cdot(8,464)+(985,725)+\left(\frac{434383,43}{24,61}\right)$

$V_{c i}=23509,44$ Psi $\rightarrow \quad V_{c i}=\frac{23509,44}{225}=104,49 \mathrm{kN}$

\section{EC2(2004) e regiões não fissuradas por flexão}

Em regiões de lajes alveolares não fissuradas por flexão, segundo o EN 1992-1-1:2004, a força cortante resistente, ou seja Tension Shear Capacity, pode ser obtida com a expressão: 
$\mathrm{V}_{\mathrm{Rd}, \mathrm{C}}=\frac{\mathrm{I} \cdot \mathrm{b}_{\mathrm{w}}}{\mathrm{S}} \cdot \sqrt{\left(\mathrm{f}_{\mathrm{ctd}}\right)^{2}+\alpha_{1} \cdot \sigma_{\mathrm{cp}} \cdot \mathrm{f}_{\mathrm{ctd}}}$

I: momento de inércia da seção considerada, $\mathrm{I}=671200000 \mathrm{~mm}^{4}$ (as características da laje analisada estão apresentadas no apêndice $A$, item 1.1.1);

$b_{w}$ : largura da seção transversal no eixo central, $b_{w}=320 \mathrm{~mm}$ (apêndice $A$, item 1.1.1);

S: $\quad$ momento estático acima do eixo central; pode ser obtido com base na figura 3.

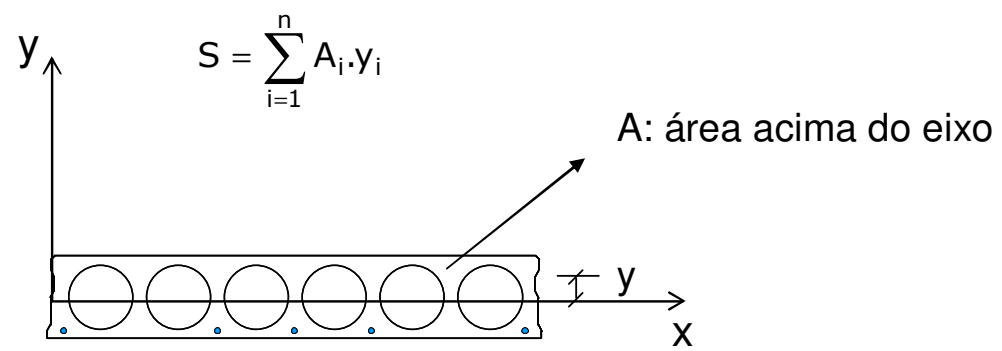

Figura 3 - Momento estático.

No caso da laje alveolar, o momento estático é determinado da seguinte forma:

$\mathrm{S}=\mathrm{A} \cdot \mathrm{y}=\left(\frac{137795}{2} \cdot \frac{200}{4}\right)$

$\mathrm{S}=3444875 \mathrm{~mm}^{3}$

$\mathrm{h}$ : altura da laje. $\mathrm{h}=200 \mathrm{~mm}$

y: distância do centro de gravidade da seção acima do eixo central em relação ao centro de gravidade da figura toda

A: área da seção considerada, acima do eixo central

$\sigma_{\mathrm{cp}}$ : tensão de compressão no concreto, no eixo central, devida à força axial e/ou à protensão

$\sigma_{\mathrm{cp}}=\mathrm{N}_{\mathrm{ed}} / \mathrm{A}_{\mathrm{c}}$ em MPa, $\mathrm{N}_{\mathrm{ed}}>0$ na compressão

$\sigma_{\mathrm{cp}}=\frac{N_{\mathrm{Ed}}}{\mathrm{A}_{\mathrm{c}}}=\frac{499,67}{0,137795} \Rightarrow \sigma_{\mathrm{cp}}=3626,18 \mathrm{kN} / \mathrm{m}^{2}=3,626 \mathrm{MPa}$

$A_{c}$ : área da seção transversal de concreto, $A_{c}=0,137795 \mathrm{~m}^{2}$

$\mathrm{N}_{\text {ed }}$ : valor de cálculo da força de protensão aplicada

Foi considerada a força de protensão descontando todas as perdas, como calculado anteriormente. No apêndice C, item 1.1, tem-se: $N_{E d}=499,67$ kN .

$\alpha_{1}=I_{x} / I_{\mathrm{pt2}} \leq 1$ para cordoalhas pré-tracionadas, $\alpha_{1}=\frac{I_{x}}{I_{p t 2}}=\frac{0,55}{0,495}=1,11 \rightarrow \alpha_{1}=1$ 
$\mathrm{I}_{\mathrm{x}}$ : distância da seção considerada a partir do ponto inicial do comprimento de transferência, $I_{x}=2,5.0,2+0,05=0,55 \mathrm{~m}$

$\mathrm{I}_{\mathrm{pt2}}$ : limite superior do comprimento de transferência do elemento protendido

\section{- Determinação de $I_{\text {pt2 }}$}

O limite superior do comprimento de transferência pode ser determinado da seguinte forma (item 8.10.2.2 da EN 1992-1-1:2004):

$I_{p t 2}=1,2 \cdot I_{p t}=1,2 \cdot 0,4125 \Rightarrow I_{p t 2}=0,495$

$I_{p t}$ : comprimento de transferência

$\mathrm{I}_{\mathrm{pt}}=\alpha_{1} \cdot \alpha_{2} \cdot \phi \cdot \frac{\sigma_{\mathrm{pm} 0}}{\mathrm{f}_{\mathrm{bpt}}}$

$I_{p t}=1,25 \cdot 0,19 \cdot 0,0127 \cdot \frac{1075}{7,859} \Rightarrow I_{p t}=0,4125 \mathrm{~m}$

$\alpha_{1}=1,25$ considerando liberação repentina da protensão

$\alpha_{2}=0,19$ considerando cordoalhas de 3 e 7 fios

$\phi$ : diâmetro nominal da cordoalha, $\phi=0,0127 \mathrm{~m}$

$\sigma_{\mathrm{pm} 0}$ : tensão na cordoalha logo após a liberação da protensão

Será considerada a tensão de protensão inicial, descontando somente as perdas imediatas, para laje sem capa. Essas perdas já foram determinadas anteriormente no apêndice A, item 4, $\sigma_{\text {pmo }}=1075 \mathrm{MPa}$

$f_{b p t}$ : tensão de aderência $\Rightarrow f_{b p t}=\eta_{p 1} \cdot \eta_{1} \cdot f_{c t d}(t)$

$f_{\text {bpt }}=3,2 \cdot 1,0 \cdot 2,456 \Rightarrow f_{b p t}=7,859 \mathrm{MPa}$

$\eta_{\mathrm{p} 1}$ : coeficiente que considera o tipo de cordoalha e a situação de aderência na liberação da protensão. $\eta_{p 1}=3,2$ para cordoalhas com 3 e 7 fios

$\eta_{1}=1,0$ para boas condições de aderência

$f_{c t d}(t)$ : valor de projeto da resistência do concreto à tração

$f_{c t d}=0,7 \cdot f_{c t m}(t) \Rightarrow f_{c t d}=0,7 \cdot 0,3 \cdot\left(f_{c j}\right)^{2 / 3}=0,21 \cdot(40)^{2 / 3}=2,456 \mathrm{MPa}$

\section{- Determinação de $\mathbf{V}_{\mathbf{R d}, \mathbf{C}}$}

$$
\begin{aligned}
& \mathrm{V}_{\mathrm{Rd}, \mathrm{C}}=\frac{\mathrm{I} \cdot \mathrm{b}_{\mathrm{W}}}{\mathrm{S}} \cdot \sqrt{\left(\mathrm{f}_{\mathrm{ctd}}\right)^{2}+\alpha_{1} \cdot \sigma_{\mathrm{cp}} \cdot \mathrm{f}_{\mathrm{ctd}}} \Rightarrow \mathrm{V}_{\mathrm{Rd}, \mathrm{C}}=\frac{6,712 \cdot 10^{8} \cdot 320}{3444875} \cdot \sqrt{(2,456)^{2}+1,0 \cdot 3,626 \cdot 2,456} \\
& \mathrm{~V}_{\mathrm{Rd}, \mathrm{C}}=240971,59 \mathrm{~N} \\
& \mathrm{~V}_{\mathrm{Rd}, \mathrm{C}}=240,97 \mathrm{kN}
\end{aligned}
$$




\section{APÊNDICE D}

\section{RESULTADOS EXPERIMENTAIS}

\section{$\Rightarrow$ Ensaios de cisalhamento para as lajes sem capa}

Os resultados experimentais obtidos a partir dos ensaios de cisalhamento para as lajes sem capa podem ser observados nas próximas figuras.

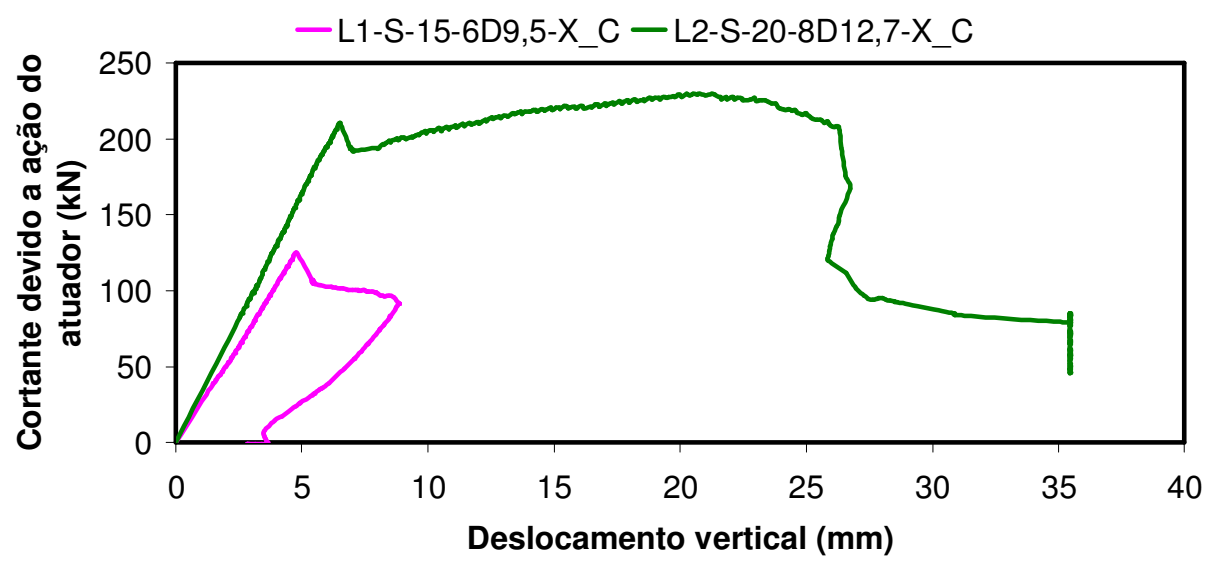

Figura 1: Gráficos de cortante versus deslocamento vertical obtidos a partir dos ensaios das lajes sem capa pertencentes ao lote $X$.

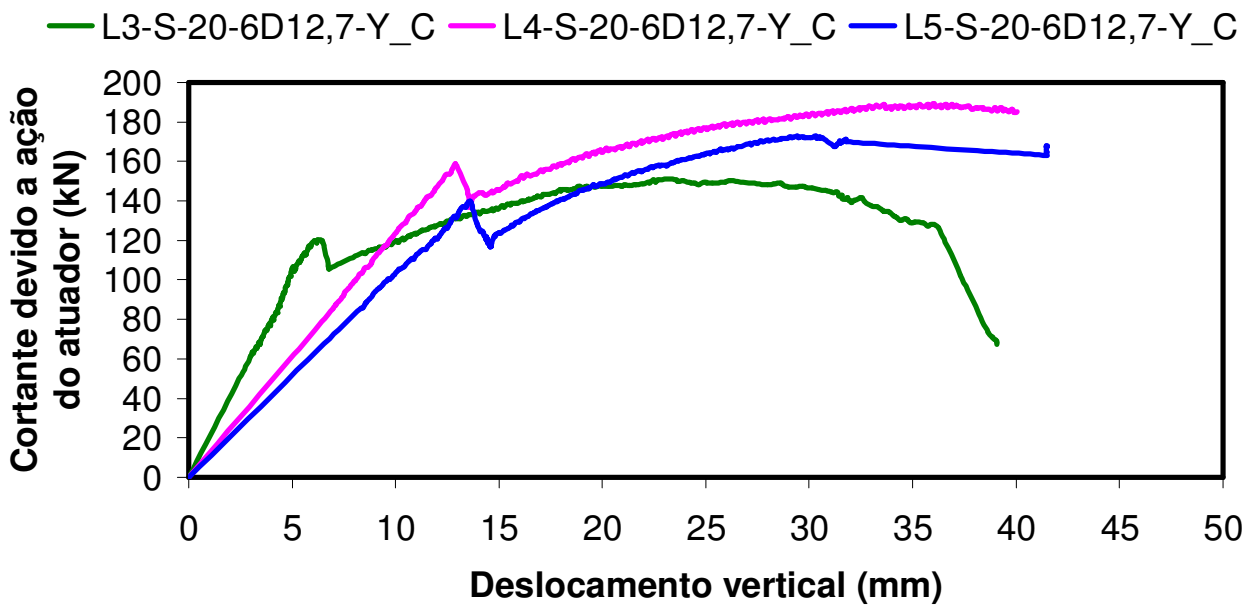

Figura 2: Gráficos de cortante versus deslocamento vertical obtidos a partir dos ensaios das lajes sem capa com $6 \phi 12,7 \mathrm{~mm}$ e comprimento de cerca de $400 \mathrm{~cm}$, pertencentes ao lote $Y$. 


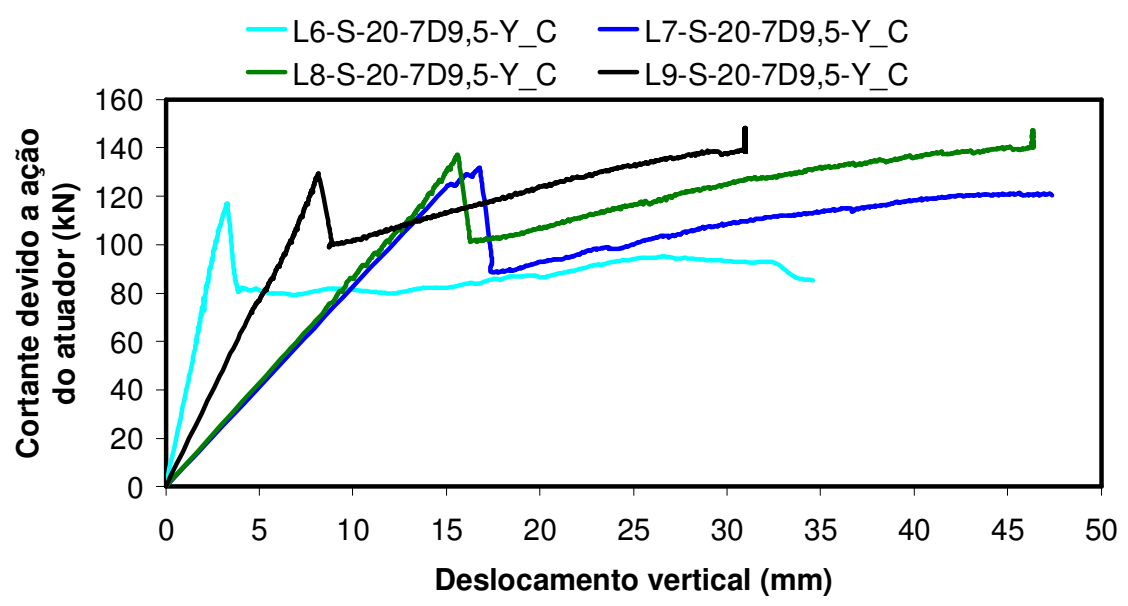

Figura 3: Gráficos de cortante versus deslocamento vertical obtidos a partir dos ensaios das lajes sem capa com $7 \phi 9,5 \mathrm{~mm}$ e comprimento de cerca de $415 \mathrm{~cm}$ e $465 \mathrm{~cm}$ (L9), pertencentes ao lote Y.

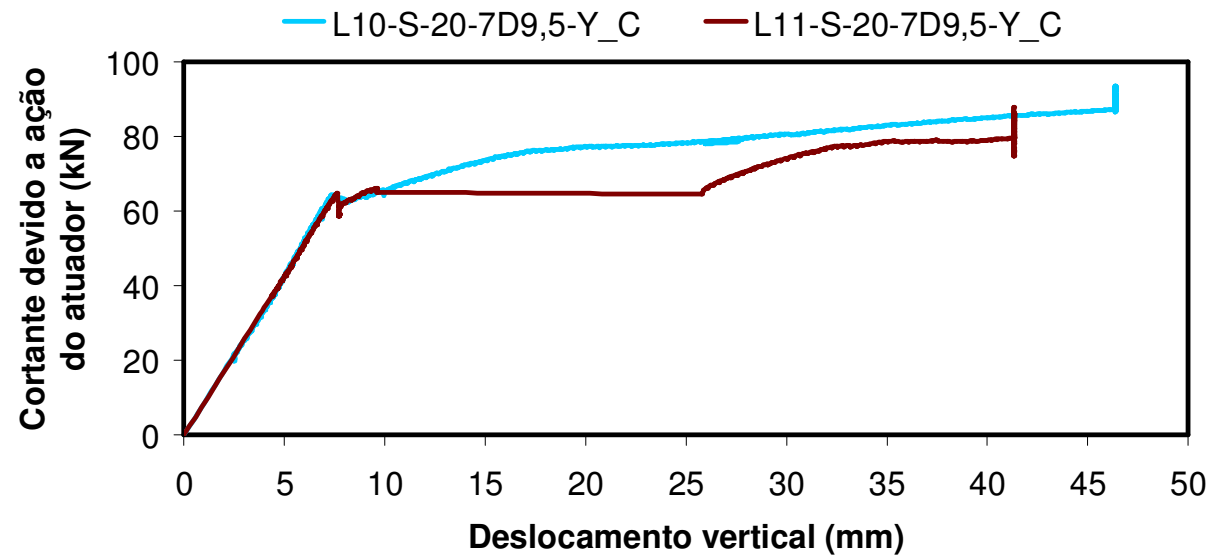

Figura 4: Gráficos de cortante versus deslocamento vertical obtidos a partir dos ensaios das lajes sem capa com $7 \phi 9,5 \mathrm{~mm}$, comprimento de $465 \mathrm{~cm}$ e força aplicada a 5,75 h do apoio, pertencentes ao lote $Y$.

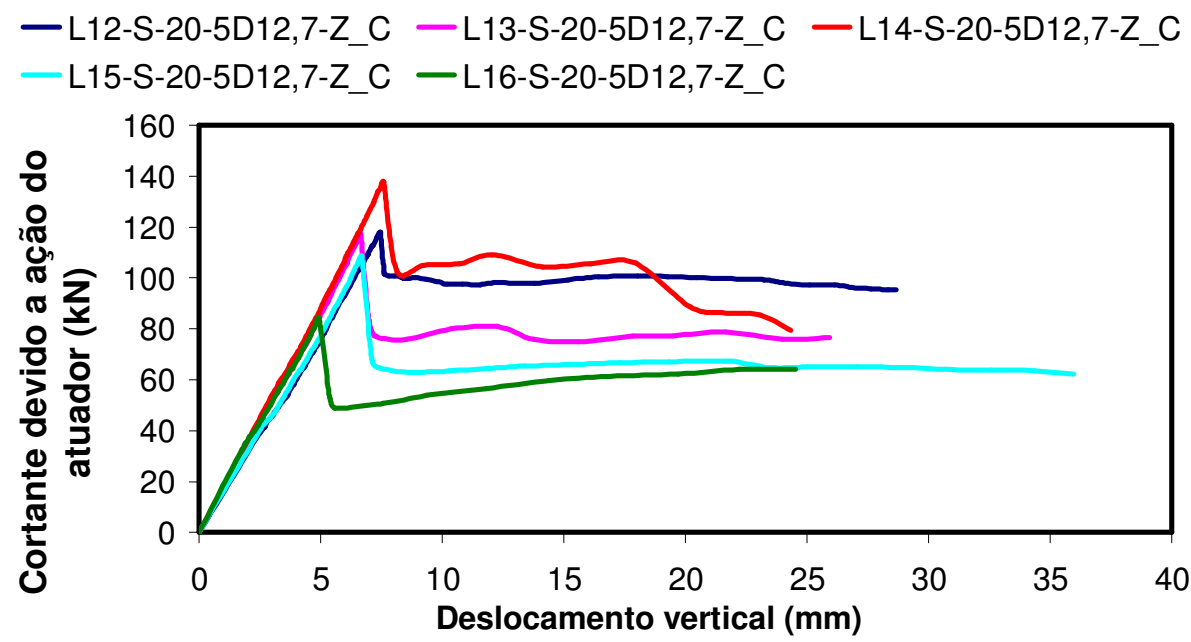

Figura 5: Gráficos de cortante versus deslocamento vertical obtidos a partir dos ensaios das lajes sem capa, com 5 \$12,7 mm e comprimento de $310 \mathrm{~cm}$, pertencentes ao lote $Z$. 


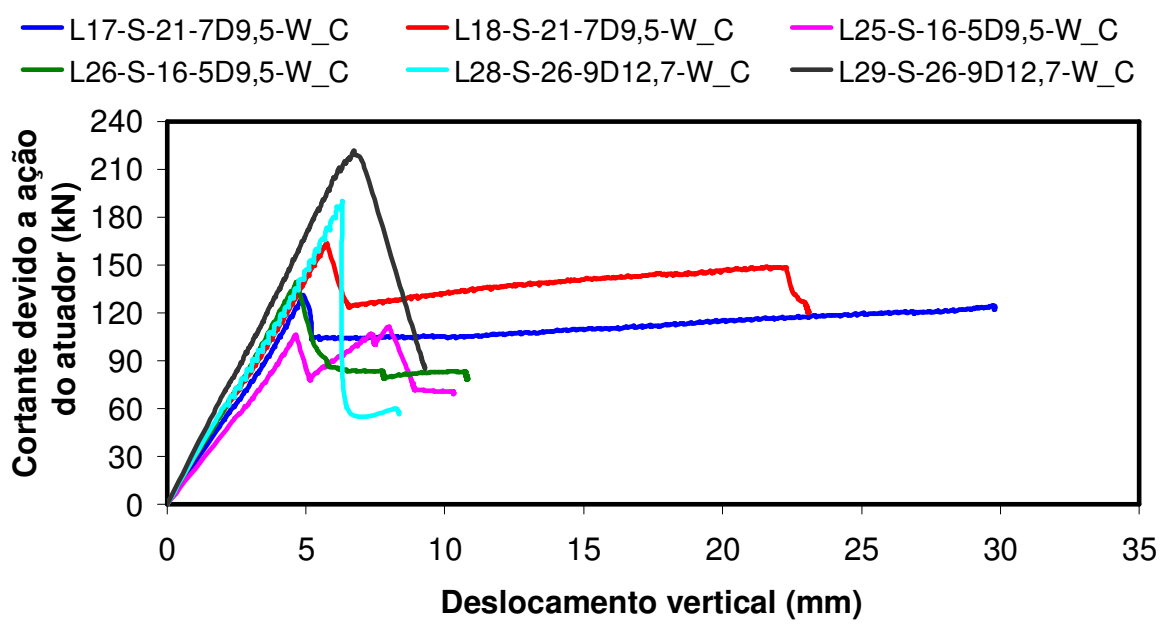

Figura 6: Gráficos de cortante versus deslocamento vertical obtidos a partir dos ensaios das lajes sem capa, com $5 \phi 9,5 \mathrm{~mm}$ e $7 \phi 9,5 \mathrm{~mm}$ e comprimento de $400 \mathrm{~cm}$, pertencentes ao lote $W$.

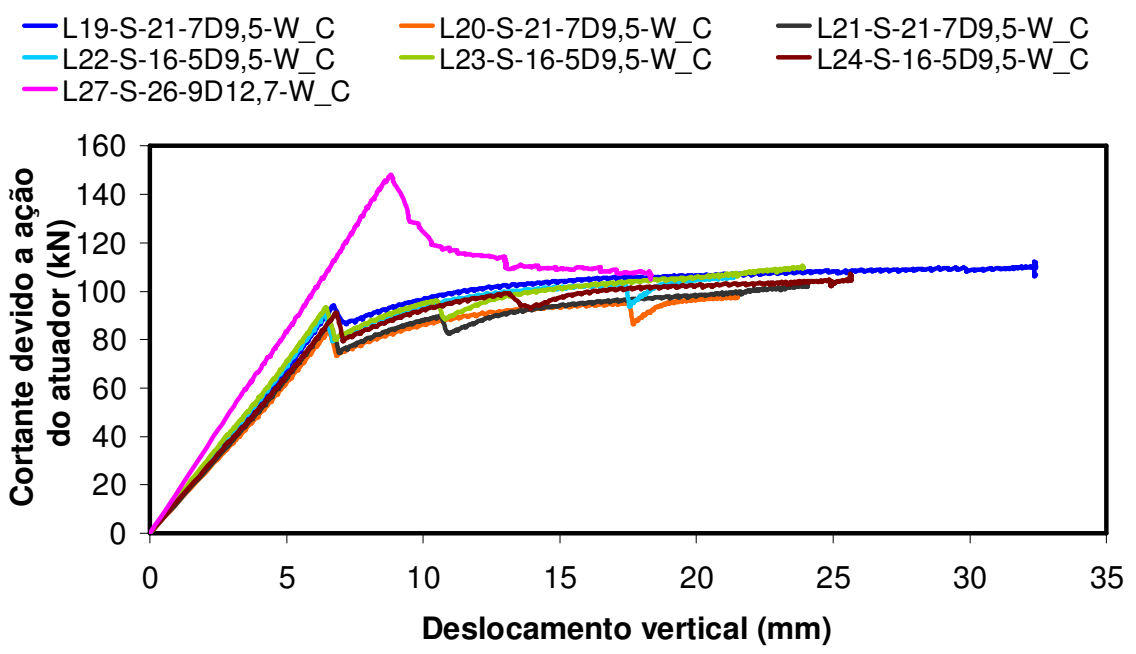

Figura 7: Gráficos de cortante versus deslocamento vertical para lajes sem capa, com 5 ф 9,5 $\mathbf{m m}$ e $7 \phi 9,5 \mathrm{~mm}$, comprimento de $400 \mathrm{~cm}$ e aplicação de força a $5 \mathrm{~h}$ do apoio, pertencentes ao lote $\mathrm{W}$.

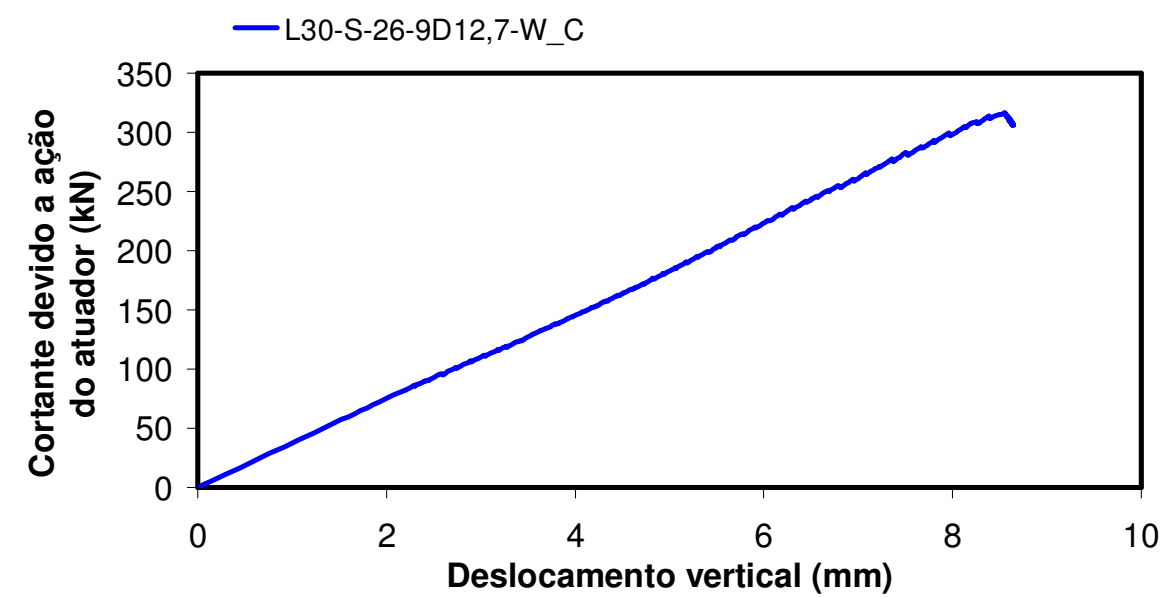

Figura 8: Gráficos de cortante versus deslocamento vertical para lajes sem capa, com $9 \phi 12,7 \mathrm{~mm}$, comprimento $400 \mathrm{~cm}$, força a $2,5 \mathrm{~h}$ do apoio (L29) e com $1 \mathrm{~m}$ de balanço (L30), do lote W. 
$\Rightarrow$ Ensaios de flexão para as lajes sem capa

Seguem os resultados obtidos a partir dos ensaios de flexão para as lajes sem capa.

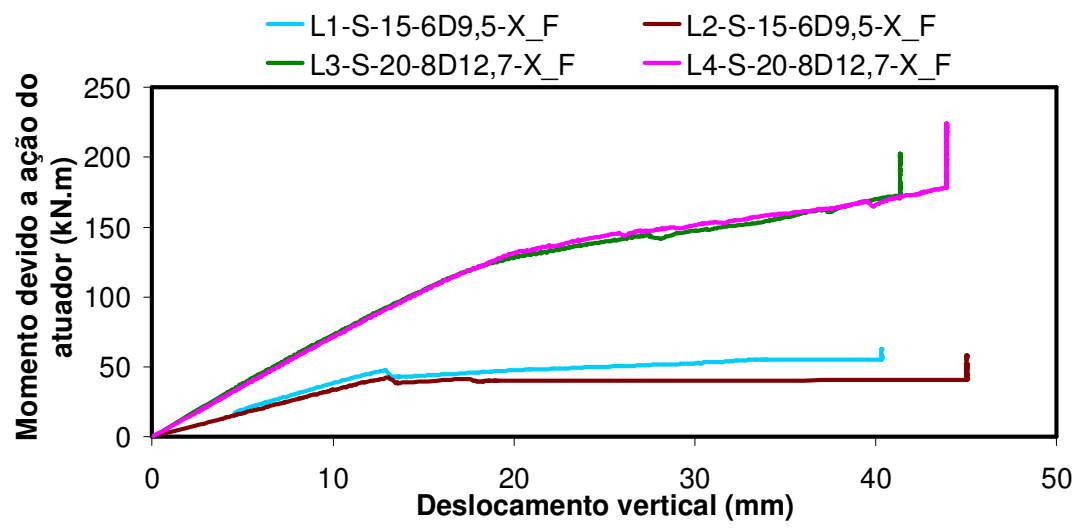

Figura 9: Gráficos de momento versus deslocamento vertical obtidos a partir dos ensaios das lajes sem capa, com $8 \phi 12,7 \mathrm{~mm}$ e $6 \phi 9,5 \mathrm{~mm}$, pertencentes ao lote $X$.

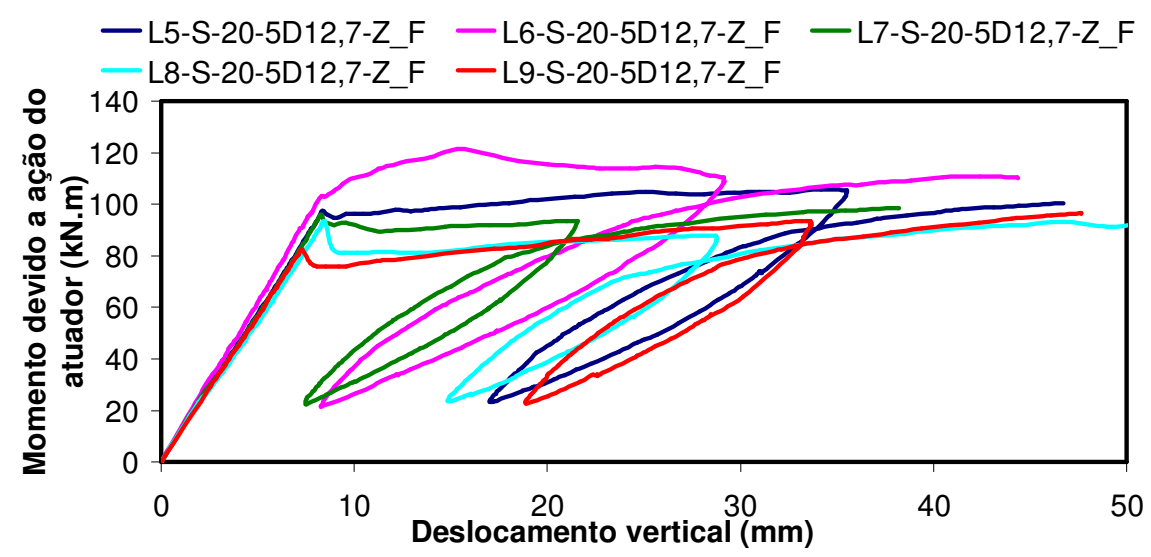

Figura 10: Gráficos de momento versus deslocamento vertical obtidos a partir dos ensaios das lajes sem capa, com $5 \phi 12,7 \mathrm{~mm}$ e comprimento de $310 \mathrm{~cm}$, pertencentes ao lote $Z$.

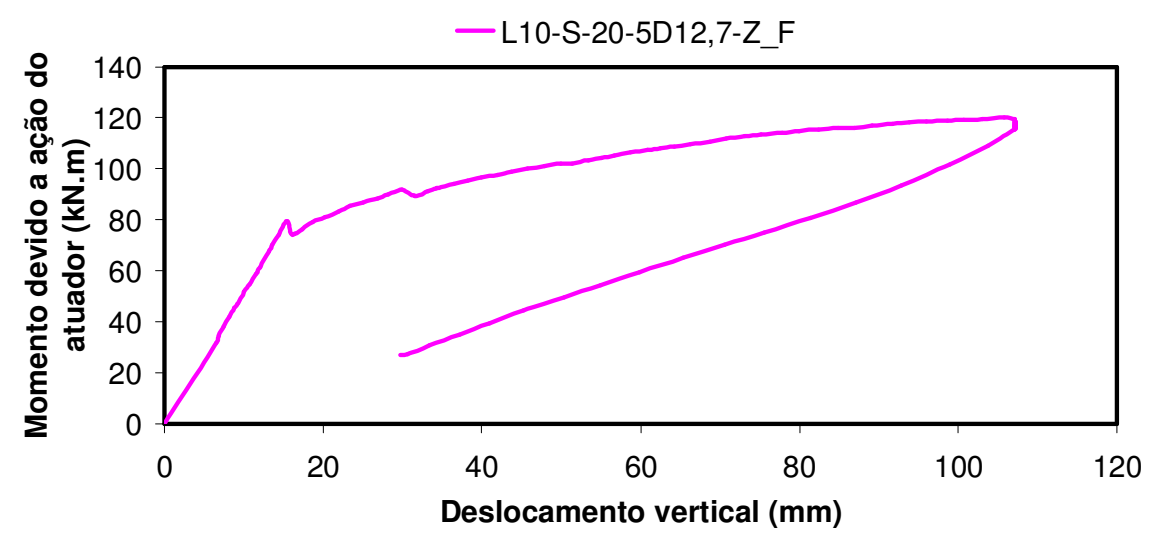

Figura 11: Gráficos de momento versus deslocamento vertical obtidos a partir dos ensaios das lajes sem capa, com $5 \phi 12,7 \mathrm{~mm}$ e comprimento de $610 \mathrm{~cm}$, pertencentes ao lote $Z$. 


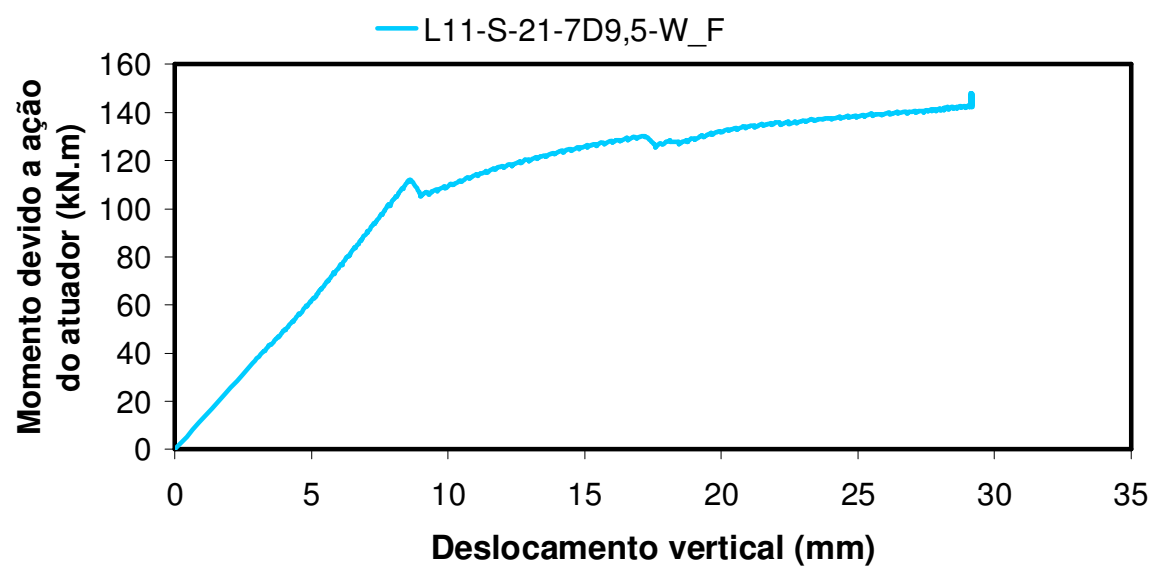

Figura 12: Gráficos de momento versus deslocamento vertical obtidos a partir dos ensaios das lajes sem capa, com $7 \phi 9,5 \mathrm{~mm}$ e comprimento de $400 \mathrm{~cm}$, pertencentes ao lote $W$.

$\Rightarrow$ Ensaios ao cisalhamento para as lajes com capa

Seguem os resultados obtidos nos ensaios de cisalhamento para as lajes com capa.

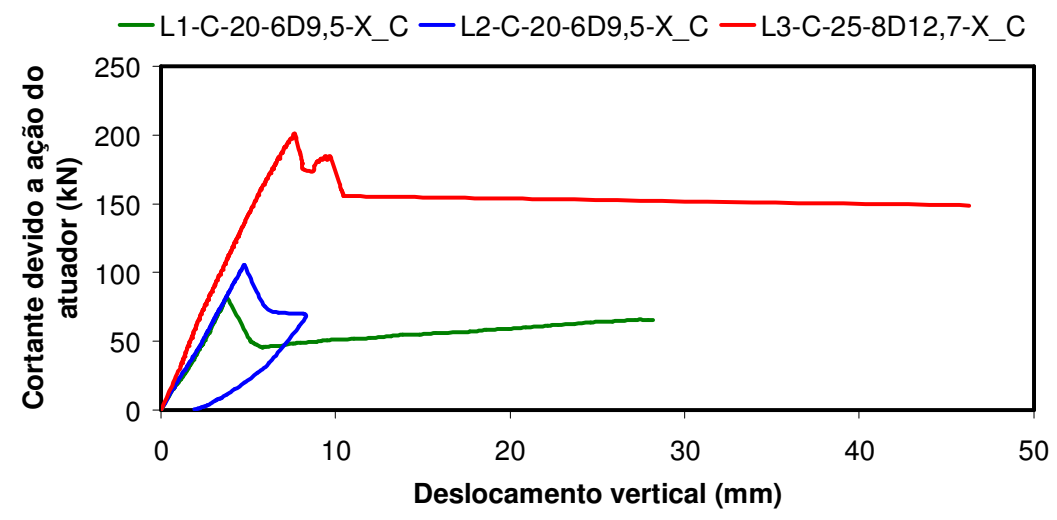

Figura 13: Gráficos de cortante versus deslocamento vertical obtidos a partir dos ensaios das lajes com capa pertencentes ao lote $X$.

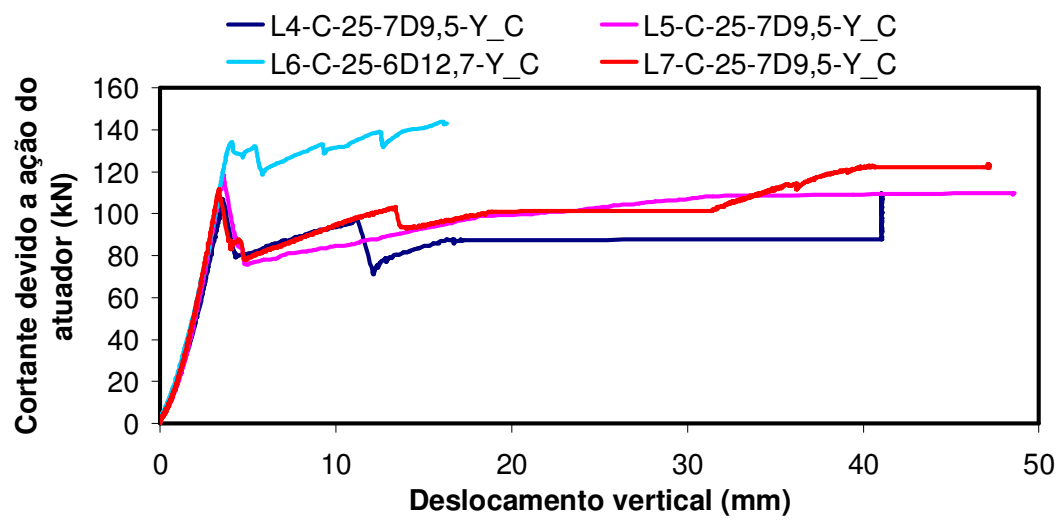

Figura 14: Gráficos de cortante versus deslocamento vertical obtidos a partir dos ensaios das lajes com capa, $6 \phi 12,7 \mathrm{~mm}$ e $7 \phi 9,5 \mathrm{~mm}$ e comprimento de cerca de $415 \mathrm{~cm}$, pertencentes ao lote $Y$. 


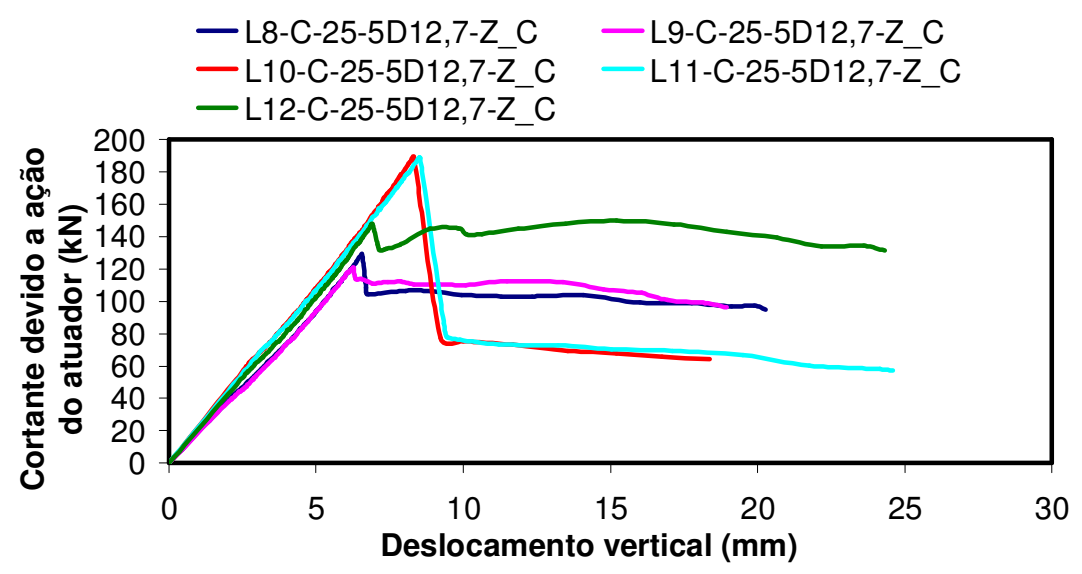

Figura 15: Gráficos de cortante versus deslocamento vertical obtidos a partir dos ensaios das lajes com capa, com $5 \phi 12,7 \mathrm{~mm}$ e comprimento de $310 \mathrm{~cm}$, pertencentes ao lote $Z$.

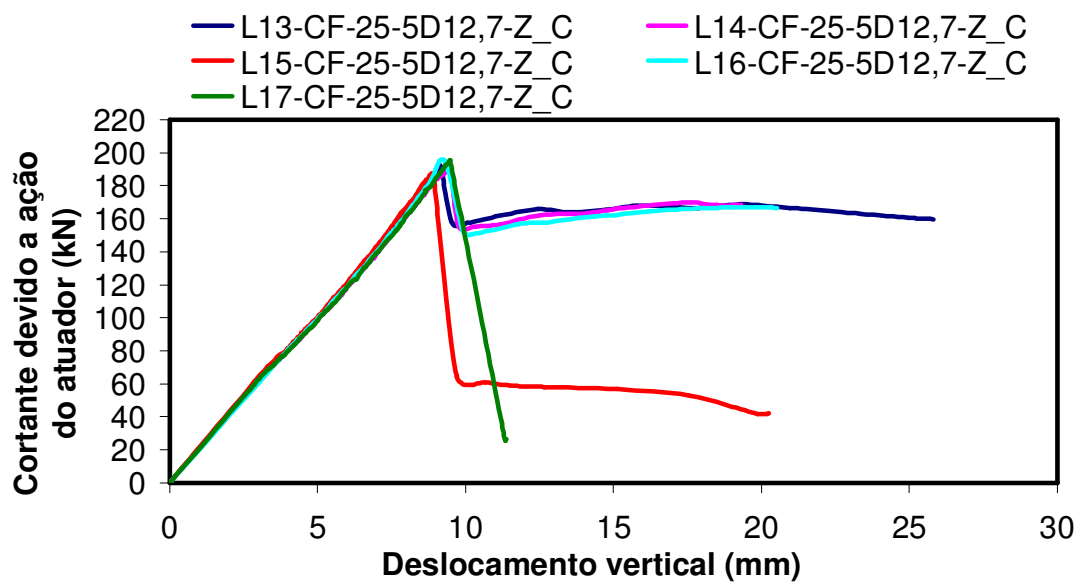

Figura 16: Gráficos de cortante versus deslocamento vertical obtidos a partir dos ensaios das lajes com capa e fibras, com $5 \phi 12,7 \mathrm{~mm}$ e comprimento de $310 \mathrm{~cm}$, pertencentes ao lote $Z$.

\section{$\Rightarrow$ Ensaios à flexão para lajes com capa}

Seguem os resultados obtidos a partir dos ensaios de flexão para as lajes com capa.

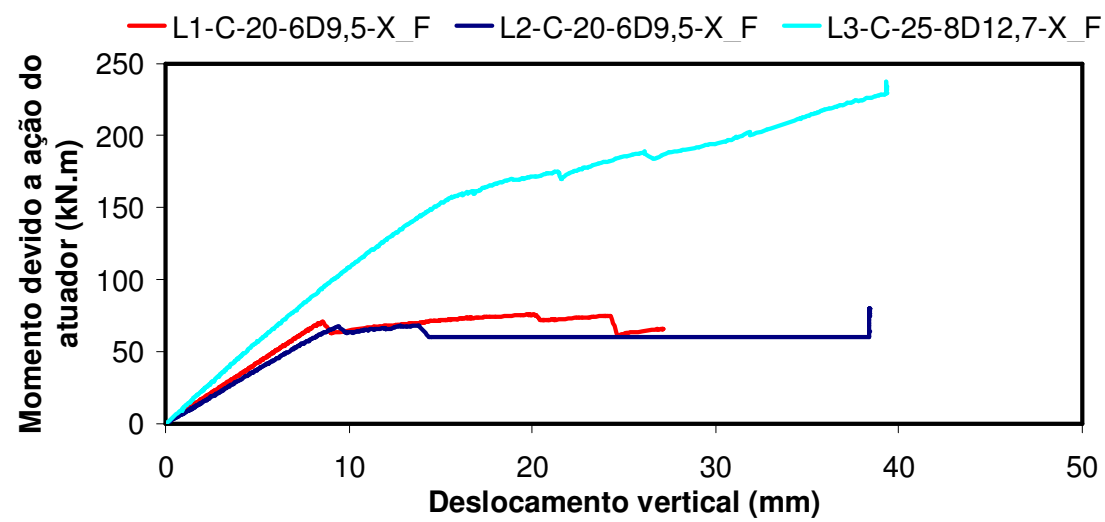

Figura 17: Gráficos de momento versus deslocamento vertical obtidos a partir dos ensaios das lajes com capa, com $8 \phi 12,7 \mathrm{~mm}$ e $6 \phi 9,5 \mathrm{~mm}$, pertencentes ao lote $X$. 


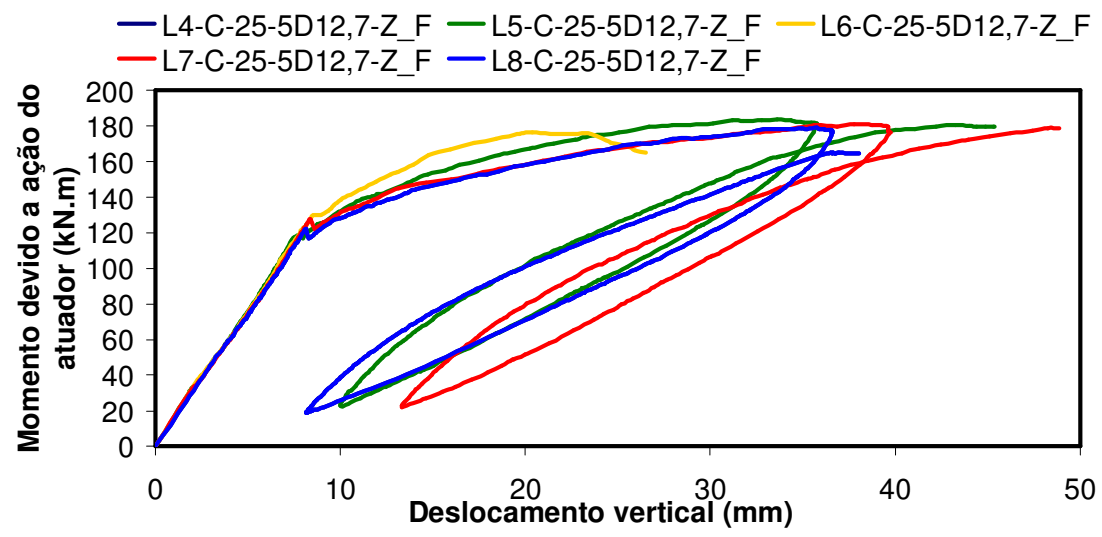

Figura 18: Gráficos de momento versus deslocamento vertical obtidos a partir dos ensaios das lajes com capa, com $5 \phi 12,7 \mathrm{~mm}$ e comprimento de $310 \mathrm{~cm}$, pertencentes ao lote $Z$.

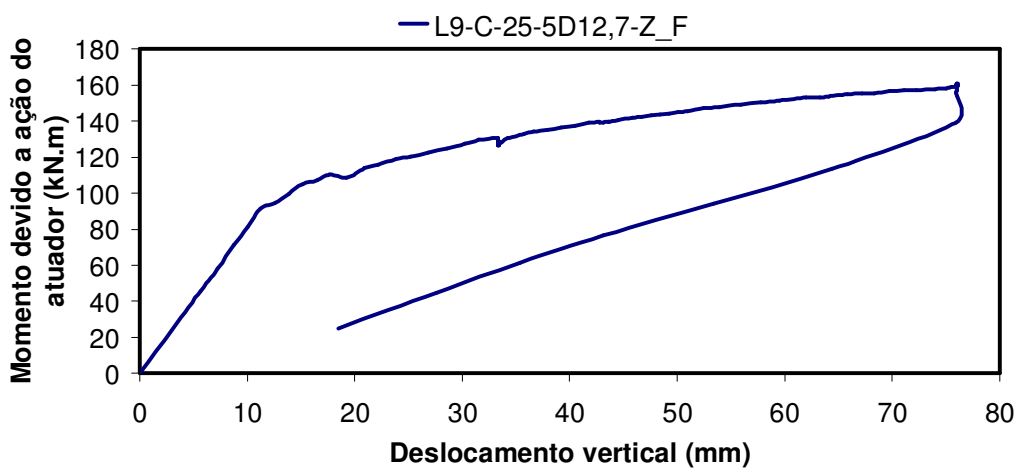

Figura 19: Gráficos de momento versus deslocamento vertical obtidos a partir dos ensaios das lajes com capa, com $5 \phi 12,7 \mathrm{~mm}$ e comprimento de $610 \mathrm{~cm}$, pertencentes ao lote $Z$.

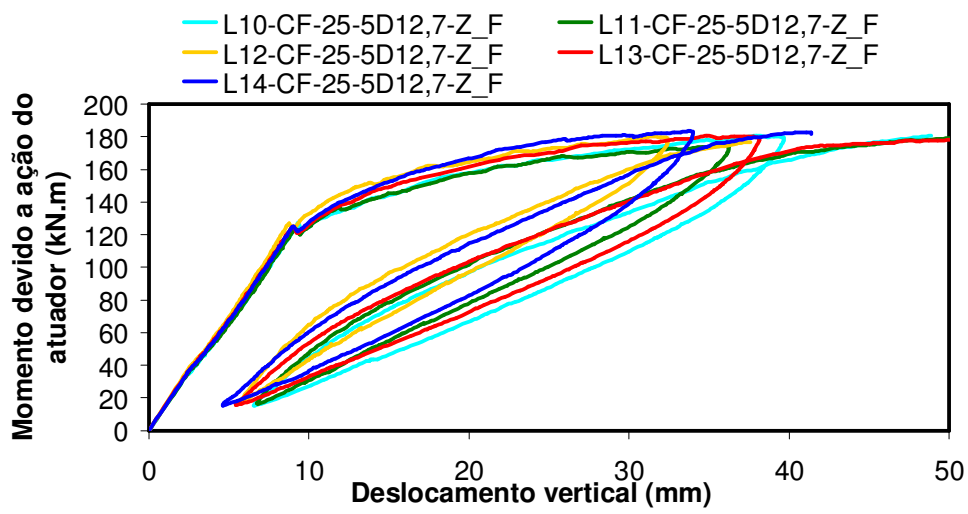

Figura 20: Gráficos de momento versus deslocamento vertical obtidos a partir dos ensaios das lajes com capa e fibras, com $5 \phi 12,7 \mathrm{~mm}$ e comprimento de $310 \mathrm{~cm}$, pertencentes ao lote $Z$.

\section{$\Rightarrow$ Ensaios ao cisalhamento para lajes com alvéolos preenchidos}

Os resultados experimentais, obtidos com os ensaios de cisalhamento para as lajes com alvéolos parcialmente preenchidos, podem ser observados nas próximas figuras. 


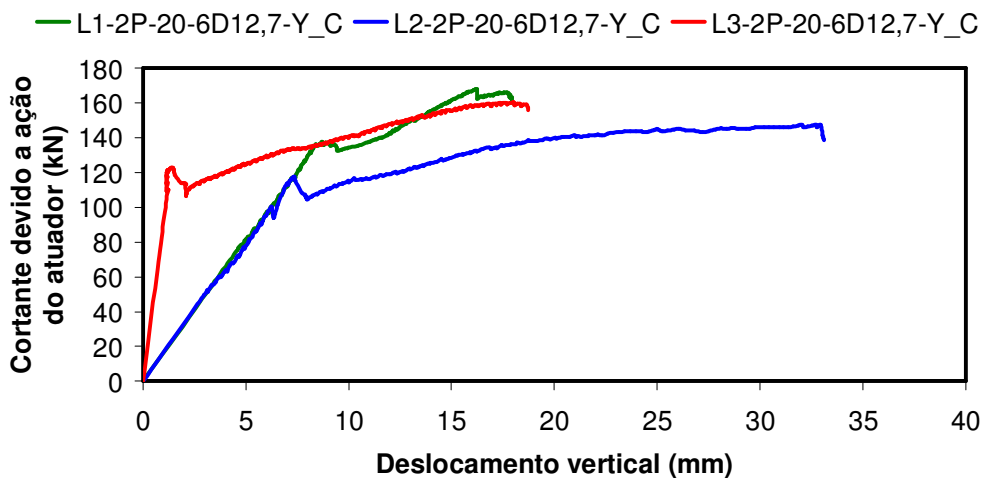

Figura 21: Gráficos de cortante versus deslocamento vertical obtidos a partir dos ensaios das lajes sem capa, com dois alvéolos preenchidos, 6 \$12,7 mm e comprimento de cerca de $415 \mathrm{~cm}$, pertencentes ao lote $Y$.

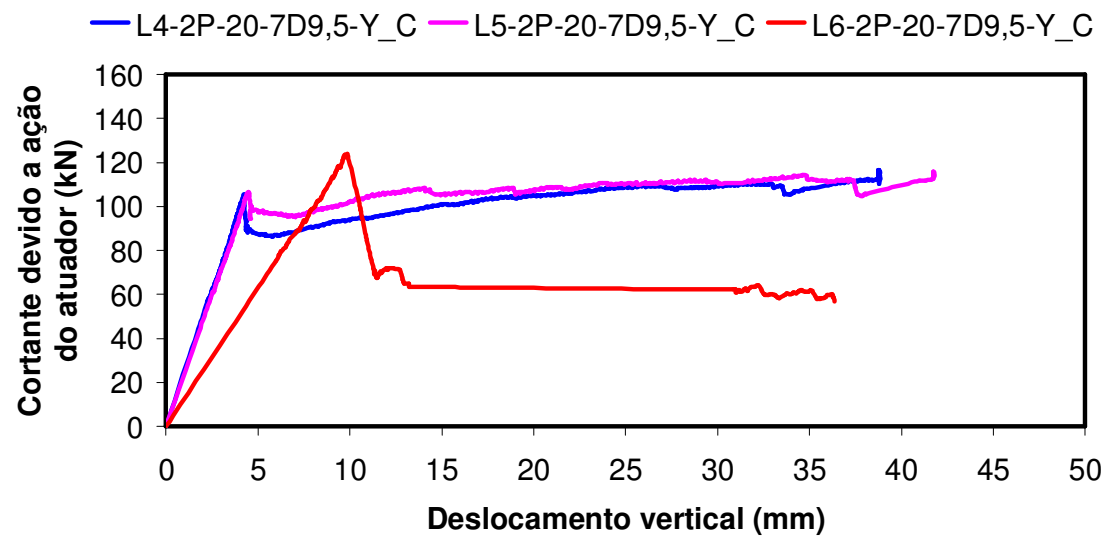

Figura 22: Gráficos de cortante versus deslocamento vertical obtidos a partir dos ensaios das lajes sem capa, com dois alvéolos preenchidos, $7 \phi 9,5 \mathrm{~mm}$ e comprimento de cerca de $415 \mathrm{~cm}$, pertencentes ao lote $Y$.

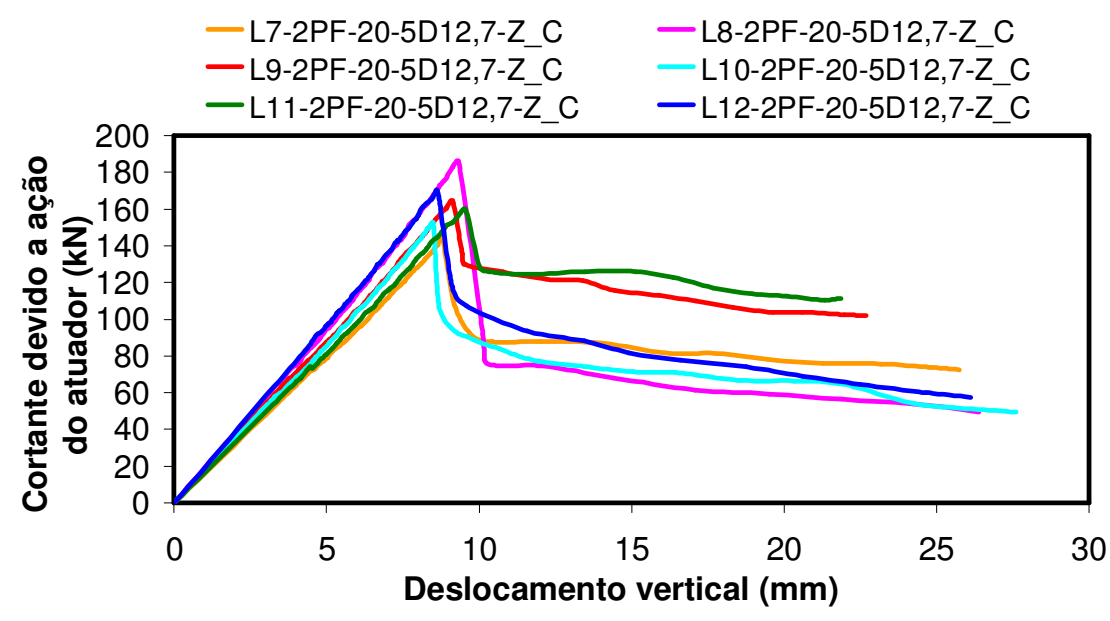

Figura 23: Gráficos de cortante versus deslocamento vertical obtidos a partir dos ensaios das lajes sem capa, com dois alvéolos preenchidos com concreto reforçado com fibras, com $5 \phi 12,7 \mathrm{~mm}$ e comprimento de $310 \mathrm{~cm}$, pertencentes ao lote $Z$. 


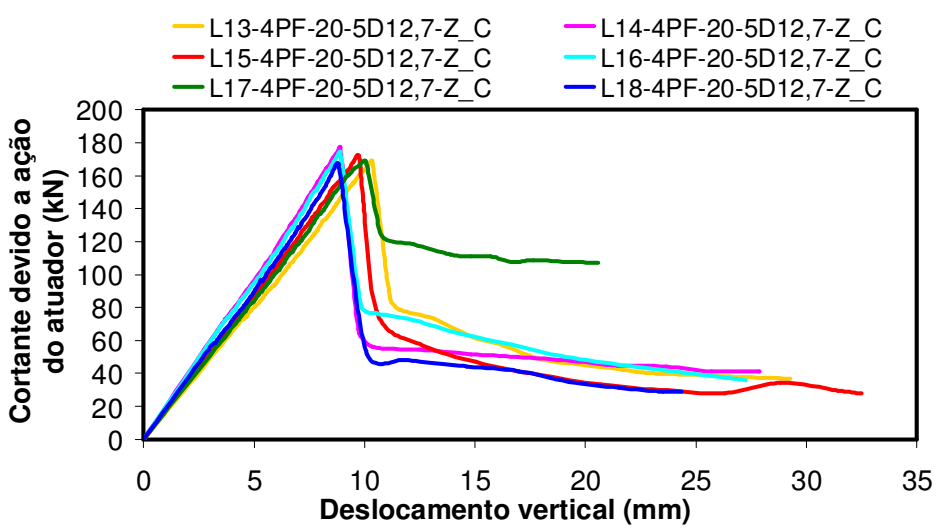

Figura 24: Gráficos de cortante versus deslocamento vertical obtidos a partir dos ensaios das lajes sem capa, com quatro alvéolos preenchidos com concreto reforçado com fibras, com $5 \phi 12,7 \mathrm{~mm}$ e comprimento de $310 \mathrm{~cm}$, pertencentes ao lote $Z$.

\section{$\Rightarrow$ Ensaios à flexão para as lajes com alvéolos preenchidos}

Os resultados experimentais, obtidos com os ensaios à flexão para as lajes com alvéolos parcialmente preenchidos, podem ser observados nas próximas figuras.

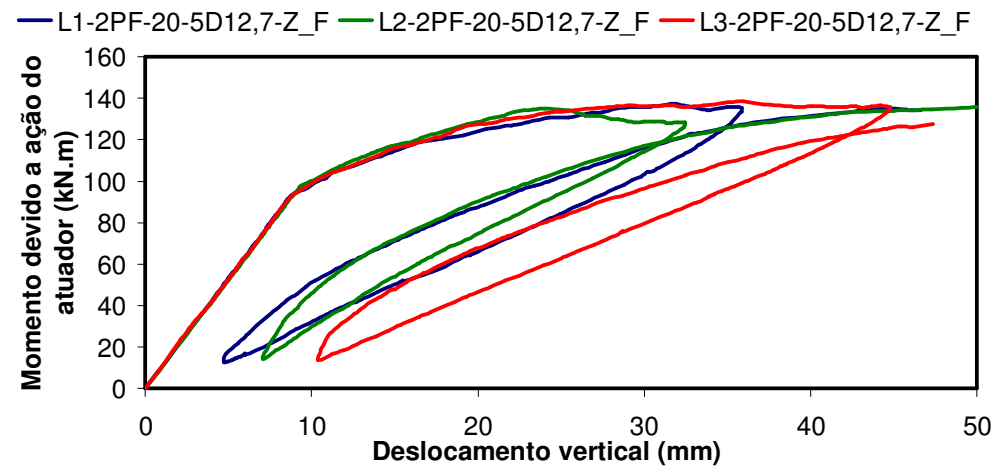

Figura 25: Gráficos de momento versus deslocamento vertical obtidos a partir dos ensaios das lajes sem capa, com dois alvéolos preenchidos com concreto reforçado com fibras, com $5 \phi 12,7 \mathrm{~mm}$ e comprimento de $310 \mathrm{~cm}$, pertencentes ao lote $Z$.

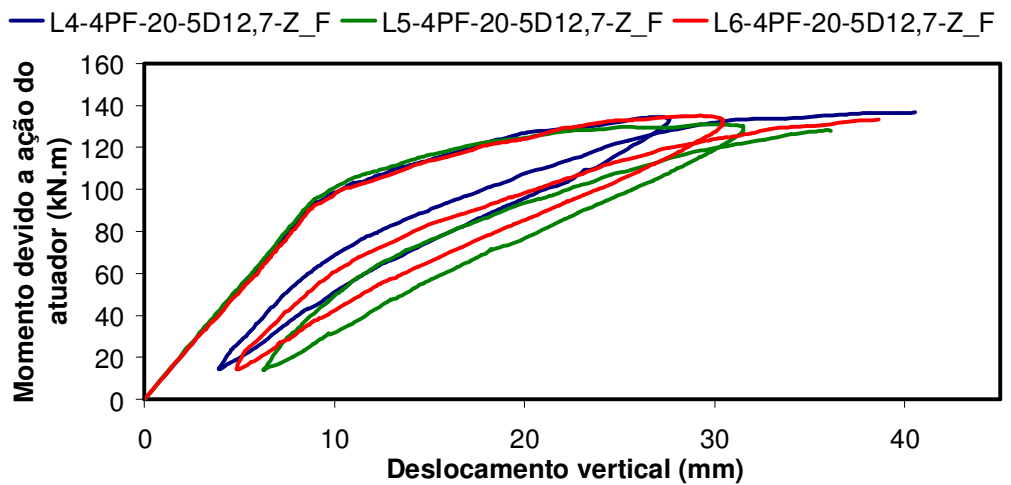

Figura 26: Gráficos de momento versus deslocamento vertical obtidos a partir dos ensaios das lajes sem capa, com quatro alvéolos preenchidos com concreto reforçado com fibras, com $5 \phi 12,7 \mathrm{~mm}$ e comprimento de $310 \mathrm{~cm}$, pertencentes ao lote $Z$. 


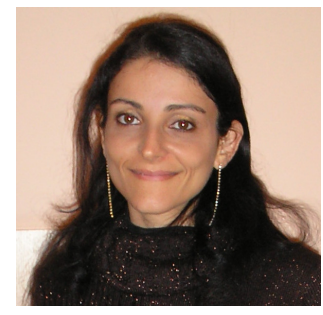

\section{BRUNA CATOIA}

Engenheira Civil pela Universidade Federal de São Carlos, UFSCar, em 2004. Concluiu o mestrado em 2007, nessa mesma instituição. Recebeu o Prêmio Destaque do Ano de 2007, com a Dissertação de Mestrado na Área de Estruturas (Comportamento de vigas protendidas pré-moldadas com ligações semi-rígidas), pelo Instituto Brasileiro do Concreto (IBRACON), em Bento Gonçalves - RS. Também em 2007, recebeu o Prêmio de Melhor Trabalho Técnico do Ano, pelo Instituto de Engenharia (IE), em São Paulo. Em 2011, concluiu o Doutorado em Engenharia Civil (Engenharia de Estruturas) na Escola de Engenharia de São Carlos da Universidade de São Paulo, EESC-USP. Durante o Doutorado, participou do PAE (Programa de Aperfeiçoamento de Ensino), nas disciplinas de graduação Estruturas de Concreto Armado I e II e Estruturas de Fundações. Nesse período, também foram realizadas outras atividades didáticas como: monitoria junto a disciplina de graduação, treinamento de Professores para Curso de Estruturas PréMoldadas de Concreto e curso de Formação de Multiplicadores do Curso Básico em PréFabricados de Concreto. Ao longo do Doutorado, foram publicados sete artigos em periódicos, sendo cinco nacionais e dois internacionais. Quatro desses artigos referem-se diretamente à pesquisa de doutorado. Também foram publicados 19 artigos em congressos, sendo dez internacionais e nove nacionais. Quatro desses artigos referem-se diretamente à pesquisa de doutorado. Também foi publicado um capítulo de livro em publicação especial do American Concrete Institute (ACI). Em 23 de março de 2011, por meio da aprovação em concurso público, foi contratada como engenheira responsável pelo NETPRE (Núcleo de Estudos e Tecnologia em Pré-Moldados de Concreto) da UFSCar. 